\title{
УВАЖАЕМЫЕ КОЛЛЕГИ!
}

В этом номере журнала «Российский вестник перинатологии и педиатрии» представляем Вашему вниманию Материалы XX Российского конгресса «Инновационные технологии в педиатрии и детской хирургии» с международным участием

Конгресс состоится

\section{1-23 октября 2021 года}

Гостиничный комплекс «КОСМОС»,

г. Москва, проспект Мира, д. 150

\section{ОРГКОМИТЕТ КОНГРЕССА:}

125412, г. Москва, ул. Талдомская, д. 2

Научно-исследовательский клинический институт педиатрии им. академика Ю.Е. Вельтищева РНИМУ им. Н.И. Пирогова Минздрава России

Российская ассоциация педиатрический центров

Конгресс «Инновационные технологии в педиатрии и детской хирургии»

Контактные телефоны:

Калашникова Татьяна Викторовна

Моб.: +7 (926) 525-16-82

E-mail: congress@pedklin.ru

Сайт: www.congress-pedklin.ru 

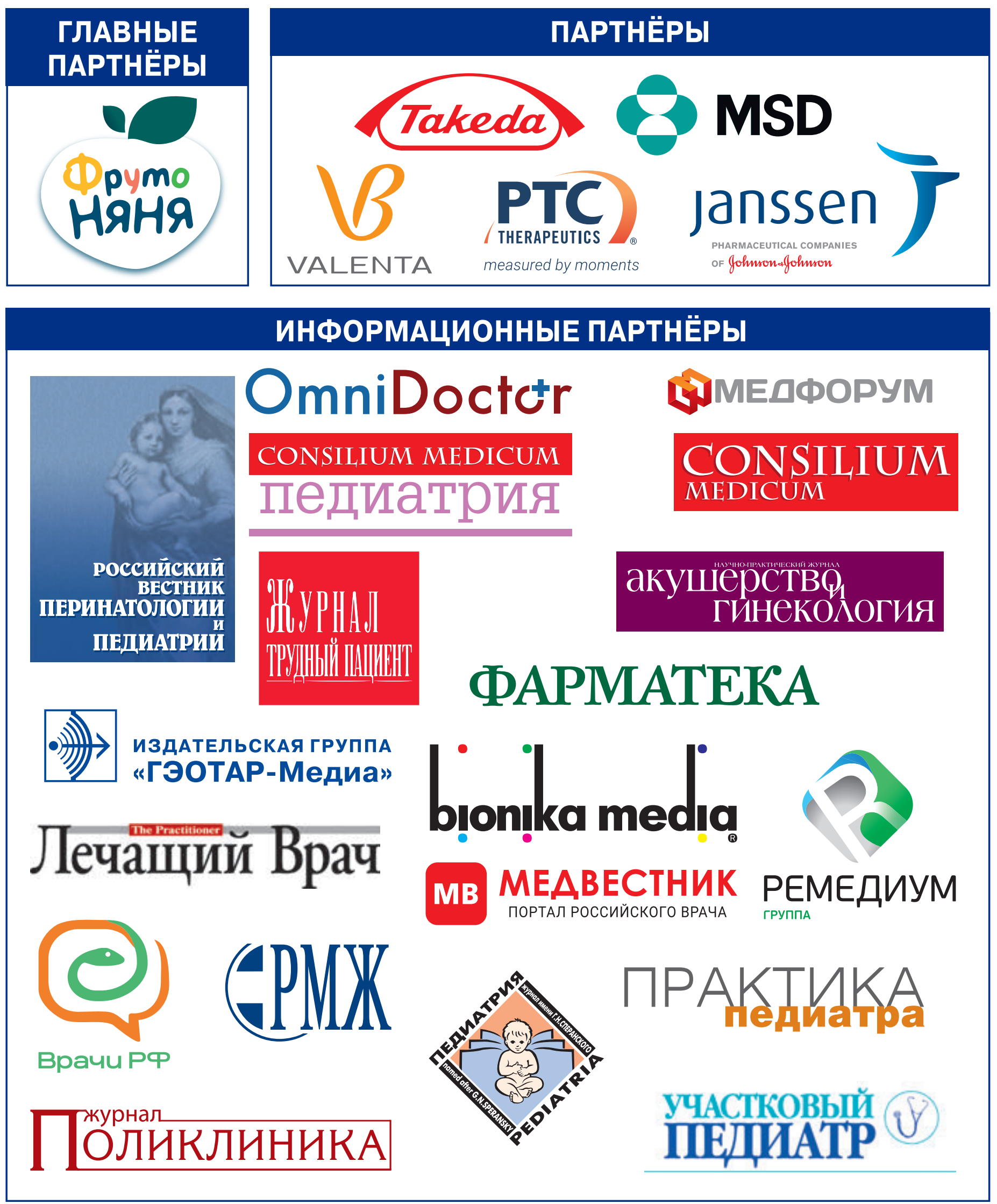

ОРГАНИЗАТОРЫ КОНГРЕССА

БРОНИРОВАНИЕ НОМЕРОВ
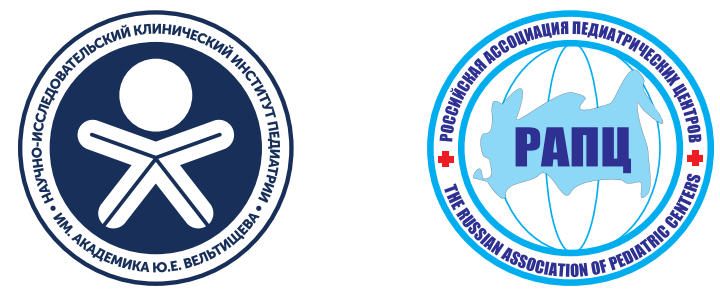

Cotel 
МИНИСТЕРСТВО ЗДРАВООХРАНЕНИЯ РОССИЙСКОЙ ФЕДЕРАЦИИ РОССИЙСКИЙ НАЦИОНАЛЬНЫЙ ИССЛЕДОВАТЕЛЬСКИЙ

МЕДИЦИНСКИЙ УНИВЕРСИТЕТ ИМ. Н.И. ПИРОГОВА

НАУЧНО-ИССЛЕДОВАТЕЛЬСКИЙ КЛИНИЧЕСКИЙ ИНСТИТУТ ПЕДИАТРИИ им. академика Ю.Е. ВЕЛЬТИЩЕВА

РОССИЙСКАЯ АССОЦИАЦИЯ ПЕДИАТРИЧЕСКИХ ЦЕНТРОВ

АССОЦИАЦИЯ ДЕТСКИХ КАРДИОЛОГОВ РОССИИ

ТВОРЧЕСКОЕ ОБЪЕДИНЕНИЕ ДЕТСКИХ НЕФРОЛОГОВ

НАЦИОНАЛЬНАЯ ПЕДИАТРИЧЕСКАЯ АКАДЕМИЯ НАУКИ И ИННОВАЦИЙ

НАЦИОНАЛЬНАЯ АССОЦИАЦИЯ ДИЕТОЛОГОВ И НУТРИЦИОЛОГОВ

ОБЩЕСТВО ДЕТСКИХ ГАСТРОЭНТЕРОЛОГОВ

РОССИЙСКАЯ АССОЦИАЦИЯ ЛОР-ПЕДИАТРОВ

РОССИЙСКАЯ МЕДИЦИНСКАЯ АКАДЕМИЯ

НЕПРЕРЫВНОГО ПРОФЕССИОНАЛЬНОГО ОБРАЗОВАНИЯ

МОСКОВСКИЙ ГОСУДАРСТВЕННЫЙ МЕДИКО-СТОМАТОЛОГИЧЕСКИЙ УНИВЕРСИТЕТ

ФЕДЕРАЦИЯ ЛАБОРАТОРНОЙ МЕДИЦИНЫ

\section{ТЕЗИСЫ ХХ РОССИЙСКОГО}

КОНГРЕССА

«ИННОВАЦИОННЫЕ ТЕХНОЛОГИИ

В ПЕДИАТРИИ И ДЕТСКОЙ

ХИРУРГИИ»

С МЕЖДУНАРОДНЫМ УЧАСТИЕМ

DOI: $10.21508 / 1027-4065$-congress-2021 


\section{СОДЕРЖАНИЕ}

Раздел 1

ОРГАНИЗАЦИЯ МЕДИЦИНСКОЙ

ПОМОЩИ ДЕТЯМ

Раздел 2

АЛЛЕРГОЛОГИЯ И ИММУНОЛОГИЯ

Раздел 3

ГАСТРОЭНТЕРОЛОГИЯ

Раздел 4

ЗДОРОВЫЙ РЕБЕНОК И ПАТОЛОГИЯ ДЕТЕЙ РАННЕГО ВОЗРАСТА . .

Раздел 5

КАРДИОЛОГИЯ

Раздел 6

НАСЛЕДСТВЕННЫЕ ЗАБОЛЕВАНИЯ И ВРОЖДЕННЫЕ ПОРОКИ РАЗВИТИЯ.

Раздел 7

НЕФРОЛОГИЯ

Раздел 8

НЕВРОЛОГИЯ

Раздел 9

ПУЛЬМОНОЛОГИЯ.

Раздел 10

ИНФЕКЦИИ И ВАКЦИНОПРОФИЛАКТИКА 303

Раздел 11

ЭНДОКРИНОЛОГИЯ

Раздел 12

МЕТАБОЛИЧЕСКИЙ СИНДРОМ И ОЖИРЕНИЕ У ДЕТЕЙ

Раздел 13

PAЗHOE.

Раздел 14

КОНКУРС

МОЛОДЫХ УЧЕНЫХ 358

АЛФАВИТНЫЙ УКАЗАТЕЛЬ АВТОРОВ. 


\section{Раздел 1}

\section{ОРГАНИЗАЦИЯ}

МЕДИЦИНСКОЙ

ПОМОЩИ ДЕТЯМ 


\section{СРАВНИТЕЛЬНАЯ ОЦЕНКА ПОКАЗАТЕЛЕЙ ЗДОРОВЬЯ ДЕТЕЙ ЭТНИЧЕСКИХ ХАНТОВ ПРИ ИСПОЛЬЗОВАНИИ ОБЩЕПРИНЯТЫХ И РАЗРАБОТАННЫХ НА ЭТОЙ КОГОРТЕ НОРМАТИВОВ}

Байтрак О.А., Мещеряков В.В., Сомова Т.М.

Сургутский государственный университет, Сургут

Введение. Комплексная оценка здоровья детей при профилактических осмотрах включает прежде всего анализ физического, полового развития и артериального давления (АД). Фенотипические особенности этнически обособленных коренных малочисленных народов Крайнего Севера (КМНС), каковыми являются ханты, определяет необходимость оптимального выбора нормативов для проведения их диспансеризации. Цель. Оценить результативность применения разработанных на когорте детей этнических хантов нормативов, в сравнении с общепринятыми. Использованы ранее разработанные и опубликованные нормативы физического, полового развития и АД для детей хантов и стандартные нормативы.

Материалы и методы. Проведено одномоментное сплошное когортное исследование - сравнительная оценка физического, полового развития и АД 423 детей этнических хантов 1-11 классов (7-17 лет) школы-интерната для КМНС с использованием международных стандартов и нормативов, разработанных на когорте детей этнических хантов. Статистическая обработка материала проведена методом углового преобразования Фишера.

Результаты. Установлены статистически значимые различия результатов оценки физического, полового развития и АД при использовании различных нормативов. Применение общепринятых нормативов искажает заключение об оценке здоровья детей хантов - уменьшает частоту выявления ожирения (мальчики: стандартные нормативы - 0,9\%, адаптированные к хантам нормативы $-4,9 \%$; девочки: $0,5 \%$ и 4,6\%, $<<0,05$ для обоих полов); избытка массы тела (мальчики $-1,4 \%$ и 13,7\%; девочки $-9,2 \%$ и $13,9 \%$, $p<0,05$ для обоих полов) и артериальной гипертензии $(0,5 \%$ и $3,8 \%$ у мальчиков и девочек вместе, $p<0,05)$; способствует гипердиагностике нанизма (мальчики $-13,2 \%$ и $2,7 \%$; девочки $-23,1 \%$ и $2,6 \%, p<0,05$ для обоих полов) и отставания от паспортного возраста в половом развитии (девочки: $26,6 \%$ и 11,8\%; мальчики: $38,6 \%$ и $11,4 \%, p<0,05$ для обоих полов).

Заключение. Внедрение в практику разработанных на детях этнических хантов нормативов физического, полового развития и АД позволяет объективизировать оценку состояния их здоровья.

\section{ДИАГНОСТИКА РИСКОВ РАЗВИТИЯ ПАТОЛОГИЧЕСКИХ СОСТОЯНИЙ У ПОДРОСТКОВ В УСЛОВИЯХ СОВРЕМЕННОГО ОБРАЗОВАТЕЛЬНОГО ПРОСТРАНСТВА}

Богачев А.Н., Вершинин Е.Г.

ФГБОУ ВО ВолгГМУ Минздрава России, Волгоград

Введение. Возможность диагностики рисков развития предпатологических и патологический состояний, а также эффективности лечебно-реабилитационных мероприятий в случае возникновения заболевания у подростков в условиях современного образовательного пространства является одной из ведущих проблем педиатрии в векторе улучшения состояния здоровья школьников.

Цель исследования: разработать диагностическую компьютерную программу по прогнозированию рисков развития морбидных состояний у подростков и научно обосновать ее диагностическую эффективность.

Материалы и методы. Экспертным методом проведена градация показателей кардио-респираторной системы, физического развития и физической подготовленности; определены диапазоны градаций и дана их бальная оценка. Использовалось вероятностное моделирование с применением метода распознавания образов по Вальду. Диагностическая эффективность программы оценивалась по результатам оценки наиболее информативных показателей у 545 подростков в возрасте от 12 до 15 лет с патологией сердечнососудистой системы, дыхания и ЖКТ. Контрольную группу составили 87 школьников без отклонений в состоянии здоровья.

Результаты. Для проверки разработанной прогностической таблицы был выбран 95\% уровень надежности, диагностические пороги для которого составили +13 (отсутствие нарушений) и -13 (снижение резервных возможностей). По приведенным порогам здоровые дети распределились следующим образом: отсутствие риска $-75 \pm 4,7 \%$, условный риск

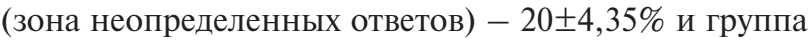
риска $-5 \pm 2,4 \%$. В группе детей с отклонениями в состоянии здоровья отсутствие нарушений составило $3 \pm 0,8 \%$, нарушение резервных возможностей организма $-79 \pm 1,9 \%$ и группа переходного состояния $18 \pm 1,8 \%$.

Заключение. Приведенные результаты указывают на достаточную высокую прогностическую информативность разработанной диагностической компьютерной программы. Кроме того, метод компьютерной диагностики прогнозирования рисков развития морбидных состояний у подростков прост, требует набора простых клинико-физиологических признаков и позволяет выносить прогностическое решение с заданным уровнем надежности. 
ДИАГНОСТИЧЕСКАЯ ИНФОРМАТИВНОСТЬ ПОКАЗАТЕЛЕЙ ФУНКЦИОНАЛЬНЫХ РЕЗЕРВОВ ОРГАНИЗМА МЛАДШИХ ШКОЛЬНИКОВ ПРИ ПРОВЕДЕНИИ ВРАЧЕБНО-ПЕДАГОГИЧЕСКОГО КОНТРОЛЯ

Богачев А.Н., Вершинин Е.Г.

ФГБОУ ВО ВолгГМУ Минздрава России, Волгоград

Введение. Диагностика функциональных резервов младших школьников в процессе физического воспитания является одной из ведущих задач современной спортивной медицины и педиатрии.

Цель. Изучить диагностическую информативность показателей функциональных резервов организма младших школьников и дать физиологическое обоснование эффективности их применения при проведении врачебно-педагогического контроля (ВПК) в процессе физического воспитания.

Материалы и методы. Оценивали диагностическую эффективность (ДЭ) 10 базовых и расчетных показателей кардио-респираторной системы, применяемых при ВПК, на основании значений их чувствительности $(\mathrm{Se})$, специфичности $(\mathrm{Sp})$ и диагностического индекса (ДИ). В исследовании приняли участие 536 школьников 7-8 лет, которые были распределены с учетом функционального состояния ведущих систем организма и уровня двигательной активности.

Результаты. Низкая Se была выявлена у диастолического давления (ДАД), систолического давления (САД), вегетативного индекса Кердо (ВИК), коэффициента экономичности кровообращения (КЭК) и общего периферического сопротивления (ОПС) - от 2 до 44\%, а высокая у показателя двойного произведения (ПДП), индекса Руфье (ИР), ЧСС, экскурсии грудной клетки (ЭГК) и индекса функциональных изменений (ИФИ) от 84 до 100\%. Низкая Sp оказалась у ЭГК, ПДП и ИФИ (от 8 до 26\%), а высокая у КЭК, ВИК $-81 \%$ и ОПС $-84 \%$. Высокая Se на фоне низкой Sp указывают на возможность необоснованного завышения уровня физического развития, а обратное соотношение на возможность занижении уровня физического развития. Низкий ДИ отмечался у ДАД и САД (7\% и 56\%), а наиболее высокий у ЧСС (64\%), КЭК (61\%), ВИК (65\%).

Заключение. В оценке снижения физического развития наибольшую информативность имеют ОПС и КЭК. Динамика ПДП, ИР, ИФИ, ЭГК значима в оценке эффективности здоровьесберегающих технологий. ДАД и САД могут использоваться лишь в оценке переносимости физических нагрузок и механизмов гемодинамического обеспечения. Высокий ДИ у ВИК, ЧСС и КЭК определяет их информативность в диагностике и прогнозировании здоровья младших школьников в процессе физического воспитания.

\section{ОРГАНИЗАЦИОННО-ПРАВОВЫЕ АСПЕКТЫ ДЕЯТЕЛЬНОСТИ РЕАБИЛИТАЦИОННЫХ ЦЕНТРОВ ДЛЯ ДЕТЕЙ-ИНВАЛИДОВ \\ С ДЕТСКИМ ЦЕРЕБРАЛЬНЫМ ПАРАЛИЧОМ}

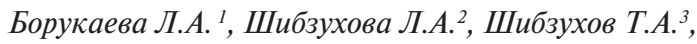
Борукаева И.Х. ${ }^{1}$, Абазова $3 . X .^{1}$

${ }^{1}$ Московский государственный юридический университет имени О.Е. Кутафина, Москва

${ }^{2}$ Кабардино-Балкарский государственный университет им. Х.М. Бербекова, Нальчик

${ }^{3}$ Государственный университет управления, Москва

Введение. В настоящее время, несмотря на развитие медицины, растет число детей-инвалидов с детским церебральным параличом (ДЦП). Разработка и усовершенствование организационно-правовых аспектов реабилитации таких детей остается весьма актуальной проблемой.

Цель исследования - выявление организационно-правовых аспектов деятельности реабилитационных центров и эффективности реабилитации детейинвалидов с ДЦП в условиях санаторно-курортного лечения.

Материал и методы. Реабилитационный центр располагался на базе ГКЦ ДСРЦ «Радуга» МТ и С3 КБР. Санаторно-курортное лечение 120 детей 8-12 лет с ДЦП включало лечебную физкультуру, медикаментозное лечение, массаж, лазеротерапию инфракрасным светом, минеральные грязевые пасты, терапию переменным электромагнитным полем, метод микрополяризации, микроволновую резонансную терапию, фонофорез и электрофорез лекарственных средств, магнитотерапию, парафинотерапию, баротерапию.

Результаты. Проведен анализ санаторно-курортного лечения в реабилитации детей-инвалидов с ДЦП. Санаторно-курортное лечение 2 раза в год значительно повышало физическую активность, улучшало неврологическую картину. Введение принципиально новых федеральных схем реализации индивидуальных программ реабилитации ребенкаинвалида требует от органов власти субъекта РФ создания организационно-правового механизма межведомственного взаимодействия многопрофильных организаций-исполнителей. Необходимо разработать стандарты оказания услуг в сфере ранней помощи и сопровождения, создать единую систему выявления и межведомственного обмена данными о потребностях инвалидов в реабилитационных мероприятиях с единой справочно-информационной системой для формирования реабилитационного маршрута, повысить уровень информационной открытости организаций.

Заключение. В настоящее время требуются единые подходы и стандарты организации предоставления услуг помощи и межведомственного взаимодействия учреждений сферы образования, здравоохранения 
и социальной защиты населения. Необходимыми условиями достижения цели комплексной реабилитации детей-инвалидов является наличие комплексности и непрерывности реабилитационных мероприятий, последовательности и преемственности в проведении комплексной реабилитации детей-инвалидов, наличие системного подхода и возможность использования современных реабилитационных технологий.

\section{АСПЕКТЫ РАЗРАБОТКИ ИННОВАЦИОННОЙ ТЕХНОЛОГИИ МЕДИЦИНСКОГО СОПРОВОЖДЕНИЯ ЮНОШЕСКОГО СПОРТА \\ Вершинин Е.Г., Мандриков В.Б. \\ ФГБОУ ВО ВолгГМУ Минздрава России, Волгоград}

Введение. В настоящее время автоматизация ведения врачебно-контрольных карт диспансерного наблюдения за юными спортсменами, которая позволяет систематизировать динамику основных показателей ребенка, занимающегося спортом, способствует выявлению на раннем этапе в разные периоды наблюдения различных предрасположенностей, является одной из ведущих проблем спортивной медицины в векторе улучшения состояния здоровья юных спортсменов.

Цель исследования: разработать инновационную технологию медицинского сопровождения юношеского спорта для повышения эффективности работы врача спортивной медицины.

Материалы и методы. Разработана компьютерная программа «Автоматизированное рабочее место врача спортивной медицины» (АРМ) в виде веб-приложения с использованием языка РНР. Созданная программа работает с базой данных (БД), подключение к которой требует авторизации пользователей. Вид и версия системы управления БД: MySQL

Результаты. При разработке АРМ был спроектирован интерфейс, максимально приближенный к внешнему виду типовых врачебно-контрольных карт диспансерного наблюдения спортсмена (форма № 062-У). Это позволяет быстро освоить работу с программой и не требует от пользователя наличия специальных навыков для работы с базой (только умение работать с браузером). БД содержит сведения врачебных наблюдений, карты здоровья спортсменов, результаты анкетирования, посвященного вопросам медицинского сопровождения спортсменов, что позволяет наблюдать за динамикой показателей спортсменов. БД может применяться врачами спортивной медицины как отдельный продукт, или интегрироваться в состав существующих медицинских информационных систем.

Заключение. Приведенные результаты указывают на высокую прогностическую эффективность разработанной инновационной технологии медицинского сопровождения юношеского спорта, которая будет способствовать созданию единого информационного пространства для всех участников процесса спортивной подготовки (юных спортсменов, врачей, тренеров) и снижает вероятность некорректного ввода информации за счет стандартизации заполняемых документов.

\section{АНАЛИЗ ВНЕШНИХ ФАКТОРОВ МЕДИЦИНСКОГО СОПРОВОЖДЕНИЯ ДЕТСКО- ЮНОШЕСКОГО СПОРТА}

Вершинин Е.Г., Соболева С.Ю.

ФГБОУ ВО ВолгГМУ Минздрава России, Волгоград

Введение. В современном мире любая организация находится в состоянии постоянного обмена с внешней средой, в которой выделяют четыре основные группы факторов - политические, экономические, социальные и технологические. Определение наиболее значимых из них поможет в выработке правильной стратегии медицинской организации в разделе медицинского сопровождения детско-юношеского спорта.

Цель исследования: разработать мероприятия по совершенствованию медицинского сопровождения детско-юношеского спорта на основании проведения стратегического PEST-анализа деятельности государственного бюджетного учреждения здравоохранения «Волгоградский областной клинический центр медицинской реабилитации» (ГБУЗ ВОКЦМР).

Материалы и методы. Исследования базируются на абстрактно-логическом методе, стратегическом анализе (PEST, STEEP), методах экспертной оценки, сравнения, сопоставления, синтеза информации, отчетов деятельности ГБУЗ ВОКЦМР.

Результаты. STEЕР-анализ факторов внешней среды ГБУЗ ВОКЦМР позволил определить наиболее значимые из них: автоматизация медицинского сопровождения, развитие технологий, дефицит кадров в отрасли (требования нормативных актов, где указано на необходимость участия ряда узких специалистов, без которых само углубленное медицинское обследование невозможно), уровень инновации в отрасли, уровень влияния врачей спортивной медицины. При разработке стратегии исследуемого учреждения здравоохранения авторы предложили администрации ГБУЗ ВОКЦМР учесть следующие рекомендации: внедрение инновационных технологичных методов реабилитации в детско-юношеском спорте; оформление целевой подготовки специалистов, начиная со студенчества; развитие телемедицины. Была просчитана рентабельность при внедрении рекомендаций, которая составила $14 \%$, что подтверждает экономическую эффективность. 
Заключение. Применение аспектов менеджмента в организации медицинского сопровождения детско-юношеского спорта, в частности методик стратегического анализа, позволяет взглянуть на проблему с различных ракурсов и выявить наиболее значимые из них. Поскольку в условиях дефицита финансирования и сокращения государственного задания необходимо изыскивать ресурсы для развития медицинских организаций, а данные управленческие методики являются актуальными.

\section{ИСПОЛЬЗОВАНИЕ ДИСТАНЦИОННЫХ ТЕХНОЛОГИЙ В ПОДГОТОВКЕ СТУДЕНТОВ К ПРАКТИЧЕСКОЙ ДЕЯТЕЛЬНОСТИ ПО СПЕЦИАЛЬНОСТИ ПЕДИАТРИЯ}

Кострова И.В., Приходько О.Б., Лучникова Т.А. ФГБОУ ВО Амурская ГМА Минздрава России, Благовещенск, Амурская область

Введение. Использование дистанционных технологий имеет ряд неоспоримых преимуществ, особенно актуальных в условиях борьбы с распространением новой коронавирусной инфекции в Российской Федерации.

Цель исследования. Анализ эффективности использования дистанционных технологий в обучении студентов по специальности 31,05,02 Педиатрия.

Материалы и методы. При выполнении поставленных задач были проанализированы результаты дистанционного обучения на платформе Moodle в электронной информационно-образовательной среде (ЭИОС).

Результаты. На кафедре госпитальной терапии с курсом фармакологии используются следующие платформы для дистанционного обучения: Moodle, Skype, Zoom, Discord, WhatsApp, электронная почта. Платформа Moodle в ЭИОС удобна для размещения как информационных материалов (конспекты и презентации лекций, методические рекомендации, клинические ситуации и клинические разборы историй болезни, гиперссылки), так и для проведения текущего и рубежного контроля, элементов промежуточной аттестации (тесты и задачи для текущего, рубежного контроля и промежуточной аттестации), размещения перечня вопросов для подготовки к практическим занятиям и к промежуточной аттестации, перечення практических навыков.

Журнал событий позволяет просматривать информационные и контролирующие материалы в режиме 24/7. Нами проанализированы итоги тестирования студентов, обучающихся по специальности 31,05,02 Педиатрия. По дисциплине «Госпитальная терапия» результат тестирования в процессе текущего контроля составил 83,1\%. При проведении промежуточного тестирования (итогового контроля) отмечено повышения уровня освоения знаний до $92 \%$.
Аналогичную динамику продемонстрировали результаты тестирования по дисциплине «Фтизиатрия» текущий контроль выполнен на 78,5\%, промежуточный (итоговый контроль) - на 88,2\%. Таким образом, ежедневный текущий контроль позволяет повысить уровень подготовки студентов к промежуточной аттестации.

Преимуществом платформы Moodle является также и возможность использования ее для размещения информационных ресурсов по воспитательной работе кафедры, что, ввиду доступности системы для всех подписанных на курс студентов, позволяет расширить формат проводимых мероприятий.

Заключение. Использование дистанционного формата обучения имеет ряд неоспоримых преимуществ: актуальная информация, экономия времени и возможность просмотра контролирующих материалов в режиме $24 / 7$.

\section{ОСОБЕННОСТИ ОРГАНИЗАЦИИ МЕДИЦИНСКОЙ ПОМОЩИ ЮНЫМ СПОРТСМЕНАМ (АНТИДОПИНГОВЫЕ АСПЕКТЫ)}

Лагутин М.П., Вершинин Е.Г.

ФГБОУ ВО ВолгГМУ Минздрава России, Волгоград

Введение. Организация медицинской помощи юным спортсменам с учетом современных антидопинговых реалий требует от врачей педиатров нестандартного подхода к медикаментозной терапии. Медикаментозная терапия подростков, профессионально занимающихся спортом, всегда сопряжена с риском случайного назначения медикаментозного средства, входящего в запрещенный список WADA с последующей дисквалификацией спортсмена.

Цель исследования: установить уровень информированности врачей-педиатров об особых требованиях к оказанию медицинской помощи подросткам, профессионально занимающихся спортом.

Материалы и методы. В опросе (анкетирование) приняло участие 120 врачей-педиатров. Всем респондентам было задано всего три вопроса: 1. Что Вам известно о списке препаратов, запрещенных WADA; 2. Что такое разрешение на терапевтическое использование? 3. Как Вы думаете, используете ли Вы в своей практике лекарственные средства из запрещенного списка WADA?

Результаты. На первый вопрос утвердительно ответили 12 человек (10\%), на второй вопрос не ответил никто - 0\%, на третий вопрос утвердительно ответили 18 человек (15\%).

Заключение. Отмечается чрезвычайно низкий уровень информативности врачей-педиатров об особенностях организации медицинской помощи подросткам, профессионально занимающихся спортом. Учитывая, что по месту жительства юные спортсмены 
при заболеваниях обращаются к врачам-педиатрам первичного звена (участковые врачи) вероятность назначения лекарственного средства из запрещенного списка чрезвычайно высока. В условиях современной антидопинговой парадигмы целесообразно повысить уровень компетентности врачей-педиатров в особенностях организации медицинской помощи юным спортсменам.

\section{ВЛИЯНИЕ ВЕДУЩИХ РЕПРЕЗЕНТАТИВНЫХ СИСТЕМ ПРИ ОРГАНИЗАЦИИ ОБУЧЕНИЯ НАВЫКАМ СЕРДЕЧНО-ЛЕГОЧНОЙ РЕАНИМАЦИИ}

Лисовский О.В., Лисица И.А., Гостимский А.В., Гавщук М.В., Лисовская Е.О.

ФГБОУ ВО СПбГПМУ Минздрава России, СанктПетербург

Введение. Внедрение персонифицированного подхода при обучении медицинских работников значительно повышает эффективность образовательного процесса, положительно влияет на формирование и закрепление практических компетенций. Современные образовательные технологии позволяют использовать ведущие репрезентативные системы обучающихся при подготовке медицинских кадров.

Цель. Провести анализ эффективности обучения навыкам базовой сердечно-легочной реанимации (СЛР) при использовании ведущих репрезентативных систем.

Материалы и методы. На кафедре общей медицинской практики Санкт-Петербургского государственного педиатрического медицинского университета проведено исследование, включившее 152 студента: 128 девушек $(84,21 \%)$ и 24 юноши $(15,89 \%)$, средний возраст - 19,9 лет. При анализе традиционной методики обучения навыку «базовая СЛР» определены репрезентативные системы опрошенных, характерные для каждого обучающегося, установлено их влияние на качество освоения навыков.

Результаты. Исходные знания, полученные при традиционных подходах к обучению, отмечены на должном уровне в 88 наблюдениях $-57,89 \%$, среди которых 81 респондент указал на отсутствие уверенности в практических умениях. В 64 случаях $(42,11 \%)$ указано на необходимость дополнительных занятий. Ритм компрессий грудной клетки механистически, путем повторных тренировок на манекенах запомнили 73 студента (48,03\%), по звуковым ассоциациям, основанным на запоминании музыкальных произведений - 41 (26,97\%), после просмотра обучающих видеофильмов - $21(13,82 \%)$ и 17 студентов $(11,18 \%)$ указали на отсутствие возможности определить ритм.

С помощью методик «Определение ведущего источника восприятия» и «Диагностика домини- рующей перцептивной модальности» С. Ефремцева выделены и распределены в 4 группы ведущие репрезентативные модальности респондентов: «Визуал» $42(27,63 \%)$, «Дигитал» - 34 (22,37\%), «Кинестетик» - 31 (20,39\%), «Аудиал» - 27 человек $(17,76 \%)$, в 18 случаях $(11,84 \%)$ тип восприятия расценен как смешанная. Сформирована подборка из 148 аудиальных композиций 15 стилей с ритмом $100-$ 120 в 1 минуту, соответствующая музыкальным предпочтениям респондентов. После обучения навыкам оказания экстренной медицинской помощи с учетом доминирующих репрезентативных систем обучающихся, через 12 месяцев, 138 анкетируемых $(90,8 \%)$ продемонстрировали высокие показатели практического владения навыками.

Заключение. Использование ведущих репрезентативных систем восприятия информации повышает эффективность обучения навыку базовой СЛР.

\section{ВНЕДРЕНИЕ ИНСТРУМЕНТОВ БЕРЕЖЛИВЫХ ТЕХНОЛОГИЙ ПРИ ОРГАНИЗАЦИИ МОБИЛЬНЫХ ЦЕНТРОВ ВАКЦИНОПРОФИЛАКТИКИ}

Лисовский О.В., Гостимский А.В., Карпатский И.В., Лисииа И.А., Лисовская Е.О.

ФГБОУ ВО СПбГПМУ Минздрава России, СанктПетербург

Введение. Напряженная эпидемиологическая ситуация и проведение вакцинопрофилактики против новой коронавирусной инфекции, вызванной SARS-COV2, определяет необходимость применения инструментов бережливых технологий, позволяющих обеспечить удовлетворенность населения от получаемой медицинской помощи.

Цель исследования - оценить возможности применения инструментов lean-технологий при организации мобильных центров вакцинопрофилактики.

Материалы и методы. Проведен анализ внедрения инструментов бережливого производства в кабинетах вакцинопрофилактики 12 детских амбулаторно-поликлинических отделений Санкт-Петербурга и Ленинградской области, выполнен хронометраж и картирование медицинских процессов в центрах вакцинопрофилактики взрослого населения против новой коронавирусной инфекции.

Результаты. Внедрение инструментов бережливого производства в медицинские организации, оказывающие первичную медико-санитарную помощь детскому населению, привело к снижению очередей, исключению пересечения потоков здоровых и больных людей. Данный опыт применения инструментов «5С», «картирование», «хронометраж», «диаграмма «спагетти», предложен при организации пунктов вакцинопрофилактики в условиях напряженной эпидемиологической ситуации. При помощи кар- 
тирования с построением карт текущего и целевого состояний 2 уровня определены основные проблемы в организации центров вакцинопрофилактики взрослого населения: пересечение потоков, в том числе возврат по потоку, очереди, длительное ожидание. Так, при отсутствии планирования и внедрения инструментов бережливого производства время ожи-

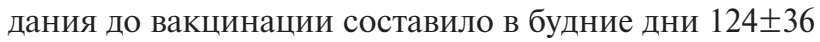
минут, в выходные - $132 \pm 42$ минуты. Введение электронных систем и записи через колл-центр позво-

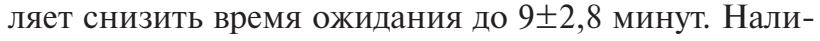
чие доступной навигации и информации о времени ожидания позволило сократить контакт пациентов и разделить потоки. Соблюдение порядка на рабочем месте в кабинете вакцинопрофилактики (с помощью методики «5С») и рациональное расположение оборудования позволили снизить время пребывания пациента в кабинете при выполнении манипуляции

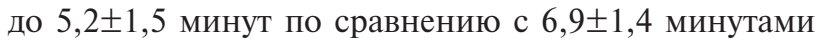
в начале исследования.

Заключение. Внедрение инструментов бережливого производства при организации мобильных пунктов вакцинопрофилактики позволяет сократить временные затраты на ожидание и выполнение вакцинации. Выделение зон комфортного пребывания после вакцинации требует наличия наглядной навигации в целях исключения смешения потоков.

\section{ВНЕДРЕНИЕ КЛИНИЧЕСКИХ СЦЕНАРИЕВ ДЛЯ ОБУЧЕНИЯ ДИАГНОСТИКИ И ЛЕЧЕНИЯ НАПРЯЖЕННОГО ПНЕВМОТОРАКСА У ДЕТЕЙ}

Лисовский О.В., Гостимский А.В., Карпатский И.В., Гавщук М.В., Лисииа И.А., Лисовская Е.О. ФГБОУ ВО СПбГПМУ Минздрава России, СанктПетербург

Введение. Формирование профессиональных навыков диагностики и оказания экстренной медицинской помощи является необходимым условием качественной подготовки врача-специалиста. Учитывая этические особенности профилактики ятрогенных осложнений и необходимость психологической адаптации обучающегося к профессиональной деятельности, освоение навыков ургентной хирургии осуществляется в симулированных условиях с использованием высоко реалистичных манекенов.

Цель исследования - разработка эффективной модели обучения диагностике и оказанию экстренной медицинской помощи при развитии напряженного пневмоторакса у детей.

Материалы и методы. На кафедре общей медицинской практики Санкт-Петербургского государственного педиатрического медицинского университета в соответствии с методикой CBL (Case-Based Learning - метод конкретных ситуаций) разработан клинический сценарий развития спонтанного напря- женного пневмоторакса у ребенка 8 лет. В ходе проведения мастер-классов и тренингов обучающихся в 2019 - 2021 г. по методике проведено 39 сценариев, обучено 226 студентов старших курсов и клинических ординаторов.

Результаты. Обучающимся определялись роли медицинских работников, родителей и наблюдателей. Задачами медработников (врач-хирург, перевязочная медсестра) являлись сбор жалоб и анамнеза, осмотр ребенка по системе ABCDE, своевременное установление диагноза и оказание медицинской помощи (пункция и дренирование плевральной полости), терапия возникающих осложнений (остановка кровообращения при смещении средостения), а также работа с симулированным пациентом. Родители обеспечивали контакт с врачом-хирургом при сборе анамнеза и осмотре, демонстрировали паническое настроение с необходимостью отработки коммуникативных навыков. Наблюдатели заполняли разработанные чек-листы для оценки правильности выполнения диагностических и лечебных манипуляций, оценивали работу членов команды. Ребенка имитировал манекен Sim-Junior, оснащенный технологиями обратной связи и дистанционного управления. Проводимые клинические сценарии позволили закрепить знания и отработать практические навыки работы в команде.

Заключение. Внедрение модели обучения на основе методики CBL способствует эффективному усвоению материала, формированию практических компетенций без риска ятрогенных осложнений для пациента. Использование клинических сценариев формирует универсальную модель оказания экстренной медицинской помощи при развитии жизнеугрожающих состояний, способствует закреплению теоретических и практических навыков.

\section{РЕГИОНАЛЬНЫЕ ОСОБЕННОСТИ ЗАБОЛЕВАЕМОСТИ И СМЕРТНОСТИ ОТ ЗЛОКАЧЕСТВЕННЫХ НОВООБРАЗОВАНИЙ У ДЕТЕЙ}

Павловская О.Г., ГладкихО.А.

ФГБОУ ВО «Оренбургский государственный

медицинский университет» Минздрава России, Оренбург

Введение. Статистические и эпидемиологические данные о заболеваемости различных групп населения злокачественными новообразованиями, а также смертности от них, являются основной базой для разработки и оценки результатов доступности и качества специализированной медицинской помощи.

Цель исследования. Установить региональные особенности заболеваемости и смертности детей при злокачественных новообразованиях в Оренбургской области. 
Материалы и методы. Использованы официальные данные Центра информационных технологий и эпидемиологических исследований в области онкологии в составе МНИОИ им. П.А. Герцена. Применены статистический и аналитический методы исследования.

Результаты. На 1,01,2020 г. под диспансерным наблюдением в онкологических учреждениях Оренбургской области состояло 63 ребенка в возрасте 0-17 лет.

Показатель заболеваемости злокачественными новообразованиями составил 14,51 на 100000 детского населения. Стандартизованный показатель у мальчиков достиг 17,1, у девочек - 11,75. Заболеваемость злокачественными новообразованиями лимфатической и кроветворной ткани составила 6,79 на 100000 детского населения, при этом у мальчиков $-10,19$, у девочек $-3,17$.

9 детей в возрасте 0-17 лет в 2019 г. умерли в регионе от злокачественных новообразований. Показатель смертности составил 2,31 на 100000 детского населения, мальчиков - 1,96, у девочек - 2,68 соответственно. Смертность от злокачественных новообразований лимфатической и кроветворной тканей в возрасте 0-17 лет составила 0,81 на 100000 детского населения, у мальчиков - 1,05, у девочек - 0,56. Удельный вес данной патологии как причины смертности составил $35 \%$.

При сравнении со среднероссийскими данными в регионе показатель заболеваемости злокачественными новообразованиями у детей 0-17 лет выше на $16,7 \%$, а смертности ниже на $22,1 \%$. Установлено, что показатель заболеваемости злокачественными новообразованиями кроветворной и лимфатической ткани ниже в области выше на 2,8\%, а показатель смертности ниже на $1,1 \%$.

Заключение. Таким образом, в регионе на фоне высоких показателей заболеваемости злокачественными новообразованиями отмечаются благоприятные тенденции в виде снижения смертности, что говорит о доступности и качестве медицинской помощи детям.

\section{РЕГИОНАЛЬНЫЕ ОСОБЕННОСТИ ПЕРВИЧНОЙ ДЕТСКОЙ ИНВАЛИДНОСТИ}

Павловская О.Г., Гладких О.А.

ФГБОУ ВО «Оренбургский государственный

медицинский университет» Минздрава России,

Оренбург

Вdедение. Первичная инвалидность детского населения является показателем важным показателем здоровья детского населения.

Цель исследования. Установить региональные особенности первичной детской инвалидности в Оренбургской области.

Материалы и методы. Использованы официальные статистические данные ФГБУ ФБ МСЭ России.
Применены статистический и аналитический методы исследования.

Результаты. Число детей, впервые признанных инвалидами в регионе на 1 января 2020 года составило 1171 человек. Уровень первичной инвалидности достиг 26,8 на 10 тысяч детского населения. В гендерной структуре преобладали мальчики $(59,5 \%)$. В возрастной структуре преобладала группа 8-14 лет $(37,8$ \%). Самой малочисленной явилась группа 15-17 лет $(2,4 \%)$.

Уровень первичной инвалидности у мальчиков составил 26,6, у девочек - 21,9 на 10 тыс. соответствующего населения. Самый высокий показатель установлен у детей в возрасте до 3 дет $(37,3)$. В других возрастных группах уровень ниже: в возрасте 4-7 лет - 28,8; в 8-14 лет - 27,0; и в 15-17 лет - 10,4 на 10 тыс. соответствующего населения.

В структуре первичной детской инвалидности по классам болезней первое место заняла инвалидность вследствие психических расстройств (40,3\%). Второе - вследствие врожденных аномалий $(15,7 \%)$, третье - болезни нервной системы $(12,3 \%)$, четвертое - болезни эндокринной системы $(8,9 \%)$, пятое вследствие новообразований $(1,4 \%)$. В указанные пять классов болезней вошли более $82 \%$ впервые признанных детей-инвалидов.

Наиболее высокий уровень первичной детской инвалидности оказался в трех классах болезней. При психических расстройствах показатель достиг 10,8 на 10 тыс. соответствующего населения, при врожденных аномалиях - 4,2, при болезнях нервной системы 3,3 соответственно.

При сравнении с российскими данными в регионе отмечается повышение уровня первичной детской инвалидности на 5,9\%. Зарегистрирован высокий уровень психических расстройств и расстройств поведения (показатель выше на 54\% . При этом в данном классе преобладает умственная отсталость, которая составляет $62 \%$ и преобладает у мальчиков.

Заключение. Таким образом, выявление региональных особенностей первичной детской инвалидности позволяет проводить профилактику данной патологии в популяции.

\section{РЕГИОНАЛЬНЫЕ ОСОБЕННОСТИ ПОВТОРНОЙ ДЕТСКОЙ ИНВАЛИДНОСТИ}

Павловская О.Г., Гладких О.А.

ФГБОУ ВО «Оренбургский государственный медицинский университет» Минздрава России, Оренбург

Введение. Повторная инвалидность детского населения значительно больше первичной детской инвалидности.

Цель исследования. Установить региональные особенности повторной детской инвалидности в Оренбургской области. 
Материалы и методы. Использованы официальные статистические данные ФГБУ ФБ МСЭ России. Применены статистический и аналитический методы исследования.

Результаты. Число детей, повторно признанных инвалидами в регионе на 1 января 2020 года составило 2650 человек. Уровень повторной инвалидности достиг 60,7 на 10 тысяч детского населения. В гендерной структуре преобладали мальчики и составляли $61,7 \%$. В возрастной структуре преобладала возрастная группа 8-14 лет (51,0\%). С увеличением возраста число инвалидов уменьшалось. Самой малочисленной явилась группа 15-17 лет (8,3\%).

Уровень повторной инвалидности у мальчиков составил 72,8 , у девочек $-47,9$ на 10 тыс. соответствующего населения. Самый высокий показатель установлен у детей в возрасте 4-7 лет $-85,5$ на 10 тыс. соответствующего населения. В других возрастных группах уровень ниже: в возрасте до 3 лет - 32,8; 8-14 лет - 82,2; 15-17 лет - 35,9 соответственно.

В структуре повторной детской инвалидности по классам болезней первое место заняла инвалидность вследствие психических расстройств (50\%). Второе - вследствие врожденных аномалий $(12,5 \%)$, третье - болезни нервной системы $(11,6 \%)$, четвертое - болезни эндокринной системы $(4,9 \%)$, пятое вследствие болезней глаза $(7,4 \%)$.

Наиболее высокий уровень повторной детской инвалидности оказался в трех классах болезней. При психических расстройствах показатель достиг 30,3 на 10 тыс. соответствующего населения, при врожденных аномалиях $-7,9$, при болезнях нервной системы 7,0.

При сравнении с российскими данными в регионе отмечается аналогичный показатель уровня повторной детской инвалидности. При этом зарегистрирован высокий уровень психических расстройств и расстройств поведения (показатель выше на 68,3\%). В данном классе преобладала умственная отсталость, которая составила $65,7 \%$ и чаще встречалась у мальчиков.

Заключение. Таким образом, выявление региональных особенностей повторной детской инвалидности позволяет внести коррекцию в третичную профилактику данной патологии в популяции и в организацию медицинской помощи детям-инвалидам.

\section{ДЕМОГРАФИЧЕСКИЕ ОСОБЕННОСТИ СЕВЕРНОГО ГОРОДА И КАДРОВОЕ ОБЕСПЕЧЕНИЕ СКОРОЙ МЕДИЦИНСКОЙ ПОМОЩИ ДЕТЯМ}

Раджабова И.К., Мещеряков В.В.

Сургутский государственный университет, Сургут

Введение. Скорая медицинская помощь (СМП) в РФ - социально значимая служба и один из самых массовых видов медицинской помощи. Отсутствие нормативных документов по планированию кадрового обеспечения СМП детскому населению определяет необходимость разработки таковых для повышения качества ее оказания. Особо это актуально для северных городов с выраженной демографической динамикой детского населения.

Цель исследования - научное обоснование необходимости планирования кадрового обеспечения СМП детскому населению с учетом демографических особенностей северного города.

Материалы и методы. Анализированы демографические показатели детского населения г.Сургут с 2010 по 2019 г.г. и показатели деятельности городской станции СМП. Результаты. В условиях высокой рождаемости и положительного миграционного прироста численность населения г.Сургут за 10 лет увеличилась на 23,3\% , детей 0-14 лет - на 53,3\%. С этим связан и более значительный рост обращаемости за СМП детского населения, чем взрослого. Удельный вес детей в структуре населения за указанный период вырос с 21,0\% до 26,0\%. Демографической особенностью северного города является и сезонная зависимость численности детского населения, что заключается в уменьшения количества детей в городе в летние месяцы на $20,0 \%$ и более. Рост круглосуточного числа бригад СМП произошел без учета демографии детского населения - за счет общеврачебных и фельдшерских бригад при сохранении педиатрических бригад количеством 2. Таким образом, увеличился удельный вес вызовов к детям, обслуживаемых фельдшерами и врачами общей практики, с 77,0\% до 89,0\%, выросло среднее время ожидания бригады СМП к детям. Анализ качества оказания СМП детям показал его более низкий уровень при вызове фельдшерской и общеврачебной бригады по следующим показателям: совпадение/расхождение диагноза СМП и при поступлении в стационар, удельный вес повторных вызовов, необоснованных транспортировок в стационар и не соответствующих актуальным клиническим рекомендациям случаев оказания СМП.

Заключение. Планирование кадрового обеспечения СМП детям должно учитывать демографические особенности северного города: ежегодный рост детского населения и сезонные колебания его численности определяют необходимость ежегодной коррекции потребности в педиатрических бригадах, в том числе - с учетом сезона года. 
ФАРМАКОЭКОНОМИКА ДИАГНОСТИКИ ЖЕЛЕЗОДЕФИЦИТНОЙ АНЕМИИ У ДЕТЕЙ РАННЕГО ВОЗРАСТА СТАВРОПОЛЬСКОГО КРАЯ

Самкина О.Н., Водовозова Э.В., Леденева Л.Н.,

Пустабаева М.С.

ФГБОУ ВО «Ставропольский государственный

медицинский университет» МЗ РФ, Ставрополь

Фармакоэкономика позволяет провести экономическую оценку эффективности использования ресурсов здравоохранения.

Цель исследования: оценить разницу в стоимости диагностики при замене рутинных исследований при железодефицитной анемии (ЖДА) на скрининговое определение микроэлементов (железа, цинка и меди) в течение года наблюдения.

Материалы и методы: проведен анализ затрат на диагностику ЖДА по стандартам и при скрининговом определении микроэлементов (железа, цинка и меди) в течение года наблюдения. Расчет проводился по стоимости на 1 клинический случай (прямые медицинские затраты без учета неосязаемых затрат).

Результаты: При использовании данной схемы сократились расходы на этапе диспансерного наблюдения, в зависимости от степени тяжести анемии в среднем на 11,0\%. Наибольший экономический эффект выявлен у пациентов с ЖДА средней степени тяжести $(18,8 \%)$.

Выводы: Использование скринингового определения микроэлементов (железа, цинка и меди) при диагностики ЖДА у детей раннего возраста сокращает затраты в среднем на 11,0\% и способствует улучшению эмоционального фона, так как любые инвазивные манипуляции причиняют боль и психологический дискомфорт больному ребенку.

\section{ОСОБЕННОСТИ ЗДОРОВЬЯ ШКОЛЬНИКОВ НА ЭТАПЕ ПЕРЕХОДА К ПРЕДМЕТНОМУ ОБУЧЕНИЮ}

Самороднова Е.А. ${ }^{1}$, Киселева И.Н. ${ }^{2}$, Киселев Р.П. ${ }^{1}$

${ }^{1}$ ФГБОУ ВО Казанский ГМУ Минздрава России, Казань

${ }^{2}$ МБОУ «Гимназия №4 им. А.С.Пушкина», Йошкар-Ола

Введение. Одним из сложных периодов для школьников является переход от начальной школы к предметному обучению в среднем звене. Адаптация к новым условиям может протекать в течение нескольких месяцев. Эмоциональная напряженность оказывает негативное влияние на поведение и успеваемость ребенка. Хроническое перенапряжение становится причиной снижения общей реактивности организма и частых интеркуррентных заболеваний, а в дальнейшем и формирования хронических заболеваний.

Цель исследования - проанализировать особенности течения адаптации детей во взаимосвязи с состоянием их здоровья на этапе перехода в среднее звено школы.

Материалы и методы. В проведено анкетирование 115 родителей пятиклассников гимназии № 4 г. Йошкар-Олы; проанализированы сведения о заболеваемости детей по данным школьных медицинских карт.

Результаты. У $100 \%$ детей в течение первого учебного месяца наблюдались признаки стресса, однако признаки дезадаптации демонстрировали 55 пятиклассников (48\%). Это может стать основой формирования «школьных» болезней: нарушении осанки, миопии, патологии пищеварительного тракта и др.

Анализ медицинских карт показал рост заболеваемости в I полугодии, т.е. в адаптационный период. Чаще всего пятиклассники жаловались на боли в животе, тошноту, ухудшение зрения, усталость, расстройство сна. Заболеваемость респираторными заболеваниями возросла в 1,8 раза по сравнению с аналогичным периодом в четвертом классе. Увеличиваются заболевания пищеварительного тракта: с $3 \%$ в четвертом классе до $10,4 \%$ у учащихся в пятом классе. Ожирение возросло с $4 \%$ до $6,4 \%$ от общего числа учащихся; снижение остроты зрения - с $26 \%$ до $31,2 \%$ учащихся. С $1,6 \%$ до 2,4\%. повысилось число детей, страдающих аллергодерматозом (атопическим дерматитом). В то же время снизились частота обострений бронхиальной астмы с 4\% до 1,6\%.

Заключение. Переход к предметному образованию является критическим периодом в жизни ребенка, оказывающим существенное влияние на состояние его здоровья. Это требует усиления профилактических мероприятий со стороны педиатров и педагогов для своевременного выявления и коррекции признаков дезадаптации.

\section{РЕГИОНАЛЬНАЯ ОРГАНИЗАЦИОННО- ФУНКЦИОНАЛЬНАЯ МОДЕЛЬ ОПТИМИЗАЦИИ ЗДОРОВЬЯ ШКОЛЬНИКОВ}

Филькина О.М., Воробьева Е.А., Малышкина А.И. ФГБУ «Ив НИИ М и Д им. В.Н. Городкова» Минздрава России, Иваново

Школьный период является важным в формирования здоровья детей и создает необходимость поиска новых межведомственных организационных решений оптимизации их здоровья в образовательных организациях.

Цель исследования - создать региональную организационно-функциональную модель оптимизации здоровья школьников на межведомственном уровне.

Материалы и методы. В исследование включены все школьники образовательных организаций Ивановской области. Методы: аналитический, экспертный, моделирования, организационного эксперимента.

Результаты. Организационно-функциональная модель оптимизации здоровья школьников основана 
на межведомственном подходе с интеграцией медиков и педагогов; организации Координационного совета; методической поддержке, создании единого информационного поля, базы данных методических и презентационных материалов по организации медико-психолого-педагогической помощи в образовательных организациях, формированию здорового образа жизни школьников; образовании регионального Центра здоровья школьников с отделением дистанционного управления здоровьем обучающихся с использованием защищенного онлайн-доступа, обеспечивающего единые подходы в организации оздоровления, создании единой профилактической среды. Сформирована межведомственная система спортивно-оздоровительных мероприятий для школьников.

В каждой образовательной организации созданы «школьные команды», включающие педагогов, психологов, медицинских работников; оздоровительная среда, содержанием которой являются условия, отвечающие санитарно-гигиеническим требованиям; лицензированный медицинский кабинет в школе; автоматизированное рабочее место медицинских работников, психологов; кабинет здоровья школьников; оздоровительная инфраструктура.

В школах сформирована система оздоровительных мероприятий с использованием современных дистанционных технологий: проведение физкультминуток, уроков здорового образа жизни и др. В каждой школе созданы волонтерские отряды, осуществляется их подготовка по вопросам формирования здорового образа жизни. В повышении компетентности учащихся по вопросам формирования здоровья принимают участие волонтеры-медики из Ивановского НИИ материнства и детства, медицинской академии. Используются как дистанционные, так и очные формы информирования.

Заключение. Улучшились показатели здоровья, повысилась удовлетворенность родителей качеством медико-психолого-педагогического сопровождения, повысилась компетентность и мотивация обучающихся, родителей, педагогов в вопросах управления здоровьем детей.

\section{ВЫЯВЛЕНИЕ И АНАЛИЗ ЖАЛОБ У ШКОЛЬНИКОВ 15-17 ЛЕТ ПО РЕЗУЛЬТАТАМ АНКЕТНОГО ТЕСТА ПРИ ПОМОЩИ АВТОМАТИЗИРОВАННОЙ ПРОГРАММЫ \\ Филькина О.М., Долотова Н.В., Воробьева Е.А., Кочерова О.Ю. \\ ФГБУ «Ив НИИ М и Д им. В.Н.Городкова» Минздрава \\ России, Иваново}

Актуальность. Сохранение и укрепление здоровья школьников является одной из приоритетных задач здравоохранения в Российской Федерации. В последние годы отмечается снижение численности детей подросткового возраста, при этом увеличивается их заболеваемость. Образ жизни российских детей в настоящее время сильно изменился, уменьшился объем двигательной нагрузки, увеличилось время использования гаджетов. Все это негативно сказывается на состоянии здоровья подростков и требует поиска путей ранней диагностики отклонений с целью своевременного выявления и лечения патологии.

Цель. Провести анализ частоты выявления жалоб у школьников 15-17 лет на примере двух общеобразовательных школ г.Иваново для выявления потребности в консультациях врачей-специалистов с использованием анкетного теста автоматизированной программы.

Материалы и методы. Проведено обследование 114 школьников 15-17 лет, обучающихся в общеобразовательных школах города Иваново, при помощи анкетного теста программы для ЭВМ «Самооценка состояния здоровья подростков 15-17 лет». Программа разработана сотрудниками отдела охраны здоровья детей ФГБУ «Ив НИИ М и Д им. В.Н. Городкова» Минздрава России, осуществляет автоматизированный анализ данных о жалобах и самооценке состояния здоровья подростков 15-17 лет.

Результаты. По результатам обследования с помощью анкетного теста выявлено, что лишь у 6,1\% детей нет жалоб. У 93,9\% есть жалобы на нарушения здоровья. При этом среднее число жалоб, приходящееся на одного ребенка, составило 13,8 . У каждого ребенка в среднем были жалобы по 5 системам. Чаще всего регистрировались жалобы со стороны нервной системы $(88,8 \%)$, психического здоровья $(76,6 \%)$, костно-мышечной системы $(65,4 \%)$, органа зрения $(60,7 \%)$. Со стороны органов дыхания жалобы были у 58,9\% детей, кожи и подкожной клетчатки у $57 \%$ детей, органов пищеварения у 53,3\%, органов кровообращения у 47,7\%, органов мочевыделительной системы у 41,1\% подростков 15-17 лет. По результатам анкетного теста 95,6\% детей нуждаются в консультации врача-педиатра, 79,8\% - невролога, $70,2 \%$ - психолога, $57,9 \%$ - офтальмолога.

Заключение. Автоматизированная оценка жалоб подростков 15-17 лет показала, что в среднем на одного ребенка приходится 13,8 жалоб по 5 системам. Большинство подростков по результатам анкетного теста нуждаются в консультации педиатра, невролога, психолога, офтальмолога. Раннее выявление жалоб при самооценке подростками имеет большое значение для своевременного выявления и коррекции имеющихся нарушений. 


\section{ИЗМЕНЕНИЕ ПАРАДИГМЫ ЗНАНИЙ ВРАЧЕЙ ПЕДИАТРОВ О ВИТАМИНЕ D \\ Ходиенко Е.В., Гири Я.В. \\ БУ ВО ХМАО-Югры «Сургутский государственный \\ университет», Сургут}

Актуальность. Заболевания органов лимфоглоточного кольца традиционно лидируют по распространенности среди ЛОР-патологии в детском возрасте. Острый аденоидит является проявлением естественной реакции органа регионарного иммунитета на антигенную стимуляцию. Хроническое воспаление и гипертрофия глоточной миндалины связаны с рядом факторов, среди которых снижение неспецифического иммунитета на фоне нарушения обеспеченности организма микронутриентами. Восполнение недостаточности витамина D имеет важное значение для активации противовирусного интерферон-зависимого иммунитета, для снижения хронического воспаления.

Цель. Провести анализ информированности врачей-педиатров, оказывающих первичную медицинскую помощь детям с острой и хронической патологией носоглотки в вопросах адекватного обеспечения витамином D.

Материалы и методы. Проанкетировано 227 врачей первичного звена. Анкета содержала 20 вопросов, позволяющих оценить уровень знаний врача по вопросам критериев дефицита витамина D, методов профилактики и терапии, профилактических / лечебных доз, тактики их назначения, источников информации. Анкетирование проведено дважды: в 2018 и 2021 гг.

Результаты. На основании анкетирования врачей первичного звена, можно сделать вывод о положительной динамике знаний врачей за 3-х летний период. В 2018 г. 91\% врачей получали информацию от представителей фармакологических компаний (56\%), на конференциях (32\%), другие источники (12\%), 9\% не ориентировались в заданных вопросах. В 2021 г. уже 87\% врачей руководствовались в своей работе данными, представленными в «Национальной программе по обеспеченности витамином D детей и подростков в Российской Федерации. 56\% врачей получили дополнительные знания в онлайн вебинарах и конференциях за 2020 г. Представителей фармацевтических компаний, как источник знаний указали только $11 \%$ врачей. Правильные ответы о дефиците (<20 нг/мл) и недостатке (20-30 мг/мл) 25(OH) D в сыворотке крови в 2018 г. дали $34 \%$ респондентов, в 2021 г. - 87\%. Наибольшую сложность представляли вопросы о дозах и схемах назначения препаратов. Только $27 \%$ врачей в 2018 г. и $53 \%$ в 2021 г. рекомендовали детям постоянный профилактический прием витамина D. Соответственно, 63\% и $47 \%$ врачей, рекомендовали сезонный прием витамина D, прием на фоне заболеваний, при наличие хрониче- ских заболеваний. На вопрос о применяемых профилактических дозах витамина D, в 2018 г. 43\% указали $1000 \mathrm{ME}, 47 \%$ опрошенных обозначили дозы значительно ниже/выше рекомендуемых. В 2021 году 74\% врачей рекомендовали профилактическую дозу витамина D 1000-1500 ME, 26\% респондентов не дали правильный ответ на поставленный вопрос.

Требуется продолжение информационной работы для врачей педиатров для повышения качества знаний.

\section{СТРАТЕГИЧЕСКИЙ АНАЛИЗ МАРКЕТИНГОВОЙ ДЕЯТЕЛЬНОСТИ ДЕТСКОЙ САНАТОРНО- КУРОРТНОЙ ОТРАСЛИ}

Шибзухова Л.А. ${ }^{1}$, Шибзухов Т.А. ${ }^{2}$, Борукаева Л.А. ${ }^{3}$, Абазова 3.Х. ${ }^{1}$, Борукаева И.Х. ${ }^{1}$

${ }^{1}$ Кабардино-Балкарский государственный университет им. Х.М. Бербекова, Нальчик 2Государственный университет управления, Москва

${ }^{3}$ Московский государственный

юридический университет имени О.Е. Кутафина, Москва

Введение. В связи с переходом отечественного здравоохранения от системы, ориентированной преимущественно на лечение заболеваний, к системе профилактики заболеваний, совершенствование системы медицинской реабилитации, включающее санаторно-курортное лечение (СКЛ), является одним из приоритетных направлений развития.

Цель исследования. Анализ маркетинговой стратегии детского санатория «Радуга».

Материалы и методы. Объектом исследования явилось детское лечебно-профилактическое учреждение здравоохранения - санаторий «Радуга». Исследование включало опрос (анкетирование), наблюдение, проектирование, статистический анализ эффективности методов маркетинга, синтез и обобщение.

Результаты. Проведенные исследования показали, что служба менеджмента и маркетинга санатория «Радуга» идет по пути максимальной адаптации СКЛ к требованиям рынка, повышения эффективности функционирования санатория. Осуществляется воздействие на рынок и потребительский спрос с помощью всех доступных средств для формирования необходимых для санатория направлений. Активно развивается творческий подход к решению технических и хозяйственных проблем, по совершенствованию и повышению качества услуг по СКЛ. Благодаря работе маркетинговой службы к сотрудничеству с санаторием «Радуга» привлечены солидные туристические и страховые компании, заключены договоры с турфирмами в различных регионах России. Активное участие в региональных и международных выставках, использование возможностей рекламы, социальная деятельность, внедрение электронной системы заявок и автоматизация бронирования мест, 
работа с корпоративными клиентами, эффективная политика ценообразования - все это позволило санаторию «Радуга» приблизиться к клиенту, что, в свою очередь, открывает широкие возможности для совершенствования маркетинга и менеджмента. Благодаря увеличению количества заключенных договоров на реализацию путевок с различными регионами, рост прибыли идет высокими темпами. За счет увеличения коечного фонда по санаторию за период с 2016 г. по 2020 г, увеличилось количество отдыхающих на $178,9 \%$, а за счет эффективного использования коечного фонда обеспечена круглогодичная $100 \%$ заполняемость здравницы.

Заключение. Маркетинговая служба санатория «Радуга» на современном этапе успешно выполняет продвижение санаторно-оздоровительных услуг на отечественном и международном рынках.

\section{МЕДИКО-СОЦИАЛЬНЫЙ МОНИТОРИНГ И УДОВЛЕТВОРЕННОСТЬ КАЧЕСТВОМ МЕДИЦИНСКОЙ ПОМОЩИ (РЕГИОНАЛЬНЫЙ АСПЕКТ) \\ Шигаев H.H. \\ ГУЗ «Саратовская ОДКБ», Саратов}

Введение. Одной из основных задач системы здравоохранения является достижение социального эффекта, в частности обеспечение удовлетворенности потребителей медицинских услуг их качеством. Нами проводилось изучение удовлетворенности родственников госпитализированных детей медицинской помощью в ГУЗ «СОДКБ» и районных больницах Саратовской области..

Цель исследования - установить взаимосвязь между медико-социальными факторами и удовлетворенностью качеством медицинской помощи оказываемой детям с хроническим заболеванием в ситуации болезни в сельских районах региона.
Материалы и методы. Проводился медико-социальный мониторинг с 360 респондентами, в августесентябре 2020 года, с помощью модифицированной автором исследования анкеты, разработанной академиком РАН А.В. Решетниковым. Обработка данных медико-социального мониторинга осуществлялась с помощью открытого программного обеспечения JASP, версия 0,13,1. Данные были введены в программу Excel, а затем конвертированы в формат .ods. Применялся корреляционный и факторный анализы.

Результаты. Получены коэффициенты корреляции (r) с определенными уровнями значимости $(p)$ : 1) на уровне $p<0,05$ не обнаружены корреляционные связи между возрастом респондента и его удовлетворенностью качеством медицинской помощи, оказываемой детям в поликлинике по месту жительства, стационаре, на дому и в частных медицинских организациях; 2) существует слабая $(r=-0,235)$ отрицательная связь между удовлетворенностью качеством медицинской помощи, оказываемой детям в поликлинике по месту жительства и в стационаре $(p=0,013)$; 3) существует слабая $(r=0,217)$ положительная связь между удовлетворенностью качеством медицинской помощи в стационаре и на дому $(p=0,022) ; 4)$ существует слабая $(r=0,278)$ положительная корреляционная связь между удовлетворенностью качеством медицинской помощи на дому и в частных медицинских организациях.

Заключение. В целом показано, что удовлетворенность родственниками больных детей с хроническим заболеванием поликлиникой по месту жительства, стационаром и, в меньшей степени, медицинской помощью на дому взаимосвязаны с качеством оказываемой в них медицинской помощью. Частные и другие медицинские организации менее востребованы жителями районов Саратовской области по различным причинам. Потребность в них заслуживает отдельного изучения. 


\section{Раздел 2}

\section{АЛЛЕРГОЛОГИЯ И ИММУНОЛОГИЯ}


ПРИМЕНЕНИЕ АЛЛЕРГЕНСПЕЦИФИЧЕСКОЙ ИММУНОТЕРАПИИ У ДЕТЕЙ С АЛЛЕРГИЧЕСКИМИ ЗАБОЛЕВАНИЯМИ

Беляков В.А., Попова И.В., Токарев А.Н.,

Колмогориева С.В.

ФГБОУ ВО Кировский ГМУ Минздрава России, Киров

Введение. Одним из патогенетически обоснованным методом лечения аллергии у детей является аллергенспецифическая иммунотерапия (АСИТ). В настоящее время изучение эффективности его использования в разных формах доставки в организм является весьма актуальным.

Цель исследования - сравнить эффективность и безопасность двух методов проведения АСИТ у детей с аллергическими заболеваниями, сенсибилизированных к пыльце деревьев.

Материалы и методы. Под наблюдением находилось 54 больных в возрасте от 5 до 16 лет. В исследование включались больные, у которых на протяжении не менее 2 сезонов подряд регистрировались симптомы аллергического риноконъюнктивита и ринита, вызванные пыльцой деревьев. У всех детей выявлен высокий уровень сенсибилизации к пыльце деревьев. Больные 1 группы получали АСИТ подкожным способом водно-солевым раствором экстрактов аллергенов пыльцы деревьев семейства березовые (береза, лещина, ольха), а 2 - сублингвальным методом стандартизированным экстрактом аллергена пыльцы березы. Оценку эффективности группах проводили ежегодно по модифицированной схеме А.Д. Адо: 4 балла - отличный, 3 балла - хороший, 2 балла удовлетворительный, 1 балл - неудовлетворительный эффект].

Результаты. После проведения АСИТ уже в первый сезон цветения у больных выраженность назальных и конъюнктивальных симптомов значительно уменьшилась. В 1 группе пациентов коэффициент эффективности составил 76,6\%, во 2 группе - 77,3\%. Также установлено уменьшение потребности в лекарственных препаратах. Эффективность сублингвальной аллергенспецифической иммунотерапии после трех курсов составила 89,6\% в отношении симптомов поллиноза по сравнению с водно-солевым раствором экстрактов аллергенов пыльцы деревьев семейства березовые - 78,6\%. Нежелательные реакции в 1 группе в виде гиперемии, зуда, отека были отмечены в $23 \%$ случаев; во 2 группе местные реакции в виде зуда, отека подъязычной области, першение в горле зарегистрированы в 12\%. При анализе нежелательных явлений выявлено, что они проявлялись на высоких дозах подкожной АСИТ и при нарушении диеты в течение курса иммунотерапии.

Заключение. Таким образом, на основании проведенного исследования установлено, что наиболее оптимальный эффект при лечении детей с аллергическими заболеваниями достигается при сублингваль- ном способе введения стандартизированного экстракта аллергена пыльцы березы в течение не менее 3 курсов.

\section{ПАТОГЕНЕТИЧЕСКАЯ И ДИАГНОСТИЧЕСКАЯ ЗНАЧИМОСТЬ МОНИТОРИНГА КИШЕЧНОЙ ФРАКЦИИ БЕЛКОВ, СВЯЗЫВАЮЩИХ ЖИРНЫЕ КИСЛОТЫ, У ДЕТЕЙ С ГАСТРОИНТЕСТИНАЛЬНЫМИ ФОРМАМИ ПИЩЕВОЙ АЛЛЕРГИИ}

Берестова Ю.С., Павличенко М.П., Приходченко Н.Г.

Тихоокеанский государственный медицинский университет, Владивосток

Введение. В настоящее время остается актуальным вопрос мониторинга течения аллергических заболеваний у детей для определения тактики лечения и профилактики возможных осложнений заболевания. В последние годы внимание исследователей сосредоточены на определении неинвазивных биологических маркеров, количество которых будет объективно отражать тяжесть течения процесса. Одним из них является белок, связывающий жирные кислоты - I-FАВР. Высокая чувствительность (88\%) и специфичность (77\%) определения I-FABР в моче особенно перспективна для использования данного биомаркера в педиатрической практике.

Целью настоящего исследования явилось количественное определение белка I-FABP в моче у детей с гастроинтестинальными формами пищевой аллергии и выявление взаимосвязи с полиморфизмом генов I-FABP

Материал и методы. Было обследовано 56 детей (от 1 мес. до 3 лет), из которых 39 - дети с гастроинтестинальными формами пищевой аллергии (1 группа), 20 здоровых детей составили контрольную группу (2 группа). Определили содержание белка I-FABP в моче методом ИФА. Исследование полиморфизма генов FABP (G163A, Ala54Thr) проводили методом полимеразной цепной реакции.

Результаты. У всех пациентов из первой группы было выявлено повышение концентрации I-FABP в моче (в 4,2 раза, $p<0,05)$ по сравнению с контрольной группой. В динамике заболевания уровень I-FABP статистически значимо снизился $(0,164 \pm 0,031$ пг/мл в первые дни и 0,091 $\pm 0,013$ пг/мл на 7-10 сутки соответственно, $\mathrm{p}<0,05)$. Известно, что полиморфизм гена FABP G163A, (Ala54Thr) ассоциирован с гиперпродукцией белка I-FABP. Частота распределения гомозиготного $\mathrm{G} / \mathrm{G}$ в нашем исследовании составила $64,1 \%$, гетерозиготного G/A-25,6\% , гомозиготного A/A - 10,3\%; частота встречаемости аллелей $\mathrm{G}$ $75 \%$ случаев, аллель А - 25\%.

Заключение. Таким образом, проведенное нами исследование выявило повышение уровня I-FABP в моче у детей с гастроинтестинальными формами 
пищевой аллергии. В нашем исследовании не выявлена ассоциация патологического генотипа FABP 163AA (Ala54Thr) с гиперпродукцией I-FABP у детей с пищевой аллергией.

\section{КОМПЛЕКСНАЯ ДИАГНОСТИКА ВТОРИЧНОЙ ЛАКТАЗНОЙ НЕДОСТАТОЧНОСТИ У ДЕТЕЙ РАННЕГО ДЕТСКОГО ВОЗРАСТА С АЛЛЕРГИЕЙ К БЕЛКАМ КОРОВЬЕГО МОЛОКА, СТРАДАЮЩИХ АТОПИЧЕСКИМ ДЕРМАТИТОМ}

Болотская Л.А.

БУ ВО «Сургутский государственный университет ХМАО-Югры», Сургут

Введение. Комплексная диагностика лактазной недостаточности (ЛН) и пищевой аллергии у детей раннего возраста вызывает некоторые сложности из-за обилия диагностических процедур, их доступности, крайне сжата во времени и важна для назначения своевременного лечения.

Цель исследования - установление последовательности определения лабораторных маркеров ЛН и пищевой аллергии к белкам коровьего молока $(\mathrm{AБКМ)} \mathrm{у} \mathrm{детей} \mathrm{раннего} \mathrm{детского} \mathrm{возраста,} \mathrm{страдаю-}$ щих атопическим дерматитом (АтД).

Материалы и методы. Под наблюдением находилось 38 детей с АтД - 22 (59\%) девочки и 16 (41\%) мальчиков в возрасте: от 2 мес до 3 лет $(8,66 \pm 5,15$ мес). У $20(52,6 \%)$ детей отмечалось сочетание ЛН и АБКМ, у 15 детей (39,5\%) - АБКМ и у троих (7,9\%)- ЛН. У всех детей определяли концентрацию специфических иммуноглобулинов E (IgE) в сыворотке иммуноферментным методом (ImmunoCap 100 Phadia AB, Швеция) к белкам коровьего и козьего молока. Проводили ПЦР-диагностику для определения генетического типа ЛН (СТ полиморфизм гена). В дальнейшем проводилось определение водородного дыхательного теста (ВДТ) с лактозой, сахарной кривой с лактозой.

Результаты. У пациентов наблюдалось тяжелое течение АтД, выявлены высокие уровни специфических $\operatorname{IgE}$ к белкам коровьего молока $(p=0,0001)$ по сравнению с больными без непереносимостью пищевых белков. При определении генотипа, выявлено превалирование генотипа СТ и СС: у 15 детей (39\%) выявлен СТ генотип, генотип СС - у 8 (21\%), генотип ТТ - у 15 человек (39\%). Повышение уровня водорода в выдыхаемом воздухе после нагрузки лактозой было у 23 детей (60,5\%). Сахарная кривая с нагрузкой лактозой коррелировала с результатами водородного теста и наличием СТ/СС генотипа у всех больных.

Заключение. У детей с тяжелым течением АтД выявление сенсибилизации к белкам растительного и животного происхождения должно проводиться немедленно, при первичном амбулаторном обращении, равно как и определение генотипа ЛН. Для надежности установления ЛН необходимо проведение сахарной кривой с лактозной нагрузкой, но уже в стационарных условиях.

\section{ЗНАЧЕНИЕ БАКТЕРИАЛЬНОЙ ИНФЕКЦИИ В ПАТОГЕНЕЗЕ АТОПИЧЕСКОГО ДЕРМАТИТА У ДЕТЕЙ РАННЕГО ВОЗРАСТА}

Галанина А.В. ${ }^{1}$, Иллек Я.Ю. ${ }^{2}$, Рыбакова T.H. ${ }^{2}$,

Рассанова Е.A. ${ }^{2}$

ФГАОУ ВО РНИМУ им. Н.И. Пирогова Минздрава

России, Москва

ФГБОУ ВО Кировский ГМУ Минздрава России, Киров

Введение. При атопическом дерматите (АД) кожные покровы склонны к вторичной инфекции. Основным осложняющим фактором течения АД является наличие патогенных микроорганизмов на поверхности кожи пациентов. Наиболее частым возбудителем является стафилококк, способный продуцировать экзотоксины, действующие как суперантигены и проникающие через эпидермальный барьер, усугубляя течение воспалительного процесса.

Цель исследования. Изучить особенности микробного пейзажа, оценить уровень специфических антител к стафилококковому экзотоксину у детей раннего возраста с АД средней степени тяжести.

Материалы и методы. Обследованы 65 детей с АД средней степени тяжести в возрастной категории от 6 месяцев до 3 лет. У всех пациентов до начала лечения производили посев материала с пораженных участков кожного покрова для определения наличия стафилококка на желтково-солевом агаре. Уровень анти- $\alpha-$ стафилолизина в образцах крови выявляли с помощью реакции нейтрализации.

Результаты. Среди обследуемых пациентов с атопическим дерматитом $66 \%$ составляли мальчики, $34 \%$ девочки. У наблюдаемых детей в 69\% случаях на поверхности эпидермиса была обнаружена колонизация стафилококком. При исследовании микробиологических посевов с пораженной поверхности кожи в фазе обострения заболевания в $44 \%$ случаев верифицировался Staphylococcus (S.) aureus, в 27\% S. epidermidis, в $19 \%$ - S. saprophyticus, a в $10 \%-$ установлена колонизация ассоциацией S. aureus + S. saprophyticus. При изучении содержания анти- $\alpha-$ стафилолизина во время обострения заболевания, регистрировалось увеличение его в образцах крови $2,00 \pm 0,26 \mathrm{ME} /$ мл $(p<0,01)$, в фазе клинической ремиссии также количество анти- $\alpha$-стафилолизина превышало его уровень 1,73 $\pm 0,21 \mathrm{ME} /$ мл $(p<0,05)$ в сравнении с соматически здоровыми детьми

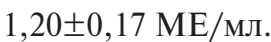

Заключение. Способность S. aureus вызывать заболевания человека зависит не только от производства на поверхности клеточной стенки возбудителя адге- 
зинов, но и выработки экзотоксинов. У детей раннего возраста с АД в период обострения отмпечается

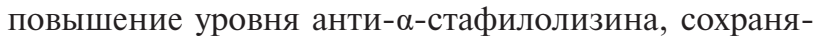
ющееся и в период клиническиой ремиссии.

\section{АССОЦИАЦИЯ УРОВНЯ ВИТАМИНА D СО СТЕПЕНЬЮ ТЯЖЕСТИ И} СЕНСИБИЛИЗАЦИЕЙ К АЛЛЕРГЕНАМ ПРИ АТОПИЧЕСКОМ ДЕРМАТИТЕ У ДЕТЕЙ 3-6 ЛЕТ

Кашинская Т.С., Шахова Н.В.

ФГБОУ ВО Алтайский государственный медицинский университет Минздрава России, Барнаул

Введение. Последние десятилетия активно изучается роль витамина D $(25(\mathrm{OH}) \mathrm{D})$ в развитии АтД. По опубликованным данным, имеется связь между уровнем витамина D в сыворотке крови и степенью тяжести АтД, а также имеется связь между 25(OH)D и уровнем специфических $\operatorname{IgE}(\mathrm{s} \operatorname{IgE})$. Исследования немногочисленные и противоречивы.

Цель исследования - изучить ассоциацию уровня $25(\mathrm{OH}) \mathrm{D}$ со степенью тяжести АтД и сенсибилизацией к ингаляционным и пищевым аллергенам у детей 3-6 лет.

Материалы и методы. Проведено одномоментное исследование с участием детей 3-6 лет с АтД ( $n=106)$ и здоровых сверстников $(n=40)$. Определяли уровень $25(\mathrm{OH}) \mathrm{D}$ в сыворотке крови хемилюминисцентным иммуноанализом на микрочастицах и уровень $\operatorname{sgE}$ к ингаляционным и пищевым аллергенам (D.pteronyssinus, D.farinae, эпителий кошки, коровье молоко, куриное яйцо) определяли методом иммунофлюоресценции на трехмерной твердой фазе. Уровень 25(ОН) $\mathrm{D}$ представлен медианой и 25-м и 75-м процентелем. Для оценки корреляции использовали коэффициент ранговой корреляции Спирмена.

Результаты. Обнаружено снижение уровня сывороточного 25(OH)D у детей с АтД по сравнению с аналогичным показателем у здоровых сверстников $26,5[19,0 ; 35,3]$ и $32,4[27,9 ; 37,5]$ нг/мл соответственно $(p=0,001)$. У детей со среднетяжелым и тяжелым АтД уровень 25(OH)D статистически значимо ниже уровня у пациентов с легким течением АтД (26,7 [22,1;35], 22,4 [18,3;30,5], 11,9 [8,7;15,5] нг/мл соответственно, $p=0,001)$. Уровень $25(\mathrm{OH}) \mathrm{D}$ в сыворотке крови у сенсибилизированных детей к ингаляционным и/ или пищевым аллергенам с АтД ниже по сравнению с детьми без сенсибилизации 22,1 [16,95; 31,1] и $29,3[23,6 ; 36,1]$ нг/мл соответственно $(p=0,019)$. Выявлена отрицательная связь уровня 25(OH)D со степенью тяжести АтД ( $r=-0,392, p=0,001)$ и уровнем $\operatorname{sIgE} D$. farinae $(r=-0,922, p=0,003)$.

Заключение. Выявлена отрицательная связь уровня $25(\mathrm{OH}) \mathrm{D}$ со степенью тяжести АтД и уровнем sIgE D. farinae.

\section{АССОЦИАЦИЯ УРОВНЯ СПЕЦИФИЧЕСКИХ IGE К АЛЛЕРГЕНАМ И ЭНТЕРОТОКСИНАМ ЗОЛОТИСТОГО СТАФИЛЛОКОКА СО СТЕПЕНЬЮ ТЯЖЕСТИ АТОПИЧЕСКОГО ДЕРМАТИТА У ДЕТЕЙ 3-6 ЛЕТ}

Кашинская Т.С., Шахова Н.В.

ФГБОУ ВО Алтайский государственный медицинский университет Минздрава России, Барнаул

Введение. В раннем возрасте у детей преобладает сенсибилизация к пищевым аллергенам, тогда как в более старшем - ингаляционные аллергены. Нарушение кожного барьера способствует увеличению колонизации золотистого стафилококка, что может приводить к более тяжелому течению АтД, а также влиять на уровень сенсибилизации.

Цель исследования - оценить спектр сенсибилизации к аллергенам и энтеротоксинам А (SEA) и В (SEB) St. aureus при АтД у детей 3-6 лет, а также оценить ассоциацию со степенью тяжести заболевания.

Материалы и методы. Работа выполнена в дизайне одномоментного исследования среди детей 3-6 лет $(n=106)$ с АтД. Определяли уровень спектра сенсибилизации с ингаляционными и пищевыми аллергенами (Dermatophagoides pteronyssinus, Dermatophagiodes farinae, эпителий кошки, коровье молоко, куриное яйцо, SEA и SEB St. aureus)

Результаты. Из 106 детей 57,0\% мальчиков и 43,0\% девочек. Средний возраст участников составил 4,4 $\pm 1,2$ года. Полисенсибилизация выявлена у 28,3\% детей. У детей 3-6 лет с АтД наиболее часто отмечалась сенсибилизация к эпителию кошки 34,9\%, к белкам коровьего молока - 22,6\%, к клещу D. pteronyssinus - 16,0\%. Сенсибилизация к SEA и SEB St.aureus выявлена у 7,5\% детей. При проведении корреляционного анализа выявлена слабая положительная ассоциация степени тяжести АтД с уровнем специфических $\operatorname{IgE}$ к клещам домашней пыли $(r=0,284$, $p=0,003)$. Обнаружена слабая положительная связь степени тяжести АтД с уровнем специфических IgE к энтеротоксинам А и В золотистого стафилококка $(r=0,293, p=0,037)$.

Заключение. У детей 3-6 лет с АтД среди ингаляционных аллергенов наиболее чаще регистрируется сенсибилизация к эпителию кошки, среди пищевых - к белкам коровьего молока. Обнаружена слабая положительная ассоциация степени тяжести АтД с уровнем специфических $\operatorname{IgE}$ к ингаляционным и пищевым аллергенам и слабая положительная связь с SEA и SEB St.aureus. 


\section{РОЛЬ КОМПЛАЕНТНОСТИ В ЛЕЧЕНИИ ДЕТЕЙ С АТОПИЧЕСКИМ ДЕРМАТИТОМ}

Крючкова А.В., Панина О.А., Семынина Н.М.

ФГБОУ ВО ВГМУ имени Н.Н. Бурденко Минздрава

России, Воронеж

Введение. Атопический дерматит (АД) относиться к заболеваниям детского возраста, который резко ухудшает качество жизни детей и их родителей, приводит к развитию депрессивных расстройств, которые, в свою очередь, отрицательно влияют на качество проводимой терапии.

Цель исследования. Изучение выраженности депрессивных тенденций у родителей детей, больных АД.

Материалы и методы. Был проведен анализ историй развития 87 детей, больных АД средней и тяжелой степени тяжести. Пациенты были взяты методом сплошной выборки. Диагноз был поставлен на основании клинических, лабораторных, функциональных методов исследования. Для изучения психологических особенностей родителей детей с АД, выявления депрессивных тенденций был использован тест Бека.

Результаты. В первые два месяца заболевания, практически у всех родителей детей, больных АД отсутствует депрессия 77(87,7\%). При ее длительности от 2 до 6 мес., число лиц с легкой депрессией остались прежними 6(7,1\%), но появились лица, имеющие депрессию средней тяжести 10(11,4\%). При длительности течения АД от 6 мес. до 1 года, число лиц, не имеющих депрессию, уменьшилось 67(76,8\%). Но впервые появились родители детей больных АД с тяжелой депрессией 7(7,6\%). При длительности заболевания более одного года, число лиц, не имеющих депрессию, так же несколько уменьшается 63(72,8\%), а при длительности более 3 лет несколько уменьшается число лиц с депрессией легкой степени 12(14,9\%), остальные показатели достоверно не отличаются от показателей с длительностью заболевания от 1 года до 3. Таким образом, наиболее существенные изменения происходят в период от 6 месяцев до 1 года. Их появление можно объяснить переходом заболевания в хроническую форму. Эти показатели важны, т.к. в рамках депрессивных расстройств наблюдается игнорирование назначений, контакт с медицинским персоналом затрудняется, дисциплина лечения при этом страдает.

Заключение. Комплаентность детей с АД и их семей является очень важной медицинской и социальной проблемой. Для повышения эффективности терапии, повышения уровня ответственности родителей при выполнении назначений врачей необходимо проводить коррекцию депрессивных расстройств. Для этого целесообразно в курс реабилитационных мероприятий включать консультацию психиатра или медицинского психолога для родителей детей, больных АД начиная с длительности заболевания 2 месяца.

\section{ХРОНИЧЕСКАЯ ИНДУЦИРУЕМАЯ КРАПИВНИЦА У ДЕТЕЙ: СОВРЕМЕННЫЕ ВОЗМОЖНОСТИ ЛЕЧЕНИЯ}

Ларькова И.А. ${ }^{1,2}$, Мухортых В.A ${ }^{1,3}$, Ревякина В.A. ${ }^{1,2}$

${ }^{1}$ ФГБУН «ФИЦ питания, биотехнологии и безопасности пищи», Москва

${ }^{2}$ ФГАУ «НМИЦ здоровья детей» Минздрава России, Москва ${ }^{3}$ ФББУ «ФНКЦ детей и подростков ФМБА России», Москва

Введение. В случае отсутствия эффекта от лечения детей с хронической индуцируемой крапивницей (ХиндК) неседативными $\mathrm{H}_{1}$-антигистаминнными препаратами в удвоенных дозах, протоколом предусмотрено назначение анти - IgE-терапии. В то же время данная терапия препаратом омализумаб одобрена у детей с ХиндК только при сочетании с хронической спонтанной крапивницей (ХCK), в противном случае, подобное назначение считается «off label». Вот почему в отечественной и мировой практике имеются ограниченные данные по эффективности омализумаба при ХиндК.

Цель исследования - оценить эффективность и безопасность омализумаба у детей с ХиндК.

Материалы и методы. В исследование вошли 7 детей с ХиндК в возрасте от 13 до 17 лет, при этом у 4 пациентов была холинергическая крапивница, у 3 - холодовая крапивница. Все дети прошли обследование для исключения аутоиммунных заболеваний, гепатита В и С, гельминтозов, пищевой и ингаляционной аллергии. Детям с холодовой аллергией назначался тест с кубиком льда, а детям с холинергической крапивницей - тест с физической нагрузкой на беговой дорожке. Определение уровня общего IgE проводилось методом иммуноферментного анализа. Всем пациентам назначался омализумаб в дозе 300 мг подкожно каждые 4 недели.

Результаты. Дети с холодовой крапивницей имели полный ответ уже после первой инъекции омализумаба, и 6 месяцев лечения оказалось достаточным для достижения и поддержания ремиссии заболевания. Пациенты с холинергической крапивницей нуждались в более продолжительном курсе лечения (3 пациента - 9 месяцев и 1 пациент - 12 месяцев), при этом важным было соблюдение режима назначения препарата - строго 4-х недельный интервал. В случае нарушения режима введения мы наблюдали возврат всех симптомов с последующим полным ответом при возобновлении терапии. Уровень общего IgE у детей до начала терапии был 280 [161; 321] МЕ/мл. Мы не отметили зависимости между исходным уровнем $\mathrm{IgE}$ и эффективностью терапии омализумабом. Побоч- 
ных явлений при назначении данной терапии у детей с ХиндК нами отмечено не было.

Заключение. Терапия препаратом омализумаб в дозе 300 мг каждые 4 недели эффективна и безопасна для детей с ХиндК. Длительность лечения должна определяться индивидуально для каждого конкретного пациента. Следует принять во внимание тот факт, что более длительная терапия может улучшить результат у детей с ХиндК.

\section{ПЕРВЫЙ ОТЕЧЕСТВЕННЫЙ ОПЫТ ПРИМЕНЕНИЯ ТАРГЕТНОЙ ТЕРАПИИ АТОПИЧЕСКОГО ДЕРМАТИТА У ДЕТЕЙ: ЭФФЕКТИВНОСТЬ И БЕЗОПАСНОСТЬ}

Ларькова И. $A^{1,2}$, Мухортых В.A ${ }^{1,3}$, Ревякина В.A. ${ }^{1,2}$

${ }^{1}$ ФГБУН «ФИЦ питания, биотехнологии и безопасности пищи», Москва

ФГАУ «НМИЦ здоровья детей» Минздрава России, Москва

ФГБУ «ФНКЦ детей и подростков ФМБА России», Москва

Введение. Атопический дерматит (АтД) принадлежит к числу широко распространенных воспалительных заболеваний кожи. Высокий объем как наружной, так и системной иммуносупрессивной терапии не всегда обеспечивает контроль над АтД. Поскольку такие цитокины воспаления 2 типа, как IL-4 и IL-13 считаются ключевыми в патогенезе АтД, то таргетная терапия моноклональным антителом, направленным против альфа-субстанции рецептора IL-4, рассматривается как перспективная при тяжелом течении АтД у детей.

Цель исследования - оценить эффективность и безопасность таргетной иммунобиологической терапии препаратом дупилумаб у детей с тяжелым АтД.

Материалы и методы. В исследование вошли 12 детей (5 мальчиков, 7 девочек) в возрасте от 10 до 17 лет с тяжелым течением АтД, 5 из которых имели предшествующий опыт безуспешной системной терапии циклоспорином. Диагноз АтД выставлялся клинически, тяжесть течения оценивалась по индексу SCORAD. Дупилумаб назначался в дозе 300 мг подкожно каждые 2 недели. Длительность наблюдения составила 1 год. Для оценки эффективности терапии использовали клинические параметры и индекс SCORAD, как исходно, так и на фоне терапии. В протоколе исследования была предусмотрена фиксация любых побочных явлений. Определение уровня общего $\mathrm{IgE} \mathrm{проводилось} \mathrm{методом} \mathrm{иммуно-}$ ферментного анализа. Также контролировался уровень эозинофилии в клиническом анализе крови.

Результаты. Уже после 1 месяца лечения дупилумабом все пациенты отметили полное купирование зуда и отсутствие потребности в наружных ГКС, что сопровождалось значимым снижением индекса

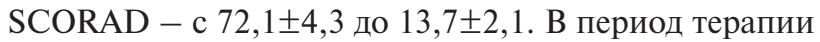
на протяжении года ни у кого из пациентов не отмечалось конъюнктивита, головных болей, присоединения вторичного инфицирования кожи. У 4 пациентов отмечалось появление локальной гиперемии лица, шеи и надплечий за 2-3 дня до 3 инъекции дупилумаба, что купировалось после инъекции и в последующем не возобновлялось. На фоне лечения мы наблюдали значимое снижение уровня общего $\operatorname{IgE~c~1186,5~[775,5;~2314,5]~до~} 601$ [424; 1005] me/ ml, при этом число эозинофилов также статистически значимо снижалось.

Заключение. Таргетная терапия препаратом дупилумаб высокоэффективна и безопасна у детей с АтД.

\section{ЭОЗИНОФИЛЬНЫЙ НЕЙРОТОКСИН В КАЛЕ КАК БИОМАРКЕР АЛЛЕРГИЧЕСКОГО ВОСПАЛЕНИЯ У ДЕТЕЙ, СТРАДАЮЩИХ ПИЩЕВОЙ АЛЛЕРГИЕЙ \\ Мухортых В.А. ${ }^{1,3}$, Ларькова И.А. ${ }^{1,2}$, Ревякина В.А. ${ }^{1,2}$ 'ФГБУН «ФИЦ питания и биотехнологии пищи», Москва ФГАУ «НМИЦ здоровья детей» Минздрава России, Москва \\ ЗФГБУ «ФНКЦ детей и подростков ФМБА России», Москва}

Введение. В последние десятилетия активно ведется поиск специфических маркеров воспаления, которые смогли бы спрогнозировать течение болезни, риски повторных обострений, а также эффективность персонализированной диетотерапии. Это воспаление как при IgE-опосредованной, так и при не-IgE-опосредованной пищевой аллергии (ПА) является эозинофильным. Область аллергического воспаления становится все более сложной с описанием новых путей и медиаторов. Поэтому изучение эозинофилов и их медиаторов (эозинофильный нейротоксин $(\mathrm{EDN}))$ является перспективным в диагностике ПА, определении степени ее активности и динамическом наблюдении на фоне терапии.

Цель исследования - изучить содержание EDN у детей раннего возраста с ПА и оценить его динамику на фоне диетотерапии.

Материалы и методы. В обследование было включено 192 ребенка в возрасте от 3 месяцев до 3 лет, страдающих ПА. Подтверждением ПА служили: отягощенный аллергологический анамнез, связь между приемом определенных пищевых продуктов и клиническими проявлениями, а также положительные результаты элиминационных диет. В группу контроля вошли 32 ребенка без проявлений ПА. Содержание EDN в копрофильтратах осуществлялась методом ИФА с использованием коммерческих тест-систем «EDN ELISA» Immundiagnostic». 
Результаты. Исходно, у детей, страдающих ПА, отмечались более высокие концентрации $\mathrm{EDN}$, чем у детей группы контроля $(p<0,05)$. На фоне адекватной диетотерапии у обследуемых детей отмечалось достоверное снижение EDN по сравнению с показателями детей контрольной группы $(p<0,05)$.

Заключение. Таким образом, адекватная диетотерапия способствует улучшению клинических проявлений и уменьшению воспалительного процесса за счет снижения $\mathrm{EDN}(p<0,05)$ у наблюдаемых больных по сравнению с группой контроля.

\section{ДИАГНОСТИЧЕСКАЯ ЗНАЧИМОСТЬ ЭОЗИНОФИЛЬНОГО КАТИОННОГО БЕЛКА У ДЕТЕЙ С ПИЩЕВОЙ АЛЛЕРГИЕЙ}

Мухортых В.А. ${ }^{1,3}$, Ларькова И.А. ${ }^{1,2}$, Ревякина В.А. ${ }^{1,2}$ 'ФГБУН «ФИЦ питания и биотехнологии пищи», Москва 2ФГАУ «НМИЦ здоровья детей» Минздрава России, Москва ЗФГБУ «ФНКЦ детей и подростков ФМБА России», Москва

Введение. Эозинофильное воспаление является одним из основных механизмов в развитии пищевой аллергии (ПА) у детей. Эозинофилы встречаются при многих аллергических заболеваниях, но их функциональная роль в значительной степени остается не ясной. Поэтому изучение эозинофилов и их медиаторов, в частности, эозинофильного катионного белка (ЕСР)) является перспективным в диагностике ПА, определении степени ее активности и динамическом наблюдении на фоне терапии.

Цель исследования - оценить содержание ЕСР у детей раннего возраста с различными проявлениями ПА и его динамику на фоне диетотерапии.

Материалы и методы. Обследовано 192 ребенка в возрасте от 3х месяцев до 3х лет с различными проявлениями ПА. Диагноз ПА был выставлен на основе результатов аллергологических обследований (специфические IgE-антитела, кожные скарификационные пробы), клинической картины заболевания и данных диагностической элиминационной диеты. Уровень ЕСР в сыворотке крови изучали методом иммуноферментного анализа с использованием коммерческих тест-систем «Human eosinophil cationic protein (ECP) ELISA KIT».

Результаты. У детей, страдающих ПА, отмечались высокие концентрации ЕСР 30,45 [27,78; 35,3] нг/мл. При этом, при легком течении ПА содержание ЕСР было достоверно ниже, чем при среднетяжелом и тяжелом ее течении $(p<0,017)$. На фоне адекватно подобранной диетотерапии через 2-4 недели отмечалась тенденция к снижению данного показателя 24,23 [19,86; 27,78] нг/мл. Снижение ЕСР коррелировало с клиническим улучшением симптомов ПА (кожных и гастроинтестинальных) у обследованных детей $(r=+0,74)$.
Заключение. Таким образом, повышенные уровни ЕСР могут указывать на тяжесть течения ПА и на наличие эозинофильного воспаления у обследованных детей. Снижение концентрации ЕСР на фоне лечения может быть использовано для контроля эффективности проводимого лечения.

\section{ОСОБЕННОСТИ ФАРМАКОЭПИДЕМИОЛОГИИ АЛЛЕРГИЧЕСКОГО РИНИТА У ДЕТЕЙ ВОЛГОГРАДСКОЙ ОБЛАСТИ}

Науменко М.Л., Магницкая О.В., Шишиморов И.Н., Пономарева Ю.В.

ФГБОУ ВО ВолгГМУ Минздрава России, Волгоград

Введение. В разных странах мира аллергическим ринитом (АР) страдают более $40 \%$ населения, в России - 10-24\% населения. АР является одним из наиболее частых аллергических заболеваний, с которым жители Волгоградского региона обращаются к специалистам амбулаторного звена.

Цель исследования: оценить структуру обращаемости педиатрической группы пациентов с АР к врачам разных профилей и установить тенденции фармакотерапии.

Материалы и методы. Проанализированы данные Территориального фонда обязательного медицинского страхования Волгоградской области о количестве первичных и повторных обращений пациентов в возрасте до 18 лет с диагнозом АР (J30,1, J30,2, J30,3 J30,4) в течение 2019-2020 годов. Проведена оценка структуры обращаемости пациентов к специалистам разных профилей; анализ фармакотерапии при повторных обращениях к аллергологам-иммунологам выполнен в соответствии с международными рекомендациями ARIA-2019.

Результаты. Число первичных обращений пациентов с диагнозом АР в течение 2019-2020 годов составило 22527 случаев. Среди них 50\% (11269/22527) пациентам впервые выставлен данный диагноз врачами аллергологами-иммунологами; оториноларингологами и педиатрами: в 27,2\% (6127/22527) и 22,8\% (2278/22527) случаев соответственно.

Повторных обращений пациентов зарегистрировано 8491 случаев (37,7\% от числа первичных обращений). Последующим контролем АР занимаются аллергологи-иммунологи в 85\% (7218/8491) случаев. Повторных обращений к оториноларингологам 7,2\% (613/8491); к педиатрам - 7,8\% (661/8491).

Наиболее часто назначаемыми препаратами для лечения АР являются антигистаминные препараты (АГП) - 91,6\% пациентов. Среди АГП преимущественно назначались АГП ІІ поколения - в 83,3\% случаев, в то же время АГП І поколения назначались в $13,3 \%$ случаев. Вторыми по частоте назначений являются ингаляционные глюкокортикостероиды (иГКС) - 86,6\% пациентов. Антилейкотриеновые 
препараты были назначены 23,3\% пациентов; кромоны $-4,4 \%$ пациентов с АР.

Заключение. Фармакотерапия АР врачами аллергологами-иммунологами осуществляется в соответствии с международными рекомендациями. Отмечается низкая (менее 40\%) повторная обращаемость пациентов с АР к специалистам амбулаторного звена.

\section{ОСОБЕННОСТИ ФУНКЦИОНАЛЬНОГО СОСТОЯНИЯ ЖЕЛУДОЧНО-КИШЕЧНОГО ТРАКТА У ДЕТЕЙ С ПИЩЕВОЙ АЛЛЕРГИЕЙ В ЗАВИСИМОСТИ ОТ ПОЛИМОРФИЗМА ГЕНОВ ГЛУТАТИОН-S-ТРАНСФЕРАЗЫ.}

Приходченко Н.Г., Коваленко Д.В., Ткаченко А.А., Шашарина Д.В., Григорян Л.А.

ФГБОУ ВО ТГМУ Минздрава России, Владивосток

Сохраняющийся рост аллергической патологии заставляет искать новые патогенетические подходы к лечению и предупреждения аллергических заболеваний. Система детоксикации ксенобиотиков имеет большое значение при многих процессах жизнедеятельности, ферменты детоксикации обеспечивают общую устойчивость организма к факторам внешней и внутренней среды. Нарушение баланса в метаболических путях за счет изменений активности ферментов, обусловленных генетическим полиморфизмом, может лежать в основе формирования аллергической сенсибилизации. Особое значение это имеет у детей первого года жизни.

Цель: Изучить функциональное состояние желудочно-кишечного тракта у детей первого года жизни с пищевой аллергией в зависимости от полиморфизма генов глутатион-S-трансферазы.

Материалы и методы: Проведено комплексное клинико-лабораторное обследование 39 детей первого года жизни с пищевой аллергией, группу контроля составили 30 здоровых детей. Комплексное обследование включало клинико-анамнестическое обледование, лабораторную диагностику, исследование полиморфизма генов глутатионтрансфераз GSTM1. Типирование аллельного полиморфизма генов GSTM1 проводили методом Real-time PCR и количественной PCR.

Результаты: Проведенное комплексное клинико-лабораторное обследование установило поражение ЖКТ у всех пациентов I группы. Регистрировали: учащенный стул, пенистый, с кислым запахом (100\%), срыгивания у $24(61,5 \%)$, метеоризм (в 92,16\% случаев), флатуленцию $(87,04 \%)$, кишечные колики $(92,16 \%)$. Копрологические нарушения характеризовались смешанной стеатореей у 15 детей $(38,4 \%)$, стеатореей II типа у $18(46,08 \%)$, амилореей у 37 (94,72\%), креатореей - у 18 (46,2\%). Также в копрограмме определяли наличие переваримой клетчатки - у 23 (58,9\%), присутствие йодофильной флоры - у $34(87,04 \%)$ детей. $\mathrm{pH}$ кала составлял $5,47+0,32$. У детей с ПА выявлено статистически значимое увеличение частоты гетерозиготных генотипов (/del) для GSTM1 по сравнению с оценкой частоты в популяции $(\chi 2=6,74 \mathrm{df}=1, p<0,001)$.

Выводы: впервые установлена ассоциация пищевой аллергии с гетерозиготным генотипом гена GSTM1, что может свидетельствовать о более высоком риске развития аллергических заболеваний для носителей данного генотипа. 


\section{Раздел 3}

\section{ГАСТРОЭНТЕРОЛОГИЯ}


ХРОНИЧЕСКИЕ ВОСПАЛИТЕЛЬНЫЕ ЗАБОЛЕВАНИЯ КИШЕЧНИКА У ДЕТЕЙ: КЛИНИКО-ЛАБОРАТОРНЫЕ ОСОБЕННОСТИ

Бурлуикая А.В., Исянова Д.Р., Сериков С.С., Статова А.В., Борлакова И.И.

ФГБОУ ВО КубГМУ Минздрава России, Краснодар

Введение. Около 25\% случаев манифестации хронических воспалительных заболеваний кишечника (ХВЗК) приходится на детский возраст. Патология характеризуются более агрессивным течением, обширностью поражения кишечника, задержкой физического и полового развития, нарушением социальной адаптации ребенка.

Цель исследования - анализ клинико-лабораторных особенностей течения ХВЗК.

Материалы и методы. Проведен ретроспективный анализ 30 историй болезни детей с ХВЗК, находившихся на обследовании и лечении в гастроэнтерологическом отделении ДККБ г. Краснодара в период с 2018 по 2020 годы (пол, возраст, жалобы, особенности клинических проявлений, параклинические показатели).

Результаты. Язвенный колит (ЯК) диагностирован 83,3\% обследованных детей, Болезнь Крона (БК) у $16,7 \% ; 63,3 \%$ составили мальчиков и $36,7 \%$ девочки.

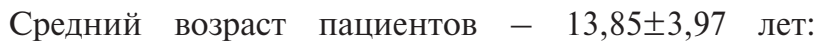
для девочек - 11,67 $\pm 5,12$ лет, для мальчиков $15,10 \pm 2,51$ лет. Распределение детей по возрастным группам при ЯК было следующим: младшего возраста $-4 \%$, дошкольного - 4\%, младшего школьного $20 \%$, старшего школьного - 72\%; при БК - младшего школьного - $20 \%$, старшего школьного - $80 \%$. Возраст больных к моменту появления первых жалоб, характерных для ХВЗК, составил 10,47士4,98 лет.

Боли в животе в дебюте ХВЗК отмечались у $52 \%$ больных ЯК и у $60 \%$ пациентов с БК; диарея при ЯК встречалась значительно чаще, чем при болезни Крона у $84 \%$ и $40 \%$ соответственно; гематохезия у $60 \%$ больных с ЯК и у $20 \%$ - с БК. В дебюте ХВЗК правильный диагноз после дообследования был установлен у $60 \%$ пациентов. В остальных случаях ХВЗК дебютировали под маской инфекционной, хирургической и гематологической патологии, что привело к увеличению времени диагностики.

Колоноскопия при первом обращении к врачу была проведена лишь $60 \%$ больным с ЯК и $40 \%$ пациентам с БК. Подтипы ХВЗК в анализируемой группе по распространенности процесса: у детей с БК: илеоколит - у 60\%пацментов , илеит - 20\%, с поражением тела желудка и илеоколит - 20\%; у детей с ЯК: проктосигмоидит - 19\%, левосторонний колит - $19 \%$ и тотальный колит - 62\%. Осложнения ХВЗК развились у $31,4 \%$ детей, из них $81,8 \%$ составили дети с БК.

Заключение. Мальчики болеют чаще ХВЗК, преимущественно в подростковом возрасте. Клинические симптомы хронических воспалительных забо- леваний кишечника манифестируют, в среднем, в возрасте 10,5 лет. Наиболее частым подтипом заболевания при БК является илеоколит (60\%), при ЯК тотальный колит (62\%).

\section{РАСПРОСТРАНЕННОСТЬ И СТРУКТУРА ФУНКЦИОНАЛЬНЫХ ЗАБОЛЕВАНИЙ ЖЕЛУДОЧНО-КИШЕЧНОГО ТРАКТА СРЕДИ ПОДРОСТКОВ - СТУДЕНТОВ БЛАГОВЕЩЕНСКОГО ГОСУДАРСТВЕННОГО ПЕДАГОГИЧЕСКОГО УНИВЕРСИТЕТА}

Григорьев Д.А. ${ }^{1}$, Сороколетова А.В. ${ }^{1}$, Горбунов M.M. ${ }^{2}$ 1 ФГБОУ ВО Амурская ГМА Минздрава России, Благовещенск

²ФГБОУ ВО Благовещенский государственный педагогический университет, Благовещенск

Актуальность. Адаптация подростков к обучению в ВУЗе сопровождается увеличением количества стрессовых ситуаций, что может влиять на ФЗ ЖКТ.

Цель: оценить распространенность функциональных заболеваний ЖКТ среди подростков-студентов педагогического университета

Материалы и методы. Обследовано 114 подростков-студентов 1 курса БГПУ(средний возраст $17 \pm 0,6$ лет). Для анализа жалоб со стороны ЖКТ использовались опросники GerdQ и GSRS. Студентов разделили на 2 группы: 1-я группа - с рейтингом зачетной книжки от 2,8 до 3,9 баллов и 2-я группа от 4,0 до 5,0 баллов. Функциональные заболевания ЖКТ выявляли на основании Римских критериев IV. Для анализа использовали пакет программ «Statistica6,1» (StatSoft Inc). Результаты считались достоверными при $\mathrm{p}<0,05$.

Результаты. Функциональные заболевания ЖКТ встречались в 36,0 \% случаев среди студентов 1-й группы и 21,0 \% - 2-й группы. Среди студентов встречались проявления синдрома раздраженного кишечника с преобладанием диареи в 21,0 \% случаев; синдрома раздраженного кишечника с преобладанием запоров - в 35,0 \%; функциональной диспепсии - в 22,0 \%; функционального запора - в 14,0\% и Рефлюкс-эзофагита - в 8,0 \% случаев. По результатам опросника GerdQ в группе А у 2-й группы проявления симптомов - в 8,0 \% случаев, у 1-й группы чаще $(78,0 \%)$; в группе В(симптомы тошноты и боли в эпигастрии)- у 1-й группы $(64,0 \%)$, у 2-й группы (47,0 \%). 2-й группа не предъявляла жалобы на абдоминалгию(лишь 6,0 \%), в то время как 1-й группа отмечала абдоминальную боль в 87,0 \% случаев. 1-й группа в 78,0 \% случаев отмечала рефлюкс-синдром, у 2-й группы - 8,0 \%. Диарейный синдром у 1-й группы- 83,0 \% случаев, из 2-й группы - 15,0 \% случаев.

Выводы. 1. Фактором риска развития функциональных заболеваний ЖКТ среди студентов явля- 
ется низкая успеваемость. 2. Распространенность Ф3 ЖКТ среди студентов 1 курса составила 57,0 \%. 3. Среди ФЗ ЖКТ у студентов наиболее часто встречается СРК - в 56,0 \% случаев.

\section{РАННИЕ МАРКЕРЫ ФОРМИРОВАНИЯ НЕАЛКОГОЛЬНОЙ ЖИРОВОЙ БОЛЕЗНИ ПЕЧЕНИ У ДЕТЕЙ С ЭКЗОГЕННО- КОНСТИТУЦИОНАЛЬНЫМ ОЖИРЕНИЕМ}

Демяненко А.Н. ${ }^{1}$, Алимова И.Л. ${ }^{1}$, Поварова О.В. ${ }^{2}$

${ }^{1}$ ФГБОУ ВО Смоленский государственный медицинский университет Минздрава России, Смоленск

ФГБОУ ВО «Московский государственный университет имени М.В.Ломоносова», Москва

Введение. Неалкогольная жировая болезнь печени (НАЖБП) у детей с ожирением в большинстве случаев характеризуется бессимптомным течением и диагностируется уже на стадии стеатогепатита. В связи с этим, целесообразен поиск ранних маркеров формирования НАЖБП для формирования групп риска и проведения превентивных мер.

Цель исследования: определить ранние маркеры неалкогольной жировой болезни печени у детей с экзогенно-конституциональным ожирением.

Материалы и методы. Обследовано 40 пациентов с диагнозом экзогенно-конституциональное ожирение 2-й $(\mathrm{n}=22)$ и 3-й $(\mathrm{n}=18)$ степени в возрасте 7-15 лет (12,0лет[8,0-15,0]). Всем определяли уровень глюкозы, АЛТ, АСТ, АЛТ/АСТ, общего холестерина, липидный спектр, инсулина, проводили расчет индекса атерогенности (ИА), HOMA-IR, УЗИ печени. Факторы риска (ранние маркеры) формирования НАЖБП оценивались по средствам построения многомерной логистической регрессионной модели. Статистическая обработка проводилась с помощью программы Statistica 7,0 (StatSoft 2009), результаты представлены в виде Ме [25-75].

Результаты. Средний уровень (ммоль/л) глюкозы составил-5,0 [3,4-6,1], общего холестерина-4,35 $[2,90-7,60]$, ЛПВП-1,3 [0,7-2,9], ЛПНП-2,9[1,5$6,1]$, Триглицеридов-1,06 [0,43-3,91], ИА-2,5 [0,6$8,2]$, АЛТ-26,0Ед $[11,0-82,0]$, АСТ-25,0Ед [15,049,0], АЛТ/АСТ-1,0 [0,5-1,6], HOMА-IR-7,6 [4,1-12,8]. Метаболический синдром был выявлен у 6 (15\%) пациентов. По данным УЗИ печени 11 (28\%) пациентов имели изменение структуры ткани печени, из них 8 (20\%)-и увеличение обеих долей. Дислипидемия установлена у 12 (30\%), ИА>3-13 (33\%) пациентов. У 20 (50\%) отношение АЛТ/АСТ было $\geq 1$, при этом АЛТ выше референсных значений лишь у 6(15\%). НОМА-IR>3,4 (инсулинорезистентность) имели $100 \%$ обследованных. При построении регрессионной модели в качестве независимых переменных были взяты: уровень холестерина, липидный спектр, уровень АЛТ, АЛТ/АСТ $\geq 1$, ИА,
HOMA-IR, наличие метаболического синдрома, дислипидемии. В качестве зависимой переменной взято наличие характерных для НАЖБП изменений на УЗИ. По данным регрессионной модели значимыми факторами риска явились: АЛТ $/ \mathrm{ACT} \geq 1$ (ОШ-9,02;95\%ДИ-8,99-9,04; $\beta-2,20, \mathrm{p}<0,001)$, индекс атерогенности (ОШ-1,73;95\%ДИ-1,72-1,75; $\beta=0,55$, $\mathrm{p}<0,001)$.

Заключение. Наиболее значимым ранним маркером формирования НАЖБП является соотношение АЛТ/АСТ $\geq 1$ (риск возникновения НАЖБП возрастает в 9 раз). Повышение индекса атерогенности на единицу увеличивает риск НАЖБП в 1,73 раза.

\section{НЕЙРО-ГУМОРАЛЬНЫЕ ПРЕДИКТОРЫ ТЯЖЕСТИ ХРОНИЧЕСКОГО ГАСТРОДУОДЕНИТА У ДЕТЕЙ В ВОЗРАСТЕ 8-14 ЛЕТ \\ Домбаян С.Х., Панова И.В., Летифов Г.М., Афонин А.А., Афонина Т.A. \\ ФГБОУ ВО РостГМУ Минздрава России, Ростов-на-Дону}

Введение. Установлено, что в патогенезе хронического гастродуоденита (ХГД) участвуют нейро-гуморальные механизмы регуляции функционального состояния гастродуоденальной области. Представляет интерес возможность участия нейронспецифической енолазы (НСЕ) как особого фермента, находящегося во всех клетках APUD-системы, частью которой является желудочно-кишечный тракт, в развитии ХГД.

Цель работы: установить взаимосвязь изменений уровня НСЕ у детей с ХГД и тяжести заболевания.

Материалы и методы. Проведено обследование 75 детей в возрасте 8-14 лет с ХГД. У 42 больных выявлен поверхностный гастродуоденитом (I группа, ПГД); у 33 детей - эрозивный гастродуоденит (II группа, ЭГД). В группу контроля (ГК) вошли 25 детей I-II группы здоровья. Диагноз ХГД был поставлен на основании данных эндоскопии и морфологического исследования биоптатов слизистой оболочки желудка. Уровень НСЕ в сыворотке крови пациентов определяли методом иммуноферментного анализа наборами фирмы Can Ag Diagnostics (Швеция). Результаты ИФА регистрировали и оценивали с помощью фотометра SUNRISE производства TECAN (Австрия).

Результаты. Уровень НСЕ у детей с ХГД был достоверно выше в сравнении с ГК: 10,87(9,9-12,12) мкг/л и $9,78(8,49-10,9)$ мкг/л соответственно $(\mathrm{p} \leq 0,01)$. У больных с ЭГД определялись более высокие показатели НСЕ $(11,31(9,65-11,985)$ мкг/л) в сравнении с ПГД $(10,82(9,98-12,10)$ мкг/л) $(p=0,05)$. При этом уровень НСЕ у детей I и II группы: 10,82(9,98$12,1)$ мкг/л и 11,31(9,65-11,98) соответственно был выше значений НСЕ группы контроля: 9,787(8,49$10,9)$ мкг/л $(\mathrm{p} \leq 0,01)$. 
Заключение. Повышенный уровень НСЕ в сыворотке крови у детей с ХГД свидетельствует о вероятном участии НСЕ в патогенезе воспалительного процесса в слизистой оболочке гастродуоденальной области. Более высокий уровень НСЕ, выявленный при эрозивном гастродуодените, может свидетельствовать об определенной роли данного белка в развитии тяжелых (эрозивных) форм заболевания. Полученные данные указывают на возможность использования НCE как предиктора развития ХГД, также имеющего значение в оценке тяжести заболевания.

\section{ЧАСТОТА ВЫЯВЛЕНИЯ ЭРОЗИВНОГО} ЭЗОФАГИТА У ДЕТЕЙ ШКОЛЬНОГО ВОЗРАСТА

Лобанов Ю.Ф., Латышев Д.Ю., Пименова Д.А., Прокудина М.П., Мартиросян М.С., Болденкова И.Ю. Алтайский государственный медицинский университет, Барнаул

Введение. Гастроэзофагеальнаярефлюксная болезнь (ГЭРБ) - хроническое рецидивирующее заболевание, характеризующееся ретроградным поступлением желудочного содержимого в пищевод. Истинная частота ГЭРБ у детей неизвестна. Частота выявления рефлюкс-эзофагита у детей с заболеваниями пищеварительной системы по данным различных авторов составляет от $8,7 \%$ до $17 \%$.

Цель исследования - изучить распространенность эрозивного эзофагита (ЭЭ) по результатам фиброгастродуоденоскопии у детей школьного возраста с персистирующими гастроэнтерологическими симптомами.

Материалы и методы. Включен 331 ребенок школьного возраста, от 7 до 17 лет, средний возраст $12,3 \pm 2,6$, проходящий первичное обследование по поводу персистирующими гастроэнтерологических симптомов, мальчиков -138, девочек- 193. Критерии включения:1 наличие повторяющихся гастроэнтерологических симптомов; 2 первичное эндоскопическое исследование; 3 отсутствие плановой терапии препаратами гастроэнтерологического профиля за три месяца до эндоскопического исследования; 4 возраст 7-17 лет; 5 наличие информированного согласия.

Результаты. ЭЭ выявлен у 76 детей (22,9\%), среди мальчиков - $51(67,1 \%)$, девочек - $25(32,8 \%)\left(\mathrm{x}^{2}=\right.$ $24,869, p<0,01)$. При оценке эндоскопической картины, ЭЭ степени А по Лос-анджелесской классификации выявлен у 72 (94,7\%) детей. Из них - единичные эпителизированные эрозии у 62 (86,1 \%), множественные эпителизированые эрозии у 9 (12,5\%) и единичные линейные эрозии менее 5 мм у $1(1,4 \%)$ ребенка. ЭЭ степени В выявлен у 4 детей $(5,3 \%)$. Из них у 3 (75\%) детей единичные эрозии более 5 мм, у $1(25 \%)$ ребенка множественные эрозии более 5 мм. ЭЭ степени C и D не выявлен ни в одном из случаев.
Заключение. Среди детей школьного возраста с персистирующими гастроэнтерологическими симптомами ЭЭ выявлен в 22, 9 \% случаев, достоверно чаще у мальчиков $(67,1 \%)$, чем у девочек $(32,5 \%)$. ЭЭ соответствовал степени А по Лос-анджелесской классификации у 94,7\% детей, степени В у 5,3\% детей. ЭЭ степени C и D не выявлен ни в одном из случаев.

\section{ОСОБЕННОСТИ ГОРМОНАЛЬНОГО СТАТУСА У ДЕВОЧЕК 9-15 ЛЕТ С ХРОНИЧЕСКИМ ГАСТРОДУОДЕНИТОМ \\ Панова И.В., Домбаян С.Х., Летифов Г.М., Брыксина Е.Ю., Давыдова Н.А.}

ФГБОУ ВО РостГМУ Минздрава России, Ростов-на-Дону

Введение. Известно, что гормоны гипофизарнотиреоидного, гипофизарно-надпочечного спектра, половые гормоны влияют на состояние моторной, слизеобразующей и секреторной функции желудка, детерминируют процессы регенерации в тканях и слизистых оболочках.

Цель работы: оценить состояние гормонального статуса у девочек, страдающих хроническим гастродуоденитом в зависимости от тяжести заболевания.

Материалы и методы. Обследовано 70 девочек в возрасте $9-15$ лет с хроническим гастродуоденитом (ХГД) в стадии клинико-эндоскопического обострения. Из них $46(65,7 \%)$ детей с поверхностным гастродуоденитом (ПГД) - 1 группа; 24 (34,3\%) - с эрозивным гастродуоденитом (ЭГД) (2 группа). Группу контроля (ГК) составили 22 девочки I-II групп здоровья. Диагноз ХГД был поставлен на основании данных эндоскопии и морфологического исследования биоптатов слизистой оболочки гатродуоденальной области. Исследование уровня соматотропного гормона (СТГ), тиреотропного гормона (ТТГ), трийодтиронина (Т3), тироксина (Т4), кортизола, инсулина, тестостерона, эстрадиола и гастрина в сыворотке крови проводилось методом иммуноферментного анализа.

Результаты. Во 2 группе выявлены более низкие значения СТГ $(1,15 \pm 0,43$ нг/мл) в сравнении с ГК $(2,78 \pm 1,03$ нг/мл) $(p<0,05)$. Установлено снижение уровня Т3 (1,98 $\pm 0,05$ нмоль/л) в сравнении с ГК $(2,24 \pm 0,05$ нмоль/л) $(p<0,05)$ на фоне повышения значений ТТГ $(1,79 \pm 0,29$ мкМЕ/ед и $1,65 \pm 0,11$ мкМЕ/ед соответственно 2 группе и ГК, $p<0,05)$. У девочек с ЭГД отмечались более высокие показатели эстрадиола $(40,92 \pm 10,29$ пг/мл) в сравнении с ГК $(26,45 \pm 7,24$ пг/мл) $(p<0,05)$; уровень же тестостерона был значительно ниже контрольных значений $(0,09 \pm 0,03$ нг/мл и $0,28 \pm 0,12$ нг/мл соответственно, $p<0,05)$. Гормональный статус девочек 1 группы не имел статистически значимых отличий в сравнении с группой контроля. 
Заключение. Полученные данные доказывают роль гормональной дисфункции в формировании более тяжелой (эрозивной) формы хронического гастродуоденита у девочек.

\section{ЛЕЙКОЦИТОГРАММА КАЛА И ЭОЗИНОФИЛЬНЫЙ КАТИОННЫЙ БЕЛОК У ДЕТЕЙ С ПИЩЕВОЙ АЛЛЕРГИЕЙ}

Папчук А.Е., Приходченко Н.Г., Шуматова Т.А. , Зернова Е.С., Быкова А.Д., ФГБОУ ВО ТГМУ Минздрава России, Владивосток

Введение. В настоящее время продолжается рост пищевой аллергии (ПА) среди детей раннего возраста. Основную роль в реализации пищевой аллергии отводят лейкоцитам, устремляющимся в очаг аллергического воспаления. Эозинофильный катионный белок (ЭКБ) - компонент специфических секреторных гранул эозинофилов человека, позволяет судить об активности аллергического воспаления, определение его в кале может быть перспективно для неинвазивного мониторинга процесса.

Цель исследования. Определить клиническую и диагностическую значимость лейкоцитограммы кала и эозинофильного катионного белка у детей из группы высокого риска по развитию пищевой аллергии.

Материалы и методы. Под наблюдением находились 100 детей раннего возраста. 30 здоровых детей составили контрольную группу. Наряду с традиционными клиническими, анамнестическими и лабораторными методами был проведен анализ лейкоцитограмм кала (с окраской по Романовскому-Гимзе) и изучение ЭКБ у всех пациентов. ЭКБ определяли при помощи анализа ELISA.

Результаты. При помощи разработанной нами прогностической шкалы, использующей клинико-анамнестические, параклинические и рутинные лабораторные методы исследования (копрограмма, лейкоцитограмма кала, проба Бенедикта) были выявлены 60 детей с высоким риском развития ПА. При динамическом наблюдении у 47 детей заболевание было реализовано, что позволило доказать высокую чувствительность (78,9 \%) и специфичность $(76,4$ \%) прогностической шкалы. У пациентов с ПА количество лейкоцитов составляло 16-45 в поле зрения, уровень ЭКБ составил 392,94+11,79 нг/мл, что превышало показатели контрольной группы $(190,56+5,72$ нг/мл). При определении коэффициента корреляции Спирмена нами была выявлена сильная прямая корреляционная связь между клиническими симптомами и лабораторными показателями: уровнем эозинофилов в кале $(0,589)$; высоким уровнем дисахаров в кале $(0,657)$; обилием слизи $(0,52)$. Умеренная прямая корреляция была выявлена с высоким уровнем лимфоцитов в кале $(0,412)$, кислой средой $(0,48)$, повышением уровня ЭКБ $(0,466)$.

Заключение. Таким образом, использование разработанной прогностической шкалы и исследование лейкоцитограммы и ЭКБ являются эффективным методом ранней неинвазивной диагностики и мониторинга пищевой аллергии на амбулаторном этапе.

\section{БИЛИАРНЫЙ СЛАДЖ У ДЕТЕЙ, ФАКТОРЫ РИСКА \\ Петрунина С.Ю., Куличков В.И. ФГБОУ ВО «Южно-Уральский государственный медицинский университет» Минздрава России, Челябинск}

Введение. В последнее время отмечается рост обменно-воспалительных заболеваний у детей. Проспективные наблюдения указывают на формирование в последующем желчных камней у каждого пятого ребенка.

Цель исследования - выявить факторы риска билиарного сладжа у детей, обратившихся на прием к гастроэнтерологу.

Материалы и методы. Исследовательскую группу составили 55 детей с билиарным сладжем в возрасте от 2,5 до 17 лет. Отбор осуществлялся путем анализа медицинской документации 301 ребенка, обратившегося к гастроэнтерологу частного медицинского центра ООО «ЦНС» в возрасте от 1 мес до 18 лет сплошным методом за период 2019-2021 г.

Результаты. Распределение по возрасту было следующим: 1 ребенок до 3 лет, 15 детей дошкольного, 15 - младшего школьного и 23 - старшего школьного возраста. Девочек с билиарным сладжем было 56\%, мальчиков - 44\%, преобладание девочек было характерно для возрастной группы старшего школьного возраста, где соотношение девочек и мальчиков 1,8:1.

У 19 человек оказалось возможным оценить эффективность лечения. Не получили назначенного лечения 2 ребенка, у них билиарный сладж сохранялся при повторном обследовании через 5-6 мес. У 9 детей лечение было эффективным, у 6 из них проспективное наблюдение составило 1,5 года. 6 детей ранее уже были пролечены по поводу билиарного сладжа, причем у 5 детей рецидив возник через 1,5-2 года, у 1 ребенка через 6 лет. У 1 ребенка ранее (2,5 года назад) обнаруживался конкремент желчного пузыря 2,7мм. То есть, у 7 детей (13\%) зафиксированы рецидивы билиарного сладжа.

Отягощенная наследственность была выявлена в 24\%, затяжная желтуха в неонатальном периоде в 20\%, предшествующее антибактериальное лечение в 22\%. Доля детей с избыточной массой тела и ожирением 18\%. У $49 \%$ выявлены деформации желчного пузыря. У $27 \%$ детей не отмечалось каких-либо факторов риска. 
Заключение. Билиарный сладж выявляется у детей начиная с раннего возраста, но более распространен в старшем школьном возрасте у девочек в соотношении $1,8: 1$. У $13 \%$ детей отмечается рецидивирование данного состояния после успешного лечения, причем нередко в отдаленные сроки через $1,5-2$ года. У $27 \%$ детей с билиарным сладжем не было выявлено факторов риска.

\section{ДИАГНОСТИЧЕСКАЯ ЦЕННОСТЬ ФЕКАЛЬНОГО КАЛЬПРОТЕКТИНА ПРИ ВОСПАЛИТЕЛЬНЫХ ЗАБОЛЕВАНИЯХ КИШЕЧНИКА В ДЕТСКОМ BОЗРАCTE}

Полянская Н.А. ${ }^{1}$, Павлинова Е.Б. ${ }^{1}$, Горбунова А.А. ${ }^{2}$, Павлюш Л.В. ${ }^{2}$, Савченко О.А. ${ }^{l}$, Киршина И.А. ${ }^{\prime}$ ${ }^{1}$ ФГБОУ ВО Омский государственный медицинский университет Минздрава России, Омск

БУЗОО Областная детская клиническая больница, Омск

Введение. Своевременное распознавание воспалительных заболеваний кишечника (В3К) зачастую вызывает трудности. В диагностике В3К используется фекальный кальпротектин (ФК).

Цель исследования. Изучить диагностическую значимость определения ФК у пациентов детского возраста с ВЗК. Изучить взаимосвязь уровня ФК с активностью течения патологического процесса у детей, страдающих В3К, для определения диагностической значимости маркера.

Материалы и методы. Проведен ретроспективный анализ 24 историй болезни детей с В3К с обработкой данных при помощи стандартного пакета программного обеспечения Statistica 10,0.

Результаты. Среднее значение ФК для ЯК в дебюте заболевания составляет 1436 мг/г, для 2046 мг/г $(p>0,05)$. Колоноскопия с биопсией была проведена всем детям с ВЗК. Эндоскопическая активность соответствовала умеренной степени. Длительность ремиссии составляла от 2 до 6 мес. При анализе результатов не установлено связи между уровнем ФК в дебюте ВЗК и степенью эндоскопической активности $(p=0,75)$, также отсутствует связь между значениями ФК в дебюте ВЗК и длительностью ремиссии $(p=0,219)$. На фоне проведенного лечения отмечено статистически значимое снижение уровня ФК при ЯК $(p=0,0001)$ и БК $(p=0,04)$.

Заключение. Простой, доступный и неинвазивный способ определения ФК дает возможность проводить динамический контроль эффективности терапии ВЗК у детей, что может стать в дальнейшем (при более масштабных исследованиях на более репрезентативной выборке) важным маркером для объективной оценки течения неспецифического воспаления в кишечнике.

\section{ОЦЕНКА ОТНОСИТЕЛЬНОГО РИСКА ЗАБОЛЕВАЕМОСТИ ГАСТРОДУОДЕНИТОМ СРЕДИ ДЕТСКОГО НАСЕЛЕНИЯ НА РЕГИОНАЛЬНОМ УРОВНЕ}

Пономарева О.В., Петров С.Б., Чагаева Н.В.,

Ляпунова Е.В.

ФГБОУ ВО Кировский ГМУ Минздрава России, Киров

Введение. В настоящее время гастродуодениты (ГД) являются важной проблемой общественного здравоохранения, в связи с чем представляется актуальным своевременное проведение анализа показателей относительного риска как своеобразных индикаторов распределения вероятности возникновения данной патологии среди детского населения.

Цель исследования. Оценить уровень относительного риска (RR) заболеваемости ГД среди детского населения областного центра и районов области по сравнению со среднерегиональным уровнем.

Материалы и методы. Данные о заболеваемости ГД детского населения (0-14 лет) получены путем анализа медико-статистической отчетности МИАЦ Минздрава Кировской области за 2019 г. В качестве учетных признаков взяты общее зарегистрированное и впервые выявленное количество случаев заболеваний ГД у детей 0-14 лет, а также численность детского населения 0-14 лет в г. Кирове и районах области.

Результаты. Уровень относительного риска для общей заболеваемости ГД: максимальный $\mathrm{RR}$ выявлен в Кильмезском районе $(\mathrm{RR}=1,98$ CI95\%(1,55-2,51)), минимальный: в Советском $(\mathrm{RR}=0,07 \mathrm{CI} 95 \%(0,06-0,09))$ и в Шабалинском районах $(\mathrm{RR}=0,08 \mathrm{CI} 95 \%(0,06-0,10))$. Уровень относительного риска для первичной заболеваемости ГД: максимальный RR выявлен в Богородском районе $(\mathrm{RR}=0,62 \mathrm{CI} 95 \%(0,48-0,78))$, минимальный: в Малмыжском ( $R R=0,03$ CI95\% $(0,02-0,04))$, Опаринском $(\mathrm{RR}=0,03 \mathrm{CI} 95 \%(0,02-0,04))$ и в Слободском районах $(\mathrm{RR}=0,02 \mathrm{CI} 95 \%(0,02-0,03))$. При расчете кластерных показателей по заболеваемости ГД выделено 3 группы кластеров. В 3 кластере по расчетам получились максимальная общая и первичная заболеваемость ГД, которые составили 12,3 и 2,8 соответственно. К данному кластеру отнесены следующие районы области: Кикнурский, Кильмезский, Кирово-Чепецкий, Котельничский, Яранский и г.Киров. Средний уровень охвата диспансеризацией в 3 кластере составил 68,3 , который является максимальным среди кластеров. Репрезентативно высокие показатели RR получены для общей заболеваемости ГД у детского населения, проживающего в Кильмезском районе. В то время как для первичной заболеваемости ГД не выявлено репрезентативных показателей RR, превышающих значение 1 .

Заключение. Показатель относительного риска может являться индикатором распределения вероятности заболевания ГД среди детского населе- 
ния в зависимости от административного деления региона, с помощью которого возможно выделение «проблемных» территорий с целью своевременного принятия управленческих решений на уровне регионального здравоохранения.

\section{РАСПРОСТРАНЕННОСТЬ ИЗМЕНЕНИЙ ОРГАНОВ ГЕПАТОБИЛИАРНОГО ТРАКТА И ПОДЖЕЛУДОЧНОЙ ЖЕЛЕЗЫ У ДЕТЕЙ С ХРОНИЧЕСКИМ ГАСТРОДУОДЕНИТОМ И СОПУТСТВУЮЩИМ ОЖИРЕНИЕМ}

Узунова А.Н., Рыбакова О.Г., Петрунина С.Ю., Субач А.С., Георгиева Е.A.

ФГБОУ ВО «Южно-Уральский государственный

медицинский университет» Минздрава России,

Челябинск

МБУЗ ДГКБ, Челябинск

Актуальность. Ожирение - актуальное, социально значимое явление, манифестируя в детском возрасте является фактором риска развития многих «болезней цивилизации». По данным ВО3 за последние четыре десятилетия в мире стало в десять раз больше детей и подростков (от 5 до 19 лет), страдающих ожирением. Наличие метаболических изменений при ожирении несомненно откладывает отпечаток на течение всех хронических заболеваний, в том числе желудочно-кишечного тракта.

Цель: выявить сопутствующие изменения органов гепатобилиарного тракта и поджелудочной железы у детей с хроническим гастродуоденитом и сопутствующим ожирением.

Материалы и методы. Исследование организовано по типу поперечного среза. Метод выборки сплошной, по мере поступления пациентов в МБУЗ ДГКБ №7. Критерии включения: возраст детей от 7 до 18 лет, нормальные и высокие значения индекса массы тела, наличие хронических воспалительных заболеваний верхних отделов пищеварительного тракта (гастродуоденит), отсутствие пороков развития и тяжелых сопутствующих заболеваний других органов и систем. Всего в исследование были включены 100 детей и разделены на 2 группы: 1 группа $(n=50)$ - дети с нормальной массой тела (SDS индекса массы тела $($ ИМТ) \pm 1$), 2$ группа $(n=50)-$ дети с ожирением (SDS ИМТ >+2).

Результаты исследования. По данным УЗИ органов брюшной полости в группе детей с ожирением статистически значимо чаще выявлялось диффузное изменение поджелудочной железы - $72 \%$ против $20 \%$ в 1 группе $(p<0,05)$, причем у $40 \%$ детей 2 группы отмечалось повышение амилазы крови, что было расценено как проявление панкреатита. У $60 \%$ детей 2 группы было выявлено увеличение размеров печени против $12 \%$ в 1 группе $(p<0,05)$, у $72 \%$ детей 2 группы была выявлена дискинезия желчевыводящих путей, против $40 \%$ в 1 группе $(p<0,05)$. Биохимическический скрининг крови показал, что среднее значение общего холестерина детей 1 группы составил 3,32 0,22 ммоль/л, в группе детей с ожирением - 4,72 \pm 0,19 ммоль/л $(p<0,05)$. По другим показателям статистически значимых отличий выявлено не было.

Заключение. В группе детей с ожирением чаще выявляются эхографические изменения со стороны паренхиматозных органов: диффузные изменения поджелудочной железы, увеличение размеров печени, c сопутствующей дискинезией желчевыводящих путей; отмечаются более высокие средние значения уровня общего холестерина, указывающие на особенности липидного обмена. Выявленные изменения в дальнейшем могут быть связаны с формированием обменных заболеваний гепатобилиарной системы.

\section{МОНИТОРИНГ ПРОНИЦАЕМОСТИ КИШЕЧНИКА У ДЕТЕЙ С СИНДРОМОМ МАЛЬАБСОРБЦИИ \\ Шуматова Т.А., Приходченко Н.Г., Коваленко Д.В., Григорян Л.А., Зернова Е.С. \\ ФГБОУ ВО «Тихоокеанский государственный медицинский университет» Минздрава России, Владивосток}

Введение. Среди детей раннего возраста широко распространены заболевания, сопровождающиеся синдромом мальабсорбции. Наиболее часто встречающиеся клинические формы - аллергия к белкам коровьего молока (АБКМ) и лактазная недостаточность (ЛН).

Цель исследования - оценить диагностическую значимость использования маркеров повышенной проницаемости кишечника (фекальный кальпротектин, зонулин) для мониторинга состояния кишечного барьера у детей с синдромом мальабсорбции.

Материалы и методы. Обследовано 96 детей первого года жизни, которые были разделены на 3 группы, сопоставимые по возрасту и полу. В первую группу (І группа) вошли 36 детей с АБКМ. Вторую группу (II группа) составили 30 детей с ЛН. Группу сравнения составили 30 здоровых детей. Биомаркеры в копрофильтратах определяли методом энзимсвязанного иммуносорбентного анализа ELISA. C использованием непараметрических методов статистики проводилась статистическая обработка полученных данных.

Результаты. Средняя концентрация зонулина у детей I и II группы оказалось достоверно выше, чем показатель контрольной группы $(1,75 \pm 0,16$ нг/мл, $1,06 \pm 0,15$ нг/мл и $0,75 \pm 0,01$ нг/мл соответственно, p <0,05). Показатели фекального кальпротектина у детей с АБКМ и ЛН определялись на следующих

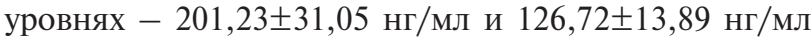
соответственно, что оказалось достоверно выше кон- 
центрации данного маркера среди здоровых детей, $(45,29 \pm 3,47$ нг/мл, $p<0,05)$.

При дальнейшем динамическом наблюдении за детьми на фоне соблюдения элиминационной диеты отмечено снижение содержания фекального кальпротектина у детей I и II групп уже на 7 день терапии, и на 14 сутки данный показатель составлял $168,23 \pm 18,57$ нг/мл и $106,28 \pm 8,91 н г /$ мл, р $<0,05$. Однако показатели зонулина у детей обоих групп оставались длительное время повышенными, с незначительной тенденцией к снижению на 14 сутки $(1,64 \pm 0,14$ нг/мл и 1,05 $\pm 0,09$ нг/мл, $p>0,05)$.

Выводы. Изучаемые биомаркеры обладают высокой диагностической значимостью при определении состояния кишечного барьера у детей с синдромом мальабсорбции. Для мониторирования состояния кишечного барьера на ранних этапах диетотерапии может использоваться фекальный кальпротектин.

\section{АСПЕКТЫ РАЗРАБОТКИ ОПРОСНИКА, КАК СРЕДСВА СКРИНИНГОВОЙ ДИАГНОСТИКИ ГАСТРОЭЗОФАГЕАЛЬНОЙ РЕФЛЮКСНОЙ БОЛЕЗНИ У ДЕТЕЙ \\ Саргсян С.А., Давыдова А.Н. \\ ФГБОУ ВО «Волгоградский государственный \\ медицинский университет» Минздрава России, Волгоград}

Введение. Гастроэзофагеальная рефлюксная болезнь (ГЭРБ) одно из наиболее частых заболеваний, поражающих пищевод. В последние годы зарубежные и отечественные исследователи отмечают рост заболеваемости ГЭРБ у детей с увеличением частоты желудочной и даже кишечной метаплазии слизистой оболочки пищевода. В связи с этим ранняя диагностика ГЭРБ в детской популяции является актуальной проблемой гастроэнтерологии.
Цель исследования - разработать опросник для выявления риска развития ГЭРБ у детей как средство скрининговой диагностики.

Материалы и методы. Разработка опросника проводилась на основании клинических рекомендации по диагностике и лечению ГЭРБ у детей. Первичная оценка валидности опросника проведена методом экспертных оценок.

Результаты. Была разработана форма, состоящая из 13 вопросов закрытого типа. Вопросы разделены на 3 блока. 1 блок - общая симптоматика при заболеваниях желудочно-кишечного тракта, в том числе и функциональных расстройствах. 2 блок -специфические симптомы при развитии ГЭРБ у детей. 3 блок - внепищеводная симптоматика.

Первичная валидация опросника проведена методом экспертных оценок. В качестве экспертов выступали практикующие врачи-педиатры, врачи-гастроэнтерологи, а также сотрудники кафедры педиатрии и неонатологии Института непрерывного медицинского и фармацевтического образования Волгоградского государственного медицинского университета.

По результатам обработки рецензий экспертов опросник доработан для продолжения дальнейшего процесса валидации, которая будет проведена на детях в возрасте 7-15 лет.

Заключение. В ходе исследования разработан опросник ранней диагностики ГЭРБ у детей. Считается необходимым проведение более детальных исследований, в ходе которых будет завершена окончательная валидация опросника. Процесс валидации будет состоять из нескольких этапов: расчет критериев информативности для исключения неинформативных вопросов; расчет порога принятия решений для бальной оценки риска развития ГЭРБ; оценка внутренней согласованности характеристик шкалы, оценка конвергентной и дискриминативной валидности опросника. 
Раздел 4

ЗДОРОВЫЙ РЕБЕНОК

И ПАТОЛОГИЯ ДЕТЕЙ

РАННЕГО ВОЗРАСТА 
РОЛЬ НЕЙРОСПЕЦИФИЧЕСКОЙ ЕНОЛАЗЫ У НЕДОНОШЕННЫХ ДЕТЕЙ С ПЕРИНАТАЛЬНЫМ ПОРАЖЕНИЕМ ЦНС

Агзамходжаева Б.У., Салихова К.Ш.

Республиканский специализированный научно -

практический медицинский центр Педиатрии, Ташкент, Узбекистан

Актуальность. Определение уровня нейроспецифической енолазы (НСЕ) в сыворотке крови является диагностический значимым и дает возможность рассматривать данный антиген в качестве биологического маркера повреждения нервной системы, т.к. повреждение нейронов на фоне гипоксически ишемического поражения ЦНС, приводит к высвобождению данного антигена в периферический кровоток.

Цель исследования. Изучение роли НСЕ при перинатальном поражении ЦНС у недоношенных новорожденных в зависимости от срока гестации.

Материалы и методы. Обследовано 49 детей недоношенных с перинатальным гипоксически-ишемическим поражением ЦНС на сроке гестации 29-35 недель. В зависимости от массы тела и срока гестации дети были разделены на следующие группы: первая группа - 12 (24,5\%) детей, родившиеся на 29-31 недели, средний вес при рождении 1032,3土36,6 г; вторая группа - 15 (30,6\%) детей - от 32 до 33 недель со средней массой тела $1374,3 \pm 106,2$ г; третья группа - $22(44,9 \%)$ от 34 до 35 недель с массой тела1784,2士106,2 г . Исследование НСЕ проводилось на 4е сутки, методом ИФА с с применением стандартных тест- систем «Fujirebio» (Швеция). Показатели НСЕ выражались в нг/мл.

Результаты. Частота перинатальных поражений ЦНС обратно пропорциональна гестационному возрасту. Это обусловлено, морфофункциональной незрелостью органов и систем, а так же высокой частотой осложнений в течение внутриутробного периода развития. Изучение уровня НСЕ у детей c перинатальными гипоксически-ишемическими поражениями ЦНС показало достоверное увеличение его содержания в сыворотке крови во всех группах. Его средние значения у детей первой группы на $4-5$ е сутки составили $64,3 \pm 9,0$ нг/мл, во второй группе - 86,8土9,7 нг/мл, в третьей группе $89,2 \pm 6,6$ нг/мл, в нормативных данных этот показатель составил $8,8 \pm 1,9$ нг/мл. Это указывает на значительное повышение (2-4 раза) данного белка у недоношенных с ГИЭ.

Заключение. При перинатальном поражении ЦНС у недоношенных новорожденных высокий уровень содержания HCE свидетельствуют о наличии нарушения проницаемости гематоэнцефалического барьера, отмечена зависимость исследуемого показателя от гестационного возраста: чем меньше гестационный возраст, тем более высокие показатели НСЕ.

\section{СРАВНИТЕЛЬНАЯ ОЦЕНКА ЭФФЕКТИВНОСТИ ДИЕТОДИАГНОСТИКИ ПИЩЕВОЙ АЛЛЕРГИИ У ДЕТЕЙ ПЕРВОГО ГОДА ЖИЗНИ}

Алексеева А.А., Шелудько Е.Ю., Катенкова Э.Ю.,

Цветкова М.М., Приходченко Н.Г.

ФГБОУ ВО ТГМУ Минздрава России, Владивосток

Введение. Пищевая аллергия у детей первого года жизни является актуальной медицинской и социально-экономической проблемой. Основным методом ее своевременной диагностики является элиминационная диетотерапия. Большое значение для оценки ее эффективности имеет оценка пищевого дневника. На настоящий момент возникает трудность интерпретации и оценки пищевого дневника, особенно в условиях современной эпидемиологической обстановки.

Цель исследования - разработка электронного пищевого дневника и оценка его эффективности по сравнению с традиционным пищевым дневником.

Материалы и методы. На первом этапе был разработан электронный дневник, в котором отображалась дата заполнения, время приема пищи, меню ребенка и мамы, патологические симптомы и время их появления. Электронный пищевой дневник был предложен для заполнения 10 мамам пациентов с гастроинтестинальной пищевой аллергией, находящимся на ГВ. Период наблюдения составил 1 месяц. Группой сравнения явились 10 пациентов, которые заполняли традиционный пищевой дневник. Анализировалась правильность заполнения мамами дневника, эффективность и наглядность предоставляемой информации, возможность удаленного доступа к электронному пищевому дневнику врача-специалиста.

Результаты. При анализе пищевых дневников было установлено, что все пациенты имели гастроинтестинальные и/или кожные проявления. Симптомы со стороны ЖКТ встречались у 100\%пациентов и характеризовались появлением слизи и/или крови в стуле, кишечными коликами и обильными срыгиваниями. У 80 \% (16 человек) отмечались кожные высыпания, сухость, гиперемия кожи. Анализируя пищевые дневники, было выявлено, что у $90 \%$ детей причинами обострений было употребление мамами продуктов на основе белков коровьего молока, куриного яйца и пшеницы, употребление других продуктов из «большой восьмерки» аллергенов встречалась в 20\% случаев. При сравнительной оценке традиционных и электронных пищевых дневников, установлено, что электронный пищевой дневник имеет ряд преимуществ: доступность, систематический контроль над патологическими появлениями, возможность удаленных коммуникаций $(p=0,008)$.

Заключение. Внедрение в практическую медицину электронного пищевого дневника с последующей оценкой его эффективности, поможет врачу проследить взаимосвязь между употребелением продуктов питания и появлением симптомов. 


\section{ОСОБЕННОСТИ ЦЕРЕБРАЛЬНОЙ}

ГЕМОДИНАМИКИ У ДЕТЕЙ, РОЖДЕННЫХ

ЖЕНЩИНАМИ С ГЕСТАЦИОННЫМ

САХАРНЫМ ДИАБЕТОМ

Афонин А.А., Бабияни А.Я., Бережанская С.Б.,

Панова И.В., Созаева Д.И., Кравченко Л.В., Афонина Т.А., Домбаян С.X.

ФГБОУ ВО РостГМУ Минздрава России, Ростов-на-Дону

Введение. Медико-социальное значение гестационного сахарного диабета (ГСД) определяется высокой частотой неблагоприятных исходов беременности как для матери, так и для новорожденного. В структуре заболеваемости данного контингента новорожденных лидирующее положение занимает патология центральной нервной системы (ЦНС), в развитии которой ведущая роль отводится нарушениям церебральной гемодинамики.

Цель исследования - определение особенностей церебральной гемодинамики у детей первого года жизни, рожденных женщинами с гестационным сахарным диабетом.

Материалы и методы. В исследование включено 50 детей, родившихся у женщин с ГСД. Всем детям проводилось допплерометрическое исследование артериального и венозного кровотока при рождении и в динамике на протяжении первого года жизни.

Результаты. Установлено, что у всех наблюдаемых детей имело место перинатальное поражение ЦНС. K концу года церебральные нарушения сохранялись у $42 \%$ больных. Динамика показателей мозгового кровотока в бассейнах среднемозговых (СМА) и переднемозговых артерий (ПМА) характеризовалась стабильным (с рождения и на протяжении первого года жизни) повышением индекса резистентности (IR) относительно контрольных данных у всех детей $(p<0,02)$. При этом независимо от исхода заболевания к концу года значения IR в артериях каротидного бассейна были достоверно выше контрольных данных $(p<0,01)$. Показатели венозного оттока также во все сроки наблюдения достоверно отличались от контрольных значений $(p<0,02)$.

Заключение. У детей, рожденных женщинами с ГСД отмечаются нарушения артериального и венозного мозгового кровотока, стойко сохраняющиеся на протяжении первого года жизни, включая пациентов с исчезновением клинических проявлений церебральной патологии к концу года, что обосновывает необходимость дальнейшего наблюдения и продолжения лечебных и реабилитационных мероприятий под контролем показателей мозгового кровотока.

\section{ПРОЦЕССЫ ЛИПОПЕРОКСИДАЦИИ \\ И АНТИОКСИДАНТНАЯ АКТИВНОСТЬ В УСЛОВИЯХ КАТАБОЛИЧЕСКИХ ПРОЦЕССОВ В СОЕДИНИТЕЛЬНОЙ ТКАНИ У ДЕТЕЙ С ВРОЖДЕННЫМ ВЫВИХОМ БЕДРА}

Белова Ю.С., Гладилин Г.П.

ФГБОУ ВО Саратовский государственный медицинский университет им. В.И. Разумовского Минздрава России, Саратов

Введение. Врожденный вывих бедра относится к тяжелой форме дисплазии тазобедренного сустава, которая обусловлена нарушением развития всех суставных структур в процессе пре- и постнатального онтогенеза. Соединительно-тканая патология характеризуется превалированием катаболических процессов над анаболическими, при этом хорошо известна негативная роль активации процессов липопероксидации в развитии типовых патологических процессов.

Цель исследования: изучение процессов липопероксидации и антиоксидантной активности в условиях активации катаболических процессов у детей с врожденным вывихом бедра.

Материалы и методы. В исследование вошли 11 практически здоровых детей и 42 ребенка с врожденным вывихом бедра. Всем детям проводилась рентгенография и лабораторное обследование. Изучались процессы липопероксидации (гидроперекиси, малоновый диальдегид), и антиоксидантная активность (тиоловые соединения, церулоплазмин), оценивающая состояние антиоксидантной системы, а также определялось состояние катаболических процессов в соединительной ткани (хрящевой олигомерный матриксный протеин). Статистическая обработка полученных цифровых данных проводилась с помощью программ Statistica 10,0 с использованием методов непараметрической статистики.

Результаты. У обследованных детей с врожденным вывихом бедра отмечалась активация процессов липопероксидации, судя по существенному повышению содержания гидроперекисей $\left(p=1,01 \cdot 10^{-5}\right)$ и малонового диальдегида $\left(p=9,32 \cdot 10^{-5}\right)$, при этом наблюдалось снижение уровня тиоловых соединений $\left(p=9,63 \cdot 10^{-7}\right)$ и повышение церулоплазмина $\left(p=1,7 \cdot 10^{-6}\right)$, что указывало на несостоятельность антиоксидантной системы. Повышенное содержание хрящевого олигомерного матриксного протеина $\left(p=2,22 \cdot 10^{-4}\right)$ свидетельствовало об активации катаболических процессов в соединительной ткани, Приведенные выше изучаемые параметры имели статистически достоверное отличие от аналогичных показателей в контрольной группе практически здоровых детей.

Заключение. В ходе работы были установлены изменения показателей, касающиеся активации процессов липопероксидации и несостоятельности 
антиоксидантной системы в условиях активации катаболических процессов в соединительной ткани. Представленный комплекс изученных показателей может быть полезен в объективизации состояния детей с врожденным вывихом бедра, а также в оценке эффективности терапии препаратами антиоксидантного и хондропротекторного действия.

\section{ПАТОГЕНЕТИЧЕСКИЕ АСПЕКТЫ РЕГУЛЯЦИИ АНГИО- И НЕЙРОГЕНЕЗА У НОВОРОЖДЕННЫХ С ЦЕРЕБРАЛЬНЫМИ НАРУШЕНИЯМИ}

Бережанская С.Б., Лукьянова Е.А., Абдурагимова М.Х., Созаева Д.И., Пузикова О.З., Попова В.А. ФГБОУ ВО РостГМУ (НИИАП) МЗ РФ, Ростов-на-Дону

Введение. Фактор роста эндотелия сосудов (VEGF-A165) является первичным регулятором ангиогенеза, стимулируя пролиферацию, миграцию и образование трубок эндотелиальных клеток. Но VEGF-A165 не является исключительно эндотелиальным медиатором и может представлять один из лучших примеров общих сигнальных механизмов в нервно-сосудистой единицеVEGF-A165 и его рецепторы не только лежат в основе формирования и гомеостаза сосудов, но также экспрессируются в астроцитах, а передача сигналов VEGF-A165 играет ключевую роль в миграции нейронов и развитии ЦНС.

Цель - опрелелить уровень и взаимосвязи между VEGF-A165 и его рецепторами и их роль в формировании церебральной патологии гипоксически-ишемического генеза.

Материалы и методы. Проведено определение уровня VEGF-A165 и его рецепторов (VEGF-R1, VEGF-R2) наборами ELISA (Австрия) в пуповинной крови у 22 новорожденных со средне-тяжелой гипоксией-ишемией (I группа) и 20 детей тяжелой церебральной гипоксией-ишемией (II группа). Контрольную группу составили 20 здоровых детей, рожденных при физиологически протекавшей беременности и родах.

Результаты. Заявлена высокая распространенность патологии матерей в обеих группах, что определяет в конечном итоге постнатальные расстройства из-за хронической внутриутробной гипоксии. Уровень VEGF-A165 у новорожденных с тяжелой церебральной ишемией (II группы) почти в три раза превышал аналогичный показатель у новорожденных I группы. Представляет интерес соотношение рецепторов, выявившее кратное превышение уровня VEGF-R2 к VEGF-R1, предотвращающему избыточный ангиогенез на фоне повышенной в условиях гипоксии активности фактора роста. В то же время сохраняются, а возможно и повышаются в условиях тяжелой гипоксии, функции VEGF-R2, который запускает сложный каскад внутриклеточных реакций, миграцию и пролиферацию эндотелиоцитов, устойчивость их к апоптотическим факторам, нарушению проницаемости сосудистой стенки, что обеспечивает сохранение нормального ангио- и нейрогенеза в постнатальном периоде.

Заключение. Ангиогенный пептид VEGF-A165 и его рецепторы могут являться диагностическими критериями тяжести гипоксии-ишемии, повреждений головного мозга, поскольку они тесно связаны с воздействием гипоксии.

\section{УРОВЕНЬ ЭРИТРОПОЭТИНА В АРТЕРИАЛЬНОЙ И ВЕНОЗНОЙ КРОВИ ПУПОВИНЫ В УСЛОВИЯХ ПЕРИНАТАЛЬНОЙ ГИПОКСИИ}

Бережанская С.Б., Лукьянова Е.А., Абдурагимова М.Х., Созаева Д.И.

ФГБОУ ВО РостГМУ Минздрава России, Ростов-на-Дону

Введение. В последние десятилетия эритропоэтин (ЭПО) привлекает внимание как неэритропоэтический полифункциональный фактор, обладающий тканезащитными свойствами, основанными на его противовоспалительном, антиапоптотическом, антиоксидантном, ангиогенном и нейротрофическом эффектах. Этим определяется повышение его уровня в условиях гипоксии в плаценте, у плода и новорожденного.

Цель исследования. Сравнение уровня эритропоэтина в артерии и вене пуповины в зависимости от тяжести гипоксически-ишемического поражения головного мозга.

Материал и методы. Обследовано 92 доношенных новорожденных со средне-тяжелым (І группа) и тяжелым гипоксически-ишемическим поражением ЦНС (II группа). Контрольную группу составили 25 новорожденных, родившихся у здоровых женщин при благоприятном течение беременности. Исследование уровня эритропоэтина в сыворотке крови из артерии и вены пуповины проводили набором реагентов «Эритропоэтин-ИФА-БЕСТ» (Россия).

Результаты. При определении уровня эритропоэтина в сыворотке артериальной и венозной крови пуповины у новорожденных обеих групп по сравнению со здоровыми отмечены достоверные отличия показателей. Особый интерес представляет сопоставление во всех обследованных группах концентрации ЭПО в сыворотке крови артерии и вены пуповины. Выявлено, что в условиях нормоксии (в контрольной группе) уровень изучаемого показателя в артерильной крови в большинстве наблюдений был выше, чем таковой в венозной, что может указывать на компенсаторные возможности плода увеличивать выброс ЭПО, обеспечивая адекватные роды. Напротив, при гипоксии уровень ЭПО в пупочной вене был достоверно выше, чем в артерии, что свидетельствовало о росте плацентарной секреции ЭПО в антенатальном периоде. 
В динамике неонатального периода имела место однонаправленность изучаемого показателя, характеризовавшаяся снижением к 5-6 дню во всех группах, с последующим повышением к 28 дню жизни в группе детей с тяжелым поражением. Наиболее высокие, достоверно значимые от здоровых, показатели во все изучаемые сроки наблюдались у детей с церебральной ишемией III степени.

Заключение. В условиях перинатальной гипоксии уровень эритропоэтина повышается в зависимости от тяжести гипоксически-ишемического поражения ЦНС, что позволяет предполагать о его диагностической и прогностичекой значимости с первых часов жизни.

\section{ОСОБЕННОСТИ СОСТОЯНИЯ СИСТЕМЫ МИКРОЦИРКУЛЯЦИИ У ДЕТЕЙ, ПЕРЕНЕСШИХ ОСТРЫЙ БРОНХИОЛИТ}

Бережанский П.В., Коваленко И.В., Елагина В.И. ГБУЗ «Морозовская ДГКБ ДЗМ», Москва

Сибирский юридический институт МВД России, Красноярск

Фармацевтический колледж КрасГМУ им.

проф. В.Ф.Войно-Ясенецкого Минздрава России, Красноярск

Введение. Заболеваемость вирусными инфекциями с поражением нижних дыхательных путей достигает 11 - $12 \%$ среди детей младше 12 месяцев. Вирусный бронхиолит - это частый клинический синдром, поражающий детей грудного и раннего возраста. Четкие инструментально-лабораторные показатели активности бронхиолита в настоящее время отсутствуют.

Цель исследования: дать характеристику показателей микроциркуляции и определить их взаимосвязь с параметрами вегетативной нервной системы у детей перенесших острый бронхиолит.

Материалы и методы В условиях стационара было обследовано 24 ребенка в возрасте от 0 до 9 месяца перенесших острый бронхиолит и 12 практически здоровых детей. Оценка состояния микроциркуляторного русла осуществлялась методом компьютерной капилляроскопии ногтевого ложа.

Результаты. В результате обследования выявлено, что у пациентов с острым бронхиолитом группы имелись более существенные изменения микроциркуляторных показателей (увеличена зона переваскулярного отека, склонность к дилятированию венозного отдела, высокий артериоло-венулярный индекс) по сравнению со здоровыми детьми.

Показатель неравномерности калибра венул у детей перенесших бронхиолит был выше по сравнению с группой сравнения (соответственно 0,91 $\pm 0,2$ и $0,69 \pm 0,3$ мкм; $p>0,05)$. Так же было установлено, что чем тяжелее была степень дыхательной недоста- точности (ДН), тем выше был показатель неравномерности калибра венул (ДН $1-0,85 \pm 0,18$ мкм. ДН $2-0,98 \pm 0,12$ мкм; $p<0,05)$. Дети с более высоким показателем неравномерности венул дольше находились на стационарном лечение вне зависимости от степени дыхательной недостаточности, что может являться скринингом оценки «эффективности микроциркуляторного русла» и степени тяжести течения заболевания.

Заключение. Таким образом, предварительные результаты свидетельствуют о том, что у детей грудного возраста, перенесших острый бронхиолит, имеются значительные микроциркуляторные нарушения, что может являться маркером патологической активности и поможет в будущем индивидуализировать тактику ведения и прогнозирования течения заболевания у детей с различными предрасполагающими факторами.

\section{ХАРАКТЕРИСТИКА ФИЗИЧЕСКОГО РАЗВИТИЯ СОВРЕМЕННЫХ ПОДРОСТКОВ}

Галактионова М.Ю. ${ }^{1}$, Махова А.С. ${ }^{3}$, Галактионова М.А. ${ }^{1}$, Лисихина Н.В. ${ }^{1,2}$, Чеснокова Л.Л. ${ }^{1}$

${ }^{1}$ Красноярский государственный медицинский университет имени проф. В.Ф. Войно-Ясенецкого ${ }^{2}$ Сибирский юридический институт МВД России, Красноярск

${ }^{3}$ детская поликлиника ФГБУЗ Клинической больницы №51 ФМБА России, Железногорск

Введение. Уровень и гармоничность физического развития подростков характеризуют адекватность общебиологических, социально-гигиенических и медико-организационных условий жизни.

Цель - изучить тенденции физического развития (ФР) современных подростков.

Материалы и методы. Проведено обследование 499 юношей и девушек в возрасте от 15-ти до 18-ти лет на базе детской поликлиники КБ№51 г. Железногорска. Анализировали показатели ФР: соматометрические (длина, масса тела, окружность грудной клетки), физиометрические (мышечная сила кистей рук, жизненная емкость легких) и соматоскопические (степень полового созревания).

Результаты. Средний уровень ФР имели 49,5\% юношей и 56,2\% девушек. Высокий уровень ФР имели 5,6\% подростков, в равной степени, как юноши, так и девушки. Низкий уровень ФР определялся у $30 \%$ подростков. С возрастом число лиц со средним ФР уменьшилось с 50,9\% среди подростков 15 -ти лет, до 45,5\%- в возрасте 18 -ти лет. Также отмечалось увеличение числа юношей со средним и ниже среднего уровнем ФР (15 лет- 46,4\% и 12,9\%; 18 лет$53,8 \%$ и $23,1 \%$ ) и девушек с уровнем ФР выше среднего (15 лет- 28,4\%; 18 лет- 55,6\%). Дисгармоничное ФР за счет ИМТ чаще регистрировалось у девушек 
в возрасте 18 -ти лет $(33,3 \%)$ и юношей в возрасте 16-ти лет (20,1\%). Дефицит массы тела чаще имели юноши в возрасте $17-$-и лет $(13,2 \%)$ и девушки в возрасте 17-ти лет $(17,8 \%)$. Избыток массы тела, превышающий 97 центиль, регистрировался одинаково часто среди юношей и девушек (6,9\% и 6,8\%), ожирение верифицировано соответственно у 4,9\% и $5,5 \%$. Показатели динамометрии с возрастом увеличивались, при этом средние показатели силы правой руки у подростков в возрасте 17-ти лет были несколько ниже 16-ти летних. Средняя величина жизненной емкости легких (ЖЕЛ) у обследованных составила $2631,36 \pm 52,74$ мл. Оценка соматоскопических параметров указывала на преобладание степени полового созревания, соответствующей биологическому возрасту, как среди юношей $(75,35 \%)$, так и среди девушек $(74,35 \%)$.

Таким образом, значительная часть подростков имеет дисгармоничные варианты физического развития. Факторами, способствующими возникновению отклонений в физическом развитии, является, несбалансированное питание, нарушение пищевого поведения и гиподинамия.

\section{ОСОБЕННОСТИ ФОРМИРОВАНИЯ ЗДОРОВЬЯ ДЕТЕЙ ПОДРОСТКОВОГО ВОЗРАСТА}

Галактионова М.Ю., Лисихина Н.В., Галактионова М.А, Алексеенко Е.A.

ФГБОУ ВО КрасГМУ им. проФ. В.Ф. Войно-Ясенецкого Минздрава России, Красноярск

Введение. Здоровье подростков социально обусловлено и зависит от различных факторов: состояния окружающей среды, здоровья родителей и наследственности, условий жизни и воспитания ребенка в семье, общеобразовательном учреждении. Значимыми факторами, формирующими здоровье детей подросткового возраста, являются система воспитания и обучения, включая физическое воспитание, охрану психического здоровья, а также организация медицинской помощи.

Цель исследования - вывить некоторые медикосоциальные аспекты формирования здоровья подростков с целью улучшения качества жизни.

Материалы и методы. Объектом исследования явились подростки 12-17 лет и их семьи, находившиеся под наблюдением медицинских работников КГБУЗ «Красноярская городская детская больница №8». Изучаемые социальные группы формировались сплошным методом выборки, в качестве критерия распределения по группам сравнения нами был взят фактор социально-демографического характера. Здоровье, факторы внутренней среды и причинно-следственные связи между ними изучались путем сравнения в полных и неполных семьях.
Результаты. Значительные изменения, произошедшие в физическом развитии данной категории детей, явились основанием для рассмотрения этого показателя, в качестве определяющего во взаимосвязи с влиянием различных факторов риска. Наименьший процент обследованных имели нормальное физическое развитие в семьях с низким образовательным уровнем $(81,4 \%$ человек, $p=0,435)$. Количество подростков с замедленным физическим развитием преобладало в группе, матери которых были рабочими $(p=0,02)$. Отклонения в виде замедления темпов физического развития отмечалось в четыре раза чаще у подростков, матери которых имели хроническую патологию (8,0\% и 2,0\% соответственно, $p=0,02)$. Замедления темпов физического развития в 2,7 раз чаще наблюдалось у подростков, воспитывающихся в конфликтной домашней обстановке $(p=0,05)$. Ускоренное физическое развитие, наоборот, в 1,5 раза чаще регистрировалось при благополучной домашней обстановке. Питание остается одной из основных проблем здоровья и развития детского населения. Дети этого возраста все в большей мере проявляют свои предпочтения в плане еды и начинают действовать независимо в отношении своего рациона питания. В иелом, нерегулярное питание подростков в семьях медико-демографического риска отмечается в 1,5 раза чаще, чем в группе подростков из полных семей и составляет 20,5\% и 31,3\% соответственно ( $p=0,006)$. Обращает внимание, что в $17,8 \%$ семей медико-демографического риска исследуемые, (при нормативе не менее четырех раз), получают пищу только три раза в день, а 2,8\% - один-два раза в день, то есть фактически голодают. Результаты социологического исследования показали, что каждый третий подросток из числа опрошенных респондентов $(34,9 \%)$ проживает в неполной семье, чаще только с матерью, что способствует ослаблению социализации подростков. Достоверно доказано, что подростки из неполных семей чаще $(p=0,001)$ проживали в неблагоустроенных квартирах, не имея своей комнаты для отдыха и занятий. условия жизни подростков из семей медико-демографического риска заметно хуже, чем условия проживания подростков из полных семей. Такое жилищное неблагополучие безусловно сказывается в дальнейшем отрицательно как на соматическом, так и на психическом здоровье подростков.

Заключение. В условиях низкой санитарно-гигиенической культуры населения подростки в семьях не получают необходимых знаний и навыков по заботе о физическом, нравственном и психическом здоровье. Поэтому возникает необходимость как развития социальных служб помощи семьи и подросткам, что должно способствовать активизации роли семьи, ее охранительной, воспитательной и оздоровительной функций, так и оказания медико-социальной помощи в условиях учреждений здравоохранения. 


\section{МЕДИКО-БИОЛОГИЧЕСКИЕ КРИТЕРИИ ЗАБОЛЕВАЕМОСТИ МАЛОВЕСНЫХ НЕДОНОШЕННЫХ}

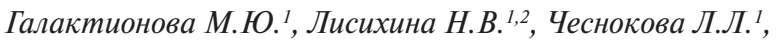
Махова А.C. ${ }^{3}$

${ }^{1}$ Красноярский государственный медицинский университет имени проф. В.Ф. Войно-Ясенецкого ${ }^{2}$ Сибирский юридический институт МВД России, Красноярск

${ }^{3}$ детская поликлиника ФГБУЗ Клинической больницы №51 ФМБА России, Железногорск

Введение. Недоношенные дети с очень низкой (ОНМТ) и с экстремально низкой массой тела (ЭНМТ) вносят значительный вклад в формирование показателей перинатальной и младенческой смертности, они подвержены высокому риску развития заболеваний и осложнений, которые могут стать фатальными или наложить отпечаток на состояние здоровья в последующие периоды.

Цель исследования - изучить факторы риска и структуру заболеваемости недоношенных детей на первом году жизни.

Материалы и методы. Проведен ретроспективный анализ форм №112/у недоношенных детей за 20172019 годы (72 ребенка). Первая группа включала 24 ребенка с ЭНМТ, родившихся в 28-29 недель беременности, во вторую группу вошли 48 детей, родившихся на сроке гестации от 30 до 37 недель с ОНМТ. Оценка физического развития проводилась по таблицам Т.М. Дементьевой и соавт. (1981), оценка нервно-психического развития проводилась с помощью шкалы И.М. Воронцова.

Результаты. Большинство матерей обеих групп находились в среднем репродуктивном возрасте (с 18 до 25 лет), низкий социально-гигиенический уровень и вредные привычки выявлен у $1 / 4$ матерей обеих групп. Отягощенный акушерский анамнез и хроническая соматическая патология зарегистрированы у всех матерей; гинекологические заболевания у $75 \%$ матерей первой и $62 \%$ второй группы, бесплодие - у $25 \%$ женщин. В структуре заболеваемости детей с ЭНМТ превалировала патология органов дыхания, признаки задержки внутриутробного развития (ЗВУР), врожденные пороки сердца (ВПС)- 100\%, на втором месте заболевания ЦНС75\%. Недоношенных с ОНМТ характеризовали в $100 \%$ случаев заболевания ЦНС, внутриутробная гипоксия и ЗВУР - 50\%. На первом году жизни у $100 \%$ детей с ЭНМТ регистрировались анемия, рахит, бронхолегочная дисплазия, заболевания ЦНС - 75\%, пневмония, ОРВИ - 25\%, отставание в нервно-психическом развитии $-25 \%$, отставание в физическом развитии $-75 \%$. У всех детей с ОНМТ диагностированы заболевания ЦНС, у $75 \%$ - ОРВИ, у 37,5\%- рахит, анемия, дисгармоничное физическое развитие $(37,5 \%)$. Незрелые к своему гестационному возрасту были $100 \%$ детей с ЭНМТ и $62,5 \%$ с ОНМТ.

Заключение. Показатели заболеваемости глубоко недоношенных младенцев обусловлены наличием у них с рождения бронхолегочной дисплазии, ВПС, незрелости органов и систем.

\section{КЛИНИЧЕСКАЯ ОЦЕНКА ЭФФЕКТИВНОСТИ АМИНОКИСЛОТНОЙ СМЕСИ У ДЕТЕЙ 1-ГО ГОДА ЖИЗНИ С ЭКЗЕМОЙ \\ Давыдова А.Н. \\ ФГБОУ ВО «Волгоградский государственный медицинский университет» Минздрава России, Волгоград}

Введение. Экзема - нередко встречающаяся проблема у детей 1-го года жизни. Это кожное заболевание возникает с первых месяцев жизни, имеет склонность к рецидивированию. Одной из главных причин развития болезни является наследственная предрасположенность, реализация которой провоцируется множеством эндогенных и экзогенных факторов.

Цель исследования - оценить клиническую эффективность аминокислотной смеси в комплексной терапии экземы у детей в возрасте от 6 до 12 месяцев.

Материалы и методы. Клиническая оценка проводилась на 14, 30 и 60 сутки от начала диетотерапии у 17 пациентов с экземой, которые получали лечение в соответствии с клиническими рекомендациями.

Результаты. В процессе комплексного лечения у всех пациентов отмечалась положительная динамика. У 9 пациентов медикаментозная коррекция была завершена на 14-21 сутки, 8 детей из группы продолжали получать комплекс лечебных мероприятий до 28-30 дней. Следует отметить, что после окончания лечения (медикаментозного), у всех детей выявлен регресс кожных проявлений, улучшение физических и психоэмоциональных показателей. На втором месяце использования аминокислотной смеси только у 4 пациентов сохранялось незначительное повреждение кожных покровов в виде мелкоточечной сыпи без зуда.

Заключение. В ходе исследования была доказана клиническая эффективность аминокислотной смеси в составе комплексной терапии экземы у детей в возрасте от 6 до 12 месяцев. Необходимость длительного использования лечебного продукта продиктована особенностями течения заболевания и высокой вероятностью возникновения рецидивов у детей. 


\section{ОЦЕНКА ПСИХОМОТОРНОГО РАЗВИТИЯ НЕДОНОШЕННЫХ ДЕТЕЙ ДО И ПОСЛЕ ИММУНОПРОФИЛАКТИКИ ПРЕПАРАТОМ ПАЛИВИЗУМАБ}

Демьяник М.А., Дроздова Е.Ю., Зайцева И.Н., Лопатина O.B.

Детская городская клиническая больница №8, Челябинск

Введение. Совершенствование методов интенсивной терапии у недоношенных детей привело к проблеме формирования у данного контингента больных хронических заболеваний легких, тяжелого течения РСВ инфекции. Частые респираторные заболевания увеличивают риск развития отставания в психомоторном развитии младенца на фоне гипоксемии.

Цель исследования. Оценить психомоторное развития недоношенных детей до и после иммунопрофилактики препаратом Паливизумаб.

Материалы и методы. В исследование включено 15 недоношенных детей в возрасте от 4 -х месяцев до 20 месяцев жизни с диагнозом бронхолегочная дисплазия, имеющих высокий риск развития тяжелой РСВ-инфекции. Среди наблюдавшихся было 8 мальчиков, 7 девочек. Оценка психомоторного развития проводилась неврологом по шкале Л.Т. Журбы, Е.М. Мастюковой (1981) до и после иммунизации. Наблюдение каждого ребенка продолжалось в течение года.

Результаты. Все дети были рождены от матерей старше 30-ти лет с крайне отягощенным акушерско-гинекологическим анамнезом. В неврологическом статусе в $100 \%$ случаев регистрировалась темповая задержка моторного развития (3МР) в сочетании с мышечной дистонией. До начала курса иммунопрофилактики оценка психомоторного развития детей по шкале развития была ниже нормы и составила 25-26 баллов. Все пациенты относились к группе риска по формированию двигательных нарушений и ЗМР. Благодаря снижению частоты и тяжести течения вирусных инфекций после иммунопрофилактики Паливизумабом все наблюдаемые дети прошли комплексную медицинскую реабилитацию. В $100 \%$ случаев показатели моторного развития улучшились, оценка по шкале развития составила 27-28 баллов, что являлось условно-возрастной нормой на текущий период наблюдения. Отмечалась хорошая адаптация к физическим нагрузкам во время реабилитации у $70 \%$ детей.

Заключение. Иммунопрофилактика Паливизумабом способствовала снижению заболеваемости недоношенных детей и повысила компенсаторные возможности организма к физической нагрузке. В свою очередь, это позволило провести в полном объеме своевременную медицинскую реабилитацию и улучшило психомоторное развитие недоношенного ребенка по шкале Л.Т. Журбы, Е.М. Мастюковой (1981) в дальнейшие возрастные периоды жизни.

\section{ФИЗИОМЕТРИЧЕСКИЕ ПОКАЗАТЕЛИ СОВРЕМЕННЫХ 7 ЛЕТНИХ ДЕТЕЙ}

Дианова Т.И., Иванова О.Н., Бушуева Э.В.,

Викторова Т.Г., Еремеева Л.Ф., Карзакова Т.А.

ФГБОУ ВО «Чувашский государственный университет

имени И.Н. Ульянова», Чебоксары

Введение. Физическое развитие растущего организма является одним из основных показателей здоровья ребенка. Наибольшее влияние на уровень здоровья оказывает образ жизни: двигательная активность, ментальные нагрузки, характер питания, полноценный отдых. Динамичность показателей физического развития требует оценки функционального состояния организма и физической подготовленности.

Цель исследования. Сравнить физиометрические показатели современных первоклассников с первоклассниками конца 20 века.

Материалы и методы. Оценили показатели жизненной емкости легких (ЖЕЛ), силу мышц правой кисти, частоту сердечных сокращений (ЧСС), систолическое артериальное давление (САД), диастолическое артериальное давление (ДАД) у 208 детей 7 лет (мальчиков 94 (45\%), девочек 114(55\%)), проживающих в Чувашской Республике. Сопоставили полученные данные с нормами и с физиометрическими показателями 7 летних детей 1999 года.

Результаты. ЖЕЛ мальчиков составила 1,26 $\pm 0,08$ л, что больше на 0,15 л чем у детей 1999 года, сила

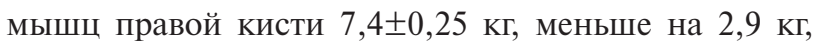
ЧСС $81 \pm 2,01$ ударов в минуту, меньше на 7 ударов в минуту, САД 108 $\pm 0,96$ мм.рт.ст, больше на 9,2 мм.рт.ст, ДАД 66,8土1,09мм.рт.ст., больше на 10,1мм. рт.ст.. ЖЕЛ девочек $1,27 \pm 0,07 л$, что больше на 0,16 л чем у детей 1999 года, сила мышц правой кисти

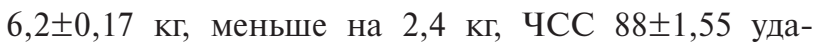
ров в минуту, больше на 2 удара в минуту, САД $103 \pm 0,81$ мм.рт.ст, больше на 9,2мм.рт.ст, ДАД

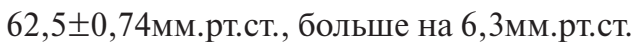

Заключение. Наблюдается разнонаправленность физиометрических показателей как у мальчиков, так и у девочек. Отмечается увеличение ЖЕЛ, снижение силы мышц кисти, увеличение САД и ДАД без гендерных различий, при этом ЧСС у мальчиков снижется, а у девочек имеет небольшое увеличение.

\section{ПЕРВЫЙ ОПЫТ ПРИМЕНЕНИЯ ПРЕПАРАТА ПАЛИВИЗУМАБ \\ Дроздова Е.Ю., Лопатина О.В., Фомина А.С., \\ Черкашина А.Л. \\ Детская городская клиническая больница №8, Челябинск}

Введение. Развитие перинатальной медицины и совершенствование методов интенсивной терапии новорожденных позволило повысить выживаемость 
детей с низкой массой тела, что актуализировало проблему формирования у данного контингента больных хронических заболеваний легких, прежде всего бронхолегочной дисплазии (БЛД). Такие дети относятся к группе высокого риска тяжелого течения респираторных заболеваний, в частности РСВ-инфекции, что увеличивает риск развития гипоксемии, апноэ, дыхательной недостаточности, с возможной последующей инвалидизацией и повышением заболеваемости.

Цель исследования - изучить переносимость и эффективность иммунопрофилактики препаратом Паливизумаб недоношенных детей.

Материалы и методы. В исследование включено 20 недоношенных детей (4 мес.-20 мес.), состоящих на учете в Городском отделении мониторинга ДГКБ №8 г. Челябинска с диагнозом БЛД средней и тяжелой степени тяжести, получающих базисную терапию.

Наблюдение каждого ребенка проводилось ежеквартально на протяжении года и ежедневно на этапе реабилитации.

Результаты. Иммунизация Паливизумабом у наблюдаемых детей за период с июня 2019 по август 2020 года показала отличную переносимость препарата. В течение первых 6 месяцев после вакцинации, респираторных инфекций у детей не отмечалось вообще.

В последующие 6 месяцев в 93\% случаев течение респираторных заболеваний оценивалось как легкая форма ОРВИ, не требующая усиления базисной терапии и госпитализации. Госпитализации в профильное отделение потребовал только один ребенок с ДЗ: БЛД на фоне врожденного порока легких с признаками дыхательной недостаточности.

Благодаря снижению частоты и тяжести заболеваний после вакцинации Паливизумабом все пациенты смогли пройти комплексную медицинскую реабилитацию в полном объеме. В $100 \%$ случаев показатели моторного и физического развития улучшились, контроль над массой тела в ходе реабилитации наблюдаемого периода не выявил отклонений.

Заключение. Иммунопрофилактика Паливизумабом показала отличную переносимость и эффективность у недоношенных детей. Снижение заболеваемости таких детей способствовало улучшению физического развития и повышению компенсаторных возможностей организма к физической нагрузке. Ставшая возможной комплексная медицинская реабилитация снизила риск формирования заболеваний и патологических состояний в последующие возрастные периоды.

\section{РЕАКТИВНОСТЬ ВЕГЕТАТИВНОЙ НЕРВНОЙ СИСТЕМЫ У ДЕТЕЙ С ДИСПЛАЗИЕЙ СОЕДИНИТЕЛЬНОЙ ТКАНИ}

Елизарова С.Ю., Сидорович О.В., Просова Е.Е., Хижняк А.В., Кузнецова Н.А.

ФГБОУ ВО Саратовский ГМУ им. Разумовского В.И. Минздрава России

Введение. Важным показателем состояния ВНС является показатель ее реактивности. Реактивность ВНС отражает скорость мобилизации энергетических ресурсов организма на внешний раздражитель, и в нашем случае определялась по выраженности глазосердечного, синокардиального и солярного рефлексов.

Материалы и метод. Основная группа 30 детей в возрасте от 11 до 15 лет с дисплазией соединительной ткани, контрольная группа 30 здоровых детей того же возраста. Реактивность ВНС определялась по глазосердечному, синокардиальному рефлексу. Проводиловь ЭКГ и кардиоинтервалография.

Глазосердечный рефлекс у детей без НДСТ в воз-

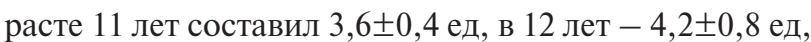
в 13 лет $-5,1 \pm 0,6$ ед и в 15 лет выражался величиной,

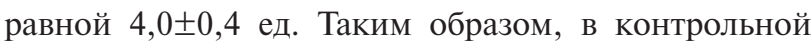
группе по мере увеличения длительности пубертатного периода вначале отмечается увеличение выраженности глазосердечного рефлекса, а затем его снижение. Отличительной особенностью изменений данного показателя у детей с НДСТ были как более его высокие значения при вступлении в пубертатный возраст, так и отсутствие его снижения к окончанию пубертата. В 11 лет его величина составила 4,6士0,2 ед, в 13 лет $-5,8 \pm 0,5$ ед и к концу пубертата выражалась величиной, равной 5,9 $\pm 0,6$ ед (различия с контрольной группой статистически значимы, $p<0,05)$. Аналогичные результаты обнаруживались при сравнительной оценке величин синокардиального рефлекса. В основной группе в начале пубертатного периода его величина составила $5,4 \pm 0,3$ ед, при достижении 15 лет была равной $5,1 \pm 0,8$ ед, в контрольной группе $-4,0 \pm 0,6$ ед и $3,8 \pm 0,6$ ед соответственно (различия статистически значимы, $p<0,05)$.

Выводы. У здоровых детей в ходе пубертата наблюдается увеличение реактивности ВНС, что отражают изменения синокардиального и гласосердечного рефлексов, а затем ее снижение. При наличии НДСТ у детей в отличие от группы контроля на всем протяжении пубертата наблюдается увеличение реактивности ВНС. Таким образом, в целом можно говорить о том, что пубертатный период у детей с НДСТ протекает более неблагоприятно, чем при ее отсутствии, на что указывает повышение реактивности ВНС. 
ЭФФЕКТИВНОСТЬ ВАКЦИНАЦИИ ПРОТИВ ПНЕВМОКОККОВОЙ ИНФЕКЦИИ У ДЕТЕЙ

Елкина Т.Н., Пирожкова Н.И., Грибанова О.А., Грибанова А.C.

ФГБОУ ВО НГМУ Минздрава России, Новосибирск

Введение. Высокий уровень распространенности пневмококковой инфекции среди детей, тяжелое течение заболевания, сопровождающееся осложнениями, диктуют необходимость проведения специфической профилактики инфекций пневмококковой этиологии.

Цель исследования - изучение эффективности специфической профилактики пневмококковой инфекции у детей, посещающих дошкольные учреждения.

Материалы и методы. Проведен анализ амбулаторных карт 84 организованных дошкольников. В основную группу включены 42 ребенка с полным курсом иммунизации пневмококковой вакциной, в контрольную группу их 42 не вакцинированных ровесника. Оценивался характер течения острых респираторных инфекций (ОРИ) на первом году социализации.

Результаты. В течение первого года посещения детского сада количество ОРИ составило в среднем $5,1+0,2$ раз в год. Дети, прошедшие курс иммунизации против пневмококковой инфекции, болели 4,2+0,3 раза в год. Заболеваемость у непривитых пациентов наблюдалась чаще $(5,9+0,3$ раз в год; $\mathrm{p}=0,001)$. В основной группе легкие формы инфекции $(3,7+0,3$ раза в год) преобладали над среднетяжелыми $(2,2+0,3$ раза в год). Среди больных контрольной группы достоверно чаще встречались заболевания средней тяжести $(3,7+0,4$ раза в год; $p=0,001)$, чем легкой степени $(0,5+0,1$ раз в год). Бактериальные осложнения ОРИ зафиксированы у 24 (28,6\%) пациентов; у детей основной группы осложненное течение отмечалось у $4(9,5 \%)$ человек, в контрольной группе у $20(47,6 \%)$ $(p=0,001)$. У детей с полным курсом иммунизации против пневмококковой инфекции антибиотики применялись реже (42,9\% против 64,3\%; $\mathrm{p}=0,02)$. Альтернативные противомикробные средства (амоксициллина/клавуланат, цефиксим, азитромицин) в контрольной группе применялись чаще $(23,8 \%$ против $16,7 \%$; $=0,04)$. В течение первого года социализации у $11(13,1 \%)$ больных зафиксировано назначение нескольких курсов антибактериальной терапии, из них у 7 (8,3\%) человек 2 медикамента и у 4 (4,8\%) детей 3 антибиотика. Повторные курсы лечения противомикробными препаратами достоверно чаще рекомендовались не вакцинированным дошкольникам $(21,4 \%$ против $4,8 \% ; \mathrm{p}=0,001)$.

Заключение. В периоде адаптации к детскому саду дети с полным курсом иммунизации против пневмококковой инфекции достоверно реже болели острыми респираторными заболеваниями, наблюдалась преиму- щественно легкая степень тяжести патологии. У не вакцинированных пациентов достоверно чаще регистрировались бактериальные осложнения и потребность в системной антибактериальной терапии.

\section{ИЗУЧЕНИЕ ЭФФЕКТИВНОСТИ СМЕСИ НУТРИЛАК КОМФОРТ В КОРРЕКЦИИ ФУНКЦИОНАЛЬНЫХ РАССТРОЙСТВ ПИЩЕВАРЕНИЯ ДЕТЕЙ НА ИСКУССТВЕННОМ ВСКАРМЛИВАНИИ}

Елкина Т.Н., Суровикина Е.А., Татаренко Ю.А.,

Лиханова М.Г.

ФГБОУ ВО НГМУ МЗ России, Новосибирск

Введение. Особенности желудочно-кишечного тракта детей раннего возраста могут приводить к функциональным нарушениям с соответствующими клиническими проявлениями. Ребенку с функциональными нарушениями желудочно-кишечного тракта (ФНЖКТ) на искусственном вскармливании важно подобрать адекватную молочную смесь, соответствующую особенностям пищеварения. Смеси категории «Комфорт» имеют измененный состав, способствующий комфортному пищеварению: снижено количество лактозы, большинство содержат частично гидролизованный белок, крахмал, пре- и/или пробиотики (Программа оптимизации вскармливания детей первого года жизни в РФ, 2019 г.).

Цель исследования - изучение эффективности смеси «НутрилакPremium Комфорт» в питании детей с ФНЖКТ (колики, запоры, метеоризм).

Материалы и методы. 20 детей на искусственном вскармливании в возрасте в начале наблюдения 5 дней - 3 месяца 29 дней получали молочную смесь «НутрилакPremium Комфорт» в течение 30 дней. В начале наблюдения средний возраст составил 1,6+1,2 месяца, среди детей было 65\% мальчиков и $35 \%$ девочек. Все находились на искусственном вскармливании и имели синдром младенческой колики, у $35 \%$ детей сочетание колик с другими ФНЖКТ.

Результаты. Отказов от нового питания не зафиксировано. Уменьшение интенсивности кишечной колики отмечено на 5-9 сутки $(7,5+2,7)$, аналогичная тенденция была в отношении метеоризма. В конце исследования данные ФНЖКТ не фиксировались. Родители пятерых детей с функциональными запорами отмечали изменения характеристик стула и к концу периода наблюдения запоры в данной группе не регистрировались. Минимальные срыгивания были у двоих детей, купированы назначением постуральной терапии. У всех отмечались адекватные возрастные прибавки в массе и длине тела. Прибавка в массе $497 \pm 75$ г, в длине тела $3,1 \pm 0,7$ см. Коэффициенты Z-score всех в начале и в конце наблюдения находились в пределах возрастных норм. 
Заключение. «НутрилакPremium Комфорт» хорошо усваивается, удовлетворяет физиологические потребности детей первого года жизни в основных пищевых веществах и энергии, обеспечивает нормальное физическое развитие, является полноценным питанием при отсутствии возможности грудного вскармливания. Состав смеси, соответствующий формулам категории «Комфорт», и включение пробиотических штаммов лактобактерий LGG обеспечивает влияние на формирование микробиома кишечника и коррекцию синдрома кишечной колики, а также сочетанных вариантов ФНЖКТ.

\section{ЧАСТОТА ВСТРЕЧАЕМОСТИ КЛИНИЧЕСКИХ ФОРМ ЮВЕНИЛЬНОГО АРТРИТА У ДЕТЕЙ В ЗАВИСИМОСТИ ОТ ВОЗРАСТА}

Ахмедова Н.Р., Ибрагимов А.А., Сайидова М.Х.

Республиканский специализированный научно-

практический медицинский центр педиатрии, Ташкент,

Узбекистан

Ташкентский педиатрический медицинский институт, Ташкент, Узбекистан

Введение. Ювенильный артрит (ЮА) является самым распространенным ревматическим заболеванием, и как правило, самой частой причиной инвалидности среди детей.

Цель исследования - изучение частоты встречаемости клинических форм ювенильного артрита у детей в зависимости от возраста.

Материалы и методы. Обследовано 189 больных с ЮА в возрасте от 1 до 18 лет, госпитализированных в кардиоревматологическое отделение Республиканского специализированного научно-практического медицинского центра педиатрии с начала 2015 года до настоящего времени. Всем больным были проведены общеклинические, биохимические и инструментальные методы исследования. Диагноз ставился на основании жалоб, данных анамнеза, объективного осмотра, лабораторно-инструментальных методов исследований согласно критерий ILAR Edmonton (2001 г.).

Результаты. Изучение частоты встречаемости различных форм ЮА среди обследованных показало, что суставная форма была зарегистрирована у 137 $(72,4 \%)$ детей, из которых полиартритическая и олигоартритическая форма составили $32,8 \%$ и 33,8\%, а энтезит ассоциированный и недифференцированный артрит встречался в $3,1 \%$ и $1,5 \%$ детей. Псориатическим артритом страдали 2 (1\%) детей. ЮА с системным началом был диагностирован у 52 детей $(27,5 \%)$. Анализ начала заболевания в зависимости от форма ЮА указывает, что олигоартрикуларная форма болезни чаще начинается в возрасте 3-4 лет и 8-9 лет, а полиартикулярная характерна для детей в возрасте 8-12 лет, что совпадает с литературными данными, в которых указан пик заболеваемости олигоартритической формой ЮА преимущественно детей в возрасте 1-5 лет, тогда как полиартикулярная форма больше развивается в 2-15 лет. По данным литературы, ЮА с системным началом может дебьютировать в любом возрасте, но чаще возникает до полового созревания. У 52 (27,5\%) больных с ЮА с системным началом чаще встречался у детей в возрасте до 5 лет. Раннее начало заболевания свидетельствует о большем количестве системных воспалительных процессов и более неблагоприятном исходе, чем у детей с более поздним началом заболевания.

Заключение. По частоте встречаемости различных форм ювенильного идиопатического артрита идет преобладание олигоартритической, полиартритической и системной форм заболевания, которые чаще дебьютируют в дошкольном и раннем школьном возрастах.

\section{ДЕФИЦИТ КОБАЛАМИНА У ДЕТЕЙ ПЕРВОГО ГОДА ЖИЗНИ: ПРИЧИНЫ И КЛИНИЧЕСКИЕ ОСОБЕННОСТИ}

Жукова Л.Ю. ${ }^{1}$, Колобова О.Л. ${ }^{1}$, Тарасенко А.H. ${ }^{2}$

1 ФГБОУ ВО СПбГПМУ Минздрава России

2ГБУЗ «ДГМ КСЦ ВМТ», Санкт-Петербург

Введение. Дефицит кобаламина, прежде всего, характеризуется мегалобластной анемией (МБА), поражением желудочно-кишечного тракта, неврологическими нарушениями. Недостаточность кобаламина у детей первого года жизни может быть ассоциирована с врожденными аномалиями метаболизма или приобретенным дефицитом микронутриента.

Цель исследования - анализ клинических особенностей и причин развития дефицита кобаламина у детей первого года жизни.

Материалы и методы. Ретроспективно проанализировано 9 случаев первичной диагностики витамин B12-дефицитной анемии (D51) у детей первого года жизни, обследованных в условиях отделения общей гематологии. Средний возраст обследованных составил 5,6 2 2,8 мес. Уровень витамина В12 в сыворотке крови определялся иммунохемилюсцентным анализом, составлял 41,9 - 55 пг/мл при нормальных значениях фолиевой кислоты. Антитела к внутреннему фактору (ВФ), париетальным клеткам желудка (ПКЖ) не обнаружены.

Результаты. Все младенцы поступили в стационар в тяжелом состоянии за счет выраженности анемического синдрома, гипотрофии II-III степени, неврологической симптоматики (мышечная гипотония, двигательные нарушения, полная утрата сформированных моторных навыков, судорожный синдром). Дети родились доношенными полновесными, без ВПР, находились на грудном вскармливании, попытки введения прикормов сопровождались 
появлением рвот и диареи. Анамнестически с 2-3 месяцев жизни задержка весовых прибавок, диспептические явления; с 4-5 месяцев задержка формирования новых моторных навыков с утратой сформированных ранее, с 5-6 месяцев анемический синдром. При обследовании у всех матерей выявлен низкий уровень витамина В12 (84-150 пг/мл) при нормальном уровне фолиевой кислоты, у 5 обнаружены антитела к ПКЖ в высоких титрах (более 100 МЕ/мл) при отсутствии антител к ВФ. Матери 4 младенцев придерживались вегетарианской/веганской систем питания с юношеского возраста.

Заключение. У всех обследованных младенцев выявлена приобретенная витамин В12-дефицитная анемия алиментарного генеза, обусловленная дефицитом витамина В12 у матерей (вегетарианство/ веганство, наличие блокирующих антител). Симптомы поражения ЖКТ с развитием гипотрофии и неврологическая симптоматика во всех случаях предшествовали появлению анемического синдрома.

\section{УРОВНИ АНТИМИКРОБНЫХ ПЕПТИДОВ И ВИТАМИНА Д ПРИ ВРОЖДЕННОЙ ПНЕВМОНИИ У НЕДОНОШЕННЫХ НОВОРОЖДЕННЫХ}

Журавлева Л.Н.

Витебский государственный ордена Дружбы народов медицинский университет, Витебск, Республика

Беларусь

Введение. Одной из ведущих причин заболеваемости у новорожденных детей является патология респираторного тракта. Среди данной группы пациентов, а в особенности недоношенных новорожденных, лидирующую роль среди заболеваний дыхательной системы занимает врожденная пневмония.

Целью работы явилось выявление взаимосвязи между уровнем витамина Д и эндогенными антимикробными пептидами при врожденной пневмонии у недоношенных новорожденных.

Материал и методы. Под нашим наблюдением находились 2 группы недоношенных новорожденных: 32 новорожденных с врожденной пневмонией и группу сравнения составили 20 «условно здоровых» новорожденных без патологии респираторного тракта.

Результаты. У пациентов с пневмонией отмечалось выраженное снижение уровня витамина Д $(9,57[6,57-17,25])$ по сравнению с условно здоровыми новорожденными (21,1 [9,2-32,02]), p <0,01. Однако, в группе пациентов уровни кателицидин LL-37 и HBD-2 были значительно выше (2,87 [2,3 $4,43]$ и 240,4 [132,4 - 406,7]) по сравнению с группой сравнения $(1,6$ [0,8-2,5] и 156,7 [82,4 - 208,7]), p $<0,01$. Более того, у пациентов с тяжелым течением врожденной пневмонии было выявлено значительно более низкое значение витамина D $(7,6$ [5,7-13,2]) и более высокое содержание кателицидина LL-37 $(3,75$ [2,8 - 4,26]) по сравнению с пациентами со средней степенью тяжести пневмонии $(13,7$ [9,7-16,5] и $2,5[2,1-3,7]$ соответственно). Но такой взаимосвязи мы не наблюдали с HBD-2 (при тяжелом течении врожденной пневмонии отмечалось снижение HBD-2 (220,4 [142,6 - 401,6] и 278,2 [154,6 - 378,6] соответственно).

Заключение. Более низкая концентрация витамина D в сыворотке может быть в значительной степени связана с врожденной пневмонией. Также уровень витамина Д может прогнозировать более тяжелое течение пневмонии, необходимость длительной ИВЛ и продолжительность госпитализации при врожденной пневмонии у недоношенных новорожденных.

\section{ДИФФЕРЕНЦИАЛЬНАЯ ДИАГНОСТИКА КОЖНЫХ ЭКЗАНТЕМ РАННЕГО НЕОНАТАЛЬНОГО ПЕРИОДА}

Захаров И.А., Панина О.С., Черненков Ю.В., Бочкова Л.Г. ФГБОУ ВО Саратовский ГМУ им. В.И. Разумовского Минздрава России, Саратов

Введение. Многообразие и частота инфекций, сопровождающихся экзантемами у новорожденных детей, не имеет тенденции к снижению. Не менее часто встречаются неинфекционные заболевания кожи. Главной задачей неонатолога является проведение дифференциальной диагностики между заболеваниями.

Цель: повышение осведомленности врачей-педиатров и неонатологов о дифференциальной диагностике при кожных изменениях.

Материалы и методы. Проведен ретроспективный анализ 42 историй развития новорожденного (ф097у) с кожными проявлениями в раннем неонатальном периоде за 2020 год.

Результаты. Врожденный везикулопустулез являлся самой распространенной патологией, выявляемой в родильном зале (79,4 \% случаев). Представляет собой стафилококковый перипорит, субстратом которого является воспаление устья потовых желез. Клинически проявляется в виде рассеянных по всему телу везикул, со сгущением в местах естественных складок, наполненных мутным содержимым, размером несколько миллиметров, при этом состояние ребенка удовлетворительное. Пузырчатка новорожденных была зафиксирована в 8,8 \% случаев всех экзантем. Отмечается появление вялых пузырей с венчиком гиперемии, наполненных гнойным содержимым, размерами до 3 см в диаметре, состояние ребенка расценивается как тяжелое, с выраженной интоксикацией. Все дети были переведены в инфекционный стационар в течении 2 часов после 
рождения. Кожные экзантемы, обусловленные проявлениями внутриутробных инфекций, составили 8,8 \% случаев. При врожденной краснухе (2,9 \% случаев) наблюдались пятнистая и пятнисто-папулезная сыпь красновато-розового цвета, геморрагическая сыпь и пятна голубовато-фиолетового цвета, напоминающие симптом «пирога с черникой», за счет очагов внекостномозгового кроветворения. ЦМВ (в 5,8 \% случае) выражалась в появлении мелкоточечной петехиальной сыпи через несколько часов после рождения и персистирующей несколько недель, иногда приобретая вид «черничного кекса». Врожденный адипонекроз (2,9 \% случаев) проявлялся появлением красно-фиолетовых болезненных уплотнений на коже, с размягчением в центре при пальпации. Не требует назначения антибактериальной терапии и перевода в инфекционный стационар.

Выводы. Повышение осведомленности врачей в дифференцировании заболеваний, проявляющихся экзантемой, позволит правильно поставить диагноз и осуществить грамотную маршрутизацию новорожденного.

\section{МЕТОДИКА НЕМЕДИКАМЕНТОЗНОЙ АБИЛИТАЦИИ НОВОРОЖДЕННЫХ С ЖЕЛУДОЧНО-КИШЕЧНЫМИ ПРОЯВЛЕНИЯМИ ВЕГЕТО-ВИСЦЕРАЛЬНОГО СИНДРОМА}

Захаров И.А., Панина О.С., Черненков Ю.В., Эйберман А.С. ФГБОУ ВО Саратовский ГМУ им. В.И. Разумовского Минздрава России, Саратов

Введение. У новорожденных в $10 \%$ случаев желудочно-кишечные нарушения являются следствием вегето-висцерального синдрома перинатального поражения ЦНС (ППЦНС). В остром периоде ППЦНС вегето-висцеральные нарушения проявляются в виде дисрегуляции сфинктеров, дискинезии ЖКТ. Ведущее звено в патогенезе данного синдрома является поражение диэнцефальных структур мозга, лимбической системы и продолговатого мозга.

Цель: оценить эффективность проведения немедикаментозной абилитации недоношенным новорожденным с проявлениями вегето-висцерального синдрома перинатального поражения ЦНС с расстройством функции желудочно-кишечного тракта.

Материалы и методы. В исследование вошли 48 детей с постконцептуальным возрастом более 33 недель. Для группы сравнения были отобраны 25 новорожденных, равноценных по клинико-лабораторным показателям. В исследовании была использована методика музыкотерапии и сухой иммерсии, предложенная профессором Г.В. Яцык, в сочетании с оролингвальным массажем. Продолжительность музыкальной терапии для детей в возрасте $3-8$ суток- 5 минут, 8-10 суток - 10 минут, старше
10 суток - 15 минут, ежедневно 2 раза в день, курс лечения составлял 10-15 дней. Длительность процедуры сухой иммерсии составляла от 10 до 40 минут. Курс 4-7 сеансов, 1 раз в день. Оролингвальный массаж проводился ежедневно 3 раза в день за 30 минут до кормления, в первые дни - 2-3 минуты, в последующие - до 10 минут. Курс составлял 10 - 15 дней.

Результаты. В ходе исследования было отмечено, что все дети, получавшие комплексную немедикаментозную абилитацию, провели в отделении в среднем $16 \pm 2$ дня, а дети из группы контроля 28 \pm 2 дня. Клиническая эффективность метода заключалась в достоверном $(p<0,05)$ улучшении акта сосания и повышении аппетита; отмечалось уменьшение частоты младенческих колик и метеоризма соответственно у $89,5 \%$ и 79,3\% детей в основной группе, тогда как в группе сравнения эти показатели составили $43,8 \%$ и $32,4 \%$. Также в основной группе был отмечен более значимый регресс гастроэзофагеальной и дуоденальной регургитации на фоне нормализации моторики желудочно-кишечного тракта. Динамический осмотр невролога выявил улучшение врожденных рефлексов новорожденных, особенно орального автоматизма. Сосательный и поисковый рефлекс достоверно $(p<0,05)$ улучшились у $96 \%$ детей группы исследования и $49 \%$ детей группы сравнения.

Выводы. Проведение комплексной немедикаментозной абилитации характеризуется щадящей стимуляцией акта сосания, спонтанной двигательной активности, восстановления адекватной рефлекторной деятельности, уменьшением проявления функциональных расстройств пищеварительного тракта. Одним из важных факторов является привлечение и обучение матерей методам немедикаментозной абилитации для продолжения терапии в домашних условиях.

\section{СОСТОЯНИЕ ЗДОРОВЬЯ НОВОРОЖДЕННЫХ ОТ МАТЕРЕЙ С БРОНХИАЛЬНОЙ АСТМОЙ В ЗАВИСИМОСТИ ОТ ПОКАЗАТЕЛЕЙ ВЕНТИЛЯЦИОННОЙ ФУНКЦИИ ЛЕГКИХ В ГЕСТАЦИОННОМ ПЕРИОДЕ}

Зенкина А.С., Приходько О.Б., Романцова Е.Б., Кострова И.В., Лучникова Т.А.

ФГБОУ ВО Амурская ГМА Минздрава России, Благовещенск

Введение. Актуальность исследования связана с неуклонным ростом числа больных бронхиальной астмой (БА), отмечаемым во всем мире, в том числе, среди женщин репродуктивного возраста.

Цель исследования: определение взаимосвязи нарушений вентиляционной функции легких (ВФЛ) у больных БА в периоде гестации с клиническим течением заболевания, с уровнем его контроля, с состоянием здоровья новорожденных. 
Материалы и методы. Изучены клинико-функциональные особенности течения БА у 98 пациенток в динамике беременности с неконтролируемым течением заболевания. I группу составили 75 пациенток с БА, у которых выявлен обструктивный тип нарушений ВФЛ (умеренной и значительной степени выраженности) по спирограмме, II группу - 23 пациентки с БА со смешанными (обструктивными и рестриктивными) нарушениями.

Результаты. Распределение больных БА в зависимости от тяжести заболевания выглядело следующим образом: в I группе - с БА легкой степени тяжести (БАЛТ) - $23(30,6 \%)$, с БА среднетяжелого течения (БАСТ $-38(50,7 \%)$, с БА тяжелого течения (БАТТ) $14(18,7 \%)$, во II группе - с БАЛТ - $3(13 \%)$, с БАСТ $10(43,5 \%)$, с БАТТ - $10(43,5 \%)$. С аллергической формой БА в I группе было 45 (60\%) пациенток, во II - 12 (52,2\%), с неаллергической - в I группе 9 (12\%), во II - 3 (13\%), со смешанной - в I группе - 21 (28\%), во II - 8 (34,8\%). То есть, среди пациенток со смешанным типом нарушений ВФЛ отмечен больший процент тяжелого течения, с неаллергической и смешанной клиническими формами БА. При морфологическом анализе плацент в исследуемых группах плацентарная недостаточность выявлялась со следующей частотой: в стадии компенсации в I группе - в 74,7\% случаев, в II группе - в $47,8, \%$; в стадии субкомпенсации - в I группе - в $8 \%$, в II группе - в 17,4\%; стадия декомпенсации отмечалась только во ІІ группе - в 8,7\%. Острая плацентарная недостаточность - в $10,7 \%$ в I группе и в $17,4 \%-$ во II группе. В структуре заболеваний новорожденных от пациенток I в сравнении со II группой, чаще отмечены: церебральная ишемия - в 1,7 раза, внутриутробное инфицирование - в 2,6 раза, нарушение периода адаптации - в 6,2 раза, задержка внутриутробного развития плода - в 3,1 раза, синдром дыхательных расстройств - в 1,9 раза $(p<0,05)$.

Заключение. У беременных с БА прослеживается взаимосвязь показателей ВФЛ с циркуляторными и воспалительными нарушениями в плаценте, что приводит к развитию плацентарной недостаточности, неблагоприятно воздействует на плод и способствует развитию заболеваний новорожденного.

\section{ОСОБЕННОСТИ КЛИНИЧЕСКОГО ТЕЧЕНИЯ МЕНИНГИТОВ У ДЕТЕЙ В ВОЗРАСТЕ ОТ 0 ДО 3 ЛЕТ \\ Зенкова Т.В., Копытова О.А., Ткачук С.П., Бельтикова А.А., Кожевникова Л.А. \\ ФГБОУ ВО Тюменский ГМУ Минздрава России, Тюмень ГБУЗ ТО «ОИКБ», Тюмень}

Введение. Нейроинфекции у детей в возрасте от 0 до 3 лет, в силу анатомо-физиологических особенностей имеют склонность к более тяжелому течению.
Цель исследования. Выяснить особенности клинического течения менингитов у детей в возрасте от 0 до 3 лет.

Материалы и методы. Проведен ретроспективный анализ 22 стационарных карт детей в возрасте от 0 до 3 лет, госпитализированных в ГБУЗ ТО «ОИКБ» г. Тюмени в период с 2014 года по 2020 год с диагнозом менингит. Из них: менингококковый $41 \%(n=9)$, гемофильный $27,3 \%(n=6)$, пневмококковый $4,5 \%(n=1)$, вызванный герпесом 6 типа 4,5\% $(n=1)$ и микст-этиологии (бактериальный менингит, ассоциированный с вирусным) $-22,7 \%(n=5)$. Диагноз, подтверждался в 100\% случаях методом ПЦР ликвора.

Результаты. Наиболее часто регистрировались менингиты менингококковой $41 \%$ и гемофильной $27,3 \%$ этиологии, реже менингиты герпетической и пневмококковой этиологии в 4,5\% соответственно, в каждом четвертом случае у детей в возрасте от 0 до 3 лет определялся менингит микст-этиологии. Пациенты поступали в $45,5 \%(n=10)$ в среднетяжелом и в $54,5 \%(n=12)$ в тяжелом состоянии, с нарушением сознания на уровне оглушения в $18 \%(n=4)$, сопора $23 \%(n=5)$ и комы в $4,5 \%(n=1)$ случаев. У всех детей при обращении обнаруживалась фебрильная температура, со стороны родителей отмечались следующие жалобы: повторная рвота $100 \%(n=22)$, общая слабость и вялость $82 \%(n=18)$, снижение аппетита $50 \%$ $(n=11)$, плач $41 \%(n=9)$, беспокойство $27,3 \%(n=6)$, судороги $13,6 \%(n=3)$. Полный менингеальный симптомокомплекс выявлялся только при бактериальных и микст менингитах, имел тенденцию к длительному сохранению и наиболее продолжительно наблюдался при менингококковом (7,3 \pm 0,8 дней) и микст-менингитах (11 1 день).

Заключение. Таким образом, у детей в возрасте от 0 до 3 лет в каждом четвертом случае менингит имеет микст-этиологию, с тенденцией к более тяжелому течению с нарушением сознания, что свойственно, в том числе и для менингококкового менингита.

\section{ПРЕДИКЦИОННАЯ СПОСОБНОСТЬ ИММУНОЛОГИЧЕСКИХ ПОКАЗАТЕЛЕЙ КРОВИ В ОЦЕНКЕ ВЕРОЯТНОСТИ ИСХОДА ПОСЛЕДСТВИЙ ПЕРИНАТАЛЬНЫХ ПОРАЖЕНИЙ ЦНС}

Зозуля С.А. ${ }^{1}$, Отман И.Н. ${ }^{1}$, Морозов С.Г. ${ }^{2}$, Клюшник Т.П. 'ФГБНУ "Научный центр психического здоровья", Москва

ФГБНУ «НИИ общей патологии и патофизиологии», Москва

Введение. Риск развития тяжелых нарушений у детей раннего возраста после перинатальных поражений (ПП) ЦНС определяет необходимость создания прогностических моделей для вероятностной 
оценки исхода этих состояний. В качестве возможных предикторов рассматриваются некоторые иммунологические маркеры, связанные, как показано ранее, с особенностями клинического состояния пациентов.

Цель исследования: сопоставить уровень активации иммунной системы (ИС) у детей первого года жизни, перенесших ПП ЦНС, с динамикой их клинического состояния через год, и создать математическую модель, позволяющую оценить вероятность развития благоприятного или неблагоприятного исхода.

Материалы и методы. Методом клинического наблюдения обследовано 114 детей с ПП ЦНС гипоксического генеза из группы риска по развитию нервно-психической патологии. Детей обследовали дважды - в возрасте от 6 до 12 месяцев и через $9-$ 12 месяцев. Группу контроля составили 73 здоровых ребенка. Активность воспалительных маркеров лейкоцитарной эластазы (ЛЭ), $\alpha 1$-протеиназного ингибитора $(\alpha 1-П И)$ и уровень антител к белкам нервной ткани (S100-B, ГФКП, ОБМ, ФРН) определяли в крови однократно при первом клиническом обследовании.

Результаты. Уровень активации ИС (по комплексу иммунологических показателей), выявляемый до года у детей с последствиями ПП ЦНС, сопряжен с разной динамикой их клинического состояния. Умеренная активация ИС в виде незначительного повышения активности ЛЭ и $\alpha 1-П И$ в последующем определяет положительную динамику клинического состояния, и, вероятно, носит санационный характер, отражая ответ ИС на нарушение гомеостаза. Выраженная активация ИС, сопровождающаяся запуском воспалительных, а у 25\% обследованных - и аутоиммунных реакций, ассоциирована с отрицательной динамикой и свидетельствует о продолжающемся патологическом процессе. Создана модель бинарной логистической регрессии, позволяющая оценить вероятность исхода ПП ЦНС по иммунологическим показателям и возрасту ребенка на момент обследования (диагностическая эффективность 79,8\%, чувствительность 78,7\%, специфичность 80,6\%).

Заключение. Иммунологические маркеры активность ЛЭ и уровень антител к белкам нервной ткани определяют динамику дальнейшего развития детей с последствиями ПП ЦНС и являются предикторами исхода этих состояний. С помощью созданной модели подтверждено, что эти показатели могут быть рекомендованы для объективизации состояния таких пациентов на доклинических этапах развития заболевания.

\section{СОМАТОМЕТРИЧЕСКИЕ ПОКАЗАТЕЛИ} СОВРЕМЕННЫХ ПЕРВОКЛАССНИКОВ

Иванова О.Н., Дианова Т.И., Бушуева Э.В., Петрова Д.П., Иванова А.Л., Иванова А.Г.

ФГБОУ ВО «Чувашский государственный университет имени И.Н. Ульянова», Чебоксары

Введение. В современных условиях физическое развитие детского населения изменчиво и проявляется периодами ускорения и снижения темпов роста, что требует постоянного динамического изучения его показателей.

Цель исследования. Выявить основные изменения соматометрических показателей современных 7 летних детей.

Материалы и методы. Проведена антропометрия 208 первоклассников 7 лет (мальчиков 94 (45\%), девочек 114(55\%)), проживающих в Чувашской Республике. Измеряли рост стоя, массу тела, окружность грудной клетки. Сопоставили полученные данные с показателями физического развития 7 летних детей 1999 года.

Результаты. Рост мальчиков составил $125,1 \pm 0,63 \mathrm{~cm}$, что больше на $4,8 \mathrm{~cm}$ чем у детей

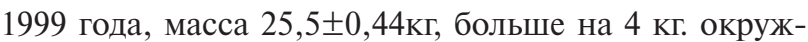
ность грудной клетки $62,5 \pm 0,44 \mathrm{~cm}$, больше на 3,2 см. Рост девочек $125 \pm 0,46$ см, что больше на 6,8 см чем у детей 1999 года, масса 24,1 0,35 кг, больше на 3,7 кг,

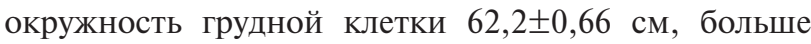
на 5,5 см.

Заключение. Сравнение соматометрических показателей с 22 летним интервалом показывает акселерацию как у мальчиков, так и у девочек по всем показателям. У современных мальчиков темпы набора массы тела на скорость роста выше, чем у девочек. Темпы «округления» девочек имеют большую скорость, чем у мальчиков.

\section{АНАЛИЗ ПРЕДРАСПОЛАГАЮЩИХ ФАКТОРОВ РИСКА У ДЕТЕЙ С ВНЕБОЛЬНИЧНОЙ ПНЕВМОНИЕЙ \\ Изюрова Н.В. \\ ФГБОУ ВО ЮУГМУ Минздрава России, Челябинск}

Введение. Внебольничная пневмония одна из распространенных форм острых респираторных заболеваний у детей, об актуальности которой свидетельствует сохраняющийся высокий уровень заболеваемости и смертности. Группами риска при внебольничных пневмониях являются дети, имеющие в анамнезе наличие разнообразных предрасполагающих и преморбидных факторов.

Цель исследования - проанализировать наличие предрасполагающих факторов риска у детей с внебольничной пневмонией.

Материалы и методы. В исследование было включено 117 детей в возрасте от 1 года до 18 лет с вне- 
больничной пневмонией средней и тяжелой степени тяжести (53 девочки и 64 мальчика). Группу сравнения составили 28 здоровых детей, не имеющих на момент включения в исследование внебольничной пневмонии, а также другой репираторной патологии. Группы были сопоставимы по полу и возрасту. Всем пациентам был проведен: сбор анамнеза (заболевания, жизни, у матерей проводился сбор гинекологического, акушерского анамнеза, данных течения беременности и родов), а также оценка амбулаторной карты ребенка.

Результаты. По данным акушерско-гинекологического анамнеза матерей детей с внебольничной пневмонией патология беременности (отеки, нефропатия, токсикозы, угрозы прерывания беременности, бактериальные инфекции во время беременности, анемии) встречалась в 58,1\% случаев. Фоновая патология (анемия, рахит, патология ЦНС) у детей с пневмонией имела место в 78,6\% случаев и в группе сравнения в $35,7 \%$ случаев (p <0,0001). Около $43,6 \%$ детей с внебольничной пневмонией имели отягощенный аллергологический анамнез, в частности, атопический дерматит, бронхиальную астму, пищевую аллергию, лекарственную аллергию, в отличие от группы сравнения $14,3 \%$ ( $<<0,004)$. К группе часто болеющих детей на момент госпитализации были отнесены около $40 \%$ детей с внебольничной пневмонией к группе сравнения около $10 \%$ ( $<<0,001)$.

Заключение. Таким образом, по данным нашего исследования в группу риска развития внебольничной пневмонии могут быть отнесены дети при наличии таких предрасполагающих и преморбидных факторов, как: наличие у матери патологии беременности, экстрагенитальной патологии, наличие у ребенка фоновых заболеваний, отягощенного аллергологического анамнеза.

\section{ОСОБЕННОСТИ НУТРИТИВНОГО СТАТУСА НОВОРОЖДЕННЫХ С ВРОЖДЕННЫМИ ПОРОКАМИ СЕРДЦА В ПЕРИ- И ПОСЛЕОПЕРАЦИОННОМ ПЕРИОДАХ}

Косинова С.Р., Ушакова С.А., Мыкаи А.А., Паршукова Л.Н., Халидуллина О.Ю., Жаркова И.Ю., Жукова Е.Ю.

ФГБОУ ВО Тюменский ГМУ Минздрава России, Тюмень ГБУЗ ТО «Перинатальный центр», Тюмень

Введение. Одной из важных задач в области лечения врожденных пороков сердца (ВПС) у новорожденных остается адекватная нутритивная поддержка оптимального развития.

Цель исследования. Оценка нутритивного статуса новорожденных с ВПС на момент рождения, в перии послеоперационный периоды, перед выпиской из стационара.

Материалы и методы. В исследование включены 31 новорожденный с различными ВПС: дефекты перегородок межпредсердной (17) и межжелудочковой (8), артериальный проток (2), тетрада Фалло (1), стеноз легочной артерии (1), транспозиция магистральных артерий (1), получавшие лечение в ГБУЗ ТО «Перинатальный центр». Нутритивный статус оценивался по биохимическим (белок, альбумин, креатинин, мочевина) и антропометрическим показателям (шкалы INTERGROWTH-21st и BO3).

Результаты. Преобладали доношенные новорожденные - 19 (61\%). Велись консервативно 19 (61\%), прооперированы в неонатальном периоде 9 (29\%), на медикаментозной терапии 3 (10\%) детей. При рождении масса тела в 23 (75\%), а длина - в 12 (40\%) случаях соответствовали сроку гестации. Частичное парентеральное питание с рождения получали 14 (45\%) детей, средняя продолжительность 5,6 дней. В послеоперационном периоде эти показатели составили 9 (29\%) детей и 7,5 дней, соответственно. Энтеральное питание с рождения через зонд получали 8 (26\%) детей, соску 13 (42\%) детей. На грудном вскармливании с рождения были 12 (39\%), при выписке - 17 (55\%), получали фортификацию 9 (29\%) детей. На искусственном вскармливании с рождения находились 9 (29\%), среди которых 4 (44\%) получали смеси для недоношенных и маловесных детей. К выписке оба показателя составили 8 (26\%). На смешанном питании с рождения 10 (32\%) детей, в динамике - 6 (19\%). Биохимические показатели белкового обмена у находящихся на различных видах вскармливания были в пределах референса. При выписке массо-ростовые показатели демонстрировали признаки белково-энергетической недостаточности: <3 перцентиля - 19 (61\%) и <-3 Zscor - 8 (26\%) детей.

Заключение. При наблюдении новорожденных с ВПС необходим персонализированный подход для поддержки достаточного нутритивного статуса. Решение этой задачи требует привлечения в многопрофильную педиатрическую команду диетолога.

\section{ВЛИЯНИЕ ДОТАЦИИ ВИТАМИНА D НА УРОВЕНЬ ХОЛЕКАЛЬЦИФЕРОЛА У ЗДОРОВЫХ БЕРЕМЕННЫХ, БОЛЬНЫХ COVID-19 И ИХ НОВОРОЖДЕННЫХ}

Косинова С.Р., Петрушина А.Д., Кукарская И.И., Максюкова Е.Н., Яркова И.А.

ФГБОУ ВО Тюменский ГМУ Минздрава России, Тюмень ГБУЗ ТО «Перинатальный центр», Тюмень

ГБУЗ ТО «Родильный дом №2», Тюмень

Введение. Витамин D играет важную роль в системе «мать-плацента-плод». Микронутриентная недостаточность во время беременности негативно влияют на течение и исходы беременности, развитие плода и здоровье новорожденных. Особенно острой эта проблема становится в период пандемии COVID-19. 
Цель исследования - оценить влияние дотации 25(OH)D в диаде мать-новорожденный, рожденных с января 2020г. по февраль 2021г. на базе ГБУЗ ТО «Перинатальный центр» и ГБУЗ ТО «Родильный дом №2» г. Тюмени.

Материалы и методы. В исследование включено 58 пар мать-новорожденный. Забор крови осуществлялся у женщины перед родами, у ребенка из пуповинной крови сразу после рождения. Определение 25(OH)D в сыворотке крови проводили методом иммуноферментного анализа, дотация оценивалась анкетированием исследуемых.

Результаты. Были выделены 2 группы: 1 группа здоровые (без признаков острых респираторных вирусных инфекций) - 42 (72,41\%), 2 группа - матери имели подтвержденный диагноз COVID-19 - 16 (27,59\%). Каждая группа делилась на подгруппы: принимающие витамин D во время беременности и не принимающие. Медиана 25(OH)D в 1 группе составила 9,33 (1,06$42,34)$ у новорожденных и $8,88(3,69-39,13)$ у матерей; во 2 группе - 16,41 (6,12-58,54) и 27,605 (6,48-55,34) соответственно. Отмечена высокая прямая корреляционная связь между уровнем витамина D у матерей и новорожденных $(\rho=0,913)$, зависимость статистически значима $(p<0,05)$. Тяжелый дефицит наиболее распространен в подгруппе здоровых беременных, не получающих дотацию витамина D (26 пар, 44,83\%): у 18 женщин $(69,25 \%)$ и 17 новорожденных $(65,38 \%)$. Нормальный уровень чаще отмечался в подгруппе с подтвержденным диагнозом COVID-19, получающих дотацию витамина D (16 пар, 27,59\%): у 4 женщин (50\%) и 3 новорожденных $(37,5 \%)$.

Заключение. Высокая частота дефицита витамина D у матерей и их новорожденных требует своевременного контроля за его уровнем с целью безотлагательной коррекции дефицита, учитывая современную роль витамина D для физиологического течения беременности, а в последующем для развития ребенка, особенно в период пандемии COVID-19.

\section{РОЛЬ НЕОНАТАЛЬНОГО СКРИНИНГА В ДИАГНОСТИКЕ И ВЫЯВЛЯЕМОСТИ МУКОВИСЦИДОЗА В СТАВРПОЛЬСКОМ КРАЕ \\ Леденева Л.Н., Водовозова Э.В., Григорьяни И.С., Белаш Т.А., Енина Е.А., Пустабаева М.С. ФГБОУ ВО «Ставропольский государственный медицинский университет» МЗ РФ, Ставрополь}

Введение. Неонатальный скрининг является способом ранней диагностики патологий, обусловленных генетическими мутациями. По рекомендации BO3 неонатальный скрининг включен в перечень обязательных медицинских тестов для детей.

Цель исследования: изучить показатели неонатального скрининга у детей Ставропольского края (CK), страдающих муковисцидозом (MB).
Материал и методы. Ретроспективный анализ данных лаборатории неонатального скрининга Ставропольского краевого клинического перинатального центра за период с 2012 по 2018 годы.

Результаты. В СК за период с 2012 по 2018 гг. количество обследуемых новорожденных практически было одинаковым (37980 в 2012 г., 37640 - в 2013 г., 37600 - в 2014 г., 38241 - в 2015 г., 38441 - в 2016 г., 38892 - в 2017 г. и 37988 - в 2018 г.). Повышенные значения ИРТ демонстрировали тенденцию к снижению (601 случай в 2012 году и 201 - в 2018 году), при этом диагноз МВ был верифицирован ежегодно у 1-3 детей, за исключением 2012 года, когда было выявлено 10 заболеваний. Заболеваемость МВ среди обследованных новорожденных колебалась от 0,02 в 2012 г. до 0,003 в 2013 г. и 2015 г. Выявляемость заболевших МВ в СК детей по отношению ко всему детскому населению составила 0,02 в 2012 г., 0,002 в 2013 г. и в 2015 г., 0,005 - в 2014 г., 2017 г. и 2018 г. и 0,007 - в 2016 г.

Заключение. Неонатальный скрининг на современном этапе развития медицинской науки направлен на раннее выявление лиц с патологическими изменениями генотипа. Он является основным методом вторичной профилактики наследственной патологии. Подобные скрининги целесообразно разрабатывать для распространенных болезней с тяжелым течением, приводящим к инвалидизации.

\section{СОСТОЯНИЕ ЗДОРОВЬЯ ДЕТЕЙ РОЖДЕННЫХ ПОСЛЕ ЭКСТРАКОРПОРАЛЬНОГО ОПЛОДОТВОРЕНИЯ}

Лежнина И.В., Токарев А.Н., Подлевских Т.С.,

Беляков В.А.

ФГБОУ ВО Кировский ГМУ Минздрава России, Киров

Введение. Бесплодие и трудности зачатия на современном этапе часто и весьма успешно преодолеваются с помощью высокотехнологичных процедур путем экстракорпорального оплодотворения (ЭКО). Однако состояние здоровья этих детей требует тщательного наблюдения и изучения.

Цель исследования - изучение состояния здоровья и резистентности детей, зачатых путем ЭКО.

Материалы и методы. В исследование включено 35 детей в возрасте 3 лет. Всем детям проводилась комплексная оценка состояния здоровья, включающая оценку анамнеза, физического (ФР) и нервно-психического развития (НПР), индекса инфекционной резистентности (ИИР), осмотр врачами-специалистами, общеклинические лабораторные исследования (ОАК, ОАМ, копрограмма), составлялся план диспансерного наблюдения.

Результаты. Акушерский анамнез отягощен в 100\% случаев. Недоношенными родилось 26 (74\%) в сроке гестации 34-36 недель, с низкими показате- 
лями массы и длины тела к сроку гестации 29 (82\%) детей, 12 (34\%) с кардиореспираторной депрессией, 5 (14\%) в асфиксии. Пролонгированные транзиторные состояния - конъюгационная гипербилирубинемия до 21 суток у 26 (74\%) детей, токсическая эритема у 33 (94\%) детей, путем кесарева сечения рождено 30 $(85 \%)$ детей. На грудном вскармливании до 3 месяцев 7 (20\%) детей, до 6 месяцев - 4 (11\%) ребенка. 100\% детей на первом году имели проявления аллергического дерматита, функциональных гастроинтестинальных расстройств. ФР с 30 месяцев не отличалось от сверстников по гармоничности, НПР - темповая задержка предречевого и речевого развития у 26 (74\%), у 13 (37\%) моторного, сенсорного и навыков. ИИР выше нормы на всем протяжении наблюдения, диспансерная группа часто болеющих детей. Анемия гипохромная у 26 (74\%) детей. В 2 года аллергический ринит, атопический дерматит у 22 (62\%), гипертрофия миндалин и аденоидов у 30 (85\%), кариес молочных зубов, нарушения дефекации у 13 (37\%), дискинезия желчевыводящих путей у 7 (20\%) детей. Вакцинированы по календарю 4 (11\%) ребенка. В 3 года 1 группа здоровья не была установлена, 2 у $13(37 \%), 3-$ у $22(62 \%)$.

Заключение. У детей, зачатых ЭКО, по сравнению с общей популяцией, чаще возникают проблемы адаптации, выше в раннем возрасте распространенность инфекционной и соматической, аллергический патологии, что требует более пристального внимания и профилактики.

\section{ОСОБЕННОСТИ ЛИПИДНОГО СПЕКТРА МЕМБРАН ЛИМФОЦИТОВ ПУПОВИННОЙ КРОВИ У НЕДОНОШЕННЫХ НОВОРОЖДЕННЫХ}

Лисихина Н.В., Галактионова М.Ю.

ФГБОУ ВО КрасГМУ им. проф. В.Ф.Войно-Ясенецкого

Минздрава России, Красноярск

Сибирский юридический институт МВД России, Красноярск

Введение. Большое значение для организма в целом и благоприятного функционирования клеточных структур имеет липидный спектр. Состояние липидного обмена оказывает немаловажное влияние на жизнедеятельность плода и новорожденного, поскольку липиды являются пластическим материалом для построения клеточных структур, основным источником энергии, служат исходным материалом для синтеза ферментов, гормонов. Непосредственное участие липидных структур в процессах активации клетки, продукции медиаторов иммунного ответа, в цитотоксических реакциях, в регуляции фагоцитоза определяет важное значение гомеостаза липидов в стабилизации иммунных реакций организма. Соотношение фракций нейтральных липидов и фосфо- липидов, являющихся основными структурными компонентами мембран клеток, в значительной мере определяют физико-химические свойства мембран, что в свою очередь оказывает существенное влияние на функциональное состояние клеток, активность клеточных рецепторов и внутриклеточных ферментов, развитие различных патологий у новорожденных.

Цель исследования - сравнить спектр структурных липидов мембран лимфоцитов пуповинной крови у недоношенных и доношенных новорожденных.

Материалы и методы. В исследование включено 104 новорожденных, из них 39 детей (контрольная группа, 38-40 недель гестации) - доношенные новорожденные и 65 детей, родившиеся недоношенными (28-36 недель гестации). Спектр нейтральных липидов и фосфолипидов определяли методом тонкослойной хроматографии.

Результаты. У недоношенных новорожденных отмечается снижение показателей общих фосфолипидов в мембране лимфоцитов пуповинной крови и повышение свободного холестерина в сравнении с контрольной группой, хотя статистической значимости в сравниваемых группах не достигнуто. В группе недоношенных детей выявлены изменения показателей спектра фосфолипидов: статистически значимое повышение содержания лизофосфатидилхолина $(p=0,014)$ и сфингомиелина $(p=0,01)$ по сравнению с показателями контрольной группы. Также отмечено повышение показателя соотношения - сфингомиелин/фосфатидилхолин у недоношенных детей $(p=0,001)$ за счет повышения содержания сфингомиелина. Выявлено снижение содержания фосфатидилхолина, легкоокисляемых фракций липидов (фосфатидилсерин +фосфатидилинозитол + фосфатидилэтаноламин) в мембране лимфоцитов пуповинной крови у недоношенных при сравнении между группами доношенных и недоношенных новорожденных.

Заключение. Анализ липидного спектра мембран лимфоцитов пуповинной крови у недоношенных детей по сравнению с доношенными выявил дестабилизацию в липидном бислое мембран. Повышение свободного холестерина свидетельствует о накоплении холестерина в мембранах, нарушении ассиметричности расположения липидов, повышении жесткости мембран лимфоцитов у недоношенных детей. Кроме того, обнаружен дисбаланс фракционного состава фосфолипидов, повышение лизофосфатидилхолина, который, накапливаясь в мембранах клеток, снижает их стабильность, приводя к фосфолипазному мембранолизу и повышение содержания сфингомиелина, что может играть роль в патогенезе различных заболеваний центральной нервной системы у недоношенных новорожденных. 


\section{АНАЛИЗ АКТИВНОСТИ МЕТАБОЛИЧЕСКИХ ПАРАМЕТРОВ КЛЕТОК ИММУННОЙ СИСТЕМЫ У НЕДОНОШЕННЫХ НОВОРОЖДЕННЫХ И ИХ МАТЕРЕЙ \\ Лисихина Н.В., Смирнова Ю.А. \\ ФГБОУ ВО КрасГМУ им. проф. В.Ф.Войно-Ясенецкого \\ Минздрава России, Красноярск \\ Сибирский юридический институт МВД России, Красноярск \\ КГБУЗ «Красноярский краевой клинический центр охраны материнства и детства»}

Введение. Одной из важнейших причин рождения недоношенного ребенка считается нарушение иммунных взаимоотношений между матерью и плодом. Изменения функционального состояния иммунной системы возможно только при соответствующих изменениях метаболических параметров клеток иммунной системы. Значительной информативной ценностью при изучении метаболизма клеток иммунной системы обладает один из показателей активности ферментов лимфоцитов крови - сукцинатдегидрогеназа (СДГ).

Цель исследования - определить патогенетическую значимость изменений активности сукцинатдегидрогеназы в лимфоцитах при недоношенности.

Материалы и методы. Нами в лимфоцитах пуповинной крови у 39 доношенных (38-40 недель гестации) и 65 недоношенных новорожденных детей (2836 недель гестации) и в лимфоцитах венозной крови у их матерей изучена активность СДГ по методу количественного цитохимического определения активности (Р.П. Нарциссов, 1969 г.).

Результаты. Выявлено, что активность СДГ в лимфоцитах пуповинной крови у недоношенных детей значительно ниже по сравнению с доношенными детьми (контрольная группа), разница статистически значима $(p=0,001)$. Снижение активности СДГ в периферической крови в первые дни жизни новорожденного многими авторами расценивалось, как проявление испытываемой недоношенным ребенком гипоксии, плацентарными нарушениями и патологией родов, а также отражением сниженных возможностей иммунитета. У матерей, родивших недоношенных детей, нами так же обнаружено статистически значимое снижение активности СДГ $(p=0,001)$ в клетках иммунной системы венозной крови по сравнению с показателями контрольной группы. Предполагать у матерей, родивших недоношенных детей, состояние гипоксии нет оснований, при нормально протекающей беременности формируется толерантность иммунной системы материнского организма, изменяется баланс цитокинов, увеличивается в циркуляции количество регуляторных Т-клеток с супрессорной активностью, угнетается функциональная активность лимфоцитов. Различные супрессивные и блокирующие факторы могут способствовать снижению актив- ности ферментов клеток иммунной системы у здоровых беременных женщин и рожениц, родивших в срок. Также известно о нарастающем угнетении клеточного иммунитета матери (усиление Т-супрессии, снижение субпопуляции Т-хелперов), и изменении уровня цитокинов при патологии беременности, в том числе при невынашивании.

Заключение. Очень низкий уровень активности СДГ у матерей, родивших недоношенных детей, по сравнению с женщинами, родившими доношенных детей, может отражать значительное снижение у них процессов обеспечения энергией клеток иммунной системы, следовательно и снижение их функциональной активности, происходящей за счет нарастания супрессии, которая переходит допустимый уровень, обеспечивающий нормальное протекание беременности, когда происходит не отторжение, a вынашивание плода, являющегося наполовину “аллотрансплантатом". Полученные данные позволяют предполагать, что низкие показатели активности сукцинатдегидрогеназы у недоношенных детей могут быть обусловлены нарушением иммунных взаимоотношений между матерью и плодом при недоношенной беременности, особенно связанными с нарастанием процессов иммуносупрессии.

\section{ФАКТОРЫ РИСКА РАЗВИТИЯ ЖЕЛЕЗОДЕФИЦИТНОЙ АНЕМИИ У ДЕТЕЙ РАННЕГО ВОЗРАСТА}

Ляпунова Е.В., Докучаева С.Ю., Пономарева О.В. ФГБОУ ВО Кировский ГМУ Минздрава России, Киров

Введение. Несмотря на относительную легкость диагностики и лечения, железодефицитная анемия остается широко распространенным заболеванием во всем мире, актуальность которой не снижается.

Цель исследования - определить ведущие факторы риска в развитии железодефицитной анемии, особенности клиники у детей раннего возраста.

Материалы и методы. Проведен анализ медицинской документации (уч.ф.112, истории болезни) у 52 обследованных детей раннего возраста с установленным диагнозом железодефицитная анемия.

Результаты. Средний возраст детей с железодефицитной анемией составил $12,6 \pm 8,9$ мес. Чаще всего анемия регистрировалась с 6 месяцев до 1 года. Возрастно-половая структура железодефицитной анемии представлена соотношением 3:1 в пользу мальчиков. Дебют анемии приходится от 0 до 6 месяцев - 60,5\%, до года $-12,9 \%$ и старше года $-26,6 \%$. По данным анализа анамнестических данных, у 46 детей $(88,46 \%)$ матери во время беременности перенесли анемию различной степени. Отягощенный акушерский анамнез: гестозы $(67,3 \%)$, угроза прерывания беременности $(38,4 \%)$, аборты и выкидыши $(30,8 \%)$, инфекции во время беременности $(15,4 \%)$, хрони- 
ческие заболевания матери $(11,5 \%)$, многоплодная беременность $(3,8 \%)$. Со стороны ребенка ХВГП, РДС $(28,9 \%)$ и недоношенность $(23,1 \%)$. Среди экзогенных постнатальных факторов: ранний перевод на искусственное вскармливание $(30,8 \%)$, нерациональное введение прикормов (30\%). У всех детей, которые находились на грудном вскармливании, диагностирована железодефицитная анемия легкой степени $(69,2 \%)$. Среднетяжелая (25\%) и тяжелая анемия $(5,8 \%)$ выявлена у детей на фоне сочетания нескольких соматических заболеваний. При этом у 2 детей уровень гемоглобина был ниже 70 г/л. Уровень гемоглобина колебался от 78 до 109 г/л. Железо сыворотки было снижено у $65 \%$ больных детей и составлял 5,7 $\pm 0,49$ мкмоль/л.

Заключение. На амбулаторном этапе необходимо уделять большое внимание раннему выявлению факторов риска, проведению комплекса профилактических мероприятий и ранней диагностике железодефицитных состояний с целью своевременной их коррекции.

\section{ОСОБЕННОСТИ ПОЛОВОГО РАЗВИТИЯ ДЕТЕЙ}

Ляпунова Е.В., Пономарева О.В., Чагаева Н.В. ФГБОУ ВО Кировский ГМУ Минздрава России, Киров

Введение. Период полового созревания является важным этапом развития детского организма. Наиболее точно определить темп полового развития позволяет оценка вторичных половых признаков. По степени их развития можно судить о физиологичности течения полового созревания, а также выявить его разнообразные отклонения.

Цель исследования - выявить особенности полового развития у детей, проживающих в г. Кирове.

Материалы и методы. Обследовано 265 детей (134 мальчика и 131 девочек) в возрасте 8-14 лет, имеющие I и II группу здоровья, проживающие на территории г. Кирова. Оценка полового развития проводилась по стандартной методике.

Результаты. При анализе полученных данных было установлено, что первые признаки полового развития определялись у мальчиков в возрасте 10,5 лет, у девочек - в 9 лет. У большинства мальчиков порядок проявления вторичных половых признаков определялся последующими стадиями: развитие волосяного покрова на лобке, изменение тембра голоса, оволосение подмышечных впадин, рост щитовидного хряща и оволосение лица. У большинства девочек отмечалась обычная последовательность появления вторичных половых признаков. Первые проявления выражались в развитии молочных желез, затем отмечался рост волос на лобке, в подмышечных впадинах, и в конце наступало менархе. Средний возраст появления менархе отмечался к 12,6 годам. При анализе темпов полового развития было установлено, что девочки в 10 лет имели средний темп полового развития в $95 \%$ случаев и в $5,0 \%$ - ускоренный. Уже в 11 лет у девочек в 62,8\% случаев регистрировался средний темп полового развития, в 23,3\% случаев замедленный и в $13,9 \%$ случаев - ускоренный темп. В возрасте 12-14 лет у многих девочек в $63,0 \%-74,6 \%$ случаев отмечался средний темп полового развития, отставание - в 24,6\% - 28,9\% случаев и опережение в 7,0\% - 8,1\% случаев. В возрасте $12-14$ лет у мальчиков в 70,5\% - 92,0\% определялся средний темп полового развития, отставание - в $13,2 \%$ - 22,0\% случаев и опережение - в $3,1 \%-8,0 \%$ случаев.

Заключение. При анализе данных, полученных в ходе проведенного исследования, у большинства подростков г. Кирова отмечалось гармоничное и последовательное развитие половых признаков. Анализ темпов полового развития показал, что достоверно больше детей со средним темпом полового развития. Детей с замедленным и ускоренным темпами полового развития соответственно меньше.

\section{ЗАБОЛЕВАЕМОСТЬ ЗЛОКАЧЕСТВЕННЫМИ НОВООБРАЗОВАНИЯМИ ДЕТСКОГО НАСЕЛЕНИЯ КАЛИНИНГРАДСКОЙ ОБЛАСТИ}

Малахова Ж.Л. ${ }^{1}$, Перминова Л.А. ${ }^{1}$, Гончарова И.В. ${ }^{2}$ ${ }^{1}$ ФГАОУ ВО «Балтийский федеральный университет имени И. Канта», медицинский институт, Калининград 2ГБУЗ «Детская областная больница Калининградской области», Калининград

Введение. На долю злокачественных новообразований у детей от 0 до 17 лет приходится менее 1\%, а общий показатель заболеваемости раком в мире находится в пределах 50-200 случаев на 1 млн. детского населения. Несмотря на относительно редкую встречаемость, злокачественные новообразования занимают одну из лидирующих позиций в структуре детской смертности.

Цель исследования: провести анализ заболеваемости злокачественными новообразованиями детского населения Калининградской обл. за период с 2009 г. по 2019 г.

Материалы и методы: в работе использовались данные детского канцер-регистра Калининградской обл. и МНИОИ им. П. А. Герцена за 2009-2019 гг., официальные статистические отчетные формы Роспотребнадзора. Статистическую обработку данных проводили с использованием программы Microsoft Office Excel 2007.

Результаты. За период с 2009 по 2019 гг. в Калининградской обл. прослеживается устойчивая тенденция к росту заболеваемости злокачественными новообразованиями детского населения от 0 до 17 лет (2009 г.- 13,4 на 100 тыс. детского населения, 2010 г.12,1, 2013 г. - 12,6, 2014 г.- 14,5, 2016 г.- 17,5, 2019 г. 16,3), которая в регионе выше, чем в РФ: 2009 г.- 12,7 
на 100 тыс. детского населения, 2010 г.- 12,9, 2013 г.12,5, 2014 г.- 12,8, 2016 г.- 13,01, 2019 г.- 12,4.

Среднемноголетняя заболеваемость выросла с 2016 г. и составила 16,75 на 100 тыс. детского населения $(2009-2015$ гг. - 12,0). При этом мальчики заболевают в 1,2 раза чаще девочек. В структуре первичной онкологической заболеваемости, за указанный период, лидирующее место занимают лейкозы - 28,8\%, (исключение составили 2010 г. - среди впервые выявленных злокачественных новообразований лимфомы диагносцированы в 20\% случаев, лейкозы - в 15\%; 2012 г. - опухоли центральной нервной системы - 29,4\%, лейкозы - 23,5\%). Максимальный подъем заболеваемости гемобластозами задокументирован в 2016 г. - 42,4\% среди всех впервые выявленных случаев злокачественных новообразований. Второе место занимают опухоли центральной нервной системы, на долю которых приходится $16,7 \%$, далее следуют лимфомы - $12,7 \%$, опухоли почек $-7,6 \%$, опухоли костной системы $-6,9 \%$.

Среднемноголетняя смертность от злокачественных новообразований в Калининградской области составила 2,8 на 100 тыс. детского населения (0-17 л.), максимальные показатели задокументированы в 2015 г.- 3,8, 2016 г. - 4,2 (в РФ: 2015 г.-3,6, 2016 г.3,5). Высокую смертность имеют злокачественные новообразования центральной нервной системы, кроветворной и лимфатической ткани.

Заключение. Таким образом, с 2009 г. по 2019 г. отмечалось повышение онкологической заболеваемости среди детского населения от 0 до 17 лет Калининградской области. В структуре заболеваемости на 100 тыс. детского населения лидирующую позицию занимали злокачественные новообразования кроветворной и лимфатической ткани, реже встречались опухоли центральной нервной системы и почек. Максимальные показатели смертности имеют злокачественные новообразования центральной нервной системы и кроветворной.

\section{АНАЛИЗ ЛЕЙКОЦИТАРНОГО РОСТКА КРОВЕТВОРЕНИЯ У ДЕТЕЙ ПЕРВОГО ГОДА ЖИЗНИ В Г.ТЮМЕНИ}

Морева Г.В., Санникова Н.А., Луговская А.А., Мешерякова К.С., Якушева Ю.В.

ФГБОУ ВО Тюменский ГМУ Минздрава России ГАУЗ ТО «Городская поликлиника №4», Тюмень

Введение. Мультивариантность современных технологий гематологических исследований обуславливает необходимость разработки новых референтных ориентиров.

Цель исследования: Анализ показателей лейкоцитарного ростка кроветворения у детей первого года жизни, сравнение данных с литературными источниками.
Материалы и методы. Проанализировано 100 историй развития детей, прикрепленных к ДП № 4 г. Тюмени. В качестве анализируемого материала учитывались данные общего анализа крови в первом полугодии жизни и в годовалом возрасте, а также наличие факторов перинатального риска и соматических заболеваний детей в данном периоде жизни.

Результаты. Получены следующие результаты: среднее значение количества лейкоцитов в первом полугодии жизни - 9,4110^9/л, в годовалом возрасте $-8,98110^{\wedge} 9 /$ л. Данные исследования отличаются в количественном плане от представленных в учебной литературе (среднее значение по данным И.М. Воронцова, 1985 г., в возрасте полугода $-10,9110^{\wedge}$ 9/л, одного года - 10,5110^9/л; по данным Р.Р. Кильдияровой и В.И. Макаровой , 2016 г., среднее значение количества лейкоцитов на первом году жизни варьирует в пределах 10,0-12,0110^9/л). Результаты соответствуют общепринятой тенденции снижения общего количества лейкоцитов от рождения до подросткового возраста. Данные изменения могут наблюдаться на фоне увеличивающегося количества факторов риска, действующих как на плод во время беременности, так и на новорожденного. В $98 \%$ случаев выявлено от двух до десяти перинатальных факторов риска. В ходе исследования выявлен ребенок с лейкоцитозом 22110^9/л в первом полугодии и $16110^{\wedge} 9 /$ в в годовалом возрасте, родители которого больны ВИЧ инфекцией; и двое детей с лейкопенией $4,05110^{\wedge} 9 / л-7,9$ и 7,9 - 4,08 110^9/л с гепатитом С у одного ребенка и гинекологической патологией во время беременности у матери другого.

Заключение. Выявлено незначительное снижение среднего количества лейкоцитов у детей ДП № 4 г. Тюмени в течение первого года жизни. Дети с экстремальными отклонениями в ОАК должны наблюдаться в поликлинике индивидуально с учетом заболевания.

\section{ПЕРСОНИФИЦИРОВАННЫЙ ПОДХОД К ПРОГНОЗИРОВАНИЮ ОРГАНИЧЕСКОГО ПОРАЖЕНИЯ ЦЕНТРАЛЬНОЙ НЕРВНОЙ СИСТЕМЫ У НЕДОНОШЕННЫХ НОВОРОЖДЕННЫХ ДЕТЕЙ}

Павлинова Е.Б., Губич А.А., Савченко О.А. ФГБОУ ВО ОмГМУ Минздрава России, Омск

Введение. Невозможно точно спрогнозировать развитие того или иного исхода со стороны (ЦНС) в неонатальном периоде у недоношенных новорожденных детей - отсутствие каких-либо изменений или возникновение тяжелого органического поражения (внутрижелудочковых кровоизлияний, перивентрикулярной лейкомаляции).

Цель исследования - оценить значимость клинико-анамнестических, лабораторно-инструменталь- 
ных данных в качестве предикторов тяжелого поражения ЦНС у недоношенных детей.

Материалы и методы. Основная группа - недоношенные новорожденные дети с гестационным возрастом менее 36 недель включительно $(n=60)$, контрольная группа - доношенные новорожденные дети $(n=25)$. В процессе динамического наблюдения основная группа была разделена на подгруппы: подгруппа 1 (с поражением ЦНС) - 25 человек, подгруппа 2 (без поражения ЦНС) - 35 человек. Проводилось исследование клинико-анамнестических данных новорожденных детей и их матерей, оценка лабораторно-инструментальных показателей при рождении и в динамике. Исследовали общий антиоксидантный статус, общий оксидативный статус, содержание в крови медь, цинк-содержащей супероксиддисмутазы (Cu,Zn-SOD), супероксиддисмутазы, содержащей марганец (Mn-SOD, SOD2), и глутатиона (в восстановленном и окисленном состояниях) в раннем неонатальном периоде. Так же определяли аллельный полиморфизм четырех генетических маркеров: мутацию 3 SOD2 (Ala16Val), мутацию 1 SOD2 (T58C), мутацию 2 SOD2 (C60T), мутацию каталитической субъединицы глутаматцистеинлигазы (GCLM C-129T).

Результаты. Срок гестации и антропометрические показатели при рождении у детей с поражением ЦНС были достоверно ниже. Ведущим синдромом при рождении у детей с органическим поражением ЦНС был синдром дыхательной недостаточности. Интубация в родильном зале проводилась этой категории пациентов чаще. Большей части детей в последующем требовалась респираторная поддержка, что было статистически значимо. Так же достоверно чаще требовалась именно инвазивная респираторная поддержка. Дети с органическим поражением ЦНС на 2-5 день жизни имели ниже уровень гемоглобина, тромбоцитов, гематокрита, что было достоверно. Антиоксидантный статус, показатели $\mathrm{Cu}, \mathrm{Zn}-\mathrm{SOD}$, глутатиона были статистически значимо ниже у этой категории пациентов. Так же дети с поражением ЦНС испытывали больший оксидативный стресс.

Заключение. Использование в качестве предикторов органического поражения ЦНС комплекса анамнестических, клинических, лабораторно-инструментальных данных с возможностью применения современных биомаркеров является наиболее перспективным, нежели применение этих данных по отдельности.

\section{ОПРЕДЕЛЕНИЕ ФАКТОРОВ РИСКА РАЗВИТИЯ НЕКРОТИЧЕСКОГО ЭНТЕРОКОЛИТА У НОВОРОЖДЕННЫХ}

Павлинова Е.Б., Беликова Д.А., Полянская Н.А.,

Савченко О.A.

ФГБОУ ВО Омский государственный медицинский

университет Минздрава России, Омск

Введение. Некротическй энтероколит (НЭК) является одним из наиболее тяжелых заболеваний в периоде новорожденности с высоким риском летального исхода. Известно, что данное заболевание является результатом воздействия множества неблагоприятных факторов, таких как недоношенность, низкая масса тела, гипоксия, отягощенный соматический и акушерский материнский анамнез, и другие. Однако диагностика на ранних стадиях до сих пор затруднена. Поэтому изучение предикторов развития НЭК является актуальным.

Цель исследования. Изучить возможные факторы риска развития НЭК у недоношенных детей.

Материалы и методы. Проведен ретроспективный анализ 60 историй болезни новорожденных с диагнозом НЭК в период с 2017 по 2020 гг. Исследование проводилось на базе БУЗОО ОДКБ г. Омска. Статистическая обработка была выполнена при помощи программного обеспечения Jamovi 1,6.

Результаты. Выделены наиболее значимые факторы риска НЭК: гестационный возраст и масса тела при рождении, наличие открытого артериального протока, начало энтерального питания, ранней анемии, никотиновой интоксикации. Средний гестационный возраст в анализируемой группе составил 29 недель, средняя масса тела - 1362 г. Гемодинамически значимый открытый артериальный проток (ОАП) встречался у $40 \%$ детей, при этом установлена сильная корреляционная связь между степенью тяжести НЭК и наличием гемодинамически значимого ОАП ( $r=0,40$, $\mathrm{p}<0,001)$. Связь с ранним началом энтерального питания и НЭК не установлена $(r=0,2 p=0,125)$. Анемия в первые сутки жизни отмечалась у $60 \%$ детей, средний уровень гемоглобина в крови новорожденных составил 143 г/л ( \pm 45 г/л), отмечена статистически значимая корреляция между ранней анемией у недоношенных детей в первые сутки жизни и развитием НЭК $(p=0,002)$. Из материнского анамнеза известно, что хронической никотиновой зависимостью страдало $30 \%$ женщин, но связи между курением и развитием НЭК установлено не было ( $p>0,05)$.

Заключение. Таким образом, в анализируемой группе детей наиболее значимыми факторами риска развития НЭК явились открытый артериальный проток и ранняя анемия новорожденных. 


\section{ОРГАНИЗАЦИЯ ГРУДНОГО ВСКАРМЛИВАНИЯ НОВОРОЖДЕННЫХ НА ЭТАПЕ РОДИЛЬНОГО ДОМА \\ Павлинова Е.Б. ${ }^{1}$, Мингаирова А.Г. ${ }^{1}$, Киршина И.А. ${ }^{1}$, Николаев С.В. ${ }^{2}$, Нестеренко Э.В. ${ }^{2}$, Кондратьева Н.A. ${ }^{2}$ ${ }^{1}$ ФГБОУ ВО «Омский государственный медицинский университет» Минздрава России \\ БЮджетное учреждение здравоохранения Омской области «Городской клинический перинатальный центр»}

Введение. Несмотря на инициальный настрой большинства материей на длительное кормление, к 1 году грудное молоко продолжают получать около 40-43\% детей. Инициатива ВОЗ/ЮНИСЕФ «Больница, доброжелательная к ребенку» способствует длительному сохранению грудного вскармливания (ГВ).

Цель исследования - оценить организацию ГВ на базе бюджетного учреждения здравоохранения Омской области «Городской клинический перинатальный центр» (БУЗОО ГКПЦ) в соответствии с Инициативой ВОЗ/ЮНИСЕФ «Больница, доброжелательная к ребенку».

Материалы и методы. В одномоментном исследовании методом поперечного среза приняли участие 42 медицинских работника БУЗОО ГКПЦ. Респондентам предлагалось ответить посредством интернет-платформы Google Формы на вопросы об организации грудного вскармливания новорожденных на этапе родильного дома. Статистический анализ результатов проводился с помощью Microsoft Office 365.

Результаты. Учреждение в своей работе руководствуется самостоятельно разработанной письменной политикой в отношении ГВ. Большинство (69\%) персонала проходит обучение по вопросам ГВ. При этом $70 \%$ опрошенных медицинских работников считает, что обучение женщин аспектам поддержания ГВ должно осуществляться на этапе подготовки к родам. В 95,2\% ответов указано, что о ГВ мать должен информировать врач-педиатр. В течение первого часа после рождения к груди прикладывается 98\% новорожденных при естественных родах, и 93\% - после родоразрешения путем кесарева сечения. В $100 \%$ ответов указано, что в стационаре преобладает круглосуточное совместное пребывание матери и новорожденного, а родильницы получают советы о правильном прикладывании ребенка к груди и сохранении лактации. В БУЗОО ГКПЦ поддерживается кормление новорожденного по требованию - только 9,5\% сотрудников считают, что кормить ребенка следует в отведенные часы. До $71 \%$ респондентов утверждают, что новорожденные не получают никакой иной пищи или питья, кроме грудного молока, за исключением случаев медицинских показаний, которые определяются врачом-неонатологом. В 74\% ответов указано, что докорм осуществляется посредством бутылочки, что способствует отказу ребенка от ГВ и противоречит Инициативе ВОЗ/ЮНИСЕФ. Недостаточно обеспечена поддержка женщин по вопросам ГВ после выписки из стационара. При возникновении вопросов и проблем с ГВ наиболее часто (26\%) рекомендуется обращение в медицинскую организацию по телефону.

Заключение. Организация ГВ частично соответствует Инициативе ВОЗ/ЮНИСЕФ «Больница, доброжелательная к ребенку».

\section{КЛИНИКО-АНАМНЕСТИЧЕСКАЯ ХАРАКТЕРИСТИКА НОВОРОЖДЕННЫХ ДЕТЕЙ, РОЖДЕННЫХ ОТ МАТЕРЕЙ С ГЕСТАЦИОННЫМ САХАРНЫМ ДИАБЕТОМ}

Панина О.С., Крошкина Д.В. ФГБОУ Саратовский ГМУ имени В.И. Разумовского Минздрава России, Саратов

Актуальность: Гестационный сахарный диабет (ГСД) - наиболее частое нарушение обмена веществ у беременных. Беременность, осложненная ГСД, увеличивает риск возникновения серьезных акушерских и перинатальных осложнений.

Цель: Изучить особенности течения неонатального периода в зависимости от проводимой инсулинотерапией матери до \во время беременности.

Материалы и методы: В исследование было включено 53 пары мать-новорожденный. У матерей был зафиксирован ГСД. Оценку физического развития детей проводили с помощью: таблицы Дементьевой и шкалы Fenton.

Результаты исследования: Анализ медицинской документации выявил, что патология углеводного обмена имела место у 77,3 \% обследованных женщин, из них у 54\% - ГСД. В ходе работы нами были выявлены существенные различия в течении неонатального периода у детей, в зависимости от адекватности проводимой инсулинотерапии до \во время беременности. Оценка по шкале Апгар при адекватной терапии матери составила $7 \pm 1$ баллов, при отсутствии адекватной терапии- $5 \pm 1$ баллов $(p>0,05)$. Тяжелое течение синдрома дыхательных расстройств отмечалось в 1,5-2 раза чаще у детей без инсулинотерапии матери. Среди детей данной группы, так же в 2-2,5 раза чаще встречались неврологические нарушения, потребовавшие длительной реабилитации. Примерно в 3 раза чаще нами была замечена офтальмопатия среди детей данной группы. В свою очередь дети, матери которых получали инсулинотерапию, находились на неинвазивной ИВЛ не более 2-х суток или вообще в ней не нуждались, имели незначительную неврологическую симптоматику и офтальмопатию.

Заключение: На сегодняшний день ГСД стал достаточно часто встречаемой патологией обмена веществ среди беременных женщин. Но, к сожалению, далеко 
не все специалисты уделяют должного внимания этой патологии. От своевременно и правильно подобранной дозы инсулина во многом будет зависеть дальнейшее течение неонатального периода у этих новорожденных. С этой целью необходимо активно внедрять в практическую деятельность междисциплинарный подход (акушер-гинеколог + эндокринолог + терапевт) к ведению и лечению подобного рода патологии.

\section{УРОВНИ ВИСФАТИНА И ЛЕПТИНА У КРУПНОВЕСНЫХ НОВОРОЖДЕННЫХ И ИХ МАТЕРЕЙ}

Прилуцкая В.А., Гончарик А.В.

Белорусский государственный медицинский университет», Минск, Беларусь

Введение. В последнее время большое внимание уделяется гормонам жировой ткани адипокинам. Доказано, что они секретируются организмом беременной женщины, плацентой и плодом. Уровни лептина у новорожденного коррелируют с жировой массой тела при рождении. Висфатин обладает эффектами, имитирующими инсулин, играет роль в развитии метаболического синдрома.

Цель исследования: оценить содержание висфатина и лептина у крупновесных к сроку гестации новорожденных и их матерей.

Материалы и методы. Обследовано 52 доношенных новорожденных. Дети разделены на 2 группы: группа 1 (Гр1) - крупновесные к сроку новорожденные $(n=28)$, Гр 2 - группа сравнения, дети с соответствующим сроку гестации физическим развитием $(n=24)$. Уровни висфатина и лептина определяли в пуповинной крови детей и сыворотке крови их матерей методом ИФА с использованием наборов Phoenix pharmaceuticals (США) и DRG International Inc (Германия). Постановку реакций проводили в соответствии с инструкциями по применению. Статобработка выполнена в Statistica.

Результаты. Содержание лептина пуповинной крови было равно 13,10 [6,40; 28,84] нг/мл в Гр1 и 5,05 $[3,80 ; 10,00]$ нг/мл в Гр $2, p<0,001$. Уровни сывороточного лептина их матерей составили 18,00 [11,60; 26,03] и $14,20[9,80 ; 21,00]$ нг/мл соответственно, $p=0,004$. Содержание висфатина пуповинной крови не имело значимых различий $(10,5[9,4 ; 15,0]$ нг/мл в Гр1 и 9, 10 $[8,0 ; 14,0]$ нг/мл в Гр $2, p=0,154$. Уровни сывороточного висфатина матерей были 8,6 [7,9; 10,5] и 11,5 $[9,4 ; 20,0]$ нг/мл, $p=0,005$. В Гр1 установлены прямые корреляционные связи между уровнем лептина пуповинной крови и массой тела при рождении $(r=0,685$, $p<0,05)$, содержанием висфатина у матери и ЛПВП в пуповинной крови $(r=0,594, p<0,05)$. В Гр2 уровень висфатина матери ассоциирован с висфатином пуповинной крови $(r=0,406, p<0,05)$.
Заключение. У крупновесных новорожденных и их матерей установлены значимо более высокие уровни лептина. Уровень висфатина сыворотки матерей крупновесных к сроку гестации был значимо ниже показателя группы сравнения. Полученные результаты подтверждают положение, что лептин и висфатин могут иметь существенный вклад в формировании макросомии при гестации и развитии доношенных новорожденных. Дисбаланс адипокинов у крупновесных при рождении младенцев может способствовать развитию метаболического синдрома в более позднем возрасте.

\section{СВЯЗЬ ГЕНОТИПОВ ПО ПОЛИМОРФНЫМ ЛОКУСАМ ГЕНА АДИПОНЕКТИНА С ПОКАЗАТЕЛЯМИ АДИПОНЕКТИНЕМИИ У НОВОРОЖДЕННЫХ С РАЗЛИЧНОЙ МАССОЙ ТЕЛА ПРИ РОЖДЕНИИ}

Прилуцкая B.A. ${ }^{1}$, Шатарнова T.M. ${ }^{2}$, Сукало A.B. ${ }^{1}$, Аксенова Е.A. ${ }^{2}$

${ }^{1}$ Белорусский государственный медицинский университет 2 Институт генетики и цитологии НАН Беларуси, Минск, Беларусь

Введение. Концентрация адипонектина в сыворотке крови находится в обратной зависимости от содержания глюкозы, инсулина и триглицеридов. Однонуклеотидные замены -11391G/A (rs17300539) и -11377C/G (rs266729) в области промотера гена адипонектина (ADIPOQ) связаны с промотерной активностью гена и, соответственно, уровнем синтеза адипонектина.

Цель исследования - провести генотипирование детей с различной массой тела (МТ) по rs17300539 и rs266729 локусам гена адипонектина и оценить взаимосвязь с уровнем адипонектинемии.

Материалы и методы. 395 доношенных детей генотипировали с помощь метода ПЦР-ПДРФ. Выделено 3 группы: крупновесные к сроку гестации $($ КСГ, $n=139)$, маловесные к сроку гестации (МСГ, $n=138)$, соответствующие сроку (группа контроля, ГрК, $n=118)$. МТ крупновесных - 4300 (4130-4510), МСГ - 2430 (2310-2580), ГрК - 3290 (3170-3500) г. Z-score MT - 1,9 (1,6-2,3), -1,9 (-2,3--1,6), 0,1 (-0,3$0,4)$. Статобработка проведена в программе Statistica, AB-Stat.

Результаты. Выявлены более низкие показатели перцентиля МТ у носителей $-11377 \mathrm{GG}$ генотипа, связанного с пониженной промоторной активностью гена. Установлена разница уровней адипонектинемии у КСГ детей в зависимости от генотипа по rs266729 локусу. При GG генотипе отмечался более низкий уровень адипонектина на 3-7 сутки жизни у КСГ $(28,3(24,9-32,2)$ мкг/мл) при сравнении с обладателями СC ( $p=0,004)$ и $\mathrm{CG}(p=0,036)$ генотипов. Не выявлено различий значений ИМТ 
у МСГ детей в зависимости от генотипа $-11377 \mathrm{C} / \mathrm{G}$ гена ADIPOQ. Установлены значимо более высокие показатели ДТ и Z-score ДТ у носителей генотипа GG по сравнению с детьми с СС генотипом ( $p=0,049$ и $p=0,038)$. Частота $-11377 \mathrm{G}$ аллеля (rs266729) гена ADIPOQ в группе КСГ девочек c z-score MT>2 была значимо ниже $(16,1 \%)$, чему у МСГ девочек c z-score $\mathrm{MT}<-2-31,4 \%\left(\chi^{2}=3,96, p<0,05\right)$ и девочек ГрК $29,7 \%\left(\chi^{2}=3,80, p<0,05\right)$. По rs17300539 локусу гена ADIPOQ значимых различий не обнаружено.

Заключение. Частоты генотипов и аллелей изученных локусов гена адипонектина в общей выборке КСГ и МСГ новорожденных статистически не различались. Аллель $-11377 \mathrm{G}$ гена ADIPOQ в группе КСГ девочек c z-score MT>2 встречался реже $(p<0,05)$, чем у МСГ девочек c z-score MT <-2 и девочек ГрК.

\section{СОСТОЯНИЕ ЗДОРОВЬЯ НОВОРОЖДЕННЫХ ОТ МАТЕРЕЙ С ДЕБЮТОМ БРОНХИАЛЬНОЙ АСТМЫ ВО ВРЕМЯ БЕРЕМЕННОСТИ}

Приходько О.Б., Романцова Е.Б., Кострова И.В., Лучникова Т.A.

ФГБОУ ВО Амурская ГМА Минздрава России, Благовещенск

Введение. Изучение вопроса взаимного отягощения бронхиальной астмы (БА) и беременности остается актуальной проблемой пульмонологии. БА у беременных является одним из наиболее распространенных заболеваний легких в гестационном периоде.

Цель исследования: изучить клинико-функциональные особенности течения бронхиальной астмы (БА), дебютировавшей во время беременности, в том числе, на фоне внелогочных проявлений аллергии, определить частоту развития осложнений беременности, родов и состояние плода и новорожденного у данной категории пациенток.

Материалы и методы. Изучены клинико-анамнестические данные течения беременности у 47 больных с дебютом БА во время гестации.

Результаты. Отягощенная наследственность по аллергии была у 14 (29,8\%) больных.). Внелегочные проявления аллергии до наступления беременности отмечались у 68,1\% пациенток, из них крапивница - у 27,7\%, атопический дерматит у $14,9 \%$, аллергический ринит - у $17 \%$, анафилактический шок - у 6,4\%, то есть, были достаточно выражены до манифестации БА. Аллергическая форма БА выявлена у 66\% больных, неаллергическая - у $12,8 \%$, смешанная - у 21,2\%. У 48,9\% больных симптомы БА появились в I триместре беременности, у 44,6\% - во II и у 6,5\% - в III триместре. У 24 больных с легким течением (БАЛТ) приступы удушья впервые появились после ОРВИ и контакта с аллергеном. При этом дебют у 15 больных был в I триместре беременности, чаще при сроке 5-6 недель, у 9 - во II триместре, при сроке беременности 16-20 недель. У 20 больных БА среднетяжелого течения (БАСТ) диагностирована при сроках гестации 6-12, 20-29 недель, после ОРВИ. У 3 пациенток приступы БАТТ появились при сроке гестации 10-14 и 21 недели на фоне ОРВИ. При этом БАЛТ наблюдалась у $51,1 \%$, БАСТ - у 42,6\%, БАТТ - у 6,4\%. Из неспецифических триггеров БА преобладали: ОРВИ - 68,1\%, психо-эмоциональное напряжение - у $57,4 \%$, влияние метеоусловий - у 59,6\%, физической нагрузки - у $38,3 \%$.

В структуре заболеваний новорожденных ведущие места занимали: церебральная ишемия - в 17 (36,2\%) случаях, внутриутробное инфицирование (инфекционные заболевания кожи и слизистых оболочек) у 14 (29,8\%), нарушение периода адаптации - у 14 $(29,8 \%)$, задержка внутриутробного развития плода у 6 (12,8\%), синдром дыхательных расстройств - у 8 (17\%), синдром двигательных нарушений - у 13 $(27,7 \%)$.

Заключение. Таким образом, для беременности и БА в большинстве случаев характерно взаимное отягощение, что требует индивидуальных подходов к ведению беременности и адекватной терапии астмы.

\section{ОТСУТСТВИЕ КОНТРОЛЯ БРОНХИАЛЬНОЙ АСТМЫ У БЕРЕМЕННЫХ КАК ПРЕДИКТОР ПЕРИНАТАЛЬНЫХ ОСЛОЖНЕНИЙ}

Приходько О.Б., Романцова Е.Б., Кострова И.В., Лучникова T.A.

ФГБОУ ВО Амурская ГМА Минздрава России,

Благовещенск

Введение. Бронхиальная астма (БА) является наиболее частым хроническим заболеванием у беременных, и ее распространенность неуклонно увеличивается во всем мире. Отсутствие контроля заболевания у этой категории больных является серьезной фоновой патологией, требующего дальнейшего изучения.

Цель исследования - определение влияния неконтролируемого течения БА на развитие осложнений беременности, родов и состояние плода и новорожденного.

Материалы и методы. Среди беременных выделены следующие группы: с контролируемой БА (I группа, 85 пациенток), с частично контролируемой (II группа, 78 больных), с неконтролируемой БА (III группа 90 больных), группа сравнения - 30 беременных без бронхолегочной патологии (IV группа).

Результаты. У больных БА с нарушениями вентиляционной функции легких по данным спирометрии и пикфлоуметрии возрастала частота осложнений беременности. По сравнению с I группой, у пациенток III группы чаще развивался гестоз (в 1,9 
раза), хроническая плацентарная недостаточность (в 1,7 раза), хроническая внутриутробная гипоксия плода (в 1,5 раза), инфекция амниотической полости и плодных оболочек (в 1, 4 раза), что свидетельствовало об ухудшении условий для внутриутрубного развития плода при наличии вентиляционных нарушений у беременных и отсутствии контроля заболевания. При этом в III группе в 2,3 раза чаще наблюдались новорожденные с оценкой по шкале Апгар ниже 6 баллов, чем в I - II группах $(p<0,05)$. У детей от матерей II-III групп чаще $(p<0,001)$ отмечались церебральная ишемия, синдром задержки внутриутробного развития плода (ЗВРП) $(p<0,01)$, гипотрофия II-III степени, постгипоксическая кардиопатия, синдром дыхательных расстройств (СДР) $(p<0,05)$, токсическая эритема. Эти патологические состояния отрицательно влияли на дальнейшее развитие детей, приводя к повышенной заболеваемости в период новорожденности. Прямо пропорционально степени вентиляционных нарушений нарастала частота дисгармоничного развития плода и новорожденного $(p<0,001)$ за счет снижения массо-ростовых показателей. Неконтролируемое течение БА приводило к достоверному учащению таких тяжелых заболеваний, как церебральная ишемия, СДР, ЗВРП, отрицательно влияющих не только на развитие плода и новорожденного, но и на состояние здоровья детей в последующие периоды.

Заключение. Отсутствие контроля БА во время беременности сопровождается увеличением полиорганной патологии у новорожденных, значительным снижением рождения здоровых детей, ранним развитием у них аллергических заболеваний.

\section{РАСПРОСТРАНЕННОСТЬ ОСТРЫХ РЕСПИРАТОРНЫХ ЗАБОЛЕВАНИЙ СРЕДИ ОБУЧАЮЩИХСЯ МЕДИЦИНСКОГО УНИВЕРСИТЕТА}

Рыбакова О.Г., Зайцева М.Л., Петрунина С.Ю., Шурхавецкая А.А, Мировчикова Т.А.

ФГБОУ ВО «Южно-Уральский государственный медицинский университет» Минздрава России, Челябинск

Введение. Острые респираторные заболевания (ОР3) - группа клинически и морфологически подобных острых воспалительных заболеваний органов дыхания, возбудителями которых преимущественно являются вирусы, реже бактерии, грибы и паразиты, все они тропны к респираторному эпителию. Восприимчивость к ним всеобщая, высокая, зависит от иммунитета и не зависит от пола.

Цель. Изучить распространенность острых респираторных заболеваний у обучающихся медицинского университета в интервале времени с апреля 2020 по апрель 2021 года.
Материалы и методы. Исследование организовано по типу поперечного среза. Метод выборки - сплошной (обучающиеся ФГБОУ ВО «ЮУГМУ» Минздрава России г. Челябинск). Нами была разработана анкета, которая распространялась в виде печатного варианта - персональный опрос и Google-формы. В исследовании приняло участие 170 респондентов. Анализируемый интервал времени с апреля 2020 года по апрель 2021 года.

Результаты. При анализе частоты случаев ОР3 было выявлено, что 15 человек $(8,8 \%)$ не болели, 66 человек болели 1 раз $(38,8 \%), 61$ человек болел 2 раза $(35,9 \%), 23$ человека болели 4 раза $(13,5 \%), 3$ человека болели еще чаще (1,8\%). Причем 121 (71,2\%) респондент отметили, что болеют так всегда, ничего не изменилось, 23 (13,5\%) респондента отметили, что год назад болели реже, $26(15,3 \%)$ - год назад болели чаще. При анализе топического диагноза, было выявлено, что изолированный «острый ринит» встречался в 16,3\% случаев, чаще всего выявлялось сочетанное поражение органов верхних дыхательных и реже нижних дыхательных путей $(83,7 \%)$. Анализ частоты заболеваемости ОРЗ в зависимости от работы в медицинских учреждениях не выявил различий среди работающих и неработающих обучающихся, заболеваемость в этих группах была одинаковой. При анализе влияния питания на частоту респираторных заболеваний, было выявлено, что респонденты, имеющие полноценные приемы пищи 3 раза в день, болеют реже, т.е. 7,6\% опрошенных ответили, что болели 4 раза в анализируемом году против 28,2\% в группе с нерегулярным питанием. 85 респондентов (50\%) ответили, что перенесли новую коронавирусную инфекцию. У 37,6\% обучающихся диагноз был верифицирован с помощью ПЦР теста, у 25,9\% были обнаружены вирусоспецифические антитела, в 4,7\% случаев было проведено КТ исследование легких и у $31,8 \%$ респондентов диагноз был выставлен на основании характерной клинической картины.

Заключение. По данным этого исследования, за анализируемый период в среднем обучающиеся медицинского ВУЗа болели 1-2 раза, среди нозологий чаще встречалось сочетанное поражение органов верхних дыхательных путей. На частоту ОРИ не влиял факт работы в медицинском учреждении, но влияла нерегулярность приемов пищи. Каждый второй из опрошенных перенес новую коронавирусную инфекцию. 


\section{НАРУШЕНИЯ ЭЛЕМЕНТНОГО СТАТУСА У ДЕТЕЙ СТАВРОПОЛЬСКОГО КРАЯ, СТРАДАЮЩИХ ЖЕЛЕЗОДЕФИЦИТНОЙ АНЕМИЕЙ \\ Самкина О.Н., Водовозова Э.В., Леденева Л.Н., Пустабаева М.С. \\ ФГБОУ ВО «Ставропольский государственный медицинский университет» МЗ РФ, Ставрополь}

Введение. Физиологическое значение микроэлементов обусловлено их ролью в составе ферментативных систем организма, оптимальное функционирование которых зависит от поступления микроэлементов из окружающей среды. Недостаток или их избыток в среде обитания, может привести к заболеваниям.

Цель. Исследовать элементный статус у детей Ставропольского края, страдающих железодефицитной анемией (ЖДА).

Материалы и методы исследования. Выполнен спектральный анализ волос (методом атомно-эмиссионной спектрометрии в индуктивно-связанной аргонной плазме и атомно-абсорбционной спектрометрии с электротермической атомизацией) на содержание 4 элементов (I, Cu, Fe, Zn) 75 детей с ЖДА. Пациенты разделены по степени тяжести на 3 группы по 25 больных.

Результаты. Концентрация $\mathrm{Cu}$ и $\mathrm{Fe}$ в волосах детей, страдающих ЖДА, достоверно снижено по сравнению со здоровыми в зависимости от тяжести заболевания. Концентрация I практически одинаков у детей контрольной группы и детей с ЖДА I степени, но достоверно это снижение отмечалось у больных с более тяжелым течением анемии, причем чем тяжелее заболевание, тем ниже концентрация данного элемента. Резко снижался уровень $\mathrm{Zn}$ у детей с ЖДА I степени, но по мере усугубления тяжести болезни данный элемент увеличивал свое присутствие в организме пациента и при ЖДА III степени стал достоверно выше.

Установлена корреляционная связь между концентрацией железа в волосах и другими исследуемыми элементами в зависимости от тяжести ЖДА. Между концентрациями железа и меди существует прямая корреляционная зависимость слабой степени при легкой анемии, увеличивающаяся по мере утяжеления заболевания $(r=+0,13,+0,2,+0,31$ соответственно). Корреляционная связь между концентрацией железа и йода является прямой положительной средней степени, увеличивающейся вместе со степенью тяжести ЖДА $(r=+0,49,+0,55,+0,55)$. Корреляционная связь между концентрацией железа и цинка у детей СК, страдающих ЖДА различной степени тяжести, была слабой отрицательной, при легкой и средней степени анемии и крайне высокой при тяжелой степени болезни $(r=-0,16,-0,16,-197$ соответственно).
Заключение. У детей Ставропольского края, страдающих железодефицитной анемией, выявлены нарушения элементного гомеостаза корреляционно связанные со степенью тяжести заболевания.

\section{ЭПИДЕМИОЛОГИЯ АНЕМИЧЕСКОГО СИНДРОМА У ДЕТЕЙ}

Самороднова Е.А., Фролов Е.В., Гарипова А.А. ФГБОУ ВО Казанский ГМУ Минздрава России, Казань

Актуальность: Анемическому синдрому подвержена половина дошкольников и четверть школьников в мире. Она может выступать, как самостоятельная нозология, так и быть вторичным звеном патогенеза на фоне хронических заболеваний, существенно утяжеляя их течение.

Цель исследования: изучить распространенность синдрома анемии у детей.

Пациенты и методы: было проанализировано 346 историй болезни детей в возрасте от 1 месяца до 18 лет, находившихся на лечении в детском стационаре ЦГКБ №18 г.Казани. Проанализированы анамнез, клиника, показатели гемограммы (Hb, $\mathrm{MCV}, \mathrm{MCH}, \mathrm{MCHC).} \mathrm{Для} \mathrm{анализа} \mathrm{учетных} \mathrm{призна-}$ ков все пациенты были распределены на 4 возрастные группы: до 1 года (48 человек), 1-3 лет (63), 4-12 лет (138 пациентов), 13-18 лет (97), далее был проведен анализ распространенности анемического синдрома в зависимости от основного заболевания.

Результаты и обсуждения: в возрастном аспекте показатели гемоглобина ниже нормативных отмечались у $25 \%$ грудных детей, $14 \%$ пациентов раннего возраста и по 4\% в остальных группах. Следует отметить, что анемический синдром (АС) в группе детей до 3 лет может быть связан с неблагоприятным течением перинатального периода, а в исследованной выборке пациентов в $15 \%$ случаев отмечались осложненные беременность или роды. Среди других лабораторных показателей наиболее часто регистрировались отклонения MCV, MCH. Тенденция к микроцитозу чаще наблюдалась у детей дошкольного и школьного возраста, а тенденция к гипохромии у детей до 3 лет.

При оценке взаимосвязи анемического синдрома с нозологией выявлено, что чаще всего он отмечался при острой инфекционной патологии дыхательной и мочеполовой системы - у 9,5\% и $30,7 \%$ соответственно, у всех этих пациентов выявлен микроцитоз и в большинстве случаев ( $56 \%$ и $57 \%$ соответственно) гипохромия.

В группе с хронической патологией пищеварительной системы снижение уровня гемоглобина было выявлено только у $11,9 \%$, микроцитоз у 44,8\%, гипохромия $-32,6 \%$.

Наименьшее число пациентов с изменениями эритроцитарных показателями наблюдалось при патологии нервной системы. 
Вывод: лабораторные признаки анемии регистрировались наиболее часто у детей до года и при острой инфекционной патологии. По нашему мнению, эти сведения можно использовать для выделения групп риска развития анемического синдрома и своевременной его профилактики.

\section{ОСОБЕННОСТИ ФИЗИЧЕСКОГО РАЗВИТИЯ У ДЕТЕЙ РАННЕГО ВОЗРАСТА С ТИМОМЕГАЛИЕЙ \\ Суразакова Т.Н., Лукашевич М.Г. \\ ФГБОУ ВО РостГМУ Минздрава России}

Введение. В настоящее время определение размеров тимуса не входит ни в объем профилактических медицинских осмотров детей раннего возраста, ни в стандарт обследования практически ни при одной патологии. В то же время, дети с тимомегалией, в силу особенностей реагирования их нейроиммуноэндокринной системы, нуждаются в индивидуальных программах диспансерного наблюдения. В связи с этим, необходим простой и доступный для практического педиатра способ раннего выявления таких детей при массовых скрининговых осмотрах.

Цель исследования. Изучить особенности физического развития детей с тимомегалией, что позволит выделить их в особую группу диспансерного наблюдения при проведении массовых осмотров для дальнейшего более детального обследования.

Материалы и методы. В исследование было включено 94 ребенка (61 мальчик, 33 девочки) 1 года, с подтвержденной при проведении УЗИ тимомегалией, контрольную группу составляли 78 детей 1 года 42 мальчика, 36 девочек) 1 и 2 группы здоровья, без признаков тимомегалии по данным УЗИ. Антропометрия детям проводилась по методике В.В. Бунака (1941)

Результаты. При проведении сравнительного анализа данных антропометрии, помимо ожидаемых отличий в массе тела, индексе массы тела и росте в группах условно здоровых детей и с тимомегалией, были выявлены статистически значимые различия $(\mathrm{p}<0,05)$, согласно которым мальчики и девочки из группы с тимомегалией отличаются от детей из группы здоровых относительно высокими значениями следующих показателей: длины верхней и нижней конечности, обхватов плеч и таза, обхватов плеча и бедра, костных диаметров, и относительно низкими значениями длины туловища.

Заключение. Учитывая особенности показателей физического развития у детей с увеличенными размерами тимуса, возможно при массовых осмотрах выделять особую группу диспансерного наблюдения детей для исключения у них тимомегалии.

\section{ОСОБЕННОСТИ НУТРИТИВНОЙ ПОДДЕРЖКИ ПРИ ФОРМИРОВАНИИ НЕВРОЛОГИЧЕСКОГО ДЕФИЦИТА У ДЕТЕЙ С ПЕРИНАТАЛЬНЫМ ПОРАЖЕНИЕМ ГОЛОВНОГО МОЗГА \\ Шимченко Е.В., Клещенко Е.И. \\ ФГБОУ ВО Кубанский ГМУ Минздрава России, Краснодар}

Введение. Перинатальные поражения головного мозга у детей первых лет жизни являются одной из основных причин отклонений нервно-психического развития, отражающихся на соматическом здоровье ребенка.

Цель исследования - изучить особенности проведения нутритивной поддержки при формировании неврологического дефицита у детей с перинатальным поражением головного мозга.

Материалы и методы. В исследование включены 68 детей с тяжелым неврологическим дефицитом, сформировавшимся в результате перинатального поражения головного мозга (детский церебральный паралич, нарушения психоречевого развития, симптоматическая эпилепсия). Нутритивная поддержка проводилась при выявлении белково-энергетической недостаточности (БЭН) или высоком риске ее развития. У $40(58,8 \%)$ детей нутритивная поддержка осуществлялась методом сиппинга (I группа), у 28 (41,2\%) детей - зондовым методом через назогастральный зонд, гастростому (II группа). Наблюдение за детьми проводилось до трехлетнего возраста.

Результаты. Проявления БЭН определены у $17(42,5 \%)$ детей I группы и у 22 (78,6\%) детей II группы $(p<0,001)$. У остальных детей отмечен высокий риск развития БЭН. Назначение легкоусвояемых смесей на основе частичного или полного гидролизита белка коровьего молока позволило уменьшить проявления недостаточности питания у детей. Выявление дисахаридазной недостаточности, непереносимости глютена требовало при проведении нутритивной поддержки назначения индивидуальной диеты с исключением дисахаридов, глютена.

Аллергия к белкам коровьего молока выявлена у $10(25,0 \%)$ детей I группы и у $15(53,6 \%)$ детей II группы $(p<0,05)$. Нутритивная поддержка у детей с аллергией проводилась с использованием смесей на основе высокогидролизированного белка коровьего молока. В назначении антирефлюксных смесей нуждались 13 (32,5\%) детей I группы и 19 (67,9\%) детей II группы $(p<0,01)$. Особенности соматической патологии на фоне выраженных отклонений нервнопсихического развития вызывали необходимость использовать для нутритивной поддержки специализированные лечебные смеси.

Заключение. Нутритивная поддержка у детей с перинатальным поражением головного мозга, про- 
явившимся формированием неврологического дефицита, является важнейшим фактором комплексной терапии и реабилитации, способным улучшить физическое и нервно-психическое развитие ребенка.

\section{ГРУДНОЕ ВСКАРМЛИВАНИЕ ВО ВРЕМЯ ЗАБОЛЕВАЕМОСТИ СОVID-19}

Якубова Л.Р., Гуменюк О.И., Черненков Ю.В. ФГБОУ ВО Саратовский государственный медицинский университет им. В.И. Разумовского МЗ РФ, Саратов

Введение. Материнское молоко обладает уникальным составом, обеспечивающим адекватное развитие детского организма и иммунную защиту. В настоящее время остается дискутабельным вопрос о возможности и целесообразности грудного вскармливания в период заболевания матери COVID-19. Высказываются опасения по поводу того, что матери с COVID-19 могут передать вирус SARS-CoV-2 своему ребенку через грудное молоко. BO3 рекомендует поощрять матерей с подозрением или подтвержденным COVID-19 начать или продолжить грудное вскармливание, аргументируя это тем, что польза от грудного вскармливания значительно превышает потенциальные риски передачи инфекции (ВО3, 2020)..
Цель исследования: установить число грудных детей, зараженных COVID-19 во время лактации.

Пациенты и методы: проведено анонимное анкетирование 23 женщин в возрасте 21-33 лет, которые во время грудного вскармливания перенесли COVID19. В исследовании использована авторская анкета. Критериями включения были следующие: кормление грудью ребенка, подтвержденный диагноз COVID-19 (ПЦР) у женщин во время лактации. Статистический анализ проводился при помощи программы Excel Microsoft 2010, статистически значимыми считали результаты при $p<0,05$.

Результаты. При анализе анкет установлено, что COVID-19 диагностирован лишь у 4-х детей в период лактации и заболевания COVID-19 их матерей. В остальных 19 случаях у детей признаков заражения вирусной инфекцией не отмечено $(p=0,001)$. Полученные результаты могут свидетельствовать о защитном свойстве грудного вскармливания в отношении SARS-CoV-2.

Заключение. В проведенном исследовании заражение грудных детей COVID-19 от больных матерей в период лактации отмечено в единичных случаях. Полученные результаты свидетельствуют о безопасности, возможности и целесообразности грудного вскармливания детей у матерей с COVID-19. 


\section{Раздел 5}

КАРДИОЛОГИЯ 


\section{ОСОБЕННОСТИ ТЕЧЕНИЯ}

НЕРЕВМАТИЧЕСКИХ МИОКАРДИТОВ У ДЕТЕЙ РАННЕГО ВОЗРАСТА

Ахмедова Н.Р., Жураева З.Р.

Ташкентский педиатрический медицинский институт,

Ташкент, Узбекистан

Введение. Неревматические миокардиты (НМ) объединяют воспалительные заболевания сердца с преимущественным поражением миокарда, чаще всего вирусной, инфекционно-аллергической этиологии. Клиническое течение неревматических миокардитов у детей отличается полиморфизмом, может быть вариабельной от бессимптомных форм до выраженных симптомов тяжелой рефрактерной сердечной недостаточности, развивающейся при диффузном поражении миокарда. Все это свидетельствует об актуальности изучения данной патологии в педиатрической практике.

Цель исследования - изучение клинических особенностей течения неревматических миокардитов у детей раннего возраста.

Материалы и методы. Обследовано 25 детей в возрасте до 3 лет с диагнозом неревматический миокардит, госпитализированных в отделения РСНПМЦП. Диагноз неревматический миокардит устанавливали на основании клинико-анамнестических, лабораторных и инструментальных исследований (рентгенография, ЭКГ, ЭхоКГ).

Результаты. Результаты исследования показали превалирование детей до 1 года (40\%), тогда как количество детей второго и третьего года жизни составили $28 \%$ и $32 \%$ соответственно. При этом средний возраст обследованных составил $1,7 \pm 0,9$ лет. При изучение анамнестических данных было установлено, что несмотря на ранний возраст у всех детей (100\%) имели место частые перенесенные острые вирусные инфекции. Основными жалобами со слов матерей были быстрая утомляемость (80\%), повышение температуры тела $(66,7 \%)$, кашель $(33,3 \%)$. Клинические проявления заболевания были связаны со степенью сердечной недостаточности. При объективном исследовании выявлялись приглушенность тонов сердца - $60 \%$, систолический шум на верхушке сердце $-86,6 \%$, тахикардия - $80 \%$, смещение границы относительной тупости сердце влево - $26,6 \%$. У детей с НМ кардиоторакальный индекс составил в среднем $59,6 \pm 0,3 \%$. По результатам электрокардиографических исследований, феномен предвозбуждения встречался у 7,5\% детей с НM, парные желудочковые экстрасистолы - 13,3\%, атриовентрикулярные блокады различной степени - 13,3\% случаев. На ЭхоКГ были определены расширение камер сердца, систолическая дисфункция со снижением фракции выброса, регургитация на митральном и трикуспидальном клапанах, а также дополнительная хорда - у $40 \%, \mathrm{OOO}$ - у $20 \%$ детей.
Заключение. Клиническое течение неревматических миокардитов зависит от степени сердечнососудистой недостаточности и характеризуется нарушениями ритма и проводимости, снижением сократительной способности и ремоделированием миокарда.

\section{ОСОБЕННОСТИ ЭЛЕКТРОКАРДИОГРАММЫ У ДЕТЕЙ С НАРУШЕНИЕМ АДАПТАЦИИ}

Беляков В.А., Подлевских Т.С., Лежнина И.В., Попова И.В. ФГБОУ ВО Кировский ГМУ Минздрава России, Киров

Введение. Критерием оценки адаптационных возможностей ребенка являются данные функционирования сердечно-сосудистой системы (ССС). У детей функциональные нарушения ССС протекают бессимптомно, поэтому их ранняя диагностика наряду с определением адаптации может использоваться для коррекции состояния здоровья.

Цель исследования - выявление изменений ЭКГ у детей раннего возраста при различных уровнях адаптации.

Материалы и методы. Обследовано 120 детей в возрасте от 1 до 3 лет I - II групп здоровья. Всем пациентам проводили кардиоинтервалографию и одновременно снимали электрокардиограмму с помощью электрокардиографа «Cardiovit».

Результаты. Синусовая аритмия при удовлетворительной адаптации установлена в $24,1 \%$, при напряженной - в 43,8\%; при неудовлетворительной в $55,9 \%$ случаев. При напряженной адаптации в $3,3 \%$ случаев отмечалась выраженная тахиаритмия. Нарушение проводимости выявлено всего у $56,2 \%$ детей $(37,1 \% ; 65,4 \%$ и $57,4 \%$ соответственно уровням адаптации). Сочетанное нарушение ритма и проводимости - в $28,9 \%$ случаев $(19,4 \% ; 34,6 \%$ и $26,2 \%$ соответственно), а нарушения проводимости и процессов реполяризации в $19 \%$ случаев $(7,6 \% ; 15,4 \%$ и $21,3 \%$ соответственно). Удлинение интервала Q-T отмечалось у $5,6 \%$ детей $(1,9 \% ; 7,7 \%$ и $8,2 \%$ соответственно уровню адаптации). При неудовлетворительной адаптации синдром «наджелудочкового гребешка» обнаружен в $14,8 \%$ и в $41 \%$ - неполная блокада правой ножки пучка Гиса. Удлинение интервала Q-Т выявлено в 6,6\% случаев $(3,8 \%$ - напряженная и $11,4 \%$ - неудовлетворительная). Все дети с удлинением Q-T относились к группе часто болеющих и имели обменные изменения на ЭКГ. Смещение интервала S-T ишемического характера выявлено у 19,2\% детей с напряженной и у $24,6 \%$ детей с неудовлетворительной адаптацией. у $39,7 \%$ детей с неудовлетворительной адаптацией выявлено нарушение процессов реполяризации миокарда обменно-гипоксического характера.

Заключение. Таким образом, установлено, что число детей, имеющих изменения на электрокардиограмме увеличивалось с ухудшением адаптаци- 
онных возможностей организма. Кроме того, выявлено, что высок удельный вес детей раннего возраста, имеющих изменения на электрокардиограмме. Это доказывает необходимость включения электрокардиографического исследования в общий комплекс диспансерного наблюдения за детьми раннего возраста.

\section{ДИАГНОСТИЧЕСКИЕ ВОЗМОЖНОСТИ КОМПЬЮТЕРНОЙ ТОМОГРАФИИ У ДЕТЕЙ С ВРОЖДЕННЫМИ ПОРОКАМИ СЕРДЦА}

Бочкова Л.Г., Черненков Ю.В., Нечаев В.Н., Панина О.С. ФГБОУ ВО Саратовский ГМУ им. В.И. Разумовского

Минздрава России, Саратов

Введение. Аномалии развития сердца у новорожденных нередко сочетаются с экстракардиальными пороками и мальформациями сосудистого и внесосудистого характера и отрицательно влияют на результаты хирургического и консервативного лечения.

Цель - анализ частоты аномалий развития сердца, оценить роль компьютерной ангиографии синхронизованной с электрокардиографией (ЭКГ-КТА) в рутинной оценке ВПС у новорожденных для уточнения экстракардиальных результатов лечения.

Материалы и методы. В исследование были включены 39 новорожденных с сочетанными ВПС, которым выполняли трансторакальную эхокардиографию (ТТЭ) и ЭКГ-КТА. Полученные данные в отношении экстракардиальных сосудистых структур, коронарных артерий и дыхательных путей, сравнивали с данными хирургической или сердечной катетеризации у 28 детей с ВПС. Качество изображения на сканере оценивали по визуальной шкале (от 1 до 4). Эффективная доза облучения рассчитывалась индивидуально.

Результаты. Среди особенностей развития плодов, стабильно высокой остается частота нарушений развития сердца и сосудов (22,5\% в 2019 г, 49,4\% в 2020 г). Частота множественных пороков развития, включая ВПС, сохраняется неизменной до $8 \%$ (7,0\% в 2019 г и 7,6\% в 2020 г), при этом около 20\% патологии связано с сочетанными хромосомными аномалиями. Возраст детей составил $20 \pm 11$ дней, масса тела при рождении - 3212士1,498 г. Качество диагностики определялось визуальным изображением 3-4 балла в 87,5\% сканирований. Благодаря ЭКГ-КТА получена дополнительная информация о структурах экстракардиальных сосудов и анатомии дыхательных путей, дополнив ТТЕ в 75,6\% исследований. Общая чувствительность КТА синхронизованной с ЭКГ для обнаружения экстракардиальных данных по сравнению с данными оперативного вмешательства и катетеризации сердца, составила 97,6\%. Расчетная средняя эффективная доза облучения $-1,4 \pm$ 0,07 милизиверт (м3в), в диапазоне 1,014-2,3 м3в.

Заключение. ЭКГ-КТА - это достаточно точный метод диагностики врожденной патологии экстра- кардиальных структур при комбинированных ВПС у новорожденных. Он предоставляет важную информацию дополнительно к ТТЕ при наличии внесердечных пороков сосудистых структур. Использование этой технологии позволяет значительно уменьшить частоту инвазивной катетеризации сердца, что способствует снижению дозы облучения.

\section{ВАРИАБЕЛЬНОСТЬ РИТМА СЕРДЦА У ДЕТЕЙ С ПЕРВИЧНОЙ АРТЕРИАЛЬНОЙ ГИПЕРТЕНЗИЕЙ \\ Буряк В.Н. \\ ФГБОУ ВО «Северо-Западный государственный медицинский университет им. И.И. Мечникова» Минздрава России, Санкт-Петербург}

Введение. Целый ряд эпидемиологических исследований в последние годы выявил значительную распространенность, а также стойкую тенденцию к росту в детской популяции первичной артериальной гипертензии. При изучении патогенетических механизмов ее развития важная роль отводится нарушениям вегетативной регуляции деятельности сердечно-сосудистой системы. О функциональной активности отделов вегетативной нервной системы при этом позволяет судить оценка вариабельности ритма сердца.

Цель исследования - исследовать вариабельность суточной организации ритма сердца у детей с первичной артериальной гипертензией.

Материалы и методы. Обследовано 92 ребенка в возрасте от 11 до 14 лет с первичной артериальной гипертензией и 30 практически здоровых детей аналогичного возраста, составивших группу контроля. Всем детям оценивали вариабельность суточной организации ритма сердца путем расчета временных и частотных показателей, полученных при холтеровском мониторировании ЭКГ посредством комплекса DX-AKM-03 Arnika.

Результаты. У обследованных больных на фоне напряжения обоих отделов вегетативной нервной системы выявлялась преобладающая активность симпатического звена, подтверждавшаяся достоверным $(\rho<0,05)$ снижением временных показателей SPANN - i (на 32\%), rMSSD (на 24\%), pNN50(на 13\%), а также инертность парасимпатического отдела, что сопровождалось преобладанием мощности низкочастотных (VLF, LF) над высокочастотными (HF) компонентами общего спектра.

Заключение. Первичная артериальная гипертензия у детей сопровождается напряжением симпатического и парасимпатического отделов вегетативной нервной системы с преобладанием симпатического звена, что требует усовершенствования вегетотропной терапии, направленной на нормализацию регулирующих влияний надсегментарных вегетативных центров. 


\section{ИММУНОЦИТОГЕНЕТИЧЕСКИЕ ФАКТОРЫ В ГЕНЕЗЕ ГИПОТЕНЗИВНОГО ТИПА ВЕГЕТО - СОСУДИСТОЙ ДИФУНКЦИИ У ДЕТЕЙ \\ Буряк В.H. \\ ФГБОУ ВО Северо-западный государственный \\ медицинский университет им. И. И. Мечникова \\ Минздрава России, Санкт-Петербург}

Введение. В структуре кардиальной патологии в детском возрасте одно из ведущих мест отводится вегето-сосудистым дисфункциям. При этом среди последних в большинстве случаев развивается вегето-сосудистая дисфункция по гипотензивному типу. Возникновение данной патологии во многом связывается с наследственной предрасположенностью.

Цель исследования - изучение роли наследственности в генезе вегето-сосудистой дисфункции по гипотензивному типу путем проведения иммуноцитогенетического анализа частоты встречаемости у пробандов антигенов главного комплекса гистосовместимости и их ассоциации с болезнью по системе HLA.

Материалы и методы. Обследовано 89 детей в возрасте от 11 до 14 лет с вегето-сосудистой дисфункцией по гипотензивному типу и 69 практически здоровых детей аналогичного возраста, составивших контрольную группу. В зависимости от сопутствующего фона пациенты с вегето-сосудистой дисфункцией по гипотензивному типу были разделены на 2 подгруппы. В первую вошло 53 ребенка с перинатальным поражением центральной нервной системы в анамнезе, во вторую - 36 пациентов с гиперплазией щитовидной железы без ее структурных изменений и в состоянии эутиреоза.В рамках исследования выполнено типирование 15 антигенов группы А и 24 антигенов группы В.

Результаты. В первой группе при сравнении со здоровыми сверстниками по критериям относительного риска и согласия обнаружена достоверная разница частоты фенотипа и частоты встречаемости гена для антигенов $\mathrm{A}_{19}$ (у 17\% больных), $\mathrm{A}_{25}$ (18,9\% пациентов), $\mathrm{A}_{29}$ (18,9\% случаев), В 13 (22,6\% наблюдений), $\mathrm{B}_{44}$ (7,5\% больных). Во второй группе частота фенотипа и частота встречаемости гена достоверно отличались от контроля и по критерию относительного риска, и по критерию согласия для антигенов $\mathrm{A}_{1}(36,1 \%), \mathrm{A}_{29}$ $(5,6 \%), \mathrm{B}_{5}(18,4 \%), \mathrm{B}_{15}(16,7 \%), \mathrm{B}_{44}(19,4 \%)$.

Заключение. Наличие у ребенка антигена $\mathrm{B}_{44}$ позволяет с высокой долей вероятности прогнозировать возможность развития у него вегето-сосудистой дисфункции по гипотензивному типу. Полученные результаты дают возможность считать антиген $\mathrm{B}_{44}$ иммуноцитогенетическим маркером возникновения гипотензивного типа вегето-сосудистой дисфункции.

\section{СОСТОЯНИЕ ПАРАМЕТРОВ ЖЕСТКОСТИ СОСУДИСТОЙ СТЕНКИ У ДЕВУШЕК}

Бушуева Э.В., Соколова И.С., Дианова Т.И., Иванова О.Н., Бушуев В.И., Метельков И.Б.

ФГБОУ ВО «Чувашский государственный университет

имени И.Н. Ульянова», Чебоксары

БУ Республиканский кардиологический диспансер Минздрава Чувашии, Чебоксары

Введение. Истоки артериальной гипертензии формируются в детском возрасте и с учетом этого необходимо раннее выявление лиц с высокой вероятностью развития данной патологии и поражений других систем, с последующим осуществлением профилактических мероприятий до субклинического поражения органов-мишеней. Особое внимание в развитии заболеваний сердечно-сосудистой системы в последнее время уделяется определению сосудистой жесткости.

Цель исследования. Определить артериальную жесткость сосудов у девушек 16,5-18 лет

Материалы и методы. Обследованы 46 девушек I и II группы здоровья, у которых во время проведения пробы с шестиминутной ходьбой было выявлено повышение артериального давления более 15 мм рт. ст. Проведена объемная сфигмография аппаратом Vasera VS-1500, FukudaDenshi Corp., Токио, Япония.

Результаты.Показатели сердечно-лодыжечного индекса соответствовали у всех девушек норме и составили справа 5,1 $\pm 0,83$, слева 5,2 \pm 0,78; показатели лодыжечно-плечевого индекса у $17,4 \%$ были ниже нормы, средние значения которых составили справа 0,98 $\pm 0,11$ и слева $1,0 \pm 0,12$. Индекс аугментации артерий был в среднем $0,79 \pm 0,12$ с минимальными показателями от 0,68 \pm 0,13 до 0,88 $\pm 0,15$. Пульсовое давление выше 60 мм рт. ст. на руках было у 8,7\% девушек, на ногах - 65,2\%.

Заключение. Изменение артериальной жесткости определяется уже у многих обследованных подростков. Повышение жесткости сосудов в детстве является фактором риска гипертонической болезни и ассоциированных с ней других заболеваний в будущем.

\section{ПРОЯВЛЕНИЯ ДИСПЛАЗИИ СЕДИНИТЕЛЬНОЙ ТКАНИ И РИТМ СЕРДЦА У ДЕТЕЙ С РЕАКТИВНЫМИ АРТРОПАТИЯМИ}

Дмитрачков В.В. ${ }^{1}$, Юшко В.Д. ${ }^{1}$, Дмитрачкова О.В. ${ }^{2}$

${ }^{1}$ Белорусский государственный медицинский университет, 2Республиканский клинический центр паллиативной медицинской помощи детям, Беларусь, Минск

Цели: определение частоты внешних (ВнП) и висцеральных признаков (ВиП) дисплазии соединительной ткани (ДСТ), нарушений сердечного ритма и проводимости (НСРП) у детей с реактивными артропатиями (РA). 
Материал и методы. Гр.наблюдения (ГрН) - 30 детей с РА (1-18 лет), находившихся на лечении в 4 ДКБ г. Минска. Проводились: оценка ДСТ соматоскопическим, морфометрическим методами; УЗИ сердца и органов брюшной полости, ЭКГ, холтеровское мониторирование ЭКГ, осмотр офтальмолога, ортопеда.

Обсуждение результатов. ВнП и/или ВиП у $80 \%$ детей: из них ВиП у 91,7\%, ВнП у 37,5\% (ВнП+ВиП $29,1 \%)$. ДСТ в костно-суставной системе - у 77,8\% (сколиоз 57,1\%, деформации грудной клетки 28,6\%, плоскостопие 71,4\%, косолапость 14,3\%). ДСТ кожи и дериватов $-66,7 \%$. Миопия, астигматизм - 22,2\%. ВиП ДСТ в ГрН у 73,3\% детей: в сердечно-сосудистой системе - 95,5\% (МАРС), мочеполовой системе $12,5 \%$ (особенности ЧЛС, дистопия почек), ЖКТ $31,8 \%$ (изгибы, перетяжки желчного пузыря). ДСТассоциированные состояния - 23,3\% (ДЖВП 57,1\%, ДГР 14,3\%, ГЭРБ 28,6\%). У детей с МАРС: ДХЛЖ $52,4 \%$ (множественные ДХЛЖ - у 54,5\%), ПМК и ПТК 1-2 ст. с R 1-2 ст.- у 38,1\% (ПМК+ДХЛЖ $37,5 \%)$, ФОО - 14,3\%. Избыточность Евстахиева кл. у 4,8\%, аневризма МПП и синуса Вальсальвы у 9,5\%, коронаро-легочная фистула - 4,8\%. В ГрН НСРП (93,3\%): номотопные: у 82,1\%: нестабильный син. ритм $(47,8 \%)$, син. брадикардия $(8,7 \%)$ и тахикардия $(26,1 \%)$, предсердные ритмы и миграция источника ритма в предсердиях $(34,8 \%)$, син. аритмия $(17,4 \%)$. Блокады (БЛ) - 32,1\%: внутрижелудочковые (ВЖБЛ) - 88,9\% детей (из них неполная БЛ правой ножки п. Гиса $-87,5 \%$, неполная БЛ левой ножки $12,5 \%)$; у 22,2\% - СА БЛ 2ст. В 14,3\% - экстрасистолия (ЭС, чаще суправентрикулярная (75\%, частая у $33,3 \%)$, левожелудочковая ЭС-25\%; с-м удлиненного QT $(17,9 \%)$, с-м укороченного PQ с приступами суправентрикулярной тахикардии в анамнезе $(3,6 \%)$, WPW-с-м (3,6\%), СРРЖ (10,7\%).

Выводы. НСРП у детей с РА встречаются часто, с преобладанием номотопных и/или ВЖБЛ, в т.ч. клинически значимые НСРП. В большом числе случаев имеются МАРС (в т. ч. потенциально аритмогенные). Полученные данные свидетельствуют о важности врачебного контроля за состоянием сердца у этих пациентов.

\section{ВЛИЯНИЕ ФУНКЦИОНИРУЮЩЕГО АРТЕРИАЛЬНОГО ПРОТОКА НА РЕМОДЕЛИРОВАНИЕ МИОКАРДА У НЕДОНОШЕННЫХ ДЕТЕЙ С ЭКСТРЕМАЛЬНО НИЗКОЙ И ОЧЕНЬ НИЗКОЙ МАССОЙ ТЕЛА}

\section{Звягина Ж.А., Цой Е.Г.}

Кафедра педиатрии и неонатологии Кемеровского

государственного медицинского университета, Кемерово

Введение. Частота открытого артериального протока (ОАП) зависит от гестационного возраста ребенка, отягощает гемодинамику и обусловливает практическую значимость функционирования артериального протока у глубоконедоношенных детей.

Цель исследования - изучение влияния ОАП на постнатальную адаптацию у детей с экстремально и очень низкой массой тела (ОНМТ и ЭНМТ).

Материалы и методы исследования. Исследованы 32 ребенка с ЭНМТ и ОНМТ (17 мальчиков и 15 девочек). Средняя масса тела при рождении составила $1015,38 \pm 70$ г $(770-1400$ г) средняя длина тела составила $35,15 \pm 3,1$ см $(28-43$ см). Срок гестации при рождении составил 28,08 $\pm 1,8$ (26 - 31 недель). Проанализированы клинико-анамнестические, результаты эхокардиографии (ЭХОКГ) с расчетом ЭХО-КГ признаков ремоделирования миокарда и гемодинамической значимости ФАП, способы и длительность респираторной поддержки.

Результаты и их обсуждение. В 1-й группе (8 детей) $25 \%$ - ОАП закрылся до 1 месяца жизни. Во 2-й группе (24 детей) 75\% - с учетом выкидышей в анамнезе $(\mathrm{R}=0,97)$, внутриутробного инфицирования $(\mathrm{R}=0,58)$, повышения СРБ в первую неделю жизни $(\mathrm{R}=0,99)$, ранней анемии, женскиого пола $(p=0,015)$, сохранялся после 1 месяца жизни и имелась дилатация правого желудочка (ПЖ) $(p=0,02)(8,4 \pm 0,33$ мм, в сравнении $7,9 \pm 0,18$ мм), больший индекс толщины передней стенки (ТПСПЖ/BSA) в первые 2 недели жизни $(p=0,002)$ $\left(41,25 \pm 0,18 \mathrm{Mм} / \mathrm{M}^{2}\right.$, в сравнении $\left.27,85 \pm 0,18 \mathrm{Mм} / \mathrm{M}^{2}\right)$. Кровоток в верхней полой вене (ВПВ) составлял менее $25 \%$ после 1 месяца (LVO/SVC> 4). Масса миокарда ЛЖ во 2 группе $=5,85 \pm 0,08$ г $(p=0,032)$, в 1-й группе $(5,5 \pm 011$ г).

Заключение. Длительному функционированию артериального протока у недоношенных детей с ЭНМТ и ОНМТ могут способствовать наличие в анамнезе выкидышей, внутриутробного инфицирования, развитие инфекционного процесса и анемии в раннем постнатальном периоде. Для детей с ФАП более 1 месяцев жизни характерно сохранение гипертрофии и дилатации ПЖ на первом месяце жизни, развитие гипертрофии миокарда ЛЖ.

\section{СТРУКТУРА ВРОЖДЕННЫХ ПОРОКОВ СЕРДЦА У ДЕТЕЙ СТАВРОПОЛЬСКОГО КРАЯ}

Карханина В.А., Водовозова Э.В., Леденева Л.Н., Пустабаева М.С.

ФГБОУ ВО «Ставропольский государственный медицинский университет» МЗ РФ, Ставрополь

Врожденные пороки сердца (ВПС) занимают 3 место в структуре детской смертности, если не была сделана своевременная операция. Большинство выживших детей в последствии становятся инвалидами.

Цель исследования: проанализировать структуру ВПС у детей Ставропольского края (СK). 
Материалы и методы. Исследовано 459 детей с ВПС в отделении кардиологии и ревматологии на базе ГБУЗ СК «КДКБ» за период с 2017 по 2020 гг. (2017 г - 120 больных; 2018 г и 2019 г - по 106 пациентов соответственно, 2020 г - 127 детей). Данные обработаны при помощи пакета прикладной программы Microsoft Excel 2010.

Результаты: Из 459 обследованных в СК антенатально ВПС диагностированы у 239 (52,1\%) детей, постнатально - у 220 (47,9\%). У 48 больных (10,5\%) выявлены критические пороки, у 411(89,5\%) - не критические; мальчиков было $259(56,5 \%)$, девочек - $200(43,4 \%)$; от 0 до 6 мес. $66(14,4 \%)$ детей, 6-12 мес. - 76 (16,6\%) пациентов, 1-3 года - $317(69,0 \%)$ больных, из них доношенных - 302 (65,8\%), недоношенных - 157 (34,2\%). Отягощенный наследственный анамнез по ВПС наблюдался - брат/сестра - 32 (7,0\%), по линии отца $-16(3,5 \%)$, по линии материи $-2(0,4 \%)$. Городские жители - 58 (12,6\%), сельские жители - 401 $(87,4 \%)$. Нозологическая структура детей с ВПС распределилась следующим образом: дефект межпредсердной перегородки (ДМПП) диагностирован в $91(19,8 \%)$ случае, дефект межжелудочковой перегородки (ДМЖП) - в 65 (14,2\%), коарктация аорты в $49(10,7 \%)$, двойное отхождение сосудов от правого желудочка (ДОС ПЖ) и частичный атриовентрикулярный клапан (частичный АВК) - по 29 (6,3\%) соответственно, тетрада Фалло в 27 (5,9\%), стеноз легочной артерии (стеноз ЛА) - в 25 (5,4\%), транспозиция магистральных сосудов (ТМС) - в 17 (3,7\%), другие сложные ВПС - в 127 (27,7 \%).

Выводы: В СК ВПС диагностируются в основном антенатально $(52,1 \%)$, в особенности не критические, преимущественно в возрасте от 1 года до 3-х лет $(69,0 \%)$, у доношенных $(65,8 \%)$ мальчиков $(56,5 \%)$ с отягощенным наследственным анамнезом по ВПС, преимущественно у жителей сельской местности. Наиболее часто встречаются такие ВПС как ДМПП, ДМЖП и коарктация аорты.

\section{ОПРЕДЕЛЕНИЕ НАТРИЙУРЕТИЧЕСКОГО ПЕПТИДА У ДЕТЕЙ СТАВРОПОЛЬСКОГО КРАЯ ПРИ ВРОЖДЕННЫХ ПОРОКАХ СЕРДЦА}

Карханина В.А., Водовозова Э.В., Леденева Л.Н., Пустабаева М.С.

ФГБОУ ВО «Ставропольский государственный медицинский университет» МЗ РФ, Ставрополь

Натрийуретические пептиды играют важную роль в регулировании внутрисосудистого объема крови и сосудистого тонуса.

Цель исследования: изучить уровень натрийуретического пептида (NT-proBNP) у детей Ставропольского края (CK) с врожденными пороками сердца (ВПС).
Материалы и методы. С 2017 по 2020 гг. в отделении кардиологии и ревматологии ГБУЗ СК «КДКБ» выявлено 459 детей с ВПС, критическими пороками из которых были 48(10,5\%), не критическими 411(89,5\%). Определение N-концевого фрагмента промозгового натрийуретического пептида (NT-proBNP) проводилось с помощью иммунохемилюминисценции. Данные обработаны при помощи пакета прикладной программы MicrosoftExcel 2010.

Результаты. NT-proBNP определяли после проведенной оперативной коррекции ВПС с сохраняющимися проявлениями недостаточности кровообращения (НК). Коррекция в 1 месяц жизни проведена 22 $(45,8 \%)$ больным, в течение 1 года жизни - 26 (54,2\%). В $100,0 \%$ степень НК соответствовала цифровым значениям уровня NT-proBNP взятым из клинических рекомендаций МЗ РФ.

Выводы. В СК при определении NT-proBNP детям с критическими ВПС после проведенной коррекции порока выявлено полное соответствие результатов исследования степени недостаточности кровообращения.

\section{НАРУШЕНИЯ ПРИЕМА ВИТАМИНА Д У ДЕТЕЙ ПЕРВОГО ГОДА ЖИЗНИ, КАК РИСК РАЗВИТИЯ АТОПИЧЕСКОГО ДЕРМАТИТА У ДОШКОЛЬНИКОВ}

Кашинская Т.С., Шахова Н.В.

ФГБОУ ВО Алтайский государственный медицинский университет Минздрава России, Барнаул

Введение Последние годы изучается влияние витамина Д на развитие атопического дерматита (АтД). Однако представленные результаты противоречивы. Влияние нарушения приема витамина Д на первом году жизни на развитие АтД ранее не изучалось.

Цель - оценить связь между нарушением приема витамина Д на первом году жизни и развитием АтД у детей к 3-6 годам жизни.

Пациенты и методы. Проведено одномоментное исследование с участием 3205 детей 3-6 лет. Из них 162 ребенка с диагнозом АтД (диагноз выставлен на основании критериев Hainifin и Rajka (средний возраст 4,3 $\pm 1,1$ год) и 2812 здоровых ребенка аналогичного возраста (средний возраст 4,5 $\pm 1,1$ год). Нарушение приема витамина Д на первом году оценивали анкетированием. Респондентами с нарушениями приема витамина Д считался ребенок, родители которого ответили отрицательно на вопросы: «Принимал ли Ваш ребенок витамин Д на первом году жизни?» «Регулярно ли принимал Ваш ребенок витамин Д на первом году жизни?», «Ваш ребенок принимал витамин Д более 6 месяцев?».

Результаты. Из 162 детей с АтД, у 68 (41,9\%) отмечались нарушения в приеме витамина Д на первом году жизни. Из них 20 (29,5\%) детей не принимали 
витамин Д на 1-м году жизни, 48 (70,5\%) детей принимали витамин Д менее 6 месяцев. Среди здоровых детей, нарушение в приеме витамина Д зафиксировано у $231(10,3 \%)$ ребенка из которых $70(30,3 \%)$ детей не принимали витамин Д, у $92(39,8 \%)$ - прием витамина Д менее 6 месяцев, а у $69(29,8 \%)$ - нерегулярный прием. Риск развития АтД у детей дошкольного возраста повышается почти в 3 раза при нарушениях приема витамина Д на первом году жизни (ОШ 2,9 (95\% ДИ 2,1- 4,0, $p=0,001$ ).

Заключение: Нарушение приема витамина Д на первом году жизни повышает риск развития АтД у детей дошкольного возраста.

\section{ЧАСТОТА ВСТРЕЧАЕМОСТИ ТИПОВ РЕГУЛЯЦИИ СЕРДЕЧНО-СОСУДИСТОЙ СИСТЕМЫ У ПОДРОСТКОВ - УРОЖЕНЦЕВ СРЕДНЕГО ПРИОБЬЯ \\ Литовченко О.Г. ${ }^{1}$, Шипилова Г.Н. ${ }^{2}$ \\ ${ }^{1}$ БУ ВО Ханты-Мансийского автономного округа - Югры «Сургутский государственный университет», Сургут, БУ Ханты-Мансийского автономного округа - Югры «Сургутская городская клиническая поликлиника №5», Сургут}

Введение. Пубертатный период сопровождается выраженными нейровегетативными и эндокринными сдвигами, у детей отмечаются функциональная неустойчивость регуляторных систем, высокая чувствительность к гормональной перестройке организма, к воздействию внешних факторов среды, в том числе природно-климатических.

Цель исследования - определить особенности встречаемости типов регуляции сердечного ритма у подростков, родившихся и проживающих в гипокомфортных климатогеографических условиях Среднего Приобья.

Материалы и методы. В обследовании принимали участие 402 подростка в возрасте от 13 до 16 лет, имеющих I и II группу здоровья. Родители обследованных детей являлись мигрантами из различных регионов РФ и стран СНГ. Запись и анализ показателей сердечного ритма проводили с помощью annaратно-программного комплекса «Поли-Спектр12/Е Нейрософт». В зависимости от типа регуляции ритма сердца обследованных подростков распределили на группы по Шлык Н.И.

Результаты. При анализе показателей вариабельности сердечного ритма, все подростки были распределены на 4 группы по преобладающему типу регуляции деятельности сердца: I группу составили $34,51 \%$ подростков с незначительным преобладанием симпатической и центральной регуляцией вегетативной нервной системы, уменьшением влияния автономного отдела регуляции. II группа - подростки со значительным преобладанием симпатической регу- ляции вегетативной нервной системы, активность центральной регуляции преобладает над автономной. Такое состояние, которое требует дополнительных резервных функций организма и может быть оценено как предпатологическое встречалось у $5,28 \%$ обследованных подростков. ІІІ группа - подростки с умеренным преобладанием парасимпатической регуляции вегетативной нервной системы. Такая регуляция считается оптимальной для функционирования и наблюдалась в 48,94\%. IV группа - школьники с выраженным преобладанием парасимпатической регуляции вегетативной нервной системы составила $11,27 \%$.

Заключение. У детей 13-16 лет, проживающих в Среднем Приобье, наблюдались возрастные, половые и региональные особенности регуляции сердечно-сосудистой системы.

\section{ФИТОПРЕПАРАТЫ В ЛЕЧЕНИИ ДЕТЕЙ С РЕКУРРЕНТНЫМИ РЕСПИРАТОРНЫМИ ИНФЕКЦИЯМИ}

Елкина Т.Н., Грибанова О.А., Суровикина Е.А., Ращупкина T.C. ФГБОУ ВО НГМУ Минздрава России, Новосибирск

Введение. Рецидивирующие респираторные инфекции у детей представляют серьезную медицинскую и социально-экономическую проблему. Терапия, назначаемая данной категории пациентов, должна эффективно контролировать симптомы респираторной инфекции, исключая при этом полипрагмазию.

Цель исследования - изучение эффективности лечения рекуррентных инфекций верхних дыхательных путей с использованием средств растительного происхождения.

Материалы и методы. 30 детям в возрасте от 2 до 6 лет для амбулаторного лечения острого ринофарингита назначался фитопрепарат синупрет. При оценке эффективности терапии учитывалась динамика клинических симптомов по 5-бальной шкале, для оценки удовлетворенности врачей и родителей использовалась интегральная шкала IMOS и IMPSS.

Результаты. Выраженность назальных симптомов уменьшилась на 3-4 день терапии. К 5 дню симптомы ринита полностью купировались у каждого третьего пациента $(30,0 \%)$, у $70 \%$ сохранялась незначительная заложенность носа со скудным серозно-слизистым отделяемым. Потребность в дополнительном назначении сосудосуживающих средств испытывали 11 человек $(36,7 \%)$ с выраженной назальной обструкцией, продолжительность использования деконгестантов не превышала 3 дней. Достаточно быстро купировались и симптомы фарингита, к 5 дню лечения лишь каждый четвертый ребенок предъявлял 
жалобы на незначительные боли в горле $(23,1 \%)$. Средняя сумма баллов выраженности симптомов, типичных для острой респираторной инфекции, в первый день обращения составляла 9,4 балла, в динамике к 5 дню терапии синупретом уменьшилась более чем в 3 раза (2,9 балла) и на 7 день заболевания составляла лишь 1 балл, что соответствует остаточным проявлениям заболевания. Лечение синупретом позволило всем 18 пациентам с очаговой инфекцией носоглотки избежать обострения хронической патологии, которое в анамнезе практически всегда $(83,3 \%)$ сопровождало течение острого ринита. Средняя продолжительность течения респираторной патологии, по сравнению с предыдущими эпизодами инфекции, уменьшилась в 1,5 раза (с 8,5 до 5,4 дней), заболевание протекало в более легкой форме.

Заключение. Применение препарата синупрет для терапии рекуррентных инфекций верхних дыхательных путей позволяет нивелировать основные клинические проявления в достаточно короткие сроки и исключить полипрагмазию.

\section{АНОМАЛЬНО РАСПОЛОЖЕННЫЕ ХОРДЫ - НОРМА ИЛИ ПАТОЛОГИЯ?}

Малинина Е.И., Мордвина В.В., Кривоносова О.А.

ФГБОУ ВО Тюменский ГМУ Минздрава России, Тюмень

Введение. В эхокардиографических заключениях часто встречаются понятия: аномально расположенные хорды (APX), «false chordae tendineae», ложные хорды желудочков сердца и др. Данное явление на протяжении последних десятилетий служит объектом громких дискуссий: «Что же представляют собой аномально расположенные хорды- норму или патологию?». Сейчас часто выявляется высокая распространенность АРХ среди ЭХО-КГ заключений у детей.

Цель исследования. Изучить причины и последствия APX, их значимость в качестве жизни пациентов.

Материалы и методы. В основе работы положен теоретический метод: проведен анализ и синтез информации из различных литературных источников.

Результаты. АРХ являются наиболее распространенными (71\%) малыми аномалиями сердца. Значительно чаще, чем у практически здоровых людей (21\%), АРХ выявляются при различных сердечно-сосудистых патологиях (ИБС, ДКМП - 43\%; атеросклеротическое и ревматическое поражение сердца - 38\%; ДМЖП - 5\%). Выявлено, что АРХ чаще всего связана с такими признаками дисплазии соединительной ткани $(\mathrm{p}<0,05)$, как III тип мочки уха $(\mathrm{r}=+0,30)$ и положительный признак большого пальца ( $\mathrm{r}=+0,30)$. При изучении семейного анамнеза в $45 \%$ случаев у одного из родителей, а в $23 \%$ - у обоих родителей имеются АРХ. В подростковом возрасте пациенты предъявляли многообразные жалобы: плохая переносимость физической нагрузки (34\%), быстрая утомляемость (27\%), частые головные боли (21\%), кардиалгии (18\%), возникновение предобморочных и обморочных состояний (9-17\%), аритмии (49,5\%). Подобная возрастная динамика жалоб косвенно свидетельствует о нарастании клинических проявлений АРX со временем. Наиболее опасное последствие АРX - отрыв хорд, которое приводит к формированию несостоятельности клапанного аппарата и, как следствие, сердечной недостаточности.

Заключение. АРХ являются следствием дисплазии соединительной ткани и носит наследственный характер. В связи с топографическими особенностями APX могут не проявляться выраженной симптоматикой. APX могут приводить к гемодинамическим нарушениям в сердце, поскольку препятствуют растяжению стенок желудочков и изменяют его нормальную форму. Последствия АРX формируются не сразу, а носят отдаленный характер. Поэтому данную микроаномалию следует регулярно наблюдать на протяжении всей жизни.

\section{ВЛИЯНИЕ САНАТОРНО-КУРОРТНОГО ЛЕЧЕНИЯ НА ПОКАЗАТЕЛИ САНОГЕНЕЗА У ДЕТЕЙ С АРТЕРИАЛЬНОЙ ГИПЕРТЕНЗИЕЙ}

Ревенко Н.А., Каладзе Н.Н., Мельцева Е.М., Алешина О.К. ФГАОУ ВО КФУ им. В.И. Вернадского, Симферополь

Введение. На сегодня актуальной является разработка саногенетически направленных методов санаторно-курортного лечения (СКЛ) детей с артериальной гипертензией (АГ).

Целью исследования было изучение влияния СКЛ на саногенез при АГ у детей.

Материалы и методы. Под наблюдением на этапе СКЛ находилось 150 детей с АГ в возрасте от 10 до 17 лет, получавших комплекс лечения - II климато-двигательный режим, диету, ЛФК, массаж, санацию очагов хронической инфекции, бальнеотерапию, электролечение, фито- и аэрофитотерапию, групповую психотерапию в течение 24 суток. До и после лечения были проведены велоэргометрия, суточное мониторирование ЭКГ, АД и вариабельности сердечного ритма, дуплексное УЗ-сканирование артерий, психологическое тестирование, ИМТ, гормоны метаболизма. Для оценки статистической значимости применяли методы непараметрической статистики.

Результаты. В динамике у больных были определены следующие вероятные изменения показателей саногенеза: увеличение толерантности к физической нагрузке, переход к нормокинетическому типу гемодинамики - в 64,3\%; стабилизация АД, его суточного профиля, снижение вариабельности АД; снижение активности симпатического отдела 
вегетативной нервной системы (LF, LF/HF), повышение уровня суммарной вариабельности (SDNN). Средняя ЧСС у детей после лечения уменьшилась, что свидетельствовало об общей тенденции к нормализации гемодинамических показателей и восстановления вегетативного баланса. Отмечена нормализация показателей медицинского качества жизни по данным болезнь-спецефического опросника в виде повышения уровня самочувствия, физического и психического функционирования. Зарегистрировано значимое снижение показателя реактивной тревожности $(p<0,01)$. По данным корректурной пробы, у детей с АГ наблюдалось увеличение объема, концентрации внимания и врабатываемости $(p<0,01)$, снижение утомляемости и сокращение числа ошибок $(p<0,01)$. СКЛ привело к разнонаправленной динамике среди гормонов метаболизма в виде снижения уровня и резистентности инсулина и лептина, повышения адипонектина, стабилизации грелина. ИМТ снизился на 2,95\%, преимущественно среди пациентов, имеющих метаболические нарушения.

Заключение. СКЛ с применением бальнеотерапии у детей с АГ улучшает клинико-функциональное состояние, качество жизни и способствует саногенезу посредством активации реституции, компенсации и эндокринной регуляции. Результаты проведенных исследований позволяют рассматривать СКЛ детей с АГ как эффективный метод по снижению риска развития сердечно-сосудистых осложнений.

\section{КЛИНИЧЕСКИЕ АСПЕКТЫ КАРДИОМИОПАТИЙ У ДЕТЕЙ}

Скударнов Е.В., Колесникова О.И., Лобанов Ю.Ф., Скударнова А.П., Волкова Ю.В., Малюга О.М. ФГБОУ ВО АГМУ МЗ РФ, Барнаул

Введение: актуальность проблемы обусловлена большой распространенностью заболеваний сердца у детей, высоким риском развития сердечной недостаточности и ухудшением качества жизни.

Цель исследования: уточнить структуру кардиомиопатий (КМП) и оценить их клинические проявления.

Материал и методы: Обследовано 28 детей с кардиомиопатиями, в возрасте от 4 до 17 лет $(12,2 \pm 3,72$ лет), которые находились на лечение в КГБУЗ «АККЦОМД» г. Барнаула. Всем больным, наряду с общеклиническим обследованием, проводились ЭКГ и ЭХОКГ с оценкой фракции выброса, систолического давления в легочной артерии, размеров камер сердца, толщины миокарда желудочков. Дети с ВПС из обследования были исключены.

Результаты исследования: В общей группе преобладали мальчики - 15 из 28 больных. Из анамнеза выяснено, что у 9 детей (32\%) была отягощена наследственность по кардиальным заболеваниям.
При проведении рентгенографии и определении кардиоторакального индекса у детей с КМП отмечено расширение границ сердца, КТИ составил от $0,51 \%$ до $0,75 \%$. Результаты обследования позволили распределить больных на 3 группы: в первую группу выделили детей с дилятационными кардиомиопатиями (ДКМП), которые диагностированы у 14 больных; во вторую группу- больных с гипертрофическими кардиомиопатиями (ГКМП), которая выявлена у 9 пациентов; в третью- 5 детей с недифференцированной кардиомиопатией, некомпактным миокардом левого желудочка (НМЛЖ). Обструктивная форма ГКМП с вовлечением эндокарда выявлена у 3 обследованных, необструктивная форма ГКМП у 6 больных. В начале заболевания для больных с ДКМП и НМЛЖ, наряду со снижением ФВ по Симпсону, было характерно увеличение КТИ. При проведении суточного мониторирования ЭКГ у большинства детей с КМП выявлены аритмии или блокады сердца.

Заключение. В структуре КМП преобладает дилатационная кардиомиопатия с наличием сердечной недостаточности. Современные методы исследования позволяют диагностировать и уточнить варианты КМП, улучшить прогноз заболевания и качество жизни больных.

\section{НАИБОЛЕЕ ЧУВСТВИТЕЛЬНЫЕ МАРКЕРЫ ДИСФУНКЦИИ МИОКАРДА У ДЕТЕЙ С ОСТРЫМИ ЛИМФОБЛАСТНЫМИ ЛЕЙКОЗАМИ}

Тарасова Н.Е., Теплякова Е.Д., Сависько А.А., Асланян К.С., Кривохлябов И.П.

ФГБОУ ВО РостГМУ Минздрава России, Ростов-на-Дону

Введение. Сердечно-сосудистые осложнения возникают на разных этапах проведения полихимиотерапии (ПХТ) у детей с острыми лимфобластными лейкозами (ОЛЛ). Своевременная диагностика кардиальных осложнений позволяет начать активную терапию и предупредить развитие угрожающих жизни состояний.

Цель исследования - определить наиболее чувствительные маркеры дисфункции миокарда у детей с ОЛЛ.

Материалы и методы. Обследовано 67 детей в возрасте от 2 до 15 лет с ОЛЛ в динамике ПХТ, лечившихся по программе ALL-MB-2008. Группу сравнения составили 53 ребенка, относящиеся к I-II группам здоровья, сопоставимые по возрасту и полу. Всем детям проведено полное клинико-лабораторное обследование, включая стандартную электрокардиографию, ультразвуковое и допплерографическое исследование сердца, биохимическое обследование.

Результаты. Определено увеличение частоты встречаемости ЭКГ-изменений у детей с ОЛЛ после 
окончания основного интенсивного курса ПХТ. При этом нарушения процессов реполяризации, свидетельствующие о формировании миокардиодистрофии различной степени, регистрировались у $61 \%$ пациентов. При оценке диастолической функции установлено, что отношение скорости трансмитрального потока у детей с ОЛЛ на всех этапах про водимой ПХТ было достоверно ниже, чем у детей контрольной группы, однако оставалось > 1. Выявлены достоверные изменения времени изоволюмического расслабления и времени замедления пика раннего диастолического наполнения, а также индекса жесткости и временного показателя В у детей с ОЛЛ на этапах ПХТ, что свидетельствовало о развитии диастолической дисфункции миокарда. Выявлено достоверное повышение белка, связывающего жирные кислоты, предсердного натрийуретического пептида и фазное повышение мозгового натрийуретического пептида на разных этапах ПХТ, что свидетельствовало о персистирующем поражении миокарда. Заключение. Таким образом, в качестве маркеров развития кардиальных осложнений у детей с ОЛЛ на этапах ПХТ целесообразно использовать индекс жесткости и временной показатель В (Е-Еа), которые определяются при проведении допплерографии, а также показатели содержания в сыворотке крови предсердного, мозгового натрийуретических пептидов и белка, связывающего жирные кислоты.

\section{РЕГИОНАЛЬНЫЕ ПОКАЗАТЕЛИ ПОВЫШЕННОГО АРТЕРИАЛЬНОГО ДАВЛЕНИЯ У ДЕТЕЙ ПОДРОСТКОВОГО ВОЗРАСТА \\ Ушакова С.А., Халидуллина О.Ю., Петрушина А.Д., Куличенко М.П. \\ ФГБОУ ВО Тюменский ГМУ Минздрава России, Тюмень}

Введение. Реализация региональной программы ранней профилактики неинфекционных заболеваний (НИЗ) требует изучения частоты встречаемости факторов риска с применением стандартизованных методов.

Цель исследования. Установить частоту встречаемости повышенного артериального давления (АД) при проведении скринингового исследования у городских и сельских детей подросткового возраста.

Материалы и методы. Обследовано 2352 детей (1144 мальчиков, 1208 девочек) 15-17 лет, учеников 9-11 классов, проживающих в городской и сельской местности Тюменской области. Измеряли АД на правой руке в первой половине дня в положении сидя, сфигмоманометром Omron M6 (НЕМ-7001-E), прошедшим процедуру валидации и рекомендованным для детей. Выполняли три измерения АД с 2-3 интервалом с анализом среднего САД и ДАД. Всем детям с САД и/или ДАД $\geq 120 / 80$ мм рт. ст. провели измерение АД дважды с интервалом в 10-12 суток. При динамическом контроле АД констатировали высокое нормальное в случае, если среднее САД и/или ДАД на трех осмотрах было $\geq 90 \%$, но $<95 \%$ или $\geq 120 / 80$ мм рт.ст. Артериальную гипертензию (АГ) фиксировали в том случае, если среднее САД и/или ДАД на трех посещениях было $\geq 95 \%$. При непостоянной регистрации в последующем повышения АД диагностировали лабильную гипертензию, факты регистрации при повторных измерениях АД $<90 \%$ относили к транзиторному повышению АД.

Результаты. Полученные показатели частоты встречаемости повышенного АД по приведенным критериям в возрастной группе 15-17 лет (при объединении данных городских и сельских подростков) представлены высоким нормальным АД у 16,7\% мальчиков и у 4,5\% девочек (критерий $\chi 2=92,805$, $\mathrm{df}=1, \quad p<0,001)$; АГ констатирована у 4,6\% мальчиков и $1 \%$ девочек (критерий $\chi 2=27,624, \mathrm{df}=1$, $p<0,001)$. При этом частота встречаемости высокого нормального АД и АГ среди мальчиков была значимо выше, чем среди девочек как для городских, так и сельских детей (критерий $\chi 2=219,497, \mathrm{df}=1$, $p<0,001$ и $\chi 2=49,921, \mathrm{df}=1, p<0,001$, соответственно оценке АД).

Заключение. Полученные показатели частоты встречаемости высокого нормального АД и артериальной гипертензии у городских и сельских детей 15-17 лет используются в процессе мониторинга эффективности региональной программы ранней профилактики НИЗ, в том числе, сердечно-сосудистых заболеваний, формирования здорового образа жизни у детей.

\section{ОЦЕНКА СВЯЗИ ДЕФОРМАЦИИ МИОКАРДА ЛЕВОГО ЖЕЛУДОЧКА И ЭЛЕКТРОГРАФИЧЕСКИХ ИЗМЕНЕНИЙ У ДЕТЕЙ С ГИПЕРТРОФИЧЕСКОЙ КАРДИОМИОПАТИЕЙ}

Черных Н.Ю. ${ }^{1}$, Тарасова А.А. ${ }^{2}$, Грознова О.С. ${ }^{1}$, Шигабеев И.М. ${ }^{3}$

${ }^{1}$ ОСП «Научно-исследовательский клинический институт педиатрии имени академика Ю. Е. Вельтищева» ФГАОУ ВО РНИМУ им. Н. И. Пирогова Минздрава РФ, Москва ФГБОУ ДПО «Российская медицинская академия непрерывного профессионального образования» Минздрава РФ, Москва

${ }^{3}$ ФГАОУ ВО НИТУ «МИСиС»

Введение. У детей с гипертрофической кардиомиопатией (ГКМП) наряду с такими методами кардиологического обследования, как электрокардиография (ЭКГ), эхокардиография несомненный интерес представляет изучение показателей деформации миокарда в режиме 2D speckle tracking. Между тем характер взаимосвязи между показателями 
деформации миокарда и электрографическими изменениями остается недостаточно изученным.

Цель исследования - оценить взаимосвязь показателей деформации миокарда левого желудочка и ЭКГ у детей с гипертрофической кардиомиопатией.

Пациенты и методы. Обследован 61 пациент с асимметричной формой ГКМП от 7 до 17 лет. $45(73,8 \%)$ детей с необструктивной формой, 16 $(26,2 \%)$ - с обструктивной формой. Проводились ЭКГ и суточное мониторирование ЭКГ по Холтеру. При эхокардиографическом исследовании на аппаpaтe Artida (Canon, Япония) в режиме 2D speckle tracking определялись глобальные продольная, циркулярная и радиальная деформации миокарда левого желудочка и их скорости.

Результаты. Корреляционный анализ показал, что у детей с обструктивной формой ГКМП по сравнению с необструктивной формой отмечались статистически значимые $(\mathrm{p} \leq 0,05)$ умеренные обратные связи между продольной деформацией и ее скоростью и ЭКГ признаками гипертрофии (преобладание зубца R над S в отведениях I, V6; преобладание зубца $\mathrm{S}$ над зубцом $\mathrm{R}$ в отведении $\mathrm{V} 1$; смещение переходной зоны влево), ишемии миокарда (инверсия зубца Т и снижение сегмента ST в I, II, V5, V6 отведениях; глубокий зубец Q в V1-V3), нарушения проводимости (расширение комплекса QRS в отведениях V1-V3, неполная блокада передней левой ветви пучка Гиса). Отмечались обратные умеренные связи с их достоверным преобладанием при обструктивной форме между показателями глобальной радиальной деформации и ЭКГ-признаками ишемии миокарда и нарушения проводимости. При этом между показателями радиальной деформации и такими ЭКГ-признаками гипертрофии миокарда, как преобладание зубца R над S в отведениях I, V6 и преобладание зубца $\mathrm{S}$ над зубцом R в отведении V1 при необструктивной форме были выявлены прямые умеренные корреляционные связи, при обструктивной форме - обратные связи. Между показателями глобальной циркулярной деформации и ЭКГ были обратные умеренные связи с достоверным преобладанием при обструктивной форме по таким признакам, как преобладание зубца S над зубцом R в отведении V1; снижение сегмента ST в I, II, V5, V6 отведениях; глубокий зубец Q в V1-V3; расширение комплекса QRS в отведениях V1-V3.

Заключение. У детей с ГКМП наблюдаются обратные корреляционные связи между показателями деформации и ЭКГ-признаками гипертрофии и ишемии миокарда, нарушениями проводимости, которые более выражены между параметрами продольной деформации и ЭКГ при сравнении с показателями радиальной и циркулярной деформации с достоверным преобладанием в группе с обструктивной формой.

\section{СЕРДЕЧНО-СОСУДИСТЫЕ НАРУШЕНИЯ У ДЕВОЧЕК ПОДРОСТКОВ С НЕРВНОЙ АНОРЕКСИЕЙ}

Шайтарова А.В., Хашагульгова Т.А., Ушакова С.А., Халидуллина О.Ю., Баштакова Е.А.,

Путилова Л.В.

ФГБОУ ВО Тюменский ГМУ Минздрава России, Тюмень ГБУЗ ТО «Областная клиническая больница №1»,

Тюмень

Введение. Проблема нервной анорексии (НА) в последние годы приобретает все большую актуальность в связи с ростом числа заболеваний среди детей и подростков.

Цель исследования. Изучить изменения сердечно-сосудистой системы (ССС) у девочек с тяжелой белково-энергетической недостаточностью (БЭН) на фоне нервной анорексии.

Материалы и методы. Ретроспективный анализ медицинской документации 12 пациенток (средний возраст $15,4 \pm 1,8$ лет) с диагнозом БЭН 3 степени на фоне НА. Проведена стандартизованная оценка результатов функциональных методов исследования ССС - электрокардиографии (ЭКГ) и эхокардиографии (Эхо-КГ).

Результаты. При госпитализации у всех пациенток установлен выраженный дефицит массы тела (SDS ИМТ 3,6士0,5). У всех отмечалась вторичная аменорея и различные нарушения основных систем жизнедеятельности. Артериальная гипотензия с систолическим АД <90 мм рт.ст. отмечена у 3 девочек. При оценке частоты сердечных сокращений (ЧСС) по данным ЭКГ покоя у 6 (50\%) пациенток выявлена синусовая брадикардия с ЧСС $<2$ перцентиля для соответствующего пола и возраста. У 6 (50\%) пациенток отмечены неспецифические нарушения фазы реполяризации. По данным Эхо-КГ при расчете массы миокарда левого желудочка (ЛЖ) с индексацией к росту в степени 2,7 у 9 (75\%) пациенток показатель был <10 перцентиля для соответствующего пола и возраста; сократительная способность миокарда ЛЖ при этом соответствовала удовлетворительной. У 3 (25\%) девушек отмечен гидроперикард с сепарацией листков перикарда от 3 мм до 19 мм без признаков тампонады. При выявлении отклонений ССС у девочек с НА необходим дифференциальный диагноз с воспалительными, дисэлектролитными, эндокринными причинами.

Заключение. У пациенток с нервной анорексией при формировании БЭН тяжелой степени часто выявляются выраженные сердечно-сосудистые нарушения: снижение массы миокарда левого желудочка (75\%), синусовая брадикардия (50\%), неспецифические нарушения фазы реполяризации (50\%), гидроперикард (25\%). Всем пациенткам с анорексией необходимо наблюдение междисциплинарной командой специалистов, включающей детского кар- 
диолога, с систематическим мониторингом состояния сердечно-сосудистой системы.

\section{АРТЕРИАЛЬНОЕ ДАВЛЕНИЕ У ШКОЛЬНИКОВ В ЗАВИСИМОСТИ ОТ ФИЗИЧЕСКОГО РАЗВИТИЯ}

Юткина О.С., Юткина Ю.Р.

ФГБОУ ВО Амурская ГМА Минздрава России,

Благовещенск

Введение. Индикатором компенсаторно-приспособительных функций организма ребенка является сердечно-сосудистая система, участвующая в адаптации к условиям окружающей среды и в формировании реакции организма на воздействие разных факторов, и зависящая от его физического развития.

Цель исследования - изучение артериального давления у детей младшего школьного возраста в зависимости от их соматотипа.

Материалы и методы. В исследование включено 47 соматически здоровых детей младшего школьного возраста, которые были распределены на 3 группы: 14 детей с микросоматотипом, 17 детей с мезосоматотипом и 16 детей с макросоматотипом. У всех изучены показатели кардиогемодинамики по данным суточного мониторирования артериального давления (СМАД).

Результаты. При исследовании суточного ритма артериального давления (АД) определили, что школьники макросоматического телосложения имели более высокий уровень всех показателей САД $(\mathrm{p}<0,05)$. Пульсовое артериальное давление (ПАД), среднединамическое давление (СДД) и вариабельность АД была более высокой у детей с микрои макросоматотипом $(\mathrm{p}<0,05)$. Оценка показателей «нагрузки давлением» у детей с разным физическим развитием показала значимое увеличение ИВ гипертензии и ИП гипертензии САД и ДАД за сутки, день и ночь у детей 3 -й группы (макросоматотип) $(\mathrm{p}<0,05)$, в то же время длительность гипотонических эпизодов (ИВ и ИП гипотензии САД и ДАД) в различные периоды суток достоверно выше у детей 1-й группы (микросоматотип) $(\mathrm{p}<0,05)$. Анализ циркадной организации суточного профиля АД показал патологическое изменение суточного профиля САД у детей с пониженным и повышенным физическим развитием у $35,7 \%$ и 45,6\% соответственно. Они были представлены группой «non-dippers», характеризующейся ригидным ритмом АД в течение суток (суточный индекс 0-10\%), небольшую долю составили дети с избыточным снижением САД вовремя ночного сна - группа «over-dippers» (СИ > 20\%).

Заключение. У детей с макросоматотипом выявлены предикторы артериальной гипертензии, у детей с микросоматотипом выявлены предикторы артериальной гипотензии, что имеет важное значение в ранней диагностики и своевременной коррекции нарушений гемодинамики. 


\section{Раздел 6}

\section{НАСЛЕДСТВЕННЫЕ ЗАБОЛЕВАНИЯ И}

\section{ВРОЖДЕННЫЕ ПОРОКИ РАЗВИТИЯ}


МОЛЕКУЛЯРНОЕ КАРИОТИПИРОВАНИЕ ДЛЯ ВЫЯВЛЕНИЯ ИЗМЕНЕНИЙ ГЕНОМА В РОССИЙСКОЙ КОГОРТЕ ДЕТЕЙ С УМСТВЕННОЙ ОТСТАЛОСТЬЮ, АУТИЗМОМ, ЭПИЛЕПСИЕЙ И НАРУШЕНИЯМИ РАЗВИТИЯ

Ворсанова С.Г. ${ }^{1,2}$, Зеленова М.А. ${ }^{1,2}$, Куринная О.С. ${ }^{1,2}$, Васин К.С. ${ }^{1,2}$, Юров Ю.Б. ${ }^{1,2}$, Юров И.Ю..$^{1,2,3}$

${ }^{1}$ ОСП «Научно-исследовательский клинический институт педиатрии имени академика Ю.Е.Вельтищева» ФГАОУ ВО РНИМУ им. Н.И. Пирогова Минздрава России, Москва 2ФГБНУ «Научный центр психического здоровья», Москва ЗФГБОУ ДПО «Российская медицинская академия непрерывного профессионального образования», Москва

Введение. Умственная отсталость (задержка психомоторного развития - ЗПМР) с врожденными пороками и/или микроаномалиями развития (ВПР и/или МАР), а также с расстройствами аутистического спектра (РАС) и эпилепсией у детей, часто обусловлены генетическими причинами. Известно, что среди этиологических факторов наиболее частыми являются генетические нарушения, затрагивающие наибольшее количество генов при хромосомных/геномных перестройках и вариациях числа копий последовательности ДНК (CNV).

Цель исследования. Выявление нарушений генома в российской когорте детей с умственной отсталостью (ЗПМР) с ВПР/МАР, РАС и эпилепсией методами молекулярного кариотипирования.

Материалы и методы. Пациенты с умственной отсталостью (ЗПМР), ВПР и/или МАР, РАС и эпилепсией были исследованы в работе $(n=573)$. Средний возраст составил 5 лет 2 месяца (от 3 месяцев и до 18 лет). Молекулярное кариотипирование выполнялось с использованием метода SNParray (Affymetrix CytoScan HD), в соответствии с протоколами производителя. Оригинальный биоинформатический анализ проводился согласно разработанному ранее алгоритму.

Результаты исследования. Хромосомные аномалии (XА) (регулярные и мозаичные делеции и дупликации) были выявлены у 14,1\% пациентов. Множественные потери гетерозиготности и импринтированные участки, ассоциированные с заболеваниями и находящиеся в районах потери гетерозиготности, рассматривались отдельно и составляли $6,5 \%$ и $4,4 \%$, соответственно. Сложные перестройки были разделены на 3 подгруппы: мозаичные и регулярные ХА, встречающиеся в перекрывающихся участках $(3,8 \%)$, две и более ХА, встречающиеся у одного пациента (4,9\%), ХА и импринтированные участки, ассоциированные с генетическими заболеваниями $(2,3 \%)$. Микроскопически видимые изменения (трисомии, моносомии, маркерные хромосомы) были подтверждены у $1,6 \%$ детей.

Заключение. Различные ХА, включая сложные и крупные хромосомные перестройки; множественные потери гетерозиготности были обнаружены в 37\% случаев (212 пациентов). В настоящей работе в российской когорте пациентов с умственной отсталостью (ЗПМР) и различными нарушениями развития, исследованной при помощи молекулярного кариотипирования, выявлены различные аномалии генома. При биоинформатическом анализе определены гены, ассоциированные с клинической картиной, многие из которых индексированы в базе данных OMIM (Online Mendelian Inheritance in Man). Анализируя полученные данные, следует сказать о том, что необходимо использовать технологии молекулярного кариотипирования в клинической практике для корректной диагностики и медико-генетического консультирования.

Работа была частично поддержана Госзаданием Минздрава России № 1210310002381 , а также частично Госзаданием Министерства науки и высшего образования России № AAAA-A19-119040490101-6.

\section{ОЦЕНКА ЭФФЕКТИВНОСТИ СКРИНИНГА НА МУКОПОЛИСАХАРИДОЗЫ У ДЕТЕЙ}

Гаджикеримов Г.Э., Аль-Зрер К., Гуменюк О.И.,

Черненков Ю.В.

ФГБОУ ВО Саратовский государственный медицинский университет им. В.И. Разумовского МЗ РФ, Саратов

Введение. Мукополисахаридозы (МПС) - группа наследственных лизосомных болезней накопления, причиной которых является нарушение обмена кислых гликозаминогликанов (мукополисахаридов), характеризующееся различными клиническими проявлениями. В настоящее время обсуждается целесообразность проведения массового скрининга детей на МПС.

Цель исследования. Оценить эффективность и целесообразность проведения скрининга МПС у детей.

Пациенты и методы. Проведено исследование уровня лизосомных ферментов, недостаточность которых приводит к развитию МПС I,II,III,IV,VI и VII типов, методом тандемной масс-спектрометрии в сухих пятнах крови у 156 детей возрасте от 18 месяцев до 18 лет в двух группах. Оценка эффективности скрининга была проведена при помощи 10 критериев (ВО3,2008 г.).

Результаты. Критериями включения в группу I $(n=138)$ были следующие: снижение интеллекта, аденоиды, наличие пупочной или пахово-мошоночной грыжи. В группу II ( $n=18)$ вошли пациенты с перечисленной симптоматикой, а также с грубыми чертами лица, низкорослостью, поражением суставов, тугоухостью, патологией органа зрения (снижение остроты зрения) и сердца (клапанные пороки сердца, пролапс клапанов). В группе I у всех пациентов уровень лизосомных ферментов в сухих пятнах крови был в пределах референсных значений, т.е. МПС не выявлены. В группе II только у одного пациента установлено сни- 
жение уровня $\mathrm{N}$-ацетил-альфа-D-глюкозаминидазы, характерного для МПС типа IIIB. При анализе эффективности скрининга в данном исследовании установлено 6 положительных в группе I и 8 положительных критериев в группе II против четырех и двух отрицательных критериев в I и II группах соответственно.

Заключение. Скрининг на МПС можно считать целесообразным в целевых группах пациентов с наибольшим набором фенотипических признаков, характерных для данной патологии.

\section{НЕДИФФЕРЕНЦИРОВАННЫЕ ФОРМЫ УМСТВЕННОЙ ОТСТАЛОСТИ С ЭПИЛЕПСИЕЙ: ЦИТОГЕНЕТИЧЕСКИЕ И МОЛЕКУЛЯРНО- ЦИТОГЕНЕТИЧЕСКИЕ ИССЛЕДОВАНИЯ ХРОМОСОМНЫХ (ГЕНОМНЫХ) АНОМАЛИЙ У ДЕТЕЙ}

Демидова И.А. ${ }^{1,2}$, Ворсанова С.Г. ${ }^{1,2}$, Юров Ю.Б. ${ }^{1,2}$, Куринная О.С. ${ }^{1,2}$, Колотий А.Д. ${ }^{1,2}$, Зеленова М.A. ${ }^{1,2}$, Васин К.С. ${ }^{1,2}$, Кравеи, В.С. ${ }^{1,2}$, Юров И.Ю. ${ }^{1,2,3}$

${ }^{1}$ ОСП «Научно-исследовательский клинический институт педиатрии имени академика Ю.Е.Вельтищева» ФГАОУ ВО РНИМУ им. Н.И. Пирогова Минздрава России, Москва ФГБНУ «Научный центр психического здоровья», Москва ЗФГБОУ ДПО «Российская медицинская академия непрерывного профессионального образования», Москва

Умственная отсталость - один из самых распространенных признаков генетических заболеваний, связанных с нарушениями функционирования головного мозга. Этиологический фактор умственной отсталости определен приблизительно у 30-40\% детей. Недифференцированные ее формы часто встречаются с эпилепсией. Известно, что до $35 \%$ умственно отсталых детей страдают повышенной судорожной (эпилептической) готовностью. Этиология и патогенез недифференцированных форм умственной отсталости с эпилепсией могут быть связаны с хромосомными (геномными) аномалиями и синдромами. Цитогенетическое исследование на клетках культуры лимфоцитов периферической крови проведено 61 ребенку с различными недифференцированными формами умственной отсталости с эпилепсией, врожденными пороками и/или микроаномалиями развития. Численные и структурные аномалии хромосом были выявлены у 5ти (8\%) детей: 1/маркерная хромосома (кариотип 47,XX,+mar,13pss); 2 /«дополнительный» материал на хромосоме 3 (46, XX, $\operatorname{add}(3)$ (p26),1qh+,21ps+); 3/инверсия с инсерцией хромосомы $11 \quad(46, X X, \operatorname{der}(11) ? \operatorname{add}(11)(\mathrm{p} 13) \operatorname{ins}(11)$ (p13q21q23,3); 4/делеция длинного плеча хромосомы 6 (46,XX,del(6)(q22.?2q23.?3); 5/делеция длинного плеча хромосомы 15 (46,XY,del(15)(q11,2q1?3). У 7 детей (11\%) обнаружена хромосомная нестабильность; в 21 случае (34\%) - хромосомные варианты (изменения околоцентромерных гетерохроматиновых районов хромосом). У одного ребенка хромосомная аномалия сочеталась с хромосомной нестабильностью и у двух - с хромосомными вариантами. Хромосомная нестабильность в сочетании с хромосомными вариантами выявлена y $3 \mathrm{x}$ детей. Для уточнения цитогенетических результатов и получения дополнительной информации о нарушениях в геноме проведено молекулярное кариотипирование (SNParray) с использованием оригинальной биоинформатической технологии. При молекулярном кариотипировании у 61 ребенка выявлено 192 аномалии генома с патогенным или вероятно патогенным эффектом. Среди них - 97 (50,5\%) делеций, 71 (37\%) дупликация, 15 (7,8\%) трипликаций и $9(4,7 \%)$ мозаичных геномных нарушений (как правило, совместно с регулярными перестройками). В 9 (15\%) случаях у детей были выявлены микроделеционные и микродупликационные синдромы. При применении оригинального биоинформатического анализа определено более 800 генов, среди них следующие: ген FMR1 [OMIM:309550], ассоциированный с умственной отсталостью, сцепленной с ломкой хромосомой $\mathrm{X}$; ген $B T R C$ [OMIM:603482], связанный с эпилепсией; гены $D A Z 2$ [OMIM:400026] и DAZ3 [OMIM:400027], AFF2 (FMR2) [OMIM:300806], SLC1A1 [OMIM:133550], SCN2A [OMIM:182390] и SCN3A [OMIM:182391], GABRB3 [OMIM:137192], NECAP1 [OMIM:615833], SHANK3 [OMIM:606230]. Вариабельность полученных данных и число обследованных детей пока не позволяют провести корректные корреляции патологической значимости геномных (хромосомных) нарушений в ассоциации с недифференцированными формами умственной отсталости и эпилепсией. Однако проведенный анализ может указывать на целесообразность продолжения исследований, направленных на поиск молекулярных механизмов умственной отсталости и эпилепсии.

Работа была частично поддержана Госзаданием Минздрава России № 121031000238-1, а также частично Госзаданием Министерства науки и высшего образования России № АААА-А19-119040490101-6.

\section{СИНДРОМ ПОТОЦКИ-ЛЮПСКИ У ПОДРОСТКА С ЗАДЕРЖКОЙ РОСТА (КЛИНИЧЕСКИЙ СЛУЧАЙ)}

Еникеева С.Р., Панкратова М.С.

ФГБУ «Национальный медицинский исследовательский центр эндокринологии» Минздрава России, Москва

Введение. Синдром Потоцки-Люпски (СПЛ) орфанное заболевание, обусловленное микродупликацией короткого плеча 17 хромосомы $(17 \mathrm{p} 11,2)$. Проявлениями СПЛ является неонатальная гипотония с дисфагией, задержка роста и психоречевого развития, а также стигмы дисэмбриогенеза (треугольное лицо, микрогнатия, широкий лоб, скученность зубов, арочное небо, сглаженный фильтр и др.). Нередко встречаются структурные аномалии сердца - атриовентрикулярные септальные дефекты, 
а также деформации костной системы. В зависимости от длины микродупликации, клинические проявления могут быть различной степени выраженности.

Описание клинического случая. Пациент А., 15 лет, обратился в ФГБУ НМИЦ эндокринологии с жалобами на низкий рост. Из анамнеза: отставание в раннем психомоторном развитии, врожденный вывих надколенника, в настоящее время задержка психоречевого развития. Отставание в росте от сверстников отмечается с 3-х лет. Семейный анамнез не отягощен. Консультирован генетиком - фенотипически не исключен синдром Сильвера-Рассела.

При осмотре: рост 149 см (SDS -3,2), удовлетво-

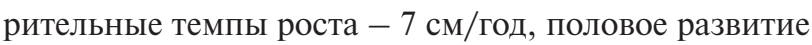
Таннер 3, челюстно-лицевой дизморфизм (треугольное лицо, большой лоб, микрогнатия, скученность зубов). Костный возраст соответствовал 13,5 годам. ИФР-1 в референсе - 272 нг/мл, показатели половых гормонов соответствовали стадии пубертата, данных за гипотиреоз, гипокортицизм не получено. Признаков нарушения секреции тропных гормонов не выявлено. На УЗИ почек выявлена двусторонняя пиелоэктазия, Эхо-КГ без патологии. По совокупности клинических данных была заподозрена синдромальная патология, для уточнения которой пациент был направлен на хромосомный микроматричный анализ (ХМА) по программе Альфа-Эндо. Выявлена микродупликация участка короткого плеча (p) 17 хромосомы с 16929087 до 20317061 позиции, захватывающая регион 17p11,2, размером 3387975 п.н., ассоциированная с синдромом Потоцки-Люпски (OMIM: 610883). Молекулярный кариотип (ISCN 2016): $\operatorname{arr}[$ hg38] 17p11,2(16929087_20317061)х3,

Заключение. Описанный клинический случай синдрома Потоцки-Люпски демонстрирует результативность ХМА при диагностике синдромальных нарушений. Учитывая редкость заболевания, ограниченную информацию о его клинических проявлениях, пациенту необходимо дальнейшее наблюдение.

\section{ТЕРАПИЯ ТОБРОМИЦИНОМ У ДЕТЕЙ СТАВРОПОЛЬСКОГО КРАЯ, СТРАДАЮЩИХ МУКОВИСЦИДОЗОМ, В ЗАВИСИМОСТИ ОТ ГЕНЕТИЧЕСКИХ МУТАЦИЙ}

Енина Е.А., Григорьяни И.С., Белаш Т.А., Леденева Л.Н., Водовозова Э.В., Пустабаева М.С.

ФГБОУ ВО «Ставропольский государственный медицинский университет» МЗ РФ, Ставрополь

Введение. При микрофлоре Pseudomonas aeruginosa нижних дыхательных путей у детей, страдающих муковисцидозом (МВ) назначение ингаляционной противосинегнойной терапии (тобрамицин) позволяет уменьшить риск обострений и степень выраженности респираторных проявлений.
Цель исследования: проанализировать результаты ингаляционной терапии тобрамицином при микрофлоре Pseudomonas aeruginosa нижних дыхательных путей у детей Ставропольского края (CK), страдающих МВ, в зависимости от генетических мутаций

Материалы, методы исследования: лечение тобромицином проводилось 12 больным МВ, с хронической инфекцией P.aeruginosa в респираторном тракте на базе Регионального центра МВ в СК. Лечение осуществляли ингаляционным способом -300 мг препарата 2 раза в день на протяжении 28 дней с повторными курсами через 28 дней (3 курса) в течении 2-4 лет. Для оценки динамики клинических данных составлена анкета.

Результаты. В СК выявлены мутации следующих генов у больных МВ с хронической синегнойной инфекцией: - del F508 - 75,0\%; del F508 и 1677del $\mathrm{A}-8,3 \%$; W1282 R - 8,3\%; W1282 R и R344W - 8,3\%. На фоне терапии тобромицином отмечалось ослабление интенсивности, уменьшение частоты кашля и количества выделяемой мокроты, улучшение физикальных данных в легких; при мутации гена del F508 улучшения фиксировались к 10-14 дню, у пациентов с другими типами мутаций - к 7-9 дню лечения. На фоне лечения отмечено достоверное увеличение ФЖЕЛ и ОФВ1 (P $\leq 0,001$ соответственно), элиминация 76,0\% штаммов P.aeruginosa, в том числе мукоидных штаммов, у 2 пациентов с «тяжелыми» мутациями после проведенных 3 курсов терапии высеивалась в мокроте синегнойная палочка (у одного пациента мутация гена del F508, у второго - сочетание del F508 и $1677 \mathrm{del}$ TA).

Заключение. В СК у детей, страдающих МВ наиболее часто встречаются пациенты с мутацией гена del F508 (75,0\%). Ингаляционная терапия тобрамицином улучшает дыхательную функцию легких за счет увеличения спирометрических показателей ФЖЕЛ и ОФВ1 и контролирует течение хронической инфекции P.aeruginosa в респираторном тракте больных. Пациенты, имеющие в генетике «тяжелые» мутации, требуют более длительных курсов ингаляционной антибактериальной терапии.

\section{АНАЛИЗ ПРОГРАММ ДЛЯ ИНТЕРПРЕТАЦИИ ДАННЫХ ПО ВАРИАЦИЯМ ЧИСЛА КОПИЙ ПОСЛЕДОВАТЕЛЬНОСТИ ДНК (CNV): ВОЗМОЖНОЕ ВЫЯВЛЕНИЕ ПРИЧИН НЕРВНЫХ И ПСИХИЧЕСКИХ ЗАБОЛЕВАНИЙ У ДЕТЕЙ}

Зеленова М.А.' ${ }^{1,2}$, Юров И.Ю. ${ }^{1,2,3}$

1 ФГБНУ «Научный центр психического здоровья», Москва ${ }^{2}$ ОСП «Научно-исследовательский клинический институт педиатрии имени академика Ю.Е.Вельтищева» ФГАОУ ВО РНИМУ им. Н.И. Пирогова Минздрава России, Москва ${ }^{3}$ ФГБОУ ДПО «Российская медицинская академия непрерывного профессионального образования», Москва 
Введение. Вариации числа копий последовательности ДНК $(\mathrm{CNV})$ являются одной из причин многих нервных и психических нарушений, включая умственную отсталость в сочетании с врожденными пороками развития. Данные о CNV могут быть получены из разных источников, основными из которых являются молекулярное кариотипирование и секвенирование. Однако получаемые данные не имеют особой ценности без дальнейшей интерпретации.

Цель исследования. Изучить спектр программ, предназначенных для анализа CNV, выявляемых при помощи молекулярного кариотипирования, с целью определения программного обеспечения, позволяющего интерпретировать различные типы вариаций генома и не требующего специальной подготовки исследователей.

Материалы и методы. Анализ литературы с использованием ресурсов «Pubmed» и «Google Scholar».

Результаты исследования. Большинство статей, в которых представлен анализ полученных данных, описывают микрочипы для анализа экспрессии генов, что не имеет отношения к настоящему поиску. Многие программы нацелены на анализ опухолей и обнаружение CNV в данных NGS. Подавляющее большинство ресурсов предназначено для использования их исследователями с опытом программирования. Мы выявили несколько программ, наиболее подходящих к цели настоящего поиска. Веб-инструмент «CNVxplorer» (http://cnvxplorer.com/) позволяет получать информацию о заданных $\mathrm{CNV}$ в визуальном и текстовом виде, и в том числе дает клиническую информацию. Данный сайт обладает доступным пониманием исследователями, однако предполагает ввод каждой $\mathrm{CNV}$ в отдельности. Веб-инструмент «pBRIT» (http://biomina.be/apps/pbrit/) позволяет приоритизировать гены, основываясь на наборе, загруженном пользователем. На сайте детально описан алгоритм, лежащий в основе данного метода, однако описание отдельных генов не может являться достаточным для анализа CNV. Исходя из анализа литературы, в задачу поиска могли войти некоторые другие ресурсы, однако доступ к ним на настоящий момент ограничен многими сервисами (например, «maGUI», «CNV-WebStore», «Ensembl Variant Effect Predictor»).

Выводы. В настоящем исследовании показано, что программ, нацеленных на интерпретацию данных по CNV, использующих в своей основе четкий алгоритм, доступных для неспециалистов в программировании и позволяющих анализировать данные после молекулярного кариотипирования, практически не существует. Учитывая широкое применение молекулярного кариотипирования по всему миру, необходимость в подобной программе крайне высока. Таким образом, разработка подобных программ для фундаментальной и практической медицины представляется актуальной.
Работа была частично поддержана Госзаданием Министерства науки и высшего образования России № AAAA-A19-119040490101-6, а также частично Госзаданием Минздрава России № 121031000238-1

\section{ВЫЯВЛЕНИЕ СЛОЖНЫХ СТРУКТУРНЫХ ХРОМОСОМНЫХ АНОМАЛИЙ МЕТОДОМ «ОБРАТНОГО» КАРИОТИПИРОВАНИЯ}

Колотий А.Д. ${ }^{1,2}$, Ворсанова С.Г. ${ }^{1,2}$, Юров Ю.Б. ${ }^{1,2}$, Куринная О.С. ${ }^{1,2}$, Демидова И.А. ${ }^{1,2}$, Зеленова М.A. ${ }^{1,2}$, Васин К.С. ${ }^{1,2}$, Юров И.Ю. ${ }^{1,2,3}$

${ }^{1}$ ОСП «Научно-исследовательский клинический институт педиатрии имени академика Ю.Е.Вельтищева» ФГАОУ ВО РНИМУ им. Н.И. Пирогова Минздрава России, Москва ${ }^{2}$ ФГБНУ «Научный центр психического здоровья», Москва ЗФГБОУ ДПО «Российская медицинская академия непрерывного профессионального образования», Москва

Внедрение таких высокоразрешающих молекулярно-цитогенетических технологий, как методы молекулярного кариотипирования, в клиническую практику позволило определять сложные «скрытые» структурные хромосомные перестройки, не выявленные классическим цитогенетическим анализом. Некоторые из них, размером от 5 млн пн, возможно выявить с помощью повторного или «обратного» кариотипирования, проведенного после молекулярных исследований. В этом случае применяется «таргетный» подход к исследованию перестроенной хромосомы на метафазных пластинках с разрешением 550-800 полос на гаплоидный кариотип. «Обратное» кариотипирование необходимо для дальнейшего цитогенетического обследования родителей и других членов семьи больного ребенка на носительство возможной сбалансированной перестройки. Известно, что методы молекулярного кариотипирования не позволяют выявлять сбалансированные хромосомные перестройки, в отличие от методов классической клинической цитогенетики. Применение «обратного» кариотипирования показало его эффективность и целесообразность для детекции небольших по размеру, но цитогенетически видимых, перестроек. Показано, что до 4-5\% обследованных детей $(\mathrm{n}=895)$ нуждались в проведении повторного цитогенетического исследования («обратного» кариотипирования). Во всех случаях первичное кариотипирование (до молекулярно-цитогенетического исследования) не выявило хромосомной патологии, тем не менее, эти перестройки были визуализированы при «обратном» кариотипировании. Наименьший размер выявленной структурной перестройки составлял 3,6 млн пн. В некоторых, особенно сложных случаях, применялся метод FISH. Наиболее частыми «скрытыми» аномалиями у больных детей были несбалансированные реципрокные транслокации, проявляющиеся при молекулярном кариотипи- 
ровании в виде сочетания терминальной делеции и дупликации в двух разных хромосомах. Особенно сложными для выявления были случаи, когда участки делеции и дупликации имели примерно одинаковые размеры, при этом обращалось внимание на изменение дифференциального окрашивания перестроенного участка дериватной хромосомы. Совместное применение молекулярно-цитогенетических и цитогенетического методов исследования позволяют достичь наиболее корректных результатов в генетической диагностике и предотвратить возможное рождение в семье ребенка с хромосомной патологией.

Работа была частично поддержана грантом РФФИ и CITMA (Ciencia, Tecnología y Medio Ambiente de la República de Cuba) в рамках научного проекта № 18-515-34005, частично Госзаданием Минздрава России № 121031000238-1, а также частично Госзаданием Министерства науки и высшего образования России № AAAA-A19-119040490101-6.

\section{СЛУЧАЙ НАРУШЕНИЯ ПОЛОВОГО РАЗВИТИЯ У ДЕВОЧКИ С НЕФРОТИЧЕСКИМ СИНДРОМОМ}

Кравеи В.С. ${ }^{1,2}$, Ворсанова С.Г. ${ }^{1,2}$, Куринная О.С. ${ }^{1,2}$,

Лепаева Т.В. ${ }^{1}$, Юров И.Ю. ${ }^{1,2,3}$

${ }^{1}$ ОСП «Научно-исследовательский клинический институт педиатрии имени академика Ю.Е.Вельтищева» ФГАОУ ВО РНИМУ им. Н.И. Пирогова Минздрава России, Москва 2ФГБНУ «Научный центр психического здоровья», Москва ЗФГБОУ ДПО «Российская медицинская академия непрерывного профессионального образования», Москва

Нарушения полового развития встречаются у детей с довольно высокой частотой (по данным литературы, они встречаются с равной частотой у лиц мужского и женского пола; до 3-4\% в популяции). Причины этих нарушений разнообразны; часто выявляются изменения, ассоциированные с различными генетическими и хромосомными аномалиями. В каждом таком случае необходимо применение высокоразрешающих цитогенетических и молекулярноцитогенетических методов, что позволяет понять природу патологических проявлений у пациента, проводить корректную персонализированную терапию и дать квалифицированный прогноз семье.

Представлено описание ребенка - девочки бти лет с стероид-резистентным нефротическим синдромом, нарушениями полового развития и поведения. При ультразвуковом исследовании обнаружили отсутствие матки и яичников. На основании клинических симптомов было рекомендовано проведение цитогенетического исследования. Культивирование лимфоцитов периферической крови, приготовление препаратов, дифференциальное окрашивание хромосом по длине и цитогенетический анализ проводились по стандартным протоколам. Кариотип пробанда после классического цитогенетического исследования - 46,XY,1qh-,9qh-, т.е. у ребенка с женским фенотипом определен мужской кариотип. Подобные случаи встречаются с частотой 1:60000 новорожденных. Ребенку рекомендованы молекулярно-цитогенетические исследования: FISH с околоцентромерными ДНК пробами на хромосомы X и Y для выявления возможного мозаицизма по половым хромосомам, а также молекулярное кариотипирование, позволяющее выявлять возможные геномные аномалии, которые не визуализируются классическими цитогенетическими методами из-за их разрешающейся способности. Кроме того, будут выявлены гены, ассоциированные с клиническими проявлениями данной патологии.

Следует отметить, что случаи с отсутствием яичников и тестикул встречаются весьма редко. Вероятно, причина патологии связана с мутациями генов, ассоциированных с половым развитием. Подобные случаи необходимо всесторонне изучать как для проведения персонализированной терапии, так и для изучения механизмов развития патологии.

Работа была частично поддержана Госзаданием Минздрава России № 121031000238-1.

\section{СЛУЧАЙ ДЕЛЕЦИИ ДЛИННОГО ПЛЕЧА ХРОМОСОМЫ 18 У ДЕВОЧКИ С ЗАДЕРЖКАМИ ПСИХОРЕЧЕВОГО РАЗВИТИЯ, РОСТА И МИКРОАНОМАЛИЯМИ}

Куринная О.С. ${ }^{1,2}$, Колотий А.Д. ${ }^{1,2}$, Боченков С.В. ${ }^{1}$, Ворсанова С.Г. ${ }^{1,2}$, Юров И.Ю. ${ }^{1,2,3}$

${ }^{1}$ ОСП «Научно-исследовательский клинический институт педиатрии имени академика Ю.Е.Вельтищева» ФГАОУ ВО РНИМУ им. Н.И. Пирогова Минздрава России, Москва ФГБНУ «Научный центр психического здоровья», Москва ${ }^{3}$ ФГБОУ ДПО «Российская медицинская академия непрерывного профессионального образования», Москва

Известно, что хромосома 18 является субметацентирической хромосомой из группы Е, небольшой по сравнению с другими хромосомами в кариотипе человека. В литературе есть сообщения о частичных моносомиях и трисомиях коротких и длинных плеч хромосомы 18, а также о кольцевых хромосомах. Известен синдром регулярной трисомии хромосомы 18 - синдром Эдвардса. Частичная моносомия - синдром делеции длинного плеча хромосомы 18 встречается гораздо реже, чем синдром частичной делеции короткого плеча этой хромосомы. Критические точки разрыва при этом синдроме расположены в интерстициальных участках 18q21q22, захватывающих более половины длинного плеча хромосомы 18. Характерными признаками для детей с моносомией длинного плеча хромосомы 18 является умственная отсталость, задержка роста, эпикант, косоглазие, нистагм, колобома радужки, гипертелоризм глаз- 
ных щелей, атрофия зрительного нерва, расщелина мягкого неба, деформированные ушные раковины с узким слуховым проходом, гипоспадия, крипторхизм, гипоплазия мошонки, врожденный порок сердца. У них также отмечают своеобразную форму лица с уплощенной спинкой маленького носа, глубоко посаженными глазными яблоками, тонкой верхней губой и опущенными вниз углами рта («рот карпа»). Пороки ЦНС и почек не совсем специфичны, несмотря на неоднократное упоминание о них в отдельных случаях.

При цитогенетическом исследовании девочки 5ти лет с задержкой психоречевого развития, задержкой роста, микроцефалией, МАР (эпикант, широкая переносица, уплощенное лицо, заостренные резцы, прогнатия, неполная синдактилия 2-3 пальцев стоп, гипертелоризм сосков, плоско-вальгусные стопы), а также с эпиактивностью на ЭЭГ, открытым овальным окном и гиперметропическим астигматизмом была выявлена делеция длинного плеча хромосомы 18. Кариотип ребенка был записан как 46,XX,del(18) (q22),9qh- (ISCN 2016). У пробанда наблюдались не все признаки, характерные для этого синдрома. После проведения цитогенетической диагностики ребенку было рекомендовано проведение молекулярно-цитогенетического исследования для уточнения точек разрыва в делеции. Это необходимо для определения корреляции генотип-фенотип, поскольку для многих частичных моносомий (делеций), связанных с хромосомой 18 (синдромы 18p-, 18q-, r18), критические точки разрыва определены недостаточно корректно. Кроме того, необходимо проведение цитогенетического и, возможно, молекулярноцитогенетического исследования родителям с целью проведения эффективного медико-генетического консультирования для дальнейшего планирования деторождения.

Работа была частично поддержана Госзаданием Минздрава России № 1210310002381 , а также частично Госзаданием Министерства науки и высшего образования России № AAAA-A19-119040490101-6.

\section{ИСПОЛЬЗОВАНИЕ СОВРЕМЕННЫХ МЕТОДОВ ИССЛЕДОВАНИЯ ДЛЯ УТОЧНЕНИЯ ДИАГНОЗА СЛОЖНОЙ ХРОМОСОМНОЙ АНОМАЛИИ У РЕБЕНКА}

Митусова Л.И., Хлевная Л.А.

Республиканский специализированный центр

медицинской генетики и пренатальной диагностики, Донецк

Введение. Стандартный цитогенетический метод обследования широко используется для выявления разнообразных хромосомных аномалий в кариотипе. Однако идентификация маркерных хромосом, в частности, малых сверхчисленных, невозможна без применения современных молекулярно-цитогенетических методов исследования.

Цель исследования - определить тип хромосомной патологии в кариотипе ребенка и сопоставить ее с имеющимися фенотипическими особенностями.

Материалы и методы. Обследован ребенок Сергей X., 9 лет, направленный в РСЦМГПД с диагнозом: задержка физического развития. Хромосомный анализ мальчика и его родителей проведен по лимфоцитам периферической крови стандартным цитогенетическим методом. Дальнейшее обследование ребенка выполнено с помощью многоцветной FISH и multicolor banding FISH.

Результаты. При осмотре ребенка врачом-генетиком отмечены пропорциональная задержка роста и большие оттопыренные ушные раковины. Имеется миопия высокой степени. Психическое развитие мальчика соответствует возрасту.

Кариотип пробанда: $\operatorname{mos} 47, \mathrm{XY}, \mathrm{t}(5 ; 6)(\mathrm{q} 31 \sim 32 ; \mathrm{q} 21)$, $+\operatorname{mar}[11] / 46, X Y, t(5 ; 6)(q 31 \sim 32 ; q 21)[9] p a t, \quad$ выявлено два аномальных клеточных клона: в первом - сбалансированная транслокация отцовского происхождения с вовлечением 5 и 6 хромосом в сочетании с маркером, имеющим кольцевую структуру, во втором - только сбалансированная транслокация.

При дообследовании ребенка дополнительная маркерная хромосома была идентифицирована как кольцевая хромосома 9, содержащая материал короткого плеча и прицентромерный гетерохроматиновый район длинного плеча: $\operatorname{ishr}(9)(\mathrm{p} 22 \mathrm{q} 12)(\mathrm{pcp}-$ $9 \mathrm{p}+, \mathrm{D} 9 \mathrm{Z1}+)$.

Заключение. При носительстве сбалансированных семейных транслокаций фенотипические и клинические проявления, как правило, отсутствуют. Следовательно, имеющиеся у мальчика особенности развития обусловлены трипликацией сегмента 9p22q12. Известно, что трисомия короткого плеча хромосомы 9 - это четкий клинический синдром, критическим участком, для развития которого является $9 \mathrm{p} 13 \rightarrow 9 \mathrm{p} 22$. При этом хромосомном заболевании описаны умственная отсталость, пороки внутренних органов и множественные стигмы дизэмбриогенеза. Минимализация клинических проявлений у ребенка в описанном нами случае - задержка роста и большие оттопыренные ушные раковины - обусловлена мозаичным вариантом частичной трисомии 9p, которая встречается в 55\% проанализированных метафаз. 


\section{ИНТЕРАКТИВНЫЙ КЛИНИЧЕСКИЙ СЛУЧАЙ ДЕТСКОЙ ФОРМЫ ГИПОФОСФАТАЗИИ}

Путинцев А.Н., Воинова В.Ю., Дживанширян Г.В., Никольский Д.А.

НИКИ педиатрии им. акад. Ю.Е.Вельтищева ФГАОУ ВО РНИМУ имени Н.И. Пирогова Минздрава России, Москва

Актуальность. Одним из редких заболеваний является гипофосфатазия - редкое жизнеугрожающее наследственное заболевание, проявляющееся нарушением минерализации костей скелета и зубов, а также системными осложнениями, включая нарушение дыхания, судороги, мышечную слабость, боли в костях и нефрокальциноз. Диагностика этого заболевания часто затруднена, однако чрезвычайно важна, поскольку для него разработана высокоэффективная ферментозаместительная терапия. Кроме того, в отсутствие своевременного лечения прогноз неблагоприятный. В связи с тем, что в НИКИ педиатрии им. Ю.Е.Вельтищева поступают дети из разных регионов России с редкими заболеваниями, сложными с точки зрения постановки диагноза, эксперты накопили богатый опыт диагностики и лечения, который важно передать врачам из регионов.

Цель работы: создание интерактивного образовательного ресурса по диагностике гипофосфатазии для дистанционного повышения квалификации врачей и обучения студентов медицинских вузов.

Метод. При создании образовательного ресурса использованы:

- кейс-метод для создания клинических ситуационных задач;

- мультимедийные технологии для визуализации образовательного контента;

- функциональные возможности инструментального средства OpenLabyrinth.

Результаты. Представлен интерактивный клинический случай, который позволяет проводить виртуальную диагностику гипофосфатазии у пациента с детской формой заболевания. На каждом этапе диагностики проводится анализ полученной к данному моменту информации о пациенте, определение плана дальнейшего обследования, формирование диагностических гипотез. В процессе виртуальной диагностики обучающийся проходит ту же последовательность этапов, что и опытный врач, при этом на каждом этапе предусмотрены контрольные вопросы. Если обучающийся отвечает правильно, он получает бонусы в виде баллов, а в случае неправильного ответа - объяснения, в чем ошибка. В результате прохождения кейса вычисляется и выводится на экран интегральная оценка - сумма баллов за правильные ответы. Обучающий блок содержит видеофрагменты лекционного материала по различным аспектам гипофосфатазии - этиологии, патогенезу, классификации, клиническим проявлениям, алгоритму диагностики и критериям выбора адекватного лечения. Повторное прохождение виртуаль- ной диагностики как правило повышает интегральную оценку, а главное - помогает закрепить знания, необходимые для правильной диагностики и выбора лечения.

Практическая значимость. Образовательный peсурс размещен на сервере института http://olab. pedklin.ru/ и может быть полезен педиатрам, а также врачам других специальностей. Возможность дистанционного доступа к мультимедийным ресурсам позволит повысить качество непрерывного профессионального образования врачей.

\section{КЛИНИЧЕСКИЕ МАСКИ НАСЛЕДСТВЕННЫХ ЛЕЙКОДИСТРОФИЙ В ДЕТСКОМ ВОЗРАСТЕ}

Савельева Н.Н., Темина Л.Б., Зимина М.Н., Якунина А.В., Герасимова Л.Ф., Шайдуллова Г.Р.

СОКБ им. В.Д. Середавина, СамГМУ, Самара

Введение. Лейкодистрофии-группа нейродегенеративных заболеваний, обусловленных наследственным нарушением обмена веществ с накоплением в головном и спинном мозге метаболитов, провоцирующих разрушение миелина. Манифестирут в основном в детском возрасте утратой когнитивных, речевых навыков, двигательными расстройствами, поражением зрительных и слуховых нервов, эпилептическими приступами. Важными диагностическими методами, помимо клинических, являются нейровизуализация, биохимический и молекулярно-генетический тесты. Лечение симптоматическое и патогенетическое, диетотерапия. Лейкодистрофии схожи с другими неврологическими заболеваниями, что затрудняет диагностику и отодвигает своевременное начало терапии.

Цель исследования - выявить клинико-диагностические особенности наследственных лейкодистрофий в детском возрасте для своевременного начала терапии.

Материалы и методы. В исследование включено 14 детей с МР-картиной лейкопатии, острым или подострым дебютом болезни в виде очаговой и общемозговой симптоматики, прогрессирующим течением, находившимся на лечении в детских неврологических отделениях г. Самары в период с 2017 по 2021г.г. Всем пациентам проводилось: МРТ головного мозга, клинико-генеалогическое исследование, биохимическая и молекулярно-генетическая диагностика, исследование иммунного статуса, анализы крови и ликвора на инфекционные агенты.

Результаты. У всех 14 детей отмечалось острое или подострое начало болезни с развитием общемозговой и очаговой симптоматики в виде центральных парезов, эпилептических приступов, корковой агнозии. Все дети поступили в стационар с направительным диагнозом Лейконцефалит. 4 из них диагноз вирусно-аутоимунный лейкоэнцефалит был подтвержден лабораторными данными, на фоне специфиче- 
ской противовирусной терапии отмечалась значительная положительная динамика, они были выписаны на 21-22 сутки с улучшением. У 10 детей, несмотря на активную терапию, отмечалось прогрессирование болезни, что вызвало подозрение в плане нейродегенераций. Проведены биохимические и молекулярногенетические тесты: тандемная масс-спектрометрия мочи и крови, количественное исследование ОДЦЖК крови, фермент-диагностика, панель Наследственные лейкодистрофии. В результате 4 мальчикам был выставлен диагноз Х-сцепленная наследственная адренолейкодистрофия, 2 детям - болезнь Канаван, 2 детям - болезнь Краббе, 1 девочке - болезнь Александера, 1 ребенку - метахроматическая лейкодистрофия. Средний срок постановки диагноза с момента обращения в отделение - 23 дня, после первичного обращения к врачу-участковому педиатру - 60 дней. Основные диагностические трудности заключались в схожести клиники с демиелинизирущими заболеваниями, лейкоэнцефалитом, ОРЭМ. Патогмоничными симптомами наследственных лейкодистрофий являются специфическая МР-картина, отсутствие инфекционного и менингеального синдрома в дебюте заболеваний, неуклонное прогрессирование очаговой и общемозговой симптоматики.

Заключение. В дебюте наследственные лейкодистрофии могут протекать под маской демиелинизирущих заболеваний, лейкоэнцефалита, ОРЭМ. Сходство придают острое или подострое начало с развитием общемозговой и очаговой симптоматики в виде центральных парезов, эпилептических приступов, корковой агнозии. Патогмоничными симптомами являются специфическая МР-картина, отсутствие инфекционного и менингеального синдрома в дебюте заболеваний, неуклонное прогрессирование симптомов. При подозрении на эти нейродегенеративные заболевания необходимо проводить биохимические и молекулярно-генетические тесты: тандемную масс-спектрометрию мочи и крови, количественное исследование ОДЦЖК крови, фермент-диагностику, панель Наследственные лейкодистрофии. Это позволяет сократить срок постановки диагноза и своевременно начать терапию заболевания.

\section{ПРЕНАТАЛЬНАЯ ДИАГНОСТИКА РЕДКОЙ ХРОМОСОМНОЙ ПАТОЛОГИИ: МОЗАИЦИЗМ ПО КОЛЬЦЕВОЙ ХРОМОСОМЕ 14}

Хлевная Л.А., Малова С.А., Митусова Л.И.

Республиканский специализированный центр

медицинской генетики и пренатальной диагностики, Донецк

Введение. В результате инвазивной пренатальной диагностики возможно выявление разнообразной хромосомной патологии. Особого внимания заслуживают сложные структур- ные перестройки и такие редкие нозологические формы, как кольцевые хромосомы.

Цель исследования - определить тип пренатально выявленной хромосомной аномалии и сопоставить ее с фенотипическими особенностями, отмеченными у плода при УЗ-исследовании.

Материалы и методы. Обследована беременная O., 35 лет, которая проходила пренатальную диагностику по комплексной программе. По результатам У3и биохимического скринингов включена в группу высокого генетического риска по рождению ребенка с синдромами Эдвардса и Патау. Кариотипирование плода выполнено в 19-20 недель по клеткам амниотической жидкости.

Результаты. При ультразвуковом исследовании перед проведением инвазивной манипуляции у плода были выявлены аномалии развития и эхо-маркеры хромосомных синдромов: аномальная установка кистей и стоп, гипоплазия легких, ретрогнатия, выраженная кардиомегалия, мезокардия, избыточная шейная складка, кисты сосудистых сплетений головного мозга, единственная артерия пуповины. Кроме того, отмечались задержка развития плода на 2 недели и гиперплазия плаценты.

Кариотип плода: $\operatorname{mos} 45, \mathrm{XX},-14[12] / 46, \mathrm{XX}, \mathrm{r}(14)$ (q24-31)[6], выявлено два аномальных клона: в первом - моносомия по хромосоме 14, во втором наличие крупной кольцевой хромосомы 14 вместо линейного гомолога. Учитывая выраженный хромосомный дисбаланс в кариотипе плода, сопровождаемый пороками развития, супруги приняли решение о прерывании беременности.

Заключение. Пренатальная диагностика этой патологии как правило затруднена в связи с отсутствием грубых пороков развития у плода, поскольку при формировании крупных колец происходит потеря незначительных участков верхнего и нижнего плеча хромосомы. В тоже время, кольцевые хромосомы митотически нестабильны, вследствие чего формируется моносомный клеточный клон, что и было продемонстрировано в нашем наблюдении. Причем, преобладающее количество моносомных метафаз свидетельствует в пользу раннего появления этой клеточной линии. Следовательно, формирование пороков развития у плода, перечисленных выше, было обусловлено мозаицизмом по моносомии хромосомы 14.

\section{МИТОТИЧЕСКАЯ НЕСТАБИЛЬНОСТЬ КОЛЬЦЕВЫХ ХРОМОСОМ \\ Шилова Н.В., Миньженкова М.Е., Маркова Ж.Г., Табаков В.Ю.}

ФГБНУ «Медико-генетический научный центр имени академика Н.П. Бочкова», Москва

Введение. Формирование кольцевой структуры хромосом могут приводить к митотической неста- 
бильности вследствие нарушения нормального расхождения таких хромосом при каждом митотическом клеточном делении. Следствием митотической нестабильности является частичная или полная анеуплоидия (трисомия или моносомия) по соответствующей кольцевой хромосоме (KX) - так называемый динамический мозаицизм (ДМ). Этот процесс может приводить либо к гибели дочерних клеток, либо к их выживанию в мозаичном статусе, что может оказывать непосредственное влияние на степень выраженности аномалий фенотипа.

Цель исследования - изучение митотической нестабильности КX $(46, r)$ при определении спектра вторичного хромосомного дисбаланса (ХД).

Материалы и методы. FISH на клетках культуры лимфоцитов периферической крови семи пациентов с различными КX в кариотипе, а также в клетках культуры фибробластов кожи в случае КX 13, проводили с использованием многоцветовых технологий (многоцветовое окрашивание хромосом), локус-специфичных ДНК-зондов на субтеломерные районы короткого и длинного плеч соответствующих хромосом, меченных различными флуорохромами (TEL), D15S10/PML, TBX1/SHANK3, ДНК-зондов на центромерные районы соответствующих хромосом (CEP) и пантеломерных ДНК-зондов (PanTel). Проводили также хромосомный микроматричный анализ (CytoScan HD Array).

Результаты. ДМ был выявлен в пяти из семи случаев $\mathrm{KX} \mathrm{3,} \mathrm{13,} \mathrm{15,} 20$ и 22. В двух случаях при наличии в кариотипе KX 18 ДМ не обнаружен. Вторичные хромосомные перестройки при КХ большего размера $(3,13,15)$ были представлены клонами клеток, содержащими различные варианты аномальных по структуре производных КХ, что свидетельствует о наличии более чем одного сестринского хроматидного обмена в S-фазе митоза. Вторичные хромосомные перестройки в случаях KX 20 и 22 представлены в основном клоном клеток с моносомией (12,5\% и $11,5 \%$, соответственно). В культуре фибробластов кожи ДМ не был обнаружен. Однако структура КX 13 в культивированных фибробластах существенно отличалась от таковой в культивированных лимфоцитах периферической крови.

Заключение. Митотическая нестабильность КХ приводит к формированию ДМ. Структура вторичного хромосомного дисбаланса определяется морфологией хромосомы, вовлеченной в формирование кольцевой структуры. Спектр вторичных хромосомных перестроек при наличии в кариотипе $\mathrm{KX}$, сформированных из хромосом большого размера, представлен перестройками, обусловленными изменением структуры кольца вследствие СХO, т.е структурной нестабильностью КХ. Вторичный хромосомный дисбаланс вследствие наличия $\mathrm{KX}$ малого размера обусловлен прежде всего ее потерей и формированием клона с моносомией соответствующей хромосомы.
Использование комплексного подхода к диагностике КХ позволяет не только уточнить точки разрывов, детализировать ХД, но и определить структуру вторичных хромосомных перестроек.

\section{ДИНАМИКА СТРУКТУРЫ ВРОЖДЕННЫХ ПОРОКОВ РАЗВИТИЯ У НОВОРОЖДЕННЫХ ЗА ПОСЛЕДНИЕ 7 ЛЕТ ДОКОВИДНОГО ВРЕМЕНИ}

Шипилова Л.М., Старчикова Т.А., Ежова А.С.

Перинатальный центр ГУЗ «Саратовская городская клиническая больница №8» ФГБОУ ВО Саратовский ГМУ им В.И. Разумовского Минздрава России

Врожденные пороки развития (ВПР), несмотря на быстрое развитие науки и техники, позволяющее их раннюю диагностику и нередко радикальное лечение, составляют еще немалую долю в структуре заболеваемости новорожденных. ВОЗ констатирует, что ВПР в различных странах мира составляют от 3 - до $6 \%$.

Целью исследования явилось изучение динамики структуры ВПР у новорожденных за 2014 - 2020 годы по данным перинатального центра ГКБ№8 г. Саратова.

Возраст матерей новорожденных колебался от 16 до 51 года, в среднем - 33 года. Доношенных детей было 92,5\%. По данным нашего учреждения, ВПР диагностировали в 2014 году у 4,3\% новорожденных, а за последние 3 года - у 3,9\%.

ВПР - это структурные или функциональные аномалии, выявляемые при рождении, но в последующем могут исчезнуть. Внедрение в практику медиков приборов экспертного класса позволяет проводить ультразвуковой и лабораторный пре и постнатальный скрининг, позволяющий высокопрофессиональным докторам иметь возможность выявлять отклонения уже у эмбрионов, который способен изменить структуру ВПР и снизить количество детей с тяжелыми ВПР ЦНС, ВПР мочевыводящей и сердечно-сосудистой систем путем разработки индивидуального алгоритма ведения беременной.

По нашим данным, частота ВПР мочевыделительной системы снизилась с $28 \%$ в 2014г. до $8,81 \%$ в 2020; ВПР ЦНС продолжают снижаться и в 2020г. составляют $1,32 \%$ (в 2019г. - 3,5\%). Наблюдается отрицательная динамика наличия ВПР ЖКТ - в 2014г. 5,4\%, а в 2020 г - 1,32\%. В структуре ВПР сердечно-сосудистой системы на фоне снижения тяжелых поражений отмечается большее выявление ДМЖП (с 44,9\% в 2014г до 70,5\% в 2020г), которые, как правило, не требуют лечения, а лишь наблюдения кардиологом.

Таким образом, анализ структурных изменений ВПР показал, что проводимая государственная политика в области здравоохранения в плане поддержки женщин и детей, способна помочь реализации резервов снижения ВПР. 


\section{СИСТЕМНЫЙ АНАЛИЗ И КОНЦЕПЦИЯ \\ РЕАЛЬНОГО ГЕНОМА КАК ОСНОВА \\ МОЛЕКУЛЯРНОЙ ДИАГНОСТИКИ \\ ГЕНЕТИЧЕСКОЙ ПАТОЛОГИИ У ДЕТЕЙ}

Юров И.Ю. ${ }^{1,2,3}$, Ворсанова С.Г. ${ }^{1,2}$, Юров Ю.Б. ${ }^{1,2}$

'ФГБНУ «Научный центр психического здоровья»,

Москва

${ }^{2} \mathrm{OCП} \mathrm{«Научно-исследовательский} \mathrm{клинический} \mathrm{институт}$ педиатрии имени академика Ю.Е.Вельтищева» ФГАОУ ВО РНИМУ им. Н.И. Пирогова Минздрава России, Москва

ЗФГБОУ ДПО «Российская медицинская академия непрерывного профессионального образования», Москва

С развитием технологий геномного сканирования и внедрением теории систем в исследовательскую и диагностическую практику геномной медицины возникает ряд проблем при определении причинноследственной связи между вариабельностью генома и заболеваниями у детей. В частности, неоправданная «мода» на поиск специфических мутаций в отдельно взятых генах приводит к тому, что геном человека воспринимается, как некая совокупность генов вне контекста молекулярной и клеточной биологии. Фактически, реальный геном, представляющий собой совокупность генов, локализированных на 46 хромосомах в каждой отдельной клетке, подменяется «виртуальным», который никак не отражает биологические процессы реализации, копирования и хранения генетической информации в клетках. Более того, подходы к анализу генома с использованием концепции «виртуального генома» приводят к тому, что человек воспринимается, как одноклеточное существо с унифицированным индивидуальным геномом. Для того, чтобы избегать подобных «сенсационных утверждений» и успешно исследовать последствия вариабельности генома при генетически обусловленных заболеваниях у детей предлагается использовать концепцию «реального генома», которая представляет собой сочетание системного анализа (системной геномики), молекулярной цитогенетики (цитогеномики) и молекулярной генетики. Необходимо принимать во внимание также и межклеточную вариабельность генома человека, включая хромосомную и геномную нестабильность. Предполагается, что представленная концепция позволит более детально и подробно описывать биологические процессы реализации, копирования и хранения генетической информации в клетках при молекулярной диагностике генетической патологии у детей.

Работа была частично поддержана грантом РФФИ и CITMA (Ciencia, Tecnología у Medio Ambiente de la República de Cuba) в рамках научного проекта № 18-515-34005, частично Госзаданием Министерства науки и высшего образования России № AAAА-A19-119040490101-6, а также частично Госзаданием Минздрава России № 121031000238-1. 


\section{Раздел 7}

\section{НЕФРОЛОГИЯ}


ОПЫТ ЛЕЧЕНИЯ ПАЦИЕНТОВ С АТИПИЧНЫМ ГЕМОЛИТИКО-УРЕМИЧЕСКИМ СИНДРОМОМ Альбот В.В., Белоусова Л.В., Мацейна С.А, Князева Н.А. гБУз Областная детская клиническая больница, Иркутск

Введение. Атипичный гемолитико-уремический синдром (а-ГУС), тяжелое, орфанное жизнеугрожающее заболевание, являющееся комплемент зависимой ТМА. В связи с отсутствием специфических клинических проявлений диагноз выставляется методом исключения.

Цель исследования - оценка эффективности применения комплементблокирующего препарата экулизумаб в лечении пациентов с а-ГУС.

Материалы и методы. Нами на базе специализированного нефрологического отделения, с 2015г. наблюдаются 6 пациентов с аГУС в возрасте от 1 до 8 лет. Всем детям проведено полное клиническое, инструментальное и лабораторное обследование, согласно стандартам диагностики и лечения, дополнительно включающее в себя определение ЛДГ, ферритина, фракций комплемента $\mathrm{C}_{3}, \mathrm{C}_{4}$ и Д-димера, уровня уровень ADAMTS 13, исследование кала на шига-токсин. В 4 случаях проведено молекулярно-генетическое исследование на наличие мутаций в генах системы комплемента методом NGS. Диагноз аГУС выставлен при исключении ТМА, обусловленных иными патогенетическими механизмами. Все пациенты получали трансфузии свежезамороженной плазмы, а после подтверждения диагноза аГУС таргетную терапию препаратом экулизумаб. Троим пациентам проводилась заместительная почечная терапия методом ПВВГДФ.

Результаты. Состояние пациентов при поступлении расценивалось как тяжелое (50\%), либо крайне тяжелое (50\%) вследствие поражения ЦНС, развития отека ГМ, комы, требовавших госпитализации в ОАР и проведения ИВЛ. В единичных случаях выявлены миокардит, острая сердечная недостаточность и панкреатит, у двоих пациентов - ТЭЛА. У всех пациентов в сроки от 11 до 23 дней развивался повторный гемолиз с тромбоцитопенией, что и явилось окончательным критерием для постановки диагноза - а-ГУС и основанием для назначения терапии экулизумабом. В результате лечения у всех больных достигнута гематологическая ремиссия, у 4 из них полное восстановление всех органов и систем, у 2 сохраняется выраженный неврологический дефицит.

Заключение. Показана высокая эффективность препарата экулизумаб, однако, отсутствие патогномоничных симптомов, несвоевременный перевод в профильное отделение, необходимость исключения TMA иного генеза, трудности в обеспечении препаратом и как следствие позднее начало таргетной терапии не позволило предотвратить развитие тяжелых осложнений.

\section{ОПЫТ ПРИМЕНЕНИЯ РИТУКСИМАБА В ТЕРАПИИ НЕФРОТИЧЕСКОГО СИНДРОМА У ДЕТЕЙ}

Альбот В.В., Мацейна С.А., Белоусова Л.В.

ГБУЗ областная детская клиническая больница, Иркутск

Введение. Лечение стероидзависимого и стероидрезистентного нефротического синдрома (СЗНС и СРНС) по-прежнему является актуальной проблемой нефрологии. Для терапии данных состояний применяются алкилирующие агенты, ингибиторы кальциневрина и микофенолата мофетил, однако их использование не всегда эффективно и может сопровождаться тяжелыми осложнениями. В последние годы предложен ритуксимаб - генно-инженерные химерные анти-CD20 моноклональные антитела.

Цель исследования - оценка эффективности и безопасности терапии препаратом ритуксимаб.

Материалы и методы. Нами на базе нефрологического отделения наблюдались 13 детей в возрасте от 8 до 17 лет, с морфологически подтвержденными вариантами $\mathrm{HC}$, ранее получавшими различные схемы иммунносупресивной терапии. Все пациенты в дебюте заболевания получали стандартную схему преднизолона, далее в связи со стероидзависимостью либо стероидрезистеностью, пульс-терапию метилпреднизолоном. После перевода на альтернирующий режим приема преднизолона и выполнения почечной биопсии с последующей морфологической верификацией диагнозов, в схему лечения добавлялся циклоспорин-А (ЦсА). Троим пациентам со СРНС назначалась пульс-терапия циклофосфаном, одному из них дополнительно микофенолата мофетил (ММФ).

Всем пациентам, в связи с неэффективностью ранее проводимого лечения, назначена терапия ритуксимабом, внутривенно в дозе 375 мг/м2, раз в неделю №2. Повторный курс ритуксимаба проводился через 6 месяцев.

Результаты. Наилучшие результаты терапии ритуксимабом получены у 7 пациентов со СЗНС (МИ) - достигнута полная ремиссия НС, отменен ЦсА. В результате применения ритуксимаба у пациентов с СРНС на фоне ФСГС у одного ребенка достигнута клиническая ремиссия и отменен ЦсА; у двоих детей - полная ремиссия НС с отменой ЦсА еще у одного полная ремиссия и отмена ЦсА и ММФ. У 2 пациентов с волчаночным нефритом на фоне проведенного курса ритуксимаба, достигнута клиническая ремиссия $\mathrm{HC}$.

Выводы. Полученные нами результаты свидетельствуют о высокой эффективности ритуксимаба в лечении стероидзависимого и стероидрезистентного вариантов НС у детей. Данный вид терапии позволяет добиться снижения частоты рецидивов и способствует отмене иммуносупрессивной терапии. 


\section{КАТАМНЕЗ ПАЦИЕНТОВ С ПЕРВИЧНЫМИ ТУБУЛОПАТИЯМИ \\ Белькевич А.Г., Козыро И.А., Сукало А.В. \\ Белорусский государственный медицинский \\ университет, Минск, Республика Беларусь}

Введение. Первичные тубулопатии (ТБ) - группа редких наследственных дисфункций канальцев, требующих своевременной диагностики и терапии с целью замедления прогрессирования поражения почек и обеспечения нормального функционирования организма.

Цель исследования - проследить катамнез пациентов с ТБ и установить характерные особенности для диагностики данной патологии.

Материалы и методы. Изучен катамнез 67 пациентов (основная группа). Соотношение по полу мальчики/девочки - 33 (49,3\%)/34 (50,7\%). Продолжительность заболевания на момент катамнеза - 9 (5-15) лет. Группу сравнения составили пациенты c BAMC $(n=100)$. Обработка данных выполнена в Statistica 10,0 .

Результаты. АР тип наследования установлен у $58(86,6 \%)$, Х-сцепленный - у $9(13,4 \%)$ пациентов с ТБ. Возраст манифестации - 1 (0-2) год, постановки диагноза - 3 (2-7) года. Основные жалобы - деформации нижних конечностей у 29 $(43,3 \%)$ пациентов и задержка физического развития (ФР) - у 28 (41,8\%). При оценке ФР у 53 $(79,1 \%)$ пациентов с ТБ отмечено отставание длины и массы тела. Очень низкое, гармоничное с задержкой роста и резко дисгармоничное ФР встречалось чаще у пациентов с ТБ, чем с ВАМС $\left(\chi^{2}=146, p<0,001\right)$. Установлены различия в уровне фосфора ( $\mathrm{U}=1783, p<0,001)$, кальция $(\mathrm{U}=2345$, $p=0,002)$, ЩФ ( $\mathrm{U}=1652, p<0,001)$, натрия $(\mathrm{U}=2736$, $p=0,045)$, относительной плотности $(\mathrm{U}=2424$, $p=0,003)$, для гематурии и разовой протеинурии нет $(p>0,05)$. $\mathrm{pH}$ крови составила $7,4(7,36-7,42)$, $\mathrm{BE}--2,6(-5--0,2)$, у $12(17,9 \%)$ пациентов диагностирован метаболический ацидоз, у 7 (10,5\%) метаболический алкалоз. Для оценки эффективности лечения проанализированы лабораторные данные и ФР до начала терапии и на момент катамнеза - ЩФ, кальций, калий, натрий, фосфатурия, относительная плотность мочи, ВЕ достигли возрастной нормы, уменьшилось количество пациентов с отставание весо-ростовых показателей с $53(79,1 \%)$ до $29(55,8 \%)$, при этом увеличилось со средним гармоничным ФР - с $9(13,4 \%)$ до 16 $(30,8 \%), \chi^{2}=2343, p<0,001$.

Выводы. Тубулопатии манифестируют в раннем возрасте, имеют клинические и лабораторные особенности, знание которых позволяет своевременно диагностировать данную патологию и назначать адекватную терапию.

\section{ОЦЕНКА ПРОДУКЦИИ НАТРИУРЕТИЧЕСКИХ ПЕПТИДОВ У ДЕТЕЙ В ЗАВИСИМОСТИ ОТ СТАДИИ ХРОНИЧЕСКОЙ БОЛЕЗНИ ПОЧЕК \\ Бижева Д.В., Мамбетова А.М. \\ ФГБОУ ВО Кабардино-Балкарский государственный университет им. Х.М. Бербекова, Нальчик}

Введение. Важнейшим положением, которое определяет способы ведения пациентов с хронической болезнью почек и сердечно-сосудистыми заболеваниями, является необходимость признания хронической болезни почек независимым фактором риска развития сердечно- сосудистых заболеваний и осложнений. Натрийуретические пептиды (NUP) имеют важное значение в поддержании нормального функционирования сердечно-сосудистой системы обеспечивая кардио и ренопротективный эффект.

Цель исследования- изучить уровень натрийуретических пептидов у детей при хронической болезни почек в зависимости от стадии развития заболевания.

Материалы и методы. Обследовано 93 ребенка с врожденными заболеваниями органов мочевой системы в возрасте от 3 до 18 лет. Выделены три группы в зависимости от стадии хронической болезни почек: группу I составили 54 пациента с 1-й стадией болезни, группу II -29 пациентов с хронической болезнью почек 2-й стадии, группу III - 10 детей с хронической болезнью почек 4-5-й стадии (пациенты с ХБП 4 и 5 стадиями объеденены в виду их малочисленности). Контрольная группа - 10 клинически здоровых детей соответствующего возраста. Иммуноферментным методом в крови определен $\mathrm{N}$-терминальный пропептид натрийуретического гормона (NT-proBNP).

Результаты. Повышение уровня NT-proBNP на $28,7 \%$ имеет место уже на ранних стадиях ХБП. При прогрессировании ХПБ отмечено нарастание уровня NT-proBNP c 57,4\% у детей в группе I больных с ХБП начальной стадией, до $80 \%$ у детей в группе III больных с терминальной стадией. Максимальные концентрации NT-proBNP, во много раз превышающие показатели при ХБП 1 и 2 ст., наблюдались у детей с ХБП 4-5 ст. Между больными с начальными стадиями ХБП и терминальной, выявлены достоверные различия в степени гиперпродукции ( $<0,0001)$. Степень повышения уровня NT-proBNP коррелирует со степенью тяжести ХБП.

Заключение. Уровень натрийуретических пептидов отражает тяжесть ХБП, повышение его уровняранний диагностический признак ХБП и кардиоренального синдрома. 


\section{ПОКАЗАТЕЛИ ЭХОКАРДИОГРАФИИ У ДЕТЕЙ В ЗАВИСИМОСТИ ОТ СТАДИИ ХБП}

Бижева Д.В., Мамбетова А.М. ФГБОУ ВО Кабардино-Балкарский государственный университет им. Х.М. Бербекова, Нальчик

Введение. Определение показателей ЭхоКГ сердца, характеризующих степень гипертрофии миокарда левого желудочка имеют важное значение в диагностике стадии ХБП и развитии кардиоренального синдрома.

Цель исследования- изучить показатели эхокардиографии у детей в зависимости от стадии ХБП.

Материалы и методы. Обследовано 93 ребенка с врожденными заболеваниями органов мочевой системы в возрасте от 3 до 18 лет. Выделены три группы по стадиям хронической болезни почек: группа I - 54 пациента с 1-й стадией, группа II -29 пациентов со 2-й стадией, группа III - 10 детей с 4-5-й стадией (пациенты с ХБП 4 и 5 стадиями объеденены в виду их малочисленности). Контрольная группа - 10 клинически здоровых детей соответствующего возраста. При проведении ЭхоКГ анализировались показатели: фракция выброса, масса миокарда левого желудочка, индекс массы миокарда левого желудочка, индекс массы миокарда левого желудочка, индексированный по росту, возведенному в степень 2,7 в зависимости от стадии ХБП. ГМЛЖ диагностирована при ИММЛЖ равном или превышающем 95-й перцентиль кривой распределения индекса для соответствующего возраста и пола.

Результаты. Показатели ЭхоКГ сердца, характеризующие степень гипертрофии миокарда - толщина межжелудочковой перегородки, толщина задней стенки левого желудочка, масса миокарда левого желудочка и индекс массы миокарда левого желудочка, - имели общую тенденцию при сравнении групп в зависимости от стадии ХБП. Их значения в группах II и III при ХБП 2 стадии и ХБП 4-5-й стадии были достоверно выше $(p<0,05)$. Достоверные различия по фракции выброса выявлены только у пациентов с ХБП 4-5 ст. в группе III (p <0,05 ). Положительная корреляция средней силы отмечена во все группах между массой миокарда левого желудочка и систолическим/диастолическим артериальным давлением $(r=0,6, p<0,05)$.

Заключение. Эхокардиографические показатели имеют общую тенденцию при сравнении групп и отражают стадию ХБП.

\section{МОЧЕВОЙ СИНДРОМ И УРОВЕНЬ NGAL ПЛАЗМЫ КРОВИ ПРИ ОСЛОЖНЕННЫХ ОСТРЫХ КИШЕЧНЫХ ИНФЕКЦИЯХ У ДЕТЕЙ}

Киричек Е.Ю., Выходиева Г.И., Морозова О.П., Зиновьева Л.И., Скударнов Е.В.

Алтайский государственный медицинский университет, Барнаул

Введение. Оценка функции почек позволит выработать дифференцированный подход к лечению детей с осложненными формами острых кишечных инфекций (ОКИ). Традиционными клиническими параметрами в диагностике острого повреждения почек (ОПП) является определение повышенных уровней креатинина, падение скорости клубочковой фильтрации (СКФ) и снижение выхода мочи, не всегда позволяющие выявлять ОПП на ранних стадиях у детей с тяжелыми формами ОКИ. Одним из ранних и наиболее изученных биомаркеров ОПП является NGAL.

Цель исследования: определить изменения мочевого осадка, CКФ и уровень NGAL плазмы крови у детей с осложненными формами ОКИ для оптимизации подходов к диагностике и терапии.

Материалы и методы исследования. У 51 ребенка с диагнозом ОКИ, осложненные токсикозом с эксикозом II степени, проведены исследование мочевого осадка, биохимического анализ крови, рассчитана CКФ по формуле SchwartzG.J. и определен уровень NGAL плазмы крови методом ИФА.

Результаты исследования. Мочевой синдром у обследованных детей был представлен протеинурией (43\%), микрогематурией (6\%), патологической лейкоцитурией (20\%) и кристаллурией (27\%). При этом достоверно чаще регистрировалась протеинурия $(\varphi 1-2=0,01818, \mathrm{p}=0,00001 ; \varphi 1-3=0,00001)$. Повышенный уровень креатинина плазмы крови был зарегистрирован у трети (31\%) обследованных детей с осложненными ОКИ, при этом в группе детей до 1 года повышение уровня креатинина регистрировалось достоверно чаще (p1-2=0,0022; p1-3=0,0255). Снижение СКФ зарегистрировано у 36 (71\%) обследованных детей. Определен уровень NGAL плазмы крови у обследованных детей. Сравнительный анализ среднего уровня NGAL показал, что в группе детей с осложненными ОКИ уровень показателя оказался достоверно выше чем, у здоровых детей группы контроля ( $\mathrm{p}=0,035638)$.

Заключение. Результаты проведенного исследования позволили установить наличие поражения почек у 2/3 обследованных детей в виде патологических изменений мочевого осадка с высокой частотой протеинурии, повышенного уровня креатинина плазмы крови и снижения СКФ. Показано значение уровня NGAL плазмы крови во всех возрастных группах. 


\section{КЛИНИКО-МОРФОЛОГИЧЕСКАЯ \\ ХАРАКТЕРИСТИКА ХРОНИЧЕСКИХ ГЛОМЕРУЛОПАТИЙ У ДЕТЕЙ ЗА 10 ЛЕТНИЙ ПЕРИОД ПО ДАННЫМ ОДНОГО ЦЕНТРА \\ Козыро И.А., Сукало А.В. \\ Белорусский государственный медицинский университет», Минск, Беларусь}

Введение. Гломерулопатии (ГП) - многочисленная и разнообразная как в клиническом, так и в морфологическом проявлении группа заболеваний. Поиск факторов, ассоциированных с прогнозом, необходим для замедления темпов прогрессирования ГП.

Цель исследования: уточнить клинико-морфологические особенности течения первичных и вторичных хронических ГП у детей для выявления факторов риска прогрессирования.

Материалы и методы. Проанализированы данные 408 пациентов с первичными (245 мальчиков, 163 девочки) и 117 с вторичными (35 мальчиков, 82 девочки) ГП, полученные методом сплошного целевого отбора. Пациенты находились под наблюдением с 2010 по 2019гг в Белорусском центре детской нефрологии. Статобработка выполнена в Statistica 10,0.

Результаты. Кумулятивная распространенность хронических ГП за 10-летний период составила 167,1 на 100тыс детского населения. В структуре преобладают первичные: ФСГС $(n=107)$, нефропатия минимальных изменений $(n=84), \operatorname{IgA}$ нефропатия $(n=72)$, наследственный нефрит (синдром Альпорта) $(n=61)$, мезангиопролиферативный ГН $(n=44)$, IgM нефропатия $(n=26)$, реже мембранопролиферативный ГН $(n=6)$, врожденный НС $(n=7)$, мембранозная нефропатия $(n=1)$. Среди вторичных почки чаще поражаются в рамках СКВ $(n=45), \operatorname{IgA}$ васкулита $(n=34)$, реже системного васкулита $(n=20)$, перенесенного ГУС ( $n=12)$, амилоидоза $(n=3)$, неуточненной иммунной ГП $(n=2)$ и диабетической нефропатии $(n=1)$. Мальчики чаще болеют первичными, девочки вторичными. Первичные дебютируют раньше ( $\mathrm{U}=150,0$, $\mathrm{p}<0,001)$, чаще с гематурии с протеинурией у 38,2\% с первичными, 53,8\% с вторичными. Нарушение почечных функций в дебюте у 41/408 (10\%) с первичными, 50/117 (43\%) с вторичными. Прогрессирующее течение к моменту завершения наблюдения (достижение 18 лет или летального исхода) у 43 детей (11\%) с первичными, у 31 (27\%) с вторичными ГП.

Заключение. Вторичные ГП прогрессируют быстрее, почечная выживаемость (Log-rank) значимо ниже при вторичных (CKB, ЛН) в сравнении с первичными $(p=0,003)$. Среди факторов, ассоциированных с прогрессированием: персистирующая протеинурия нефротического уровня, ночная АГ, ремоделирование миокарда, поражение сосудов, васкулит, серозит, поражение ЖКТ, нейролюпус.

\section{ВИТАМИН D-ЗАВИСИМЫЙ РАХИТ ВСЛЕДСТВИЕ МУТАЦИИ ГЕНА СУР27В1 У ДВУХ СИБСОВ}

Леви Н.Л., Левиашвили Ж. Г.

Санкт-Петербургский государственный педиатрический медицинский университет» Министерства

здравоохранения Российской Федерации, СанктПетербург

Актуальность. Наследственный аутосомно-рецессивный витамин D-зависимый рахит обусловлен мутациями в генах CYP27B1 (тип 1A), CYP2R1 (тип 1B), VDR (тип 2A), VDDR2B (тип 2B).

Цель исследования. Изучить катамнез 2х сибсов с витамин D-зависимым рахитом (тип 1A).

Пациенты и методы. Изучен 11- летний катамнез у сибсов с витамин D - зависимым рахитом (тип 1A). Пробанд (мальчик), 14л7мес (28,01,06 г.р). В возрасте 1 года начал отставать в росте и весе. В 1 год 3 мес. на рентгенограмме нижних конечностей выявлено отсутствие точек окостенения, трактовка диагноза: гипофосфатемический рахит. Проводилась терапия препаратами витамина D в дозе 20 тыс. ЕД/сутки в течение 3-4 мес, наблюдалось улучшение, ребенок начал ходить. C 4x лет терапия витамином D не проводилась, прогрессировала деформация нижних конечностей X-образная - вальгусная, проведена корригирующая остеотомия нижних конечностей, без положительной динамики. Сибс пробанда, 12л (15,04,2008г.р.) С 1 года отмечалось прогрессирование X-образной (вальгусной) деформации нижних конечностей. В 3г9мес. начата терапия препаратами витамина D в дозе 7-10 тыс. ЕД/сут. В крови увеличение щелочной фосфатазы до 1721,0 ммоль/л, гипофосфатемия 0,80 ммоль/л, гиперпаратиреоз до 61,37 пг/мл.

У сибсов заболевание клинически проявлялось задержкой роста, рахитоподобными изменениями скелета, деформацией нижних конечностей, гипотонией мышц, задержкой прорезывания зубов (гипоплазия зубной эмали), параклинически: гипофосфатемией, гипокальциемией, высокой активностью щелочной фосфатазы, снижением 1,25 (OH)2D3, нормальным 25(OH) ${ }_{2} \mathrm{D}_{3}$. Показатели канальцевой реабсорбции фосфатов в пределах нормы: КРФ $(88,33 \pm 3,09)$, МКРФ $(1,33 \pm 0,22)$, ФЭФ $(11 \pm 2,99)$, МКРФ/СКФ $(1,44 \pm 0,36)$, что свидетельствует об отсутствии нарушения транспорта фосфатов в проксимальных канальцах почек, СКФ по формуле Шварца 125,1土10,24 мл/мин, функция почек сохранна.

На основании клинико-генетического исследования установлен Витамин-D-зависимый рахит (тип 1A) вследствие мутации гена CYP27B1. Терапия кальцитриолом и кальцидиолом, препаратами кальция, фосфатного буфера (Reducto special) дала эффект.

Выводы. В результате длительной терапии активными метаболитами витамина D (кальцитриолом/ кальцидиолом), препаратами кальция и фосфатного 
буфера отмечены положительная динамика роста, нормализация фосфорно-кальциевого обмена, статико-динамические нарушения не прогрессируют.

\section{КЛИНИЧЕСКИЙ СЛУЧАЙ ЭФФЕКТИВНОГО ПЕРИТОНЕАЛЬНОГО ДИАЛИЗА У НОВОРОЖДЕННОГО С ТЯЖЕЛОЙ ПОЧЕЧНОЙ ПАТОЛОГИЕЙ}

Морозов В.В., Молев Д.А., Валитова Л.А.

ГБУЗ Астраханской области «Областная детская

клиническая больница им. Н.Н. Силищевой», Россия, Астрахань

Введение. У новорожденных с критическими состояниями частота встречаемости острых повреждений почек (ОПП) составляет 8-24\%, при этом летальность достигает 61\%. В связи с этим, при наличии показаний, детям с ОПП проводится заместительная почечная терапия, предпочтительным методом которой является перитонеальный диализ.

Цель исследования: описать клинический случай перитонеального диализа у ребенка с тяжелой сочетанной патологией почек.

Ребенок родился доношенным с массой тела 2450,0 гр, длиной 47 см. Оценка по шкале Апгар - 5/6 баллов. Поступил в тяжелом состоянии, обусловленном пороками развития: атрезией пищевода с нижним трахеопищеводным свищом (ТПС), частичной агенезией мозолистого тела, кистозной дисплазией левой почки, гипоплазией обеих почек. По поводу атрезии пищевода с ТПС ребенок был прооперирован в 1-е сутки жизни. С рождения находился на искусственной вентиляции легких, диагностирована пневмония. В первую неделю у ребенка был выявлен кариотип синдрома Эдвардса. На 35 сутки жизни наросли явления полиорганной недостаточности и на 38 сутки жизни выставлен диагноз сепсиса. В этот период, на фоне олигоанурии (диурез менее 0,3 мл/кг/час) вследствие ОПП, стали нарастать уровни креатинина (до 312 мкмоль/л) и калия (до 7,1 ммоль/л) сыворотки крови. Ситуация усугублялась наличием у ребенка порока развития почек. Учитывая эти обстоятельства, было принято решение о проведении перитонеального диализа. Был установлен перитонеальный катетер Tenckhoff, для проведения диализа использовался диализный раствор "Balance 1,5\% Glucose 1,25 mmol/1 Calcium”. Разовый объем диализирующего раствора составлял $10-20$ мл/кг. Время экспозиции - 45 минут. Опорожнение брюшной полости - пассивное, за 15 минут. Общая продолжительность диализа - 41 час. Процедура перитонеального диализа оказалась эффективной и привела к устойчивому снижению уровней креатинина (80 мкмоль/л), калия (3,5 ммоль/л) крови и нормализации диуреза.

Заключение. Перитонеальный диализ остается эффективным методом детоксикации у новорожденных детей с тяжелой патологией почек.

\section{МИКРОБИОЛОГИЧЕСКИЕ ОСОБЕННОСТИ ИНФЕКЦИИИ МОЧЕВЫВОДЯЩИХ ПУТЕЙ У ДЕТЕЙ ПЕРВОГО ГОДА ЖИЗНИ \\ Петров Ю.М., Нахапетян Р.Л. \\ ФГБОУ ВО ИГМУ Минздрава России, Иркутск}

Введение. Инфекции мочевыводящих путей (ИМВП) у детей раннего возраста лидируют среди тяжелых бактериальных заболеваний. При развитии ИМВП на первом году жизни риск развития рецидивов повышается до 50\%, а риск формирования хронической болезни почек многократно увеличивается.

Цель исследования - сравнение микробного спектра и особенностей антибактериальной терапии у детей первого года жизни с ИМВП на фоне врожденной аномалии развития органов мочевой системы (ВАРОМС) и с изолированной бактериурией.

Материалы и методы. Участниками исследования явились дети в возрасте до года, госпитализированные в ОГАУЗ «ГИМДКБ» г. Иркутска за период 20192020г. Проведен ретроспективный анализ 277 карт. Дети разделены на 2 группы: I - 98 (35,4\%) ИМВП с изолированной бактериурией, II - 179 (64,6\%) ИМВП на фоне ВАРОМС.

Результаты. В I группе преобладали девочки $57,1 \%$, во II - значительно преобладали мальчики $(68,2 \%)$. Средний возраст по группам (в месяцах): I $5,3 \pm 3,1$ и II $-3,6 \pm 2,5(p>0,05)$. Акушерский анамнез отягощен в $59,1 \%$ I группы и в $82,6 \%$ - II $(p<0,05)$. В I группе большинство пациентов $(89,9 \%)$ госпитализировано в экстренном порядке, а во II - ИМВП чаще диагностировались при плановом обследовании и при отсутствии жалоб. Лейкоцитурия в I - 92,9\%, во II $-73,7 \%(p<0,05)$. Значительный лейкоцитоз $\left(>12110^{9}\right)$ : I $-47,9 \%$, II - 34,6\% $(p<0,05)$. При изолированных ИМВП моноинфекция Е. Coli встречалась чаще: $55,1 \%$ против $22,9 \%(p<0,05)$. А частота микстинфекций в разы выше в группе с ВПРОМС: 24,6\% против 5,1\% $(p<0,01)$. При лечении предпочтение в обеих группах отдавалось антибиотикам широкого спектра (цефалоспоринам III поколения), однако, как монотерапия они применялись: в I - 85,7\%, во II $63,1 \%(p<0,05)$. Комбинированная терапия или смена нескольких антибиотиков потребовалась в I - 11,1\%, во II $-24,6 \%(p<0,05)$. Уросептики off-label/c согласия родителей во II группе назначались в $11,7 \%$.

Заключение. Высев микстной инфекции из мочи затрудняет определение причинного фактора клинических проявлений. Чаще оправдан эмпирический выбор цефалоспоринов III поколения. Полирезистентность возбудителей ИМВП на фоне ВАРОМС требует назначения комбинированной антибактериальной и длительной «ступенчатой» терапии. 
КЛИНИЧЕСКИЙ СЛУЧАЙ СТЕРОИДРЕЗИСТЕНТНОГО НЕФРОТИЧЕСКОГО СИНДРОМА АСОЦИИРОВАННОГО С МУТАЦИЕЙ $C R B 2$

Пирузиева О.Р., Обухова В.А., Морозов С.Л. ОСП НИКИ педиатрии им. академика Ю.Е. Вельтищева ФГАОУ ВО РНИМУ им. Н.И. Пирогова Минздрава России, Москва

Введение. Моногенные мутации в гене $C R B 2$ приводят к врожденной церебральной вентриколомегалии и развитию инфантильного нефротического синдрома (НC). Одной из функции гена $C R B 2$ является регуляция экспрессии белков, входящих в состав цито скелета щелевидной мембраны подоцита. Нарушение структуры гломерулярной базальной мембраны приводит к развитию фокального сегментарного гломерулосклероза и как следствие развитию нефротического синдрома.

Цель. Представить клинический случай стероидрезистентного нефротического синдрома, ассоциированного с мутацией $C R B 2$.

Клиническое наблюдение. Девочка А.М., 6 лет, поступила в отделение нефрологии НИКИ педиатрии им. ак. Ю.Е. Вельтищева для обследования и лечения, в связи с течением стероид-резистентного нефротического синдрома. Наследственность по патологии органов мочевой системы не отягощена. Внутриутробно диагностирована гидроцефалия. Учитывая прогрессирующую гидроцефалию с рождения установлен вентрикуло-перитонеальный шунт справа. Дебют нефротического синдрома после перенесенной вирусной инфекции в 3 года в виде полного нефротического синдрома, по поводу чего ребенок получал глюкокортикостероидную терапию (преднизолон) с пульсами метилпреднизолона - без эффекта, и иммуносупрессивную терапию Циклоспорином А на котором отмечался незначительный эффект в виде снижения уровня протеинурии. По результатам нефробиопсии имеет место фокальный сегментарный гломерулосклероз. Учитывая сочетание НС с вентрикуломегалией проведено молекулярно-генетическое обследование по результатам которого выявлена гомозиготная мутация гена CRB2 приводящая к замене аминокислоты в 605 позиции белка (chr 9:126133145; rs 778681490 , с.1813C>T) Данная мутация валидирована методом прямого секвенирования у ребенка, a также у обоих родителей в гетерозиготном состоянии.

Заключение. Таким образом у ребенка с ранним дебютом нефротического синдрома в сочетании с вентрикуломегалией выявлена мутация гена $C R B 2$, приводящая к развитию ФСГС девятого типа. Ранее развитие нефротического синдрома, стероидная резистентность, сочетание НС с патологией других органов и систем являются показанием для про- ведения молекулярно-гененического исследования и верификации моногенных форм патологии, что важно для определения прогноза заболевания и определения дальнейшей терапевтической тактики ведения пациента.

\section{ВРОЖДЕННЫЕ АНОМАЛИИ ОРГАНОВ МОЧЕВОЙ СИСТЕМЫ У ДЕТЕЙ С ГЕМАТУРИЕЙ}

Подпружникова Д.А., Хридина А.И., Хридин. М.В., Зенченко О.A.

ФГБУ ВО АГМУ Минздрава России, Барнаул

Введение. В последние десятилетия отмечается тенденция к увеличению частоты врожденных аномалий развития органов мочевой системы. Пороки развития ОМС (органы мочевой системы) являются одной из актуальных проблем нефрологии и педиатрии, поскольку могут приводить к развитию хронической болезни почек и нарушению их функционального состояния уже в раннем возрасте. Поиск маркеров хронической болезни почек является актуальным.

Цель исследования - провести анализ частоты встречаемости, возрастного и полового состава, структуры аномалий развития органов мочевой системы у детей с гематуриями.

Материалы и методы. В исследование было включено 301 пациент с синдромом гематурии, находящихся на стационарном лечении в нефрологическом отделении Алтайского Краевого Клинического Центра Охраны Материнства и Детства г. Барнаула

В возрасте 0-5 лет-60 (19,9\%);5-10лет-88 (29,2\%); 10-14лет- 93 (30,8\%);15-17лет- 60 (19,9\%) пациентов.

Результаты. В соответствии с номенклатурой врожденных и наследственных заболеваний почек и мочевых путей были получены следующие результаты. Из 301 пациента с синдромом гематурии у $288(95,6)$ выявлены различные аномалии развития органов мочевой системы. Аномалии развития почек: количественные - агенезия (одностороняя)-3(1,04\%), удвоение почек-2 (0,69\%). Позиционные: дистопии почек- 14 (4,8\%), нефроптоз-13 (28,2\%), избыточная подвижность почек$33(11,4 \%)$. Аномалии формы - подковообразная почка -2 (0,69\%). Аномалии чашечно - лоханочной системы: 90(31,25\%). Аномалии почечных сосудов: $38(13,1 \%)$. Аномалии формирования почечной ткани с деформацией паренхимы: гипоплазия- 1(0,34\%). В структуре аномалий развития ОМС у детей с синдромом гематурии наиболее частой встречались аномалии чашечно - лоханочной системы - в 90(31,25 $\%)$ и позиционные аномалии - 60(20,83\%), а также аномалии сосудов почек-38(13,1\%).Наиболее часто пороки развития ОМС встречались у девочек. Самой распространенной возрастной группой, в которой встречались аномалии является: (10-14 лет). Одина- 
ково распространены были аномалии в остальных возрастных группах: (0-5;5-10;15-17)

Заключение. Аномалии развития ОМС с синдромом гематурии являются риском развития прогрессирования заболевания и исхода в ХПН.

\section{НЕФРОЛОГИЧЕСКАЯ СИМПТОМАТИКА В «НЕПРОФИЛЬНОЙ» ПЕДИАТРИЧЕСКОЙ КЛИНИКЕ: А ТАК ЛИ ВСЕ ПРОСТО, ЕСЛИ РАСШИРИТЬ ПОИСК? \\ Просова Е.Е., Сидорович О.В., Спиваковский Ю.М., Кузнецова Н.А., Елизарова С.Ю., Хижняк А.В., Горемыкин В.И. \\ ФГБОУ ВО Саратовский ГМУ им. Разумовского В.И. Минздрава России}

Введение. Заболевания почек и мочевыделительных путей составляет высокий удельный вес в общей структуре заболеваемости. В этой связи сохраняется актуальность поиска ранних клинических маркеров заболеваний мочевыводящих путей в детском возрасте.

Цель исследования. Поиск дополнительных клинических симптомов «тревоги», позволяющих обоснованно расширить диагностический поиск с целью исключения заболеваний МВС у пациентов, наблюдающихся с различной соматической патологией.

Материалы исследования: Дополнительному анкетированию по специально созданному опроснику подвергнуты 63 пациента соматических отделений Клиники факультетской педиатрии УКБ №1 им. С.Р.Миротворцева СГМУ. В анкету были включены вопросы, касающиеся нарушений акта мочеиспускания (кратность, болезненность, дополнительные субъективные ощущения и т.п.), особенности гигиены органов мочевыделительной системы, особенности диеты с точки зрения соблюдения или нарушения нефропротективной диетотерапии и т.д. В анкетирование включались дети преимущественно школьного возраста, которые на условиях анонимности могли самостоятельно ответить на поставленные вопросы.

Результаты исследования и их обсуждение: при анализе заполненных анкет было зарегистрировано, что в отделениях эндокринологического и гастроэнтерологического профиля по ответам пациентов жалобы на нарушения мочеиспускания разной степени выраженности отмечены у 55\% и 77,3\% соответственно. У пациентов нефрологического отделения жалобы подобного плана присутствовали в $80 \%$ случаев. При этом, далеко не всегда в непрофильных отделениях данные жалобы были своевременно выявлены и отражены в медицинской документации. Нами были выявлены определенные корреляционные связи с высокой частотой диетологических нарушений и семейно-наследственной предраспо- ложенностью у групп детей с выявленными жалобами нефрологической природы. При детализации санитарно-гигиенических аспектов анамнеза, было установлено, что в сопоставимых долях пациенты различных отделений с жалобами нефрологического профиля, вне зависимости от ведущей патологии, неадекватно информированы об основах гигиены наружных половых органов, а также об основах профилактики нефрологических заболеваний.

Вывод. Частота выявления жалоб, характерных для пациентов с возможными нарушениями системы мочевыделения, значимо выше ее первичной выявляемости. Это связано, как с высокой частотой комбинированных психовегетативных расстройств, так и с недостаточной первичной нацеленностью непрофильных специалистов на поиск подобной патологии.

\section{ОСОБЕННОСТИ ТЕЧЕНИЯ ОСТРОГО ПОСТИНФЕКЦИОННОГО ГЛОМЕРУЛОНЕФРИТА У ДЕТЕЙ РЕСПУБЛИКИ МОРДОВИЯ}

Раздолькина Т.И., Козлова О.Ю., Московская Е.Ф., Дзюбич Л.И., Акашкина Е.Ю. ФГБОУ ВО «МГУ им. Н.П. Огарева», ГБУЗ РМ «Детская республиканская клиническая больница», Саранск

Введение. Острый постинфекционный гломерулонефрит (ОГН) до настоящего времени остается актуальной проблемой детской нефрологии. Отличительной особенностью течения современного ОГН является преобладание малосимптомных вариантов, которые встречаются в десятки раз чаще, чем манифестные.

Цель исследования: провести анализ характера течения острого постинфекционного гломерулонефрита у детей Республики Мордовия.

Материалы и методы. Проведен ретроспективный анализ 40 историй болезней детей, находившихся на стационарном лечении в нефрологическом отделении Детской республиканской клинической больницы г. Саранска с 2009 г. по 2019 г. по поводу острого постинфекционного гломерулонефрита. Возраст детей составил от 1 года 3 месяцев до 17 лет, мальчиков было 27, девочек - 13.

Результаты. Установлено, что в дебюте ОГН за анализируемый период значительно реже диагностировался нефритический синдром (25\%) по сравнению с изолированным мочевым синдромом (75\%; $p<0,001)$, чаще болели мальчики (67\%) в возрасте $12-$ 17 лет (50\%) в зимне-весенний период (65\%). Ведущим симптомом в дебюте была боль в поясничной области (57\%), несколько реже отмечались: макрогематурия $(46,7 \%)$, повышение температуры тела $(46,7 \%)$, отеки $(26,7 \%)$, повышение артериального давления (16,7\%). Из предшествующих факторов в большинстве случаев указывалось на ОРВИ (55\%), 
значительно реже $(12,5 \%$; $p<0,05)-$ стрептококковую инфекцию, 1 ребенок $(2,5 \%)$ до дебюта заболевания перенес ветряную оспу и более чем у четверти (30\%) пациентов манифестация ОГН произошла без явных предшествующих факторов. Повышение АСЛ-О отмечено в $38,7 \%$ случаев, снижение скорости клубочковой фильтрации до 66,26 \pm 14,24 мл/мин/ $1,73 \mathrm{M}^{2}$, рассчитанной по формуле Шварца - в 17,5\% случаев. Уменьшение относительной плотности мочи в пробе Зимницкого менее 1020 при диурезе не более 1 л у детей старше 3 лет и меньше возрастных показателей у пациентов до 3 лет отмечалось в $30 \%$ случаев. По результатам УЗИ в 47,5\% случаев было диагностировано увеличение объема, $67,5 \%$ - уплотнение паренхимы почек.

Заключение. В большинстве случаев острый постинфекционный гломерулонефрит был диагностирован у мальчиков $12-17$ летнего возраста после острых респираторных вирусных инфекций в зимневесенний период, реже имел манифестный дебют в виде нефритического синдрома, проявляясь атипичным субклиническим течением в виде изолированного мочевого синдрома.

\section{ФЕНОТИП ГИПОПЛАСТИЧЕСКОЙ ГЛОМЕРУЛОКИСТОЗНОЙ БОЛЕЗНИ ПОЧЕК (ОRРНА93111) ВСЛЕДСТВИЕ МУТАЦИЙ ГЕНОВ HNF1B, PKHD1, PKD2}

Савенкова Н.Д., Хапугина Е.С., Зеленин Н.М., Андреева Э.Ф.

ФГБОУ ВО СПбГПМУ Минздрава России, СанктПетербург

Актуальность: HNF1ß контролирует транскрипцию генов, ответственных за формирование почечных кист (PKHD1, PKD2, UMOD, NPHP1).

Цель: описать фенотип орфанной гипопластической гломерулокистозной болезни почек вследствие мутаций генов HNF1及, PKHD1 и PKD2 у ребенка 5 месяцев.

Методы: проведены оценка фенотипа гипопластической гломерулокистозной болезни почек, УЗИ и функции почек, молекулярно-генетическое исследование (в лаборатории, имеющей лицензию на проведение ДНК тестов и медицинское оборудование, зарегистрированное в РФ).

Результаты: Девочка В. от здоровых родителей, 1 беременности, протекавшей на фоне маловодия, родилась на 34 неделе гестации с массой тела 2040 г, длиной 47 см, оценка по Апгар 7/7 баллов. Кисты в почках плода выявлены по УЗИ на 33 неделе гестации. В 1 сутки состояние тяжелое (респираторный дистресс-синдром, ДН 2ст, акроцианоз, мышечная гипотония, гипорефлексия, пастозность мягких тканей), на 2 сутки геморрагическое отделяемое по желудочному зонду, нарастание креатинина и мочевины в крови. На 7 сутки у новорожденной диагностировано острое повреждение почек 3 стадии, начат перитонеальный диализ (ПД). Ребенку с тяжелой анемией на 16 сутки и в 1мес 17 дней проведены трансфузии эритроцитарной массы, в 3 месяца диагностирован бактериальный перитонит. По УЗИ выявлено уменьшение общего объема почек в 3 мес $(8,5 \mathrm{~cm} 3)$ и в 4,5 мес $(11,7 \mathrm{~cm} 3)$, множественные кисты (5-8мм) коркового слоя паренхимы. Методом полноэкзомного секвенирования ДНК выявлены: патогенная мутация $H N F 1 \beta$ гена (17:g.37739611T>A ENST00000617811,5:c.373A >T ENSP00000480291,1:p. Ile125Phe) и ранее не описанные варианты в гетерозиготном состоянии с аминокислотными заменами в генах PKD2 (p.Glu48Asp) и PKHD1 (p.Arg73Trp), предсказанные непатогенными. У пациентки 5 месяцев, получающей ПД, констатированы нормальное артериальное давление, СКФ по формуле Schwartz 13 мл/мин, глюкозурия, протеинурия. Девочке планируется трансплантация почки.

Заключение: представлены особенности фенотипа гипопопластической гломерулокистозной болезни почек с очень ранним началом вследствие мутации гена $H N F 1 \beta$ и предсказанных непатогенными генетическими вариантами в $P K H D 1$ и $P K D 2$ генах.

\section{COVID-19 У ПАЦИЕНТА С СИНДРОМОМ GOODPASTURE C АНTИТЕЛАМИ К ГБМ, БЫСТРО ПРОГРЕССИРУЮЩИМ ГЛОМЕРУЛОНЕФРИТОМ}

\section{И ГЕМОРРАГИЧЕСКИМ АЛЬВЕОЛИТОМ, ХБП С5, ПОЛУЧАЮЩЕГО ПРОГРАММНЫЙ ГЕМОДИАЛИЗ}

Савенкова Н.Д., Любимова О.В., Папаян К.А.,

Поздняков А.В., Ревнова М.О., Карпова Т.В., Барсукова В.Н., Баннова С.Л., Дмитриева Е.М., Пименова А.Р.

Санкт-Петербургский государственный педиатрический медицинский университет, Россия

Актуальность: Болезнь Goodpasture's определяют как аутоиммунный васкулит мелкого калибра вследствие образования антител (АТ) класса IgG к домену- 1 3-цепи (а3NC1) коллагена IV типа к альвеолярной и гломерулярной базальным мембранам.

Пациент и методы: клинико-лабораторный, иммунологический, фибробронхоскопия, КТ. Результаты: У подростка, 2003 г.р., клиническая манифестация геморрагического альвеолита с кровохарканьем, при фибробронхоскопии выявлено кровотечение из базальных отделов легких. Через 4 месяца при поступлении в клинику установлен синдром Гудпасчера с АТ к ГБМ (182,9 ед/мл) и быстро прогрессирующим гломерулонефритом с нефротическим синдромом, гематурией, артериальной гипертензией, геморрагическим альвеолитом с кровохарканьем, острым повреждением почек, требующим терапии 
гемодиализом. На КТ в обоих легких обнаружены уплотнения, затемнения в виде «матового стекла», диффузная консолидация. Повышение D-димера 3366 нг/мл, нормальный уровень фибриногена, тромбоцитов, НМО и С3 компонента комплемента. и Лечение: гемодиализ ежедневно, далее через день, пульс-терапия метипредом 1000 мг в/в капельно в течение 1 часа №3, преднизолонотерапия 60 мг; пульс-терапия в/в циклофосфаном 500 мг №2; в/в инфузии иммуноглобулинов 0,4 г/кг №5; по протоколу плазмаферез в синхронизации с пульс-терапией солумедролом; в/в антитела к CD20- Ритуксимаб. Констатировано угнетение пула В-лимфоцитов, B-lymphocytes CD 19+ (0\%). В результате терапии достигнута экстраренальная ремиссия (AТ к ГБМ 0,49 ед/мл), с исходом в ХБП C5 (D). Подросток перенес новую коронавирусную инфекцию COVID19, острую двустороннюю полисегментарную пневмонию (S9 с обеих сторон, S10 слева) с ДН2. АТ к ГБМ 0,029 ед/мл, D-димер 2029 нг/мл, МНО 5,6. Терапия гемодиализом и кетостерилом, преднизолоном, феронами, противотромботическая, антигипертензивная, антибактериальная и антимикотическая; $20 \%$ альбумином в/в еженедельно, иммуноглобулинами (2 курса) привела к выздоровлению от SARSCOV-2.

Заключение: У пациента не установлено рецидива синдрома Goodpasture при заболевании COVID-19. Пациент с ХБП С5 (D) переведен во взрослую нефрологическую службу.

\section{ФАРМАКОПРОФИЛАКТИКА РЕЦИДИВИРОВАНИЯ ИНФЕКЦИЙ МОЧЕВЫВОДЯЩИХ ПУТЕЙ У ДЕТЕЙ В МНОГОПРОФИЛЬНОМ СТАЦИОНАРЕ \\ Саломатина О.С., Шапошникова Н.Ф. \\ ФГБОУ ВО «Волгоградский государственный медицинский университет» Минздрава России, Волгоград}

Введение. В отечественной практике профилактическая терапия рецидивирующих инфекций мочевыводящих путей у детей заключается в длительном назначении фуразидина или ко-тримоксазола детям при наличии пузырно-мочеточникового рефлюкса 2-5 степени, рецидивах ИМВП (более 2 рецидивов за последние 6 месяцев) и тяжелых аномалиях развития мочевыводящих путей до хирургической терапии. Несмотря на клинические рекомендации, назначения разнятся и выбор тактики остается спорным вопросом.

Цель исследования - изучить тактику фармакопрофилактики ИМВП у детей в многопрофильном стационаре.

Материалы и методы. Учитывая анатомические особенности, возникновение рецидивов ИМВП пре- валирует у девочек. Был проведен ретроспективный анализ 359 историй болезней девочек от 3 до 7 лет с диагнозом ИМВП, находящихся на стационарном лечении в нефрологическом отделении в ГБУЗ ДКБ №8 за 2019 г. Для сбора информации была разработана форма, состоящая из 60 пунктов, включающих информацию об анамнезе жизни и болезни, особенностях течения заболевания и проведенной диагностике и терапии.

Результаты. В ходе исследования было установлено, что 9,91\% детей получили рекомендации по применению полной терапевтической дозы ко-тримоксазола, а 5,41\% применение профилактической дозы; 18,02\% пациентов получили рекомендации применения полной дозировки фуразидина, $10,81 \%$ - профилактической. Сочетание терапевтической и профилактической дозировок фуразидина имело место в 9,01\% случаев, тогда таких сочетаний у ко-тримоксазола в назначениях обнаружено не было, хотя есть случаи назначения терапевтической полной дозы ко-тримоксазола и профилактической фуразидина, а также сочетание назначений профилактических дозировок обоих препаратов. По 2,7\% назначений имели рекомендации по применению только канефрона или нитроксолина соответственно. Особое внимание обращает на себя отсутствие рекомендаций по профилактической терапии уросептиками у $36,94 \%$, хотя у $7 \%$ из них отмечено наличие ПМР 2 степени, у 37\% частота обострений 1-2 в год, что является показанием для назначения этих препаратов.

Заключение. Наличие данных о случаях отсутствия назначения согласно клиническим рекомендациям может служить основанием для более детального изучения тактики профилактики рецидивов ИМВП, изучение критериев выбора и дозировки препаратов.

\section{ИННОВАЦИОННЫЙ МЕТОД В ЛЕЧЕНИИ НЕРВНО-МЫШЕЧНОЙ ДИСФУНКЦИИ МОЧЕВОГО ПУЗЫРЯ}

Текутьева Н.А., Лобанов Ю.Ф., Латышев Д.Ю., Куликов В.П.

ФГБОУ ВО Алтайский государственный медицинский университет, Барнаул

Введение. Нейрогенные расстройства мочеиспускания занимают ведущие позиции в детской нефрологии и их распространенность может достигать $15 \%$ среди детского населения. Гипокси - гиперкапнические тренировки могут оказывать потенциальное влияние на такое звено патогенеза данных заболеваний, как нарушение регионального и центрального кровотока.

Цель исследования - оценить динамику регионального кровотока на фоне гипокси - гиперкапнических тренировок на аппарате «Карбоник» у боль- 
ных с нервно-мышечной дисфункции мочевого пузыря.

Материалы и методы.Включено 20 детей/ Критерии включения:1частота мочеиспусканий менее 3 и более 9 раз в сутки 2. отсутствие воспалительных и других заболеваний мочевой системы, потенциально влияющих на частоту мочеиспусканий 3. наличии информированного согласия пациента. Проводилось исследование почечного и брахицефального кровотока на аппарате SonoScape2012 в режиме цветового доплера двукратно: до и после курса тренировок на аппарате «Карбоник». Для оценки клинической эффективности терапии применяли квалиметрическую (бальную) оценку терминологически стандартизированных симптомов по Вишневскому Е.Л. Для, оценки достоверности полученных результатов проводился расчет критерия Уилкоксона. Значения менее 0,05 расценивались, как значимые.

Результаты.При оценке клинической эффективности терапии с включение гипокси-гиперкапнических тренировок, установлена выраженная положительная динамика по всем разделам квалиметрической шкалы (шкалы Вишневского). При оценке брахицефального кровотока отмечается достоверное снижение сосудистого сопротивления (индекса резистентности) на уровне позвоночных артерий, экстракраниальный участок справа и слева.

При исследовании почечного кровотока также отмечается тенденция к снижению индекса резистентности крупных артерий, достоверно на уровне стволовых артерий справа и на уровне сегментарных артерий справа и слева.

Заключение. Включение гипокси-гиперкапнических тренировок в комплексную терапию пациентов с нейрогенными расстройствами мочеиспускания повышает ее клиническую эффективность. Возможные механизмы положительного влияния данного вида лечения реализуются через регуляцию почечного и брахицефального кровотока.

\section{МЕТАБОЛИЧЕСКИЕ И РЕПРОДУКТИВНЫЕ НАРУШЕНИЯ У ДЕВУШЕК-ПОДРОСТКОВ, СТРАДАЮЩИХ ИНФЕКЦИЯМИ МОЧЕВОГО TPAKTA}

Чеботарева Ю.Ю. ${ }^{1}$, Летифов Г.М. ${ }^{1}$, Тангиева М.Ю. ${ }^{2}$, Костоева 3. $A^{2}$.

${ }^{1}$ Федеральное государственное бюджетное образовательное учреждение высшего образования

«Ростовский государственный медицинский

университет» Министерства здравоохранения

Российской Федерации, Ростов-на-Дону

ФГБОУ ВО Ингушский государственный университет

Введение. Нормальное функционирование женской половой системы зависит от количества жировой ткани, которая в свою очередь является эндо- кринным органом участвующим в метаболизме и продуцировании половых гормонов, цитокинов и хемокинов. Так, избыточная масса тела в подростковом возрасте непосредственно связана с нарушениями менструального цикла по типу аменореи и олигоменореи, синдромом формирующихся поликистозных яичников. В ряде исследований показан, что на фоне рецидивирующих инфекций мочевого тракта (ИМТ) имеет место развитие метаболических расстройств.

Цель исследования - изучить особенности физического развития и становление репродуктивной функции у девушек-подростков, страдающих рецидивирующими инфекциями мочевого тракта.

Материалы и методы. В исследование включено 46 девушек-подростков $(15,28 \pm 1,5$ года) с рекуррентными инфекциями мочевого тракта $(3,8 \pm 0,5$ раз за 6 месяцев, N30,1 - хронический интерстициальный цистит, первичные, без наличия структурных аномалий мочевыводящих путей). У всех пациенток изучены антропометрические показатели, включая соматометрию и соматотипирование, гинекологический и гормональный статусы. Проведен иммуноферментный анализ гормонов сыворотки крови (кортизол, пролактин, ЛГ, ФСГ, прогестерон).

Результаты. Установлено, достоверное увеличение случаев макросоматического типа телосложения $(p<0,05)$. Каждая третья девочка имела признаки ожирения 1 степени (индекс массы тела $-33,28 \pm 1,5$ кг/м²), показатели массы тела были значимо выше, чем у девушек-подростков 1,2 групп здоровья $(p<0,05)$. Наличие бактериального вульвовагинита выявлено у 34 (73,9\%) пациенток, у 12 (26,1\%) - бактериальный вагиноз. Достоверное повышение возрастных уровней кортизола и пролактина, отмечалась гипопрогестеронемия $(p<0,05)$. У $12(26,1 \%)$ пациенток выявлена первичная олигоменорея, у 10 (21,7\%) - обильные менструации, у $10(21,7 \%)$ - синдром формирующихся поликистозных яичников.

Заключение. У девушек-подростков, страдающих рецидивирующими ИМТ отмечаются метаболические расстройства, которые могут привести к нарушению репродуктивного здоровья. Имеют место дисбиозы влагалища и различные нарушения менструального цикла. В данной когорте пациенток необходимо разработать междисциплинарные принципы диспансерного ведения для первичного звена здравоохранения. 


\section{МОТОРНЫЕ РАССТРОЙСТВА КИШЕЧНИКА КАК ОДНА ИЗ ПРИЧИН ЧАСТОГО РЕЦИДИВИРОВАНИЯ ИМВП У ДЕТЕЙ \\ Шапошникова Н.Ф. \\ ФГБОУ ВО «Волгоградский государственный \\ медицинский университет» Министерства \\ здравоохранения Российской Федерации, Волгоград}

Введение. У детей «неосложненная» инфекция мочевыводящих путей встречается достаточно редко, но не всегда можно объяснить причины частого рецидивирования ИМВП. В связи с этим только этиотропная терапия не дает желаемого результата в санации мочевого синдрома и наступлении стойкой ремиссии. Целесообразным представляется поиск внеренальных причин частого рецидивирования «неосложненной» инфекции мочевыводящих путей у девочек дошкольного возраста.

Цель исследования - поиск внеренальных причин частого рецидивирования «неосложненной» инфекции мочевыводящих путей у девочек дошкольного возраста и отработка комплексного лечения для достижения ремиссии ИМВП.

Материалы и методы. В исследование включено 38 девочек с диагнозом «неосложненная» инфекция мочевыводящих путей, но со стойким мочевым синдромом, в возрасте от 4 до 7 лет, с 100\% положительным высевом бактериологической флоры из мочи. У всех пациенток выявлены моторные расстройства кишечника с преобладанием нарушений в виде запоров (стул не чаще $2-3$ раз в неделю) у $76 \%$ (n-29) и послабления стула (до 2-3-х раз в день) у $24 \%$ (n-9). Всем пациенткам, кроме этиотропной терапии ИМВП, назначался тримебутин 0,1 по 1/4 таблетки 3 раза в день, курсом от 1,5 до 2-х месяцев под контролем нормализации стула.

Результаты. По результатам исследования у $86 \%$ (n- 24) пациентов с запорами на третьей недели лечения стул стал ежедневным и сохранялся в катамнезе, а у $82 \%$ (n - 23) наступила ремиссии ИМВП до конца срока наблюдения (в течение 6 месяцев). У пациентов с послаблением стула нормализация моторные расстройства кишечника на фоне лечения отмечена у $67 \%$ $(\mathrm{n}-6)$ только на четвертой или пятой неделе, а ремиссия ИМВП до конца срока наблюдения (в течение 6 месяцев) наступила только у 5 пациенток (56\%).

Заключение. Использование в комплексной терапии ИМВП спазмолитического средства тримебутина приводит не только к нормализации стула, но и установлению стойкой ремиссии ИМВП на весь срок наблюдения у большинства пациентов.

\section{ПРОТЕОМНОЕ ИССЛЕДОВАНИЕ МОЧИ ПРИ МИКРОАЛЬБУМИНУРИИ С РАЗЛИЧНОЙ ПАТОЛОГИЕЙ ПОЧЕК У ДЕТЕЙ}

Летифов Г.М. ${ }^{1}$, Кривоносова Е.П. ${ }^{1,2}$
1ФГБОУ ВО «РостГМУ» МЗ РФ, Ростов-на-Дону

МБУЗ КДЦ «Здоровье», Ростов-на-Дону

Введение. Исследование протеомного спектра мочи позволяет оценить вероятность прогрессирования различных нефропатий, что является актуальным, учитывая возрастающую частоту заболеваний органов мочевой системы у детей, в том числе с бессимптомным течением.

Цель. Поиск информативных неинвазивных маркеров поражения почечной паренхимы при различной патологии мочевой системы у детей.

Материалы и методы. Протеомное исследование мочи выполнено с помощью методов протеомики («MALDI-TOF-MS/MS, Ultraflex II», «Bruker», США). Сведения о молекулярных взаимодействиях получены с помощью базы данных «STRING 10.0». Исследование включало 30 детей в возрасте от 1 года до 18 лет с различной патологией почек, ведущими лабораторными симптомами при которых являлись микроальбуминурия (МАУ) и эритроцитурия.

Результаты. Уровень МАУ у обследованных детей составлял: А0 (до 10 мг/сут) - у 17\% (5 пациентов), A1 (от 10 до 30 мг/сут) - у 13\% (4 ребенка), А2 (от 30 до 299 мг/сут) - у $60 \%$ (18 детей), А3 (от 300 мг/сут и более) - у 10 \% (3 человека). Выделены 39 различных белков. При изолированной эритроцитурии наиболее часто обнаруживались антиген тубулоинтерстициального нефрита (100\%), аквапорин-1 (75\%), фактор роста тромбоцитов $\beta(65 \%)$, вазорин (50\%), антиэпителиальный мембранный антиген (50\%). При присоединении МАУ возрастала частота выявления молекулы повреждения почечной ткани (100\%), апоптоз-индуцирующего фактора (100\%), аквапорина-1 (100\%), нейтрофильного желатиназо-связанного липокалина $(75 \%)$. По мере прогрессирования процесса, при хронической болезни почек III стадии, в протеомном спектре мочи определялись фактор, стимулирующий простациклин, интерлейкин 16, матриксная металлопротеиназа, толлоидоподобный белок 2.

Заключение. Таким образом, оценка протеомного спектра мочи позволяет выделить неинвазивные маркеры прогрессирования повреждения тубулоинтерстициальной ткани почек, связанного с различной патологией, сопровождающейся МАУ и эритроцитурией.

\section{ОРФАННОЕ ЗАБОЛЕВАНИЕ: АТИПИЧНЫЙ ГЕМОЛИТИКО - УРЕМИЧЕСКИЙ СИНДРОМ У ДЕВОЧКИ 3 ЛЕТ \\ Баринов В.Н., Решетова С.Н. \\ ФГБОУ ВО Самарский государственный медицинский университет Минздрава России \\ Самарская областная клиническая больница имени В.Д.Середаина}


Введение: Атипичный гемолитико-уремический синдром (аГУС) - проявление тромботической микроангиопатии, в основе которой лежит первичное нарушение регуляции альтернативного пути комплемента.

Цель: описать клиническое наблюдение ребенка с аГУС.

Девочка заболела в январе 2019 года, в возрасте 3 лет. На 7 сутки после развития симптоматики острого инфекционного гастроэнтерита неясной этиологии и высеянного вируса гриппа типа А (H1N1) был установлен диагноз гемолитико-уремический синдром. Выявлен симптомокомплекс тромботической микроангиопатии в виде анемии, тромбоцитопении, острая почечная недостаточность, олигоанурия, протеинурия. После установления диагноза девочка была переведена из инфекционной клиники, где получала лечение по поводу инфекционного гастроэнтерита, в СОКБ им. В.Д. Середавина в отделение нефрологии, чуть позже переведена в отделение реанимации, в связи с ухудшением состояния. Появились экстаренальные проявления: артериальная гипертензия, полиорганная недостаточность (поражение поджелудочной железы, печени, эрозивный гастрит, поражение пищевода, что сопровождалось кровотечением, прогрессирующий ДВС-синдром, поражение ЦНС: токсическая энцефалопатия. Частые сомнико-моторные и тонические приступы.
Отмечены повторные эпизоды падения гемоглобина и тромбоцитов на фоне трансфузии эритроцитарной взвеси и свежезамороженной плазмы. При проведении молекулярно-генетического исследования генов, входящих в панель «Атипичный гемолитико-уремический синдром», патогенных мутаций выявлено не было. Но были выявлены мутации в генах CFHR5, CFHR1, CFHR3. Данные генетической экспертизы нельзя трактовать однозначно, но, учитывая клиническую симптоматику, полиорганность поражений, рецидивы гемолитического синдрома был выставлен диагноз: аГУС. Проведена патогенетическая терапия Экулизумабом, согласно международным рекомендациям. В процессе лечения использовалась заместительная почечная терапии (перитонеальный диализ), симптоматическая терапия. Девочка выписана в удовлетворительном состоянии с неполной клинико-лабораторной ремиссией. По настоящее время проводится клинико-функциональный мониторинг, осуществляется индивидуальная реабилитация. Функция почек постепенно восстанавливается.

Заключение. Особенность данного случая заключается в том, что генетических мутаций однозначно говорящих за аГУС не найдено, но симптомокомплекс и тяжесть течения заболевания, а также эффект от проведенной патогенетической терапии экулизумабом однозначно свидетельствует о правомочности постановки диагноза. 


\section{Раздел 8}

\section{НЕВРОЛОГИЯ}




\section{ФУНКЦИОНАЛЬНОЕ СОСТОЯНИЕ СТВОЛОВЫХ СТРУКТУР МОЗГА ПРИ АТОПИЧЕСКОЙ ФОРМЕ БРОНХИАЛЬНОЙ АСТМЫ У ДЕТЕЙ \\ Буряк В.Н., Дудко М.В. \\ ФГБОУ ВО «Северо-Западный государственный \\ медицинский университет им. И.И. Мечникова» \\ Минздрава России, Санкт-Петербург}

Введение. Одной из актуальнейших медико-социальных проблем современности является проблема бронхиальной астмы. Наименее изученный из патогенетических механизмов еe развития остается вопрос нейрогенной вегетативной регуляции гладкомышечного тонуса бронхов. Известно, что в переднем отделе гипоталамуса располагаются центры парасимпатической, а в туберальном и заднем отделах - симпатической частей вегетативной нервной системы. Активность данных структур во многом определяется функциональным состоянием дыхательного центра ствола мозга.

Цель исследования - изучить биоэлектрическую активность стволовых структур мозга у детей, страдающих атопической формой бронхиальной астмы.

Материалы и методы. Обследовано 26 детей в возрасте от 11 до 14 лет, которым был установлен диагноз бронхиальная астма, атопическая форма. Обследование проводилось всем больным детям в межприступном периоде. Группу контроля составили 20 здоровых детей аналогичного возраста. У всех обследованных проводилось изучение коротколатентных слуховых вызванных потенциалов с помощью электродиагностического комплекса “Amplaid MK 15” (Италия).

Результаты. При сравнительном анализе у больных бронхиальной астмой и здоровых детей выявлены отличия, касающиеся амплитуды I компонента, величина которой у лиц с бронхиальной астмой была значительно ниже, чем в контрольной группе (критерий Стьюдента $\mathrm{t}=4,27 ; \rho<0,001)$. Дисперсионным анализом выявлена также разница в значениях латентного периода I компонента (критерий Фишера $\mathrm{F}=2,94 ; \rho<0,001)$. Кроме того, у обследованных пациентов по сравнению с детьми контрольной группы статистически значимо отличались латентные периоды III $(\mathrm{H}(1 . \mathrm{N}=82)=4,22 ; \rho<0,05)$ и V (F $=3,44 ; \rho<0,001)$ компонентов. Дисперсионный анализ также выявил значимые различия у обследованных больных и здоровых детей продолжительности межпикового интервала I - III ( F = 1,88; $\rho<0,05)$.

Заключение. Учитывая наличие тесной функциональной и морфологической взаимосвязи через ретикулярную формацию центров преобразования слуховой информации и дыхательного центра ствола мозга, установленные отличия, вероятнее всего, обусловлены развитием дисфункции именно дыхательного центра.

\section{ОЦЕНКА ТРОФИЧЕСКИХ ПРОЦЕССОВ В МЫШЕЧНОЙ ТКАНИ У ДЕТЕЙ, БОЛЬНЫХ СПАСТИЧЕСКИМИ ФОРМАМИ ДЕТСКОГО ЦЕРЕБРАЛЬНОГО ПАРАЛИЧА}

Голубова Т.Ф., Отинов М.Д., Нуволи А.В., Власенко С.В. ГБУЗ РК Научно-исследовательский институт детской курортологии, физиотерапии и медицинской реабилитации, Евпатория

Введение. Исследованиями последних лет отмечено, что типологический профиль скелетных мышц формируется под действием эндогенных и экзогенных факторов. К эндогенным факторам относятся нейротрофические и ростовые факторы, нейротрофический контроль, гормональные факторы, а к экзогенным - физическая нагрузка и питание. Рост мышечной ткани способны регулировать большинство ростовых факторов и интерлейкинов, однако, ведущая роль в процессе стимуляции регенерации и роста мышц принадлежит инсулиноподобному фактору роста -1 (IGF-1).

Цель- изучение содержания инсулиноподобного фактора роста - 1 (IGF-1) и гормона роста $(\mathrm{GH})$ у детей, больных ДЦП, поступающих на санаторнокурортный этап реабилитации.

Материалы и методы - обследовано 68 детей в возрасте от 7 до 12 лет, больных ДЦП. Средний возраст больных составил $10,1 \pm 0,4$ года. Обследование включало осмотр ребенка специалистами, проведение антропометрических измерений, оценку в сыворотке крови IGF-1 и GH. Контрольную группу (КГ) составили 32 ребенка I и II групп здоровья.

Результаты. Выявлено снжение IGF-1 и GH у детей с показателями физического развития ниже нормы, при выраженной спастике мышц и при повышенном мышечном тонусе $(p<0,001)$. Отмечено, что GH у детей с невыраженной спастикой и легкими двигательными нарушениями находился в пределах нормы, однако, было достоверно $(p<0,01)$ ниже, чем в КГ, а IGF-1 был снижен при всех тяжестях заболевания $(p<0,001)$.

Выводы. Установлено, что на уровень IGF-1 в значительной мере воздействует регуляция центрального звена гипоталямо-гипофизарно-надпочечниковой оси, и в данном исследовании - гормон роста, однако, значительную роль в синтезе и транспорте IGF-1 оказывает состояние взаимоотношения «мотонейрон - скелетное мышечное волокно». что необходимо учитывать при организации реабилитационного комплекса. 
РОЛЬ ШАПЕРОНОВ В РЕАЛИЗАЦИИ ЭНЕРГОТРОПНОГО МЕХАНИЗМА НЕЙРОПРОТЕКТИВНОГО ДЕЙСТВИЯ МОЗГА У ДЕТЕЙ С РАССТРОЙСТВАМИ АУТИСТИЧЕСКОГО СПЕКТРА

Голубова Т.Ф., Цукурова Л.А., Нуволи А.В., Власенко С.В. ГБУЗ РК Научно-исследовательский институт детской курортологии, физиотерапии и медицинской реабилитации, Евпатория

Введение. Наиболее важной медико-социальной проблемой в нейропедиатрии является расстройство аутистического спектра, частота которого непрерывно увеличивается. В организме существует значительное количество веществ и биологических систем, обладающих нейропротективными действиями, позволяющих противодействовать воздействию агрессивных факторов. Шапероны способны оказывать защитную функцию на нервные клетки.

Цель исследования - оценка роли шаперонов в реализации нейропротективного действия головного мозга у детей с расстройствами аутистического спектра.

Материалы и методы. Было обследовано 45 детей с аутизмом в возрасте от 3 до 15 лет, которые составили общую группу (ОГ) обследования, Контрольную группу (КГ) составили 25 здоровых детей. Комплексное обследование детей включало: осмотр специалистами, оценку тяжести заболевания с помощью шкалы CARS, биохимические исследования по определению в сыворотке крови содержание Hsp27 и Hsp70.

Результаты. Содержание Нsp27 и Нsp70 в сыворотке крови у детей с аутизмом было достоверно сниженно в ОГ в сравнении с показателями КГ ( $p=0,0018$, $p=0,025$, соответственно). Оценка содержания шаперонов в зависимости от тяжести аутизма показала, что при тяжелой степени заболевания значения как Hsp27, так и Нsp70 были достоверно ниже, чем в КГ $(p=0,001)$. Показатели Нsp27 при средней степени заболевания были достоверно ниже $(p=0,03)$ в сравнении с КГ, а значения Нsp70 не имели статистически значимых различий от КГ. Исследуя разницу показателей между средней и тяжелой степенью аутизма отмечено, что значения Hsp27 и Hsp70 были достоверно ниже при тяжелой степени аутизма в сравнении со средней степенью ( $p=0,001$ и $p=0,01$, соответственно).

Таким образом, исходное содержание шаперонов у детей с аутизмом было достоверно ниже (Hsp27 и Hsp70) в сравнении со здоровыми сверстниками с более значительным уменьшением концентрации антиапоптотического Нsp27. Уровень изучаемых показателей в зависимости от тяжести заболевания показал значительное снижение при тяжелой степени заболевания, не только относительно здоровых детей, но и относительно значений при средней степени заболевания.
Выводы. Выявлено, что у детей с аутизмом ослаблены нейропротективные свойства головного мозга, связанные с низкими значениями Нsp27, а также, ослаблен энерготропный механизм нейропротективного действия головного мозга при тяжелой степени заболевания, связанный со снижением уровня Hsp70. Полученные данные свидетельствуют о необходимости дальнейшего исследования патогенетических механизмов заболевания.

\section{ОЦЕНКА ТРОФИЧЕСКИХ ПРОЦЕССОВ В МЫШЕЧНОЙ ТКАНИ У ДЕТЕЙ, БОЛЬНЫХ СПАСТИЧЕСКИМИ ФОРМАМИ ДЕТСКОГО ЦЕРЕБРАЛЬНОГО ПАРАЛИЧА}

Голубова Т.Ф., Отинов М.Д., Нуволи А.В., Власенко С.В. ГБУЗ РК Научно-исследовательский институт детской курортологии, физиотерапии и медицинской реабилитации, Евпатория

Введение. Исследованиями последних лет отмечено, что типологический профиль скелетных мышц формируется под действием эндогенных и экзогенных факторов. К эндогенным факторам относятся нейротрофические и ростовые факторы, нейротрофический контроль, гормональные факторы, а к экзогенным - физическая нагрузка и питание. Рост мышечной ткани способны регулировать большинство ростовых факторов и интерлейкинов, однако, ведущая роль в процессе стимуляции регенерации и роста мышц принадлежит инсулиноподобному фактору роста -1 (IGF-1).

Цель- изучение содержания инсулиноподобного фактора роста - 1 (IGF-1) и гормона роста $(\mathrm{GH})$ у детей, больных ДЦП, поступающих на санаторнокурортный этап реабилитации.

Материалы и методы - обследовано 68 детей в возрасте от 7 до 12 лет, больных ДЦП. Средний возраст больных составил 10,1 $\pm 0,4$ года. Обследование включало осмотр ребенка специалистами, проведение антропометрических измерений, оценку в сыворотке крови IGF-1 и GH. Контрольную группу (КГ) составили 32 ребенка I и II групп здоровья.

Результаты. Выявлено снжение IGF-1 и GH у детей с показателями физического развития ниже нормы, при выраженной спастике мышц и при повышенном мышечном тонусе $(p<0,001)$. Отмечено, что GH у детей с невыраженной спастикой и легкими двигательными нарушениями находился в пределах нормы, однако, было достоверно $(p<0,01)$ ниже, чем в KГ, а IGF-1 был снижен при всех тяжестях заболевания $(p<0,001)$.

Выводы. Установлено, что на уровень IGF-1 в значительной мере воздействует регуляция центрального звена гипоталямо-гипофизарно-надпочечниковой оси, и в данном исследовании - гормон роста, однако, значительную роль в синтезе и транспорте IGF-1 оказы- 
вает состояние взаимоотношения «мотонейрон - скелетное мышечное волокно». что необходимо учитывать при организации реабилитационного комплекса.

\section{РЕЗУЛЬТАТЫ ОЦЕНКИ АКТИВНОСТИ ФЕРМЕНТОВ ПЕЧЕНИ У БОЛЬНЫХ ЭПИЛЕПСИЕЙ ДЕТЕЙ, ПОЛУЧАЮЩИХ БАЗОВЫЕ АНТИКОНВУЛЬСАНТЫ}

Заболотских Т.В., Носаль Л.А., Симонова Н.В., Анохина P.A.

ФГБОУ ВО Амурская ГМА Минздрава России, Благовещенск

Введение. В спектре побочных эффектов антиконвульсантов одно из ведущих мест занимают лекарственные поражения печени, патофизиологическими механизмами которых являются повышение интенсивности процессов липопероксидации и снижение активности антиоксидантной системы, что было подтверждено результатами проведенных нами ранее исследований. Поэтому изучение активности печеночных ферментов как маркеров функциональных изменений печени и предикторов осложнений противоэпилептической терапии является, на наш взгляд, обоснованным.

Цель исследования - оценка активности ферментов печени у больных эпилепсией детей, получающих базовые антиконвульсанты.

Материалы и методы. В ГАУЗ АО «Амурская областная детская клиническая больница» обследовано 2 группы больных эпилепсией детей 6-17 лет (27 мальчиков и 29 девочек). В первой группе $(n=31)$ терапия проводилась карбамазепином, во второй $(n=25)$ - вальпроевой кислотой (депакин). Контрольная группа - 20 здоровых детей, сопоставимых по полу и возрасту. Забор крови производили в 1-й и 6-й день наблюдения с последующей оценкой аспартатаминотрансферазы (АсАТ), аланинаминотрансферазы (АлАТ), щелочной фосфатазы (ЩФ) на биохимическом анализаторе Humastar 600 (Германия). Статистическую обработку результатов проводили с использованием критерия Стъюдента (t).

Результаты. Оценка активности печеночных трансаминаз у больных эпилепсией детей свидетельствовала, что применение карбамазепина способствует повышению уровня АсАТ в 1,4 раза и АлАТ в 1,8 раза по сравнению с аналогичными параметрами у детей контрольной группы в 1-й день наблюдения $(p<0,05)$, в 1,3 и 2 раза соответственно - на 6-й день $(p<0,05)$. Использование вальпроевой кислоты в меньшей степени влияло на активность печеночных трансаминаз, уровень которых превышал контроль на 11-17\%. Анализ активности ЩФ позволил установить увеличение параметра относительно здоровых сверстников в 3 раза на фоне монотерапии карбамазепином, в 1,9 раза - вальпроевой кислотой $(p<0,05)$.
Заключение. Повышение активности печеночных ферментов при монотерапии эпилепсии у детей, более выраженное при использовании карбамазепина, свидетельствует о негативном влиянии антиконвульсантов на функциональное состояние печени и предполагает проведение фармакокоррекции.

\section{ОЦЕНКА ПЕРИНАТАЛЬНОГО АНАМНЕЗА И СТРУКТУРА ПАТОЛОГИИ У ДЕТЕЙ С ЗАДЕРЖКОЙ РЕЧЕВОГО РАЗВИТИЯ \\ Изюрова Н.В., Суптелло А.А., Соленов В.В. ФГБОУ ВО ЮУГМУ Минздрава России, Челябинск}

Введение. В настоящее время заметно увеличивается число детей, в анамнезе у которых имеется диагноз задержки речевого развития. Большинство специалистов отмечают большое значение неблагополучия перинатального периода в этиологии нарушения формирования речи. Однако до настоящего времени не выявлено, какие именно факторы или их сочетания играют решающую роль в развитии тех или иных видов расстройств речи.

Цель исследования. Оценить особенности перинатального анамнеза и проанализировать особенности и структуру патологии у детей с задержкой речевого развития.

Материалы и методы. Был проведен ретроспективный анализ историй болезни 49 детей с задержкой речевого развития в возрасте от 1 года до 17 лет, госпитализированных в неврологическое отделение МАУЗ ДГКБ №8 г. Челябинска.

Результаты. Отягощенный акушерско-гинекологический анамнез у матерей детей с задержкой речевого развития по данным нашего исследования встречался в $85,4 \%$ случаев, в частности, хроническая фетоплацентарная недостаточность была диагностирована в $75 \%$ случаев, ОРВИ в первые 12 недель беременности отмечена у 47,9\% матерей. Интранатальный период сопровождался обвитием пуповиной у 41,7\% детей. Около $17 \%$ детей находились на искусственной вентиляции легких. Конъюгационная желтуха в раннем неонатальном периоде встречалась у 29,2\% детей. Системное недоразвитие речи на момент обследования отмечалось у $48 \%$ детей, общее недоразвитие речи диагностировано у $52 \%$ детей. В структуре диагнозов у детей с системным недоразвитием речи ДЦП регистрировался в $20,8 \%$ случаев в отличие от детей с общим недоразвитием речи $2,1 \%$ ( $<<0,001)$. Кроме того, у детей с системным недоразвитием речи достоверно чаще встречалась эпилепсия $(8,3 \%)$, психические расстройства $(4,2 \%)(\mathrm{p}<0,004)$. У детей с общим недоразвитие речи в структуре диагноза чаще встречалась двусторонняя пирамидная недостаточность $(10,4 \%)$, синдром гиперактивности с дефицитом внимания $(16,7 \%)$. 
Заключение. Проведенная работа показала, что неблагоприятный перинатальный анамнез и тяжелое течение интранатального и постнатального периода позволяют выделить детей, которые находятся в группе риска по задержке развития речи.

\section{ФОРМИРОВАНИЕ КОГНИТИВНЫХ И ПСИХИЧЕСКИХ НАРУШЕНИЙ У ДЕТЕЙ С ЭПИЛЕПСИЕЙ: СОВРЕМЕННЫЙ ВЗГЛЯД НА АКТУАЛЬНУЮ ПРОБЛЕМУ}

Изюрова Н.В. ${ }^{\text {, }}$ Суптелло А.А. ${ }^{1}$, Соленов В.В. ${ }^{1}$, Шевченко H.A. ${ }^{2}$

'ФГБОУ ВО ЮУГМУ Минздрава России, Челябинск МАУЗ ДГКБ №8, Челябинск

Введение. Когнитивные и психические нарушения достаточно часто встречаются при эпилепсии и значительно снижают качество жизни пациентов. Дети являются особенно уязвимой категорией пациентов: кроме стойких нарушений интеллекта у них возможны специфические нарушения в виде задержки психического и речевого развития, трудностей обучения. При этом негативное влияние на когнитивные и психические функции у детей с эпилепсией может оказывать как само заболевание, так и его лечение.

Цель исследования - оценить особенности когнитивных и психических функций у детей с различными формами эпилепсии.

Материалы и методы. Были проанализированы истории болезни 104 детей с различными формами эпилепсии в возрасте от 1 года до 17 лет, госпитализированных в неврологическое отделение МАУЗ ДГКБ №8 г. Челябинска.

Результаты. Фокальные формы эпилепсии были зарегистрированы у 86,5\% детей, генерализованные у 13,5\%. Большую долю среди фокальных форм составляет фокальная вероятно симптоматическая эпилепсия (58\% случаев). При изучении анамнеза получены данные, свидетельствующие о том, что у матерей детей с генерализованной эпилепсией достоверно чаще $(\mathrm{p}<0,05)$ встречается отягощенный акушерско-гинекологический анамнез. Среди когнитивных нарушений у детей с эпилепсией отмечены снижение памяти (27,9\% случаев), нарушение внимания (43,3\% случаев), различные виды поведенческих нарушений $(34,6 \%)$. При чем когнитивные и психические нарушения достоверно чаще регистрировались у детей с генерализованными формами эпилепсии ( $<<0,05)$. По данным историй болезни монотерапия была эффективна у $73 \%$ детей. Среди детей, получающих 2 и более противоэпилептических препарата, одинаково часто встречались как генерализованные, так и фокальные формы эпилепсии (р $>0,05)$. Когнитивные нарушения достоверно чаще регистрировались у детей, стаж заболевания которых составлял более 3 лет ( $<0,002)$.
Заключение. Таким образом, изучение нарушений когнитивных и психических функций при эпилепсии остается актуальной проблемой детской неврологии и продолжается дискуссия о роли каждого фактора в развитии данных нарушений.

\section{ПЕРИНАТАЛЬНЫЙ ИНСУЛЬТ, ОСОБЕННОСТИ ТЕЧЕНИЯ}

Камышанская Д.Н., Панина О.С., Сушкова А.А. ФГБОУ ВО Саратовский ГМУ им. В.И. Разумовского, Саратов

Введение. Для типичной картины перинатального инсульта характерно острое начало заболевания; парциальные эпилептические припадки; генерализованные судороги; очаговая симптоматика; угнетение уровня сознания. Возможно бессимптомное течение, манифестация заболевания после 28 дней жизни, 4 месяцев, что характерно для недоношенных новорожденных. Факторы риска: мутации V фактора Лейдена у матери, антифосфолипидные антитела, гипертриглицеридемия и повышение липопротеина (a), тромбоз сосудов плаценты со стороны плода, «тромботическая васкулопатия плода», герпетический или ЦМВ-менингоэнцефалит, ПЭ. УЗИ и НСГ позволяют определить зону ишемии к концу 2-го началу 3-го дня заболевания. УЗДС сосудов ГМ уже с 1-го дня заболевания выявляет локальные изменения кровотока.

Цель исследования - проведение ретроспективного анализа течения неонатального периода у новорожденных с инсультами, прогнозирование рисков развития осложнений.

Материалы и методы. Ретроспективный анализ медицинской документации стационара родовспомогательного профиля.

Результаты. Перинатальный инсульт был выявлен у ребенка от 4 беременности, протекавшей на фоне ПЭ в 3 триместре, 3 родов путем кесарева сечения на сроке гестации 38 недель. Масса тела при рождении 3560г, рост - 55см. Оценка по шкале Апгар 8-9 баллов. На 2 сутки у ребенка отмечаются клонические судороги, выраженный тремор левой руки и ноги. НСГ без особенностей. Нейроинфекции исключены. По данным МРТ - острая фаза ишемического инсульта в бассейне СМА. Проведено противосудорожное лечение (“Конвулекс" 25 мг/кг/сут) с положительной динамикой. Диагноз: Перинатальный артериальный ишемический инсульт в бассейне правой задней корковой ветви СМА. Несмотря на проведенное лечение и своевременную постановку диагноза в раннем исходе был выявлен ДЦП.

Выводы. Перинатальные инсульты манифестируют уже в периоде новорожденности, протекают бессимптомно, но дают выраженный неврологический дефицит в будущем. На НСГ, УЗИ очаги чаще 
выявляются на 5-7 сутки от начала заболевания. Неспецифическая симптоматика, сложность ранней визуализации обуславливают позднюю постановку диагноза, усугубляя тяжесть течения заболевания и увеличивая риск развития осложнений.

\section{КАЧЕСТВО ЖИЗНИ ДЕТЕЙ С ДЕТСКИМ ЦЕРЕБРАЛЬНЫМ ПАРАЛИЧОМ}

Каримуллин Г.А., Левитина Е.В., Змановская В.А. ФГБОУ ВО Тюменский ГМУ Минздрава России, Тюмень ГАУЗ ТО «ДПН ЛРЦ» Надежда», Тюмень

Введение: Современные стандарты осмотра детей с детским церебральным параличом включают в себя оценку глобальных моторных функций, оценку функционирования верхних конечностей, речь, функцию глотания. Это позволяет объективно оценить проблемы пациента, составить план реабилитационных мероприятий. Не менее важным является оценка качества жизни пациента - для ее объективизации используются международные шкалы, в том числе, переведенные на русский язык.

Цель исследования - провести оценку качества жизни детей с детским церебральным параличом, сравнить показатели пациентов и их родителей

Материалы и методы: Исследование проведено на группе из 35 пациентов и их родителей, в возрасте от 2х до 17 лет, обоего пола, с диагнозом детский церебральный паралич. Всем детям был проведен неврологический осмотр, с оценкой по шкалам GMFCS, MACS, CFCS, EDACS. Проведена оценка способности к передвижению по опроснику Gillette, оценка качества жизни по опроснику PedsQL, модуль «Церебральный паралич».

Результаты: По результатам исследования, наиболее низкие показатели качества жизни отмечались в блоке «Повседневная деятельность» (среднее 53,51). Наиболее высокие показатели были отмечены в блоке «Речь и общение» (среднее 75). При оценке результатов пациентов и их родителей, возникали различия, в виде более высокой оценке качества жизни самими пациентами, чем их родителями. Большинство пациентов (86\%), при прохождении тестирования, указали болевые синдромы различной интенсивности. Заполнение опросника на приеме у врача-невролога заняло не более 5-10 минут, возникали единичные уточняющие вопросы по поводу формулировки вопросов.

Заключение: Опросники по качеству жизни позволяет практическому врачу получить более детальную информацию о состоянии пациента с ДЦП, помогает в разработке плана реабилитации. Важным является подробный опрос о различных болевых синдромах с целью своевременного и адекватного обезболивания. Применение данных шкал для пациентов и их родителей позволяет оценить трудности при уходе за ребенком и увеличивает роль родителей в процессе лечения.

\section{GNAO1-АССОЦИИРОВАННАЯ \\ ЭПИЛЕПТИЧЕСКАЯ ЭНЦЕФАЛОПАТИЯ \\ (КЛИНИЧЕСКИЙ СЛУЧАЙ)}

Кожанова Т.В. ${ }^{1,2}$, Жилина С.С. ${ }^{1,2}$, Мещерякова Т.И. ${ }^{1}$,

Большакова Е.С. ${ }^{1}$, Осипова К.В. ${ }^{1}$, Айвазян C.O. ${ }^{1}$,

Канивеи И.В. ${ }^{3}$, Пьянков Д.В. ${ }^{3}$, Притыко А.Г. ${ }^{1,2}$,

Заваденко H.H. ${ }^{2}$

'ГБУЗ «НПЦ спец.мед.помощи детям ДЗМ», Москва,

Россия;

ФГАОУ ВО РНИМУ им. Н.И. Пирогова Минздрава

России, Москва, Россия

${ }^{3} \mathrm{OOO}$ «Геномед» Москва, Россия

De novo мутации в гене GNAO1 у детей являются причиной развития ранней эпилептической энцефалопатии и тяжелой задержки развития, с более поздним развитием дискинетических двигательных расстройств. В психоневрологическом отделении ГБУЗ «НПЦ спец.мед.помощи детям ДЗМ» наблюдался ребенок (мальчик, 2 мес.) с диагнозом: Эпилепсия симптоматическая фокальная. Детский церебральный паралич, смешанная форма. Задержка психо-речевого развития. Ребенок болен с рождения, с возраста 1,5 недель, когда появились эпизоды в виде подергиваний мимической мускулатуры, гиперемии лица, тонического напряжения в конечностях. Противосудорожная терапия без эффекта. Неврологический статус: двигательные навыки-голову не держит. Походка отсутствует. Мышечный тонус: дистоничен. Стереотипии. Не сидит. Интерес к окружающему не стойкий. Редкие приступы в виде миоклоний левого века, слюнотечения, тонического напряжения в виде 1 мин. В результате проведенного исследования выявлен ранее не описанный вариант нуклеотидной последовательности во 2 экзоне гена GNAO1 в гетерозиготном состоянии (с.155A>G; Gln52Arg; NM_020988,2). Мутации в гене GNAO1 в гетерозиготном состоянии описаны у пациентов с «Энцефалопатией развития и эпилептической энцефалопатией, тип 17» (Developmental and epileptic encephalopathy 17; MIM\#615473). Выявленный вариант валидирован секвенированием по Сенгеру у пробанда, родители не являются носителями данного варианта, что дает основание предполагать его de novo происхождения. При наблюдении в динамике (возраст 1 г. 8 мес.) ребенок развивается с задержкой. В еде капризен. Неврологический статус - переворачивается на живот. В положении на животе опора на руки не сформирована. Хват непродолжительный. Вложенную игрушку пытается облизовать. Иногда пытается переворачиваться, тянуть в рот предметы, вложенные в ручку, выраженная дистония в руках. Данное клиническое наблюдение показывает, что мутации в гене GNAO1 являются причиной ранней эпилептической энцефалопатии и демонстрирует важность проведения ДНК-диагностики с использованием метода экзомного секвенирования с целью поиска молекулярного дефекта. 


\section{ПОГРАНИЧНАЯ ПСИХИЧЕСКАЯ ПАТОЛОГИЯ У ДЕТЕЙ РАННЕГО ВОЗРАСТА В ПЕРИОД АДАПТАЦИИ К ЗАМЕЩАЮЩЕЙ СЕМЬЕ \\ Кочерова О.Ю., Филькина О.М., Антышева Е.Н. ФГБУ «Ив НИИ М и Д им. В.Н. Городкова» Минздрава \\ России, Иваново}

Введение. При помещении в замещающие семьи у ряда детей раннего возраста, под влиянием различных средовых факторов происходит срыв адаптации и развитие пограничных психических расстройств, которые редко попадают к психиатру и находятся под наблюдением педиатра или невролога.

Цель исследования: изучить особенности пограничной психической патологии у детей раннего возраста в первый год воспитания в замещающих семьях (3С).

Материалы и методы. Объектом исследования явились 59 детей раннего возраста в первый год воспитания в 3С и 41 сверстник, воспитывающийся в кровных семьях (KC). Все дети имели ППЦНС легкой и средней степени тяжести. Исследование проводилось путем клинического обследования детей, наблюдения за их поведением, анализа медицинской документации, методики «ГНОМ» (Г.В. Козловская). Статистическая обработка материала осуществлялась с использованием программ MS Excel ХР и Statistica 6,0.

Результаты исследования.

Психические расстройства и расстройства поведения у детей в ЗС встречались достоверно чаще, чем в $\mathrm{KC}(79,66 \%$ и 53,5\%, $p=0,007)$. Расстройства психического развития (F80-89) у детей в ЗС выявлялись чаще, чем в $\mathrm{KC}(61 \%$ и $39 \%, p=0,041)$, преимущественно за счет смешанного специфического расстройства психического развития (F83 - 40,7\% и $12,2 \%$ соответственно, $p=0,002)$.

Эмоциональные расстройства и расстройства поведения, начинающиеся обычно в детском и подростковом возрасте (F90-98), наблюдались у детей из 3С так же чаще, чем в КС $(75,3 \%$ и $14,5 \%$, $p<0,0001)$, за счет: смешанных расстройств поведения и эмоций (F92,8 - 20,3\% и 2,4\%, $p=0,009)$, тревожного расстройства у детей, вызванного разлукой (F93,0 - 14\% и 2,4\%, $p=0,043)$, расстройств привязанностей (F94,1 и $\mathrm{F} 94,2)(10 \%$ и $0 \%, p=0,04)$, гиперкинетического расстройства поведения (15,3\% и 7,3\% $p=0,04)$.

Выводы. Отклонения психического здоровья у детей с последствиями ППЦНС, воспитывающихся в 3С, через год воспитания в ЗС проявлялись преимущественно комплексной психоречевой ретардацией в сочетании с эмоционально-поведенческими расстройствами.

\section{ЧАСТОТА ВСТРЕЧАЕМОСТИ ПЕРИВЕНТРИКУЛЯРНЫХ КРОВОИЗЛИЯНИЙ ПРИ ПЕРИНАТАЛЬНОМ ПОРАЖЕНИИ ЦНС У НОВОРОЖДЕННЫХ В ЗАВИСИМОСТИ ОТ СТЕПЕНИ ЗАДЕРЖКИ ВНУТРИУТРОБНОГО РАЗВИТИЯ}

Кравченко Л.В., Крукиер И.И., Афонин А.А., Левкович М.А., Бережанская С.Б.

ФГБОУ ВО РостГМУ Минздрава России, Ростов-на-Дону

Введение. В структуре основных причин перинатальной заболеваемости синдром задержки внутриутробного развития (ЗВУР) составляет 65-70\%. У данного контингента больных первично развивается ишемия герминативного матрикса, что предрасполагает к образованию перивентрикулярных кровоизлияний.

Цель исследования: выявить частоту встречаемости перивентрикулярных кровоизлияний у новорожденных с различной степенью ЗВУР.

Материалы и методы: исследование проведено у 58 доношенных новорожденных с ЗВУР по гипотрофическому типу. В зависимости от степени ЗВУР выделены следующие группы: I группа (20 человек) - легкая степень, II группа (17 человек) - средне-тяжелая, III группа (21 человек) - тяжелая степень. Ультразвуковое исследование головного мозга (нейросонография) проводилось с помощью аппаратов Aloca 1400 (Япония), Toshiba (Eccocee) SSA-340A (Япония), Combison 320-5 (Австрия) со сферическим датчиком 5 МГц, Vivid-3 Pro (GeneralElectric, США) с датчиком 5 МГц.

Результаты. Мышечная гипотония встречалась у новорожденных I-III групп, преобладая в третьей группе: 4 (30,8\%); 7 (50,0 \%) и $17(89,5 \%)$ пациентов соответственно ( $\mathrm{P}=0,006)$.

При нейросонографическом исследовании у пациентов всех групп регистрировались перивентрикулярные кровоизлияния: I -группа - у 6 (30\%) новорожденных, II группа - у $6(35,3 \%)$ новорожденных, в III группе - в 6 (28,5 \%) случаях. Статистической значимости различий между группами выявлено не было.

Также у детей I-III групп с одинаковой частотой выявлялись субэпендимальные псевдокисты: у 11 $(55 \%), 10(58,8 \%)$ и $8(38 \%)$ обследованных соответственно по группам.

Заключение. У новорожденных с тяжелой степенью ЗВУР перинатальное поражение ЦНС характеризовалось преобладанием с высокой статистической значимостью мышечной гипотонии по сравнению с пациентами I-II групп. Однако частота встречаемости перивентрикулярных кровоизлияний у новорожденных не зависела от степени ЗВУР и составила $28 \%-35 \%$.

Мониторинг нейросонограммы у новорожденных с ЗВУР наряду с катамнестическим наблюдением у невролога целесообразно использовать для прогноза неврологического исхода к концу первого года жизни. 


\section{КЛИНИЧЕСКИЕ ПРОЯВЛЕНИЯ ПЕРИНАТАЛЬНОГО ПОРАЖЕНИЯ ЦНС У НОВОРОЖДЕННЫХ В ЗАВИСИМОСТИ ОТ СТЕПЕНИ ЗАДЕРЖКИ ВНУТРИУТРОБНОГО РАЗВИТИЯ}

Кравченко Л.В., Крукиер И.И., Афонин А.А., Левкович М.А. ФГБОУ ВО РостГМУ Минздрава России, Ростов-на-Дону

Введение. У новорожденных с задержкой внутриутробного развития (ЗВУР) на первом году жизни имеют место признаки минимальных мозговых дисфункций, двигательные нарушения, когнитивные расстройства. Отмечено, что на первом году жизни у них медленнее исчезают последствия перинатальных поражений ЦНС.

Цель исследования - выявить частоту встречаемости неврологических симптомов и синдромов у новорожденных с различной степенью ЗВУР.

Материалы и методы. Обследовано 66 доношенных новорожденных с ЗВУР. Пациенты по степени выраженности ЗВУР распределены на 3 группы: I (легкая степень) - 13 человек $(28,3 \%)$, II (среднетяжелая степень) -14 человек $(30,4 \%)$ и III (тяжелая степень) - 19 человек $(41,3 \%)$. Обработка исходных рядов признаков осуществлялась с использованием пакетов прикладных программ Statistica версии 6,0 и EXCEL 2003, SPSS 13,0, MegaStat. Для сравнения межгрупповых различий использовали непараметрический критерий хи-квадрат Пирсона для независимых групп.

Результаты. У всех детей имело место перинатальное поражение ЦНС. Мышечный гипертонус отмечался только в I и II группах: $6(46,2 \%)$ и $5(35,7 \%)$ человек соответственно ( $\mathrm{P}=0,019)$, мышечная гипотония встречалась у всех новорожденных, преобладая в III группе: 4 (30,8\%); 7 (50,0 \%) и $17(89,5 \%)$ человек соответственно ( $\mathrm{P}=0,006)$. Снижение сухожильных рефлексов чаще регистрировалось в III группе: $4(30,8 \%) ; 7(50,0 \%) ; 17(89,5 \%)$ человек соответственно ( $\mathrm{P}=0,001)$. Напротив, рефлексы оральноспинального автоматизма более часто определялись в I группе: 9 (69,2 \%); 6 (46,2\%); 1 (5,3\%) человек соответственно (P =0,001). Выявлено преобладание синдрома угнетения в группе детей с тяжелой формой ЗВУР: 4 (30,8 \%); 6 (42,8\%) и $17(89,5 \%)$ соответственно $(\mathrm{P}=0,002)$.

Заключение. У новорожденных с тяжелой степенью ЗВУР перинатальное поражение ЦНС характеризовалось более высокой частотой регистрации синдрома угнетения, мышечной гипотонии, угнетения рефлексов орально-спинального автоматизма. Выявленные изменения являются основанием для дальнейшего катамнестического наблюдения у невролога новорожденных с тяжелой степенью ЗВУР.

\section{ОПЫТ ВЕДЕНИЯ РЕГИСТРА \\ ОСТРЫХ НАРУШЕНИЙ МОЗГОВОГО КРОВООБРАЩЕНИЯ У ДЕТЕЙ В ТЮМЕНСКОЙ ОБЛАСТИ \\ Мокина А.В., Левитина Е.В., Рахманина О.А. ГБУЗ ТО ОКБ №1, ФГБОУ ВО ТюмГМУ, Тюмень}

Введение. Актуальность проблемы острых нарушений мозгового кровообращения (ОНMК) у детей определяется увеличением их частоты в последние годы, недостаточным изучением проблемы этиологии в детском возрасте, особенностями клинической картины, сложностью диагностики.

Цель. Проанализировать распространенность и клинические проявления ОНМК у детей по материалам регистра Тюменской области.

Материалы и методы. В период с 2004 по 2020 г сформирован регистр детей в возрасте от 0 до 18 лет с ОНМК. Проводится мониторинг распространенности, этиологии.

Результаты и обсуждение. Зарегистрировано 72 случая ишемического инсульта (ИИ) $(28,8 \%$ от общего числа детей с ОНМК), 76 случаев геморрагического инсульта (ГИ) $(26,7 \%), 124(43,5 \%)$ транзиторных ишемических атак (ТИА), 2 (0,7\%) спинальных ишемических инсульта и 1 (0,4\%) геморрагический (СМГИ). Заболеваемость на 100000 детского населения ИИ составила 2, 1 случай, ГИ - 2,05, ТИА - 3,5. СМИИ - 0,05, СМГИ - 0,02. ИИ превалирует у мальчиков $(63,4 \%$ и $36,6 \%)$, как и ГИ $(53,9 \%$ и 46,1\%). ТИА, напротив, преобладает у девочек $(52,4 \%$ и 47,6\%). По возрасту, ИИ чаще встречался в дошкольном возрасте (76,8\%): до 1 г - 16 (19,5\%), от 1 до 3 л $-37(45,1 \%)$, от 4 до 7 л -10 (12,2\%), от 8 до 10 л- 4 (4,9\%), от 11 до 14 л - $5(6,1 \%)$, от 15 до 18 л - $10(12,2 \%)$. ГИ чаще зафиксирован на первом году жизни $-47(61,8 \%)$; от 1 до 3 л - $4(5,3 \%) ; 4-7$ л $6(7,9 \%) ; 8-10$ лет - 6 (7,9\%); 11-14 л - 6 (7,9\%); 15-18 л -7 (9,2\%). ТИА максимально диагностированы в пубертатном возрасте $(74,1 \%)$ : до 1 г - $1(0,8 \%)$, от 1 до 3 лет - 9 (7,3\%), от 4 до 7 лет - $10(8,1 \%)$, от 8 до 10 л - $12(9,7 \%)$, от 11 до 14 лет - $43(34,6 \%)$, от 15 до 18 л - 49 (39,5\%). Умерло 7 детей $(2,5 \%)$, из них $6(2,1 \%)$ с ГИ, 5 в возрасте до 1 года.

Заключение. Ведение регистра позволило уточнить в динамике распространенность, факторы риска, демографические и клинические показатели ОНМК у детей Тюменской области, а также способствовало разработке комплекса мероприятий по оптимизации экстренной помощи, планированию и эффективному распределению ограниченных ресурсов диагностической и лечебной помощи пациентам данной категории, обучению специалистов стандартизированному протоколу наблюдения за детьми. Знания причинно-следственной связи и последствий ОНМК послужат основой для профилактики данной патологии у детей. 
АНАЛИЗ КОГНИТИВНЫХ ФУНКЦИЙ У ДЕТЕЙ ПРИ МОНОТЕРАПИИ ЭПИЛЕПСИИ КАРБАМАЗЕПИНОМ ИЛИ ВАЛЬПРОЕВОЙ КИСЛОТОЙ

Носаль Л.А., Заболотских Т.В., Симонова Н.В., Анохина Р.A.

ФГБОУ ВО Амурская ГМА Минздрава России, Благовещенск

Введение. Известно, что некоторые базовые антиконвульсанты негативно влияют на когнитивный потенциал пациентов с эпилепсией. Естественно, что нагрузка самого заболевания и существующего эпилептического очага на высшую нервную деятельность снижает мнестические функции у ребенка, однако, учитывая прооксидантное действие антиконвульсантов и чрезвычайно высокую чувствительность мозга к оксидативному стрессу, анализ когнитивных функций у больных эпилепсией детей должен входить в обязательный диагностический минимум при проведении плановых обследований пациентов с данной нозологией.

Цель исследования - оценка когнитивных функций у больных эпилепсией детей, получавших карбамазепин или вальпроевую кислоту.

Материалы и методы. В ГАУЗ АО «Амурская областная детская клиническая больница» обследовано 2 группы больных эпилепсией детей 6-17 лет. В первой группе $(n=31)$ терапия проводилась карбамазепином, во второй $(n=25)$ - вальпроевой кислотой. Оценку когнитивных функций проводили при поступлении в стационар и на 6-й день наблюдения по методике Шульте с последующим анализом эффективности работы и степени врабатываемости; слуховая память оценивалась с помощью теста «10 слов». Результаты обрабатывались с использованием программы Statistica v.6,0 (Statsoft Inc., США).

Результаты. Монотерапия эпилепсии вальпроевой кислотой приводит к более выраженному снижению эффективности работы по сравнению с аналогичным параметром у детей, получавших карбамазепин (на 17\%), зарегистрировано ухудшение внимания, снижение степени врабатываемости. Также в группе вальпроевой кислоты при тестировании была ниже психическая устойчивость (на 11\%). В свою очередь, фактически идентичными были показатели оценки слуховой долговременной и кратковременной памяти, и если в отношении первого параметра полученные результаты входили в диапазон физиологической нормы, то значения второго параметра в обеих группах (4,5 $\pm 0,4$ слов, у пациентов, принимающих

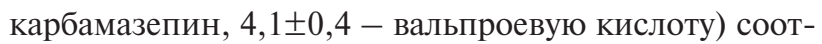
ветствовали расстройствам кратковременной памяти легкой степени.

Заключение. Тенденцию к снижению когнитивного потенциала у больных эпилепсией детей, принимающих базовые антиконвульсанты, более выра- женную при монотерапии вальпроевой кислотой, необходимо учитывать при проведении фармакологической коррекции побочных эффектов противоэпилептических препаратов.

\section{ВЛИЯНИЕ ДЕЛЬФИНОТЕРАПИИ НА НОРМАЛИЗАЦИЮ НЕЙРОМОДУЛЯТОРНОЙ И ГОРМОНАЛЬНОЙ СИСТЕМ У ДЕТЕЙ С РАССТРОЙСТВОМ АУТИСТИЧЕСКОГО СПЕКТРА}

Нуволи А.В. ${ }^{1}$, Каладзе Н.Н. ${ }^{2}$, Голубова Т.Ф. ${ }^{1}$

${ }^{1}$ ГБУЗ РК Научно-исследовательский институт детской курортологии, физиотерапии и медицинской реабилитации, Евпатория

ФГАОУ ВО «Крымский федеральный университет имени В.И. Вернадского», Медицинская академия имени С.И. Георгиевского, Симферополь

Введение. Расстройство аутистического спектра (РАС) является хроничеким и во многих случаях резистентным к терапии, что требует расширение круга специалистов, поиск генетических, биохимических особенностей, новых подходов к лечению и коррекции этого расстройства

Целью исследования явилась оценка влияния дельфинотерапии на моноаминергическую и гормональную системы у детей с расстройствами аутистического спектра.

Материалы и методы. Обследовано 47 детей с РАС в возрасте от 3 до 14 лет, которые составили общую группу (ОГ). Обследование включало осмотр специалистами, оценку в сыворотке крови серотонина, норадреналина и кортизола до и после проведенных комплексов лечения. I группа - 23 ребенка, получивших общее санаторно-курортное лечение (СКЛ); II группа - 24 ребенка, которые на фоне СКЛ получили курс дельфинотерапии (ДТ). ДТ проводилась на базе Евпаторийского дельфинария «Нептун» в заливе Донузлав. Сеансы ДТ проводились ежедневно, длительностью 20 минут, в количестве 8 процедур. Контрольную группу (КГ) составили 23 здоровых ребенка.

Результаты. В ОГ отмечалось достоверное снижение уровня серотонина и норадреналина и повышение кортизола $(p<0,01)$ в сравнении с КГ. В группах с тяжелой и средней степенью тяжести заболевания отмечено значимое $(p<0,05)$ снижение серотонина и норадреналина, повышение кортизола $(p<0,05)$ при умеренно выраженном аутизме относительно КГ, а также, значимое снижение серотонина $(p<0,01)$, норадреналина $(p<0,001)$ и повышение $(p<0,001)$ кортизола при тяжелой форме РАС. Значения серотонина и норадреналина в группах с тяжелой формой РАС были значимо ниже $(p<0,01)$, а кортизола значимо выше $(p<0,05)$ в сравнении с группой с умеренно выраженными симптомами заболевания.

После проведенного лечения отмечено, что общее СКЛ повышало уровень норадреналина и сни- 
жало содержание исходно повышенного кортизола при средней степени тяжести РАС и не оказывало существенного влияния при тяжелой степени. Показатели серотонина при данном комплексе лечения имели слабую положительную динамику. Применение в СКЛ курса ДТ существенно стимулировало синтез и выброс серотонина и норадреналина, снижало уровень кортизола при всех степенях тяжести.

Выводы. Установлена тесная взаимосвязь моноаминов и кортизола у детей с РАС и участие их в патогенетических механизмах заболевания. Включение в курс СКЛ дельфинотерапии способствует разрыву порочного круга и нормализацию взаимоотношений моноаминов и кортизола у детей с РАС.

\section{ХАРАКТЕРИСТИКА ВНУТРИЖЕЛУДОЧКОВЫХ КРОВОИЗЛИЯНИЙ У НОВОРОЖДЕННЫХ \\ Подлевских Т.С., Лежнина И.В., Беляков В.А., Токарев А. $H$. \\ ФГБОУ ВО Кировский ГМУ Минздрава России, Киров}

Введение. Внутрижелудочковые кровоизлияния (ВЖК) являются весьма серьезной проблемой, требующей пристального внимания исследователей.

Цель исследования - изучить распространенность, клинико-диагностические особенности и факторы риска внутрижелудочковых кровоизлияний (ВЖК) у новорожденных.

Материалы и методы. У 90 новорожденных проведен анализ историй болезни, проходивших стационарное лечение. ВЖК различной степени тяжести диагностировано по нейросонографии (НСГ).

Результаты. Распространенность ВЖК у новорожденных составила 6\%, у недоношенных 10\%. ВЖК: I ст. $6,7 \%$, II ст. $83,3 \%$, III ст. $10 \%$. До срока родились $85,6 \%$ детей (<28 нед. 10,3\%; 28-32 нед.57,4\%; 33-37 нед. 2,3\%). ВЖК І ст. у недоношенных составила 5,2\%, при этом большинство $(66,7 \%)$ детей родились $>32$ нед. с массой тела $>1800$ г. У большинства $(83,3 \%)$ отмечалась асфиксия. В 83,3\% ВЖК I ст. клинически было «немым». Преобладали дыхательные и метаболические нарушения. На НСГ ВЖК определялись как гиперэхогенные участки в перивентрикулярной зоне. Чаще всего диагностировано ВЖК II ст. (у доношенных 84,6\%, у недоношенных $83 \%) ; 36,4 \%$ родились $>41$ нед.; $60,2 \%$ имели гипотрофию. ИВЛ длительностью более 7 суток проводилась в $30,7 \%$ случаев. В 97,3\% ВЖК сочетались с нестабильной гемодинамикой. У 21,3\% были судороги, признаки внутричерепной гипертензии. НСГ: гиперэхогенные зоны в области герминативного матрикса с признаками вентрикуломегалии, кисты. ВЖК III ст. сформировались у детей с массой 760-1340 г., <29 нед. на фоне тяжелой асфиксии и в 84,4\% ВУИ, продолжительность ИВЛ более 2 недель, длительная инфузионная терапия. Клинически: нарушение мозговых и витальных функций, повторные судороги. НСГ: обширные гиперэхогенные области перивентрикулярной локализации, отсутствие визуализации бокового желудочка на стороне кровоизлияния, дилатация и деформация боковых желудочков. Факторы риска: асфиксия $(83,3 \%)$, внутриутробная инфекция.

Заключение. Тяжелые ВЖК развиваются преимущественно у крайне незрелых недоношенных с экстремально малой массой тела. Их формированию способствуют: асфиксия, инфекция, выраженная дыхательная недостаточность с длительной ИВЛ, нарушения центральной гемодинамики. В связи с «немым» течением ВЖК І ст. целесообразно проводить НСГ в раннем неонатальном периоде всем новорожденным с риском развития ВЖК независимо от срока гестации.

\section{ДОЛЯ, ПОЛОВО-ВОЗРАСТНЫЕ ХАРАКТЕРИСТИКИ И НАИБОЛЕЕ ЧАСТЫЕ МУТАЦИЙ ПРИ МОНОГЕННЫХ ЭПИЛЕПТИЧЕСКИХ ЭНЦЕФАЛОПАТИЯХ У ДЕТЕЙ}

Рахманина О.А., Волков И.В., Шестакова О.И., Волкова О.К., Беляев О.В., Панюкова И.В., Томенко Т.Р., Левитина Е.В., Лебедева Д.И.

ФГБОУ ВО Тюменский ГМУ Минздрава России, Тюмень Городской неврологический центр «Сибнейромед», Новосибирск

ФГБОУ ВО Омский ГМУ Минздрава России, Омск ФГБОУ ВО Волгоградский ГМУ Минздрава России, Волгоград

МАУ «Детская городская клиническая больница №9», Екатеринбург

Европейский медицинский центр «УГМК-Здоровье», Екатеринбург

ГАУЗ ТО «Областной лечебно-реабилитационный центр», Тюмень

Цель исследования - определение доли эпилептических энцефалопатий в общей структуре моногенных эпилепсий и эпилептических синдромов у детей и сравнительный анализ их основных полово-возрастных характеристик

Материалы и методы. Обработаны данные амбулаторных карт 138 детей (80 девочек, 58 мальчиков), средний возраст $6,7 \pm 5,3$ лет с установленными секвенированием последнего поколения генетическими мутациями и эпилепсией/эпилептической энцефалопатией. Пациенты для сравнения были разделены на 2 группы: моногенных эпилептических энцефалопатий (ЭЭ) - 77 детей, и моногенных эпилепсий -61 ребенок.

Результаты. Доля детей с эпилептическими энцефалопатиями в общей структуре моногенных эпилепсий и эпилептических синдромов составила 55,8\% (77 из 138 детей). Наиболее часто мутации при моногенных ЭЭ выявлялись в генах SCN1A 14\%, CDKL5 
9\% и РCDH19 6,5\%. В соотношении по полу среди детей с моногенными ЭЭ преобладали девочки 55\%, в группе моногенных эпилепсий девочки составили $62,3 \%(p=0,630)$. Средний возраст дебюта моногенных ЭЭ составил $1,1 \pm 1,0$ лет, а в группе моногенных эпилепсий $-2,2 \pm 2,1$ лет $(p=0,637)$.

Заключение. На сегодняшний день эпилептические энцефалопатии составляют большую часть среди моногенных эпилепсий и эпилептических синдромов с установленной мутацией. При этом по нашим данным, как и во всем мире, наиболее часто моногенные ЭЭ связаны с мутациями в гене SCN1A. В целом при диагностированных моногенных эпилепсиях/эпилептических энцефалопатиях преобладали девочки, но для моногенных эпилептических энцефалопатий характерен более ранний возраст дебюта.

\section{ЭКСАЙТОТОКСИЧЕСКОЕ ПОВРЕЖДЕНИЕ ГОЛОВНОГО МОЗГА У НЕДОНОШЕННЫХ ДЕТЕЙ: ПРОГНОСТИЧЕСКАЯ ЦЕННОСТЬ БИОМАРКЕРОВ ГЛУТАМАТ ОПОСРЕДОВАННОГО ПОВРЕЖДЕНИЯ}

Савченко О.А., Павлинова Е.Б., Полянская Н.А., Губич А.А., Паладий Е.E.

ФГБОУ ВО «Омский государственный медицинский университет» Минздрава России, Омск

Введение. Эксайтотоксичность - основной механизм повреждения олигодендроцитов в развивающемся мозге, опосредуемый через популяцию глутаматергических ионотропных рецепторов. Прогностическая значимость пептида и антител к фрагментам глутаматных рецепторов в оценке тяжести гипоксического повреждения ЦНС у недоношенных новорожденных - предмет настоящего исследования.

Цель исследования - установить диагностическую значимость биомаркеров эксайтотоксического повреждения ЦНС у недоношенных детей.

Материалы и методы. В исследование включены 24 ребенка с ГВ 28-34 недель и массой тела 10002000 гр., получавших лечение в БУЗОО ГКПЦ г.Омск. Новорожденные разделены по группам: группа 1 дети с ЗВУР $(n=8)$ и группа 2 - без ЗВУР $(n=16)$. Проводился забор пуповинной крови для определения уровня пептида NR2 субъединицы NMDA рецептора и венозной крови на 21 день жизни для определения антител к NR2 субъединице NMDA и GluR1 субъединице AMPA рецептора глутамата.

Результаты. У новорожденных 1 группы установлены высокие значения уровня пептида пуповинной крови $(0,041$ нг/мл $[0,014 ; 0,113]$ и 0,030 нг/мл $[0,008 ; 0,048]$ соответственно) $(\mathrm{U}=22,0 ; p=0,013)$. Новорожденные со значением лактата крови 2,95-7,8 ммоль/л имели пограничные значения RI сосудов головного мозга $-0,795$
$(\mathrm{CKO}=0,084)$ и высокие значения уровня антител K NR2 субъединице NMDA рецептора на 21 день жизни $-0,987$ нг/мл $(\mathrm{CKO}=0,360)$. У новорожденных с поражением ЦНС на 21 сутки жизни получены статистически значимые высокие показатели уровня антител к NR2 субъединице NMDA рецептора $(1,24$ нг/мл $[0,98 ; 1,36]$ и 0,29 нг/мл $[0,19$; $0,50]$ соответственно) ( $\mathrm{U}=6,0 ; p=0,006)$ и антител к субъединице GluR1 AMPA рецептора (0,53 нг/мл $[0,48 ; 0,64]$ и 0,22 нг/мл[0,198; 0,27$]$ соответственно) $(\mathrm{U}=1,0 ; p=0,001)$, чем у новорожденных без поражения ЦНС.

Заключение. Эксайтотоксическое поражение ЦНС у недоношенных новорожденных с ЗВУР происходит внутриутробно. Определение компонентов глутаматергической системы ЦНС у недоношенных новорожденных возможно имеет диагностическую и прогностическую значимость.

\section{ОСОБЕННОСТИ ПОСТУРАЛЬНОГО ТРЕМОРА ПРИ НАРУШЕНИИ МОТОРНОГО РАЗВИТИЯ У ДЕТЕЙ ПЕРВОГО ГОДА ЖИЗНИ \\ Самсонова Т.В., Назаров С.Б., Чистякова А.А., \\ Рыльская Ю.А. \\ Федеральное государственное бюджетное учреждение «Ивановский научно-исследовательский институт материнства и детства им. В.Н. Городкова» Минздрава России, Иваново}

Введение. Ранняя диагностика двигательных нарушений у детей первого года жизни затрудняется вследствие физиологической незрелости и возрастных особенностей развивающегося мозга. В данной ситуации особое значение приобретает объективная оценка последовательного освоения ребенком первых антигравитационных поз.

Цель исследования - выявление особенностей постурального тремора при удержании первых антигравитационных поз у детей первого полугодия жизни с нарушением моторного развития и диагностической значимости треморографических показателей.

Материалы и методы. В исследование включено 43 ребенка в возрасте 3-5 месяцев. Основную группу составили дети с последствиями перинатального поражения нервной системы в виде нарушения моторного развития $(n=33)$, контрольную - без неврологической патологии $(n=10)$. Всем детям проводились неврологическое обследование в динамике; исследование постурального тремора в позе лежа на животе с опорой на предплечья и удержанием головы по средней линии, с установкой на область шейного отдела позвоночника микроэлектромеханического сенсора, оснашенного акселерометром и гироскопом. Определялись показатели частоты тремора и его амплитуды по трем взаимно перпендикулярным осям X, Y и Z. 
Результаты. У детей с нарушением моторного развития амплитуда постурального тремора по осям X, Y и Z была выше, чем в контрольной группе ( $p=0,0001)$. При проведении индивидуального и ROC-анализа установлена высокая диагностическая значимость этого показателя. Показатель площади под ROCкривой составил 1,0, что свидетельствует о высокой специфичности предложенного критерия. На основании этого разработан способ диагностики нарушения моторного развития у детей в возрасте $3-5$ месяцев (Приоритетная справка по заявке на изобретение № 2021110391 от 14,04,2021).

Заключение. Для детей с нарушением моторного развития в возрасте 3-5 месяцев характерно повышение амплитуды постурального тремора при удержании первых антигравитационных поз. Данный показатель может служить дополнительным объективным критерием для повышения точности диагностики нарушения моторного развития в первом полугодии жизни.

\section{ОЦЕНКА НЕКОТОРЫХ ГЕМАТОЛОГИЧЕСКИХ ПАРАМЕТРОВ ПРИ МОНОТЕРАПИИ ЭПИЛЕПСИИ У ДЕТЕЙ}

Симонова Н.В., Заболотских Т.В., Носаль Л.А., Анохина Р.A.

ФГБОУ ВО Амурская ГМА Минздрава России, Благовещенск

Введение. Монотерапия эпилепсии у детей базовыми антиконвульсантами (карбамазепин, вальпроевая кислота), обладающими прооксидантным действием и, следовательно, индуцирующими развитие побочных эффектов, сопровождается изменениями со стороны системы крови, что было продемонстрировано в ряде работ и свидетельствует о необходимости оценки гематологических параметров у больных эпилепсией детей, получающих противоэпилептические препараты.

Цель исследования - оценка некоторых гематологических показателей при монотерапии эпилепсии у детей.

Материалы и методы. В ГАУЗ АО «Амурская областная детская клиническая больница» обследовано 2 группы больных эпилепсией детей 6-17 лет (27 мальчиков и 29 девочек). В первой группе $(n=31)$ терапия проводилась карбамазепином, во второй группе $(n=25)$ - вальпроевой кислотой (депакин). Контрольная группа - 20 здоровых детей, сопоставимых по полу и возрасту. Забор крови производили в 1-й и 6-й день наблюдения. Параметры клинического анализа крови определяли общепринятыми методами с использованием счетной камеры Горяева. Статистическую обработку результатов проводили с использованием критерия Стъюдента (t), результаты считали достоверными при $p<0,05$.

Результаты. Монотерапия карбамазепином способствовала снижению количества эритроцитов на $6 \%$ (1-й день) и 9\% (6-й день) в сравнении с аналогичным параметром у детей контрольной группы, гемоглобина - на $7 \%$ и $10 \%$ соответственно, тромбоцитов на $17 \%$ и $28 \%(p<0,05)$. Лечение больных эпилепсией детей вальпроевой кислотой привело к снижению содержания эритроцитов в 1-й день наблюдения на $9 \%$ и $11 \%$ - 6-й день, гемоглобина - на 6-7\%, тромбоцитов - на $21 \%$ и $31 \%$ соответственно $(p<0,05)$.

Заключение. Оценка некоторых параметров клинического анализа крови у больных эпилепсией детей свидетельствует о необходимости включения на стационарном этапе в комплексную терапию фармакокорректоров, нивелирующих отрицательную динамику содержания гематологических показателей, особенно тромбоцитарного звена, что позволит снизить риск развития осложнений противоэпилептической терапии.

\section{ДИАГНОСТИКА НЕЙРОИММУННЫХ НАРУШЕНИЙ У ДЕТЕЙ РАННЕГО ВОЗРАСТА С ЭПИЛЕПСИЕЙ}

Созаева Д.И., Бережанская С.Б., Афонин А.А., Пузикова О.З., Попова В.А.,

Каушанская Е.Я.

ФГБОУ ВО РостГМУ Минздрава России, Ростов-на-Дону

Введение. Возникновение пароксизмальных деполяризационных сдвигов с образованием патологических интеграций и фокуса усиленного возбуждения является характерным признаком эпилептизации нейронов с активацией натриево-кальциевых каналов. Формирующиеся, вследствие нарушения резистентности гематоэнцефалического барьера циркулирующие нейроантитела, поддерживают нейрональную активацию и эпилептиформную активность клеточных структур головного мозга путем нарушения межнейрональной передачи и создания зон дополнительной повышенной ирритации.

Цель исследования - диагностика нейроиммунных нарушений у детей раннего возраста с различными формами эпилепсии.

Материалы и методы. Под наблюдением находились 150 новорожденных и детей грудного возраста с различными формами эпилепсии. Контрольную группу составили 30 здоровых детей аналогичного возраста, рожденных при физиологически протекавших беременности и родах. Всем детям в возрасте 1-3 и 6 месяцев жизни проводилось исследование уровня антител к основному белку миелина (ОБМ) и антител к миелинассоциированному гликопротеину (MAG) методом иммуноферментного анализа с использованием тест-систем фирмы Buhlmann (Германия).

Результаты. Выявлено, что если концентрация антител к ОБМ составляет 1,5 условных единиц оптической плотности и выше, а антител к MAG 172,4 пг/мл и выше, то это является высокоинфор- 
мативным признаком возникновения нейроиммунного конфликта, способствуя, в свою очередь, нарушению функционирования межнейрональных сетей и/или синаптической передачи, что, в конечном итоге, может быть сопряжено с утяжелением течения основного заболевания и формированием рефрактерности к терапии.

Заключение. Своевременная, в первые 6 месяцев жизни, диагностика возникновения нейроиммунных нарушений у детей раннего возраста с различными формами эпилепсии, несомненно, будет способствовать оптимизации и коррекции лечебно-диагностической тактики, купированию судорожного синдрома и улучшению общего прогноза течения заболевания.

\section{ВОЗРАСТ НАЧАЛА ПРИСТУПОВ И КАРТИНА НАРУШЕНИЯ ПСИХИЧЕСКОГО РАЗВИТИЯ У ДЕТЕЙ С ЦЕРЕБРАЛЬНЫМИ ПАРОКСИЗМАМИ В АНАМНЕЗЕ \\ Туровская Н.Г., Раевская Л.Г., Завражнова А.Б., Михайленко Е.В. \\ ФГБОУ ВО ВолгГМУ Минздрава России, ГБУЗ ВОДКПБ, Волгоград}

Введение. Актуальность изучения особенностей психического развития детей с церебральными пароксизмальными состояниями определяется необходимостью поиска стратегий оказания им адекватной медико-психологической помощи.

Цель исследования - изучение связи между возрастом начала приступов в истории болезни и особенностями психического развития детей с церебральными пароксизмами в анамнезе.

Материалы и методы. В исследовании приняли участие 54 ребенка в возрасте от 6 до 8 лет, имевшие в анамнезе различные по этиопатогенетическому признаку церебральные пароксизмальные состояния. В качестве экспериментально-психологических методов исследования использовались методы нейропсихологический диагностики высших психических функций у детей (Цветкова, 2002), диагностический комплекс «Прогноз и профилактика проблем обучения в школе» (Ясюкова, 2002). Статистический анализ был проведен с помощью компьютерной программы анализа статистических данных SPSS.

Результаты. Анализ результатов исследования с помощью коэффициента корреляции Спирмена показал, что чем позже в онтогенезе ребенка начинаются приступы, тем реже они сопровождаются нарушениями развития слухового $(\rho=0,293 ; p=0,043)$ и фонематического восприятия ( $\rho=0,334 ; p=0,020)$, активного внимания $(\rho=0,349 ; p=0,015)$, кратковременной речевой памяти $(\rho=0,450 ; p=0,001)$, всех видов мышления (визуального линейного ( $\rho=0,337$; $p=0,022), \quad$ визуального структурного $\quad(\rho=0,402$; $p=0,006), \quad$ понятийного интуитивного $\quad(\rho=0,364$; $p=0,014), \quad$ понятийного логического $\quad(\rho=0,354$; $p=0,017)$, понятийного речевого $(\rho=0,361 ; p=0,015)$, понятийного образного $(\rho=0,359 ; p=0,015))$. Чем позже в анамнезе начинаются приступы, тем менее выражены у больных лабильность $(\rho=0,378 ; p=0,007)$ и пресыщаемость $(\rho=0,371 ; p=0,008)$ психической деятельности, и, напротив, более выражены снижение скорости переработки информации ( $\rho=0,365$; $p=0,016)$ и явления амнестической афазии $(\rho=0,298$; $p=0,038)$.

Дисперсионный анализ выявил наличие прямой статистически значимой связи между возрастом начала приступов и уровнем развития у ребенка слухового восприятия $(\mathrm{F}=3,263 ; p=0,030)$, кратковременной речевой памяти $(\mathrm{F}=5,312 ; p=0,003)$, визуального линейного мышления $(\mathrm{F}=3,272 ; p=0,030)$, крупной и мелкой моторики $(\mathrm{F}=4,111 ; p=0,012)$.

Заключение. Результаты исследования показали, что более раннее начало церебральных пароксизмов в истории болезни ребенка сопровождается более выраженной тотальностью нарушения его психического развития.

\section{ШИЗОФРЕНОПОДОБНАЯ СИМПТОМАТИКА У РЕБЕНКА СО СТРУКТУРНОЙ ФОКАЛЬНОЙ ЭПИЛЕПСИЕЙ (АНАЛИЗ КЛИНИЧЕСКОГО СЛУЧАЯ)}

Туровская Н.Г., Раевская Л.Г., Завражнова, А.Б., Михайленко Е.В.

ФГБОУ ВО ВолгГМУ Минздрава России, ГБУЗ ВОДКПБ, Волгоград

Введение. Изучение особенностей психического онтогнеза детей с различной церебральной патологией важно с целью дифференцированного оказания им клинико-психологической помощи.

Цель исследования - изучение картины психического развития у ребенка со структурной фокальной эпилепсией.

Материалы и методы. За консультацией к нейропсихологу обратилась мама мальчика 5 лет 11 месяцев с жалобой на нарушения в поведении и развитии ребенка. В ходе сбора анамнестических сведений выяснилось, что ребенок перенес геморрагическую болезнь новорожденных. В 2,5 года у мальчика дебютировали церебральные пароксизмы в виде приступов страха, позже появились эпизоды внезапного крика по утрам. Результаты ЭЭГ (в динамике): «... Эпилептиформная активность в лобно-височноцентральных отделах левого полушария...». Результаты МРТ головного мозга: «В оперкулярной области левого полушария выявляется обширная зона глиозно-атрофических изменений с заместительным расширением левого бокового желудочка (последствия острого нарушения мозгового кровообращения (далее - ОНМК) в бассейне левой средней мозговой 
артерии (далее - CMA))». Пациенту был выставлен диагноз: «Структурная фокальная (левополушарная) эпилепсия. Последствия ОНМК в левой СМА» и назначено противоэпилептическое лечение, на фоне которого была достигнута медикаментозная ремиссия. С ребенком было проведено нейропсихологическое и патопсихологическое обследование.

Результаты. В ходе исследования у пациента было выявлено выраженное отставание в развитии регуляторных функций, динамического и кинестетического праксиса на фоне незначительной задержки или возрастно-нормативного развития других высших корковых функций. Мыслительные и речевые процессы сформированы в соответствии с возрастной нормой. Выявились значительные нарушения целенаправленности мыслительных процессов по типу разорванности, обилие неологизмов - в речи («Враги чутьчуть есть - Шерлок, Шерлин, Шурин...Франдер, это французский враг.. мечтает стать таким же вракови (неологизм)»), приступы негативизма и дурашливость - в поведении на фоне отсутствия избегания зрительного и тактильного контакта, стремления к взаимодейтсвию с детьми и взрослыми, доброжелательности и синтонности в общении.

Заключение. Можно предположить, что шизофреноподобная симптоматика при структурной фокальной (левополушарной) эпилепсии характеризуется отсутствием признаков аутизации.

\section{ДИАГНОСТИКА НАРУШЕНИЙ МОЗГОВОГО КРОВООБРАШЕНИЯ У НЕДОНОШЕННЫХ ДЕТЕЙ С ПЕРИНАТАЛЬНЫМ ГИПОКСИЧЕСКИ- ИШЕМИЧЕСКИМ ПОРАЖЕНИЕМ ГОЛОВНОГО} МОЗГА

Шимченко Е.В., Клещенко Е.И.

ФГБОУ ВО Кубанский ГМУ Минздрава России, Краснодар

Введение. Воздействие гипоксии в перинатальном периоде приводит к существенным нарушениям мозгового кровообращения у детей, проявляющимся в дальнейшем необратимыми структурными изменениями нервной ткани. Особое значение для обнаружения гипоксически-ишемических повреждений головного мозга имеет использование такого высоко- технологичного метода диагностики, как магнитнорезонансная томография (МРТ).

Цель исследования - провести анализ показателей магнитно-резонансного исследования структур головного мозга для ранней диагностики нарушений мозгового кровообращения у недоношенных детей, перенесших воздействие гипоксии в перинатальном периоде.

Материалы и методы. В исследование включены 40 недоношенных новорожденных (гестационный возраст 29-37 недель), получавших интенсивную терапию по поводу тяжелой асфиксии и/или внутриутробной гипоксии в краевом перинатальном центре ДККБ г. Краснодара. У всех детей на 2-10 сутки жизни проведена МРТ головного мозга в режиме диффузионно-взвешенных изображений (ДВИ). Наблюдение за детьми осуществлялось до трехлетнего возраста.

Результаты. Проведенное исследование позволило выделить три типа гипоксически-ишемического повреждения структур головного мозга у недоношенных новорожденных по данным МРТ: 1-й тип последствия острого нарушения мозгового кровообращения в результате острой антенатальной гипоксии плода, выявленные у 12 (30,0\%) детей и проявляющиеся диффузным понижением сигнальных характеристик на ДВИ; 2-й тип - последствия хронического нарушения мозгового кровообращения в результате хронической внутриутробной гипоксии плода, выявленные у 17 (42,5\%) детей и проявляющиеся очагами повышения сигнальных характеристик в перивентрикулярных областях на ДВИ; 3-й тип - последствия острого нарушения мозгового кровообращения в результате острой интранатальной гипоксии плода, выявленные у $11(27,5 \%)$ детей и проявляющиеся диффузным повышением сигнальных характеристик на ДВИ. В дальнейшем у всех детей с острым нарушением мозгового кровообращения, отразившимся изменением сигнальных характеристик на ДВИ, сформировался неврологический дефицит.

Заключение. Ранняя диагностика нарушений мозгового кровообращения, приводящих к формированию неврологических нарушений у детей, способствует своевременному проведению лечебных и реабилитационных мероприятий на основе объективной оценки выявленных нарушений. 


\section{Раздел 9}

\section{ПУЛЬМОНОЛОГИЯ}




\section{ЗНАЧИМОСТЬ ОПРЕДЕЛЕНИЯ С- РЕАКТИВНОГО БЕЛКА И ЦИТОКИНОВ У НОВОРОЖДЕННЫХ С ВРОЖДЕННОЙ ПНЕВМОНИЕЙ \\ Абдурахманова Ф.Р., Салихова К.Ш., Ииниязова Н.Д. Республиканский специализированный научно - практический медицинский центр педиатрии, Узбекистан, Ташкент}

Введение. Врожденная пневмония является одной из основных причин высокой заболеваемости и смертности новорожденных детей. Возникновению этих пневмоний способствует недостаточность получаемых от матери факторов иммунитета и «физиологическая иммунодефицитность» новорожденного, затрагивающая механизмы врожденного иммунитета. Большое диагностическое значение отводится определению содержания С-реактивного белка (СРБ) и цитокинов.

Цель исследования - изучить содержание СРБ, интерлейкина- 6 (ИЛ-6) и фактора некроза опухоли (ФНО- $\alpha$ ) у новорожденных с врожденной пневмонией.

Материалы и методы. Обследовано 54 новорожденных с подтвержденной врожденной пневмонией, находившихся в ОРИТ новорожденных РСНПМЦ педиатрии. На основании гестационного возраста эти дети разделены на 2 группы. В 1 группу вошли 28 недоношенных новорожденных, во $2-26$ доношенных новорожденных. Контрольную группу составили 20 здоровых доношенных новорожденных. Всем детям проводилось определение содержания в крови СРБ, ИЛ-6 и ФНО- $\alpha$ на 3-и и 7-е сутки жизни методом ИФА.

Результаты. Оценка системной воспалительной реакции показала, что в 1 группе повышение СРБ отмечалось в 50,0\% случаев, во 2 группе у 77,9\% младенцев. Содержание ИЛ-6 в 1 группе младенцев на 3-и сутки было повышенным в 3,9 раза, во второй - в 4,6 раза относительно контрольной группы. У новорожденных 1 группы отмечалось повышение содержания ФНО- $\alpha$ в 6 раз, во 2 группе - в 6,9. Исследование уровня цитокинов на 7-е сутки жизни у обеих групп новорожденных показало снижение их концентрации, но при этом оставалось повышенным, по сравнению с контролем. Уровень ИЛ-6 снизился в 1 группе в 1,8, а во 2 группе - в 2,3раза. Уровень содержания ФНО- $\alpha$ в 1 группе новорожденных снизился в 2,8, во 2 группе $-3,1$ раза.

Заключение. При врожденной пневмонии иммунная система недоношенных детей, как и доношенных способна к более высокой продукции СРБ и провоспалительных цитокинов, но у недоношенных новорожденных она относительно низкая, за счет незрелости системы врожденного иммунитета.

\section{ИЗМЕНЕНИЕ ЦИТОКИНОВОГО ПРОФИЛЯ В СЫВОРОТКЕ КРОВИ У ДЕТЕЙ, ПЕРЕНЕСШИХ ОСТРЫЙ БРОНХИОЛИТ}

Анджель А.Е., Бережанский П.В., Русакова В.А., Доброток А. B.

ГБУЗ «Морозовская ДГКБ ДЗМ», Москва

Введение. Бронхиолит является нередким проявлением инфекции нижних дыхательных путей у детей в возрасте до 9 месяцев. Степень тяжести течения и выраженности патогенетических проявлений бронхиолита у детей зависит в первую очередь от причинного вирусного агента, а также от иммунологической реактивности. Ведущая роль в регулировании тканевого гомеостаза и межклеточного взаимодействия в легочной ткани при бронхиолите отводится цитокинам.

Цель исследования - выявить особенности цитокинового профиля в сыворотке крови у пациентов с острым бронхиолитом.

Материалы и методы. В исследование было включено 36 детей в возрасте от 0 до 9 месяцев с установленным клиническим диагнозом острый вирусный бронхиолит. Забор крови для определения концентрации цитокинов методом ИФА производился в остром периоде заболевания.

Результаты. Выявленные этиологические факторы бронхиолита соответствуют международным данным: респираторно-синцитиальный вирус $70 \%$, риновирус $14,2 \%$, вирус парагриппа 9\%, метапневмовирус 6,5\%, бокавирус $1,3 \%$, из которых коинфекция установлена у $15 \%$ детей. У пациентов без дыхательной недостаточности (ДН) концентрация ИЛ-4 в сыворотке состав-

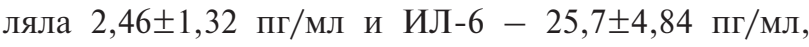

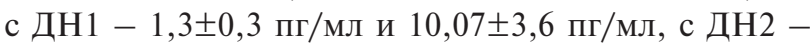

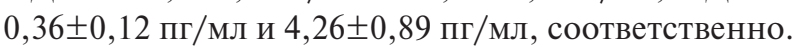

Заключение. Полученные результаты свидетельствуют о наличии связи между степенью ДН и концентрациями цитокинов в сыворотке крови: снижение ИЛ-4 и ИЛ-6 при нарастании тяжести течения заболевания. Пациенты с коинфекцией дольше находились на стационарном лечении и имели более высокие показатели интерлейкинового профиля. Таким образом, уровень цитокинов может быть маркером тяжести инфекционного бронхиолита, что может помочь определиться с дальнейшей тактикой ведения пациентов и улучшить клинические исходы. 


\section{ОСОБЕННОСТИ ТЕЧЕНИЯ БРОНХИАЛЬНОЙ} АСТМЫ НА ФОНЕ COVID-19 У ДЕТЕЙ

Байрамова И.А., Гуменюк О.И., Черненков Ю.В.,

Балашова Е.В.

СГМУ им. В.И. Разумовского, Саратов

Введение. По имеющимся данным, дети болеют COVID-19 реже, чем взрослые, и с менее выраженной клинической симптоматикой. Наиболее частыми симптомами новой коронавирусной инфекции у детей являются лихорадка, непродуктивный кашель, возможно появление признаков интоксикации (миалгии, тошнота, слабость). У некоторых детей отмечаются фариналгии, заложенность носа, симптомы поражения желудочно-кишечного тракта (боли в животе, диарея, рвота), «ковидные» пальцы (отек, гиперемия с цианозом, как при обморожении). Патогномоничный для COVID-19 у взрослых симптом гипосмии/аносмии и/или дисгевзии отмечается и у детей, однако активных жалоб они в силу возраста не предъявляют (Клинические рекомендации М3 PФ, 2020). Изучение особенностей течения COVID19 у детей на морбидном фоне - актуальная проблема педиатрии.

Цель. Описание двух клинических случаев с особенностями течения новой коронавирусной инфекции (COVID-19), вызываемое коронавирусом SARS$\mathrm{CoV}-2$ у детей на фоне бронхиальной астмы (БА).

Пациенты и методы. Проведен анализ историй болезней двух клинических случаев COVID19 (у мальчиков 2004 и 2015 г.р.) с БА, атопическая форма, персистирующее течение.

Результаты. При анализе историй болезней установлено, что заражение новой коронавирусной инфекцией произошло от родителей (матери). COVID-19 был подтвержден лабораторным методом ПЦР. Среди клинических симптомов отмечались симптом интоксикации, повышение температуры тела до фебрильных цифр, усиление кашля, шумное свистящее дыхание. У ребенка 2020 г.р. было отмечена дисгевзия. После перенесенной COVID-19 родители отмечали у детей ухудшение памяти, концентрации внимания, слабость. Особенностью течения БА на фоне COVID-19 в данных клинических случаях явилось развитие двухсторонней очаговой пневмонии, что потребовало назначения антибактериальной терапии, усиления бронхолитической и включение ноотропной терапии.

Выводы. Сопутствующее заболевание неконтролируемой БА приводит к более тяжелому течению. Согласно GINA 2021, всем пациентам с БА, особенно в период пандемии новой коронавирусной инфекции COVID-19, важно выполнять контроль БА, что снижает риск обострения основного заболевания и развития инфекционных заболеваний.

\section{КОРРЕКЦИЯ ПИТАНИЯ У ДЕТЕЙ ШКОЛЬНОГО ВОЗРАСТА, СТРАДАЮЩИХ МУКОВИСЦИДОЗОМ, В ЗАВИСИМОСТИ ОТ ЭЛЕМЕНТНОГО ГОМЕОСТАЗА}

Белаш Т.А., Водовозова Э.В., Леденева Л.Н., Енина Е.А., Пустабаева М.С.

ФГБОУ ВО «Ставропольский государственный

медицинский университет» МЗ РФ, Ставрополь

Введение. Муковисцидоз (МВ) - неизлечимое заболевание, диктующее необходимость диспансерного наблюдении и непрерывной терапии в течение всей жизни, причем терапия не ограничивается рамками медикаментозного лечения, включает также продукты питания содержащие элементы необходимые для нутрицевтической коррекции.

Цель исследования: провести анализ микроэлементного гомеостаза у детей школьного возраста, страдающих МВ, с целью диетической его коррекции.

Материалы и методы. В исследовании принимали участие 23 ребенка школьного возраста, страдающие $\mathrm{MB}$, проживающие в Ставропольском крае (СК). Все пациенты наблюдаются в Региональном центре МВ г. Ставрополя. Для определения элементов в биосубстратах использованы два метода анализа: ИСП-АЭС и ИСП-МС в лаборатории АНО «Центр биотической медицины», аккредитованной в Федеральном центре госсанэпиднадзора при МЗ РФ, г. Москва. Контролем служили нормативы у здоровых детей.

Результаты. У школьников СК, страдающих МВ, уровень $\mathrm{Al}^{+3}, \mathrm{As}^{+5}, \mathrm{Be}^{+2}, \mathrm{Cd}^{+2}, \mathrm{Co}^{+8}, \mathrm{Cu}^{+}, \mathrm{Fe}^{+2}, \mathrm{Hg}^{+2}$, $\mathrm{I}^{+7}, \mathrm{Li}^{+}, \mathrm{Mn}^{+7}, \mathrm{Ni}^{+8}, \mathrm{P}^{+5}, \mathrm{~Pb}^{+4} \mathrm{Se}^{+6}, \mathrm{Sn}^{+4}$ и $\mathrm{V}^{+5}$ ниже, чем в контрольной группе, а уровень $\mathrm{B}^{+3}, \mathrm{Ca}^{+2}, \mathrm{Cr}^{+6}, \mathrm{~K}^{+}$, $\mathrm{Mg}^{+2}, \mathrm{Na}^{+}, \mathrm{Si}^{+4}$ и $\mathrm{Zn}^{+2}$ - выше, чем у здоровых сверстников, что позволяет рекомендовать диету, включающую крупы (пшенная, гречневая, овсяная, кукурузная, отруби), макароны, мясные продукты (говядина, говяжья печень), морские продукты (печень трески, креветки, кальмары, скумбрия, горбуша, морская капуста, морская соль, мидии, устрицы, лангусты), яйца, молочные продукты (молоко, сливочное масло, сыр), фрукты, сухофрукты овощи. Потребление продуктов, содержащих $\mathrm{B}^{+3}, \mathrm{Ca}^{+2}, \mathrm{Cr}^{+6}, \mathrm{~K}^{+}, \mathrm{Mg}^{+2}, \mathrm{Na}^{+}, \mathrm{Si}^{+4}$ и $\mathrm{Zn}^{+2}$, наоборот, следует уменьшить. К ним относятся: соленое масло, или маргарин, все виды сыров, бекон, копченое мясо, мясо кролика, окорок, сосиски, колбасы, солонина, консервированное мясо, студень, мясные и рыбные полуфабрикаты, жареные и соленые орехи, любые промышленные соусы, подливки, кетчупы, бульонные кубики, чипсы, сухарики, какао, рис, овсяная мука, горох, фасоль, кунжут.

Заключение. Питание школьников СК, страдающих МВ, необходимо коррегировать, исходя из изменений в их элементном гомеостазе. 


\section{ХАРАКТЕРИСТИКА РАННЕГО}

БАКТЕРИОЛОГИЧЕСКОГО СТАТУСА ДЕТЕЙ С БРОНХОЛЕГОЧНОЙ ДИСПЛАЗИЕЙ

Брыксина Е.Ю., Летифов Г.М., Панова И.В.,

Давыдова Н.А., Домбаян С.Х., Лазарев А.Н.

ФГБОУ ВО Ростовский государственный медицинский университет Минздрава России, Ростов-на-Дону

Введение: Одним из факторов, отягощающих течение бронхолегочной дисплазии (БЛД), является инфекционный процесс, в связи с чем, актуальным является изучение микробиологического спектра у недоношенных детей с инфекционно-воспалительной патологией на фоне БЛД.

Цель исследования: определить особенности раннего бактериологического статуса у недоношенных детей с различной тяжестью течения БЛД.

Материалы и методы: обследовано 157 недоношенных детей, рожденных в сроке гестации от 27 до 36 недель и массой тела от 690 до 2900 граммов. Диагноз БЛД устанавливался согласно критериям, предложенным Job и Bancalari, степень тяжести БЛД определялась в соответствие с классификацией клинических форм бронхолегочных заболеваний у детей. Оценка инфекционного статуса проводилась посредством изучения антенатального анамнеза, бактериологического исследования трахеобронхиального аспирата, мазков из зева, а также серологического исследования сыворотки крови. При статистической обработке использовался пакет программ «Statistica $10 »$.

Результаты: анализ антенатального анамнеза выявил, что у $86 \%$ матерей, дети которых родились недоношенными и развили БЛД, отягощен инфекционный анамнез. Так у $67 \%$ имели место инфекции мочеполовой сферы, в $41 \%$ случаев - инфекционновоспалительные процессы в бронхолегочной системе и ротоглотке. Патологическое течение беременности: хроническая фетоплацентарная недостаточность, анемия, угроза прерывания на разных сроках гестации присутствовали у всех женщин, хорионамнионит был выявлен в 29\% случаев, длительный безводный промежуток - в $43 \%$ случаев. Согласно данным бактериологического исследования, контаминация слизистой зева, трахеобронхиального аспирата была представлена следующим микробиологическим спектром: Staphylococcus epidermidis - 46\%, Staphylococcus aureus - 12\%, Klebsiella pneumonia $23 \%$, Enterobacter $-11 \%$, E. coli $-8 \%$, Pseudomonas aeruginosae $-16 \%$, Candida albicans $-35 \%$. Как показало серологическое исследование, сероконверсия имела место в случае Chlamydia trachomatis - у 49\%, Ureaplasma urealyticum - y 26\%, Mycoplasma hominis - у $31 \%$ детей. Отмечено, что наиболее тяжелое течение БЛД было ассоциировано с Klebsiella pneumonia, Enterobacter, Pseudomonas aeruginosae и Ureaplasma urealyticum.
Заключение: Таким образом, для всех детей с БЛД характерен отягощенный инфекционный анамнез с разнообразной бактериальной контаминацией. Сочетание грамотрицательной микробиоты и Ureaplasma urealyticum, является прогностически наиболее неблагоприятным и сопровождающееся более тяжелым течением БЛД.

\section{ЭТИОЛОГИЧЕСКАЯ СТРУКТУРА И КЛИНИЧЕСКИЕ ПРОЯВЛЕНИЯ ВНЕБОЛЬНИЧНОЙ ПНЕВМОНИИ У ПОДРОСТКОВ}

Бурлуцкая А.В., Савельева Н.В.

ФГБОУ ВО «Кубанский государственный медицинский университет» Минздрава России, Краснодар.

Введение. Острая патология нижних отделов дыхательных путей является актуальной социальной проблемой медицины в целом. Заболеваемость внебольничной пневмонией в регионах составляет от 5 до 17 случаев на 1000 детского населения в год.

Цель исследования: изучить этиологическую структуру и клинические проявления внебольничной пневмонии у детей подростков.

Материалы и методы. Методом случайной выборки проведен анализ медицинских карт (форма 003/у) 62 стационарных больных с диагнозом внебольничная пневмония, находящихся на обследовании и лечении в ГБУЗ «Детской городской клинической больницы города Краснодара» МЗ КК в период 2018-2019 гг.

Результаты. В исследование вошли подростки от 10 до 17 лет, средний возраст - 13 лет( \pm 2$)$. Преимущественно дети были в возрасте 10-13 лет $(64,5 \%)$, а 14-17-летних оказалось $35,5 \%$. Мальчиков было больше $-56,5 \%$, чем девочек $(43,5 \%)$.

До госпитализации пиретическая лихорадка (более $39^{\circ} \mathrm{C}$ ) выявлена в $12,9 \%$ случаев, фебрильная лихорадка $\left(38-39^{\circ} \mathrm{C}\right)-50 \%$, субфебрильное повышение температуры $(37-38$ C) - у 37,1 \%. Кашель беспокоил почти всех больных $(95,2 \%)$, в $85 \%$ случаев он был малопродуктивным и редким. Признаки дыхательной недостаточности выявлены у 6 подростков $(9,5 \%)$. При объективном осмотре и рентгенографии органов грудной клетки больным выявлены пневмонии: правосторонняя в 55\% случаев, левосторонняя $-40,2 \%$ и двусторонняя $-4,8 \%$; очаговая в $35,5 \%$, сегментарная - 24,2\%, полисегментарная $12,9 \%$ и долевая $-27,4 \%$.

В общем анализе крови нейтрофильный лейкоцитоз выявлен у 27,4\% подростков, а лейкопения (менее $\left.5,0 * 10^{9} / л\right)$ - у 6,5\%. Высокие показатели СОЭ и С-реактивного белка в плазме крови отмечены в $60,3 \%$ и $64,5 \%$ случаях соответственно.

В 17,7\% выявлен атипичный возбудитель пневмонии - Mycoplasma pneumoniae (положительные AT класса IgM), а в 14,5\% - вирус гриппа A (H1N1). 
Из осложнений пневмонии выявлен только левосторонний синпневмонический плеврит у $6,5 \%$ подростков.

При поступлении назначалась антибактериальная терапия (цефалоспоринами II-III поколения). При выявлении микоплазменной инфекции назначался азитромицин. При подтверждении вирусной инфекции (грипп А) назначался осельтамивир.

Заключение. Таким образом, среди подростков с внебольничной пневмонией преобладали мальчики в возрасте 10-13 лет. Преимущественно выявлялись правосторонние и очаговые пневмонии. Из атипичных возбудителей пневмонии выявлена Mycoplasma pneumoniae, а из вирусных - вирус гриппа А (H1N1). На фоне проводимой терапии у всех подростков отмечена стойкая положительная динамика.

\section{НАРУШЕНИЯ ЛИПИДНОГО ОБМЕНА ПРИ МУКОВИСЦИДОЗЕ У ДЕТЕЙ СТАВРОПОЛЬСКОГО КРАЯ}

Водовозова Э.В., Белаш Т.А., Леденева Л.Н., Григорьяни И.С., Енина Е.А., Быков В.О., Пустабаева М.С. ФГБОУ ВО «Ставропольский государственный медицинский университет» МЗ РФ, Ставрополь

Введение. Липиды обеспечивают нормальное течение процессов клеточного метаболизма, стимулируют неспецифический иммунитет, являются предшественниками стероидных и половых гормонов. Муковисцидоз (МВ) - тяжелое моногенное заболевание, характеризующееся ухудшением качества жизни больного.

Цель исследования: анализ изменений липидного обмена у детей Ставропольского края (CK), страдающих МB.

Материалы, методы исследования. В исследование включено 102 ребенка с МВ, которым проводился анализ кала на панкреатическую эластазу. Для определения спектра липидов сыворотки крови и их транспортных форм использовали анализатор для биохимических исследований COBASc 311, фирма RocheDiagnosticsGmbH, Германия. Статистический анализ производили с использованием интегрированного пакета статистических программ STATISTICA 6.0 (StatSoftInc., США) и пакета программных приложений MicrosoftExcel XP (MicrosoftCorp., США).

Результаты. До лечения у детей с МВ уровень фракций холестерина (ХC) и липопротеидов низкой плотности (ЛПНП) достоверно ниже, чем в контроле $(\mathrm{p} \leq 0,05)$; уровень триглицеридов (ТГ) достоверно выше $(\mathrm{p} \leq 0,001)$, чем у здоровых детей, а показатель липопротеидов высокой плотности (ЛПВП) не отличался от такового в контрольной группе; ЛПВП у больных МВ без панкреатической недостаточности достоверно снижены $(\mathrm{P} \leq 0,001)$, с панкреа- тической недостаточностью - достоверно повышены $(\mathrm{P} \leq 0,05)$; ЛПНП при МВ без панкреатической недостаточности достоверно ниже $(\mathrm{P} \leq 0,001)$, с панкреатической недостаточностью - выше, но не достоверно $(\mathrm{P} \geq 0,05)$.

Заключение. Исследование липидного спектра сыворотки крови у детей, страдающих МВ, выявило выраженную дислипидемию, усугубляющую тяжесть заболевания и ухудшение качества жизни. При МВ с панкреатической недостаточность обнаружена обратная, статистически значимая зависимость между эластазой кала и ЛПВП; уменьшение расходов холестерина на синтез стероидов, временная дисфункция надпочечников, что, в свою очередь, может усугублять обструктивный синдром.

\section{ВОЗМОЖНОСТЬ ПРИМЕНЕНИЯ КОМПЬЮТЕРНОЙ БРОНХОФОНОГРАФИИ В УСТАНОВЛЕНИИ ФУНКЦИОНАЛЬНОГО ДИАГНОЗА У ДЕТЕЙ В БРОНХИАЛЬНОЙ АСТМОЙ}

Головко В.А., Мещеряков В.В., Максутов Ш.М.

Сургутский государственный университет, Сургут

Введение. Бронхиальная астма (БА) - одно из наиболее распространенных хронических заболеваний среди детей. Особенно остро в детском возрасте стоит вопрос инструментальной диагностики БА. Одним из вариантов решения данного вопроса является использование компьютерной бронхофонографии (КБФГ).

Цель исследования - представить возможности КБФГ в постановке функционального диагноза у детей с БА.

Материалы и методы. Проведено одномоментное сплошное когортное исследование - 66 детям 2-17 лет после купирования очередного эпизода бронхообструктивного синдрома в периоде клинической ремиссии проведено стандартное клиниколабораторное и функциональное исследование, последнее включало бронходилатационный тест методом КБФГ с использованием фиксированной комбинации Ипратропия бромид + Фенотерол в возрастных дозировках. Диагноз БА установлен у 45,5\% детей, обструктивного бронхита (ОБ) - у 54,5\%. Статистическая обработка осуществлялась методом $\mathrm{U}-$ Манна-Уитни и углового преобразования Фишера, характеристика числовых множеств представлялась как Me[Q1; Q3], удельный вес признака - в \%.

Результаты. Отягощенность аллергоанамнеза у пациентов с БА отмечена в $80,0 \%$, с ОБ - в $11,1 \%$ случаев, наследственного анамнеза по БА - в 70,0\% и $13,9 \%$, соответственно ( $p<0,01$ в обоих случаях). По результатам проведенного КБФГ исследования у пациентов с установленным диагнозом БА медиана исходных показателей акустического компонента 
работы дыхания (АКРД) в высокочастотном спектре составила $0,22[0,21 ; 0,25]$, с ОБ - 0,1[0,06; 0,12$]$ МкДж, $\mathrm{p} \leq 0,01$. После проведения пробы с бронхолитиком медиана АКРД в высокочастотном спектре у пациентов с БА составила 0,1[0,08;0,12], с ОБ - 0,07[0,05; 0,08] МкДж, $\mathrm{p} \leq 0,01$. Таким образом, у пациентов с БА показатель $\triangle$ АКРД в среднем составил (-)54,5\%, после перенесенного ОБ - (-)30\% при пороговом уровне - (-)50\%.

Заключение. Установленные закономерности определяют информативность метода КБФГ при постановке функционального диагноза БА. Наличие обратимости бронхиальной обструкции в периоде клинической ремиссии отличает БА от ОБ и определяет необходимость осуществления комбинированной базисной терапии.

\section{ОСОБЕННОСТИ ЛАБОРАТОРНЫХ ПОКАЗАТЕЛЕЙ КРОВИ ПРИ БРОНХИТАХ У ДЕТЕЙ}

Гостищева Е.В., Черняева Е.С., Тончева К.С. ФГАОУ ВО «КФУ ИМ.В.И. ВЕРНАДСКОГО», МеДИцинская академия им. С.И. Георгиевского, Симферополь

Введение. Статистика отмечает неуклонный рост бронхолегочной патологии у детей и подростков. Большое число клинических форм болезней органов дыхания определяют уровень детской заболеваемости и младенческой смертности. Знание особенностей лабораторной картины крови у детей позволяет своевременно и более точно поставить предварительный диагноз и назначить дополнительные методы исследования для уточнения диагноза и выбрать верную тактику лечения.

Цель исследования - изучение особенностей лабораторной картины крови у детей с бронхитами.

Материалы и методы. Проведено ретроспективное исследование 78 историй болезней пациентов (от 3 до 12 лет). Критерием включения в исследование было наличие установленного диагноза: бронхит. Статистическую обработку полученных данных проводили с использованием стандартных методов статистики.

Результаты. В первые дни заболевания у $58 \%$ больных отмечался умеренный лейкоцитоз в основном за счет нейтрофилов и анэозинофилия, которая к периоду реконвалесценции, трансформировалась в эозинофилию у 65\%. В $50 \%$ случаев острые бронхиты сопровождались синдром бронхиальной обструкции, детерминированной непосредственно эозинофилами и нейтрофилами. При купировании приступов бронхообструкции на фоне терапии в крови происходило умеренное постепенное нарастание эозинофилов. В $66 \%$ случаев обструктивных бронхитов отмечалась лимфопения на фоне рецидива очередной обструкции и определялся выраженный нейтрофильный сдвиг и повышение СОЭ. У 15-20\% пациентов был выявлен лимфоцитоз.

При бронхитах, сопровождающихся бронхообструкцией, в 50\% выявлен лимфоцитоз с моноцитозом, также отмечался длительный моноцитоз - более 10 дней.

Заключение. Следовая эозинофилия объясняется как перераспределением циркулирующих эозинофилов к очагу воспаления, так и действием глюкокортикостероидов, применяемых для купирования синдрома бронхиальной обструкции. Для бронхитов, сопровождающихся бронхообструктивным синдромом характерен длительный моноцитоз. После стихания клинических проявлений инфекции происходит нормализация уровня моноцитов. Таким образом, устранение моноцитоза может быть критерием выздоровления. Если же после клинического выздоровления сохраняется хотя бы небольшой моноцитоз, можно с определенной уверенностью утверждать о хронизации инфекции, неполном уничтожении инфекционного агента.

\section{ФАРМАКОЭКОНОМИЧЕСКИЙ АНАЛИЗ ТЕРАПИИ ОБОСТРЕНИЯ БРОНХИАЛЬНОЙ АСТМЫ У ДЕТЕЙ РАЗНЫХ ВОЗРАСТНЫХ ГРУПП В УСЛОВИЯХ СТАЦИОНАРА}

Гриднев Н.С., Батищева Г.А., Жданова О.А., РогачеваРадинская А.C.

ФГБОУ ВО ВГМУ имени Н.Н. Бурденко Минздрава России, Воронеж

Введение. Бронхиальная астма (БА) одна из распространенных проблем среди неинфекционных заболеваний легких в детской популяции на территории РФ. Терапия обострения и подбор базисной терапии БА зависят от возраста пациента, так как существуют возрастные ограничения по применению и форме доставки лекарственных препаратов у детей.

Цель исследования - определение структуры лекарственных препаратов в терапии обострения БА с оценкой стоимости случая в условиях стационара у детей разного возраста.

Материалы и методы. Изучена структура лекарственных назначений в трех возрастных группах детей: 2-5 лет (61 ребенок), 6-11 лет (87 детей), 12-17 лет (70 детей), госпитализированных с обострением БА в ФГБОУ ВО ВГМУ им. Н.Н. Бурденко в 2017-2019 гг. В исследовании учитывались прямые медицинские затраты, проведен расчет стоимости лечения стационарного случая с использованием метода «минимизации затрат».

Результаты. Назначение лекарственных препаратов в терапии обострения БА и дальнейшая базисная терапия соответствовали возрастным ограничениям и клиническим рекомендациям. Ингаляционный глюкокортикостероид (ИГКС) будесонид получали 
дети 2-5 лет $-90 \%, 6-11$ лет - 79\% и старше 12 лет $57 \% \quad(p<0,001)$. Антилейкотриеновый препарат монтелукаст назначался у детей 6-11 лет - в 8\%, 12-17 лет - в 10\%. Частота назначения комбинированной терапии ИГКС и длительно действующими бета2-ангонистами (ДДБА) увеличивалась с возрастом пациентов - от $10 \%$ случаев у детей 2-5 лет до $51 \%$ у детей старше 12 лет $(p<0,001)$. Коротко действующие бета2-агонисты: сальбутамол назначался у 56\% детей 2-5 лет, 34\% - 6-11 лет и $37 \%$ пациентов 12-17 лет ( $p=0,025)$, ипратропия бромид/ фенотерол - у 29\%-26\%-27\% пациентов разных возрастных групп соответственно. Частота назначения системных глюкокортикостероидов и препаратов теофилина была невысокой во всех группах $(15,16 \%$, $14 \%$ - для дексаметазона и $3 \%, 1 \%$ и 1,4\% для аминофиллина). Стоимость 1 дня терапии составила 2032,5 руб. в группе детей 2-5 лет, 2132,5 руб. у детей 6-11 лет и 1982,5 руб. в группе 12-17 лет.

Заключение. Анализ лекарственных назначений подтвердил возрастные отличия применения ИГКС и ИГКС/ДДБА. Но результаты фармакоэкономического анализа показали, что стоимость терапии пациентов с обострением БА в стационаре не зависела от возраста и структуры врачебных назначений. Полученные данные важны для оптимизации лечения обострения БА у детей.

\section{КЛИНИЧЕСКАЯ ЭФФЕКТИВНОСТЬ} КУРСОВОГО ПРИМЕНЕНИЯ АНТИ-IGЕТЕРАПИИ ПРИ БРОНХИАЛЬНОЙ АСТМЕ У ДЕТЕЙ

Дьякова С.Э., Мизерницкий Ю.Л., Соколова Л.В., Зорина И.Е., Богорад А.Е.

НИКИ педиатрии им. акад. Ю.Е. Вельтищева ФГАОУ ВО РНИМУ им. Н.И. Пирогова Минздрава России

Нами обобщены результаты проведенной по заданию Минздрава РФ клинической апробации: «Персонифицированная терапия бронхиальной астмы у детей с применением курсового метода использования моноклональных антител (анти-IgЕ-терапии)» в целях оценки влияния данного вида лечения на частоту обострений БА, в том числе - ассоциированных с сезонными острыми респираторными инфекциями (ОРИ). Сделан вывод о высокой клинической эффективности в отношении всех изучаемых параметров и безопасности данного вида лечения. Установлено, что сопутствующий анти-IgE-терапии мониторинг уровня специфических рецепторов к IgE на базофилах методом цитофлоуметрии делает возможным прогнозирование эффективности и индивидуальной продолжительности анти-IgE-терапии неконтролируемой атопической бронхиальной астмы у детей (https://doi.10/21508/1027-4065/2020-65-6116-121).

\section{ТЕРАПИЯ ТОБРОМИЦИНОМ У ДЕТЕЙ, СТРАДАЮЩИХ МУКОВИСЦИДОЗОМ, В ЗАВИСИМОСТИ ОТ ГЕНЕТИЧЕСКИХ МУТАЦИЙ}

Енина Е.А., Григорьяни И.С., Белаш Т.А., Леденева Л.Н., Водовозова Э.В., Пустабаева М.С.

ФГБОУ ВО «Ставропольский государственный медицинский университет» МЗ РФ, Ставрополь

Введение. При микрофлоре Pseudomonas aeruginosa нижних дыхательных путей у детей, страдающих муковисцидозом (МВ), назначение ингаляционной противосинегнойной терапии (тобрамицином) позволяет уменьшить риск обострений и степень выраженности респираторных проявлений.

Цель исследования: проанализировать результаты ингаляционной терапии тобрамицином при микрофлоре Pseudomonas aeruginosa нижних дыхательных путей у детей Ставропольского края (CK), страдающих MB, в зависимости от генетических мутаций

Материалы, методы исследования: лечение тобромицином проводилось 12 больным МВ, с хронической инфекцией P.aeruginosa в респираторном тракте на базе Регионального центра МВ в СК. Лечение осуществляли ингаляционным способом -300 мг препарата 2 раза в день на протяжении 28 дней с повторными курсами через 28 дней (3 курса) в течении 2-4 лет. Для оценки динамики клинических данных составлена специальная анкета.

Результаты. В СК выявлены мутации следующих генов у больных МВ с хронической синегнойной инфекцией: - del F508 - 75,0\%; del F508 и 1677del A - 8,3\%; W1282 R - 8,3\%; W1282 R и R344W-8,3\%. На фоне терапии тобромицином отмечалось ослабление интенсивности, уменьшение частоты кашля и количества выделяемой мокроты, улучшение физикальных данных в легких; при мутации гена del F508 улучшения фиксировались к 10-14 дню, у пациентов с другими типами мутаций - к 7-9 дню лечения. На фоне лечения отмечено достоверное увеличение ФЖЕЛ и ОФВ1 ( $\mathrm{P} \leq 0,001$ соответственно), элиминация 76,0\% штаммов P.aeruginosa, в том числе мукоидных штаммов, у 2 пациентов с «тяжелыми» мутациями после проведенных 3 курсов терапии высевалась в мокроте синегнойная палочка (у одного пациента - мутация гена del F508, у второго - сочетание del F508 и 1677del TA).

Заключение. В СК среди детей, страдающих МВ наиболее часто встречаются пациенты с мутацией гена del F508 (75,0\%). Ингаляционная терапия тобрамицином у них улучшает дыхательную функцию легких за счет увеличения спирометрических показателей ФЖЕЛ и ОФВ1 и контролирует течение у них хронической респираторной инфекции P.aeruginosa. Пациенты с «тяжелыми» мутациями, требуют более длительных курсов ингаляционной антибактериальной терапии. 


\section{ПРИМЕНЕНИЕ ПРЕПАРАТА БРОНХИТОЛ- ФАРМАКСИС У ПАЦИЕНТОВ С МУКОВИСЦИДОЗОМ \\ Енина Е.А., Кириченко А.И., Водовозова Э.В., Леденева Л.Н., Быков В.О., Белаш Т.А., Григорьяни И.С., Пустабаева М.С. \\ ФГБОУ ВО «Ставропольский государственный медицинский университет» МЗ РФ, Ставрополь}

Введение. Муковисцидоз (МВ) - тяжелое генетическое прогрессирующее заболевание, поражающее экзокринные железы, приводящее к нарушению функции ионных каналов и формированию обезвоженного вязкого секрета. Применение препарата Бронхитол-Фармаксис (ингаляционный маннитол) способствует восстановлению у больных мукоцилиарного клиренса.

Цель исследования: оценить клиническую эффективность препарата Бронхитол-Фармаксис у детей Ставропольского края (СK), страдающих МВ.

Материалы и методы. Исследование проводилось в Региональном центре МВ на базе пульмонологического отделения ГБУЗ СК «КДКБ» в 2020 году. В исследование включены 4 подростка 14-17лет, получавшие ингаляционный маннитол 2-3 недели в дозе 400 мг х 2 раза в день. Контрольной группой, служили 4 подростка, больные МВ такого же возраста, не получавшие препарат. Оценка исследования проводилась по результатам динамического наблюдения в условиях стационара.

Результаты и обсуждение. Клинические изменения отмечены на 4-5 день наблюдения за больными, получавшими препарат, в виде увеличения продуктивности кашля и улучшения отхождения мокроты. Динамика показателей функции внешнего дыхания (ОФВ1 и ЖЕЛ) на фоне терапии бронхитолом имела тенденцию к увеличению ОФВ1 и ЖЕЛ в основной группе (до лечения - ОФВ1-58,7\%, ЖЕЛ-71,0\%, после - ОФВ1-70,2\%, ЖЕЛ-89,0\%). В контрольной группе клинические данные оставались без динамики, показатели ОФВ1 и ЖЕЛ - стабильно низкими (исходно ОФВ1-72,0\%, ЖЕЛ-75,0\%, на 10 день ОФВ1-70,0\%, ЖЕЛ-74,7\%).

Вывод. В ходе исследования препарат «Бронхитол-Фармаксис» показал клиническую эффективность и может рекомендоваться в качестве муколитической терапии для улучшения отхождения мокроты у пациентов с муковисцидозом.

\section{СРАВНИТЕЛЬНАЯ ЭФФЕКТИВНОСТЬ РАЗЛИЧНЫХ СХЕМ ТЕРАПИИ ОРВИ С БАКТЕРИАЛЬНЫМИ ОСЛОЖНЕНИЯМИ У ДЕТЕЙ ДОШКОЛЬНОГО ВОЗРАСТА \\ Ермакова И.Н. ${ }^{1}$, Мизерницкий Ю.Л. ${ }^{2}$}

${ }^{1}$ Тверской государственный медицинский университет (Тверь)

2НИКИ педиатрии им. акад. Ю.Е.Вельтищева ФГАОУ ВО РНИМУ им. Н.И.Пирогова Минздрава России, Москва.

Актуальность исследования: течение ОРВИ у детей II-IV групп здоровья часто протекает с бактериальными осложнениями, особенно у детей раннего и дошкольного возраста.

Цель исследования: разработать эффективные лечебные мероприятия при острых респираторных вирусных инфекций (ОРВИ) с осложнениями, у детей 1 мес. -6 лет.

Материалы и методы исследования: обследовано 60 детей II-IV группы здоровья, из них 46 детей $(76,7 \%)$ в возрасте до 2-х дет и 14 детей $(23,3 \%)-$ 2-6 лет, которые находились на стационарном лечении в ДГКБ№1 г.Твери и были госпитализированы, в первые 3-е суток ОРВИ (80\% пациентов), на 5-6-е сутки (20\%). Диагноз ОРВИ устанавливался при наличии гипертермии, катарального синдрома, симптомов общей интоксикации. В случае присоединения бактериальной инфекции, проводились лабораторные и инструментальные методы исследования для уточнения диагноза. Распределение пациентов по группам в соотношении 1:1 (по 30 человек) проводилось по желанию родителей (без рандомизации). Группы были сопоставимы по возрасту, полу, патологии респираторной системы. Дети основной группы на фоне стандартной терапии получали ректальные суппозитории ВИФЕРОН ${ }^{\circledR}$ в дозировке по 150000 ME 2 раза в день в течение 5 дней. Пациенты группы сравнения получали только стандартную терапию ОРВИ. Всем пациентам проводилось обследование: клинический анализ крови (СОЭ, лейкоцитарная формула); общий анализ мочи; биохимический анализ крови (СРБ), ИФА крови на АТ к микоплазме и хламидии пневмонии, Ig A, M, G; пульсоксиметрия, рентгенограмма органов грудной клетки (по показаниям). Основные критерии для оценки эффективности и безопасности: динамика клинической картины заболевания; клинических лабораторных показателей: длительность госпитализации.

Результаты: при сравнительном анализе результатов оценки основных клинических симптомов заболевания на протяжении исследования в пользу эффективности схемы терапии с включением препарата ВИФЕРОН ${ }^{\circledR}$ отмечались значимые различия по показателю синдрома бронхиальной обструкции, начиная с 1 дня терапии и 2, 4, 5, 6, 7 дни исследования ( $p=0,005$ во всех случаях), по показателю кашель на $4,5,6,7,9$ дни ( $p=0,005$ во всех случаях) и 10 день 
исследования $(p=0,000)$ и по суммарному баллу основных клинических симптомов заболевания на 4 , 6, 7, 9 дни ( $p=0,005$ во всех случаях) и на 10 день исследования $(p=0,000)$. В связи с тем, что средняя длительность заболевания ОРВИ с осложнениями, составила 8 к/дней $(7,80 \pm 2,37$ к/дней и $8,77 \pm 2,60$ соответственно), наличие значимо лучших результатов в группе пациентов, применявших препарат ВИФЕРОН ${ }^{\circledR}$, указывает на более высокую эффективность данной лечебной схемы терапии.

Таким образом, доказана терапевтическая эффективность включения ректальных суппозиториев ВИФЕРОН $^{\circledR}$ (интерферон альфа-2b, 150000 МЕ) в комплекс лечения ОРВИ с осложнениями у детей от 1месяца до 6 лет.

\section{КЛИНИКО - МОРФОЛОГИЧЕСКИЕ ОСОБЕННОСТИ ВНЕБОЛЬНИЧНОЙ ПНЕВМОНИИ У ДЕТЕЙ}

Зайцева М.Л., Шундеева Ю.В., Попова Е.В. ФГБОУ ВО «Южно-Уральский государственный медицинский университет» Минздрава России, Челябинск

Введение. В последние годы отмечается тенденция к росту заболеваемости пневмонией в нашей стране, особенно у детей. Изучение клинико-морфологических особенностей внебольничной пневмонии у детей в современных условиях представляется актуальным.

Цель исследования. Выявить клинико-морфологические особенности пневмонии у детей в современных условиях.

Материалы и методы. Проведен ретроспективный анализ 176 историй болезни детей с диагнозом «внебольничная пневмония» (ВП). Возраст пациентов от 6 месяцев до 18 лет. Девочки - 91 пациент $(51,7 \%)$, мальчики - 85 (48,3\%).

Результаты. При анализе возраста развития ВП установлено, что наибольшее число заболевших было в возрасте от 1 года до 3-х лет - 40,3\% случаев $(n=71)$, дети до 1 года $-12,0 \%(n=21), 3-7$ лет $22,2 \%(n=39), 8-12$ лет $-15,3 \%(n=27)$ и $13-18$ лет $10,2 \%(n=18)$. Правосторонне поражение легких было выявлено у 95 детей (54\%), левостороннее - у 58 (33\%), двустороннее - у 23 детей (13\%). У 35 пациентов (20\%) была поражена доля, у 31 (18\%) - очаговая пневмония, у 104 (59\%) - сегментарная (сегменты S8 и S9) и у 6 (3\%) - полисегментарная. У большинства детей -127 (72\%) ВП выявлена впервые, повторные случаи ВП - 40 детей (23\%), больше 2-х эпизодов у 9 детей (5\%). Среднюю степень тяжести ВП имели 167 детей, что составило 95\%, тяжелое течение - 5\% $(n=9)$. При анализе клинических проявлений установлено, что повышение температуры встречалось у 130 человек (74\%), у большинства (62\%) была феб- рильная лихорадка; субфебрильная - 31\% случаев и у $14 \%$ подъем температуры достигал 39-40,9. Катаральные явления были выражены у 147 детей (84\%). Жалобы на кашель предъявили 135 человек (77\%), а именно: сухой кашель - $21 \%$; влажный кашель $75 \%$, лающий кашель - 4\%. Аускультативно хрипы выслушивались у $57 \%(n=100)$ : сухие хрипы $-37 \%$; влажные - 60\% и проводные - 3\%. У 14\% (24 человека) отмечалась одышка смешанного генеза.

Заключение. Особенностями ВП на современном этапе является преимущественный возраст возникновения заболевания с 1 года до 3-х лет, чаще поражается правое легкое, поражение чаще носит сегментарный характер $(\mathrm{S} 8, \mathrm{~S} 9)$, у каждого пятого пациента пневмония возникает повторно, и у каждого двадцатого выявляется больше 2-х эпизодов ВП. В 95\% случаев пневмония имеет среднетяжелое течение. Примерно в половине случаев ВП протекает с фебрильной температурой, у подавляющего большинства пациентов (84\%) выявляются катаральные симптомы, у каждого седьмого пациента определяется смешанная одышка, хрипы выслушиваются лишь у $57 \%$ пациентов.

\section{ПРИЧИНЫ, ПРЕПЯТСТВУЮЩИЕ ДОСТИЖЕНИЮ КОНТРОЛЯ БРОНХИАЛЬНОЙ АСТМЫ У ДЕТЕЙ}

Зебрина Т.И., Медведева Л. В., Минина Е. Е. ФГБОУ ВО ЮУгМУ Минздрава России, Челябинск

Введение. Основные задачи в лечении бронхиальной астмы (БА) - достижение контроля над симптомами болезни и поддержание его на уровне, обеспечивающем улучшение качества жизни.

Цель исследования - определить причины отсутствия контроля заболевания при бронхиальной астме у детей.

Материалы и методы. В исследовании приняло участие 27 детей 3-17 лет, госпитализированных в детское аллергологическое отделение МАУЗ ОТКЗ ГКБ №1 г. Челябинска с диагнозом Бронхиальная астма, ремиссия (по типу поперечного среза, метод выборки сплошной).

Результаты. По данным ACQ и АCT тестов более половины детей имеют неконтролируемое течение БА (55,6\% и 59,2\% соответственно). Базисную терапию используют только 62,9\% детей; 81,5\% пациентов принимают лекарственные средства в ингаляционной форме, а 18,5\% - в таблетированной. Карманный ингалятор имеется у 29,6\% детей. У 59,2\% пациентов члены семьи курят; домашние животные имеются у 55,6\%; пользуются парфюмами - 74\%.

По уровню контроля заболевания, определенным лечащим врачом, дети были разделены на 3 группы: 1 группа - неконтролируемая/частично контролируемая БА $(n=10), 2$ группа - контролируемая БА 
$(n=7), 3$ группа - БА впервые выявленная $(n=10)$. У детей 1 группы в 40\% была средняя степень тяжести БА и в 20\% - тяжелая. При этом во 2-й группе все дети имели легкую степень БА. Установлено, что в 1 группе $20 \%$ детей, несмотря на неконтролируемое течение, не получают базисную терапию (БТ). В то же время 20\% этой группы в качестве БТ получали ксолар, $30 \%$ - ингаляционные глюкокортикостероиды (ИГКС), 30\% - комбинированные препараты (ИГКС + длительно действующий В2-агонист). Во 2 группе $43 \%$ использовали ИГКС, 42\% - антилейкотриеновые препараты и $14 \%$ не получали препараты БТ. В группе 3 дети еще не начали использовать БТ.

Вывод. Показано, что недостаточный контроль БА у детей предсказуемо связан с тяжестью заболевания, а также с отсутствием БТ и гипоаллергенной обстановки дома.

\section{УРОВЕНЬ ТИМИЧЕСКОГО СТРОМАЛЬНОГО ЛИМФОПОЭТИНА ПРИ ЮРОНХИАЛЬНОЙ АСТМЕ У ДЕТЕЙ ЗАВИСИТ ОТ СПЕКТРА СЕНСИБИЛИЗАЦИИ}

Камаев А.В., Трусова О.В., Ляшенко Н.Л.

Первый Санкт-Петербургский государственный медицинский университет им. акад. И.П. Павлова

Обоснование: Тимический стромальный лимфопоэтин (ТСЛП) - один из ключевых прововоспалительных цитокинов при атопической бронхиальной астме (БА). Известно, что тип причинного аллергена влияет на клинические проявления астмы; пока неясно, оказывает ли спектр сенсибилизации влияние на иммунологические механизмы.

Цель: сравнить уровни сывороточного ТСЛП у пациентов с БА, сенсибилизированных только к клещам домашней пыли (КДП), только к эпидермальным аллергенам (кошки и собаки, Эп) или полисенсибилизрованных (ПС).

Пациенты и методы: Включены 104 городских пациента с нетяжелой (61 с легкой, 58.7\%; 43 со среднетяжелой, $41.3 \%$ ) контролируемой БА, диагноз которой установлен $\geq 1$ года назад. Возраст пациентов от 6 до 17 лет, медиана $\left[\mathrm{Q}_{25} ; \mathrm{Q}_{75}\right]$ составила 12.6 [7.3; 12.8] лет; 76 (73.1\%) мужского пола. Аллергический эндотип БА подтверждали при $\geq 1$ положительном кожном тесте с ингаляционными аллергенами (КДП, кошка, собака, смесь плесеней, смеси пыльцы деревьев, луговых трав и сорняков), подтвержденным анамнезом. Образцы сыворотки отбирались при отсутствии признаков острой респираторной инфекции $\geq 14$ дней. Концентрацию ТСЛП сыворотки измеряли коммерческим набором ELISA, предел чувствительности 10 пг/мл. Данные представлены как среднее $\pm \mathrm{SD}$; сравнения проведены в ANOVA тестом Краскела-Уоллиса; различия считали значимыми при $p<0,05$.
Результаты: Чаще всего положительными были пробы с аллергеном кошки $(42 ; 40.4 \%)$, на втором месте КДП (37; 35.6\%), на третьем - пыльца деревьев $(29 ; 27.9 \%)$. Большинство включенных пациентов (49;

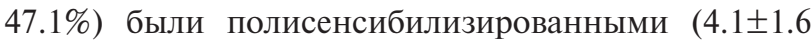
положительных пробы на пациента); в группу КДП вошли 25 пациентов (24\%) и в группу Эп 21 пациент (20.2\%). Средняя концентрация ТСЛП сыворотки

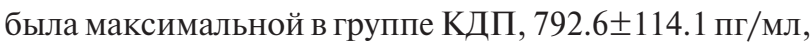

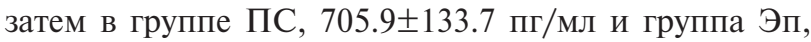
$581.4 \pm 83.3$ пг/мл. Различие между группами КДП и Эп было значимым, $p=0.009$. Тяжесть БА, стаж заболевания и частота обострений не влияли на уровень ТСЛП сыворотки.

Заключение: При аллергии к КДП развивается выраженное повреждение эпителия дыхательных путей, что выражается в более высоком уровне ТСЛП.

\section{УРОВЕНЬ ТИМИЧЕСКОГО СТРОМАЛЬНОГО ЛИМФОПОЭТИНА У ПАЦИЕНТОВ РАЗНЫХ ВОЗРАСТНЫХ ГРУПП С БРОНХИАЛЬНОЙ АСТМОЙ: СВЯЗЬ С ДРУГИМИ МАРКЕРАМИ, ПОКАЗАТЕЛЯМИ ФУНКЦИИ ЛЕГКИХ И КОНТРОЛЕМ ЗАБОЛЕВАНИЯ \\ Камаев А.В. ${ }^{1}$, Кривская С.А. ${ }^{2}$, Ляшенко Н.Л. ${ }^{1}$, Камаева И.А. ${ }^{1}$, Мизерниикий Ю.Л. ${ }^{3}$, Шапорова Н.Л. ${ }^{1}$ ${ }^{1}$ ФГБОУ ВО «Первый Санкт-Петербургский государственный медицинский университет имени академика И.П. Павлова» Минздрава России, Санкт- Петербург \\ 2Покровский банк стволовых клеток, Санкт-Петербург ${ }^{3}$ Научно-исследовательский клинический институт педиатрии имени академика Ю. Е. Вельтищева ФГАОУ ВО РНИМУ им. Н. И. Пирогова Минздрава России}

Материалы и методы. В открытое проспективное исследование длительностью 1 год включили 104 пациента трех возрастных групп: дети (6-11 лет, $n=38)$, подростки (14-17 лет, $n=35)$, взрослые (2550 лет, $n=31)$. Давность установления диагноза БА $\geq 12$ месяцев, отсутствие контроля БА на момент включения, отсутствие острой респираторной инфекции $\geq 14$ дней использовали как критерии включения. На визите включения выполняли сбор анамнеза, оценивали контроль астмы по вопросникам АCТ/cАCТ, исследовали функцию внешнего дыхания (ФВД), клинический анализ крови, получали сыворотку крови и назальный материал для исследования тимического стромального лимфопоэтина (ТСЛП). После коррекции терапии пациенты дважды повторно обследовались (через 6 месяцев). Статистическая обработка включала ANOVA (критерий КраскелаУоллиса) и коэффициент Пирсона. Различия считали значимыми при $p<0,05$.

Результаты. Частота выявления основных факторов риска потери контроля БА (низкий компла- 
йенс, ожирение, неатопический фенотип, неполная обратимость обструкции в тесте с сальбутамолом) различалась в разных возрастных группах. Не обнаружено значимого содержания ТСЛП в назальном материале. Концентрация ТСЛП сыворотки не зависела от возраста пациентов, но значимо коррелировала с длительностью неконтролируемого течения БА в предшествующие 12 месяцев $(r=0,74)$. У пациентов с атопической БА, концентрация ТСЛП была максимальной в группе с клещевой сенсибилизацией. Подгруппа пациентов, не достигших нормальных значений ОФВ 1 на фоне оптимальной терапии БА (к Визиту 3), также отличалась более высокой концентрацией ТСЛП в сыворотке крови.

Заключение. Содержание ТСЛП в назальном эпителии не информативно. Концентрация ТСЛП в сыворотке может выступать фактором риска будущих обострений БА и снижения показателей ФВД.

\section{РЕФЛЕКСО - И ФИЗИОТЕРАПИЯ В КОМПЛЕКСЕ РЕАБИЛИТАЦИОННЫХ МЕРОПРИЯТИЙ У ДЕТЕЙ С БРОНХИАЛЬНОЙ АСТМОЙ, ПЕРЕНЕСШИХ НОВУЮ КОРОНАВИРУСНУЮ ИНФЕКЦИЮ COVID-19.}

Капустин А.В., Дубровская Т.В., Кириллова В.П., Соловей Т.Н., Захаров П.П.,

Соколова Л.В., Мизерницкий Ю.Л.

НИКИ педиатрии им. акад. Ю.Е.Вельтищева ФГАОУ ВО РНИМУ им. Н.И.Пирогова Минздрава России, Москва.

Введение. У детей, перенесших новую коронавирусную инфекцию COVID-19 даже в легкой степени, в дальнейшем возможно развитие и/или усугубление болезненных проявлений в различных органах и системах, прежде всего в респираторном тракте. Для пациентов с бронхиальной астмой это является наиболее зрачимым. Существует мнение, что уже в первые два месяца после острого периода коронавирусной инфекции следует применять комплекс респираторной реабилитации с использованием рефлексотерапии [Zhang Jiale, 2020; Бодрова P.A. с соавт.,2021]. В тяжелых случаях восстановительное лечение начинают уже и в реанимационных палатах. Известно, что рефлексотерапия повышает защитные силы организма, положительно влияет на бронхиальную проходимость, вентиляцию легких, функциональную способность диафрагмы, легочную гемодинамику.

Цель исследования - оценить возможности применения немедикаментозных методов рефлексотерапии (РТ) и физиотерапии (ФТ), как начального этапа в комплексе реабилитационных мероприятий, при плановой госпитализации детей с бронхиальной астмой (БА), перенесших новую коронавирусную инфекцию COVID-19.
Большинство детей с БА, которые перенесли новую коронавирусную инфекцию, поступают в институт для плановой госпитализации с целью коррекции базисного лечения основного заболевания. Обычно это происходит не ранее 4-6 месяцев после COVID-19 и на очень непродолжительный срок. Однако уже и в этот период возможно использовать рефлексотерапию и физиотерапию (низкоинтенсивное лазерное излучение, магнитотерапия), в качестве начального этапа реабилитационных мероприятий постковидного синдрома. Выбор точек акупунктуры при РТ для респираторной реабилитации осуществляется согласно современным представлениям о патогенезе БА, клинической картины заболевания и с учетом традиционных восточных концепций РТ. Раннее применение немедикаментозных методов РТ и ФТ позволяет снизить лекарственную нагрузку на организм ребенка, предупредить развитие осложнений, способствует уменьшению частоты приступов и улучшению качества жизни.

Заключение. Представляется целесообразным использование рефлексотерапии и физиотерапии, как начального этапа в комплексе последующих реабилитационных мероприятий (массаж, кинезиотерапия, дыхательная гимнастика, санаторно-курортное лечение, прерывистая интервальная гипокситерапия и др.) [Фесюн А.Д. с соавт., 2020; Tsyganova T.N., 2021] у детей с бронхиальной астмой, перенесших новую коронавирусную инфекцию COVID-19.

\section{ЭФФЕКТИВНОСТЬ ПРИМЕНЕНИЯ ИММУНОМОДУЛЯТОРОВ ПРИ ВНЕБОЛЬНИЧНОЙ ПНЕВМОНИИ У ДЕТЕЙ}

Каримджанов И.А. ${ }^{1}$, Файзиева У.P. ${ }^{2}$

1Ташкентская медицинская академия, Ташкент, Узбекистан

2Термезский филиал Ташкентской медицинской академии, Термез, Узбекистан

Введение. Основным средством при лечении внебольничной пневмонии до настоящего времени остается антибиотикотерапия. Наряду с ней, в настоящее время перспективно применение иммуномодуляторов, мобилизующих иммунную систему на подавление воспалительного процесса.

Цель исследования - изучение эффективности применения иммуномодулятора полиоксидоний при внебольничной пневмонии у детей.

Материалы и методы. Под нашим наблюдением, находилось 40 детей от 6 месяцев до 3 лет, из них мальчиков - 22, девочек - 18. Все дети были разделены на 2 группы: в первую группу включены дети с внебольничной пневмонией $(n=20)$, получавшие базисную терапию + полиоксидоний. Во вторую группу включены дети с внебольничной пневмонией $(n=20)$, получавшие только базисную терапию 
$(n=20)$. Полиоксидоний назначался пациентам с 3-4-го дня пребывания в стационаре с 6 месяцев из расчета 50-100 мкг/кг массы тела, через день, в течение 5-7 дней.

Результаты. Применение иммуномодулятора полиоксидоний у всех 20(100\%) больных детей с внебольничной пневмонией способствовало улучшению общего состояния и ранней нормализации температуры тела, у 18(90\%) больных - уменьшению симптомов интоксикации в сроки от $2 \mathrm{x}$ до 5дней по сравнению с больными второй группы $(\mathrm{P}<0,001)$. У больных детей первой группы по сравнению с больными второй группы в более ранние сроки уменьшились и исчезали одышка, кашель, разнокалиберные хрипы в легких, уменьшились лейкоцитоз, палочкоядерный сдвиг и СОЭ в крови, отмечалась положительная рентгенологическая динамика в легких, что привело к уменьшению длительности пребывания в стационаре на 2 дня $(\mathrm{P}<0,001)$.

Заключение. Применение полиоксидония в комплексной терапии внебольничной пневмонии у детей, способствует раннему улучшению общего состояния и исчезновению клиническо-рентгенологических признаков внебольничной пневмониии у детей и сокращению сроков пребывания в стационаре.

\section{ИЗМЕНЕНИЕ ПОКАЗАТЕЛЕЙ ЦИТОКИНОВ ПРИ ВНЕБОЛЬНИЧНОЙ ПНЕВМОНИИ У ДЕТЕЙ \\ Каримджанов И.А. ${ }^{1}$, Файзиева У.Р. ${ }^{2}$ \\ ${ }^{1}$ Ташкентская медицинская академия, Ташкент, Узбекистан \\ ${ }^{2}$ Термезский филиал Ташкентской медицинской академии, Термез, Узбекистан}

Введение. Исход внебольничной пневмонии у детей зависит от возраста ребенка, этиологии болезни, жилищных условий, наличия фоновой патологии (недоношенность, гипотрофия, анемия, заболевания нервной системы). У части детей с пневмонией развиваются легочные и внелегочные осложнения. Несмотря на большое количество исследований о роли цитокинов при воспалительных процессах в легких, продукция цитокинов при пневмонии у детей до конца не изучена.

Цель исследования. Изучение клинико-иммунологических особенностей внебольничной пневмонии у детей.

Материал и методы. Обследовано 35 детей, больных внебольничной пневмонией в возрасте от 1 года до 5 лет. Мальчиков было 18, девочек - 17. Иммунологические исследования включали изучение содержания ИЛ-1, ИЛ-4 в сыворотке крови методом твердофазного иммуноферментного анализа проводились в лаборатории Научно-диагностического центра при Институте иммунологии и геномики человека АН РУЗ.
Результаты. Проведенные исследования показали что, у 22(63\%) больных детей внебольничной пневмонией заболевание было средней тяжести и в 13(37\%) случаях у пациентов было установлено тяжелое течение заболевания. Первыми признаками заболевания были гипертермия 35(100\%), влажный кашель 28(80\%). Одышка выявлена у 26(74\%) больных, аускультативно у 23(65,7\%) больных на фоне жесткого дыхания выслушивались влажные мелкопузырчатые хрипы, а у 17(48\%) больных детей -крепитация. Уровни ИЛ-1 и ИЛ-4 у детей больных внебольничной пневмонией были повышены, причем более выраженный цитокиновый дисбаланс отмечался при тяжелом течении заболевания $(p<0,001)$.

Заключение. У детей с внебольничной пневмонией наблюдаются изменения уровней про- и противовоспалительных цитокинов (ИЛ-1, ИЛ-4) в крови, выраженность которых коррелирует с тяжестью течения заболевания. Наличие дисбаланса в содержании цитокинов может служить информативным показателем в прогнозирования течения внебольничной пневмонии у детей.

\section{ПОЛИМОРФИЗМ ГЕНА ФЕРМЕНТА АНТИКСИДАНТНОЙ СИСТЕМЫ (SOD1 G7958А) У ДЕТЕЙ С ХРОНИЧЕСКИМИ НЕСПЕЦИФИЧЕСКИМИ ЗАБОЛЕВАНИЯМИ ЛЕГКИХ}

Книжникова Е.В. ${ }^{1}$, Евсеева Г.П. ${ }^{1}$, Наговицына Е.Б. ${ }^{1}$, Супрун С.B. ${ }^{1}$, Ракицкая E.B. ${ }^{1,2}$, Лебедько О.A. ${ }^{1}$

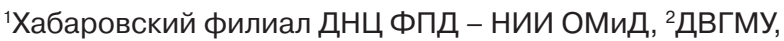
Россия, Хабаровск

Введение. В мультифакториальном патогенезе хронических неспецифических заболеваний легких (ХНЗЛ) ведущую роль, наряду системными эффектами воспаления, играет окислительный стресс (OC). Одним из перспективных направлений исследований является определение однонуклеотидных замен в генах антиоксидантных ферментов. Полиморфные варианты гена SOD1 могут обусловливать функциональную вариативность белковых продуктов, влиять на широкий спектр биохимических реакций, детерминируя тем самым риск реализации целого спектра патологических состояний.

Цель исследования. Сравнительный анализ распределения частот генотипов гена SOD1 у пациентов с неспецифическими заболеваниями легких с исходом в пневмофиброз.

Материалы и методы. В исследование были включены 79 детей (средний возраст 6,5土1,2 лет) с ХНЗЛ с исходом в пневмофиброз (пороки развития легких, бронхолегочная дисплазия, хронический бронхит). Для исследования полиморфных маркеров использовали ДНК, выделенную из лейкоцитов венозной 
крови стандартным методом с использованием коммерческих наборов «ДНК-экспресс крови».

Результаты. Сравнительный анализ распределения частот генотипа G7958A гена SOD1 показал, что гомозиготный вариант GG у детей с ХНЗЛ выявлялся достоверно реже $(71,2 \%)$, чем у детей группы контроля $(96,7 \%, p<0,05)$. Достоверных различий по данному генотипу между группами с ХНЗЛ без фиброза $(80,4 \%)$ и с пневмофиброзом $(64,6 \%)$ не выявлено $(p>0,05)$. Генотип GA гена SOD1 определен у $30,4 \%$ больных ХНЗЛ, из них у 21,7\% у детей с фиброзом и у $8,7 \%$ детей с ХНЗЛ без пневмофиброза и только y $3,3 \%$ здоровых $(p<0,05)$. При наличии генотипа GA риск развития фиброза у детей с ХНЗЛ увеличивается в 2,5 раза (ОШ $\left.=2,53 ; \mathrm{p} \chi^{2}=0,0043\right)$, более значимый для детей с БЛД, где генотип GA имели 50\% детей, при $37,5 \%(p>0,05)$ у детей с хроническим бронхитом и $5,9 \%(p<0,001)$ у детей с врожденными пороками легких.

Заключение. У пациентов с ХНЗЛ (и особенно с БЛД) с исходом в фиброз статистически значимо чаще регистрировался гетерозиготный вариант GA гена $S O D 1$.

\section{ТЯЖЕЛАЯ БРОНХИАЛЬНАЯ АСТМА У ДЕТЕЙ: ВОЗРАСТНАЯ ТРАНСФОРМАЦИЯ И ПРЕДИКТОРЫ ЕЕ ФОРМИРОВАНИЯ}

Кожевникова Л.А., Кунгурцева Л.Е., Грахова М.А. ФГБОУ ВО Тюменский ГМУ Минздрава России, Тюмень ГБУЗ ТО «Областная клиническая больница №1», Тюмень

Введение. Бронхиальная астма во всем мире является глобальной проблемой здравоохранения. Тяжелая, трудно контролируемая БА встречается в 5-10\% всех случаев заболевания. И часто дебютирует уже в детском возрасте.

Цель исследования. Установить частоту раннего (от 0 до 15 лет) дебюта бронхиальной астмы и предикторы формирования тяжелой бронхиальной астмы у взрослых пациентов.

Материалы и методы. Проведен ретроспективный анализ 47 медицинских карт и анкетирование пациентов в возрасте от 21 до 74 лет с установленным диагнозом тяжелой бронхиальной астмы. Всем пациентам проводилось клиническое, аллергологическое обследование, включающее определение специфических IgЕ иммунофлуоресцентным методом (ImmunoCAP 100 Phadia AB, Швеция), спирография.

Результаты. Из 47 пациентов, включенных в исследование у 12 заболевание началось в детском возрасте: у одного - в раннем возрасте, в дошкольном - у 5, в школьном - у 6 человек. В исследуемой группе преобладали девочки (9), у мальчиков заболевание диагностировано в 3 раза реже. Большинство (8 человек) проживали в городе и только $4-$ в селе. У всех имелись сопутствующие заболевания: атопи- ческий дерматит, аллергический ринит, проявления пищевой, медикаментозной аллергии. По результатам исследования, у всех пациентов отмечена эозинофилия в анализе крови и в мокроте, повышение общего IgE в крови (от 200 до $700 \mathrm{ME} / \mathrm{M})$, поливалентная аллергия: бытовая - у 11 человек, грибковая - у 3, пыльцевая - у 4, эпидермальная - у 4, пищевая - у 2 человек. Всем больным назначалась комбинированная терапия в соответствии с Национальными клиническими рекомендациями, однако достичь полного контроля не удавалось. Уже в детском возрасте 3 пациентам была установлена инвалидность.

Заключение. На основании проведенных исследований можно сделать выводы, что аллергическая БА, дебютировав в детстве, трансформировалась в тяжелую бронхиальную астму взрослых у 25\% пациентов. Предикторами тяжелой бронхиальной астмы у взрослых являются: аллергический фенотип в детском возрасте, наличие поливалентной аллергии, сочетание бытовой сенсибилизации $(91,6 \%)$ с другими видами аллергенов, женский пол, проживание в городе.

\section{БИОЛОГИЧЕСКАЯ ТЕРАПИЯ БРОНХИАЛЬНОЙ АСТМЫ У ДЕТЕЙ В КЛИНИЧЕСКОЙ ПРАКТИКЕ: ЧТО ПРЕДПОЧЕСТЬ И КАК ВЫБРАТЬ?}

Ларькова И.А. ${ }^{1,2}$, Мухортых В.А ${ }^{1,3}$, Ревякина В.А. ${ }^{1,2}$ 1ФГБУН «ФИЦ питания, биотехнологии и безопасности пищи», Москва

${ }^{2}$ ФГАУ «НМИЦ здоровья детей» Минздрава России, Москва ЗФГБУ «ФНКЦ детей и подростков ФМБА России», Москва

Актуальность. В детском возрасте бронхиальная астма (БА) очень часто сочетается с другими аллергическими заболеваниями - атопический дерматит (АтД), аллергический ринит (АР), патогенез которых связан с Th-2 воспалением. Несмотря на общие патофизиологические механизмы, существуют различия между АтД и БА, что сказывается на разных подходах к биологической терапии. Из-за отсутствия надежных биомаркеров в клинической практике трудно сделать выбор и прогнозировать результат той или иной терапии.

Цель исследования - оценить биомаркеры и клинические особенности БА при выборе биологической терапии в клинической практике.

Материалы и методы. В исследование вошли 24 пациента от 12 до 18 лет со среднетяжелой/тяжелой БА, а также АтД и АР. Определение уровня общего $\mathrm{IgE}$ проводилось методом иммуноферментного анализа. В клиническом анализе крови контролировался уровень эозинофилов. 10 пациентов со среднетяжелой БА в сочетании с тяжелым АД получали дупилумаб в дозе 300 мг подкожно каждые 2 недели. 14 пациентов, 8 из которых имели среднетяжелую БА в сочетании с АР, 4 - тяжелую БА в сочетании с АР 
и 2 - тяжелую БА с легким АтД и АР получали омализумаб каждые 2-4 недели в индивидуальной дозе, зависящей от уровня $\operatorname{IgE}$ и массы тела. Кроме того, для 12 из этих 14 пациентов значимым фактором обострений БА была вирусная инфекция.

Результаты. Было установлено, что атопия, значимость вирусного триггера в обострении БА, уровень общего IgE, не превышающий $1500 \mathrm{me} / \mathrm{ml}$, среднетяжелое/тяжелое течение БА в сочетании с АР любой тяжести и АтД легкого течения являются показанием для выбора терапии омализумабом. В то же время, количество эозинофилов не влияло ни на выбор терапии, ни на прогноз эффективности. На фоне терапии омализумабом у всех пациентов был достигнут контроль над БА. Также был отмечен профилактический эффект омализумаба в отношении вирус-индуцированных обострений БА. Очень высокий уровень $\mathrm{IgE}-3068.5$ [2470.25; 3649.5] me/ml и высокая эозинофилия, ассоциированные с тяжелым АтД, были поводом для выбора терапии дупилумабом. Терапия дупилумабом обеспечила контроль над БА и АтД при значимом снижении уровня общего $\operatorname{IgE}-878$ [731.5; 1000.5$] \mathrm{me} / \mathrm{ml}$ и достоверном снижения количества эозинофилов $(p<0.001)$.

Заключение. Таким образом, в клинической практике при выборе биологической терапии БА у детей нужно учитывать такие биомаркеры, как уровень IgE и эозинофилов в крови, а также такие клинические параметры, как сопутствующий тяжелый/среднетяжелый АтД и зависимость обострений БА от вирусных инфекций.

\section{ФАКТОРЫ РИСКА НЕКОНТРОЛИРУЕМОГО ТЕЧЕНИЯ БРОНХИАЛЬНОЙ АСТМЫ У ДЕТЕЙ \\ Левченко Н.В., Потапова Н.Л.}

ФГБОУ ВО Читинская государственная медицинская академия, Чита

Введение. Контролируемое течение бронхиальной астмы регистрируется у 30-40\% пациентов, в остальных случаях контроль над заболеванием отсутствует или является частичным. Уточнение неблагоприятных факторов позволит сформировать группу высокого риска неконтролируемого течения бронхиальной астмы у детей.

Цель исследования - установить факторы риска неконтролируемой бронхиальной астмы у детей.

Материалы и методы. Обследовано 68 пациентов с хорошим уровнем контроля заболевания (Ме возраста 9,5 лет) и 32 пациента с неконтролируемой бронхиальной астмой (Ме возраста 10,0 лет). Степень контроля определялась согласно рекомендациям GINA (2020).

Результаты. Отягощенный семейный анамнез отмечен у 20\% пациентов с отсутствием контроля, более половины из них (53\%) имели аллергические заболевания по обеим родственным линиям $(p<0,05)$. Наличие перинатального поражения центральной нервной системы значимо повышало риск развития неконтролируемой астмы (ОШ=5, ДИ 95\% 1,2-21,5, $p<0,05)$. Пациенты с неконтролируемой астмой отличались мультитриггерным характером обострений - в 40,6\% случаев больные связывали обострение с физической нагрузкой, воздействием аллергенов и ОРИ (против 5,8\% в случае контролируемой БА, $p<0,01)$. Отмечено неблагоприятное действие пассивного курения: каждый четвертый ребенок, являющий пассивным курильщиком, не имел полного контроля над симптомами - в сравнении с 7,4\% при полном контроле над заболеванием. Превалирующим коморбидным состоянием явился аллергический ринит, отмеченный в группе неконтролируемой БА значимо чаще - в 4 раза (87,5 против $22,1 \%$; ОШ=24,7, ДИ95\% $7,5-81,6, p<0,05)$. Атопический дерматит в обеих группах встречался одинаково часто $(p>0,05)$.

Заключение. Пациенты с ППЦНС, сопутствующим аллергическим ринитом, на фоне пассивного курения и мультитриггерным характером обострений имеют более высокий риск неконтролируемого течения бронхиальной астмы. Учет неблагоприятных факторов при выборе тактики ведения пациентов с бронхиальной астмой, может способствовать достижению полного контроля заболевания.

\section{РОЛЬ НЕОНАТАЛЬНОГО СКРИНИНГА В ДИАГНОСТИКЕ И ВЫЯВЛЯЕМОСТИ МУКОВИСЦИДОЗА В СТАВРПОЛЬСКОМ КРАЕ \\ Леденева Л.Н., Водовозова Э.В., Григорьяни И.С., \\ Белаш Т.А., Енина Е.А., Пустабаева М.С. \\ ФГБОУ ВО «Ставропольский государственный \\ медицинский университет» МЗ РФ, Ставрополь}

Введение. Неонатальный скрининг является способом ранней диагностики патологий, обусловленных генетическими мутациями. По рекомендации ВO3 неонатальный скрининг включен в перечень обязательных медицинских тестов для детей.

Цель исследования: изучить показатели неонатального скрининга у детей Ставропольского края (CK), страдающих муковисцидозом (MB).

Материал и методы. Ретроспективный анализ данных лаборатории неонатального скрининга Ставропольского краевого клинического перинатального центра за период с 2012 по 2018 годы.

Результаты. В СК за период с 2012 по 2018 гг. количество обследуемых новорожденных практически было одинаковым (37980 в 2012 г., 37640 - в 2013 г., 37600 - в 2014 г., 38241 - в 2015 г., 38441 - в 2016 г., 38892 - в 2017 г. и 37988 - в 2018 г.). Повышенные значения ИРТ демонстрировали тенденцию к снижению (601 случай в 2012 году и 201 - в 2018 году), при этом диагноз МВ был верифицирован ежегодно 
у 1-3 детей, за исключением 2012 года, когда было выявлено 10 больных. Заболеваемость МВ среди обследованных новорожденных колебалась от 0,02 в 2012 г. до 0,003 в 2013 г. и 2015 г. Выявляемость заболевших МВ в СК детей по отношению ко всему детскому населению составила 0,02 в 2012 г., 0,002 в 2013 г. и в 2015 г., 0,005 - в 2014 г., 2017 г. и 2018 г. и $0,007-$ в 2016 г.

\section{ПРОФИЛАКТИКА МЕТЕОПАТИЧЕСКИХ РЕАКЦИЙ У ДЕТЕЙ С БРОНХИАЛЬНОЙ АСТМОЙ В МОСКОВСКОМ РЕГИОНЕ}

Лян Н.А. ${ }^{1,3}$, Хан М.A. ${ }^{1,2}$, Рассулова М.А. ${ }^{1}$, Уянаева А.И. ${ }^{1}$

'ГАУЗ Москвы «МНПЦ медицинской реабилитации, восстановительной и спортивной медицины ДЗМ», Москва, Россия

2ГБУЗ «ДГКБ им. Н.Ф. Филатова ДЗМ», Москва, Россия ${ }^{3}$ ФГАОУ ВО «Первый Московский государственный медицинский университет им. И.М. Сеченова» Минздрава России, Москва, Россия

Высокая чувствительность детей с бронхиальной астмой к погодно-климатическим условиям, а также развитие у них патологических реакций на неблагоприятную погоду обосновывают разработку немедикаментозных технологий профилактики метеопатических реакций у детей с бронхиальной астмой. Результаты проведенных исследований показали, что в условиях климата Московского региона наиболее неблагоприятным служит формирование погодной гипоксии, что явилось научным обоснованием для применения нормобарической гипокситерапии (НГ) в профилактике метеопатических реакций у детей с бронхиальной астмой.

Клинические наблюдения проведены в динамике у 43 детей с бронхиальной астмой в возрасте от 6 до 15 лет. Основную группу составил 21 ребенок, получавший НГ.

На фоне проведения НГ выявлена положительная динамика основных клинических симптомов бронхиальной астмы: купировался приступообразный кашель, прекратились приступы затрудненного дыхания, нормализовалась аускультативная картина в легких. Под влиянием курса НГ выявлено улучшение функции внешнего дыхания по данным компьютерной флоуметрии, достоверное увеличение средних значений пикфлоуметрии уже к середине курса лечения. Анализ результатов психологического тестирования показал благоприятное влияние НГ на показатели психологического статуса у детей с бронхиальной астмой, характеризующееся уменьшением раздражительности, эмоциональной лабильности, снижением тревожности, нормализацией уровня активности, повышением работоспособности.

В ответ на курсовое воздействие НГ у большинства детей снизились проявления повышенной метеочувствительности, уменьшилось число метеопатических реакций в дни с выраженными условиями погодной гипоксии.

Таким образом, НГ оказывает благоприятное влияние на клиническое течение, бронхиальную проходимость, психо-эмоциональный статус детей с бронхиальной астмой, способствует уменьшению частоты и степени тяжести погодообусловленных обострений, что определяет патогенетическую обоснованность метода в профилактике повышенной метеочувствительности у детей с бронхиальной астмой.

\section{ЦИТОМОРФОЛОГИЧЕСКАЯ ХАРАКТЕРИСТИКА НЕЙТРОФИЛОВ ИНДУЦИРОВАННОЙ МОКРОТЫ У ЧАСТО БОЛЕЮЩИХ ДЕТЕЙ С ВНЕБОЛЬНИЧНОЙ ПНЕВМОНИЕЙ}

Маланичева Т.Г. ${ }^{1}$, Мизерницкий Ю.Л. ${ }^{2}$, Можгина С.С. ${ }^{4}$, Агафонова Е.В. ${ }^{1,3}$, Кузнецова О.Ю. ${ }^{5}$

${ }^{1}$ Казанский государственный медицинский университет, Казань

${ }^{2}$ Научно-исследовательский клинический институт педиатрии имени академика Ю.Е. Вельтищева ФГАОУ ВО РНИМУ им.Н.И.Пирогова Минздрава РФ, Москва ${ }^{3}$ ФБУН КНИИЭМ Роспотребнадзора, Казань 4Детская республиканская клиническая больница Республики Татарстан, Казань

${ }^{5}$ Казанский федеральный университет. Казань

Введение. Актуальность обусловлена высокими показателями заболеваемости внебольничной пневмонией (ВП) у часто болеющих детей (ЧБД) и недостаточной изученностью функционального состояния нейтрофильных гранулоцитов и их роли в мукозальном иммунитете

Цель работы: изучить цитоморфологический профиль нейтрофилов индуцированной мокроты у ЧБД с ВП.

Материалы и методы. Обследовано 83 ребенка ВП от 3 до 7 лет. Основная группа - 50 ЧБД с ВП, группа сравнения - 33 ребенка с ВП, не входящие в группу ЧБД. Определяли количество нейтрофилов в индуцированной мокроте и оценивали выраженность их деструктивных изменений с выделением 4 классов деструкции: n0, n1, n2, n3 и n4. В класс п0 включали клетки без признаков деструкции цитоплазмы и ядра, в n1 - клетки с минимальной деструкцией цитоплазмы, без повреждения ядра, в n2 - клетки со значительной деструкцией цитоплазмы и минимальными повреждениями ядра, в n3 - клетки с полной деструкцией цитоплазмы и существенным повреждением ядра, в n4 -клетки с полной деструкцией и распадом цитоплазмы и ядра.

Результаты. Относительное количество нейтрофилов в основной группе было в 2,2 раза ниже, чем в группе сравнения и составило $20,7 \pm 6,2 \%$ против $45,6 \pm 3,9 \%(p<0,001)$. Дальнейшее изучение цито- 
морфологического состава клеток в популяциях нейтрофилов выявили достоверные различия в сравниваемых группах. Так, в основной группе отмечалось статистически значимое увеличение не только содержания нейтрофилов, имеющих значительные признаки деструкции (класс n3) в 1,8 раза, но и нейтрофилов с полной деструкцией и распадом цитоплазмы и ядра (класс n4) - в 8,5 раз. Также выявлено, что количество нейтрофилов с незначительными признаками деструкции (классы n1 и n2) не имело статистически значимых отличий в сравниваемых группах. Таким образом, у детей основной группы в отличии от группы сравнения происходило увеличение индекса цитолиза клеток в 6,5 раза $(p<0,001)$, индекса деструкции клеток - в 1,5 раза $(p<0,05)$ и среднего показателя деструкции в 1,6 раза $(p<0,05)$.

Заключение. Таким образом, у часто болеющих детей с ВП, отмечается замедление выхода нейтрофилов в бронхиальный секрет, что подтверждается развитием нейтропении на фоне выраженного роста нейтрофилов с полной деструкцией и распадом цитоплазмы и ядра.

\section{ПРОФИЛАКТИЧЕКАЯ ЭФФЕКТИВНОСТЬ АНТИЛЕЙКОТРИЕНОГО ПРЕПАРАТА ПРИ РЕЦИДИВИРУЮЩЕЙ БРОНХИАЛЬНОЙ ОБСТРУКЦИИ У ДЕТЕЙ}

Марковская А.И. ${ }^{1}$, Гаймоленко И.Н. ${ }^{1}$, Мизерницкий Ю.Л. ${ }^{2}$ ${ }^{1}$ ФГБОУ ВО «Читинская государственная медицинская академия», Чита

${ }^{2}$ НИКИ педиатрии им. Ю.Е.Вельтищева ФГАОУ ВО РНИМУ им. Н.И.Пирогова Минздрава России, Москва.

Актуальность. Повторные эпизоды бронхиальной обструкции (БО) на фоне ОРВИ и выраженная бронхиальная гиперреактивность соотносятся с высоким риском фенотипической манифестации бронхиальной астмы у дошкольников. Оптимальной стратегией профилактики при этом является ранняя противовоспалительная терапия (Мизерницкий Ю.Л., 2021).

Цель исследования. Определить профилактическую эффективность курсового приема монтелукаста у детей с рецидивирующей БО.

Материалы и методы. В проспективном когортном клиническом исследовании участвовали дети в возрасте от 2 до 5 лет $(n=50)$, с положительным API (Asthma Predictive Index). Из них 30 детей (основная группа), наряду с традиционным лечением ОР3, принимали антилейкотриеновый препарат монтелукаст (Сингуляр) по 1 таблетке (4 мг) 1 раз в день курсом 3 месяца, мониторинг состояния проводился дважды (в 1 и 3 месяца). Пациенты группы сравнения $(n=20)$ монтелукаст не получали, ограничиваясь симптоматической терапией в период респираторных инфекций. Исследование было одобрено Этическим комитетом ЧГМА.
Результаты. Нами установлено достоверное снижение продолжительности течения ОРИ у детей основной группы с 17,5 $\pm 5,5$ до 9,9 2 , 1 суток $(p<0,05)$, в группе сравнения средняя длительность заболева-

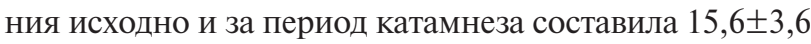
и $15,3 \pm 3,4$ суток, соответственно (p 0,05$)$. Выявлено снижение частоты свистящих хрипов у детей основной группы $(1,4 \pm 0,7$ против $0,38 \pm 0,2 ; p<0,05)$, в группе сравнения значимых изменений не зафиксировано $(1,3 \pm 0,6$ против $1,1 \pm 0,5 ;$ p 0,05). Согласно опросу родителей, косвенные признаки бронхиальной гиперреактивности (свистящее дыхание и/или спастический кашель при физической нагрузке, резких запахах, смехе, плаче) отмечались у каждого второго ребенка обеих групп (15 (51,7\%) и $9(45 \%)$, соответственно), через 1 месяц терапии монтелукастом сохранялись у 9 (31\%) человек и через 3 месяца у 4 (13,8\%) из 29 человек $(p=0,02)$, а в группе не получавших монтелукаст через 3 мес сохранялись у 7 (35\%) (p 0,05).

Заключение. Наши результаты показывают эффективность антилейкотриена для уменьшения частоты свистящих хрипов и признаков гиперреактивности бронхов у детей 2-5 лет с рецидивирующей бронхообструкцией на фоне ОРИ, что может способствовать предупреждению формирования у них бронхиальной астмы.

\section{ОСОБЕННОСТИ ПАТТЕРНА ДЫХАНИЯ У ДЕТЕЙ С РЕКУРРЕНТНЫМ БРОНХООБСТРУКТИВНЫМ СИНДРОМОМ}

Марковская А.И. ${ }^{1}$, Гаймоленко И.Н. ${ }^{1}$, Мизерницкий Ю.Л. ${ }^{2}$ 'ФГБОУ ВО «Читинская государственная медицинская академия», Чита НИКИ педиатрии им. Ю.Е.Вельтищева ФГАОУ ВО РНИМУ им. Н.И.Пирогова Минздрава России, Москва.

Введение. Повторные случаи синдрома бронхиальной обструкции на фоне ОРВИ являются фактором формирования гиперреактивности бронхов и риска бронхиальной астмы. В этом отношении исследование у этих детей функционального состояния дыхательных путей методом бронхофонографии представляется актуальным.

Цель исследования. Изучить особенности показателей компьютерной бронхофонографии у детей с рецидивирующей бронхиальной обструкцией.

Материалы и методы. В исследование включено 75 детей с острым обструктивным бронхитом, в возрасте от 1 года до 5 лет $(2,8 \pm 1,2$ лет). На основании данных анамнеза пациенты были распределены в 2 подгруппы: 1 подгруппа $(n=32)$ - дети, имеющие 3 эпизодов БО на фоне ОРВИ за прошедшие 12 месяцев; 2 подгруппа $(n=43)$ - дети, имеющие $\geq 3$ эпизодов БО в течение последнего года. Запись БФГ осуществлялась в остром периоде заболевания с помощью компьютерного акустического диагностического ком- 
плекса «Паттерн-01», в трех частотных диапазонах. Группу контроля составили 29 здоровых детей, сопоставимых по возрасту и полу.

Результаты. Нами выявлено, что паттерн дыхания у детей с ООБ $(n=75)$, в сравнении со здоровыми детьми, характеризуется повышением показателей акустической работы дыхания как в целом, так и в различных частотных диапазонах: АРД1 - в 30,8 раз $(1278,9(569,6 ; 2077,9)$ и 41,5 $(29,5 ; 54,3)$ мкДж, $p<0,001)$, АРД2 - в 38,3 раз $(154,3 \quad(58,9 ; 228,1)$ и $4,03(3,05 ; 5,7)$ мкДж, $p<0,001)$, АРД3 - в 19,1 раз $(3,24(2,1 ; 4,9)$ и $0,17(0,13 ; 0,4)$ мкДж, $p<0,001)$, АРД в общем частотном диапазоне - в 37,8 раз $(158,9$ $(63,3 ; 232,4)$ и $4,2(3,3 ; 5,9)$ мкДж, $p<0,001)$. При парном сравнении между первой и второй подгруппами обнаружено, что у детей, имеющих $\geq 3$ эпизодов БО, величины всех показателей БФГ в среднем были в два раза выше, в сравнении с детьми первой подгруппы: АРД1 $(1561,5(856,3 ; 2256,3)$ и $744,8(428,9 ; 1367,6)$ мкДж, соответственно, $p<0,05)$, АРД2 $(177,4(64,8$; $301,2)$ и $74,5(54,5 ; 169,7)$ мкДж, $p<0,05)$, АРД3 $(4,29$ $(2,5 ; 5,6)$ и $2,44(1,8 ; 3,5)$ мкДж, $p<0,05)$, АКРДобщ $(179,9(66,9 ; 304,4)$ и $78,1(57,4 ; 172,1)$ мкДж, $p<0,05)$.

Заключение. Нами установлено, что у детей с острым обструктивным бронхитом повышены показатели акустической работы дыхания во всех частотных диапазонах. При этом нарушения нарастают с повышением частоты рецидивов обструкции, что указывает на формирование у этих детей гиперреактивности бронхов и риск манифестации бронхиальной астмы.

\section{ПРЕДИКТОРЫ БРОНХИАЛЬНОЙ АСТМЫ И КЛИНИЧЕСКАЯ ЭФФЕКТИВНОСТЬ ЕЕ ПРОФИЛАКТИКИ МОНТЕЛУКАСТОМ У ДЕТЕЙ 1-5 ЛЕТ С ОСТРЫМИ БРОНХИТАМИ}

Марковская А.И. ${ }^{1}$, Гаймоленко И.Н. ${ }^{1}$, Мизерницкий Ю.Л. ${ }^{2}$ 'ФГБОУ ВО «Читинская государственная медицинская академия», Чита

НИКИ педиатрии им. Ю.Е.Вельтищева ФГАОУ ВО РНИМУ им. Н.И.Пирогова Минздрава России, Москва.

Актуальность. Бронхиты у детей 1-5 лет нередко сопровождаются развитием бронхообструктивного синдрома, что ставит сложные вопросы дифференциального диагноза с бронхиальной астмой или профилактики ее формирования.

Цель исследования. Посредством оценки факторов риска, клинических характеристик, этиологии, маркеров воспаления в сыворотке крови, показателей функции внешнего дыхания, определить предикторы бронхиальной астмы и клиническую эффективность ее профилактики монтелукастом у детей с острыми бронхитами.

Материалы и методы. В исследование включено 109 детей в возрасте от 1 года до 5 лет $(2,8 \pm 1,2$ лет) с острыми бронхитами (группа наблюдения) и 29 прак- тически здоровых детей $(3,6 \pm 0,8$ лет), составивших контрольную группу. Пациенты группы наблюдения были разделены в зависимости от клинического варианта течения на две группы: первую группу составили 75 детей с острым обструктивным бронхитом (2,8土1,2 лет); вторую группу - 34 пациента с острым

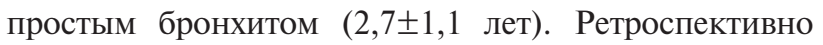
пациенты с ООБ были распределены в 2 подгруппы: 1 подгруппа $(n=32)$ - дети, имеющие в анамнезе 3 эпизодов БО на фоне ОРВИ за прошедшие 12 месяцев; 2 подгруппа ( $n=43)$ - дети, имеющие $\geq 3$ эпизодов БО в течение предшествующего года. Протокол включал анкетирование, носоглоточные мазки для определения этиологии, забор крови на уровни цитокинов и хемокинов, бронхофонографию (БФГ).

$90(82,6 \%)$ детей группы наблюдения, в возрасте от 1 года до 3 лет, из них 62 (82,7\%) с ООБ, 28 (82,4\%) пациентов с ОПБ, опрошенных в острый период заболевания по опроснику «Asthma Prediction Tool», проспективно наблюдались в течение 1,5 лет.

Для оценки эффективности пролонгированного курса монтелукаста, 30 детей (основная группа) с положительным API (Asthma Predictive Index) принимали препарат Сингуляр по 1 таблетке (4 мг) 1 раз в день курсом 3 месяца, мониторинг состояния проводился дважды (в 1 и 3 месяца). Пациенты группы сравнения $(n=20)$ монтелукаст не получали, ограничиваясь симптоматической терапией в период респираторных инфекций. Исследование было одобрено Этическим комитетом ЧГМА.

Результаты. Нами выявлено, что основными триггерами развития острого обструктивного бронхита являются: неблагоприятный аллергологический наследственный анамнез, аллергическая конституция в грудном возрасте, атопический дерматит, пассивное табакокурение, гипертрофия носоглоточной миндалины. При этом отмечено, что у детей, имеющих $\geq 3$ эпизодов БО в течение года, отягощенный семейный аллергоанамнез встречался в 1,6 раз чаще, чем в первой подгруппе $(\mathrm{OR}=5,4 ; 95 \% \mathrm{CI}$ 1,8-16,5). Пациенты 2 подгруппы в 3 раза чаще, чем в первой, страдали проявлениями атопического дерматита $(\mathrm{OR}=7,7 ; 95 \% \mathrm{CI}$ 2,7-21,9). Гипертрофия носоглоточной миндалины I-II степени в 4 раза чаще регистрировалась у детей второй подгруппы, чем в первой, что является предрасполагающим фактором развития повторной БО на фоне ОРИ $(\mathrm{OR}=5,8 ; 95 \% \mathrm{CI}=1,2-28,2)$.

Клинико-лабораторная картина острого обструктивного бронхита в сравнении с острым простым бронхитом отличается умеренным респираторно-катаральным и интоксикационным синдромом, наличием эозинофилии. В этиологическом спектре острых бронхитов лидирует респираторно-синцитиальная инфекция. При остром обструктивном бронхите значимо чаще регистрируется риновирусная инфекция.

Паттерн дыхания у детей с острыми бронхитами $(n=109)$, в сравнении со здоровыми детьми, харак- 
теризуется повышением показателя акустической работы дыхания (АРД) во всех частотных диапазонах и зависит от клинического варианта течения заболевания. Нами обнаружено, что у детей, имеющих $\geq 3$ эпизодов БО, величины всех показателей АРД при БФГ в среднем в два раза выше, в сравнении с детьми первой подгруппы.

В ходе анализа цитокинового профиля у детей с ООБ и ОПБ выявлены сходные сдвиги иммунологических показателей, с тенденцией к большей их выраженности при ООБ.

Катамнестическое обследование (уже через 18 месяцев) показало, что диагноз БА легкой степени был верифицирован у 19 (30,6\%) пациентов из группы ООБ, имеющих средний и высокий риск развития заболевания; у детей из группы низкого риска, в том числе с ОПБ случаев манифестации БА за анализируемый период катамнестического наблюдения не зарегистрировано.

В ходе исследования установлено, что пролонгированный курс монтелукаста у детей с положительным API способствует уменьшению длительности, тяжести течения последующих респираторных заболеваний, снижению частоты возникновения бронхообструктивного синдрома и формирования бронхиальной астмы.

Заключение. Комплексный анализ анамнестических данных, клинико-этиологических, функциональных и иммунологических показателей дает возможность персонифицированного подхода к ребенку 1-5 лет с острым бронхитом. Наши результаты показывают, что среди детей этого возраста с рекуррентным бронхообструктивным синдромом и высоким риском последующего развития бронхиальной астмы, целесообразно и эффективно проведение ранней профилактической противовоспалительной терапии монтелукастом.

\section{К ДВАДЦАТИЛЕТИЮ ИЗДАНИЯ ЕЖЕГОДНОГО АЛЬМАНАХА: «УЛЬМОНОЛОГИЯ ДЕТСКОГО ВОЗРАСТА: ПРОБЛЕМЫ И РЕШЕНИЯ» \\ Мизерницкий Ю.Л.}

НИКИ педиатрии им. Ю.Е.Вельтищева ФГАОУ ВО РНИМУ им. Н.И.Пирогова Минздрава России, Москва.

С целью популяризации современных медицинских знаний и технологий, внедрения их в педиатрическую практику, обмена опытом и совершенствования специализированной медицинской помощи Детским научно-практическим центром Минздрава России, функционирующим на базе отделения пульмонологии НИКИ педиатрии им. акад. Ю.Е.Вельтищева по инициативе профессора С.Ю.Каганова и главного детского пульмонолога Минздрава РФ Ю.Л.Мизерницкого с 2001г. стал издаваться ежегодный альманах «Пульмонология детского возраста: проблемы и решения». В 2020г в ИД «МЕДПРАКТИКА-М» вышел юбилейный 20-й выпуск. В работе редколлегии ежегодника участвуют ведущие специалисты страны - профессора, члены-корреспонденты РАН, заслуженные врачи, деятели науки, работники здравоохранения. Сборник цитируется в РИНЦ, включает вызвавшие за очередной год наибольший интерес аудитории лекции и доклады на различных научно-практических конференциях по актуальным проблемам пульмонологии и аллергологии детского возраста, таким как: современные методы диагностики и лечения, острые и хронические инфекционно-воспалительные и аллергические заболевания органов дыхания, муковисцидоз, туберкулез органов дыхания, Covid-19, а также страницы истории, хронику, вопросы организации пульмонологической помощи детям, обмен опытом, интересные случаи из медицинской практики, различные другие информационные материалы. Ежегодник адресован практикующим детским пульмонологам и аллергологам. Тираж ежегодника за годы его издания вырос до 4500. Жизнь подтвердила высокую актуальность данного проекта. Подводя итоги, нельзя не отметить высокую востребованность этого издания, неизменность положительных отзывов на него практических врачей - педиатров, пульмонологов, аллергологов из различных территорий Российской Федерации, СНГ и ближнего зарубежья.

Редколлегия ежегодника постарается и впредь содействовать реализации главной задачи - распространению передового опыта и новейших знаний, оправдывать высокое доверие коллег и всемерно способствовать росту их профессионализма. Спрашивайте, обсуждение каких наиболее актуальных разделов практической пульмонологии детского возраста, Вы хотели бы видеть в будущих выпусках. - Ведущие специалисты ответят на Ваши вопросы.

Все прошлые издания ежегодника представлены в интернете, их легко найти на сайте института www. pedklin.ru

\section{СЛУЧАЙ МУЛЬТИСИСТЕМНОГО ВОСПАЛИТЕЛЬНОГО СИНДРОМА, АССОЦИИРОВАННОГО С НОВОЙ КОРОНАВИРУСНОЙ ИНФЕКЦИЕЙ (COVID-19) У РЕБЕНКА 8 ЛЕТ}

Мингаирова А.Г. ${ }^{1}$, Павлинова Е.Б. ${ }^{1}$, Вологжанина Е.В. ${ }^{2}$, Глущенко Е.A. ${ }^{2}$

'ФГБОУ ВО «Омский государственный медицинский университет» Минздрава России, Омск

²БУЗОО «Областная детская клиническая больница, Омск

Введение. Мультисистемный воспалительный синдром (МВС), ассоциированный с инфекцией COVID-19, привлекает все большее внимание педиатров, что связано со сложностями его диагностики, 
развитием жизнеугрожающих состояний, отсутствием оптимальных схем терапии и диспансерного наблюдения.

Цель. Представить случай МВС у ребенка 8 лет.

Материалы и методы. Мальчик 8 лет поступил в приемное отделение на 10 день болезни с жалобами на лихорадку до $40^{\circ} \mathrm{C}$, цефалгию, вялость, боли в животе, мелкоточечную местами сливную сыпь на ладонях, в области запястий, над правым коленным суставом, по боковой поверхности правого бедра. При поступлении состояние тяжелое, обусловлено интоксикацией, абдоминальным болевым синдромом. Губы сухие, слизистые полости рта ярко розовые. Дыхание стонущее, с частотой 72 в мин. Тоны сердца приглушены, ЧСС 150 в мин. Гепатомегалия. Живот напряжен. В крови - нейтрофильный лейкоцитоз, увеличение СОЭ, СРБ, пресепсина, прокальцитонина. При УЗИ - свободная жидкость в плевральной полости слева. В динамике появились боли в области сердца, вынужденное положение (сидя), при ЭхоКГ - перикардит. Натрийуретический пропептид значительно повышен - 1099,41 пг/мл. Серологический тест на COVID-19 положительный. Пациенту потребовалось проведение лапароскопии, плевральной, люмбальной, костномозговой, перикардиальной пункции. На основании полученных данных был установлен диагноз: мультисистемный воспалительный синдром, ассоциированный с новой коронавирусной инфекцией COVID-19. Проводилась антибактериальная, гормональная, антикоагулянтная, мочегонная терапия, использовался ВВИГ.

Результаты. На фоне лечения отмечалась медленная положительная клиническая динамика. Лабораторно был зафиксирован агранулоцитоз, сохранявшийся в течение 2-х недель, что потребовало назначение лейкостима. Генез его остается до конца не ясным. Ребенок выписан с улучшением под наблюдение педиатра, кардиолога, рекомендована кардиометаболическая терапия.

Заключение. Данный клинический пример демонстрирует, что МВС представляет сложную диагностическую и лечебную задачу, требует исключения болезни Кавасаки, гемофагоцитарного синдрома при системном варианте ювенильного идиопатического артрита и опухолевого процесса.

\section{ЭВОЛЮЦИЯ ПАРАДИГМ АСТМАЛОГИИ: РЕКОМЕДАЦИИ GINA В ОПТИМИЗАЦИИ ПРО- ТИВОАСТМАТИЧЕСКОЙ ТЕРАПИИ У ДЕТЕЙ}

Нестеренко 3. В.

Федеральное государственное бюджетное

образовательное учреждение высшего образования

«Санкт-Петербургский государственный

педиатрический медицинский университет»

Министерства здравоохранения Российской

Федерации, Санкт-Петербург

Введение. Диагностика и лечение бронхиальной астмы (БА) с 1995 года проводится согласно рекомендациям GINA, что существенно изменило тактику ведения больных с БА.

Цель исследования: изучить особенности клинического течения БА у детей на разных этапах внедрения рекомендаций GINA (2008-2010 гг. - 2016-2018 гг.).

Материалы и методы: под наблюдением находились дети с 1 года до 18 лет 2008-2010гг. - 132 ребенка (1 группа); 2016-2018 гг. - 52 больных (2 группа), во всех случаях использовались рекомендации GINA. Оценивалась и сравнивалась тяжесть течения БА, частота коморбидных заболеваний; формирования осложнений.

Результаты: легкое интермиттирующее течение БА в 1 группе имело место в 1,5 раза реже, чем во 2-ой $(58,4 \%-88,5 \%)$; среднетяжелое персистирующее - достоверно чаще $((\mathrm{p}<0,005))-$ в 3,6 раз $(41,6 \%$ - 11,5\%). Диагноз в первый год наблюдения устанавливался в 1 группе в 1,6 раза реже, чем во 2-ой - 53,8,4\% - 88,5\%; а после 2 -х и более лет проявления симптомов БА достоверно чаще, чем во 2-ой группе $(46,2 \%-11,5 \%)$. Из коморбидных заболеваний внебольничная пневмония (ВП), вызвавшая обострение БА, отмечена в 1,4 раза чаще во 2-ой группе $(85,1 \%-52,2 \%)$; аллергический ринит в 2,6 раз был чаще у пациентов 2 группы $(44,2 \%$ $-16,7 \%)$; атопический дерматит имел место почти одинаково в обеих группах: 18,2\% - 17,3\%. Этиология ВП представлена микоплазменной инфекцией (МПИ) незначительно чаще во 2-ой группе $(85,1 \%$ $61,1 \%)$; как и герпесвирусная инфекция-ГИ (цитомегаловирус, герпесвирус) - 62,9\% - 28,4\% (в 2,2 раза). Хламидийная инфекция - немного чаще выявлена в 1 группе - 16,6\% - 14,8\%. У больных с БА и ВП формирование легочной гипертензии (ЛГ) выявлено одинаково часто в обеих группах: $34,1 \%$ - 34,6\%; признаки пневмофиброза (ПФ) несколько чаще отмечались в 1 группе $(15,1 \%-11,5 \%)$.

\section{Выводы:}

1. Использование рекомендаций GINA позволило выявлять БА у детей в первый год появления симптомов достоверно чаще.

2. Среднетяжелое течение БА имело место достоверно реже у пациентов 2 группы. 
3. Частота коморбидных заболеваний у больных из обеих групп разнилась незначительно с тенденцией к увеличению во 2 группе.

4. Выявлено увеличение ГИ в этиологической структуре ВП у детей с БА.

5. Применение таргетной антибактериальной терапии при ВП изменило соотношение ГИ и уменьшению МПИ.

6. Формирование ЛГ, ПФ у детей с БА из 2 группы было несколько реже.

7. Применение рекомендаций GINA оказало существенную помощь в ранней диагностике БА у детей и назначении адекватной терапии, что сопровождалось снижением степени тяжести заболевания и уменьшением числа осложнений.

\section{СОВРЕМЕННЫЕ МЕТОДЫ КОНТРОЛЯ БРОНХИАЛЬНОЙ АСТМЫ У ДЕТЕЙ \\ Подкорытов А.А., Мещеряков В.В. \\ Сургутский государственный университет, Сургут}

Введение. Бронхиальная астма (БА) - самое распространенное хроническое бронхолегочное заболевание у детей. Целью базисной терапии БА является достижение контролируемого состояния. Для оценки уровня контроля заболевания используются различные клинические и функциональные методы.

Цель. Представить характеристику современных методов контроля БА в зависимости от возраста пациента и условий их применения - дома или в медицинской организации. Материалы и методы. Проанализированы публикации зарубежных и отечественных авторов, обзоры рандомизированных контролируемых исследований из различных источников, включая платформы PubMed, Cyberleninka, eLibrary, Scholar.google.ru и др. с глубиной поиска 10 лет.

Результаты. Клинико-анамнестические объективные методы контроля используются как при сборе анамнеза врачом, (основываются на конкретных ранжированных критериях наличия симптомов БА, их выраженности и частоте возникновения), так и оценки симптомов болезни самим ребенком или родителями (Asthma Control Test - ACT тест для детей до 12 лет и старше 12 лет). Функциональным критерием контролируемого состояния является нормальная бронхиальная проходимость в сочетании с отсутствием обратимости бронхиальной обструкции. Ввиду сложности выполнения форсированного выдоха у детей до 6 лет используются функциональные методы, выполняемые при спокойном дыхании (компьютерная бронхофонография, метод перекрытия потока и импульсная осциллометрия, флоуметрия спокойного дыхания), в более старшем возрасте - дополнительно спирометрия, бодиплетизмография, пикфлоуметрия (ПФМ). В домашних условиях основным методом служит ПФМ, информативность которой повышается при выполнении ее модификации - «парной» ПФМ, отражающей наличие/отсутствие бронхиальной обструкции и ее обратимости. Новым направлением совершенствования методов контроля является использование различных дистанционных технологий, которые включают одновременное участие пациента и врача. Это позволяет осуществлять мониторинг болезни и оперативно принимать решение о коррекции терапии.

Заключение. Для повышения результативности контроля над БА у детей необходимо использовать в комплексе клинико-анамнестические и функциональные методы самоконтроля и оценки контроля врачом, выбор которых зависит от возраста ребенка. Наиболее эффективным является оперативный дистанционный мониторинг БА.

\section{ОЦЕНКА ОТНОСИТЕЛЬНОГО РИСКА ЗАБОЛЕВАЕМОСТИ БРОНХИАЛЬНОЙ АСТМОЙ СРЕДИ ДЕТСКОГО НАСЕЛЕНИЯ НА РЕГИОНАЛЬНОМ УРОВНЕ}

Пономарева О.В., Петров С.Б., Чагаева Н.В.,

Ляпунова Е.В.

ФГБОУ ВО Кировский ГМУ Минздрава России, Киров

Введение. Ввиду высокой распространенности бронхиальной астмы (БА) представляет актуальность анализ показателей ее относительного риска у детского населения.

Цель исследования. Оценить уровень относительного риска (RR) заболеваемости БА среди детского населения областного центра и районов области по сравнению со среднерегиональным уровнем.

Материалы и методы. Данные о заболеваемости БА детского населения (0-14 лет) получены из медико-статистической отчетности МИАЦ Минздрава Кировской области за 2019 г. В качестве учетных признаков взяты общее зарегистрированное и впервые выявленное количество случаев заболеваний БА у детей 0-14 лет, а также численность детского населения 0-14 лет в г. Кирове, Верхнекамском, Лузском, Вятскополянском и Санчурском районах области.

Результаты. Уровень относительного риска для общей заболеваемости БА: г. Киров $-\mathrm{RR}=1,22$ CI95\%(1,13 - 1,32) CI95\%(11,82\% - 24,13\%), Bepxнекамский район $-\mathrm{RR}=0,54 \mathrm{CI} 95 \%(0,34-0,86)$, Лузский район $-\mathrm{RR}=1,03 \mathrm{CI} 95 \%(0,64-1,56)$, Вятскополянский район $-\mathrm{RR}=0,9 \mathrm{CI} 95 \%(0,71-1,15)$, Санчурский район $-\mathrm{RR}=1,17 \mathrm{CI} 95 \%(0,67-2,06)$. Уровень относительного риска для первичной заболеваемости БА: г. Киров - RR= 1,35 CI95\%(1,04$1,75)$ CI95\%(3,48\% - 42,85\%), Лузский район $-\mathrm{RR}=$ 0,6 CI95\%(0,08 - 4,26), Вятскополянский район $\mathrm{RR}=1,64 \mathrm{CI} 95 \%(0,87-3,12)$, Санчурский район $\mathrm{RR}=1,24 \mathrm{CI} 95 \%(0,17-8,88)$. Репрезентативно высо- 
кие показатели относительного риска были получены в отношении общей и первичной заболеваемости БА у детского населения, проживающего в г. Кирове. Данная картина говорит о неравномерном распределении случаев заболевания БА среди детского населения области с преобладанием в областном центре, что может являться следствием неблагоприятной экологической обстановки, а также большей доступности специализированной медицинской помощи, лучшей и своевременной диагностики данного хронического аллергического заболевания.

Заключение. Показатель относительного риска позволяет выделять «проблемные» в отношении риска бронхиальной астмы у детей территории с целью своевременного принятия управленческих решений на уровне регионального здравоохранения.

\section{КОМПЬЮТЕРНАЯ БРОНХОФОНОГРАФИЯ В КОМПЛЕКСЕ РАННЕЙ ДИАГНОСТИКИ БРОНХИАЛЬНОЙ АСТМЫ У ДЕТЕЙ}

Попова И.В., Леушина Н.А., Гришковеи Н.А., Кирсанова Е.Г. ФГБОУ ВО Кировский ГМУ Минздрава России, Киров

Введение. Бронхиальная астма (БА) - одно из самых частых хронических заболеваний детского возраста. Одним из неинвазивных перспективных методов акустической оценки функционального состояния бронхолегочной системы является компьютерная бронхофонография (КБФГ). Она позволяет своевременно диагностировать обструктивные проявления, характерные для БА.

Цель исследования - оценить диагностическую значимость КФБГ для раннего выявления БА у детей.

Материалы и методы. У 45 детей раннего возраста (19 девочек $(42,2 \%)$ и 26 мальчиков $(57,8 \%)$ ) с риском развития бронхиальной астмы проводилась (КБФГ) с помощью аппаратно-диагностического комплекса «Паттерн» (Россия).

Результаты. При оценке амплитудно-частотных характеристик паттерна дыхания у всех детей регистрировались значимые амплитуды спектральной мощности в диапазоне 5,0-12,6 кГц. Данные результаты были расценены как следствие изменений аэродинамики нижних дыхательных путей, которые сохраняются и в периоде клинико-лабораторной ремиссии БА, что характерно для их хронического аллергического воспаления. Среднее значение акустического компонента работы дыхания

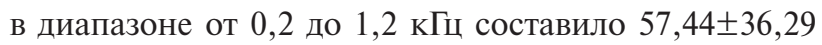

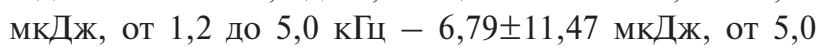

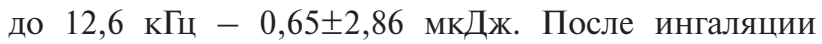
селективного бета-2-адреномиметика (сальбутамол) через небулайзер через 20 минут проводилась повторная КБФГ. При анализе повторных КБФГ выявлено значительное уменьшение интенсивности акустического компонента работы дыхания: в диапа-

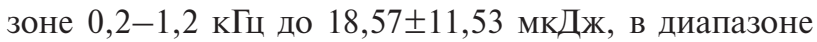

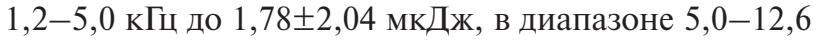
кГц до 0,08 $\pm 0,05$ мкДж. Следовательно, после проведенного бронхолитического теста зарегистрировано достоверное снижение значений акустического компонента работы дыхания - более $15 \%$ от исходного уровня. Результаты теста отражают характерный для БА симптом - обратимость скрытой бронхиальной обструкции.

Заключение. Таким образом, установлено, что компьютерная бронхофонография позволяет оценить наличие обструктивных нарушений органов дыхания и может быть рекомендована в комплексе ранней диагностики бронхиальной астмы у детей.

\section{ОСОБЕННОСТИ СЕНСИБИЛИЗАЦИИ ПРИ ТЯЖЕЛОЙ БРОНХИАЛЬНОЙ АСТМЕ \\ Потапова Н.Л., Левченко Н.В. \\ ФГБОУ ВО Читинская государственная медицинская академия, Чита}

Введение. Сенсибилизация к различным аллергенам определяет особенности и тяжесть течения бронхиальной астмы у детей. Уточнение характера сенсибилизации позволяет осуществлять персонифицированный профилактический подход к пациентам.

Цель исследования - уточнение особенностей сенсибилизации у пациентов с тяжелым течением бронхиальной астмы.

Материалы и методы. В исследование включено 144 пациента в возрасте от 1 до 17 лет с диагнозом бронхиальной астмы (легкая БА - 51, среднетяжелая - 45, тяжелая БА - 48) (медиана возраста $6,0 \pm 2,3$ года). Всем обследуемым проведено определение специфические IgE к пищевым, респираторным и бытовым аллергенам.

Результаты. У пациентов, страдающих тяжелой БА, в 2 раза чаще регистрировалась сенсибилизация к аллергенам животных - 24 /50,0\% против $11 / 24,4 \%$ при легкой астме $(p<0,05)$. У тяжелобольных пациентов превалировала чувствительность к шерсти кошки - 11 (45,8\%), отмечалось сочетание сенсибилизации к эпителию кошек и собак - 10 (41,7\%), эпителию хомяка, морской свинки и кролика - 2 $(8,3 \%)$, к перхоти лошади - 1 (4,2\%). Пищевая аллергия преобладала у больных легкой БА, составив 29,4\% против 20,8\% при тяжелом течении заболевания. Проявления пыльцевой сенсибилизации не имели достоверных отличий и встречались у каждого второго ребенка. Микогенная сенсибилизация при тяжелой БА отмечена у 1 пациента $(2,1 \%)$, у 7 больных $(13,8 \%)$ в случае легкого течения $(p>0,05)$. В структуре лекарственной аллергии у больных тяжелой БА преобладала сенсибилизация к препаратам 
пенициллинового ряда -8 (80\%) против 3 (42,8\%) с легкой астмой $(p<0,05)$. При анализе сенсибилизации к пищевым аллергенам значимых различий не выявлено. У половины пациентов с тяжелой БА выявлена поливалентная сенсибилизация $(p<0,01)$.

Заключение. Для детей с эпидермальной, лекарственной и поливалентной сенсибилизацией характерно тяжелое течение бронхиальной астмы. Наличие данных особенностей обосновывает необходимость детального аллергологического обследования с целью организации профилактических мероприятий.

\section{РОЛЬ ГЛУТАТИОНПЕРОКСИДАЗЫ В ПАТОГЕНЕЗЕ БРОНХИАЛЬНОЙ АСТМЫ У ДЕТЕЙ}

Семерник О.Е., Лебеденко А.А., Пятницкая С.А., Швыдченко Н.Ю.

Ростовский государственный медицинский университет, Ростов-на-Дону

Введение. Глутатионпероксидаза 3 (GPx3) - это фермент, который восстанавливает перекись водорода до воды путем окисления глутатиона. Особое значение изменение экспрессии данного фермента играет в патогенезе бронхиальной астмы (БА). Дыхательная система в силу своих структурных и физиологических особенностей подвергается множеству внутренних и внешних воздействий, приводящих к избыточной генерации активных форм кислорода, a GPх обеспечивает антиоксидантную защиту клеток.

Цель исследования: изучить особенности экспрессии GPх3 в сыворотке крови детей, страдающих БА.

Материалы и методы: В исследование были включены 12 больных с тяжелым неконтролируемым течением БА [4 из которых имели сопутствующий диагноз - атопический дерматит (АД)] и 8 детей I группы здоровья (контрольная группа). Всем включенным в исследование детям проведено комплексное клинико-лабораторное обследование, а также протеомный анализ сыворотки крови. Фракционирование белков пулированной предварительно обедненной от альбуминов и иммуноглобулинов сыворотки крови осуществляли методом высокоразрешающего двумерного электрофореза. Для выявления дифференциально-экспрессирующихся белков проводили сравнительный анализ гелей с помощью программы PDQuest версии 8.0.1. (Bio-Rad, США).

Результаты. По данным протеомного анализа сыворотки крови было установлено, что у всех больных БА и сочетанием БА и АД отмечается снижение содержания GPx3 в сыворотке крови по сравнению со здоровыми детьми (на $37,5 \%$ и 55,1 \% соответственно). Это свидетельствует об истощении антиоксидантной защиты и инициирует развитие окислительного стресса - одного из ключевых механизмов возникновения БА, а также может приводить к вторичным патологическим изменениям дыхательных путей и легочной ткани на фоне уже сформировавшегося заболевания.

Заключение. Исследование уровня GPx3 показало, что у больных БА происходит снижение уровня данного фермента в сыворотке крови, что диктует необходимость проведения коррегирующей терапии у детей.

\section{ВОЗМОЖНОСТИ МОРФОГИСТОХИМИЧЕСКОГО МЕТОДА В ДИАГНОСТИКЕ АЛЛЕРГИЧЕСКИХ ЗАБОЛЕВАНИЙ ДЫХАТЕЛЬНОЙ СИСТЕМЫ У ДЕТЕЙ И ПОДРОСТКОВ}

Тестов Р.М., Минина Е.Е., Медведева Л.В.

ФГБОУ ВО ЮУГМУ Минздрава России, Челябинск

Введение. Дополнительное применение гистохимических методов позволяет расширить диагностическую ценность цитологических исследований путем количественного определения биологически активных веществ в месте их прижизненной локализации в клетке.

Цель работы - выявить морфологические особенности эозинофилов индуцированной мокроты у пациентов с бронхиальной астмой различной степени контролируемости с использованием различных гистохимических методов.

Материалы и методы. Обследовано 36 детей в возрасте от 6 до 17 лет с диагнозом бронхиальная астма (БА). Контролируемость БА оценивалась по опроснику АСТ. Исследование мокроты проводилось в двух вариантах окраски: бромфеноловым синим и азур-эозином с оценкой насыщения цитоплазмы эозинофилов (ЭО) гранулами и определения значений гистограммы распределения яркости.

Результаты. В группе пациентов с контролируемым течением БА $(n=12)$ значение гистограммы распределения яркости цитоплазмы ЭО составило $150 \pm 30$ у.е. Эозин-положительные гранулы (ЭПГ) визуализировались у $50 \%$ пациентов, встречаясь

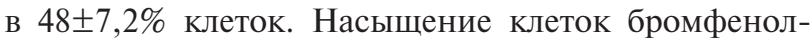
положительными гранулами (БФПГ) в среднем составило до 50\% цитоплазмы клетки.

У пациентов с частично контролируемой БА $(n=12)$ значение гистограммы в среднем составило $83,5 \pm 7,5$ у.е., т.е. цитоплазма эозинофилов характеризовалась как «темная». Слабоокрашенные эозинофилы встречались в 50\% случаев, не превышая при этом 22\% от всех описанных клеток. ЭПГ четко визуализировались среди $81,2 \pm 12,4 \%$ клеток. Насыщение цитоплазмы БФПГ составляло от 50 до $100 \%$ визуализируемого пространства.

В группе с неконтролируемым течением БА $(n=12)$ значение гистограммы в среднем составило $113 \pm 14,2$ у.е., что связано с появлением активно дегранулирую- 
щих ЭО, содержащих малое количество гранул. ЭПГ в данной группе визуализировались у $100 \%$ пациентов. Насыщение БФПГ составляло от 75 до $100 \%$.

Выводы. Усиление интенсивности клинических проявлений у 100\% пациентов ассоциируется с повышением степени зернистости цитоплазмы эозинофилов за счет прироста эозин-положительных и бромфенол-положительных гранул. Повышение зернистости может расцениваться как ранний признак, указывающий на активизацию клеточного компонента аллергического воспаления до изменений клинической картины.

\section{ОЦЕНКА РИСКА РАЗВИТИЯ БРОНХИАЛЬНОЙ АСТМЫ У ДЕТЕЙ РАННЕГО ВОЗРАСТА С ПОМОЩЬЮ ОПРОСНИКА «АSТНМА PREDICTION TOOL» \\ Токарев А.Н., Попова И.В., Подлевских Т.С., \\ Лежнина И.В., Докучаева С.Ю. \\ ФГБОУ ВО Кировский ГМУ Минздрава России, Киров}

Введение. Прогнозирование риска развития бронхиальной астмы (БА) является актуальной проблемой.

Цель исследования - изучить вероятность развития БА у детей раннего возраста с помощью опросника «Asthma Prediction Tool».

Материалы и методы. В исследование был включен 41 пациент с повторными бронхообструктивными синдромами. В условиях дневного стационара проведено клинико-диагностическое обследование и у каждого ребенка определялась итоговая сумма баллов по опроснику «Asthma Prediction Tool» с вычислением вероятности развития БА у них через 3 года.

Результаты. У 23 (56\%) пациентов в анамнезе было до трех эпизодов свистящего дыхания, более трех эпизодов бронхообструктивного синдрома отмечалось у $7(17,1 \%)$ детей. Приступы свистящего дыхания сопровождались одышкой у $20(48,7 \%)$ пациентов и мешали в повседневной деятельности 25 $(60,9 \%)$ детям, из них слегка - 19 (67,9\%), сильно - 7 $(17,7 \%)$. У 9 (21,9\%) детей эпизоды свистящего дыхания возникали на фоне физической нагрузки. У 4 (9,8\%) эпизоды бронхообструкции провоцировались контактом с бытовыми аллергенами. Установлено, что более половины детей - 24 (58,5\%) имели низкий риск развития БА в ближайшие 3 года, 15 $(36,6 \%)$ - средний риск и $2(4,9 \%)$ ребенка - высокий риск. В группе детей со средним и высоким риском вероятности развития БА у $4(23,5 \%)$ пациентов отмечалось более трех эпизодов бронхообструктивного синдрома за последние 12 месяцев. Эпизоды бронхообструкции возникали без сопутствующей ОРВИ у 5 $(29,4 \%)$ детей. Свистящее дыхание сильно затрудняло повседневную деятельность у 5 (29,4\%) детей, слегка затрудняло -у 9 (52,9\%). Атопический дерматит в анамнезе встречался у 7 (41,2\%) пациентов. Отягощенная наследственность по БА со стороны матери или отца имелась у $6(35,3 \%)$ детей. В группе детей с низким риском вероятности БА у 3 (12,5\%) отмечалось от 1 до 3 эпизодов бронхообструктивного синдрома за последние 12 мес. У 2 (8,3\%) детей эпизоды свистящего дыхания развивались без сопутствующей ОРВИ. Приступы свистящего дыхания, связанные с физической нагрузкой установлены у 3 $(12,5 \%)$ детей, слегка нарушали повседневную деятельность у $5(29,4 \%)$ пациентов. Проявления атопического дерматита на первом году жизни отмечались у $3(12,5 \%)$, а отягощенная наследственность по БА со стороны родственников первой линии выявлена у $3(16,7 \%)$ детей.

Заключение. Применение опросника «Asthma Prediction Tool» показало, что он может служить дополнительным методом оценки риска развития БА у детей.

\section{СРАВНИТЕЛЬНАЯ КОМПЬЮТЕРНО- ТОМОГРАФИЧЕСКАЯ ХАРАКТЕРИСТИКА ИНТРАЛОБАРНОЙ И ЭКСТРАЛОБАРНОЙ СЕКВЕСТРАЦИИ ЛЕГКОГО \\ У НОВОРОЖДЕННЫХ \\ Туманова У.Н., Дорофеева Е.И., Подуровская Ю.Л., Быченко В.Г., Щеголев А.И. \\ ФГБУ НМИЦ АГП им. академика В.И.Кулакова \\ Минздрава России, Москва}

Введение. Секвестрация легкого относится к врожденным аномалиям развития легких, основным видом лечения которой считается хирургический. При этом объем оперативного вмешательства зависит от формы (интралобарной или экстралобарной) секвестрации легкого.

Цель исследования - изучить компьютерно-томографические (КТ) характеристики интралобарной и экстралобарной секвестрации легкого с целью разработки критериев неинвазивной дифференциальной диагностики.

Материалы и методы. В исследование включено 26 новорожденных с секвестрацией легкого. Всем пациентам в предоперационном периоде проводили компьютерно-томографическое исследование легких в нативную, артериальную и венозную фазы с последующим определением КТ плотности ткани секвестрации, легкого на стороне секвестра и контрлатерального легкого на полученных томограммах. Операционный материал подвергали комплексному макроскопическому и микроскопическому исследованию.

Результаты. На основании проведенных клиникоинструментальных и морфологических исследований у 18 новорожденных была диагностирована интра- 
лобарная и у 8 экстралобарная форма секвестрации легкого. На основании полученных показателей КТ плотности ткани секвестрации в нативную и артериальную фазы и КТ плотности ткани контрлатерального легкого в нативную и артериальную фазы были рассчитаны градиенты повышения плотности ткани легкого в очаге секвестрации и в ткани контрлатерального легкого. В результате сравнительного анализа установлено, что все наблюдения, где значение градиента повышения плотности ткани легкого в очаге секвестрации больше значения градиента повышения плотности ткани контрлатерального легкого, соответствуют интралобарной форме секвестрации. Наблюдения со значениями градиента повышения плотности ткани легкого в очаге секвестрации меньшими, чем в ткани контрлатерального легкого, указывают на экстралобарную форму секвестрации. У новорожденных с интралобарной формой секвестрации легкого выполняли лобэктомию, при экстралобарной форме секвестрации - операцию резекции патологического участка.

Заключение. На основании результатов компьютерной томографии разработан критерий неинвазивной дифференциальной диагностики интралобарной и экстралобарной форм секвестрации легкого, являющийся основанием для выбора объема оперативного вмешательства.

\section{ЭТИОЛОГИЧЕСКИЕ ОСОБЕННОСТИ ВНЕБОЛЬНИЧНОЙ ПНЕВМОНИИ У ГОСПИТАЛИЗИРОВАННЫХ ДЕТЕЙ СЕВЕРНОГО РЕГИОНА В 2014-2019ГГ.}

Ушакова О.Н..$^{2,3}$, Углева Т.Н. ${ }^{1,2}$, Курганская А.Ю. ${ }^{3}$

${ }^{1}$ Ханты-Мансийская государственная медицинская академия, Ханты-Мансийск

${ }^{2}$ Сургутский государственный университет, Сургут

${ }^{3} О$ кружная клиническая больница, Ханты-Мансийск

Введение. Внебольничная пневмония (ВП) является полиэтиологическим заболеванием и, по мнению многих исследователей, Streptococcus pneumoniae является наиболее распространенной причиной бактериальной ВП во всех возрастных группах детей.

Цель исследования - установление особенностей этиологической структуры ВП у детей, проживающих в условиях Крайнего Севера, за многолетний период.

Материалы и методы. Проведена оценка этиологической структуры и клинических особенностей ВП у 652 пациентов детского возраста, госпитализированных в период с 2014 по 2019гг. Бактериальная культура была выполнена на образцах крови, смывов из ротоглотки, плевральной жидкости и бронхоальвеолярного секрета с использованием стандартных методов. Проведена полимеразная цепная реакция в реальном времени (ПЦР) на гены Streptococcus pneumoniae, C. pneumoniae, C. trachomatis,
M. pneumoniae, вирусов гриппа А/В мазков из ротоглотки у детей с ВП.

Результаты. При идентификации возбудителей ВП методом ПЦР мазка из ротоглотки, наиболее высокий удельный вес составила Mycoplasma pneumonia (36\%) и Mycoplasma hominis (23\%), значительно реже выявлялась C. pneumoniae (5\%), Streptococcus pneumoniae (1\%), а также вирусы гриппа А (2\%) и В (1\%). Из мокроты микроорганизмы идентифицировались в 22\% случаев, наибольший удельный вес из них составил Streptococcus pneumoniae (12\%), значительно реже высевался Staphylococcus aureus (4,5\%) и Staphylococcus pyogenes $(4,5 \%)$. Установлено несоответствие бактериологических результатов из носо - и ротоглотки с таковыми из мокроты. Из плеврального экссудата и культуры крови микрофлора не получена на фоне антибиотикотерапии.

Заключение. Среди бактериальных возбудителей ВП у детей в 2014-2019гг. доминировали Мусоplasma pneumoniae (36\%) и Mycoplasma hominis (23\%), реже выявлялся Streptococcus pneumoniae (12\%). Таким образом, в современных условиях имеет место перераспределение спектра бактериальных возбудителей ВП у детей, с увеличенной частотой выявления микоплазменной инфекции. Возможно, это связано с массовой вакцинацией детского населения против Streptococcus pneumoniae и Haemophilus influenzae type $b$.

\section{ДИАГНОСТИКИ МИКРОАСПИРАЦИИ НА ФОНЕ ГЭР У ДЕТЕЙ С БРОНХИАЛЬНОЙ АСТМОЙ. \\ Федоров И.А., Рыбакова О.Г., Горева Е.А. \\ ФГБОУ ВО «Южно-Уральский государственный \\ медицинский университет» Минздрава России, Челябинск}

Введение. В настоящее время не вызывает сомнение тот факт, что экстрапищеводные проявления гастроэзофагеальной рефлюксной болезни могут провоцировать бронхиальную астму, ухудшать ее течение. Однако диагностика микроаспирации, т.е. подтверждение факта ее наличия все еще не является рутинной и порой затруднена.

Целью данного обзора литературных источников стало изучение этапов становления диагностики микроаспирации нижних дыхательных путей у детей. Глубина поиска публикаций составила 30 лет.

Основные положения. В настоящее время существуют многочисленные отечественные и иностранные согласительные документы, созданные с целью улучшения диагностики и подходов к лечению гастроэзофагального рефлюкса и «тихой» микроаспирации нижних дыхательных путей. Доказательная база в отношении обсуждаемой проблемы довольно ограниченна, что обусловлено недостаточной специфичностью симптомов заболевания и отсутствием «золотого стандарта» диагностики. Однако появляются методики, способствующие, 
наряду с общепринятыми подходами, объективизации (более точной) диагностики микроаспирации. Одной из таких методик является неинвазивный способ выявления лактозы в индуцированной мокроте респираторного тракта и дополнительное определение среднего цитохимического коэффициента альвеолярных макрофагов. С одной стороны, проводится обнаружение двух биомаркеров «тихой» микроаспирации в одной пробе: качественное определения лактозы и макрофагов, нагруженных липидами у детей с бронхиальной астмой. С другой стороны, неинвазивное получение мокроты из нижних дыхательных путей в результате ее индукции по специальной методике. Кроме многочисленных достоинств метода индуцированной мокроты, есть и еще одно очень важное с практической точки зрения: возраст детей для получения мокроты не является каким-либо препятствием, а наличие альвеолярных макрофагов подтверждает получение секрета непосредственно из нижних дыхательных путей респираторного тракта.

Таким образом, согласно данным литературы, можно говорить о новых диагностических возможностях по выявлению «тихой» микроаспирации у детей с бронхиальной астмой на фоне гастроэзофагального рефлюкса. Совместное определение двух маркеров может служить эффективной методикой, усиливающей верификацию «тихой» микроаспирации у детей с бронхиальной астмой и хроническим кашлем, а также способом мониторирования проводимой антирефлюксной терапии по динамике исчезновения лактозы и альвеолярных макрофагов, нагруженных липидами, в индуцированной мокроте.

\section{АНАЛИЗ ОСОБЕННОСТЕЙ ТЕЧЕНИЯ ВНЕБОЛЬНИЧНОЙ ПНЕВМОНИИ У ДЕТЕЙ ГРУДНОГО ВОЗРАСТА.}

Шурховецкая А.А., Радаева Е.А., Микрюкова В.С., Шаталова Е.C.

ФГБОУ ВО ЮУГМУ Минздрава России, Челябинск

Введение. Несмотря на значимые достижения в профилактике и лечении внебольничных пневмоний, это заболевание и сегодня распространено среди детей, является одной из основных причин детской смертности.

Цель исследования - проанализировать особенности анамнеза и клинического течения внебольничной пневмонии (ВП) у детей грудного возраста по материалам МБУЗ ДГКБ №7 г.Челябинска.

Материалы и методы. Проведен анализ 16 историй болезни пациентов грудного возраста. Диагноз ВП у всех детей подтвержден рентгенологически. Дети первого года жизни составили $3,3 \%$ от общего числа госпитализированных в респираторное отделение с диагнозом пневмония. Из них на долю мальчиков пришлось $-81 \%$, девочек - 19\%. Абсолютное большинство составили дети второго полугодия жизни (94\%).

Результаты. При оценке анамнеза жизни пациентов, выявлено, что у 44\% матерей имело место осложненное течение беременности, оперативные роды зарегистрированы у 25\% женщин. Большинство детей были приложены к груди матери в родзале (69\%). На грудном вскармливании на момент госпитализации было 50\% младенцев. У $75 \%$ детей отмечалась «фоновая» патология, среди которой превалировал рахит $(37,5 \%)$, атопический дерматит $(31,25 \%)$. Важно отметить, что 37,5\% младенцев наблюдались у невролога с диагнозами: гипертензионно-гидроцефальный синдром, синдром двигательных и вегетовисцеральных нарушений. У кардиолога на диспансерном учете по поводу врожденных пороков сердца находилось $25 \%$ детей.

Длительность респираторного заболевания до поступления в стационар в среднем составила 6 суток. Основными жалобами при поступлении были кашель, повышение температуры, одышка, причем у 56\% больных она носила экспираторный характер в связи с чем в приемном покое до проведения рентгенологического исследования не было возможности исключить обструктивный бронхит (ОБ). По локализации инфильтративного процесса в легких преобладала правосторонняя нижнедолевая пневмония у $69 \%$ детей. Ведущей морфологической формой ВП являлась очаговая (75\%). Деструкция легочной ткани с образованием булл имела место у 1 больного.

Заключение. Подавляющее большинство пациентов имеют выраженные особенности преморбидного фона. Чаще пневмония развивается у детей, имеющих патологию нервной и сердечно-сосудистой систем. У половины детей отмечалось сочетание пневмонии и ОБ.

\section{ОСОБЕННОСТИ БИОИМПЕДАНСОМЕТРИИ У ДЕТЕЙ С БРОНХИАЛЬНОЙ АСТМОЙ И ОЖИРЕНИЕМ}

Ячейкина Н.А.

ОГБУз Смоленская областная детская клиническая больница, Смоленск

Введение. Оценка состава тела, полученная с помощью биоимпедансометрии (БИМ), является более достоверной, чем с использованием только антропометрии, позволяет судить о пищевом поведении и двигательной активности.

Цель исследования - анализ особенностей состава тела с помощью БИМ у детей с бронхиальной астмой (БА) и ожирением.

Материалы и методы. Обследовано 72 ребенка в возрасте от 10 до 14 лет с 1 и 2 степенью ожирения, из них в основной группе - 30 детей с БА, в группе 
сравнения - 42 ребенка без хронических заболеваний. Проводилось определение стандартного отклонения индекса массы тела (SDS ИМТ), показателей БИМ на аппарате АВС-01 «Медасс». Оценивались: фазовый угол (ФУ), жировая масса тела (ЖМТ), доля ЖМТ, безжировая масса тела (БМТ), активная клеточная масса (АКМ), доля АКМ, скелетно-мышечная масса (CMМ), доля СММ, удельный основной обмен (УОО), основной обмен (ОО), общая вода в организме (ОВО), внеклеточная жидкость (ВКЖ).

Результаты. SDS ИМТ в основной группе составил 2,56 [2,26-2,95] и оказался сопоставимым с группой сравнения 2,66 [2,31-2,99] $(p>0,05)$. У детей основной группы величина ФУ $(5,95$ [5,42-6,30]) оказалась ниже, чем у детей группы сравнения $(6,45$ [5,91-6,81], $p<0,001)$. Избыток ЖМТ $(17,4$ кг [14,6$23,1])$ и \% доли ЖМ (195 [146-220]) оказались выше у детей основной группы, чем у детей группы сравнения $(15,65$ кг [10,2-23,5], $p=0,018$ и 176,5 [123-199], $p=0,024)$. При этом, у детей с БА отмечались более низкие показатели доли АКМ (56\% [53,1-57,6], $p=0,045)$. Отмеченные тенденции подтверждает процент отклонения от нормы УОО, который снижен у детей основной группы (92 [83-107]) по отношению к детям группы сравнения (97,5 [90-107], $p=0,028)$. По результатам исследования статистически значимых различий показателей БЖМ, СММ, ОВО и ВКЖ в обеих группах не получено $(p>0,05)$. Как в основной группе у мальчиков (18,2 кг [16,3-27,9]), так и в группе сравнения $(19,45$ кг $[13,5-23,5])$ по сравнению с девочками $(15,9$ кг [13,45-17,95] и 18,55 кг [16,85-22,4]) отмечались более высокие показатели CMM ( $p=0,024$ и $p=0,027$ соответственно). При этом, по остальным показателям гендерных различий не получено $(p>0,05)$.

Заключение. У детей с БА и ожирением выявленные изменения свидетельствует о низкой скорости обмена веществ, уменьшении активности метаболических процессов, снижении физической активности. 


\section{Раздел 10}

\section{ИНФЕКЦИИ И}

ВАКЦИНОПРОФИЛАКТИКА 


\author{
ФАКТОРЫ РИСКА РАЗВИТИЯ КЛИНИЧЕСКИХ \\ ФОРМ COVID-19 У ДЕТЕЙ Г. СМОЛЕНСКА \\ Бекезин В.В. ${ }^{1}$, Дружинина Т.В. ${ }^{1}$, Цветная И.Н. ${ }^{2}$, \\ Олейникова B.M. ${ }^{2}$ \\ ${ }^{1}$ Смоленский государственный медицинский \\ университет, Смоленск \\ ²Детская клиническая больница, Смоленск
}

Введение. Имеющиеся на сегодня данные свидетельствуют о том, что дети составляют до 10\% в структуре инфицированных SARS-CoV-2 и до 2\% в структуре пациентов с диагностированными клиническими случаями Covid-19.

Цель: изучить значимые факторы риска развития клинических форм Covid-19 у детей школьного возраста.

Материалы и методы. Проведено ретроспективное исследование медицинской документации детей школьного возраста, перенесших заболевание Covid-19, подтвержденное положительным результатом лабораторного исследования на наличие РНК или антигена SARS-CoV-2. Все включенные в исследование методом случайной выборки дети были условно разделены на 2 группы в зависимости от степени тяжести инфекции (в соответствии с временными методическими рекомендациями Минздрава России, версия 9). В 1-ю группу вошли 30 детей с бессимптомной формой Covid-19. Вторую группу составили 82 ребенка с легкой и средне-тяжелой формами Covid-19. В третью группу вошли 3 ребенка с тяжелой формой Covid-19 (изменения в легких при компьютерной томографии (рентгенографии) - КТ 3-4).

Результаты. В ходе исследования были рассчитаны относительные риски развития клинических форм Covid-19 (легкая, средне-тяжелая и тяжелая формы) у детей школьного возраста. Выявлено, что относительный риск развития клинических форм Covid-19 достоверно выше у детей: с перинатальными поражениями (ПП) ЦНС в 1,282 раза $(\chi 2=4,104 ; p=0,043)$, с низкой резистентностью к острым инфекциям (более 4 раз в год) в 1,274 раза $(\chi 2=4,245 ; p=0,040)$, с аллергическими заболеваниями (дерматит, ринит, бронхиальная астма) в 1,337 раза $\left(\chi^{2}=4,245\right.$; $\left.p=0,040\right)$, с индексом массы тела (ИМТ) более + 2 SDS с учетом возраста и пола ребенка в 1,405 раза $(\chi 2=4,293$; $p=0,039)$, с возрастом 15 лет и старше в 1,301 раза $(\chi 2=4,076 ; p=0,044)$.

Заключение. Таким образом, частота встречаемости тяжелых клинических форм Covid-19 в общей структуре инфицированных детей составляет - 2,6 $\%$, при этом факторами риска развития клинических форм Covid-19 являются ПП ЦНС, аллергические заболевания, ожирение, низкая резистентность к инфекционным заболеваниям и подростковый возраст (15-17 лет).

\section{СОВРЕМЕННЫЕ АСПЕКТЫ КОНТРОЛЯ ХРОНИЧЕСКИХ ЗАБОЛЕВАНИЙ НОСОГЛОТКИ У ДЕТЕЙ ПУТЕМ ВАКЦИНАЦИИ ПРОТИВ ПНЕВМОКОККОВОЙ ИНФЕКЦИИ \\ Вавилова В.П., Вавилов А.М., Черкаева А.Х., Добряк Т.А., Бурмистрова Е.Ю. \\ ФГБОУ ВО КемГМУ МЗ РФ, Кемерово}

Введение. Проблема лечения и профилактики хронических воспалительных заболеваний носоглотки у детей, несмотря на развитие современной фармакотерапии, остается актуальной для практического здравоохранения.

Цель исследования - оценить клиническую эффективность использования пневмококковой конъюгированной 13-валентной вакцины (ПКВ13) у детей с хроническими заболеваниями носоглотки.

Материалы и методы. За период 2012-2019 г.г. наблюдали 876 детей в возрасте 2-5 лет. Пациенты I группы $(n=448)$ были вакцинированы ПКВ13. В группе II $(n=428)$ дошкольники вакцинацию ПКВ13 не получали. Хронические заболевания носоглотки в виде хронического аденоидита (83\%), хронического рецидивирующего отита (17\%) имели место в $100 \%$ случаев. Кроме этого 51 ребенок $(5,82 \%)$ являлся реконвалесцентом острой пневмонии. Проведен анализ заболеваемости ОРИ до и после вакцинации в течение 12 месяцев.

Результаты. За год до вакцинации ПКВ13 заболеваемость ОРИ в I группе составила 2103,5 , а в группе II $-2115,5$ на $1000(p=0,0650)$. В течение года после вакцинации ПКВ13, названный показатель составил $1005,35$ и 1917,28 соответственно ( $p=0,0022)$. Внебольничную пневмонию перенесли за год до вакцинации 24(5,36\%)/I и 27(6,03\%)/II детей $(p=0,4135)$, после вакцинации - у 12(2,68\%)/I и у 23(6,78\%)/ II наблюдаемых $(p=0,0008)$. Обострения хронического гайморита за год до вакцинации составили $27(6,03 \%) / \mathrm{I}$ и $31(7,24 \%) / \mathrm{II}$ случаев $(p=0,07314)$, после вакцинации у 12(2,68\%)/I и 29(6,78\%)/II пациентов $(p=0,0007)$. Острый средний отит за год до вакцинации перенесли 35(7,81\%)/I и 37(8,64\%)/ II детей $(p=0,098)$, после вакцинации у $16(3,57 \%) / \mathrm{I}$ и $38(8,88 \%) /$ II соответственно $(p=0,0009)$. Анализ течения поствакцинального периода показал, что большинство детей $(432 / 96,43 \%)$ перенесли вакцинацию бессимптомно. Общие поствакцинальные реакции слабой силы в виде повышения температуры до 37,5С имели место у 15(3,35\%) детей.

Заключение. Использование ПКВ13 у детей с хроническими заболеваниями носоглотки позволяет снизить кратность ОРИ, пневмоний, отитов практически в 2 раза. Таким образом, вакцинация является эффективным и экономически выгодным мероприятием для профилактики хронических воспалительных заболеваний носоглотки. 


\section{ИНФЕКЦИОННЫЕ ЗАБОЛЕВАНИЯ НА ПЕДИАТРИЧЕСКОМ УЧАСТКЕ, ПРОТЕКАЮЩИЕ С СИНДРОМОМ ОСТРОГО ТОНЗИЛЛИТА \\ Елкина Т.Н., Пирожкова Н.И., Грибанова А.С., Сеикова С.Ю. \\ ФГБОУ ВО НГМУ Минздрава России, Новосибирск}

Введение. В детском возрасте часто встречаются заболевания, протекающие с поражением миндалин. Они имеют различную этиологию, но особое место занимают острые тонзиллиты, обусловленные вирусами и бета-гемолитическим стрептококком группы А (БГСА). Среди вторичных тонзиллитов в педиатрической практике наиболее значимы острые тонзиллиты при скарлатине и инфекционном мононуклеозе (ИМН).

Цель исследования - оценить соответствие тактики ведения детей со скарлатиной и ИМН на педиатрическом участке современным нормативным документам.

Материалы и методы. Проведен анализ 20 амбулаторных карт детей, перенесших скарлатину (1 группа; 8 человек) и ИМН (2 группа; 12 человек). Средний возраст 4,8 и 7 лет соответственно. Практически все дети были организованные. Заболевания протекали на неотягощенном преморбидном фоне. 41,6\% детей с ИМН потребовалась госпитализация от 3 до 12 дней. Продолжительность скарлатины составила в среднем 15,3 дня, ИМН - 18,8 дня. Течение заболеваний гладкое неосложненное.

Результаты. В дебюте налеты на миндалинах были у 87,5\% пациентов со скарлатиной и 25,0\% с ИМН, в динамике - у всех. Продолжительность активного наблюдения составила в 1 группе 3,8 дня, во 2 группе - 1,6 дня. Обследование на BL и микрофлору выполнено у 87,5\% со скарлатиной и 83,3\% с ИМН. БГСА обнаружен у 71,4\% детей в 1 группе. Маркеры ИМН - у 16,6\%. Всем проводилась системная антибактериальная терапия, в среднем 9,1 дня в обеих группах. 62,5\% больных скарлатиной получали незащищенные пенициллины (амоксициллин), остальные макролиды. Дети с ИМН - 25,0\% незащищенные пенициллины (амоксициллин и пенициллин), 33,3\% - макролиды и 41,6\% цефалоспорины, а у 50\% имела место смена антибиотика. План наблюдения, общий анализы крови и мочи выполнены у всех при постановке на учет.

Заключение. Активно наблюдались врачом 3 дня ежедневно все дети с налетами на миндалинах со скарлатиной и $16,6 \%$ с ИМН. Бактериологическое обследование выполнено практически у всех, а верификация возбудителя при ИМН в недостаточном объеме. Стартовая антибактериальная терапия при скарлатине соответствовала нормативным документам. 16,6\% пациентов с ИМН получали аминопенициллины, которые им противопоказаны.

\section{ОТНОШЕНИЕ РОДИТЕЛЕЙ}

К ВАКЦИНОПРОФИЛАКТИКЕ

Жданова И.А., Смычкова Е.В., Осадчая Е.И.,

Краковеи И.В., Картавцева А.В.

ГБУЗ«Детская краевая клиническая больница»МЗ

Краснодарского края, Краснодар

Введение. На сегодняшний день ВО3 озабочена массовыми отказами родителей от вакцинации детей.

Цель исследования проанализировать результаты анкетирования родителей детей Краснодарского края.

Материалы и методы. Проведено анонимное анкетирование 104 родителей детей первого года жизни. Отбор респондентов проводился случайным сплошным методом. Анкета включала 10 вопросов демографического и социального характера, степень информированности и приверженности к вакцинации.

Результаты. Участвовали в анкетировании женщины (100\%). Доля городских жителей составила 67 (64,4 \%), сельских - 37 (35,6 \%). Средний возраст 25-40 лет (79,5\%). Количество детей в семье: $70 \%$ - 1 ребенок, 15,7\%- двое, $13,1 \%$ - трое, $1,2 \%$ более 6 детей. Превалировали родители с высшим или средним специальным образованием (69\%). 90 семей $(86,5 \%)$ прививают своих детей, а 14 респондентов $(13,5 \%)$ заявили об отказе от вакцинации, 8 из них $(7,7 \%)$ не привиты в детском возрасте. Частота отказов от вакцинации не зависела от образования родителей. Больше случаев отказа от вакцинации отмечено среди родителей старше 35 лет (64,3\%). Отмечается относительно низкий уровень (79\%) привитых детей от гепатита В и туберкулеза. Не планируют прививать детей вакциной АКДС - 17 (16,3\%) матерей. Родители, имеющие одного ребенка, чаще отказываются от прививок - $11(10,6 \%)$ из-за страха развития осложнений вакцинации. В 3-х случаях $(2,9 \%)$ высказано недоверие к качеству вакцин. В 4-х случаях $(3,8$ \%) - причина отказа не аргументирована. Нарушении графика вакцинации в связи с временными медицинскими противопоказаниями у $11(10,6 \%)$ детей. Для большинства респондентов (79\%) основным источником информации о прививках становился врач-педиатр. От людей, не имеющих медицинского образования, сведения о вакцинации получали 9,5\% матерей. Интернет-ресурсы были актуальны для $11,5 \%$ участников опроса. $75 \%$ родителей высказывали заинтересованность в получении дополнительной информации о прививках.

\section{Заключение.}

1. Большинство респондентов прививают своих детей согласно Национальному календарю профилактических прививок.

2. $86,5 \%$ респондентов положительно относятся к вакцинации, но 13,5\% родителей отказываются от прививок из-за страха осложнений и недоверия к вакцине. 
3. Отмечено, что родители в возрастной группе старше 30 лет, имеющие одного ребенка, чаще отказываются от вакцинации $(10,6 \%)$ против родителей двух и более детей (2,9\%).

4. Основным источником информации о вакцинопрофилактике являются медицинские работники.

5. Отмечается недостаточная информированность родителей о вакцинации.

\section{РОЛЬ ИНФЕКЦИОННЫХ ТРИГГЕРОВ В РАЗВИТИИ IGA-ВАСКУЛИТА У ДЕТЕЙ В СОВРЕМЕННЫХ УСЛОВИЯХ}

Жукова Л.Ю. ${ }^{1}$, Колобова О.Л. ${ }^{1}$, Петруничева Е.В. ${ }^{2}$ ФГБОУ ВО СПбГПМУ Минздрава России ${ }^{1}$, ГБУЗ «ДГМ КСЦ ВМТ»², Санкт-Петербург

Введение. $\operatorname{Ig} \mathrm{A}$-васкулит $(\operatorname{Ig} \mathrm{AB})$ - системный васкулит сосудов мелкого калибра с развитием поражения кожи, суставов, желудочно-кишечного тракта, почек. Повреждение сосудов микроциркуляции нередко запускается инфекционными триггерами.

Цель исследования - анализ частоты встречаемости и влияния инфекционных триггеров на возникновение различных клинических форм и течение $\operatorname{IgAB~у~детей.~}$

Материалы и методы. Проанализировано 57 случаев $\operatorname{IgAB}$ у детей, обследованных в условиях отделения общей гематологии $(n=50)$ и соматических отделений стационаров Санкт-Петербурга. Длительность наблюдения пациентов составила от 4 месяцев до 5 лет. Диагноз установлен в соответствии с диагностическими критериями, разработанными EULAR/ PRINTO/PRES, 2010. Морфологическая верификация диагноза у больных данной выборки не проводилась. Поиск инфекционных триггеров осуществлялся культуральными, серологическими, вирусологическими методами.

Результаты. Наиболее часто $\operatorname{IgAB}$ диагностировали у больных в возрасте 4-11 лет (40; 70\%). Анамнестически у 51 (90\%) пациентов появлению первых симптомов IgAB предшествовало острое респираторное заболевание с лихорадкой, из них 7 пациентов амбулаторно обследованы на наличие Sars-Cov-2. При первичной верификации $\operatorname{IgAB}$ преимущественно отмечались смешанные формы заболевания: кожно-суставно-абдоминальная (30; 53\%), кожносуставная $(21 ; 37 \%)$, изолированная кожная форма диагностирована у 6 (10\%) детей. Инфекционные триггеры обнаружены у 54 (95\%) больных, из них, бактериальные инфекции у 48 (81\%), вирусные у 6 (11\%). У больных с бактериальными инфекциями выделены стрептококк группы А $(44,81 \%)$, эшерихия коли $(2,4 \%)$, иерсиния энтероколитика $(1,2 \%)$, сальмонелла небрюшнотифозная $(1,2 \%)$. У больных с вирусными триггерами обнаружены цитомегаловирус $(2,4 \%)$, вирус герпеса 6 типа $(2,4 \%)$, коронавирус
Sars-Cov-2 (2, 4\%). Острое циклическое течение IgAB выявлено у 19 (33\%), подострое у 18 (31\%), рецидивирующее у 20 (36\%) больных. У 5 детей с рецидивирующим течением заболевания отмечено развитие гломерулонефрита, из них у обоих пациентов, перенесших новую коронавирусную инфекцию.

Заключение. Стрептококковая инфекция явилась основным инфекционным триггером $\operatorname{IgAB}$, у данной когорты больных превалировали кожно-суставно-абдоминальная форма и подострое или рецидивирующее течение заболевания.

\section{РЕГИОНАЛЬНЫЕ ОСОБЕННОСТИ ТЕЧЕНИЯ COVID-19 У ДЕТЕЙ}

Кайб И.Д., Халидуллина О.Ю., Ушакова С.А., Петрушина А.Д., Патрашков Д.М., Кузнецов И.С., Ваганова А.Е., Селиванов О.К.

ФГБОУ ВО Тюменский государственный медицинский университет МЗ РФ, Тюмень

ГБУЗ ТО «Областная клиническая больница №1», Тюмень

Введение. Согласно опубликованным данным у детей новая коронавирусная инфекция COVID19 протекает не так тяжело, как у взрослых, особенно имеющих тяжелую коморбидную патологию. При этом у многих детей в острый период выявлялись бессимптомные формы.

Цель исследования. Изучить особенности клинических проявлений COVID-19 у детей по данным стационарного наблюдения в моноинфекционном госпитале ГБУЗ ТО «ОКБ №1».

Материалы и методы. В исследование было включено 110 детей в возрасте от 5 дней до 17 лет с подтвержденной инфекцией. Период наблюдения составил с апреля по декабрь 2020 г. Были выделены 4 возрастные группы: дети до года -25 ; с 1 года до 7 лет - 25; от 7 до 12 лет - 31; старше 12 лет - 29 детей. Ретроспективно выполнен анализ клинических проявлений по стационарным картам.

Результаты. В гендерной структуре во всех возрастных группах различий не было (мальчики составили 54\%, девочки 51\%). Подъем госпитализаций наблюдался с мая по ноябрь 2020 г. Пик пришелся на июнь 2020 т. - 28,2\%. По степени тяжести выделили: бессимптомное течение - у $15,5 \%$, легкое у $45,5 \%$, среднетяжелое - у $37,2 \%$, и тяжелое - у $1,8 \%$ детей. Легкое течение преимущественно наблюдалось у детей до года $(19 \%, p=0,005)$. В возрасте $1-7$ лет и 7-12 лет, с равной частотой отмечалось как легкое $-10 \%$ и $14 \%$, так и среднетяжелое течение $-10 \%$ и $12 \%$, соответственно. У детей старше 12 лет среднетяжелое течение имели $17 \%$. Тяжелое течение - у 2 детей до года и у 1 ребенка в группе 7-12 лет. С коморбидной патологией выявлено 16 детей; из них у 9 человек отмечено среднетяжелое течение. Сопутству- 
ющие заболевания (сахарный диабет, лейкозы, ревматическая и органические заболевания центральной нервной системы, хронические болезни почек, бронхиальная астма) были в состоянии клинико-лабораторной ремиссии и не повлияли на тяжесть течения COVID-19. У детей с тяжелым течением заболевания коморбидной патологии выявлено не было. Средняя продолжительность госпитализации составила 9,3 койко-дней.

Заключение. Для детей с новой коронавирусной инфекцией характерно отсутствие гендерных различий, чаще встречалось легкое и среднетяжелое течение, а также не выявлено влияния коморбидной патологии на тяжесть течения COVID-19.

\section{РЕФЛЕКСО - И ФИЗИОТЕРАПИЯ В КОМПЛЕКСЕ РЕАБИЛИТАЦИОННЫХ МЕРОПРИЯТИЙ У ДЕТЕЙ С БРОНХИАЛЬНОЙ АСТМОЙ, ПЕРЕНЕСШИХ НОВУЮ КОРОНАВИРУСНУЮ ИНФЕКЦИЮ COVID-19}

Капустин А.В., Захаров П.П., Дубровская Т.В., Кириллова В.П., Соловей Т.Н., Соколова Л.В., Ю.Л.Мизерницкий НИКИ педиатрии им. Ю.Е.Вельтищева ФГАОУ ВО РНИМУ им. Н.И.Пирогова Минздрава России, Москва

Введение. У детей, перенесших новую коронавирусную инфекцию COVID-19 даже в легкой степени, в дальнейшем возможно развитие и/или усугубление болезненных проявлений в различных органах и системах, прежде всего в респираторном тракте. Для пациентов с бронхиальной астмой это является наиболее значимым. Существует мнение, что уже в первые два месяца после острого периода коронавирусной инфекции следует применять комплекс респираторной реабилитации с использованием рефлексотерапии [Zhang Jiale a.o.- 2020, Бодрова P.A. с соавт.- 2021]. В тяжелых случаях восстановительное лечение начинают в реанимационных палатах. Известно, что рефлексотерапия повышает защитные силы организма, положительно влияет на бронхиальную проходимость, вентиляцию легких, функциональную способность диафрагмы, легочную гемодинамику.

Цель исследования - оценить возможности применения немедикаментозных методов рефлексотерапии (РТ) и физиотерапии (ФТ), как начального этапа в комплексе реабилитационных мероприятий, при плановой госпитализации детей с бронхиальной астмой (БА), перенесших новую коронавирусную инфекцию COVID-19.

Большинство детей с БА, которые перенесли новую коронавирусную инфекцию, поступают в институт для плановой госпитализации с целью коррекции базисного лечения основного заболевания. Обычно это происходит не ранее 4-6 месяцев после COVID-19 и на очень непродолжительный срок. Однако уже и в этот период можно использовать рефлексотерапию и физиотерапию (низкоинтенсивное лазерное излучение, магнитотерапия), как начальный этап реабилитационных мероприятий постковидного синдрома. Выбор точек акупунктуры при РТ для респираторной реабилитации осуществляется согласно современным представлениям о патогенезе БА, клинической картины заболевания и с учетом традиционных восточных концепций РТ. Раннее применение немедикаментозных методов РТ и ФТ позволяет снизить лекарственную нагрузку на организм ребенка, предупредить развитие осложнений, способствует уменьшению частоты приступов и улучшению качества жизни.

Заключение. Представляется целесообразным использование рефлексотерапии и физиотерапии, как начального этапа в комплексе последующих реабилитационных мероприятий (массаж, кинезиотерапия, дыхательная гимнастика, санаторно-курортное лечение, прерывистая интервальная гипокситерапия и др.) [Фесюн А.Д. с соавт.- 2020, Tsyganova T.N. a.o.2021] у детей с бронхиальной астмой, перенесших новую коронавирусную инфекцию COVID-19.

\section{ПРОБЛЕМЫ ДИАГНОСТИКИ И ЛЕЧЕНИЯ ПРИ ЛАТЕНТНОЙ ТУБЕРКУЛЕЗНОЙ ИНФЕКЦИИ У ДЕТЕЙ}

Кашуба Е.В., Наркулова А.Е., Козлова О.Ф., Козлова А.В. ФГБОУ ВО Тюменский ГМУ Минздрава РФ, Тюмень ФГАОУ ВО «Балтийский федеральный университет им. Иммануила Канта», Калининград

Введение. Латентная туберкулезная инфекция (ЛТИ)- состояние, при котором микобактерии туберкулеза присутствуют в организме, обусловливая положительные реакции на иммунологические тесты, при отсутствии признаков заболевания туберкулезом (ТБ). Своевременная диагностика ЛТИ важна из-за возможности развития локального ТБ, но трудна, поскольку существующие методы скрининговой диагностики не всегда позволяют сделать верный вывод о наличии заболевания.

Цель исследования -установить критерии дифференциальной диагностики поствакцинной и инфекционной аллергии через сопоставление информативности пробы Манту с 2ТЕ ППД-Л и внутрикожного теста с аллергеном туберкулезным рекомбинантным на основе белков ESAT-6 и CFP-10 (проба АTPДиаскинтест) у детей из группы риска развития ТБ для корректного подхода к назначению профилактической химиотерапии.

Материалы и методы. В исследование включено 207 детей до 8 лет, с измененной туберкулиновой чувствительностью: вираж туберкулиновой пробы - 176, гиперергическая реакция- 6, нарастание чувствительности к туберкулину- 25 случаев. 
Результаты. Для уточнения характера специфической сенсибилизации всем детям с измененной туберкулиновой чувствительностью выполнялась проба АТР- диаскинтест, который оказался положительным у 33 человек $(16,1 \%)$, сомнительным - у 4-х $(1,9 \%)$, у 170 (83,0\%) - отрицательным. Кроме того, при дообследовании по результатам КТ расширение корней легких выявлено у 9 пациентов (4,3\%), мелкие кальцинаты в проекции лимфатических узлов корня легкого - у 1 ребенка $(0,48 \%)$, изменения в гемограмме имели $12,7 \%$ детей. Аллергизирующие организм ребенка состояния, влияющие на ответную реакцию на туберкулин, установлены в $10,5 \%$ случаев. У $18 \%$ пациентов динамика туберкулиновых проб по годам изначально укладывалась в поствакцинную аллергию.

Заключение. Диаскин- тест является ведущим в дифференциальной диагностике между поствакцинной и инфекционной аллергией. Параллельно с другими диагностическими параметрами результат пробы АТР-Диаскинтест позволил отобрать детей с ЛТИ в группу риска по развитию локального ТБ и корректно подойти к назначению профилактического курса химиотерапии в $21,8 \%$ случаев, вместо предполагаемых 78,2\%.

\section{СУБПОПУЛЯЦИОННЫЙ СОСТАВ ЛИМФОЦИТОВ ПРИ ПЕРВИЧНОЙ И РЕАКТИВАЦИИ ЭПШТЕЙНА-БАРР ВИРУСНОЙ ИНФЕКЦИИ У ПОДРОСТКОВ \\ Кашуба Э.А., Антонова М.В., Дроздова Т.Г. ${ }^{,}$ Любимцева О.А., Ханипова Л.В., Огошкова Н.В., Бельтикова А.А., Чехова Ю.С. \\ ФГБОУ ВО Тюменский ГМУ Минздрава РФ, Тюмень}

Введение. Эпштейна-Барр вирусная инфекция (ЭБВИ) - иммунопатологический процесс, склонный к рецидивированию. С учетом накопленных данных, актуально изучение иммунопатогенеза при реактивации данного вируса в разные критические периоды становления иммунной системы ребенка.

Цель исследования- сравнить субпопуляционный состав лимфоцитов на первой неделе клинической манифестации первичной (пЭБВИ) и реактивации (рЭБВИ) Эпштейна-Барр вирусной инфекции у детей подросткового возраста (12-17лет).

Материалы и методы. В исследование включено 25 детей с пЭБВИ и 11 детей с рЭБВИ. Для подтверждения диагноза в крови определяли ДНК ЭпштейнаБарр вируса методом ПЦР и антител VCA $\operatorname{IgM}$ и IgG, EA IgG и EBNA IgG методом ИФА. Оценивали уровень маркеров дифференцировки и активации лимфоцитов $\mathrm{CD} 7+, \mathrm{CD} 3+, \mathrm{CD} 4+, \mathrm{CD} 8+$, ИРИ, CD16+, $\mathrm{CD} 11 \mathrm{~b}+, \mathrm{CD} 54+, \mathrm{CD} 71+, \mathrm{HLA}-\mathrm{DR}+, \mathrm{CD} 38+$.

Результаты. У детей с реактивацией ЭБВИ содержание тимоцитов (CD7+) было значимо меньше, чем в группе с пЭБВИ ( $\left.\mathrm{p}_{\text {п-р }}=0,05\right)$. Количество активированных В-Лф, Т-хелперов и Т-цитотоксических Лф не отличалось от показателей при пЭБВИ. Поэтому величина ИРИ была сопоставима в группах и отличалась низкими значениями по сравнению с контролем $(p=0,001)$. Уровень клеток с киллерной активностью - CD116+ и CD11b+Лф также был сопоставим при первичной ЭБВИ и ее реактивации, но значимо превышал контрольный показатель $(p=0,05)$. Содержание активационных маркеров при рЭБВИ не отличалось от группы с пЭБВИ. Число плазматических клеток - CD38+ Лф при рЭБВИ в 2 раза превышало уровень в группе с пЭБВИ ( $\left.\mathrm{p}_{\text {п-р }}=0,01\right)$.

Заключение. Таким образом, у детей 12-17 лет, на ранней стадии манифестации, инфекционный мононуклеоз в результате реактивации ЭБВИ в сравнении с первичной ЭБВИ характеризовался статистически значимым уменышением числа тимоцитов и двукратным преобладанием количества плазматических клеток. Подобное отклонение в содержании плазматических клеток можно расценить, как косвенное подтверждение длительного инфицирования ЭпштейнаБарр вирусом организма детей с реактивацией ЭБВИ.

\section{ОПРЕДЕЛЕНИЕ ВИРУСНОЙ НАГРУЗКИ У БЕРЕМЕННЫХ ПРИ ПЕРВИЧНОЙ И ВТОРИЧНОЙ ИНФЕКЦИИ, ВЫЗВАННОЙ ВИРУСОМ ВАРИЦЕЛЛА-ЗОСТЕР \\ Кольцова И.В. ${ }^{1}$, Домонова Э.А. ${ }^{2}$, Кистенева Л.Б. ${ }^{1}$, Сильвейстрова О.Ю. ${ }^{2}$, Цветкова Н.А. ${ }^{3}$, Лялина Е.В. ${ }^{3}$, Архангельская И.В. ${ }^{3}$ \\ ${ }^{1}$ НИИ вирусологии им. Д.И. Ивановского ФГБУ НИЦЭМ им. Н.Ф. Гамалеи, Москва \\ ФБУН Центральный НИИ эпидемиологии \\ Роспотребнадзора, Москва \\ ${ }^{3}$ Инфекционная клиническая больница №2 Д3, Москвы}

Введение. Несмотря на вакцинацию и карантинные мероприятия заболеваемость ветряной оспой в РФ сохраняется на стабильно высоком уровне. Инфицирование беременной может привести к гибели плода, развитию у ребенка синдрома врожденной ветряной оспы, неонатальной ветряной оспы, опоясываюшего лишая в раннем детском возрасте. Описаны случаи инфицирования плода при виремии у беременной с опоясывающим лишаем. В настоящее время в РФ определение уровня виремии не входит в алгоритм диагностического обследования беременных с ВГЧ-3-инфекцией.

Цель исследования. Определить прогностически значимую концентрацию ДНК ВГЧ-3 в крови беременных с первичной и вторичной инфекцией для верификации инфицирования плода.

Материалы и методы. В исследование включено 29 беременных (медиана 28 лет) с ветряной оспой и 8 беременных (медиана 28 лет) с опоясывающим 
лишаем. 16 (55\%) пациенток переносили ветряную оспу во II триместре беременности, 13 (45\%) пациенток в III триместре. Всем беременным в период разгара и ранней реконвалесценции определяли вирусную нагрузку ВГЧ-3 в крови методом ПЦР-РВ (специфическая мишень - фрагмент гена, кодирующий открытую рамку считывания 38 (ORF38)) (ФБУН ЦНИИЭ Роспотребнадзора). Постановку и анализ результатов амплификации проводили на приборе «Rotor-Gene Q» (Qiagen, ФРГ).

Результаты. У пациенток с ветряной оспой в период разгара заболевания виремия выявлена в $100 \%$ случаев, концентрация ДНК варьировала от $1,3 \times 10^{2}$ до $6,6 \times 10^{4}$ копий/мл (медиана $6,0 \times 10^{3}$ копий/мл). В период ранней реконвалесценции (7-9 сутки) уровень вирусной нагрузки у $80 \%$ пациенток снижался, у 10\% повышался, у 10\% произошла полная элиминация вируса.

У 4 пациенток с опоясывающим лишаем в период разгара заболевания выявлена виремия: 4,0х10²$7,2 \times 10^{3}$ копий/мл (медиана $2,6 \times 10^{3}$ копий/мл). У двух пациенток наблюдалась генерализация сыпи; у одной заболевание осложнилось менингитом; у одной ВИЧ-инфицированной пациентки виремия протекала бессимптомно.

Катамнестическое наблюдение 29 детей, рожденных от матерей с ветряной оспой выявило один случай заболевания опоясывающим лишаем 9-месячного соматически здорового ребенка. Виремия у матери составила $5,3 \times 10^{2}$ копий/мл на 2 сутки и $1,0 \times 10^{3}$ копий/мл на 7 сутки болезни.

Заключение. Несмотря на то, что большинство исследователей относит ВГЧ-3-инфекцию к группе ToRCH, в настоящее время порог диагностической значимости концентрации ДНК ВГЧ-3 в крови беременных не установлен. Необходимо дальнейшее наблюдение за исходами беременностей и катамнестическое наблюдение детей.

\section{ИНФОРМИРОВАННОСТЬ РОДИТЕЛЕЙ ОТНОСИТЕЛЬНО ПРОФИЛАКТИЧЕСКИХ ПРИВИВОК СВОИМ ДЕТЯМ: РЕЗУЛЬТАТЫ АНКЕТИРОВАНИЯ ВРАЧЕЙ - ПЕДИАТРОВ \\ Королева М.М., Деларю В.В., Деларю Н.В. \\ ФГБОУ ВО «Волгоградский государственный}

медицинский университет» Минздрава России, Волгоград

Введение. Проведение профилактических прививок (ПП) детям и подросткам предполагает согласие их родителей. Соответственно, актуальным являются оценки оказывающих данную медицинскую услугу врачей - педиатров информированности родителей (ИР) относительно ПП, т.к. именно ИР во многом и является определяющим фактором.

Цель исследования - изучить мнение врачей педиатров относительно ИР относительно ПП своим детям.
Материалы и методы. Анкетирование 106 врачей педиатров Волгоградского региона; со стажем работы в профессии до 5-ти лет был 21 человек (19,8\%; 1-я группа), со стажем работы 5 и более лет - 85 (80,2\%; 2-я группа).

Результаты. О том, что информированы относительно полезности проведения ПП не более $25 \%$ родителей, высказались 17,0\% респондентов $(33,3 \%$ в 1-й группе и $13,0 \%$ во 2-й); что примерно $50,0 \%$ родителей - 18,9\% врачей (19,1\% и $18,8 \%$ соответственно); что около $75 \%$ и больше - 64, $1 \%$ врачей $(47,6 \%$ и $68,2 \%)$.

По мнению 23,6\% врачей информированы относительно Национального календаря ПП не более $25 \%$ родителей (так считали $42,8 \%$ врачей 1-й группы и $18,9 \%$ - 2-й); что примерно $50,0 \%$ родителей $-22,6 \%$ врачей (42,9\% и 17,6\% соответственно); что около $75 \%$ и больше $-53,8 \%$ врачей $(14,3 \%$ и $63,5 \% ; p<0,001)$.

$27,4 \%$ специалистов (42,9\% врачей 1-й группы и $23,6 \%$ - 2-й) ответили, что ответственно относятся к проведению вакцинаций, соблюдая существующий Национальный график ПП, не более $25 \%$ родителей; $25,5 \%$ врачей $(47,6 \%$ и $20,0 \%$ соответственно) что примерно $50,0 \%$ родителей; $47,1 \%$ врачей $(9,5 \%$ и $56,4 \% ; p<0,001)$ - что около $75 \%$ и больше родителей.

$17,0 \%$ врачей (19,0\% в 1-й группе и $16,5 \%$ во 2-й) были удовлетворены состоянием просветительной работы среди населения относительно полезности ПП; $52,8 \%$ (38,1\% и 56,5\% соответственно) были неудовлетворенны и $30,2 \%$ (42,9\% и 27,5\%) затруднились ответить.

Заключение. По мнению врачей - педиатров, особенно специалистов со стажем до 5-ти лет, ИР относительно ПП своим детям является недостаточной. Но основными факторами, влияющими на ИР, являются санитарно-просветительные материалы в медицинских учреждениях, тематические материалы в СМИ и, особенно, позиция участковых педиатров. Вышеизложенное аргументирует мероприятия по оптимизации ИР, в первую очередь, по данным трем направлениям.

\section{ПРИЧИНЫ ОТКАЗА РОДИТЕЛЕЙ ОТ ПРОФИЛАКТИЧЕСКИХ ПРИВИВОК СВОИМ ДЕТЯМ}

Королева М.М., Деларю Н.В., Деларю В.В. ФГБОУ ВО «Волгоградский государственный медицинский университет» Минздрава России, Волгоград

Введение. Необходимым условием реализации Национального календаря профилактических прививок (ПП) является согласие родителей на их проведение своим детям; поэтому для оптимизации стратегии действий организаторов здравоохранения и врачей - педиатров актуальным является выяснение причин отказа родителей от их проведения. 
Цель исследования - дефиниция причин отказа родителей от ПП по мнению специалистов - врачейпедиатров.

Материалы и методы. Анкетирование 106 врачей - педиатров Волгоградского региона; со стажем работы в профессии был 21 человек $(19,8 \%)$, со стажем работы 5 и более лет - 85 (80,2\%).

Результаты. Согласно мнения специалистов причины, по которым родители отказываются от ПП, следующие (можно было выбрать несколько): частая негативная информация о прививках в различных СМИ, Интернете (на это указали 91,5\% респондентов); страх родителей развития побочных эффектов / осложнений у ребенка после ПП $(88,7 \%)$; желание родителей делать прививку другой, более лучшей, по их мнению, вакциной $(47,2 \%)$; неверие родителей в полезность ПП (46,2\%); наличие медицинских противопоказаний у ребенка $(43,4 \%)$; недостаточная информированность родителей о полезности ПП $(30,2 \%)$; отсутствие соответствующих вакцин в учреждении $(19,8 \%)$; родители часто забывают о сроках проведения очередной вакцинации (также 19,8\%); неудобное для родителей или ребенка время проведения вакцинации $(5,7 \%)$; другие причины (религиозные представления, удаленность медицинского учреждения от места жительства; 9,4\%).

Соответственно, $17,0 \%$ врачей считали, что от проведения ПП не из-за медицинских противопоказаний у ребенка, а из-за собственного негативного отношения к ним отказываются 1-2\% родителей; $33,0 \%$ врачей - что около $10 \%$ родителей; $33,0 \%$ врачей - что примерно $25 \%$ родителей и $17,0 \%$ врачей - что $50 \%$ родителей или даже больше.

Заключение. Недостаточная приверженность родителей к проведению ПП во многом обусловлена не объективными причинами (в первую очередь, наличием медицинских противопоказаний у ребенка), а субъективным (и, во многом, неправильным) отношением родителей, что может быть скорректировано при оптимизации PR-сопровождения реализации Национального календаря ПП.

\section{КЛИНИКО-ЭТИОЛОГИЧЕСКАЯ СТРУКТУРА ОСТРЫХ КИШЕЧНЫХ ИНФЕКЦИЙ ГОСПИТАЛИЗИРОВАННЫХ ДЕТЕЙ Г. КРАСНОДАР (РЕТРОСПЕКТИВНОЕ ИССЛЕДОВАНИЕ) \\ Корчагина Е.А., Карамова Э.Г.}

Кубанский государственный медицинский университет, Краснодар

Введение. По данным Росстата число зарегистрированных случаев заболеваемости острыми кишечными инфекциями среди детей до 14 лет в 2018 году составило 503,1 тысячи. В 2020 году заболеваемость ОКИ снизилась практически в 2 раза (296 692 случая), что безусловно связано с введением строгих санитарных норм, направленных на борьбу с новой коронави- русной инфекцией. Однако это не умоляет значимость и актуальность данной проблемы в современном мире.

Цель исследования - изучить клинико-этиологическую структуру ОКИ у госпитализированных детей в г. Краснодар.

Материалы и методы. Проведен одномоментный ретроспективный анализ 505 историй болезни детей (М/Д 267/238) с ОКИ, госпитализированных в ДГКБ г. Краснодар (2020 г.) возрастной категории от 0 до 18 лет.

Результаты. В ходе исследования установлено, что среди верифицированной этиологической структуры $(44,4 \%)$ преобладают вирусные диареи в моно и микст формах (2/3 исследуемых). По возрастной структуре превалировали дети до года, преимущественно второго полугодия жизни (35\%), а также дети от 1 до 3-х лет (31\%) - группа риска. В большинстве случаев (84\%) госпитализация детей была произведена на 1-2-е сутки. Каждый второй дебют сопровождался диареей и рвотой одновременно, а первые клинические проявления только в виде рвоты отмечались у $17 \%$, более $3 \%$ дебют ОКИ в виде абдоминального синдрома. Температурная реакция наблюдалась у $87,4 \%$ больных. Характер лихорадки коррелировал с тяжестью течения ОКИ. Диспепсические проявления в виде тошноты и рвоты установлены у 396 пациентов (78,4 \%). Диарейный синдром отмечался у $60,4 \%$ госпитализированных: водянистая диарея $(79,8 \%)$, жидкий стул со слизью $(9,7 \%)$, гемоколит $(6,9 \%)$, жидкий стул с зеленью $(4,4 \%)$. В качестве топического диагноза превалировал гастроэнтерит (95\%), в 3\% случаев регистрировался энтероколит. Преобладало среднетяжелое течение $(97,4 \%)$. По степеням эксикоза достоверных различий не было.

Заключение. Доля больных с верифицированным этиологическим диагнозом составляет менее половины всех случаев ОКИ; в этиологической структуре госпитализированных детей превалируют вирусные диареи в моно и микст формах; группу риска по ОКИ составляют дети до года и раннего возраста; в топической структуре диагноза превалирует гастроэнтерит (95\%) средней степени тяжести $(97,4 \%)$.

\section{ПРИЧИНЫ ДИАГНОСТИЧЕСКИХ ОШИБОК ПРИ ИНФЕКЦИЯХ ЦЕНТРАЛЬНОЙ НЕРВНОЙ СИСТЕМЫ У ДЕТЕЙ НА СОВРЕМЕННОМ ЭТАПЕ Крамарь Л.В. \\ Волгоградский государственный медицинский университет Минздрава России, Волгоград}

Введение. Несмотря на то, что инфекции центральной нервной системы (ЦНС) имеют низкий удельный вес в структуре патологии детей, их течение и зависимость исходов от ранней и адекватной диагностики и терапии имеют огромное значение. 
Цель исследования: изучить структуру заболеваний ЦНС у детей на современном этапе; выявить основные причины диагностических ошибок.

Материалы и методы. Проведен ретроспективный анализ 78 медицинских карт пациентов, проходивших лечение в отделении нейроинфекций Волгоградской областной детской клинической больницы за трехлетний период (20018-2020 гг. включительно).

Результаты. Установлено, что в структуре госпитализированных пациентов дети с заболеваниями ЦНС составляли от $0,1 \%$ в 2018 г. до $0,3 \%$ в 2019 году. Анализ направительных диагнозов показал, что профильная госпитализация была в $94,9 \%$ случаев (74 больных). Из общего числа детей только у 4 (5,1\%) инфекционная природа заболевания ЦНС не подтвердилась. При углубленном обследовании этих пациентов в 2 случаях был выставлен диагноз «Рассеянный энцефалит», у одного пациента обнаружена опухоль головного мозга и еще в одном случае дегенеративное заболевание ЦНС. Было установлено, что вирусы явились наиболее частой причиной поражения нервной системы $(58,1 \%)$, тогда как бактерии - только в $29,7 \%$ наблюдений, неуточненные полинейропатии составляли $12,2 \%$ случаев. Оценка клинических проявлений показала, что полный классический синдромокомплекс был диагностирован только у 45 детей $(60,8 \%)$, тогда как у $39,2 \%$ (29 детей) отмечалось выпадение каких-либо симптомов и диагноз был установлен только на приемном покое инфекционной больницы. При этом направительными диагнозами были следующие: ОРВИ 7 (30,4\%); ОРВИ с судорожным синдромом - 15 $(51,7 \%)$; ОРВИ с явлениями менингизма $-4(13,8 \%)$; острая кишечная инфекция с токсикозом - $3(10,3 \%)$.

Заключение. В настоящее время нейроинфекции сохраняют все основные клинические черты, однако полный синдромокомплекс выявляется только у $60 \%$ пациентов. Это, в сочетании с низкой настороженностью врачей, является причиной диагностических ошибок на догоспитальном этапе.

\section{РАСПРОСТРАНЕННОСТЬ САМОЛЕЧЕНИЯ ПРИ ОСТРЫХ РЕСПИРАТОРНЫХ ИНФЕКЦИЯХ У ДЕТЕЙ}

Крамарь Л.В.

Волгоградский государственный медицинский университет Минздрава России, Волгоград

Введение. Самолечение - применение пациентом лекарственных средств с целью лечения расстройств здоровья до оказания профессиональной медицинской помощи, широко распространено во всем мире, однако в Российской Федерации этот феномен является малоизученным.

Цель исследования: изучение причин и удовлетворенности использования пероральных лекарствен- ных препаратов для лечения острых респираторных инфекций у детей родителями, проживающими в городе Волгограде.

Материалы и методы. Одномоментное анонимное анкетирование 390 матерей детей в возрасте от 1 года до 14 лет было проведено в течение октября-марта 2018-2019 гг. в г. Волгограде (Россия). В исследование включались только женщины, имеющие детей в возрасте старше 1 года. Матери детей, имеющих хронические соматические заболевания, лица с медицинским образованием не включались в анкетирование. Полученные данные были проанализированы с использованием программного пакета statistica-10.

Результаты. Установлено, что 277 матерей (71,0\%) постоянно использовали самолечение, при этом его частота зависела только от уровня семейного дохода $\left(\chi^{2}=7,077, p=0,030\right)$ и не зависела от возраста респондентов $\left(\chi^{2}=0,211, p=0,976\right)$, образования $\left(\chi^{2}=2,626\right.$, $p=0,270)$, количества детей в семье $\left(\chi^{2}=2,819, p=0,421\right)$. Наиболее часто применялись жаропонижающие средства $(93,8 \%)$, деконгестанты $(72,9 \%)$, антигистаминные препараты $(49,5 \%)$, энтеросорбенты $(44,4 \%)$, иммуномодуляторы $(26,7 \%)$, в 7,9\% - антибиотики. Среди причин самолечения большинство (57,8\%) указало на знакомые симптомы заболевания, 25,6\% на нетяжелое состояние ребенка, 10,5\% - невозможность посетить поликлинику. Чаще всего препараты использовались по предыдущим назначениям врача $(89,2 \%)$, в 27,8\% случаях - по рекомендации фармацевтов в аптеке, 20,9\% - по совету родственников или знакомых. Согласно опросу 59,6\% мам было полностью удовлетворено результатами самолечения, тогда как 40,4\% не получили ожидаемого результата.

Заключение. Самолечение детей при острых респираторных вирусных инфекциях практикует более $70 \%$ матерей, при этом используется широкий спектр препаратов, включая антибиотики. Все это показывает актуальность проблемы, требующей дальнейшего изучения и юридического регулирования.

\section{ПОТЕНЦИАЛЬНОЕ ВЛИЯНИЕ ВИТАМИНА D НА TЕЧЕНИЕ COVID-19 У ДЕТЕЙ}

Лучникова Т.А., Приходько О.Б.

ФГБОУ ВО Амурская ГМА Минздрава России, Благовещенск, Амурская область

Введение. Открытие «геномных» и «негеномных» эффектов витамина D повлекло массу исследований влияния дефицита витамина D на организм человека. Гормонально-активная форма (кальцитриол) взаимодействует через специальные рецепторы, имеющиеся практически во всех тканях организма, в том числе на клетках иммунной системы: Т- и В-лимфоцитах, макрофагах, легочных альвеолоцитах, на гладкомышечных клетках бронхов, влияя тем самым на возможность модулировать врожденный и адаптивный иммунитет. 
Цель исследования: определить содержание витамина D у пациентов с COVID-19 и его степень влияния на течение инфекции у детей.

Материалы и методы: В исследовании приняли участие 30 детей с подтвержденным диагнозом Covid19. Из них у 15 было легкое течение, протекшее в виде острой респираторной инфекции, у 10 детей средней тяжести с проявлениями пневмонии и 5 бессимптомные носители. Средний возраст составил $14,5 \pm 3,1$ года. Уровни 25- $(\mathrm{OH})$ D в сыворотке анализировали с использованием анализатора высокоэффективной жидкостной хроматографии. Для статистической обработки использовалась программа Statistica 10,0. Это исследование было выполнено в соответствии с Хельсинкской декларацией. Это исследование на людях было одобрено этическим комитетом Амурской государственной медицинской академии.

Результаты исследования и их обсуждение: Средний уровень 25- (OH) D у пациентов с Covid-19 составил $22,83 \pm 4,16$. У детей с клиническими симптомами дефицит витамина D выявлен в $63 \%$ случаев, недостаточное потребление - в 30\%, оптимальное содержание витамина D - в 7\%. В то же время у пациентов с проявлениями пневмонии дефицит витамина D имел место в $78 \%$ случаев $(p=0,01)$. У детей c бессимптомным носительством Covid-19 средний уровень витамина D составлял $25,8+3,4$ нг/мл, что значительно выше, чем у детей с клиническими проявлениями Covid-19.

Заключение. Низкий уровень витамина D приводит к более обширному повреждению легких. Дефицит витамина D можно считать маркером тяжелого течения и неблагоприятного исхода инфекционных заболеваний легких.

\section{СИНДРОМ НЕТИРЕОИДНОГО ЗАБОЛЕВАНИЯ У ДЕТЕЙ С ОРВИ}

Малинина Н.В., Малюгина Т.Н., Матвеева М.А. ФГБОУ ВО «Саратовский ГМУ» им. В. И. Разумовского Минздрава России, Саратов

Введение. «Синдром нетиреоидного заболевания» или «синдром низкого $\mathrm{T}_{3}$ » сопровождает многие инфекционные и неинфекционные заболевания.

Цель исследования - оценить частоту и особенности течения ОРВИ на фоне низкого уровня трийодтиронина $\left(\mathrm{T}_{3}\right)$.

Материалы и методы. В исследовании, проведенном на базе 5-й детской инфекционной больницы г. Саратова приняли участие 70 пациентов в возрасте от 1 до 12 лет с острой респираторной вирусной инфекцией (ОРВИ). У больных определяли уровень гормонов щитовидной железы ( $\mathrm{T}_{4}$ свободный, $\mathrm{T}_{3}$ свободный) (ЗАО «Вектор-Бест» п. Кольцово Новосибирской области), проводили стандартный комплекс обследования при ОРВИ. По показаниям проводилась рентгенография легких. Контрольную группу составили 15 здоровых детей от 1 до 12 лет.

Результаты. Синдром «низкого $\mathrm{T}_{3}$ в выявлен у 20 детей $(28,6 \%)$ с ОРВИ, уровень $\mathrm{T}_{3}$ у них составил 3,1 $(2,6 ; 3,7)$ ммоль/л и был ниже результата контрольной группы 6,2 (5,3; 7,1 пмоль/л ( $p<0,05$, критерий Манна-Уитни). У остальных 50 больных уровень $\mathrm{T}_{3}$ составил $5,9(4,7 ; 6,6)$ пмоль/л $(p>0,05)$. В группе пациентов с низким $\mathrm{T}_{3}$ отмечалось снижение $\mathrm{T}_{4}$ до 11,4 (9,5; 12,7) пмоль/л, в группе сравнения этот показатель был значимо выше 14,6 (12,1; 21,1), ( $p<0,05$, критерий Манна-Уитни).

В общем анализе крови у пациентов с низким $\mathrm{T}_{3}$ наблюдали статистически значимое увеличение числа палочкоядерных нейтрофилов до 2 (1; 3)\% и снижение лейкоцитарного индекса резистентности до $1,8(1,0 ; 4,1)$, свидетельствующие о возможном наличии осложнений. В группе сравнения эти показатели составили $1(1 ; 2) \%$ и $3,4(1,3 ; 9,7)$ соответственно ( $p<0,05$, критерий Манна-Уитни).

В клинической картине частота осложнений не зависела от уровня $\mathrm{T}_{3}$ возможно это связано с малой выборкой.

Заключение. «Синдром низкого $\mathrm{T}_{3}$, возникающий практически у $1 / 3$ детей с ОРВИ, может указывать на возможные осложнения ОРВИ, этот вопрос требует дальнейшего изучения. Возможно - это один из способов адаптации к острой респираторной вирусной инфекции.

\section{ОПЫТ ПРИМЕНЕНИЯ ИНТЕРФЕРОНА АЛЬФА-2В НОВОРОЖДЕННЫМ С КОНТАКТОМ ПО ИНФЕКЦИИ COVID-19}

Малюгина Т.Н., Малинина Н.В., Железников П.А. ФГБОУ ВО «Саратовский ГМУ» им. В. И. Разумовского Минздрава России, Саратов

Введение. Как поступать с новорожденными, если они родились от инфицированной вирусом SARSCoV-2 матери или подверглись контакту в периоде новорожденности? Какое профилактическое лечение можно применить? Возрастной арсенал препаратов очень скуден, но разрешены препараты интерферона альфа $2 b$.

Цель исследования - изучить эффективность применения интерферонов альфа-2b у новорожденных детей с контактом по инфекции COVID -19.

Материалы и методы. Проведено наблюдение за 235 новорожденными, лечившимися в ОДИБ им Н.Р. Иванова г. Саратова с апреля 2020 года по февраль 2021 года. Всем пациентам проводилось стандартное лабораторное и инструментальное обследование. Верификация SARS-CoV-2 осуществлялась методом ПЦР. Всем новорожденным с первого дня в качестве профилактики были назначены препараты 
интерферона альфа-2b курсом 7 дней. В зависимости от путей введения интерферонов пациенты были разделены на 2 группы: детям первой группы (125 человек) интерфероны вводились назально и ректально, пациентам второй группы (110 новорожденных) только назально.

Результаты. Всего было подтверждено 17 случаев коронавирусной инфекции: в первой группе инфекция COVID-19 развилась у 4 новорожденных $(3,2 \%)$, во второй - у 13 детей $(11,8 \%)$, то есть, встречалась почти в 4 раза чаще. Эхо-признаки мультифокальных изменений в легких выявлены у 2,4\% больных первой группы и у 5,5\% детей второй группы. Сатурация снижалась до 95-96\% у 2,4\% новорожденных первой группы и у 4,5\% больных второй группы. Повышение уровня СРБ в первой группе встречалось в 2,4\% случаев и составляло $12[6 ; 16]$ мг/л, во второй - в 5,5\% и соответствовало $18[6 ; 18]$ мг/л. Во второй группе, кроме того, отмечались эпизоды ОРВИ в 5,5\% случаев в виде фарингитов и ринофарингитов. В первой группе данная патология не наблюдалась.

Заключение. Новорожденным детям с контактом по инфекции COVID -19 в качестве профилактического лечения рекомендуется комплексное назначение интерферонов альфа-2b (одновременно ректальные и назальные формы).

\section{ФУНКЦИОНАЛЬНОЕ СОСТОЯНИЕ}

\section{РЕСПИРАТОРНОЙ СИСТЕМЫ У СПОРТСМЕНОВ- ПОДРОСТКОВ, ПЕРЕНЕСШИХ ИНФЕКЦИЮ, ВЫЗВАННУЮ COVID-19 \\ Маринич В.В.}

Учреждение образования «Полесский государственный университет», Пинск, Республика Беларусь

Введение. Современный спортивный мир столкнулся с новым вызовом: сохранение работоспособности спортсменов, перенесших инфекцию, вызванную COVID-19. Неоднозначны существующие протоколы, затрагивающие профилактику осложнений со стороны респираторной системы даже у лиц с легким или субклиническим течением заболевания, отсутствует рекомендательная база фармакологической поддержки у спортсменов-подростков, сталкивающихся с высокими нагрузками на систему внешнего дыхания.

Цель исследования - оценка функционального состояния респираторной системы квалифицированных спортсменов, перенесших инфекцию, вызванную COVID-19, создание рекомендательной базы по коррекции тренировочного процесса и фармакологической поддержки в скоростно-силовых видах спорта.

Материалы и методы. В исследование включено 19 спортсменов подростков 15-18 лет, занимающихся скоростно-силовыми видами спорта $(8,5$ часов в неделю), имевших поражение легкой и сред- ней степени тяжести верхних и нижних дыхательных путей с доказанной (SARS-CoV2, ПЦР) этиологией. Исследовалась динамика показателей функции внешнего дыхания (спирограф - Spiro Scout «Genshorn», Germany), мониторинг окиси азота в выдыхаемом воздухе (портативный электрохимический NO-анализатор «NObreath», Bedfont Scientific Ltd.).

Результаты. Установлено, что средний уровень NOex в покое составил 24,5 $\pm 4,15$ ppb, в динамике тренировки отмечались значительные колебания с максимальным значением 45 pрb после нагрузки анаэробного характера. В периоде восстановления $-28,2 \pm 4,18$. Отмечено колебание проходимости дыхательных путей на уровне мелких бронхов (MEF75) в диапазоне $65-75 \%$ от нормы у 9 из 19 спортсменов при снижении субъективной толерантности к физической нагрузке $(p=0,02)$. Значимое снижение ОФВ1 у обследованных спортсменов-подростков не регистрировалось, показатель на фоне максимальной скоростной работе колебался в диапазоне $85-90 \%(p=0,001)$.

Заключение. Повышение значений NO в выдыхаемом воздухе свыше 20 pрb у отдельных спортсменов свидетельствуют о возможном риске протекающего хронического воспаления в респираторном тракте. Отсутствие значимого падения ОФВ1 свидетельствует о достаточной степени компенсаторных изменений и высоком респираторном потенциале. У спортсменов-подростков, перенесших поражение дыхательных путей необходим мониторинг функционального состояния дыхательной системы, ранний перевод организма в диапазон анаэробного энергообеспечения при возобновлении тренировок создает риски перенапряжения, отражается на функциональном состоянии респираторной системы. При сохранении высоких значений NO в выдыхаемом воздухе, снижении проходимости дыхательных путей следует рассматривать вопрос ранней фармакологической интервенции с использованием противовоспалительной и бронхолитической ингаляционной терапии.

\section{ОСОБЕННОСТИ ТЕЧЕНИЯ COVID-19 У ДЕТЕЙ С БРОНХИАЛЬНОЙ АСТМОЙ}

Мухортых В.А. ${ }^{1,3}$, Ларькова И.А. ${ }^{1,2}$, Ревякина В.А. ${ }^{1,2}$

'ФГБУН «ФИЦ питания и биотехнологии пищи», Москва ФГАУ «НМИЦ здоровья детей» Минздрава России, Москва ЗФГБУ «ФНКЦ детей и подростков ФМБА России», Москва

Введение. Данные о клинических особенностях инфекции SARS-CoV-2, проявляющейся тяжелым острым респираторным синдромом, у детей с аллергическими заболеваниями ограничены. Особый интерес представляют данные о развитии постковидного синдрома у больных БА.

Цель исследования - оценить особенности течения COVID-19 у детей с бронхиальной астмой. 
Материалы и методы. В исследование были включены 12 детей с БА в возрасте от 6 до 17 лет, в том числе - 1 с тяжелой, 2 со среднетяжелой и 9 с легкой БА, перенесших COVID-19. Все дети были обследованы на предмет клинических проявлений инфекции, а также симптомов БА. Инфекция была подтверждена эпидемиологическим анамнезом, а также результатами ПЦР-тестирования. Всем пациентам проводилась пикфлоуметрия с оценкой РЕF в течение всего периода заболевания. Через месяц после заражения все пациенты прошли иммунологическое обследование на уровень антител IgG к COVID19 методом ИФА. Через месяц после заражения у 3 пациентов с легкой формой БА появились жалобы на одышку на фоне небольшой физической активности, слабость, тяжесть в груди, снижение переносимости физической нагрузки. Детям были проведены дополнительные обследования - КТ органов грудной клетки, ЭКГ, ЭХО-КГ для исключения постковидного миокардита, коронарита, пневмонии.

Результаты. Все дети с БА были инфицированы SARS-CoV-2 и имели следующие симптомы: слабость, лихорадка, боль в горле и заложенность носа в течение 3-4 дней, что не повлияло на течение БА (как клинически, так и по результатам PEF) и не требовало увеличения базисной терапии. 10 детей дали положительный результат на COVID-19 при ПЦРтестировании, у 2х был отрицательный результат. Однако, у всех детей были обнаружены высокие титры антител IgG к этой инфекции через месяц после заболевания. Хотя наличие миокардита, коронарита и пневмонии не было подтверждено при дополнительном обследовании у 3 детей с вновь появившимися жалобами, а PEF имел обычные значения, было принято решение увеличить объем базисной терапии на 50\%, что привело к стабилизации состояния и облегчению жалоб. В то же время причина этих жалоб оставалась неясной.

Заключение. Инфекция SARS-CoV-2 не вызывала обострения БА и не требовала увеличения базисной терапии на период острой инфекции. В то же время нельзя исключать развитие постковидного синдрома у детей с БА, и поэтому даже в случае легкого течения COVID-19 эти пациенты нуждаются в наблюдении и своевременной коррекции терапии.

\section{ЭФФЕКТИВНОСТЬ И БЕЗОПАСНОСТЬ ПРОТИВОГРИППОЗНЫХ ВАКЦИН УЛЬТРИКС® И СОВИГРИПП® У ШКОЛЬНИКОВ \\ Пономарева Ю.В., Шишиморов И.Н., Плахотнюк Т.В., Мезениева О.Ю. \\ ФГБОУ ВО «ВолгГМУ Минздрава России», Волгоград}

Введение. Вакцинопрофилактика является самым эффективным и безопасным методом предупреждения тяжелого течения гриппа. С этой целью приме- нялись иннактивированные трехвалентные вакцины Ультрикс ${ }^{\circledR}$ (содержит по 15 мкг антигена на каждый штамм, без добавления адъюванта) и Совигрипп ${ }^{\circledR}$ (содержит по 5 мкг антигена на каждый штамм, с добавлением совидона) у школьников г.Волгограда.

Цель исследования - сравнить реактогенность и клиническую эффективность вакцин Ультрикс $®$ и Совигрипп® у школьников.

Материалы и методы. Исследование проводилось с участием здоровых детей, вакцинированных Ультриксом ${ }^{\circledR}$ и Совигриппом ${ }^{\circledR}$ в рамках сезонной профилактики гриппа. Для оценки реактогенности отмечались местные и общие нежелательные реакции. Клиническая эффективность оценивалась по количеству и тяжести острых респираторных инфекций (ОРИ) за период эпидемического сезона 2020-2021 гг.

Результаты. В исследование включено 140 детей 7-12 лет, вакцинированных Ультриксом® (70 человек) и Совигриппом® (70 человек). В группе Ультрикса ${ }^{\circledR}$ в 4,2\% случаев зафиксированы реакции на введение вакцины (лихорадка, местная реакция). В группе Совигриппа ${ }^{\circledR}$ поствакцинальные реакции отмечались у $10 \%$ участников (местная реакция, лихорадка, симптомы ОРИ). За последующий период наблюдения в группе Ультрикса® у 52 человек (74,3\%) отсутствовали симптомы ОРИ; 10 человек $(14,3 \%)$ болели однократно, 8 человек $(11,4 \%)$ - два и более раз. В 9 случаях (50\% заболевших) течение заболеваний было средней тяжести, в 1 случае с клинической картиной гриппа. В группе Совигриппа ${ }^{\circledR} 45$ школьников (64\%) не болели ОРИ; 12 человек $(17,7 \%)$ болели однократно, 13 человек $(18,6 \%)$ - два и более раз. В 7 случаях (28\%) отмечалось средне-тяжелое течение. Клинической картины гриппа в этой группе не отмечалось.

Заключение. Применение противогриппозных вакцин Ультрикс ${ }^{\circledR}$ и Совигрипп ${ }^{\circledR}$ у школьников г.Волгограда характеризовалось низкой реактогенностью, частота нежелательных реакций в группах была сопоставима $(p=0,190)$. Вакцины продемонстрировали высокую эффективность - клинические симптомы гриппа зарегистрированы в одном случае $(0,7 \%)$. Частота и тяжесть ОРИ, за исследуемый период, в группах достоверно не различались $(p=0,2)$.

\section{АНАЛИЗ КЛИНИЧЕСКОГО ТЕЧЕНИЯ КОРОНОВИРУСНОЙ ИНФЕКЦИИ У ДЕТЕЙ. \\ Пушкарева О.С., Тараторина А.С., Куколев В.А. ФГБОУ ВО ЮУГМУ Минздрава России, Челябинск}

Введение. C 31 декабря 2019 пандемия COVID-19 (COrona VIrus Disease 2019, коронавирусная болезнь 2019 года) привлекла к себе внимание так как не было ясного представления о клинике, патогенезе воспаления и специфической терапии, что является актуальным на данный момент. Дети и подростки, как правило, подвержены низкому риску инфициро- 
вания, однако известны и тяжелые случаи этого заболевания, вплоть до летальных исходов.

Цель исследования - провести анализ клинического течения COVID-19 у детей города Челябинска.

Материалы и методы. Был проведен анализ 42 историй болезни детей, в возрасте от 0 до 10 лет, находившихся на лечении с июля по ноябрь 2020 года в отделении для лечения пациентов с COVID-19 г. Челябинска с подтвержденным диагнозом “новая коронавирусная инфекция”.

Результаты: при анализе историй болезней детей, госпитализированных в стационар, с COVID-19, выявлено, что заболеваемость выше среди детей дошкольного и раннего школьного возраста, что составило соответственно $38 \%$ и $31 \%$, преимущественно болели мальчики (58\%). Лихорадка наблюдалась в 64,2\% случаев (27 детей), при этом стойкая лихорадка до фебрильных цифр регистрировалась у 30,9\% больных. Кашель наблюдался в $38 \%$ случаев, преимущественно сухой. Слабость отмечена у 13 пациентов (30,9\% детей), заложенность носа у 9 детей $(21,4 \%)$, отделяемое из носа - у 14,2\%, инсомния у 1 ребенка. Среди исследуемой группы пациентов 7,1\% (3 детей) жаловались на затрудненное дыхание, среди них пневмония у 2 пациентов. В 83,4\% случаев заболевание имело легкое течение, в 14,3\% случаев среднетяжелое, тяжелое течение у 2,3\% случаев (1 ребенок) отмечено у ребенка с миокардитом. Все пациенты получали интерфероны в стационаре, в 54,7\% случаев антибактериальную терапию.

Выводы. Заболеваемость новой коронавирусной инфекцией COVID-19 выше у детей в дошкольном и раннем школьном возрасте. Пневмонией заболело только 2 ребенка, при этом тяжесть заболевания была среднетяжелой, лечение не требовало применения ИВЛ.

\section{ЗАБОЛЕВАЕМОСТЬ ВИЧ-ИНФЕКЦИЕЙ У ДЕТЕЙ ГОРОДА ЧЕЛЯБИНСКА}

Пушкарева О.С., Пишулов К.А., Ткаченко Е.А.

ФГБОУ ВО ЮУГМУ Минздрава России, Челябинск

Введение. Актуальность проблемы ВИЧ-инфекции среди детей определяется высоким вовлечением в эпидемию этой группы населения и риском инфицирования ВИЧ, высокой смертностью, связанной со СПИД. В южноуральском регионе России, несмотря на предпринимаемые профилактические и организационные мероприятия, неуклонно растет количество ВИЧ-инфицированных жителей.

Цель исследования. Анализ заболеваемости ВИЧинфекцией у детей в г. Челябинске и Челябинской области, с впервые установленным диагнозом ВИЧинфекции.

Материалы и методы. Проведен анализ данных медицинской документации: журналов регистрации и постановки на диспансерный учет ВИЧ-инфицированных детей и амбулаторных карт 47 детей в возрасте от 1 месяца до 18 лет с впервые установленным диагнозом ВИЧ-инфекция.

Результаты. Анализ медицинской документации показал, снижение заболеваемости среди детей, при этом диагноз ВИЧ-инфекция был впервые выставлен в разные возрастные периоды, чаще же в возрасте до 3 месяцев и после 12 лет. Частота постановки диагноза ВИЧ у детей до 3 месяцев, можно объяснить перинатальным контактом с матерью и дефектами проведения трехэтапной высокоактивной антиретровирусной терапии (ВААРТ) у матери (у 20\% женщин терапия проводилась только в родах, у $80 \%-$ не проводилась совсем). Дети старше 12 лет (заражение ВИЧ-инфекцией половым путем в подростковом возрасте). Важно, что среди инфицированных ВИЧ половым путем подавляющее большинство 8 (88,9\%) составили девочки подросткового возраста. Следует отметить, что 21 ребенок $(44,7 \%)$ из ВИЧ-положительных детей проживал в полной семье, из них двое детей усыновлено, в неполной семье - 26 (55,3\%).

Выводы. У детей до трехмесячного возраста заражение ВИЧ-инфекцией четко коррелирует с дефектами ВААРТ во время беременности и в родах у ВИЧинфицированной матери. Преимущественный путь передачи ВИЧ - вертикальный у 33 (70,2\%) детей. В случаях заражения ВИЧ половым путем 88,9\% детей были девочками.

\section{КЛИНИЧЕСКИЕ ПРОЯВЛЕНИЯ МИКОПЛАЗМЕННОЙ ПНЕВМОНИИ У ДЕТЕЙ \\ Скачкова М.А., Карпова Е.Г., Тарасенко Н.Ф., Рыбалкина М.Г. \\ ФГБОУ ВО ОрГМУ Минздрава России, Оренбург}

Актуальность: В 2019 г. в Оренбургской области заболеваемость внебольничными пневмониями (ВП) микоплазменной этиологии составила 3,7\% от бактериальных ВП. Среди заболевших 90,2\% детей, с преобладанием школьников 7-14 лет и подростков 15-17 лет.

Цель - выявление клинических особенностей течения микоплазменной пневмонии у детей г. Оренбург.

Материалы и методы. Анализ 14 историй болезни детей в возрасте 7-17 лет с внебольничной пневмонией микоплазменной этиологии, находившихся на лечении в пульмонологическом отделении детского стационара г. Оренбург с октября по декабрь 2019 года.

Результаты. Среди пациентов 64\% - подростки 12-15лет, четверо - из одного класса. Две трети детей (71\%) заболели в ноябре, 1 - в октябре, 3 - в декабре. В $71 \%$ случаев ВП предшествовал острый ринофарингит. Лечились амбулаторно до 10 дней 57\% детей, 4-5 и 12-14 дней по 21,5\% детей. Все получали противо- 
вирусную терапию (арбидол), 2 ребенка - антибиотики (амоксициллин, цефотаксим). ВП подтверждена рентгенологически, из них у 77\% детей амбулаторно. При поступлении у всех отмечался сухой навязчивый кашель, субфебрильная температура, катаральный синдром, ослабленное дыхание и влажные мелкопузырчатые хрипы (на стороне поражения). Поражение справа (чаще в сегментах S4, S5) у 9 детей (65\%), слева - у 5 детей (35\%). Средняя степень тяжести ВП у $92 \%$ детей, тяжелая ВП у $8 \%$ (у 2-х детей 14 и 17 лет синпневмонический и осумкованный плеврит соответственно). В ОАК: лейкоцитоз у $28 \%$ детей, СОЭ выше 20мм/ч у 42\% детей, у остальных - без изменений. У всех выявлены IgМ к микоплазме (метод ИФА). В терапию ВП добавлен азитромицин. Госпитализация у $50 \%$ детей - 8 дней, у 28\% 11 дней, у 14\% 14 дней, с синпневмоническим плевритом 21 день.

Заключение. Микоплазменная пневмония чаще встречается в подростковом возрасте, имеет сезонный характер (с пиком в ноябре). Постановке диагноза помогает скудный катаральный синдром, упорный кашель, незначительные изменения в анализе крови, положительный результат IgG на микоплазму, отсутствие эффекта от амоксициллина и эффективность лечения азитромицином.

\section{КЛИНИЧЕСКИЙ СЛУЧАЙ ЛИХОРАДКИ ДЕНГЕ}

Сутовская Д.В., Бурлуцкая А.В., Пекина О.А.,

Моисеева Л.Х., Карамова Э.Г., Корчагина Е.А.

ФГБОУ ВО КубГМУ Минздрава России, Краснодар

Введение. Лихорадка Денге (ЛД) распространена почти во всех тропических и субтропических зонах мира и включена в перечень заболеваний, которые требуют санитарного надзора на территории РФ.

Цель исследования - демонстрация клинического случая ЛД у мальчика 14лет.

Материалы и методы. Мальчик А., 16,08,2005 г.p., находившийся на лечении в ГБУЗ «ККБ №4» с 22,04,2020 г. по 04,05,2020 г.

Результаты. Мальчик доставлен в инфекционное отделение 22,04,2020г. с симптомами: повышение температуры тела до 39,5, выраженная слабость. Из анамнеза: ребенок в течение 1 месяца находился в Тайланде, контакт с инфекционными больными не установлен. При перелете 21,04,2020 г. из Тайланда поднялась температура до 39,5. По прибытию ребенок и члены семьи направлены в обсерватор, в связи с эпид. обстановкой по COVID-19, где подъемы температуры до 40 повторялись без эффекта на жаропонижающие препараты. При поступлении состояние средней степени тяжести за счет интоксикационного синдрома, катаральные симптомы верхних дыхательных путей, периферические лимфоузлы:подчелюстные, передние и задние шейные 1,0×2,0 см, подмышечные размером 1,2×0,8 см, единичные, эластичные, подвиж- ные, умеренно болезненные. По данным параклинических методов исследования: лейкопения $(5,1 \times 109 /$ л), нейтрофилез $(81,7 \%)$, тромбоцитопения $(132 \times 109 / л)$, СРБ+. Предварительный диагноз: острый фарингит средней степени тяжести. Лечение: арпефлю, цефтриаксон, инфузионная терапия с целью дезинтоксикации, дексаметазон, аципол, парацетамол. 23,04,2020 г. сохраняется фебрильная лихорадка, усиление боли в горле, инъекция склер. 25,04,2020 г. головокружение, бледность кожных покровов, на щеках румянец, по задней стенке глотки слизь, положительной динамики нет: гепатоспленомегалия (печень $+2,5$ см и селезенка+1,5 см), ОАК-лейкопения $(2,4 \times 109 / л)$, тромбоцитопения (90×109/л). В лечение добавлен иммуноглобулин человеческий. На фоне терапии-положительная динамика (29,04): состояние средней тяжести, самочувствие ближе к удовлетворительному, лихорадка купирована. Размер периферических лимфоузлов в пределах нормы. Методом ПЦР в крови обнаружена RNK Dengue virus 2 типа. (30,04,2020 г.). Клинический диагноз: лихорадка Денге 2 типа, классическая форма, средней степени тяжести. 04,05,2020 г. выписан с выздоровлением.

Заключение. Данный случай демонстрирует недооценку эпидемиологического анамнеза, что отражается в несвоевременных диагностических решениях и ошибках в тактике и ведении пациентов, которые усугубляют течение болезни и увеличивают риск осложнений.

\section{РОТАВИРУСНАЯ ИНФЕКЦИЯ: АНАЛИЗ ВАКЦИНОПРОФИЛАКТИКИ И КЛИНИКО- ЭТИОЛОГИЧЕСКАЯ СТРУКТУРА ГОСПИТАЛИЗИРОВАННЫХ ДЕТЕЙ Г. КРАСНОДАР (РЕТРОСПЕКТИВНОЕ ИССЛЕДОВАНИЕ)}

Сутовская Д.В., Бурлуцкая А.В., Тетенкова А.А., Литвинская М.А., Науменко Г.В., Крылова Д.Р., Епинетова А.A.

ФГБОУ ВО КубГМУ Минздрава России, Краснодар

Введение. Среди всех госпитализаций детей с ОКИ от 20 до $60 \%$ ассоциировано с ротавирусной инфекцией (РИ). Высокая интенсивность распространения эпидемического процесса и летальность от РИ свидетельствует о необходимости внедрения вакцинации.

Цель исследования - оценить состояние вакцинопрофилактики и изучить клинико-этиологическую структуру РИ у госпитализированных детей в г. Краснодар.

Материалы и методы. Проведен одномоментный ретроспективный анализ 505 историй болезни детей (М/Д 267/238) с ОКИ госпитализированных в ДГКБ г. Краснодар (2020 г.) возрастной категории от 0 до 18 лет. Изучено состояние вакцинопрофилактики (2013-2020 гг.) на базе центра вакцинопрофилактики в ГБУЗ СКИБ г. Краснодар. 
Результаты. Количество иммунизированных детей составило 6552 и увеличилось с 10 (2013 г.) до 1460 (2020 г.). Охват вакцинацией в 2020 г. составил 5,9\% целевой когорты. Установлено менее $1 \%$ побочных проявлений после иммунизации. В структуре ОКИ зарегистрировано 140 случаев РИ (27,7\%): моно-РИ 50(35,7\%), микст-РИ 90 (64,3\%). Среди микст-РИ: норо-РИ 67,9\%, норо-адено-РИ 17,8\%, адено-РИ 3,3\%; сальмонелезноноро-РИ 3,3\%, сальмонелезно-РИ, сальмонелезно-норо-адено-РИ, кампилобактериально-норо-РИ по 2,2\% случая и ешерихио-РИ-1,1\%. В повозрастной структуре РИ преобладали дети до 1 года-59,3\%, 1-3 года21,4\%, 4-6 лет-7,2\%, 7-18 лет-12,1\%. Моно-РИ встречалась в виде гастроэнтерита в среднетяжелой (78\%) и тяжелой (22\%) форме с различной степенью выраженности обезвоживания (I ст.-74\%, II ст.-4\%, III ст.-22\%). Микст-РИ встречалась в виде гастроэнтерита $80(88,9 \%)$ и энтероколита $10(11,1 \%)$ в среднетяжелой $(81 \%)$ и тяжелой (19\%) форме с эксикозом I ст. (63\%), II ст. (18\%), III ст. (19\%). Среди всех госпитализированных детей, ни один не был привит против РИ.

Заключение. Первичная иммунопрофилактика РИ составила 5,9\% целевой когорты. Каждый третий случай госпитализации с ОКИ обусловлен РИ, превалируют вирусно-вирусные ассоциации (60\%). Наиболее часто при моно- и микст-РИ встречается гастроэнтерит, тяжесть течения сопоставима. Основную группу риска составляют дети раннего возраста, особенно до года. Иммунизированных детей против РИ с ОКИ не зарегистрировано.

\section{ОСОБЕННОСТИ ТЕЧЕНИЯ COVID-19 У ДЕТЕЙ НА ДОГОСПИТАЛЬНОМ ЭТАПЕ \\ Файзуллина P.M. ${ }^{\text {, }}$ Гильфанова A.A. ${ }^{\text {, }, ~ Г а ф у р о в а ~ P . P . ~}{ }^{\text {, }}$ Абсалямова Н.T. ${ }^{2}$ \\ 1ФГБОУ ВО БГМУ Минздрава России, Уфа \\ 2 ГБУЗ РБ ГДКБ №17, Уфа}

Введение. Дифдиагностика COVID-19 у детей с другими ОРИ, симптомы которых имеют схожую клиническую картину важно. Ранее выявление COVID -19 позволит назначить терапию и профилактику с целью снижения риска формирования осложнений и ее вторичного распространения.

Цель. Изучить клинико-эпидемиологические особенности течения COVID-19 у детей на педиатрическом участке.

Материалы и методы. Под наблюдением находились дети, контактные и заболевшие COVID-19. Исследование проводилось в поликлинике ГБУЗ РБ ГДКБ №17 г. Уфа с мая 2020 по июнь 2021 гг. Проведено клинико-лабораторное исследование и назначена терапия в соответствии с Методическими рекомендациями «Особенности клинических проявлений и лечения заболевания, вызванной новой коронавирусной инфекцией (COVID-19) у детей» 2020 г.
Результаты. Число детей на педиатрическом участке-1000 человек, из которых у 80(8\%) детей при оценке эпиданамнеза он был отягощен, чаще по внутрисемейному контакту с заболевшими COVID-19 в 80\%(64) случаев. Из числа контактных по COVID-19 - 25(31\%) детей имели «+» результат ПЦР и 55(69\%) детей «-» ПЦР. Дети распределились по возрасту: до 5 лет - 5(20\%); 6-12 лет - 6(24\%); старше 12 лет - 14(56\%). Чаще болели девочки 14(56\%), мальчики - 44\%(11). Среднетяжелая форма COVID-19 была у 44\%(11), легкое -7(28\%) и бессимптомное течение у 7(28\%). Тяжелого течения COVID-19 не было. Все дети находились под амбулаторным наблюдением. Сопутствующую патологию имели 9(36\%) детей. Кашель отмечался у 16(64\%) детей, чаще сухой непродуктивный, либо покашливание; признаки ринита отмечались в 4(16\%), что не типично для ОРИ, для которых наличие ринита является одним из ключевых признаков заболевания; повышение температуры тела было у 19(76\%) детей: субфебрильная-12(63\%); фебрильная - 5(26\%) и гипертермия - 2(11\%); такие специфичные симптомы, как аносмия и агевзия у 3(12\%) детей; наличие симптомов поражения ЖКТ у 2(8\%). Поражения легких и осложнений пневмонией не было. К 7 дню заболевания основные симптомы болезни купированы. Дети имели контрольные результаты «-» ПЦР.

\section{Выводы.}

1. В 80 \% случаев инфицирование детей возникало в результате семейного контакта; чаще встречалось у девочек. 36 \% заболевших имели сопутствующую патологию.

2 Для клиники COVID-19 характерно наличием сухого кашля, повышением температуры тела, реже нарушением обоняния, вкуса и наличием симптомов поражения ЖКТ.

3 Не требовалось дополнительного назначения антибактериальной терапии.

\section{ВАКЦИНОПРОФИЛАКТИКА ПНЕВМОКОККОВОЙ ИНФЕКЦИИ В ПЕРИОД ПАНДЕМИИ COVID-19}

Чудакова Т.К., Матвеева М.А., Канунникова Т.А, Пономаренко Ю.А.

ФГБОУ ВО Саратовский ГМУ им. В.И. Разумовского Минздрава России, Саратов

Введение. Пневмококк остается ведущим возбудителем пневмонии.

Цель. Оценить эффективность вакцинопрофилактики пневмококковой инфекции.

Материалы и методы. Проведен анализ 3632 карт больных детей в ГУЗ «ДИКБ №5» г. Саратова, госпитализированных в 2020-2021 гг. с острыми респираторными инфекциями (ОРИ) верхних и нижних дыхательных путей, и 415 карт больных новой 
коронавирусной инфекцией COVID-19 (из них - 20 детей в возрасте от 4 месяцев до 17 лет и 395 взрослых). Анализировали показатели вакцинопрофилактики пациентов против пневмококковой инфекции и частоту встречаемости ОРИ бактериальной этиологии, вызванных пневмококком и респираторными вирусами в ассоциации с пневмококкоком.

Результаты. Показатель вакцинации против пневмококковой инфекции у детей в возрасте до 1 года составил 29,1\% (118 пациентов из 405), у детей в возрасте от 2 до 3 лет - 98,8\% (502 ребенка из 508), у пациентов в возрасте от 3 до 4 лет - 100\% (556 детей из 556), у детей в возрасте от 4 до 5 лет - 99,8\% (584 детей из 585), у детей в возрасте от 5 до 6 лет - 99,5\% (599 пациентов из 602), у детей в возрасте от 6 до 7 лет 100\% (596 пациентов из 596). Показатели вакцинации против пневмококковой инфекции у детей в возрасте от 2 до 7 лет приближались к 100\%. По данным анализа медицинских карт больных старше 7 лет установлено, что вакцинопрофилактика против пневмококковой инфекции им не проводилась.

Проведен анализ частоты обнаружения пневмококка в назофарингеальных мазках у 3632 больных ОРИ. При исследовании назофарингеальных мазков у 878 пациентов с ОРИ верхних дыхательных путей и 2174 больных с ОРИ нижних дыхательных путей (1188 больных бронхитом и 986 больных пневмонией) пневмококк обнаружен в 33,9\% случаев у пациентов, не получивших вакцинацию против пневмококковой инфекции. При исследовании мокроты у 412 больных новой коронавирусной инфекцией COVID-19, осложненной пневмонией, S. pneumoniae был выявлен у 153 (37\%) пациентов, не получивших вакцинацию против пневмококковой инфекции.

Заключение. Отмечается достоверное снижение частоты развития осложнений, вызванных пневмококком, у вакцинированных пациентов по сравнению с невакцинированными против пневмококковой инфекции. В период пандемии COVID-19 проблема вакцинопрофилактики против пневмококковой инфекции становится особенно актуальной.

\section{ПОРАЖЕНИЕ ПЕЧЕНИ ПРИ ИНФЕКЦИОННОМ МОНОНУКЛЕОЗЕ У ДЕТЕЙ}

Чудакова Т.К., Михайлова Е.В., Цека Ю.С. ФГБОУ ВО Саратовский ГМУ им. В.И. Разумовского Минздрава России, Саратов

Введение. За последние годы отмечается рост удельного веса поражения печени у детей, вызванным герпетическими вирусами.

Цель. Определить клинико-лабораторные особенности поражения печени при инфекционном мононуклезе у детей

Материалы и методы. Под наблюдением находились 125 детей в возрасте от 6 месяцев до 16 лет, госпи- тализированных в ГУЗ «ДИКБ №5» г. Саратова с диагнозом инфекционный мононуклеоз (ИМ). Диагноз был установлен методом ИФА крови при обнаружении антител $(\operatorname{IgM} / \operatorname{IgG})$ к вирусам Эпштейна-Барр (ВЭБ) и цитомегаловируса (ЦМВ) и с помощью ПЦР с определением ДНК вирусов ВЭБ и ЦМВ в крови. Всем больным проводили общие клинические исследования и УЗИ внутренних органов.

Результаты. У 100(80\%) больных ИМ протекал с клинико-лабораторными проявлениями поражения печени с синдромом вторичного гепатита. В этиологической структуре у больных ИМ с синдромом вторичного гепатита отмечено преобладание смешанной этиологии ИМ, обусловленной 2 вирусами (ВЭБ+ЦМВ) - у 48(48\%) больных. ИМ ВЭБ-этиологии наблюдали у 44(44\%) пациентов, ИМ ЦМВ-этиологии - у 8(8\%). Смешанная (ВЭБ+ЦМВ) этиология ИМ у больных, в большинстве случаев, была выявлена у детей в возрасте до 7 лет - в 40 случаев. ИМ ВЭБэтиологии с вторичным гепатитом чаще регистрировали у больных в возрасте старше 7 лет - в 19 случаев. У госпитализированных больных ИМ в 92\% случаев отмечена безжелтушная форма гепатита. Гипербилирубинемия с повышением уровня билирубина до 45 мкмоль/л наблюдалась в единичных случаях (у 8\% пациентов). Синдром цитолиза характеризовался умеренным повышением уровня показателей АЛТ и АСТ до 2-5 норм. При УЗИ исследовании органов брюшной полости у больных ИМ наблюдали гепатосплненомегалию в $64 \%$ случаев, гепатомегалию - в $34 \%$ случаев, спленомегалию - в 22\% случаев, в сочетании с дискинезией желчевыводящих путей - в 44\% случаев, реактивными изменениями поджелудочной железы. Отмечена быстрая положительная динамика клинико-лабораторных показателей у больных ИМ на фоне лечения.

Заключение. У детей ИМ часто протекает с поражением печени с развитием вторичного гепатита. К особенностям поражения печени при ИМ у детей можно отнести: безжелтушную форму гепатита, умеренное увеличение уровня АЛТ и АСТ до 2-5 норм, гепатоспленомегалию и быструю положительную динамику клинико-лабораторных показателей на фоне лечения.

\section{АНАЛИЗ ОСОБЕННОСТЕЙ ТЕЧЕНИЯ НОВОЙ КОРОНАВИРУСНОЙ ИНФЕКЦИИ У ОБУЧАЮЩИХСЯ МЕДИЦИНСКОГО ВУЗА \\ Шурховецкая А.А., Рыбакова О.Г., Петрунина С.Ю., Шаталова Е.С. \\ ФГБОУ ВО ЮУГМУ Минздрава России, Челябинск}

Введение. Появление новой коронавирусной инфекции будоражит каждого жителя земного шара. Однако существуют группы лиц, которые подвергаются большему риску заражения.

Цель исследования - проанализировать особенности анамнеза и клинического течения новой коро- 
навирусной инфекции у обучающихся ФГБОУ ВО ЮУГМУ, г. Челябинск.

Материалы и методы. Проведен анализ 259 анкет, заполненных обучающимися различных факультетов медицинского университета. Большинство респондентов работают в медицинских организациях $(56,8 \%)$ или являются волонтерами, участвующими в мероприятиях по уменьшению распространения инфекции (18\%). Из числа опрошенных с начала пандемии по май 2021г. инфекцию перенесли 68\% однократно, 4,2\% - дважды, а 1,5 - 3 раза.

Результаты. При оценке анамнеза жизни пациентов, выявлено, что у 7,3\% исследуемых имеются хронические заболевания, которые могут сказаться на тяжести течения инфекции (бронхиальная астма, сахарный диабет, ревмопатология). Указали, что перенесли коронавирусную инфекцию 74\%. Однако подтвержденных случаев из них 47,4\% (подтвержден методом ПЦР (PHK SARSCoV-2 или выявлением Ig M, Ig G, Ig А методом ИФА в диагностическом титре), вероятных - 1,6\%, подозрительных на COVID-19 случаев - 50\% (клинические проявления ОРИ вне зависимости от эпидемического анамнеза). Наибольшее количество случаев инфекции пришлось на осень 2020г $(47,4 \%)$. Основными клиническими симптомами явились: лихорадка - 62,5\%, кашель (сухой или малопродуктивный) - 53\%, одышка - 29,2\%, слабость и утомляемость - 77\%, потеря вкуса и/или обоняния - $64,1 \%$, головные боли $-60,1 \%$, сердцебиение - 22,4\%, мышечные боли $-45,3 \%$, диспепсические проявления - $16,7 \%$, конъюнктивит $-6,3 \%$. Редкими проявлениями $(<5 \%)$ стали сыпи, потливость, инсомния, панические атаки, артралгии. Диагноз пневмонии был выставлен у $2 \%$ переболевших. 34\% Респондентов отметили более тяжелое течение инфекции относительно обычной сезонной ОРИ.

Заключение. Студенты медики имеют высокий риск заражения новой коронавирусной инфекцией. Частота основных клинических проявления отличается от данных статистики по РФ (Временные методические рекомендации версия 11) выраженностью головных болей, утомляемостью, меньшей частотой лихорадки. Большинство студентов перенесли данную инфекцию в легкой форме. 


\section{Раздел 11}

\section{ЭНДОКРИНОЛОГИЯ}




\section{КЛИНИКО-ИММУНОЛОГИЧЕСКАЯ ОЦЕНКА ЭФФЕКТИВНОСТИ ИНТЕРВАЛЬНОЙ ГИПОКСИЧЕСКОЙ ТРЕНИРОВКИ В ЛЕЧЕНИИ АУТОИММУННОГО ТИРЕОИДИТА У ДЕТЕЙ И ПОДРОСТКОВ}

Абазова 3.X.

Кабардино-Балкарский государственный университет им. Х.М. Бербекова, Нальчик

Введение. В течение последних десятилетий отмечается неуклонный рост заболеваемости аутоиммунным тиреоидитом (АИТ), в том числе среди детей и подростков. Учитывая важность иммунологического звена в патогенезе АИТ, подходить к лечению необходимо с позиции коррекции иммунного статуса. Традиционная терапия не всегда эффективна в нормализации иммунного звена патогенеза при АИТ.

Цель исследования. На основании динамики иммунологических, гормональных и клинических показателей оценить эффективность гипокситерапии в курсе интервальной гипоксической тренировки (ИГТ) у детей и подростков с аутоиммунным тиреоидитом.

Материалы и методы. Курс ИГТ, состоящий из 15 сеансов, прошли 110 детей и подростков в возрасте от 6 до 16 лет с диагнозом АИТ в стадии эутиреоза или гипотиреоза. Гипоксическая смесь подавалась от гипоксикатора фирмы “Био-Нова-204” (Россия).

Результаты. После курса ИГТ увеличилось содержание в крови тиреоидных гормонов, и снизилась продукция тиреотропного гормона гипофиза и, что очень важно, снизился титр антитиреоидных антител, поскольку именно нарастание этих антител приводит к гипотиреозу. Наблюдалось улучшение общего состояния, памяти, нормализация сна, АД, ЧСС, моторики ЖКТ, уменьшение отеков. После курса ИГТ у детей и подростков с АИТ выявлены определенные положительные сдвиги в иммунном статусе: увеличилось количество исходно сниженных общих Т-лимфоцитов $(\mathrm{CD} 3+)$ и $\mathrm{CD} 8+-$-клеток, уменьшился уровень исходно повышенных T-хелперов (CD4+). При исследовании показателей гуморального иммунитета в динамике отмечено снижение исходно повышенного количества общих В-лимфоцитов (CD20+), одновременно у большинства больных после курса ИГТ констатировано статистически достоверное $(\mathrm{p}<0,05)$ уменьшение уровня сывороточных $\operatorname{IgA}, \operatorname{IgM}, \operatorname{IgG}$, кроме того снизилось содержание циркулирующих

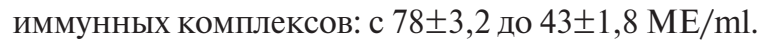

Заключение. Полученные данные дают возможность предполагать, что лечебное действие гипокситерапии реализуется не только через усиление компенсаторных механизмов, обеспечивающих доставку кислорода в ткани, но и через торможение гуморальных иммунных реакций и стимуляцию Т-клеточного звена иммунитета у больных АИТ, что, в конечном итоге, усиливает эффективность проводимого лечения.
ЧАСТОТА ВСТРЕЧАЕМОСТИ АУТОИММУННОГО ТИРЕОИДИТА У ДЕТЕЙ РАЗЛИЧНОГО ВОЗРАСТА Джабраилова Г.И., Габулов Г.Г.

Азербайджанский медицинский университет, Баку

Введение. В последние годы распространенность аутоиммунного тиреоидита среди детей неуклонно растет.

Целью нашей работы явилось изучение частоты развития аутоиммунного тиреоидита у детей в разные периоды жизни.

Материалы исследования. Нами в учебно-терапевтической клинике Азербайджанского медицинского университета было обследовано 83 ребенка с аутоиммунным тиреоидитом Дети с аутоиммунным тиреоидитом были разделены на 3 группы: дошкольники (4-6 лет), препубертатный (7-11 лет) и пубертатный периоды (12-18 лет).

Результаты. Из обследованной группы детей с аутоиммунным тиреоидитом 5 (6\%) пациентов относились к дошкольникам. 28 (33,7\%) пациентов находились в препубертатном периоде. Однако наиболее часто аутоиммунный тиреоидит встречался у детей в пубертатном возрасте - 50 пациентов $(60,3 \%)$.

Заключение. Таким образом, проведенное исследование показало, что аутоиммунный тиреоидит чаще развивается у детей в препубертатном и пубертатном возрасте (в 94,0\% случаев). При этом данное заболевание достоверно чаще развивается у детей в пубертатном возрасте в сравнении с детьми препубертатного возраста $(\mathrm{p}<0,05)$ и дошкольниками $(\mathrm{p}<0,001)$.

\section{ВЛИЯНИЕ ЦИНКА НА РАЗВИТИЕ ЗАБОЛЕВАНИЙ ЩИТОВИДНОЙ ЖЕЛЕЗЫ \\ Клепалова В.В. \\ ФГБОУ ВО Южно-Уральский государственный \\ медицинский университет Минздрава России, Челябинск}

Введение. Цинк необходим клеткам организма человека, так как участвует в различных ферментативных реакциях, способствует нормальному функционированию многочисленных органов и систем. Данный микроэлемент необходим для синтеза, метаболизма гормонов щитовидной железы- тироксина и трийодтиронина, а также влияет на образование тиреотропин-рилизинг-гормона и, соответственно, на уровень тиреотропного гормона.

Цель исследования- определить влияние цинка на развитие патологии щитовидной железы у детей.

Материалы и методы. Было обследовано 114 детей в возрасте 14,32 + 1,6 года. Все подростки проживали в одинаковых климатических и экологических условиях более 10 лет. Из них 30 детей имели 
1 или 2 группу здоровья и составили контрольную группу. Остальные обследованные пациенты имели заболевания щитовидной железы- хронический аутоиммунный тиреоидит (ХАИТ), эутиреоз; ХАИТ с зобом и гипотиреозом; диффузный нетоксичесикй зоб (ДНЗ) с нормальной функцией и с гипотиреозом. Распределение по нозологиям было в равных соотношениях. Других заболеваний, кроме патологии щитовидной железы, у этих детей, выявлено не было. У всех подростков был определен уровень цинка крови.

Результаты. Подростки контрольной группы имели нормальные показатели цинка крови, однако, приближенные к нижней границе референсных значений. Пациенты с сохраненной функцией щитовидной железы как при ДНЗ , так и при ХАИТ достоверных различий в значениях цинка крови не имели $(p=0,65)$, но при сравнении этих групп с контрольной было отмечено, что дети без патологии щитовидной железы имели показатели цинка выше, чем с ДНЗ и ХАИТ ( $p=0,008$ и $p=0,003$ соответственно). Значительное снижение микроэлемента было выявлено у подростков с гипотиреозом по сравнению с пациентами, у которых отмечалось увеличение щитовидной железы без нарушения ее функции $(p=0,002)$, и тем более с детьми группы контроля $(p=0,0007)$.

Заключение. Снижение показателей цинка у детей с патологией щитовидной железы свидетельствует о том, что данный микроэлемент необходим для нормального функционирования этого эндокринного органа и, соответственно, для полноценного роста и развития детей.

\section{РОЛЬ СЕРОТОНИНА В РАЗВИТИИ ОВАРИАЛЬНОЙ ДИСФУНКЦИИ У ДЕВОЧЕК-ПОДРОСТКОВ С ОЖИРЕНИЕМ И ГИПЕРАНДРОГЕНИЕЙ}

Пузикова О.З., Московкина А.В., Попова В.А., Созаева Д.И., Бережанская С.Б.

НИИАП ФГБОУ ВО РостГМУ Минздрава России, Ростов - на - Дону

Введение. Серотонин участвует в регуляции различных физиологических параметров организма, он тесно связан с функциями, вовлекаемыми в регуляцию эмоциональной сферы, полового и пищевого поведения.

Цель исследования - выявление особенностей секреции серотонина у девочек- подростков с ожирением и гиперандрогенией и оценка его значения в формировании дисфункции яичников.

Материалы и методы. Обследовано 85 девочекподростков 14-17 лет с конституционально-экзогенным ожирением 1-3 степени (sds ИМТ от 2,0 до 3,9) и клиническими проявлениями гиперандрогении (гирсутизм, акне), а также 30 девочек-подростков ана- логичного возраста с нормальной массой тела без проявлений гирсутизма и нарушений менструального цикла (контрольная группа). Пациентки с ожирением были разделены на 2 группы. В 1-ю группу вошли 50 пациенток с регулярным менструальным циклом. 2-ю группу составили 35 девочек-подростков с дисфункцией яичников по типу олигоменореи. Исследование включало определение уровня серотонина, 17-оксипрогестерона (17-ОН), тестостерона (Т), дегидроэпиандростерона (ДГЭА), дигидротестостерона (ДГТ), эстрадиола в сыворотке крови методом ИФА.

Результаты. Уровень серотонина во 2-й группе был в 2,5 раза выше, чем в контроле $(6,4 \pm 1,4$ нг/мл и $2,7 \pm 0,8$ нг/мл соответственно, $p=0,02)$, в то время как его средние значения в 1-й группе достоверно не отличались от контроля. Во 2-й группе наблюдалась достоверная прямая корреляция концентрации серотонина с уровнем 17-ОН $(\mathrm{R}=0,54, p=0,05)$, ДГЭА $(\mathrm{R}=0,61, p=0,03), \mathrm{T}(\mathrm{R}=0,68, p=0,02)$, ДГТ $(\mathrm{R}=0,77$, $p=0,008)$, а также отрицательная корреляция с уровнем эстрадиола $(\mathrm{R}=-0,78 ; p=0,02)$. Примечательно, что 44,7\% пациенток с ожирением имели начальные клинические проявления тревоги и/или субклинической депрессии по сравнению с $6 \%$ в контрольной группе $(p=0,001)$.

Заключение. Повышенный уровень серотонина у девочек-подростков с гиперандрогенией и олигоменореей при ожирении можно рассматривать как один из факторов, нарушающих функционирование яичников. Возможно, что снижение уровня эстрадиола при гиперандрогении вызывает активацию обратного захвата серотонина в синапсах нейронов, облегчая передачу этого нейромедиатора.

\section{ОПЫТ РАБОТЫ ГРУППЫ ДЛЯ ДЕТЕЙ С САХАРНЫМ ДИАБЕТОМ В ДОШКОЛЬНОМ ОБРАЗОВАТЕЛЬНОМ УЧРЕЖДЕНИИ \\ Романенко E.C. \\ ФГБОУ ВО ЮУГМУ Минздрава России, Челябинск}

Введение. Когда заболевает сахарным диабетом (СД) ребенок дошкольник, то в семье появляется большая проблема-посещение детского сада. В 2018 году, 5 сентября, в Челябинском детском саду № 17 открылась первая в Челябинске группа для детей с сахарным диабетом. Малыши в ней находятся под постоянным контролем не только воспитателей, но и медсестер и врачей-детских эндокринологов.

Цель исследования - проанализировать результаты работы группы для детей с сахарным диабетом в ДОУ.

Материалы и методы. В 2018 году группу посещали 17 детей в возрасте от 3 до 7 лет. С 2019 года количество детишек увеличилось до 23 человек: девочек в два раза больше , чем мальчиков. Все они из разных районов города. 
Результаты. Задачами работы специализированной группы были: предоставление возможностей для детей с СД посещать дошкольное образовательное учреждение, расширить возможности родителей детей с СД заниматься своей профессиональной деятельностью, адаптировать детей к социуму, подготовить ребенка к школе, контролировать уровень глюкозы крови во время пребывания ребенка в дошкольном образовательном учреждении с коррекцией инсулинотерапии. Контроль гликемии осуществляется медицинскими сестрами на протяжении всего периода пребывания ребенка в детском саду. У $84 \%$ детей установлены системы непрерывного мониторинга гликемии, половина детей для терапии СД использует инсулиновые помпы. Вся информация- показатели гликемии, доза вводимого инсулина, количество съеденных углеводов, заносится в дневники самоконтроля. Ведение дневника позволяет врачу детскому эндокринологу объективно оценивать полученные результаты, при необходимости проводить коррекцию. Медицинскими сестрами проводится обучение детей навыкам самоконтроля, что позволяет им в будущем легче адаптироваться к школьным условиям.

Заключение. Открытие специализированной группы позволило объединить возможность получения дошкольного образования и специализированной медицинской помощи для детей с СД . Полученный положительный опыт, рост заболеваемости СД среди дошкольников, все это привело к решению вопроса об открытии еще одной специализированной группы в городе Челябинске.

\section{СТРУКТУРА ЭНДОКРИННОЙ ПАТОЛОГИИ У ДЕТЕЙ ГОРОДА ЧЕЛЯБИНСКА \\ Романенко E.C. \\ ФГБОУ ВО «Южно-Уральский государственный медицинский университет» Минздрава России, Челябинск}

Введение. Эндокринологические заболевания являются весьма распространенными среди детской популяции в России. Наиболее часто встречающимися из них являются ожирение, заболевания щитовидной железы. Эпидемиология эндокринных заболеваний имеет свои особенности в разных странах и может различаться в разных регионах России.

Цель исследования: изучить структуру эндокринной патологии среди детей города Челябинска.

Материалы и методы. Проведен анализ годовых отчетов детских эндокринологов, обслуживающих детское население на территории г. Челябинска.

Результаты. Патология эндокринной системы у детей в г.Челябинске за последнее десятилетие имеет неуклонную тенденцию к росту. Среди эндокринной патологии превалируют ожирение, сахарный диабет и патология щитовидной железы. Распространенность сахарного диабета 1 типа у детей в г. Челябинске в 2020 году составила 202,69 на 100 тыс. детского населения, заболеваемость - 28,8 на 100 тыс. детского населения. Неуклонно растет количество пациентов, имеющих ожирение разной степени выраженности. Рост заболеваемости ожирением связан с одной стороны с уменьшением физической активности детей, с другой - нерациональным, гиперкалорийным питанием. Патология щитовидной железы преимущественно представлена аутоиммунным тиреоидитом, диффузным нетоксическим зобом, узловым зобом, значительно реже встречается диффузный токсический зоб и новообразования щитовидной железы. Нарушения полового развития в большинстве случаев представлено преждевременным половым развитием. В этой группе превалируют девочки, в то время как группу пациентов с гипогонадизмом преимущественно составляют мальчики.

Заключение. Патология эндокринной системы на территории г.Челябинска разнообразна. Структура патологии остается стабильной, но отмечается рост заболеваемости эндокринной патологией среди детей и подростков. 


\section{Раздел 12}

МЕТАБОЛИЧЕСКИЙ

СИНДРОМ И ОЖИРЕНИЕ

У ДЕТЕЙ 
ОСОБЕННОСТИ СНА У ДЕТЕЙ

ПОДРОСТКОВОГО ВОЗРАСТА С АРТЕРИАЛЬНОЙ ГИПЕРТЕНЗИЕЙ, АССОЦИИРОВАННОЙ С ОЖИРЕНИЕМ

Бекезин В.В., Гуляева А.А., Майорова А.В., Митрохина Р.В., Пересеикая О.В.

Смоленский государственный медицинский университет, Смоленск

Введение. Известно, что факторами риска развития первичной артериальной гипертензии у детей являются избыточная масса тела или ожирение, приводящие к развитию тревожно-депрессивных и стрессовых состояний. В свою очередь эти состояния вызывают у ребенка диссомнию (нарушение качества сна), которая сопровождается активацией симпатоадреналовой системы, гиперлептинемией/ гипергрелинемией (т.е. формируется порочный круг).

Цель: изучить особенности качества сна у детей подросткового возраста с первичной артериальной гипертензией, ассоциированной с ожирением.

Материалы и методы. Проведено комплексное обследование 51 ребенка школьного возраста, включенного в исследование методом случайной выборки. В 1-ю группу (основную) вошел 21 ребенок с ожирением (I-II степени) и артериальной гипертензией (11 детей с АГ «белого халата» и 10 детей с АГ 1 степени по результатам СМАД). 2-ю группу (группа сравнения) составили 30 детей подросткового возраста с нормальным профилем АД и индексом массы

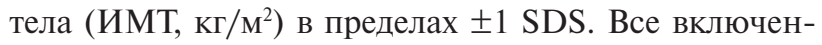
ные в исследование дети прошли анкетирование с использованием шкалы нарушения сна, адаптированной для подростков.

Результаты. У детей 1-й группы по сравнению с детьми группы сравнения регистрировались: нарушения сна (блок 1 - шкала сна) разной степени выраженности в 1,67 раза чаще $(p<0,05)$; дневная сонливость (блок 2 - шкала сонливости) разной интенсивности в 1,67 раза чаще $(p<0,05)$; умеренный и выраженный стресс (блок 3 - шкала оценки стресса по сновидениям) в 1,84 раза чаще $(p<0,05)$.

Положительная оценка по 3 разделу шкалы апноэ сна (блок 4) у детей с АГ, ассоциированной с ожирением, определялась в 14,9 раза чаще $(p<0,05)$, чем у детей 2-й группы. Высокий риск развития апноэ сна регистрировался у 42,9 \% детей 1-й группы и лишь у 6,7 \% детей группы сравнения $(p<0,05)$.

Заключение. Таким образом, выявляемые у детей с АГ, ассоциированной с ожирением, диссомния и, особенно, высокий риск развития апноэ сна требуют дообследования таких пациентов с целью исключения синдрома обструктивного апноэ сна (COAC); при этом адаптированная шкала нарушения сна может использоваться для ранней скрининговой диагностики диссомнии у детей.

\section{ОСОБЕННОСТИ СУТОЧНОГО ПРОФИЛЯ АД У ДЕТЕЙ ПОДРОСТКОВОГО ВОЗРАСТА С ОЖИРЕНИЕМ В ЗАВИСИМОСТИ ОТ РИСКА НАРУШЕНИЯ ДЫХАНИЯ, СВЯЗАННОГО СО СНОМ}

Бекезин В.В. ${ }^{1}$, Пересецкая О.В. ${ }^{1}$, Козлова Л.В. ${ }^{2}$

${ }^{1}$ Смоленский государственный медицинский университет, Смоленск

${ }^{2}$ Смоленская областная детская клиническая больница, Смоленск

Введение. В последние годы уделяется много внимания изучению синдрома обструктивного апноэ сна (COAC) у детей и подростков, изучается вклад СОАС в кардиоваскулярные и метаболические риски.

Цель исследования: определить влияние нарушения дыхания, связанного со сном, у детей подросткового возраста с ожирением на суточный профиль артериального давления с целью уточнения кардиоваскулярных рисков.

Материалы и методы. Проведено комплексное обследование 65 детей подросткового возраста (11-17 лет) с ожирением I-II степени, включающее антропометрию, суточное мониторирование АД (СМАД) на аппарате BP Lab (Россия), а также анкетирование родителей детей с использованием шкалы SRBD-PS (Sleep-Related Breathing Disorder scale of the Pediatric Sleep, США). Методом случайной выборки в исследование было включено 47 детей. 1-ю группу составили 17 детей с высоким риском нарушения дыхания, связанного со сном: по шкале SRBD-PS расчетный показатель $\geq 0,33$. Во 2-ю группу вошли 30 детей с низким риском нарушения дыхания, связанного со сном: расчетный показатель <0,33. 1-я и 2-я группы были однородными по полу и возрасту.

Результаты. Сравнительный анализ средних значений показателей СМАД у детей 1-й и 2-й групп выявил их достоверные различия. Так, индекс времени (ИВ) систолического АД (САД) у детей 1-й группы в 1,15 и 1,89 раза соответственно превышали $(p<0,05)$ аналогичные показатели у детей 2-й группы. Суточный индекс (СИ) САД день и СИ САД ночь $у$ детей 2-й группы в 1,73 и 1,31 раза соответственно превышали $(p<0,05)$ аналогичные показатели у детей 1-й группы. У детей 1-й группы по сравнению с детьми 2-й группы достоверно чаще регистрировались в структуре степени ночного снижения САД "non-dippers" $(\chi 2=5,419 ; p=0,02)$ и “night-peakers» $(\chi 2=5,655 ; p=0,018)$. Величина и скорость утреннего подъема САД у детей 1-й группы в 1,42 и 1,93 раза соответственно превышали $(p<0,05)$ аналогичные показатели у детей 2-й группы. Коэффициент вариации САД день $у$ детей 1-й группы в 1,55 раза был выше по сравнению с детьми 2-й группы.

Заключение. Таким образом, суточный профиль АД у детей с высоким риском нарушения дыхания, 
связанного со сном, свидетельствует о значимых кардиоваскулярных рисках: высокая нагрузка давлением, недостаточное снижение АД в ночные часы, значительная вариация АД, высокие значения величины и скорости утреннего подъема АД.

\section{ПИТАНИЕ И ИНДЕКС МАССЫ ТЕЛА ДЕТЕЙ ШКОЛЬНОГО ВОЗРАСТА}

Бушуева Э.В., Кулакова К.С., Смирнова Е.И., Петров А.Г. ФГБОУ ВО «Чувашский государственный университет им И.Н. Ульянова», Чебоксары

Введение. Рациональное питание принадлежит к числу факторов, играющих ключевую роль в поддержание здоровья детей и подростков, их высокой работоспособности и устойчивости к действию инфекций и других неблагоприятных внешних воздействий.

Цель исследования - оценить физическое развитие детей школьного возраста в зависимости от рациона питания.

Материалы и методы. Исследование проводилось на базе БУ «ГДКБ» МЗ ЧР. В исследование приняло участие 230 детей, поступивших с диагнозом синдром вегетативной дисфункции, в возрасте от 7 до 18 лет, средний возраст 13,08土2,7 лет. Участвовали 112 девочек $(48,7 \%)$ и 118 мальчиков $(51,3 \%)$. Были проанализированы истории развития ребенка, собраны физикальные данные. Так же проводилось интервьюирование по поводу недельного рациона питания. C помощью пакета прикладных программ STATISTICA10 выполнен анализ данных функционального состояния сердечно-сосудистой системы ребенка.

Результаты. При изучении раннего развития ребенка: отмечалось преимущественно естественное вскармливание в $66,6 \%$ случаев, искусственное $26,5 \%$, смешенное $6,9 \%$. Дети в $91,2 \%$ случаев родились в срок, в основном на 38-39 неделе, раныше срока - 8,8\% на 35-37 неделе. Так же изучались дети со ЗВУР в $5,5 \%$ случаев и дети с весом более 4000 г в 5,1\% случаев. ИМТ ниже и выше среднего отмечался у мальчиков - 13,02\% и $11,6 \%$, у девочек $8,8 \%$ и $13,95 \%$. В 52,63\% случаев дети имеют нормальный показатель ИМТ. Выявлена достоверная корреляция $(p<0,05)$ между ИМТ и массой тела при рождении, у детей со ЗВУР $(\mathrm{Rs}=0,42)$, между ИМТ и массой тела, у детей родившихся более 4 кг $\left(\mathrm{Rs}_{s}=0,35\right)$. Выявлена обратная корреляционная связь $(p>0,05)$ между ИМТ и функциональным классом $(\mathrm{Rs}=0,3)$, то есть чем меньше показатель ИМТ, тем больше ФК (2 ФК). Выявлена достоверная $(p<0,05)$ корреляция $(\mathrm{Rs}=-0,5)$ между видом вскармливанием и функциональным классом: $72 \%$ детей со 2 ФК вскармливались искусственно.

Заключение. Сбалансированное питание, обеспечивающие поступление всех необходимых пищевых веществ, является важным фактором гармоничного развития и профилактики заболеваний школьного возраста.

\section{КОМПЛЕКСАНЯ ПРОГРАММАЛЕЧЕНИЯ ОЖИРЕНИЯ У ПОДРОСТКОВ СЕВЕРНЫХ ТЕРРИТОРИЙ: ОПЫТ И ТРУДНОСТИ \\ Верховых Е.В., Гирш Я.В. \\ БУ ВО ХМАО-Югры «Сургутский государственный университет»}

В основу программы положена рациональная диетотерапия, включающая обучение пациентов принципам правильного питания, подбор индивидуального рациона, использование разгрузочных дней, ведение пищевого дневника, психотерапевтические мероприятия и поведенческие рекомендации. Широко используются физиотерапевтические методы, такие как различные виды массажа, водные процедуры, электросон, лечебная физкультура. Ведущим специалистом данной программы выступает врач детский эндокринолог, который разрабатывает индивидуальную схему лечения, осуществляет контроль проводимого лечения пациентом. Результаты оценивали через 6 и 12 месяцев. При каждом осмотре проводили взвешивание, измерение окружности талии и бедер, оценивали самочувствие пациента.

В группу лечения вошли 24 пациента в возрасте

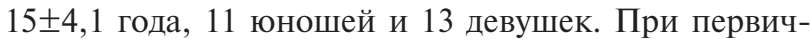
ном осмотре индекс массы тела всех пациентов превышал 27, с отложением жира по андроидному типу. У $24 \%$ пациентов выявлено нарушение толерантности к углеводам, у $34 \%$ пациентов артериальная гипертензия.

Для каждого пациента была разработана индивидуальная комплексная программа снижения веса, с учетом противопоказаний и индивидуальных особенностей. 9 пациентов в ходе наблюдения занимались спортом и плаванием в спортивных клубах.

За первые 6 месяцев снизили вес 5 пациентов на 2\%, 8 пациентов на 4\%, 6 пациента на 5\%, 2 пациента сохраняли свою массу на исходных цифрах, 2 пациента прибавили в весе, так как не придерживались данных рекомендаций и не имели мотивации к лечению. Через 12 месяцев ни один пациент не увеличил массу тела, 11 пациентов снизили массу тела еще на $8 \%$. Все пациенты отмечали хорошее самочувствие, улучшение настроения и работоспособность. У пациентов с положительной динамикой в весе отмечалось улучшение показателей углеводного обмена и гормонального профиля.

Данное наблюдение позволяет считать данную комплексную программу достаточно эффективной, обеспечивающей стабильное снижение массы тела без ухудшения самочувствия пациентов при наличии мотивации к лечению. Все пациенты отметили эффективность такового метода диетотерапии, как ведение пищевого дневника. Программа позволяет выработать у пациента новые пищевые привычки, которые помогают поддерживать массу тела на достигнутом уровне. 
ПИЩЕВОЕ ПОВЕДЕНИЕ И ЭМОЦИОНАЛЬНОЛИЧНОСТНЫЕ ОСОБЕННОСТИ ДЕТЕЙ С ОЖИРЕНИЕМ

Верховых Е.В., Гирш Я.В.

БУ ВО ХМАО-Югры «Сургутский государственный

университет», Сургут

Цель исследования. Оценить субъективные ощущения пациентов с ожирением по восприятию себя и своей массы в социуме.

Материалы и методы. В исследование было включено 144 подростка 11 - 17 лет с избыточной массой тела/ожирением. Проведены: сбор анамнеза, оценка антропометрических данных пациентов, результатов визуально-аналоговой шкалы (VAS Visual Analogue Scale; ВАШ, русс.) и визуальных нормативов правильного питания (ПП).

Результаты исследования. Средний возраст пациентов составил $14,3 \pm 2,2$ года, $44 \%$ девочек и $56 \%$ мальчиков. При сборе анамнеза жизни было выявлено, что у $34 \%$ подростков наследственность по ожирению была отягощена и по линии матери, и по линии отца, у $47 \%$ пациентов с одной стороны, в $19 \%$ наследственность не была отягощена.

В группе исследования пациенты распределились следующим образом: 58\% подростков имели избыточную массу тела, $42 \%$ - ожирение. В структуре ожирения: SDS ИМТ 2,0-2,5 - 38\% детей, SDS ИМТ 2,6-3,0 - 43\% пациентов, SDS ИМТ 3,1-3,9 - 17\% случаев, $2 \%$ SDS ИМТ более 4,0 .

ВАШ является простым способом определения субъективных ощущений пациента по восприятию своей массы тела. Анализ ВАШ позволил выявить ряд закономерностей. Максимальное число баллов 10 , минимальное -0 .

Насколько вы счастливы? На 8 баллов - 25\% детей, на 3 балла $-2 \%$;

Как вы оцениваете качество вашей жизни? На 8 баллов $-27,2 \%$, на 1 балл $-4,5 \%$;

Как вы оцениваете ваш аппетит? На 6 баллов $25 \%$, на 0 баллов $-2 \%$;

Вы чувствуете угнетение, страх, травлю со стороны окружающих людей? На 10 баллов $-2 \%$, на 0 баллов $-25 \%$;

Вы хотите похудеть? На 9 баллов - 22,5\%, на 0 баллов $-2 \%$;

Вы действительно хорошо себя чувствуете в своем теле или нет? На 5 баллов - 22,5\%, на 1 балл $-4,5 \%$ детей.

Анализ ПП показал, что 17,3\% подростков соблюдали принципы правильного питания, $43 \%$ пациентов питались «условно» неправильно. Выявлен ряд нарушений: отсутствие завтрака у $39 \%$ подростков, преобладание в рационе легкоусвояемых углеводов (69\%), недостаточное употребление воды (41\%), недостаточное количество овощей и фруктов (23\%), употребление энергетических, алкогольных напитков (13\%).
Заключение. В возрастной группе подростков происходит постепенное изменение восприятие своего тела, в сравнении с младшей возрастной группой, появляется понимание повышенного аппетита, ухудшение восприятия своего тела и желание похудеть.

\section{ПРИВЕРЖЕННОСТЬ ПАЦИЕНТОВ С ОЖИРЕНИЕМ К РЕКОМЕНДАЦИЯМ ВРАЧА О РЕГУЛЯРНОЙ ФИЗИЧЕСКОЙ НАГРУЗКЕ}

Власенко Н.Ю. ${ }^{1}$, Юдицкая Т.А. ${ }^{2}$, Павлинова Е.Б. ${ }^{1}$,

Миронова Т.В. ${ }^{3}$, Шевченко С.A. ${ }^{1}$, Захаренко А.C. ${ }^{1}$

${ }^{1}$ ФГБОУ ВО «Омский государственный медицинский

университет» Минздрава России, Омск;

БУЗОО «Областная детская клиническая больница»,

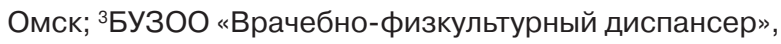
Омск

Введение. В последние десятилетия проблема ожирения стала одной из ключевых в общественном здравоохранении. В мире резко возросла распространенность избыточной массы тела и ожирения в детском возрасте. В соответствии с клиническими рекомендациями «Российской ассоциации эндокринологов» 2021 года, одним из методов профилактики и терапии ожирения является ежедневная 60-и минутная физическая нагрузка, в том числе три раза в неделю с высокой интенсивностью (аэробика, езда на велосипеде, плавание, одиночный теннис и бег в быстром темпе). Противопоказанием является индекс массы тела более 30 кг/ $\mathrm{M}^{2}$.

Цель исследования. Оценить, какое количество детей с избыточной массой тела и ожирением занимается в спортивных секциях Омской области, какие виды спорта они предпочитают. Определить приверженность к регулярной физической нагрузке детей с избыточной массой тела и ожирением, проживающих в Омской области.

Материал и методы. На первом этапе проанализированы данные профилактических осмотров 5038 подростков 14 лет. Проведен диспансерный осмотр 297 детей в возрасте 2-7 лет, посещающих детский сад. На втором этапе проанализировано 3133 «врачебно-контрольных карт физкультурника и спортсмена» детей и подростков, ежегодно проходящих осмотр в физкультурном диспансере.

Результаты. В Омской области проживает 418 тысяч детей и подростков. По данным отчетов медицинских организаций, детей с ожирением на учете стоит 5169 (1,2\%). При проведении профилактических осмотров 14-летних подростков (более 5000 детей) в Омской области, избыточная масса тела/ожирение выявлены в $10,6 \%$ случаев (ожирение составляет 3,1\%). При анализе данных физического развития дошкольников, избыточная масса тела диагностирована в $16,2 \%$ у жителей города и в $13 \%$ у сельских детей, ожирение - у $5,3 \%$ в области, $4,5 \%$ - в городе $(p>0,05)$. 
Среди детей, занимающихся в спортивных секциях, в 6,38 \% (200 человек из проходивших медицинский осмотр) встречались дети с избыточной массой тела и ожирением. Чаще они выбирали бокс $(17,4 \%$ от детей в секции), греко-римскую борьбу (12\%), бадминтон (11,2\%), дзюдо $(9,8 \%)$, теннис $(9 \%)$.

Заключение. Только $10 \%$ детей с избыточной массой и ожирением, выявленных при проведении профилактического осмотра, доходят до специалиста и встают на учет. Среди детей, зарегистрированных с ожирением, в спортивных секциях занимаются всего 4\%. При этом чаще пациенты с ожирением выбирают боевые искусства. Таким образом, отмечается низкая приверженность к рекомендациям врача о регулярной физической нагрузке, полученным на консультативном приеме. Необходимо увеличение количества школ «коррекции веса» для более детального обучения детей и их родителей формированию правильного образа жизни и пищевых привычек в семье.

\section{БИОИМПЕДАНСНЫЙ АНАЛИЗ СТРУКТУРЫ ТЕЛА У ПОДРОСТКОВ С РАЗЛИЧНОЙ МАССОЙ ТЕЛА}

Герасимчик О.А., Гирш Я.В.,

БУ ВО «Сургутский государственный университет», Сургут

Введение. Основным показателем избыточной массы тела и ожирения является индекс массы тела (ИМТ). Однако ИМТ не отражает содержание висцерального жира в организме, поэтому необходимо применение дополнительных методов диагностики, таких как биоимпедансометрия, что позволяет определить индивидуальный подход к выбору профилактических и лечебных воздействий на ребенка с ожирением.

Цель исследования: определить композиционный состав тела подростков с различной массой тела.

Материалы и методы. Для определения композиционного состава был обследован 121 подросток в возрасте 10-17 лет, $(13,9 \pm 2,1)$. Определение ИМТ позволяет выделить 3 группы подростков: 1-я группа подростки с нормальной массой тела 40 человек (33\%), 2-я группа с избыточной массой тела 48 человек (40\%), 3 группа с ожирением 33 подростка (27\%). Для определения композиционной структуры тела использован аппарат «Диамант-Аист».

Результаты. Жировая ткань является одним из важных компонентов состава тела

человека. В группе подростков с ожирением и избыточной массой тела в $100 \%$ случаев диагностировано повышенное содержание жировой массы, в группе подростков с нормальной массой тела жировая ткань выше нормы выявлена в 24,5\% случаев. Активная клеточная масса (АКМ) - является частью безжировой массы и состоит из мышц, органов, мозга и нервных клеток. В 1-й группе подростков в 57\% выявлен недостаток АКМ, что может свидетельствовать о недостаточном поступлении белка в организм ребенка. Во 2-й группе подростков в $84 \%$ избыток AKM, в 3 группе в 100\% случаев отмечается увеличение АКМ. В процессе снижения массы тела важно, чтобы расщеплялся именно жир и сохранялась АКМ, так как именно в ней сжигается жир. Потеря АКМ является причиной того, что большинство попыток выдержать диету остаются безуспешными.

Основной обмен (ккал) отражает энерготраты организма в состоянии покоя, обеспечивающие функции всех органов, систем, поддержание температуры тела. В 1-й группе пациентов в $100 \%$ имел место недостаток калорий. Во 2-й группе в $26 \%$ случаев и в 3 группе детей в $40 \%$ случаев диагностировано избыточное содержание калорий.

Заключение. Метод биоимпедансометрии позволяет определять исходные показатели, проследить динамику для оценки адекватности проводимой терапии, выявить соотношение жировой/безжировой массы для создания комплекса мероприятий по снижению веса.

\section{КОМОРБИДНОСТИ ПРИ ДЕТСКОМ ОЖИРЕНИИ}

Гири Я.В., Тепляков А.А.

БУ ВО ХМАО-Югры «Сургутский государственный университет», Сургут

Ожирение призвано новой «глобальной неинфекционной эпидемией», в виду его высокой распространенности во всех возрастных группах. Ожирение сопровождается целым комплексом изменений со стороны органов и систем, многие из которых уже в детстве становятся самостоятельными, не менее значимыми хроническими заболеваниями и требуют постоянной терапии.

Цель. На основе данных ретроспективного анализа историй болезни пациентов $(\mathrm{n}=222)$, находящихся на обследовании и лечении с основным диагнозом «Ожирение», определить частоту встречаемости, варианты метаболических расстройств и сопутствующих заболеваний.

Результаты. В репрезентативную группу вошли 222 пациента (45,5\% девочек, 54,5\% мальчиков) с ожире-

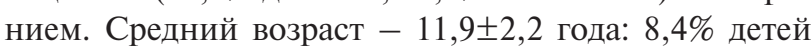
дошкольного возраста (3-7 лет), 33,8\% - 7-12 лет и 57,8\% - 12-18 лет. Ожирение 1 степени (SDS ИМТ $2,0-2,5)$ диагностировали у 14,8\% детей, SDS ИМТ 2,6 - 3,0 - у 45,9\%, SDS ИМТ 3,1 - 3,9 - у 35,6\% и $\operatorname{SDS}$ ИМТ $\geq 4,0$ - морбидное ожирение имели 3,6\% подростков.

Определена высокая частота метаболические проявлений у детей с ожирением: артериальная гипертензия - 26,1\%; сахарный диабет - 5\%; гиперинсулизм - 8,6\%; нарушение углеводного обмена $17,1 \%$. Нарушения жирового обмена проявлялись изменениями липидного профиля в 7,7\% случаев, жировым стеатозом / гепатозом, выявленными 
по данным УЗИ, в 20,7\% и изменениями ферментов печени - в 36,9\%. В 3,6\% случаев дети имели все 3 комплекса изменений, в 9,9\% комбинацию 2-х параметров.

Сопутствующие заболевания были представлены: заболеваниями центральной нервной системы $10,4 \%$; глаз - 27,5\%; патологией эндокринной системы - 27\%; заболеваниями опорно-двигательного аппарата $-10,5 \%$; патологией мочевыделительной системы - 17,1\%; сердечно-сосудистой патологией - 2,2\%. Определена наибольшая частота заболевания желудочно-кишечного тракта в группе детей с ожирением (55,9\%): дискинезия желчного пузыря, долихосигма, хронический гастрит, дисфункция сфинктера Одди, хронический запор, липоматоз поджелудочной железы, реактивный панкреатит, желчекаменная болезнь.

Ограничение медикаментозных методов лечения ожирения у детей и подростков требует активной разработки и проведения ранних мер профилактики. Своевременная диагностика и терапия сопутствующей патологии позволит скорректировать влияние на прогрессирование массы тела в детской возрастной группе.

\section{НАРУШЕНИЯ ПИЩЕВОГО ПОВЕДЕНИЯ У ПОДРОСТКОВ С ЭКЗОГЕННО- КОНСТИТУЦИОНАЛЬНЫМ ОЖИРЕНИЕМ}

Куличенко М.П., Ушакова С.А., Шайтарова А.В., Кайб И.Д.

ФГБОУ ВО Тюменский ГМУ Минздрава России, Тюмень

Введение. Ожирение - хроническое заболевание, в патогенезе и клинической картине которого сочетаются и взаимодействуют соматические и психологические факторы и симптомы.

Цель исследования. Дать характеристику вариантов нарушений пищевого поведения у подростков с абдоминальным ожирением экзогенно-конституционального генеза.

Материалы и методы. Обследованы 73 подростка (34 девочки и 39 мальчиков). Протокол исследования включал антропометрию, заполнение голландского опросника пищевого поведения DEBQ. B основную группу вошли 38 подростков (18 девочек и 20 мальчиков) с абдоминальным ожирением, возраст $16,21 \pm 0,87$ лет, длительность ожирения $-8,2 \pm 2,3$ лет,

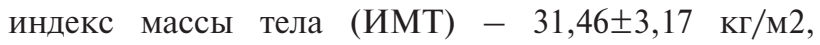

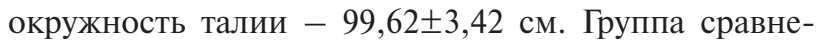
ния представлена 35 подростками (16 девочек и 19 мальчиков) без избыточной массы тела и ожирения,

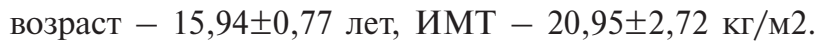
Данные приведены в виде $\mathrm{M} \pm \mathrm{SD}$ (M - среднее значение, SD - стандартное отклонение). Достоверность различий между группами оценена с помощью t-критерия Стьюдента.
Результаты. По данным опросника DEBQ у подростков без избытка массы тела средние значения показателей ограничительного, эмоциогенного и экстернального пищевого поведения соответствовали в баллах: $1,69 \pm 0,71,1,44 \pm 0,48$ и 2,38 $\pm 0,55$, соответственно. При анализе ответов подростков с абдоминальным ожирением показатели отличались более высокими значениями по всем трем шкалам: $3,02 \pm 0,73,1,62 \pm 0,8$ и $2,77 \pm 0,85$, соответственно. Статистически достоверным было различие по показателям ограничительного пищевого поведения $(p<0,001)$, что свидетельствовало о попытках подростков достичь желаемого веса посредством самоограничения в питании. Проведенный в последующем анализ дневников питания у подростков с ожирением выявил нерациональный стереотип, не уменьшающий фактическое энергопотребление и достаточно дефицитный рацион по основным микронутриентам.

Заключение. Пищевое поведение у подростков с экзогенно-конституциональным ожирением часто характеризуется неэффективным ограничительным поведением, что следует учитывать при организации индивидуального диетологического контроля и проведении профилактического консультирования.

\section{ОЦЕНКА КАЧЕСТВА НОЧНОГО СНА ПРИ ОЖИРЕНИИ У МАЛЬЧИКОВ-ПОДРОСТКОВ}

Пузикова О.З., Попова В.А., Созаева Д.И.,

Бережанская С.Б.

НИИАП ФГБОУ ВО РостГМУ Минздрава России, Ростов - на - Дону

Введение. Формирование многих патологических процессов взаимосвязано с нарушениями нормальной физиологии сна. Одним из факторов риска развития неблагоприятных метаболических нарушений, возникающих у подростков с ожирением, является ухудшение качества ночного сна.

Цель исследования - изучение качества сна ночного сна у мальчиков-подростков с ожирением.

Материалы и методы. Под наблюдением находились 54 мальчика-подростка 14-16 лет с конституционально-экзогенным ожирением (SDS ИМТ от 1 до 3,9). Для выявлений нарушений сна использовалась анкета шкалы оценки качества сна и анкета субъективной характеристики ночного сна. Нарушения сна по типу инсомний или парасомний по результатам шкалы оценки качества сна регистрировались при сумме баллов более 12 , а по результатам субъективной характеристики ночного сна регистрировались при сумме баллов менее 19 баллов. Контрольную группу составили 55 школьников от 14 до 16 лет без нарушений жирового обмена.

Результаты. Средний балл анкеты качества и анкеты субъективной характеристики сна у паци- 
ентов с ожирением также достоверно отличался от такового в контрольной группе ( $p=0,005$ и $p=0,03$, соответственно). По данным шкалы субъективной характеристики ночного сна частота инсомний была в 2 раза выше $(p=0,04)$, а по данным анкеты оценки качества сна почти в 3 раза выше частоты нарушений сна $(p=0,02)$, выявленной по результатам жалоб пациентов. Нарушения сна у пациентов с ожирением были представлены инсомниями в 64,8\%, парасомниями в $51,8 \%$, вегетативными нарушениями во время сна (вариабельность ЧСС, никтурия, потливость) в $74 \%$ случаев. Сон у $48 \%$ подростков с ожирением также отличался значительным количеством эпизодов храпа, что указывало на риск развития у них ночной гипоксемии.

Заключение. У подростков с ожирением по данным анкетирования выявлена повышенная частота инсомнических и парасомнических расстройств, которые могут способствовать усугублению гормонально-метаболического дисбаланса. Нарушения дыхания во сне у подростков с ожирен

ием могут становиться важным патогенетическим фактором развития осложнений - гипоталамической дисфункции и сердечно-сосудистой патологии.

\section{ПОЛИМОРФИЗМ АLА54TНR ГЕНА FАВР2 У ДЕТЕЙ С РАЗЛИЧНОЙ МАССОЙ ТЕЛА}

Телепнева Р.С., Евсеева Г.П., Наговицына Е.Б., Супрун С.В., Лебедько О.А.

Хабаровский филиал ДНЦ ФПД - НИИ ОМиД, Россия, Хабаровск

Введение. Ген протеина-2, связывающий жирные кислоты (fatty acid-binding protein 2, FABP2), является геном, мутации которого играют важную роль в развитии ожирения и метаболического синдрома.

Целью данного исследования стало выявление ассоциаций между полиморфизмами генетических вариантов однонуклеотидных замен гена FABP2 Ala54Thr (G163A) с индексом массы тела (ИМТ) у подростков.

Материалы и методы исследования. В условиях клиники НИИ ОМиД проведено обследование 73 подростков с повышенной массой тела/ожирением. Группу контроля составили 30 подростков с нормальным ИМТ. Средний возраст детей составил $13,08 \pm 0,52$ лет. Пациентам было выполнено полное клиническое обследование. Для исследования полиморфизмов гена FABP2 Ala54Thr (G163A) использовали ДНК, выделенную из лейкоцитов венозной крови стандартным методом с использованием коммерческих наборов «ДНК-экспресс крови».

Результаты и обсуждение. Сравнительный анализ распределения частот генотипа Ala54Thr (G163A) гена FABP2 показал, что преобладающим генотипом у обследованных подростков оказался GG вариант гена $(56,3 \%)$, что в 2 раза больше чем полиморфизм $\mathrm{GA}(28,1 \%, p<0,05)$ и в 3,5 раза больше, чем генотип AА $(15,6 \%, p<0,05)$. По полу различий не выявлено. ИМТ у подростков с GG генотипом был достоверно выше $(26,34 \pm 1,06)$, чем у подростков с GA генотипом $(22,87 \pm 1,23, p<0,05)$ и АА генотипом $(22,19 \pm 1,68$, $p<0,05)$. Корреляционный бисериальный анализ выявил взаимосвязи наличия полиморфизма гена в уровнем глюкозы $(r=0,3, p<0,05)$ и $\beta$-липопротеидов $(r=0,379, p<0,05)$.

Заключение. Преобладающим генотипом в обследованной популяции оказался GG вариант гена FABP2. Изучение особенностей индивидуальных генетических и метаболических профилей пациентов может явиться основой для создания индивидуальных программ первичной профилактики и коррекции ожирения у подростков.

\section{РОЛЬ МЕТАБОЛИЧЕСКИХ РАССТРОЙСТВ ПРИ ПРЕЖДЕВРЕМЕННОМ ПОЛОВОМ СОЗРЕВАНИИ У ДЕВОЧЕК \\ Чеботарева Ю.Ю. ${ }^{1}$, Родина М.А. ${ }^{2}$, Романенко Ю.В. ${ }^{1}$ \\ ${ }^{1}$ Федеральное государственное бюджетное образовательное учреждение высшего образования «Ростовский государственный медицинский университет» Министерства здравоохранения Российской Федерации, Ростов-на-Дону ${ }^{2}$ КДЦ «Здоровье» Ростов-на-Дону}

Введение. Сегодня известно, что содержание жировой ткани играет критическую роль в механизмах полового созревания. У здоровых девочек

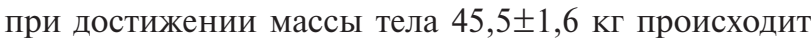
повышение уровня лептина в сыворотке крови, котоpoe «сигнализирует» головному мозгу с помощью нейропептида кисспептина об активации процессов развития репродуктивной системы. Происходит увеличение синтеза гонадотропин-рилизинг-гормона в гипоталамусе, повышаются уровни гонадотропинов и появляются вторичные половые признаки. Наличие ожирения у девочек запускает процесс образования лептина быстрее и срок начала полового созревания уменьшается. Так, возраст наступления менархе при избыточной массе снижается до 9-11 лет, а в отдельных случаях и ранее.

Цель исследования - изучить особенности гормонального статуса у девочек, имеющих клинические признаки преждевременного полового созревания на фоне избыточной массы тела.

Материалы и методы. В исследование включено 36 девочек $(4,11 \pm 1,2$ года) с признаками изолированного телархе. У всех пациенток изучены антропометрические показатели, включая соматометрию и соматотипирование, гинекологический и гормональный статусы. Проведен иммуноферментный анализ гормонов сыворотки крови (кортизол, пролактин, ЛГ, ФСГ). 
Результаты. Установлено, что 26 (72,2\%) пациенток имели макросоматический тип телосложения, a $10(27,8 \%)$ - мезомакросоматический. Показатели массы тела были значимо выше, чем у девочек 1,2 групп здоровья $(p<0,05)$. Наличие аэробного бактериального вульвовагинита выявлено у $24(66,7 \%)$ пациенток. Определено достоверное повышение возрастных уровней кортизола и пролактина $(p<0,05)$. Концентрации ФСГ, ЛГ достоверных отличий от аналогичных параметров девочек 1,2 групп здоровья не имели $(p>0,1)$. У 9 (25\%) пациенток при эгографии выявлены признаки мультифолликулярно измененных яичников (МФЯ).

Заключение. У девочек с преждевременным телархе отмечаются метаболические расстройства, связанные с избыточным весом. Нередко отмечается вагинит. МФЯ и повышение концентраций стрессорных гормонов свидетельствуют о напряжении адаптационных механизмов, что требует разработки патогенетически обоснованных методов лечения и профилактики.

\section{ФОРМИРОВАНИЕ МЕТАБОЛИЧЕСКОГО СИНДРОМА У ДЕВОЧЕК ДОШКОЛЬНОГО ВОЗРАСТА. СТРАДАЮЩИХ РЕЦИДИВИРУЮЩИМИ ИНФЕКЦИЯМИ УРОГЕНИТАЛЬНОГО ТРАКТА}

Чеботарева Ю.Ю. ${ }^{1}$, Летифов Г.М. ${ }^{1}$, Костоева 3.А. ${ }^{2}$, Тангиева М.Ю. ${ }^{2}$

${ }^{1}$ Федеральное государственное бюджетное образовательное учреждение высшего образования

«Ростовский государственный медицинский

университет» Министерства здравоохранения

Российской Федерации, Ростов-на-Дону

ФГБОУ ВО Ингушский государственный университет

Введение. Ожирение является одной из главных проблем современного здравоохранения. Будучи основным фактором риска нарушений функций различных систем органов, в том числе репродуктивной системы, избыточная масса тела приводит к возникновению метаболических нарушений в детском возрасте. Только за 2014-2018 годы заболеваемость ожирением в Российской Федерации среди детей в возрасте 0-17 лет увеличилась на 21,4\%. Неблагоприятное влияние ожирения на репродуктивную систему прослеживается уже на этапе начала ее функционирования.

Цель исследования - установить особенности физического развития и гормональный статус у девочек дошкольного возраста, страдающих рецидивирующими инфекциями мочеполового тракта

Материалы и методы. В исследование включено 56 девочек $(5,28 \pm 0,5$ года) с рекуррентными инфекциями урогенитального тракта. У всех пациенток проведено специализированное гинекологическое обследование, измерение антропометрических показателей, иммуноферментный анализ гормонов сыворотки крови (кортизол, пролактин, эстрадиол, эстриол, ЛГ, ФСГ).

Результаты. Наличие бактериального вульвовагинита выявлено практически у всех пациенток, из них у $36(64,3 \%)$ отмечались рецидивирующие тяжелые формы аэробного вульвовагинита. С структуре ИМП у $45(80,4 \%)$ пациенток имел место хронический пиелонефрит, у 11(19,6\%) - хронический интерстициальный цистит. Установлено, что у пациенток имелась тенденция к ускорению линейного роста, при этом показатели массы тела были значимо выше, чем у дошкольниц 1,2 групп здоровья $(p<0,05)$. Отмечалось достоверное увеличение случаев мезомакросоматического типа $(p<0,05)$, а каждая третья девочка имела макросоматический тип телосложения. Выявлено достоверное повышение возрастных уровней эстрадиола, кортизола и пролактина $(p<0,05)$.

Заключение. У девочек дошкольного возраста с рекуррентными ИМП отмечается нарушенное формирования репродуктивного здоровья. Имеют место тяжелые рецидивирующие бактериальные вагиниты. Обращает на себя внимание умеренно дисгармоничное и, реже, гетерохронное физическое развитие с ранними признаками метаболических нарушений. Наличие повышения концентрации стрессорных гормонов служит основанием для рассмотрения вопроса о назначении адаптационной коррекции и междисциплинарного подхода в диспансерном ведении данной когорты пациенток.

\section{СТРУКТУРА КОМОРБИДНОЙ ПАТОЛОГИИ У ДЕТЕЙ С ОЖИРЕНИЕМ РАЗЛИЧНОЙ СТЕПЕНИ}

Чубаров Т.В., Жданова О.А., Шаршова О.Г., Артющенко А.И., Крутских А.В.

Воронежская детская клиническая больница ФГБОУ ВО ВГМУ им. Н.Н. Бурденко Минздрава России, Воронеж

Введение. Детское ожирение является важной медицинской и социально-экономической проблемой. Численность детей с ожирением неуклонно растет, увеличивается и количество сопутствующих заболеваний - артериальной гипертензии, патологии желудочно-кишечного тракта, нарушений углеводного и липидного обмена.

Цель исследования - изучение структуры коморбидной патологии среди детей с ожирением 1-4 степени.

Материалы и методы. Проведен ретроспективный анализ историй болезни детей с ожирением, находившихся в эндокринологическом отделении в 20192021 гг.

Результаты. В исследование включен 261 пациент (160 мальчиков - 61,3\%, 101 девочка - 38,7\%). Всех 
детей разделили на четыре группы согласно степени ожирения. Ожирение 1 степени имел 51 ребенок, ожирение 2 степени - 97 пациентов, 3 степени - 75 детей, 4 степени - 38 пациентов. Во всех группах преобладали мальчики. Нарушение углеводного обмена выявлено у 3 пациентов (5,9\%) с первой степенью ожирения, 8 детей $(8,2 \%)$ со второй степенью, 10 человек $(13,3 \%)$ - с третьей степенью и у 3 человек $(7,9 \%)$ с морбидным ожирением, $p=0,496$. Инсулинорезистентность отмечалась у 13 человек $(25,5 \%)$ с 1 степенью, 18 детей $(18,5 \%)$ со второй степенью ожирения, 22 человек $(29,3 \%)$ и 7 детей $(18,4 \%)$ с 3 и 4 степенью ожирения соответственно, $p=0,333$. Дислипидемия диагностирована у 6 пациентов $(11,7 \%)$ первой группы, 17 пациентов (17,5\%) 2 группы, 12 (16,0\%) третьей и $4(10,5 \%)$ - четвертой группы, $p=0,668$. Неалкогольная жировая болезнь печени среди детей с ожирением 1 степени выявлена у 7 пациентов $(13,7 \%), 2$ степени - у 42 человек $(43,3 \%), 3$ степени $42(56,0 \%), 4$ степени - у 30 детей (78,9\%), $p<0,001$. Артериальная гипертензия наблюдалась в первой группе у 3 детей $(5,9 \%)$, второй группе - у 17 человек $(17,5 \%)$, в группе с ожирением 3 степени - у 19 пациентов $(25,3 \%), 4$ степени у 9 человек $(23,7 \%), p=0,038$.

Заключение. Распространенность коморбидной патологии зависела как от степени ожирения, так и от вида сопутствующей патологии. Ожирение более высокой степени ассоциировано с развитием артериальной гипертензии, поражением печени. Частота встречаемости нарушений углеводного и липидного обмена не зависела от степени ожирения. Полученные данные необходимы для разработки профилактических и лечебных мероприятий у детей с учетом степени ожирения. 


\section{Раздел 13 PA3HOE}




\section{ОСОБЕННОСТИ ГЕМОСТАЗА У ДЕТЕЙ С ВНУТРИЧЕРЕПНЫМИ КРОВОИЗЛИЯНИЯМИ, РОДИВШИЕСЯ У ЖЕНЩИН \\ С НАСЛЕДСТВЕННОЙ ТРОМБОФИЛИЕЙ}

Ильина А.Я., Мищенко. А.Л., Ворона Л.Д., Мартынов А.А., Ахалова Е.А., Рогова А.С.

ФГАОУ ВО РНИМУ им. Н.И. Пирогова Минздрава

России, Москва

Введение. Выявление первичных и/или вторичных факторов тромбогенного риска в системе “женщина-плод-новорожденный” позволяет выработать определенный алгоритм наблюдения детей с целью предотвращения развития у них тромбогеморрагических осложнений.

Группа исследования. Нами клинически и гемостазиологически обследованы дети $(\mathrm{N}=30)$ в возрасте от 0 до 2 месяцев жизни с внутричерепными кровоизлияниями (ВЧК), родившиеся у женщин с наследственной тромбофилией (НТ).

Результаты. Состояние здоровья при рождении у детей определялось диагностикой ишемией мозга (100\%) в связи с перенесенной внутриутробной гипоксией. У $70 \%$ детей к концу первого месяца и у $30 \%$ в течение второго месяца жизни, манифестировали внутричерепные кровоизлияния: субдуральные $(35,7 \%)$ и внутримозговые $(35,6 \%)$.

У $71 \%$ детей была постгеморрагическая анемия, а тромбоцитоз (70\%) в условиях еще не потребившихся тромбоцитов объяснялся реализацией кровоизлияния после тромбоза. У детей с ВЧК показатель Протромбина по Квику был как повышен (18\%), так и снижен (21\%). При этом показатель АТ III был снижен (12\%) в связи с персистирующим его потреблением, а повышен $(21 \%)$ в связи со спонтанной компенсацией и/или на фоне терапии свежезамороженной плазмой. Повышенные показатели D-димеров (100\%) констатировали посттромботическую ситуацию. Показатель фибриногена в одинаковом проценте случаев был как повышен (в связи с повышенной гемостатической готовностью), так и понижен (в связи с его потреблением в ходе тромбогенеза) (по $16 \%$ соответственно).

Отмечалось снижение агрегационной активности тромбоцитов $(87 \%)$ в связи со снижением гемостатической функции крови и повышение ристомицин-кофакторной активности (27\%), отражающей тенденцию к повышенному внутрисосудистому свертыванию крови. При этом маркерами тромбинемии были фибрин-мономеры (10\%).

Таким образом, полученные гемостазиологические данные объясняют патогенетические этапы реализации тромбогеморрагических осложнений у детей, родившихся у женщин с НТ. То есть, усиленная генерация тромбина, и в том числе вторично, в момент активации свертывания крови вызывает повышение генерации плазмина и затем вторичный гиперфибринолиз, что и может быть причиной кровоизлияния на фоне тромбоза сосудов у детей, родившихся у женщин с НT.

\section{ИНТЕРВАЛЬНАЯ ГИПОКСИТЕРАПИЯ В ЛЕЧЕНИИ ПАРОДОНТОЗА У ДЕТЕЙ}

Абазова А.А., Борукаева И.Х.

ФГБОУ ВО «Кабардино-Балкарский государственный

университет им. Х.М. Бербекова», Нальчик

Введение. Этиологию пародонтоза у детей довольно сложно выявить, так многие заболевания могут явиться причиной его развития. Своевременная диагностика и лечение являются профилактикой прогрессирования дистрофических процессов в пародонте. Учитывая детский возраст, использование немедикаментозных методов лечения является весьма актуальным и современным методом лечения пародонтоза у детей.

Цель исследования - выявление патофизиологических механизмов эффективности интервальной гипокситерапии в лечении и профилактике пародонтоза у детей.

Материалы и методы. Было обследовано 50 детей 12-14 лет с легкой степенью пародонтоза (обнажение корня и уменьшение высоты межзубной перегородки до $1 / 3$ ее величины). Определялись показатели функциональной системы дыхания: скорость потребления кислорода по формуле Дуглас-Холдейну, сатурация $\mathrm{O}_{2}$ в артериальной крови и частота сердечных сокращений - пульсоксиметром, минутный объем сердца по методу Фика, гемоглобин крови - фотометрически. Курс гипокситерапии включал 15 сеансов с 14\% кислорода во вдыхаемом воздухе.

Результаты. После гипокситерапии отмечается снижение повышенной чувствительности шеек и корней зубов, явления парестезии перестали беспокоить больных. При осмотре слизистая полости рта нормальной окраски. Возросла скорость и интенсивность потребления кислорода тканями, что уменьшило дистрофические изменения в пародонте. Отмечалось повышение содержания гемоглобина и кислорода в артериальной крови, в результате чего возросла кислородная емкость крови до $184,86 \pm 4,69$ мл/л. Нормализация вентиляционно-перфузионных соотношений привела к повышению сатурации артериальной крови кислородом до $99,21 \pm 1,02 \%$.

Заключение. Гипокситерапия оказалась эффективным методом лечения детей с пародонтозом легкой степени. Улучшение кислородтранспортной системы привело к нормализации кровоснабжения тканей пародонта и усилению окислительновосстановительных процессов в ней. В результате дистрофические изменения в пародонте стабили- 
зировались, прогрессирование процесса было остановлено, что можно рассматривать как положительный эффект от проведенной гипокситерапии, который можно рекомендовать в комплексном лечении пародонтоза у детей.

\section{ВЛИЯНИЕ ЦИФРОВОЙ СРЕДЫ НА ЗДОРОВЬЕ СТУДЕНТОВ}

Акимов И.Е., Абдулаев Г.Х., Ахмедов Г.И., Магадова Д.Ш., Мин У.С., Орлов М.А., Павлюк А.В., Разумная С.С., Салеева А.С., Таран К.П., Гуменюк О.И., Трифонов В.Д. Кафедра госпитальной педиатрии и неонатологии ФГБОУ ВО СГМУ им. В.И. Разумовского Минздрава России, Саратов

Введение. В настоящее время значительная часть жизнедеятельности и учебы человека тесно связана с гаджетами и сетью «Интернет», которые прямым или косвенным способом влияют на здоровье и состояние человека.

Цель исследования - изучение влияния сети «Интернет», мобильных и компьютерных устройств на здоровье студентов и их обучение.

Материалы и методы. Проведено дистанционное анкетирование 223 человек студентов вузов и колледжей г. Саратова в возрасте 15-23 лет (средний возраст составил $17,1 \pm 1,5$ лет). Использовалась авторская анкета, включающая 78 вопросов, посвященных различным сторонам жизни студентов и использованию ими сети «Интернет».

Результаты. По данным исследования по популярности использования 1-ое место заняли смартфоны, на 2-ое - компьютеры, 3-ье - планшеты. Используются они в $90 \%$ случаев для общения, оставшиеся $10 \%$ - для работы и обучения. При изучении влияния использования гаджетов на состояние здоровья респондентов установлено, что у $100 \%$ анкетированных за время использования цифровых источников длительность сна сократилась до 6 часов, пребывание на свежем воздухе и занятия физической культурой сократилось до 2-3 часов в день. Выраженная усталость глаз (астенопия) отмечена 58\%; головные боли - 39\%, цервикалгии - 34\%, боли в запястье (туннельный синдром) - 33\% опрошенными. В $34 \%$ случаев студенты отметили, что пребывание в сети Интернет влияет на отношения с окружающими.

Заключение. Активное использование цифровой среды студентами вузов и колледжей приводит к сокращению длительности сна и пребыванию на свежем воздухе, способствует гиподинамии. Наиболее частыми жалобами, ставшими последствиями цифровизации жизни студентов, стали: астенопия, головные боли, цервикалгии и туннельный синдром. Полученные результаты диктуют необходимость рационализации работы молодежи с диджитал-источниками.

\section{ФЕНОТИПИЧЕСКИЕ ПРОЯВЛЕНИЯ ДИСПЛАЗИИ СОЕДИНИТЕЛЬНОЙ ТКАНИ У ДЕТЕЙ С АРИТМИЯМИ \\ Аксенов А.В. \\ ФГБОУ ВО ЮУГМУ Минздрава России, Челябинск}

Введение. На сегодняшний день имеет место широкое распространение дисплазии соединительной ткани у детей. Как известно, дисплазия соединительной ткани является фоном для развития различных соматических заболеваний, в том числе сердечно-сосудистых.

Цель исследования - определить наиболее распространенные фенотипические проявления дисплазии соединительной ткани у детей с аритмиями.

Материалы и методы исследования. Проведено обследование 80 детей с нарушениями ритма и проводимости, имеющих признаки дисплазии соединительной ткани.

Результаты. В результате проведенного исследования была отмечена высокая распространенность различных фенотипических признаков дисплазии соединительной ткани у детей с нарушениями ритма и проводимости. Наиболее часто регистрировались такие фены, как гипермобильность суставов, сколиоз, плоскостопие, нарушение рефракции зрения $(p<0,05)$, гораздо реже - аномалии ушных раковин, деформации грудной клетки и аномалии пальцев.

Заключение. У детей с аритмиями среди фенотипических проявлений дисплазии соединительной ткани чаще встречаются гипермобильность суставов, сколиоз, плоскостопие и нарушение рефракции зрения.

\section{КАРДИАЛЬНЫЕ ПРОЯВЛЕНИЯ ДИСПЛАЗИИ СОЕДИНИТЕЛЬНОЙ ТКАНИ У ДЕТЕЙ}

Аксенов А.В.

ФГБОУ ВО ЮУГМУ Минздрава России, Челябинск

Введение. Среди висцеральных проявлений дисплазии соединительной ткани у детей высокую распространенность имеют аномалии со стороны сердечно-сосудистой системы, так называемые малые аномалии развития сердца, к которым относятся пролапсы клапанов, аномальные хорды левого желудочка, открытое овальное окно.

Цель исследования - определить наиболее распространенные малые аномалии развития сердца в детском возрасте.

Материалы и методы исследования. Проведено обследование 60 детей с дисплазией соединительной ткани. В комплекс обследования детей исследуемой группы входило проведение эхокардиоскопии на предмет диагностики малых аномалий развития сердца.

Результаты. В результате проведенного исследования была отмечена высокая распространенность 
различных малых аномалий развития сердца у детей. Наиболее часто были зарегистрированы аномальные хорды левого желудочка $(91,7 \%)$ и пролапс митрального клапана $(88,3 \%)$. Открытое овальное окно было отмечено у $10 \%$ детей, пролапс трикуспидального клапана - у 6,5\% детей.

Заключение. Наиболее распространенными кардиальными проявлениями дисплазии соединительной ткани у детей являются аномальные хорды левого желудочка и пролапс митрального клапана.

\section{СОДЕРЖАНИЕ СВИНЦА В СЫВОРОТКЕ КРОВИ У ДЕТЕЙ С ЮВЕНИЛЬНЫМ АРТРИТОМ ПРОМЫШЛЕННОГО РЕГИОНА \\ Аксенов А.В. \\ ФГБОУ ВО ЮУГМУ Минздрава России, Челябинск}

Введение. Город Челябинск является крупным промышленным центром Южного Урала. Одним из веществ, присутствующих в валовых выбросах в атмосферный воздух от стационарных источников, является токсический элемент свинец.

Цель исследования - определить содержание свинца в сыворотке крови у детей с ювенильным артритом, проживающих в крупном промышленном центре Южного Урала - городе Челябинске.

Материалы и методы исследования. Проведено обследование 60 детей с ювенильным артритом, включающее в себя исследование в сыворотки крове свинца методом атомно-абсорбционной спектрофотометрии. Контрольную группу составили 20 здоровых детей аналогичного возраста, проживающих в городе Челябинске.

Результаты. В исследуемой нами группе детей с ювенильным артритом было выявлено статистически значимое повышение уровня свинца $(p<0,05)$ в сыворотке крови. Следует отметить, что наиболее выраженные изменения свинца в сыворотке крови были зарегистрированы у детей с полиартикулярным и системным вариантами ювенильного артрита $(p<0,05)$, протекающих с 2 и 3 степенями активности $(p<0,05)$.

Заключение. Для детей с ювенильным артритом, проживающих в промышленном центре Южного Урала - городе Челябинске, характерно повышение уровня свинца в сыворотке крови, наиболее выраженные изменения которого отмечаются при полиартикулярном и системном вариантах ювенильного артрита, протекающих с 2 и 3 степенями активности.

\section{ПСИХОЛОГО-ВЕГЕТАТИВНЫЕ ОСОБЕННОСТИ ДЕТЕЙ С ЧАСТЫМИ РЕСПИРАТОРНЫМИ ЗАБОЛЕВАНИЯМИ \\ Арутюнян К.А., Чупак Э.Л. \\ ФГБОУ ВО Амурская ГМА Минздрава России, \\ Благовещенск}

Введение. Частые острые респираторные инфекции, следующие одно за другим, оказывают на организм ребенка негативное воздействие, нарушая развитие эмоциональной сферы, способствуя возникновению дисбаланса вегетативной регуляции внутренних органов.

Цель исследования. Изучить у детей с частыми респираторными инфекциями психолого-вегетативный статус.

Материалы и методы. Проведен анализ 84 историй болезни детей, находившихся на обследовании в отделении дневного стационара Детской городской клинической больнии г. Благовещенска. Первую группу составили дети с частыми респираторными заболеваниями в возрасте 3-9 лет (64 ребенка). Группу сравнения (2 группа) составили эпизодически болеющие дети этого же возраста (20 детей). Всем детям проводились кардиоинтервалография, психологический тест на уровень тревожности Р. Теммпл, В. Амен, М. Дорки.

Результаты. Дети 1 группы достоверно чаще $(p<0,05)$ показывали значения индекса тревожности выше $50 \%$. Эти дети характеризовались повышенной тревожностью, неуверенностью в себе, сложностями в общении со сверстниками и взрослыми. У 32,8\% детей 1 группы выявили исходную эйтонию, из них у трети детей отмечается асимпатикотонический вариант вегетативной реактивности, что указывает на повышенную истощаемость адаптационных возможностей. Выявлена средняя обратная корреляционная связь между частотой острых респираторных инфекций в год и значением вегетативной реактивности $(r=-0,58 ; p<0,05)$, сильная прямая корреляционная связь между частотой острых респираторных инфекций в год и уровнем тревожности $(r=0,77 ; p<0,05)$, умеренная обратная корреляционная связь между уровнем тревожности и значением вегетативной реактивности $(r=-0,32 ; p<0,05)$.

Заключение. Описанные результаты свидетельствуют о тесной взаимосвязи характера вегетативной регуляции с особенностями организации эмоциональной сферы. Значительное напряжение регуляторных механизмов является сопровождением вегетативных проявлений тревожности, приводящей к недостаточной активации эрготропных структур. Выявлено, что дети с частыми острыми респираторными инфекциями имеют вегетативную дисфункцию, которая у 1/3 выражается асимпатикотонической вегетативной реактивностью на фоне высокого уровня тревожности. Это может привести к хронизации инфекционного процесса и формированию психосоматической патологии. 
ЧАСТОТА ВСТРЕЧАЕМОСТИ КЛИНИЧЕСКИХ ФОРМ ЮВЕНИЛЬНОГО АРТРИТА У ДЕТЕЙ В ЗАВИСИМОСТИ ОТ ВОЗРАСТА

Ахмедова Н.Р., Ибрагимов А.А., Сайидова М.Х.

Республиканский специализированный научно-

практический медицинский центр педиатрии, Ташкент, Узбекистан

Ташкентский педиатрический медицинский институт, Ташкент, Узбекистан

Введение. Ювенильный артрит (ЮА) является самым распространенным ревматическим заболеванием, и как правило, самой частой причиной инвалидности среди детей.

Цель исследования - изучение частоты встречаемости клинических форм ювенильного артрита у детей в зависимости от возраста.

Материалы и методы. Обследовано 189 больных с ЮА в возрасте от 1 до 18 лет, госпитализированных в кардиоревматологическое отделение Республиканского специализированного научно-практического медицинского центра педиатрии с начала 2015 года до настоящего времени. Всем больным были проведены общеклинические, биохимические и инструментальные методы исследования. Диагноз ставился на основании жалоб, данных анамнеза, объективного осмотра, лабораторно-инструментальных методов исследований согласно критерий ILAR Edmonton (2001 г.).

Результаты. Изучение частоты встречаемости различных форм ЮА среди обследованных показало, что суставная форма была зарегистрирована у 137 $(72,4 \%)$ детей, из которых полиартритическая и олигоартритическая форма составили $32,8 \%$ и $33,8 \%$, а энтезит ассоциированный и недифференцированный артрит встречался в 3,1\% и 1,5\% детей. Псориатическим артритом страдали 2 (1\%) детей. ЮА с системным началом был диагностирован у 52 детей $(27,5 \%)$. Анализ начала заболевания в зависимости от форма ЮА указывает, что олигоартрикуларная форма болезни чаще начинается в возрасте 3-4 лет и 8-9 лет, а полиартикулярная характерна для детей в возрасте 8-12 лет, что совпадает с литературными данными, в которых указан пик заболеваемости олигоартритической формой ЮА преимущественно детей в возрасте 1-5 лет, тогда как полиартикулярная форма больше развивается в 2-15 лет. По данным литературы, ЮА с системным началом может дебьютировать в любом возрасте, но чаще возникает до полового созревания. У $52(27,5 \%)$ больных с ЮА с системным началом чаще встречался у детей в возрасте до 5 лет. Раннее начало заболевания свидетельствует о большем количестве системных воспалительных процессов и более неблагоприятном исходе, чем у детей с более поздним началом заболевания.

Заключение. По частоте встречаемости различных форм ювенильного идиопатического артрита идет преобладание олигоартритической, полиартритической и системной форм заболевания, которые чаще дебьютируют в дошкольном и раннем школьном возрастах.

\section{ВЗАИМОСВЯЗЬ МЕЖДУ НАРУШЕНИЕМ КАЧЕСТВА СНА И СТРЕССОМ У ДЕТЕЙ ШКОЛЬНОГО ВОЗРАСТА В ЗАВИСИМОСТИ ОТ УРОВНЯ АРТЕРИАЛЬНОГО ДАВЛЕНИЯ И ИНДЕКСА МАССЫ ТЕЛА}

Бекезин В.В. ${ }^{1}$, Пересецкая О.В. ${ }^{1}$, Козлова Л.В. ${ }^{2}$

${ }^{1}$ Смоленский государственный медицинский университет, Смоленск

${ }^{2}$ Смоленская областная детская клиническая больница, Смоленск

Введение. В последние годы отмечается рост артериальной гипертензии в детском возрасте, часто ассоциированной с ожирением. При этом известно, что нарушение качества сна приводит к невротическим расстройствам и стрессу, которые в свою очередь являются факторами высокого риска увеличения жировой массы тела.

Цель: провести корреляционный анализ между качеством сна и выраженностью стресса у детей подросткового возраста в зависимости от уровня АД и индекса массы тела (ИМТ).

Материалы и методы. Проведено комплексное обследование 117 детей подросткового возраста с индексом массы тела (ИМТ, кг/м²) равным или более 2 SDS с учетом пола и возраста, включающее антропометрию, измерение АД (амбулаторное и СМАД), анкетирование (шкалы нарушение сна и стресса, адаптированные к подростковому возрасту). Методом случайной выборки в исследование были включены 79 детей. В зависимости от уровня АД и ИМТ все обследованные были разделены на 4 группы: 1-я группа $(n=21)$ - дети с артериальной гипертензией (АГ) белого халата и избыточной массой тела; 2-я группа $(n=24)$ - дети с АГ белого халата и ожирением I-II степени; 3-я группа $(n=11)$ - дети с АГ 1-й степени и избыточной массой тела; 4-я группа $(n=23)$ - дети с АГ 1-й степени и ожирением I-II степени. При статистической обработке использовали коэффициент корреляции Спирмена.

Результаты. Выявлено, что корреляционные связи между показателями шкал нарушения сна и стресса у обследованных детей зависят от уровня артериального давления и индекса массы тела. Так, корреляционная связь между шкалой сна (блок 1) и шкалой стресса была отрицательной и равнялась: у детей 2-й группы - 0,341 $(p<0,05)$, у детей 4-й группы $-0,528$ $(p<0,05)$; у детей 1-й группы отсутствовала, а у детей 3 -й группы - 0,437 $(p<0,05)$. Корреляционная связь между шкалой апноэ сна (блок 4, раздел 3) и шкалой стресса была положительной и равнялась: у детей 2-й 
группы $-0,357(p<0,05)$, у детей 1 -й группы $-0,304$ $(p<0,05)$; у детей 4-й группы - 0,701 $(p<0,05)$ и у детей 3-й группы - 0,448 $(p<0,05)$.

Заключение. Таким образом, корреляционный анализ показал, что усиление нарушения качества сна и выраженности стресса у детей школьного возраста на фоне нарастания индекса массы тела сопровождаются повышением уровня артериального давления. В связи с этим первичная профилактика артериальной гипертензии должна включать немедикаментозные и психологические подходы, направленные на коррекцию диссомнии и стресса у детей.

\section{ИЗМЕНЕНИЯ ЛИПИДНОГО ОБМЕНА У ДЕТЕЙ ШКОЛЬНОГО ВОЗРАСТА, СТРАДАЮЩИХ МУКОВИСЦИДОЗОМ \\ Белаш Т.А., Водовозова Э.В., Леденева Л.Н., \\ Григорьяни И.С., Енина Е.А., Пустабаева М.С. \\ ФГБОУ ВО «Ставропольский государственный \\ медицинский университет» МЗ РФ, Ставрополь}

Введение: Большинство детей Ставропольского края (СК), страдающих муковисцидозом (МВ), отстают в физическом развитии от своих здоровых сверстников, особенно по массе тела. Установлено, что при МВ у детей снижается способность организма к синтезу сложных липидов.

Цель исследования: изучить изменения жирового обмена у школьников СК, страдающих МВ.

Материалы и методы исследования. Обследовано 23 ребенка школьного возраста, страдающих МВ. Исследование проводилось на базе Регионального центра МВ г. Ставрополь. Контрольную группу составили 23 ребенка того же возраста, не страдающие хроническими заболеваниями и не относящиеся к группе часто болеющих детей. Фракции липидов определяли методом тонкослойной хроматографии, транспортные формы липидов (липопротеиды-ЛП)методом диск-электрофореза в полиакриламидном геле. При статистическом анализе использовались программы STATISTICA 6,0 (StatSoftInc., США) и MicrosoftExcel XP (MicrosoftCorp., США), для определения степени взаимосвязи между признаками коэффициент ранговой корреляции Спирмена.

Результаты: Выявлено, что у школьников СК, страдающих MB, ярко выражена дислипидемия по сравнению с контрольной группой (достоверное повышение общих липидов (ОЛ), ХС, хиломикронов (ХМ), ЛП очень низкой (ЛПОНП) и низкой плотности (ЛПНП) при достоверном снижении ЛП высокой плотности (ЛПВП), причем эти изменения прямо коррелируются со снижением массы тела больного $(r=+0,71)$.

Заключение Выявленная связь дислипидемии с нарушением физического развития больных диктует необходимость коррекции питания детей-школьников СК, страдающих МВ, для чего использовалась программа «Аспон - питание», позволяющая проводить анализ по 52 основным нутриентам, входящим в состав продуктов питания, руководствуясь которой можно рекомендовать диету, содержащую повышенное на 10-15\% количество белка и нормальное количество жиров и углеводов. При этом в рацион включены только легко усваиваемые жиры (сливочное и растительное масло).

\section{КОРРЕКЦИЯ ПИТАНИЯ У ДЕТЕЙ ШКОЛЬНОГО ВОЗРАСТА, СТРАДАЮЩИХ МУКОВИСЦИДОЗОМ, В ЗАВИСИМОСТИ ОТ ЭЛЕМЕНТНОГО ГОМЕОСТАЗА}

Белаш Т.А., Водовозова Э.В., Леденева Л.Н., Енина Е.А., Пустабаева М.С.

ФГБОУ ВО «Ставропольский государственный медицинский университет» МЗ РФ, Ставрополь

Введение. Муковисцидоз (МВ) - неизлечимое заболевание, диктующее необходимость диспансерного наблюдении и непрерывной терапии в течение всей жизни, причем терапия не ограничивается рамками медикаментозного лечения, но и включает продукты питания содержащие элементы необходимые для нутрицевтической коррекции.

Цель исследования: провести коррекцию питания детям школьного возраста, страдающих МВ, в зависимости от изменений элементного гомеостаза

Материалы и методы. В исследовании принимали участие 23 ребенка школьного возраста, страдающие MB, проживающие в Ставропольском крае (CK). Все пациенты наблюдаются в Региональном центре МВ г. Ставрополя. Для определения элементов в биосубстратах используются два метода анализа: ИСП-АЭС и ИСП-МС в лаборатории АНО «Центр биотической медицины», аккредитованной в Федеральном центре госсанэпиднадзора при МЗ РФ, г. Москва. Контролем служили нормативы содержания элементов у здоровых детей.

Результаты. У школьников СК, страдающих МВ, уровень $\mathrm{Al}^{+3}, \mathrm{As}^{+5}, \mathrm{Be}^{+2}, \mathrm{Cd}^{+2}, \mathrm{Co}^{+8}, \mathrm{Cu}^{+}, \mathrm{Fe}^{+2}, \mathrm{Hg}^{+2}$, $\mathrm{I}^{+7}, \mathrm{Li}^{+}, \mathrm{Mn}^{+7}, \mathrm{Ni}^{+8}, \mathrm{P}^{+5}, \mathrm{~Pb}^{+4} \mathrm{Se}^{+6}, \mathrm{Sn}^{+4}$ и $\mathrm{V}^{+5}$ ниже, чем в контрольной группе, а уровень $\mathrm{B}^{+3}, \mathrm{Ca}^{+2}, \mathrm{Cr}^{+6}, \mathrm{~K}^{+}$, $\mathrm{Mg}^{+2}, \mathrm{Na}^{+}, \mathrm{Si}^{+4}$ и $\mathrm{Zn}^{+2}$ - выше, чем у здоровых сверстников, что позволяет рекомендовать диету, включающую крупы (пшенная, гречневая, овсяная, кукурузная, отруби), макароны, мясные продукты (говядина, говяжья печень), морские продукты (печень трески, креветки, кальмары, скумбрия, горбуша, морская капуста, морская соль, мидии, устрицы, лангусты), яйца, молочные продукты (молоко, сливочное масло, сыр), фрукты, сухофрукты овощи. Потребление продуктов, содержащих $\mathrm{B}^{+3}, \mathrm{Ca}^{+2}, \mathrm{Cr}^{+6}, \mathrm{~K}^{+}, \mathrm{Mg}^{+2}, \mathrm{Na}^{+}, \mathrm{Si}^{+4}$ и $\mathrm{Zn}^{+2}$, следует уменьшить. К ним относятся: соленое масло, или маргарин, все виды сыров, бекон, копченое мясо, мясо кролика, окорок, сосиски, колбасы, 
солонина, консервированное мясо, студень, мясные и рыбные полуфабрикаты, жареные и соленые орехи, любые промышленные соусы, подливки, кетчупы, бульонные кубики, чипсы, сухарики, какао, рис, овсяная мука, горох, фасоль, кунжут.

Заключение. Питание школьников СК, страдающих МВ, необходимо корригировать, исходя из изменений в элементном гомеостазе больных.

\section{ОЦЕНКА ЭФФЕКТИВНОСТИ ИСПОЛЬЗОВАНИЯ ОПТИМИЗИРОВАННОЙ СХЕМЫ ЛЕЧЕНИЯ ПАРОДОНТИТА}

Брагин А.В., Орлова Е.С.

ФГБОУ ВО Тюменский ГМУ Минздрава России, Тюмень; ФГАОУ ВО РНИМУ им. Н.И. Пирогова Минздрава

России, Москва

Введение. Заболевания пародонта, превалируя в структуре стоматологической патологии, поражают более $80 \%$ населения и являются одной из актуальных проблем здравоохранения.

Цель исследования. Сравнительный анализ клинической эффективности комплексного лечения пародонтита с применением новой фармакологической композиции (НФК).

Материалы и методы. Нами было предложено «Средство лечения пародонтита и заболеваний слизистой оболочки рта, ассоциированных с геликобактерной инфекцией и способ его применения», (патент РФ, №2549445). Сравнительный анализ клинической эффективности комплексного лечения пародонтита с применением НФК проведен с традиционным антибактериальным препаратом для местного применения «Метрогил Дента» $1 \%$ и изучен на примере совокупной клинической выборки 39 человек в возрасте 16-18 лет.

Результаты. Лекарственная форма была создана на основе запатентованного отечественного препарата «Силативит» (патент РФ № 2255939). В качестве активной лекарственной добавки для лечения пародонтита на фоне хеликобактериоза нами было предложено добавление висмута трикалия дицитрата. Изготовление НФК для применения в комплексной терапии у пациентов с хеликобактерной патологией производилось в Институте органического синтеза им. И.Я. Постовского УрО РАН. Использование висмута трикалия дицитрата для формулы препарата объясняется специфическим действием в отношении Helicobacter pylori (Нр) и отсутствием резистентности бактерии к нему.

Заключение. Наличие заболеваний пародонта и пародонтальных карманов как главного экстрагастрального резервуара Нр, может служить дополнительным источником реинфицирования организма, что необходимо учитывать при лечении пациентов с сочетанной патологией. Полученные результаты использования оптимизированной схемы лечения пародонтита свидетельствуют об уменьшении воспалительных процессов в тканях пародонта и характеризуются стойкой клинической ремиссией в контрольные сроки наблюдения.

\section{ЛИПИДНОГО ОБМЕН ПРИ МУКОВИСЦИДОЗЕ У ДЕТЕЙ СТАВРОПОЛЬСКОГО КРАЯ}

Водовозова Э.В., Леденева Л.Н., Григорьяни И.С., Енина Е.А., Быков В.О., Пустабаева М.С. ФГБОУ ВО «Ставропольский государственный медицинский университет» МЗ РФ, Ставрополь

Введение. Липиды обеспечивают нормальное течение процессов клеточного метаболизма, стимулируют неспецифический иммунитет, являются предшественниками стероидных и половых гормонов. Муковисцидоз (МВ) - тяжелое моногенное заболевание, характеризующееся ухудшением качества жизни больного.

Цель исследования: анализ изменений липидного обмена у детей Ставропольского края (CK), страдающих МВ.

Материалы, методы исследования. В исследование включено 102 ребенка с МВ, которым проводился анализ кала на панкреатическую эластазу. Для определения спектра липидов сыворотки крови и их транспортных форм использовали анализатор для биохимических исследований COBASc 311, фирма RocheDiagnosticsGmbH, Германия. Статистический анализ производили с использованием интегрированного пакета статистических программ STATISTICA 6,0 (StatSoftInc., США) и пакета программных приложений MicrosoftExcel XP (MicrosoftCorp., США).

Результаты. До лечения у детей с МВ уровень фракций холестерина (ХC) и липопротеидов низкой плотности (ЛПНП) достоверно ниже, чем в контроле $(p \leq 0,05)$; уровень триглицеридов (ТГ) достоверно выше $(p \leq 0,001)$, чем у здоровых детей, а показатель липопротеидов высокой плотности (ЛПВП) не отличался от такового в контрольной группе; ЛПВП у больных МВ без панкреатической недостаточности достоверно снижены $(p \leq 0,001)$, с панкреатической недостаточностью - достоверно повышены $(p \leq 0,05)$;

ЛПНП при МВ без панкреатической недостаточности достоверно ниже $(p \leq 0,001)$, с панкреатической недостаточностью - выше, но не достоверно $(p \geq 0,05)$.

Заключение. Исследование липидного спектра сыворотки крови у детей, страдающих МВ, выявило выраженную дислипидемию, усугубляющую тяжесть заболевания и ухудшение качества жизни. При МВ с панкреатической недостаточность обнаружена обратная, статистически значимая зависимость между эластазой кала и ЛПВП; уменьшение расходов холестерина на синтез стероидов, временная дисфункция надпочечников, что, в свою очередь, может усугублять обструктивный синдром. 


\section{ПСИХОЛОГИЧЕСКАЯ ПОМОЩЬ ДЕТЯМ \\ И ПОДРОСТКАМ В ВЫПУСКНЫХ \\ КВАЛИФИКАЦИОННЫХ РАБОТАХ СТУДЕНТОВ, ОБУЧАВШИХСЯ ПО СПЕЦИАЛЬНОСТИ «КЛИНИЧЕСКАЯ ПСИХОЛОГИЯ» \\ Волчанский М.Е., Деларю В.В. \\ ФГБОУ ВО «Волгоградский государственный \\ медицинский университет» Минздрава России, \\ Волгоград}

Введение. Образовательная профессиональная программа 37,05,01 «Клиническая психология» ориентирована, в первую очередь, на подготовку соответствующих специалистов для работы в сфере здравоохранения. Поэтому актуальным представляется выяснение их предпочитаемых / предполагаемых направлений будущей профессиональной деятельности (БПД), в частности, работы с детьми и подростками (ДиП), тем более, что оказание психологической помощи (ОПП) ДиП получает все более широкое признание, а одним из наиболее реалистичных прогностических вариантов сферы БПД служит анализ тематики выпускных квалификационных работ (ВКР).

Цель исследования - анализ представленности ОПП ДиП в ВКР студентов, обучавшихся по специальности «Клиническая психология».

Материалы и методы. Контент-анализ 205 ВКР, защищенных в 2017-2021 гг. по специальности «Клиническая психология» студентами ВолгГМУ (сплошная выборка).

Результаты. Всего вопросам ОПП ДиП были посвящены 33 работы (16,1\% от всех ВКР; от 8,6\% до 22,9\% по анализируемым годам). ОПП ДиП при нервно-психических расстройствах (умственной отсталости, задержки психического развития, невротических нарушениях, шизофрении, эпилепсии, ДЦП) рассматривались в $10,2 \%$ от всех ВКР (в 63,6\% от работ «педиатрической тематики»); при соматических заболеваниях (онкологических, аллергических, опорно-двигательного аппарата, нарушениях зрения, послеоперационном периоде) - в 3,9\% (24,2\% соответственно); оказавшимся в сложной жизненной ситуации (в детских домах, при алкоголизме родителей) - в 2,0\% (12,1\%).

С известной долей условности к «педиатрической тематике» можно отнести еще 14 работ $(6,8 \%)$, посвященных ОПП семьям / родителям, имеющих ДиП с различными заболеваниями (нервно-психическими, онкологическими).

Заключение. Согласно тематике ВКР, у каждого шестого-седьмого студента - будущего клинического (медицинского) психолога имеется интерес к работе с ДиП, что с определенной долей вероятности позволяет прогнозировать их БПД в данном направлении. В целом, подобное количество будущих специалистов, ориентированных на ОПП ДиП, представляется достаточным; при этом соотношение «нервно-психических» и «соматических» исследований соответствует потенциально возможным местам будущего трудоустройства.

\section{ПРЕДПОЧТЕНИЯ ОБУЧАЮЩИХСЯ В ШКОЛЬНОМ ПИТАНИИ ОБРАЗОВАТЕЛЬНЫХ ОРГАНИЗАЦИЙ Г.МОСКВЫ}

Горелова Ж.Ю., Соловьева Ю.В., Летучая Т.А.

ФГАУ «НМИЦ здоровья детей» Минздрава России, Москва

Введение. Организация в школе основного и дополнительного рациона питания для обучающихся является одним из основных факторов формирования правильных пищевых привычек и навыков у детей и подростков, но в ассортименте буфетов нередко преобладают кондитерские изделия и напитки низкой пищевой ценности. В ассортимент продуктов для свободной продажи, кроме входящих в состав основного рациона питания, необходимо включать продукты, которые школьник не получил в этот день в составе завтрака или обеда.

Цель исследования. Оценка пищевого поведения, особенностей выбора основной и буфетной продукции и предпочтений в питании школьников.

Материалы и методы. Обследовано 128 детей. Оценивали пищевые предпочтения блюд в школе и дома в основные приемы пищи и питание в буфете. Методы - гигиенические /анкетирование/, статистические, оценка качественного состава пищи с использованием компьютерных программ «Stadia», $1 \mathrm{C}$ «Школьное питание».

Результаты. Большинство детей к началу обучения имели определенный стереотип пищевого поведения. На завтрак предпочитали йогурт - 89,6\%, сырники $73,4 \%$, омлет $-71,8 \%$, кашу $-66,4 \%$, оладьи $-62,5 \%$. В качестве напитка на завтрак школьники выбирали какао - 56,2\%, молоко - 43,7\%. На обед - в 51,5\% борщ, 28,1\% - щи. На второе блюдо в обед: запеканку $-71 \%$, котлеты - 18,7\%, картофельное пюре $10,1 \%$. В буфете предпочитали из напитков - какао 72\%. На полдник: фрукты - 68,7\%, печенье - 49,2\%, йогурт - 33,5\%. В ассортименте буфета преобладали кексы, круассаны, сосиски в тесте, ватрушки, блины. На ужин - рыба, мясная запеканка, котлеты, овощи, вареники, плов, картофель, овощной салат, из напитков компот $-37,5 \%$, кисель $-21,8 \%$, чай $-23,4 \%$.

Заключение. Питание обучающихся в целом является сбалансированным, за исключением самостоятельного выбора продукции в буфете, пищевые предпочтения которой остаются не разборчивыми. Выявлена необходимость коррекции дополнительного ассортимента путем сокращения выпечки, сладких напитков, добавления в рацион фруктов, витаминизированных продуктов, соков. 
ОКАЗАНИЕ МЕДИЦИНСКОЙ, ПСИХОЛОГИЧЕСКОЙ И СОЦИАЛЬНОЙ ПОМОЩИ ДЕТЯМ С РАННИМ ДЕТСКИМ АУТИЗМОМ В ОЦЕНКАХ ПСИХОЛОГОВ

Деларю В.В., Кондратьев Г.В., Ворожейкина Л.И., Шутова О.И.

ФГБОУ ВО «Волгоградский государственный медицинский университет» Минздрава России, Волгоград

Введение. В настоящее время общепризнан комплексный подход при реабилитации детей с ранним детским аутизмом (РДА), согласно которому ее эффективность во многом определяется сочетанностью оказания медицинской, психологической и социальной помощи. При этом существенное (или даже определяющее) значение отдается психологической помощи, что делает актуальным изучение мнения психологов по данному вопросу.

Цель исследования - оценки психологов оказания медицинской, психологической и социальной помощи детям с РДА.

Материалы и методы. Анкетирование в 2009г. 61 работающих с детьми психологов, стаж работы менее 5-ти лет был у 44,3\%, стаж 5 лет и более у 55,7\%; в 2019-2020гг. - 63 психологов $(39,7 \%$ и $60,3 \%$ соответственно).

Результаты. Оценки оказания медицинской помощи детям с РДА в 2009г: по мнению 3,3\% специалистов она носит достаточно полный характер; $24,6 \%$ ответили, что носит явно недостаточный характер; 29,5\% решили, что верно нечто среднее между этими крайними точками зрения и $42,6 \%$ затруднились ответить. Спустя 10 лет распределение ответов было: $11,1 \% ; 23,8 \% ; 42,9 \%$ и $22,2 \%$ соответственно.

То, что психологическая помощь носит достаточно полный характер в 2009г. ответили 3,3\%; что носит явно недостаточный характер - 62,3\%; $13,1 \%$ решили, что верно нечто среднее и $21,3 \%$ затруднились ответить. Спустя 10 лет ответы распределились следующим образом: $12,7 \% ; 57,1 \% ; 28,6 \%$ и $1,6 \%$ соответственно.

Относительно социальной помощи: в 2009г. о ее оказании в полном объеме высказались 1,6\% психологов; о явно недостаточном объеме - 57,4\%; что верно нечто среднее между этими крайними точками зрения - 16,4\% и затруднились ответить 24,6\%. Через 10 лет распределение ответов было: $11,1 \% ; 63,5 \% ; 22,2 \%$ и $3,2 \%$ соответственно.

Заключение. Проведенное в рамках компарационного подхода анкетирование работающих с детьми психологов в 10-ти летнем интервале показало, что реабилитация детей с РДА продолжает осуществляется недостаточно эффективно; при этом более положительно оценивается оказание медицинской помощи. Позитивно можно отметить уменьшение количества психологов, затруднившихся ответить на входящие в спектр их профессиональной деятельности вопросы (оценить оказание медицинской, психологической и социальной помощи данной категории детей).

\section{МЕДИЦИНСКИЕ ПСИХОЛОГИ ОБ УЧАСТИИ ПЕДАГОГОВ ДЕТСКИХ САДОВ И ШКОЛ В РЕАБИЛИТАЦИИ ДЕТЕЙ С РАННИМ ДЕТСКИМ АУТИЗМОМ \\ Деларю В.В. \\ ФГБОУ ВО «Волгоградский государственный \\ медицинский университет» Минздрава России, \\ Волгоград}

Введение. Традиционно в качестве агентов реабилитации детей (РД) с ранним детским аутизмом (РДА) рассматриваются врачи, психологи и сотрудники социальных служб. Но в последние годы получают все большее распространение «мягкие» критерии диагностики расстройств аутистического спектра, что способствует не только статистическому росту количества детей с данной патологией, но и актуализирует участие в реабилитационном процессе других специалистов, в частности, педагогов детских садов и школ.

Цель исследования - выяснить мнение медицинских психологов относительно участия педагогов детских садов и школ в реабилитации детей с РДА.

Материалы и методы. Анкетирование в 2009г. 61 работающих с детьми психологов, стаж работы менее 5-ти лет был у 44,3\%, стаж 5 лет и более у 55,7\%; в 2019-2020гг. - 63 психологов (39,7\% и $60,3 \%$ соответственно).

Результаты. В 2009г. 52,1\% медицинских психологов считали, педагоги детских садов и школ могут помочь в реабилитации детей с РДА; спустя 10 лет так думали уже 71,4\% (p<0,05); прямо противоположной точки зрения («не могут помочь») придерживались $10,4 \%$ и $1,6 \%$ соответственно $(\mathrm{p}<0,05)$; решили, что верно нечто среднее между этими крайними точками зрения $27,1 \%$ и $14,3 \%$ ( $>0,05)$; затруднились ответить $10,4 \%$ и $12,7 \%$.

В тоже время, что педагоги детских садов и школ реально помогают в реабилитации детей с РДА в 2009г. считали 10,4\% медицинских психологов, спустя 10 лет - 14,3\%; что «не помогают» ответили 39,6\% и $49,2 \%$ соответственно; $18,8 \%$ и $11,1 \%$ решили, что верно нечто среднее; затруднились ответить $31,2 \%$ и $25,4 \%$.

Заключение. Согласно проведенному исследованию, медицинские психологи считают, что педагоги детских садов и школ могут помочь, но реально не помогают в реабилитации детей с РДА, при этом, в 10-ти летнем интервале, количество специалистов, считающих, что «могут помочь» увеличилось, а считающих, что «реально не помогают» практически не изменилось. Вышеизложенное актуализирует 
необходимость проведения с педагогами занятий, посвященных их возможностям участия в реабилитации детей с РДА, особенно с учетом того, что большинству детей с данным расстройством оказываются образовательные услуги в детских садах и школах обычного типа.

\section{НЕКОТОРЫЕ ЭПИДЕМИОЛОГИЧЕСКИЕ И КЛИНИКО-АНАМНЕСТИЧЕСКИЕ ОСОБЕННОСТИ РЕАКТИВНЫХ АРТРОПАТИЙ У ДЕТЕЙ}

Дмитрачков В.В. ${ }^{1}$, Юшко В.Д. ${ }^{1}$, Дмитрачкова O.B. ${ }^{2}$ ${ }^{1}$ Белорусский государственный медицинский университет, ²Республиканский клинический центр паллиативной медицинской помощи детям, Беларусь, Минск

Цели: выявить эпидемиологические, клинико-анамнестические особенности, значимые коморбидные состояния (KoC) реактивных артропатий (PA) у детей.

Материал и методы. Гр.наблюдения (ГрН) - 30 детей с РА (1-18 лет). Проводились: анализ клиникоанамнестических данных, амбулаторных и медкарт, анкетирование детей.

Обсуждение результатов. Наследственность отягощена у 46,7\% детей: по линии матери - 50\%, отца $(28,6 \%)$ обоих родителей - 21,4\%; по патологии сердечно-сосудистой системы $(42,9 \%)$, опорнодвигательного аппарата $(21,4 \%)$, аллергопатологии $(35,7 \%)$. У $26,7 \%$ - отягощен аллергоанамнез: медаллергия, пищевая аллергия (Ал) 50\%, бытовая Ал $12,5 \%$. Крайние варианты физразвития (рост высокий и вышесреднего) - у 23,3\% детей. Вирусные, вирусно-бактериальные инфекции, перенесенные накануне $(53,3 \%)$ : ОРИ $(43,8 \%)$, грипп $(18,8 \%)$, ангина $(6,3 \%)$, о. бронхит $(12,5 \%)$, ИМВП $(12,5 \%)$, о. гастроэнтерит $(6,3 \%) ; 13,3 \%$ - предшествующая травма, 33,3\% - причина РА неизвестна. КоС в ГрН (90\%): у 18,5\% патология пищеварительного тракта (ПТ, патология его верхних отделов у 4 детей, ДЖВП у 1 ; СВД $(18,5 \%)$, анемии $(3,7 \%)$, БРА-3,7\%, хр. очаги инфекции у 74,1\%, (верхних дыхательных путей (85\%)). ВнП и/или ВиП ДСТ у $80 \%$ : из них ВиП у 91,7\%, ВнП у 37,5\% (ВнП+ВиП $29,1 \%)$. Миопия, астигматизм у 22,2\%. ВиП ДСТ ГрН - в 73,3\%. МАРС - 95,5\%. НСРП у 93,3\%. Чаще поражались суставы (Су): (коленные $(80 \%)$, тазобедренные $(26,7 \%)$, голеностопные $(16,7 \%)$; реже: лучезапястные (10\%), межфаланговые $(6,7 \%)$. Моно-(40\%), олиго-(40\%), полиартрит (20\%). Артралгии-у всех детей ГрН: при ходьбе (80\%), в покое $(33,3 \%)$, ночные $(13,3 \%)$; ограничение движений в Су $(16,7 \%)$, их отечность, дефигурацию $(53,3 \%)$, нарушение походки $(20 \%)$, гиперемию, повышение Т над Су (10\%), хруст при ходьбе (10\%); жалобы на кардиалгии $(23,3 \%)$, цефалгии $(36,7 \%)$, абдоминальный синдром $(13,3 \%)$. Лабораторно: лимфо- цитоз (53,3\%), нейтрофильный сдвиг влево - 13,3\%, эозинофилия - 6,7\%; СРБ повыщен у $10 \%$ детей.

Выводы. У детей с РА КоС встречаются часто, преобладают: патология ПТ, СВД, хр.очаги инфекции, варианты НСРП, МАРС, что может затруднить подбор базисной терапии. Курация детей с РА требует междисциплинарного подхода, взаимодействия врачей разных специальностей.

\section{УЗЛОВАТАЯ ЭРИТЕМА У РЕБЕНКА С ОСТРЫМ ЛИМФАДЕНИТОМ ШЕИ}

Дмитрачков В.В. ${ }^{1}$, Лапковский В.И. ${ }^{2}$, Синица Ю.Н. ${ }^{2}$, Кадыров M.T. ${ }^{2}$

'Белорусский государственный медицинский университет,

2УЗ «4-я Городская детская клиническая больница», Беларусь, Минск

Под наблюдением находился пациент Ш. 11 лет. Жалобы на боли, образование в верхней 1/3 шеи слева, появились 2 нед. назад. Отек тканей в этой области появился накануне обращения в клинику, температура (Т) $38^{\circ} \mathrm{C}$. В анамнезе с-м Жильбера. Состояние удовлетворительное. Сознание ясное. $\mathrm{T} 36,7^{\circ} \mathrm{C}$. По органам без патологии. ЧД=19уд/мин. ЧСС $=88$ уд/мин. Конфигурация лица не изменена, в области верхней 1/3 шеи слева округлое образование 4,0x4,5см, болезненное, ограниченно подвижно, кожа над ним не изменена. В ан. крови: Эр-4,87х10 12 , Нb-138г/л, Тр-166х109, Л-4,2×109, Б-1, П-5, С-24, Лф-61, М-20, Э-1, М-9, СОЭ 23 мм/час. УЗИ: данные в пользу о. лимфаденита (ОЛА) шеи. Диагноз: неодонтогенный ОЛА верхней 1/3 шеи слева? Воспалившаяся боковая киста шеи (БКШ)? От диагностической пункции - отказ. Терапия: цефамед, амикацин, димексид. Состояние улучшилось, но ч/з 15 дн. от поступления (4 дн. отмены а/б терапии) $-\mathrm{T} 37,7^{\circ} \mathrm{C}$, появилась пятнистая розовая сыпь на ногах и руках, зуд(?). Назначен хлоропирамин. На следующий день: состояние ср. тяжести - выражен с-м токсикоза, болезненные узлы на голенях, руках; образование боковой поверхности шеи слева; слабость. Т36, $4^{\circ} \mathrm{C}$. Желтушность кожи, склер. На голенях, руках множественные ярко-розовые узлы (d=1-5см), болезненные, горячие, возвышаются над кожей. Слизистые чистые, катаральных явлений нет. В области шеи слева - образование, б/б, неоднородное, мягко-эластическое (конгломерат л/узлов?). Кожа над ним без гиперемии. По органам без патологии. Диагноз: Узловатая эритема, инф/аллергическая, о.течение. Верхнешейный ЛА. БКШ? Лечение: цефепим, дексаметазон, индометациновая мазь. Эр-4,85×10 12 , Нb-136 г/л, Тр-186×109, Л-9,4×109, Б-1, П-13, С-45, Лф-34, М-7, Э-1, СОЭ 34 мм/час. Б/х ан.крови: мочевина - 2,45ммоль/л, биллирубин общ. - 50,2, своб. - 34,5, связ. - 15,7мкмоль/л, ALT-11, AST-25, 
ГГТП-16Е/л, белок-78г/л, СРБ-27мг/л. R-гр.ОГКN. УзИ ОБП: увеличение печени, селезенки, л/узел в проекции тела ПЖЖ. Ребенок переведен в РНПЦ детской онкогематологии для проведения биопсии (исключить ЛГМ): гнойно-некротический ЛА.

Выводы: все обнаруженные у пациента изменения следует стремиться объяснить одним заболеванием. Выполнение принципов диагностики позволит выявить редкую патологию, воссоздать полную картину заболевания.

\section{ИЗМЕНЕНИЕ ПОКАЗАТЕЛЕЙ ГЕМОСТАЗА И ГОМОЦИСТЕИНА НА ФОНЕ ДИСПЛАЗИИ СОЕДИНИТЕЛЬНОЙ ТКАНИ У ДЕТЕЙ}

Дорохов Н.А., Трофимова А.В., Скударнов Е.В., Лобанов Ю.Ф., Строзенко Л.А.

ФГБОУ ВО «Алтайский государственный медицинский университет» МЗ РФ, Барнаул

Введение. Жалобы на кровоточивость и кровотечения у детей различного возраста довольно распространены и вызывают беспокойство как самих детей, так и их родителей. Специалистам в этой проблеме важно понять причины кровоточивости и возможное влияние недифференцированной дисплазии соединительной ткани (НДСТ) на проявления кровоточивости, показатели гемостаза и изменение гомоцистеина как фактора, провоцирующего кровоточивость.

Цель. Установить клинико-лабораторные проявления патологии системы гемостаза и уровня гомоцистеина у детей на фоне дисплазии соединительной ткани.

Материалы и методы. В исследование включено 210 детей, обратившихся на прием к гематологу в возрасте от 1 до 17 лет с жалобами на повышенную кровоточивость. Критерии включения: наличие у ребенка жалоб на повышенную кровоточивость; отсутствие признаков наследственных нарушений соединительной ткани. Было сформировано две группы: І группа дети с клиническими проявлениями НДСТ (12 и более баллов по внешним признакам и 20 по висцеральным признакам) $(n=58)$; II группа контроля без клинических признаков НДСТ $(n=152)$. Исследование системы гемостаза: Активированное парциальное тромбопластиновое время (АПТВ), активность фактора фон Виллебранда, Агрегация тромбоцитов с адреналином, коллагеном, АДФ, ристомицином, уровень гомоцистеина крови.

Результаты. Наличие НДСТ у детей с повышенной кровоточивостью сопровождается гипокоагуляцией по АПТВ, снижением агрегации тромбоцитов с адреналином и АДФ. Повышение гомоцистеина отмечено в $46 \%$ с сильной прямой зависимостью у детей с НДСТ.

Заключение. У пациентов с повышенной кровоточивостью отмечено снижение агрегации тромбоцитов с адреналином коллагеном, АДФ, ристомицином, гипокоагуляция по АПТВ, снижение активности ф. Виллебранда и в $46 \%$ повышение уровня гомоцистеина. На фоне НДСТ отмечена в большей степени гипокоагуляция по АПТВ, снижение агрегации тромбоцитов с адреналином и АДФ, и прямая сильная связь гомоцистеина с уровнем активности ф. Виллебранда.

\section{ФРЕНУЛОПЛАСТИКА ПРИ АНКИЛОГЛОССИИ: КТО ВЛИЯЕТ НА РЕШЕНИЕ РОДИТЕЛЕЙ О ЕЕ ПРОВЕДЕНИИ СВОИМ ДЕТЯМ?}

Кроман Ю.О., Фоменко И.В., Деларю В.В.

ФГБОУ ВО «Волгоградский государственный

медицинский университет» Минздрава России,

Волгоград

Введение. Анкилоглоссия является часто встречающимся у детей стоматологическим заболеванием, предполагающим оперативное лечение (френулопластику). В специальной литературе подробно рассматриваются соответствующие медицинские вопросы и практически не уделяется внимания сопутствующим психологическим и биоэтическим аспектам. В частности, чьи мнения учитывают родители, соглашаясь на проведение френулопластики своим детям.

Цель исследования - выяснить, кто влияет на принятие решения родителями о проведении френулопластики своим детям.

Материалы и методы. Анкетирование родителей 129 детей, которым была проведена френулопластика при анкилоглоссии. В возрасте 3-6 лет данная операция была произведена 45,0\% детей, в 7-9 лет - 40,3\%, в 10-12 лет - 14,7\%. Мальчиков было 49,6\%, девочек $-50,4 \%$.

Результаты. Большинство родителей - 67,5\% считали, что врачи-стоматологи предоставили им достаточно полную информацию о предстоящей операции; 17,8\% - что их частично проинформировали; 2,3\% - что информации практически не было и $12,4 \%$ затруднились ответить.

33 родителя $(25,6 \%)$ согласие на данную операцию дали исключительно самостоятельно; 96 (74,4\%) после консультирований с другими людьми, их советов или знакомства с другими источниками.

Агенты влияния на решение этих 96 родителей о проведении операции (можно было указать несколько): другие врачи в других медицинских организациях для 37,5\%; найденная информация в Интернете - для 32,3\%; рекомендации, полученные в социальных сетях - для $17,7 \%$; советы членов семьи - для 16,7\%; мнения родителей, чьим детям уже сделали подобную операцию для - 14,6\%; советы друзей / подруг / сослуживцев, которые не имеют медицинского образования - для 6,3\%.

Заключение. Основными агентами влияния на согласие родителей являются лечащие врачи-стоматологи, которые, по мнению двух третей опрошен- 
ных родителей, предоставили им достаточно полную информацию. Однако каждый третий из четырех родителей дает согласие только после изучения другой информации, среди которых половина получают ее из общедоступных электронных СМИ. В тоже время в специальной литературе преобладает критическая оценка данных источников из-за частой ошибочности содержащихся в них сведений. Это следует учитывать врачам-стоматологам при информировании родителей.

\section{ГИПОКСИТЕРАПИЯ И ЭНТЕРАЛЬНАЯ ОКСИГЕНОТЕРАПИЯ В ЛЕЧЕНИИ НЕСПЕЦИФИЧЕСКИХ ВОСПАЛИТЕЛЬНЫХ ЗАБОЛЕВАНИЙ В ПОДРОСТКОВОЙ ГИНЕКОЛОГИИ}

Мисирова И.А., Борукаева И.Х., Карданова Л.Д. ФГБОУ ВО «Кабардино-Балкарский государственный университет им. Х.М. Бербекова», Нальчик

Введение. В последние годы проблема воспалительных заболеваний женских половых органов в детском и подростковом возрасте все больше привлекает внимание врачей акушеров-гинекологов. Несвоевременное и неадекватное лечение заболевания приводит к рецидивированию, хронизации, что может быть причиной серьезных осложнений: нарушения менструальной функции, бесплодия, невынашивания.

Цель исследования - выявление эффективности нормобарической интервальной гипокситерапии и энтеральной оксигенотерапии в лечении неспецифического сальпингоофорита у подростков 12-15 лет.

Материалы и методы. Обследовано 50 подростков 12-15 лет женского пола с хроническим неспецифическим сальпингоофоритом в стадии ремиссии. Всем пациенткам проводилось клиническое, гинекологическое и лабораторное обследование до и после гипокситерапии и оксигенотерапии. Также оценивались интенсивность боли внизу живота. Курс интервальной гипокситерапии составлял 15 сеансов вдыхания гипоксической смеси с 14\% кислорода; энтеральная оксигенотерапия заключалась в употреблении 300 мл кислородного коктейля в течение 15 дней.

Результаты. Применение гипокситерапии в комбинации с оксигенотерапией привело к достоверному уменьшению интенсивности боли внизу живота, уменьшению подавленности настроения. Снизилось количество лейкоцитов до 7,5 $\pm 0,1 \times 10^{9} /$ л, лимфоцитов до $23,5 \pm 0,02 \%$, СОЭ до $12 \pm 0,01$ мм/ч, что свидетельствовало об уменьшении хронического воспалительного процесса в придатках. По результатам УЗИ органов брюшной полости отмечалось улучшение кровоснабжения яичников и придатков, что привело к уменьшению гипоксических изменений и склерозирования. Об улучшении кислородного режима организма больных свидетельствовало повы-

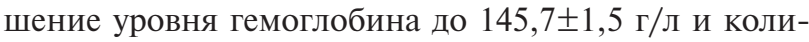
чества эритроцитов в крови до $4,7 \pm 0,01 \times 10^{12} / л$.

Заключение. Комбинированное применение интервальной гипокситерапии и энтеральной оксигенотерапии привело к достоверному улучшению клинического состояния больных с хроническим неспецифическим сальпингоофоритом, уменьшению болевого синдрома, нормализации лабораторных и инструментальных показателей. Интервальная адаптации к гипоксии стимулировала компенсаторные механизмы, а энтеральная оксигенотерапия повысила кислородную емкость крови больных, что привело к снижению воспалительного процесса в яичниках.

\section{ПРОБЛЕМА ДИАГНОСТИКИ УЗЛОВАТОЙ ЭРИТЕМЫ У ДЕТЕЙ \\ Морева Г.В., Селиванов О.К., Василевская А.В., Фатхуллаева А.ШІ. \\ ФГБОУ ВО Тюменский ГМУ Минздрава России, Тюмень ГБУЗ ТО «ОКБ №1», Тюмень}

Введение. Узловатая эритема - септальный панникулит, характеризующийся наличием глубоких эритематозных болезненных узлов преимущественно на нижних конечностях. Критерии дифференциального диагноза определяются клинически. Заболеваемость 1-5 случаев на 100000 населения в год. Статистика по детям неизвестна, в связи с малой распространенностью данного заболевания у этой группы населения.

Цель. Изучить клинико-лабораторные особенности течения и анамнеза узловатой эритемы у детей различных возрастных групп и пола в г. Тюмень за 2018-2019 гг.

Материалы и методы. Проведен ретроспективный анализ 50 историй болезни, из них 11 больных детей с УЭ, госпитализированных с предварительным диагнозом геморрагический васкулит, проходивших стационарное лечение в ГБУЗ ТО ОКБ №1 г. Тюмень за период 2018-2019 гг.

Результаты. Большинство заболевших -8 детей $(72,7 \%)$ - группа младшего школьного возраста. Дети поступали в стационар преимущественно весной и летом. Дебюту УЭ предшествовали частые ОРВИ, сопутствующими диагнозами при поступлении у $81,8 \%$ детей был острый бактериальный назофарингит, у 36,3\% функциональные нарушения ЖКТ. У больных $(81,8 \%)$ отмечалось острое начало заболевания с лихорадкой от $38,0^{\circ}$ до $39^{\circ}$. У всех детей в клинике выявлялся кожный синдром на нижних конечностях в виде красно-багровых узлов («шишек») с четкими границами и пастозностью окружающей ткани от 1 до 5 см в диаметре, болезненных при пальпации. В последующем узлы приобретают вид «синяка». Лабораторно УЭ проявляется повышением 
уровня СРБ у 6 детей $(54,5 \%)$, СОЭ у 9 детей $(72,7 \%)$ и нейтрофильным лейкоцитозом у 5 детей $(45,5 \%)$. Так же было отмечено повышение уровня антител к кардиолипину у 5 детей $(45,5 \%)$ и к цитруллинированному виментину у 4 детей $(36,4 \%)$.

\section{Заключение.}

1. УЭ чаще всего встречается у детей школьного возраста $(72,7 \%)$, различий по половым показателям не выявлено.

2. У всех больных анамнез свидетельствовал о высоком инфекционном индексе.

3. У $81,8 \%$ больных отмечалась высокая активность воспалительной реакции, сопровождающаяся лихорадкой и синдромом интоксикации средней степени тяжести.

4. У всех детей выявлялся кожный синдром в виде возвышающихся над кожей красно-багровых узлов с четкими границами, болезненных при пальпации.

\section{ТОПОГРАФО-ОПТИЧЕСКИЕ ПОКАЗАТЕЛИ ДОРЗАЛЬНОЙ ПОВЕРХНОСТИ ТУЛОВИЩА У ДЕВУШЕК ОТДЕЛЬНЫХ СОМАТОТИПОЛОГИЧЕСКИХ ГРУПП}

Орлов С.А., Юхвид Е.В., Ахматов В.Н., Орлова И.С. ФГБОУ ВО Тюменский ГМУ Минздрава России, ГБУЗ ТО ОКБ №2, Тюмень

Введение. Нарушения осанки и деформации позвоночного столба приводят к многомерным и разносторонним изменениям топографии многих анатомических структур. Для определения нарушений осанки и деформации позвоночного столба у девушек, представительниц различных соматотипов, после проведения антропологических измерений проводилось исследование дорзальной поверхности туловища оптико-топографическим методом «КОМОТ».

Цель исследования. Изучение нарушений осанки и деформации позвоночного столба у русских девушек 16-20 лет.

Материалы и методы. Топографическим методом «КОМОТ» проведено обсследование дорзальной поверхности туловища девушек 16-20 лет с учетом 35 оптико-топографических размеров у 90 девушек.

Результаты. Нами были определены средние значения и их ошибка для 35 наиболее значимых топографических показателей. Значение отношения длины позвоночного столба к ширине грудной клетки (RWL) у девушек астенического типа телосложения характеризуется минимальными пока-

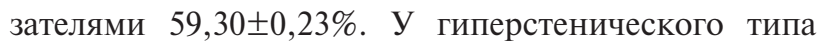
рассматриваемый показатель достигает максимума $67,80 \pm 0,39 \%$ и это различие является достоверным $(p<0,001)$. Для нормостеников это значение составляет $63,0 \pm 0,21 \%$, различие между рассматриваемыми группами является достоверным $(p<0,001)$. Значения угла разворота левой/правой лопатки GSL/R и расстояние угла левой/правой лопатки от срединной линии туловища DSL/R увеличивается от астеников $16,05 \pm 1,42$ и $64,56 \pm 1,57$ к гиперстеникам $21,52 \pm 0,91$

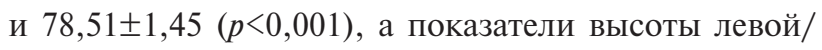
правой лопатки H1SL/R и «крыловидность» левой/ правой лопатки H2SL/R - наоборот, уменьшаются $(p<0,05$ и $p<0,001)$.

Заключение. От знания причин возникновения нарушений осанки зависит дальнейшее ведение и лечение пациента. При обследовании оптико-топографическим методом «КОМОТ» определены и описаны нормативные показатели в трех плоскостях для девушек без органических нарушений осанки.

\section{КЛИНИЧЕСКОЕ ОБСЛЕДОВАНИЕ ПАЦИЕНТОВ, ОБРАТИВШИХСЯ ЗА СТОМАТОЛОГИЧЕСКОЙ ПОМОЩЬЮ С ПОРАЖЕНИЯМИ ПАРОДОНТА Орлова Е.C.}

ФГАОУ ВО РНИМУ им. Н.И. Пирогова Минздрава России, Москва

Введение. Хеликобактериоз является наиболее распространенной хронической бактериальной инфекцией у человека, в то время, как исследования, касающиеся вопросов идентификации Helicobacter pylori (HР) в полости рта при воспалительных реакциях слизистой оболочки рта, носят весьма противоречивый характер. Эпидемиологические исследования свидетельствуют о том, что заражение НР начинается уже с раннего детского возраста

Цель исследования. Повышение эффективности лечения заболеваний слизистой оболочки рта у пациентов с Helicobacter pylori инфекцией.

Материалы и методы. Было обследовано 29 пациентов (16-18 лет) с воспалительными заболеваниями слизистой оболочки рта, ассоциированных с НР-инфекцией, а в группе сравнения - 22 пациента НР - не инфицированных. Экспресс-диагностику хеликобактериоза проводили «Хелик-скан» и уреазным тестом «Хелпил-тест».

Результаты. У пациентов молодого возраста с поражениями пародонта частота выявления латентной инфекции Helicobacter pylori составила 59,7\%. Стоматологический статус Helicobacter pylori - инфицированных пациентов отличался высокой интенсивностью кариеса зубов (КПУ (з) = $12,51 \pm 3,74)$, неудовлетворительным уровнем индивидуальной гигиены полости рта (OHIS $=1,94 \pm 0,55$; $\mathrm{WTC}=4,78 \pm 1,76)$, выраженным воспалением тканей пародонта (PMA $=53,60 \pm 8,14 \%, \mathrm{PI}=2,71 \pm 0,75$, $\mathrm{PBI}=2,38 \pm 0,73)$, смещением $\mathrm{pH}$ ротовой жидкости в кислую сторону $(6,87 \pm 0,137)$ и сниженным показателем неспецифического иммунитета слизистой обо-

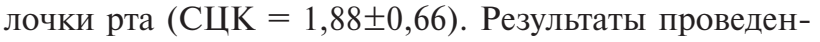
ной клинико-лабораторной сравнительной оценки 
стоматологического статуса пациентов и тенденция к утяжелению патологии пародонта на фоне хеликобактериоза, показали необходимость комплексного стоматологического лечения таких пациентов.

Заключение. В настоящее время, многие вопросы колонизации Нр слизистой оболочки рта до конца не изучены. Течение заболеваний, ассоциированных с инфекцией Н. pylori и эффективность проведения эрадикационной терапии, во многом зависит от рациональной антибиотикотерапии с учетом социальных аспектов проводимого лечения.

\section{ПРОБЛЕМЫ ПРИМЕНЕНИЯ ЛЕКАРСТВЕННЫХ ПРЕПАРАТОВ У ДЕТЕЙ}

Пономарева Ю.В., Науменко М.Л., Мезенцева О.Ю., Краснова К.ШІ.

ФГБОУ ВО «ВолгГМУ Минздрава России», Волгоград

Введение. Рациональная фармакотерапия в педиатрии связана не только с особенностями выбора и дозирования препаратов, но и необходимостью подбора оптимальной лекарственной формы с учетом индивидуальных особенностей ребенка. Терапевтический ответ может зависеть от возможности родителями выполнять рекомендации по назначению лекарственных средств (ЛС).

Цель исследования. Выявить и проанализировать основные проблемы применения ЛС в педиатрической практике.

Материалы и методы. Проведено анонимное анкетирование родителей дошкольников, проживающих в г.Волгограде, по вопросам применения ЛС у детей.

Результаты. В исследовании приняли участие 159 респондентов. Медиана возраста опрашиваемых 35 лет. 31,4\% респондентов (50 человек) отметили, что всегда получают от врача подробную информацию по применению ЛС; 4,4\% (7 человек) ответили, что никогда не получали таких инструкций. $44 \%$ родителей (70 человек) отметили, что не всегда удается следовать рекомендациям по приему ЛС в зависимости от приема пищи. Часто дети отказываются принимать ЛС, потому что им не нравится вкус (64,8\% опрошенных), для 30,2\% (48 человек) трудности были связаны с большим разовым объемом препарата. 10,7\% родителей (17 человек) хотя бы однажды испытывали трудности при приготовлении суспензии и ее дозировании, а $64,8 \%$ родителей (108 человек) отметили, что им приходилось разламывать таблетки без установленной производителем резки. $81,1 \%$ респондентов (129 человек) используют специальные мерные устройства для дозирования; $15,1 \%$ (24 человек) - обычные столовые приборы, а 1,9\% (3 человека) дают примерный объем ЛС. 41,5\% опрошенных (66 человек) отмечали возникновение аллергических реакций на прием ЛС в форме сиропов и суспензий.
Заключение. Недостаточный терапевтический эффект и возникновение нежелательных реакций при проведении фармакотерапии у детей могут быть связаны с проблемами применения ЛС. Многие родители испытывают сложности в дозировании препаратов ребенку. Более половины респондентов отмечают, что дети отказываются принимать препарат из-за неприятного вкуса или большого разового объема, в трети случаев родителям не удается выполнять рекомендации о назначении препарата в зависимости от приема пищи.

\section{САМОСТОЯТЕЛЬНАЯ ПРАКТИКА ПРИМЕНЕНИЯ ОБЕЗБОЛИВАЮЩИХ ПРЕПАРАТОВ В ПЕДИАТРИЧЕСКОЙ ПРАКТИКЕ: ЕСТЬ ЛИ ВРЕД? \\ Самороднова Е.А., Сахабетдинов Б.А. \\ ФГБОУ ВО Казанский Государственный Медицинский Университет МЗ РФ}

Введение. Болевой синдром у детей характеризуется полифакторностью и полиэтиологичностью, что всегда требует персонифицированного подхода к терапии. Степень выраженности боли связана не только с конкретным патологическим процессом, но и с выраженной эмоциональной составляющей, поэтому зачастую родители или сами дети применяют для купирования боли анальгетики без предварительной консультации с медработником.

Цель исследования. изучить практику самостоятельного лечения боли у детей и подростков.

Материалы, методы: проведено анонимное анкетирование 48 детей и подростков в возрасте от 10 до 18 лет (мода - 15 лет). Гендерное распределение было следующим : 70,8\% - девочки, 29,2 \%мальчики.

Результаты. Все респонденты хотя бы однократно отмечали болевой синдром различного происхождения с интенсивностью от 4 до 7 баллов по субъективной 10-балльной шкале, со следующей частотой: ежедневно - 20,8 \%, еженедельно - 20,8 \%, ежемесячно - $25 \%$, реже - 37,5\% ; различной локализации: в области живота - 62,5\%, цефалгии - 58,3 $\%$, артралгии - 29,2 \%, кардиалгии - 18,8 \%, денталгии $-14,6 \%$.

Более $80 \%$ опрошенных купируют боль с помощью перорального и/или местного применения нестероидных противовоспалительных средств (НПВС) , остальные используют препараты группы антацидов, спазмолитиков и комбинированные средства. Только 53,3\% опрошенных обратились к врачу с целью диагностики и назначения лечения, а более $60 \%$ детей отмечают начало самостоятельного приема анальгетиков с $10-14$ лет.

Для терапии болевого синдрома $89 \%$ опрошенных детей и подростков принимают анальгетики не более 
2-х раз в день, остальные - чаще. Более $80 \%$ респондентов отметили, что хорошо осведомлены о побочных действиях НПВС, но 6,3\% - уверены в отсутствии побочного эффекта, при этом более $18 \%$ отметили у себя жалобы после длительного применения в виде чувства дискомфорта, колющей или жгущей боли в эпигастрии, 6,3\% - аллергии.

Заключение. В ходе исследования была установлена широкая распространенность практики самостоятельного применения анальгетиков для лечения болевого синдрома, выявлены негативные тенденции в виде несвоевременного обращения к врачу при болевом синдроме, длительного бесконтрольного применения НПВС детьми и подростками, недооценки пациентами риска побочных эффектов.

\section{ВЛИЯНИЕ СТРОГОЙ ЭЛИМИНАЦИОННОЙ ДИЕТЫ КОРМЯЩЕЙ МАТЕРИ \\ НА ПСИХОЭМОЦИОНАЛЬНОЕ СОСТОЯНИЕ СЕМЬИ}

Сахабетдинов Б.А., Васильев Э.А., Габдрахманова А.И., Валитов Б.P.

ФГБОУ ВО Казанский Государственный Медицинский Университет МЗ РФ

Введение. В настоящее время проблемы пищевой аллергии (ПА) с различными ее проявлениями неуклонно возрастают. Заболевание как правило дебютирует с грудного возраста, проявлениями со стороны ЖКТ и кожных покровов. В большинстве случаев высокоаллергенными агентами, запускающие аллергическую реакцию у младенцев, выступают продукты входящие в традиционную кухню среднестатистической русской семьи. Основным профилактическим и лечебным мероприятием, при возникновении данной патологии, является элиминационная диета (ЭД), что может отрицательно сказаться на психоэмоциональном состоянии матери и всей семьи.

Цель исследования: изучить влияние ЭД кормящей матери на психоэмоциональное состояние семьи.

Материалы и методы исследования: было проведено интервьюирование 87 женщин, придерживавшихся строгой элиминационной диеты в период грудного вскармливания.

Результаты. В опросе принимали женщины в возрасте от 21 до 35 лет. У 92\% семей ребенок с ПА был первым в семье. В ходе исследования были заданы вопросы касательно психоэмоционального состояния матери и остальных членов семьи во время ЭД. По итогам исследования респонденты были поделены на две группы. В первую группу (1г) вошли семьи, где диеты придерживалась только мать- составил $60 \%$ от общего числа. Во второй (2г) оказались семьи, в которой все члены придерживались диеты- составила 40\%. 83\% опрошенных из 1г отметили плохую переносимость данной диеты, ссылаясь на: снижение настроения, плохой сон, раздражительность, трудность передерживания диеты, когда окружение питается иначе, возникновение конфликтных состояний с другими членами семьи, что нередко приводило к срывам диеты и обострению состояния ребенка. Оставшиеся $15 \%$ отметили удовлетворительное принесение, без особенностей. Во 2г напротив большинство- 74\%, отметили быстрое приспособление и удовлетворительное перенесение. У остальных $26 \%$ в семье наблюдались противоречия и конфликтные состояния, связанные с диетой.

Выводы. Исходя из результатов исследования можно сделать вывод, что соблюдение матерью строгой ЭД может отрицательно сказаться на психоэмоциональном состоянии матери и семьи в целом. Это влияние уменьшается во много раз, если семья поддерживает мать, и сама придерживается данной ЭД.

\section{ЛЕЧЕНИЕ БОЛЕВОГО СИНДРОМА У ДЕТЕЙ ГРУДНОГО И РАННЕГО ДЕТСКОГО ВОЗРАСТА ГОМЕОПАТИЧЕСКИМИ СРЕДСТВАМИ. ЕСТЬ ЛИ ЭФФЕКТИВНОСТЬ? \\ Сахабетдинов Б.А., Габдрахманова А.И., Васильев Э.А., Валитов Б.Р. \\ ФГБОУ ВО Казанский Государственный Медицинский Университет МЗ РФ}

Введение. Наличие или отсутствие болевого синдрома, так же как значения артериального давления, частоты сердечных сокращений, температуры и сатурации, является одним из важных показателей состояния здоровья пациента. Родители зачастую прибегают в терапии болевого синдромак гомеопатическим средствам, учитывая его преимущество отсутствие побочных эффектов.

Цель исследования: изучить распространение терапии боли у детей гомеопатическими средствами и оценить ее эффективность.

Материал исследования: анкетирование 91 родителя детей в возрасте от 7 месяцев до 6 лет (медиана 3 года), купирующих болевой гомеопатическими средствами.

Результаты. В ходе опроса были учтены возрастные особенности детей - 4 года $(13,2 \%), 3$ года $(12,1 \%), 2$ года $(14,2 \%), 1$ год $(8,8 \%), 5$ и 6 лет по 5,8\%, дети 7-11 месяцев составили - 45,9\%. В ходе сбора анамнеза была отмечена распространенность болевого синдрома по топике : зубная боль - $59 \%$, головная боль $-45 \%$, боль в области живота $-23 \%$. Частота боли в $63 \%$ не превышала 2- х эпизодов острой боли в течение года, остальные более 3 - х эпизодов. Предпочтение отдавалось пероральным препаратам в виде драже, сиропов, капсул, таблеток, в состав которых входят ингредиенты растительного 
и животного генеза (ромашка, кора дуба, сахароза, фруктоза, желатин, пчелиный воск, соли натрия и кальция и др.), обладающие преимущественно приятным сладким вкусом, которые выполняли отвлекающую функцию, что несколько купировало болевой синдром у ребенка. $28 \%$ родителей отметили полное купирование болевого синдрома, $45 \%$ - частичное купирование, остальные - отметили крайне низкую эффективность, требуюшую добавления нестероидных противовоспалительных препаратов. Наибольшая эффективность гомеопатических средств отмечена при лечении зубной боли.

Заключение. В ходе исследования обнаружено высокое распространение терапии болевого синдрома гомеопатическими средствами. Высокая эффективность отмечена у $28 \%$ опрошенных родителей, $45 \%$ отметили частичное купирование. Наиболее эффективны гомеопатическиесредства в лечении зубной боли.

\section{ТРОМБОЦИТОПАТИИ У ДЕТЕЙ С НЕДИФФЕРЕНЦИРОВАННОЙ ДИСПЛАЗИЕЙ СОЕДИНИТЕЛЬНОЙ ТКАНИ}

Скударнов Е.В., Выходиева Г.И., Колесникова О.И., Строзенко Л.А., Малюга О.М., Мироненко И.И., Зенченко О.А., Волкова Ю.В.

ФГБОУ ВО «Алтайский государтвенный медицинский университет» МЗ РФ, Барнаул

Актуальность. Одной из частых причин обращений детей к врачу педиатру является наличие петехиальной сыпи, у части детей в сочетании с носовыми кровотечениями, которые возникали спонтанно.

Цель и задачи исследования. Уточнить этиологические причины наличия кровоточивости у детей различных возрастных групп.

Материал и методы исследования. Проведено обследование 72 детей в возрасте от 2 лет до 17 лет (средний возраст составил $12 \pm 3,5$ лет), которые обратились к врачу с жалобами на наличие петехиальной сыпи. В общей группе больных преобладали мальчики 41 (56,9\%) из 72 обследованных. Чаще наличие кровоточивости и сыпи отмечалось у детей школьного возраста, что вероятно связано с высокой физической активностью, занятием физкультурой и спортом. При осмотре детей мы отмечали наличие признаков недифференцированной дисплазии соединительной ткани (НДСТ). Всем больным проведено исследование системы гемостаза (фактор Виллебранда, количество и функцию тромбоцитов, адгезия и агрегация тромбоцитов). У большинства пациентов $(70,7 \%)$ появление сыпи и кровоточивость из носа возникала спонтанно, и только у 27 из 72 детей под действием провоцирующих факторов, таких как физическая нагрузка, эмоциональное и умственное перенапряжение, механическое воздей- ствие, изменениями погодных условий. При оценке объективного статуса у детей исследуемой группы мы обращали внимание на выявление стигм дисэмбриогенеза, как одного из проявления мезенхимальной дисплазии соединительной ткани. В общей группе больных признаки НДСТ выявлены у 58 $(80,5 \%)$ из 72 детей. Анализ сосудисто-тромбоцитарного звена гемостаза свидетельствовал о наличии тромбоцитарных дисфункций у значительной части детей с признаками НДСТ. Обследование позволяло выявлять наличии парциальной или развернутой тромбоцитопатии у 84,2\% детей с признаками ДСТ, снижение уровня фактора Виллебранда у $78 \%$ детей. Тромбоцитарные дисфункции у наших больных лабораторно подтверждалась снижением уровня фактора Виллебранда и замедлением агрегации тромбоцитов, что и служило причиной обращения детей.

Выводы. Таким образом, нами отмечено частое сочетание тромбоцитопатии и дисплазии соединительной ткани, что необходимо учитывать при обследовании детей с НДСТ.

\section{ДИНАМИКА ПОКАЗАТЕЛЕЙ А1-ТИМОЗИНА, СОМАТОТРОПНОГО ГОРМОНА И ИНСУЛИНОПОДОБНОГО ФАКТОРА РОСТА-1 У БОЛЬНЫХ ЮВЕНИЛЬНЫМ РЕВМАТОИДНЫМ АРТРИТОМ НА ЭТАПЕ САНАТОРНО-КУРОРТНОГО ЛЕЧЕНИЯ С ВКЛЮЧЕНИЕМ МЕТОДА БИОРЕЗОНАНСНОЙ ВИБРОСТИМУЛЯЦИИ}

Соболева Е.М., Каладзе Н.Н. ФГАОУ ВО «КФУ им. В.И. Вернадского», Медицинская академия им. С.И. Георгиевского (структурное подразделение), Симферополь, Россия

Цель исследования - оценить влияние санаторно-курортного лечения с использованием метода биорезонансной вибростимуляции на показатели функциональной активности тимуса, соматотропной функции гипофиза и концентрацию ИФР-1 у больных ювенильным ревматоидным артритом.

Материал и методы исследования. Обследовано 50 пациентов с ювенильным ревматоидным артритом. Воздействие целенаправленной биологической коррекции (аппарат «БРС-2М») проводилось насадкой В, режим интенсивности I на область проекции тимуса (продолжительность процедуры 3 минуты). Курс лечения 8-10 процедур, проводимые через день. Влияние санаторно-курортной реабилитации на состояние функциональной активности тимуса оценивали по динамике его основного гормона- $\alpha 1$-тимозина, гипофиза-по концентрации соматотропного гормона (СТГ) и периферического трансмиттера-инсулиноподобного фактора роста-1 (ИФР-1). Контрольную группу составили 15 здоровых сверстников. 
Результаты. У больных ювенильным ревматоидным артритом выявлено достоверное (по сравнению с контрольной группой) снижении уровня $\alpha 1$-тимозина, (связанное с высокой активностью заболевания и прогрессировавшее в зависимости от его стажа), снижении соматотропной функции гипофиза (наиболее существенное снижение уровня СТГ отмечалось у детей с системной формой заболевания и при 1-ой степени активности), повышении уровня ИФР-1. Проведенное стандартное санаторно-курортное лечение оказывало нормализующий эффект на динамику исследуемых параметров: повышение низких уровней $\alpha 1$-тимозина и СТГ, а включение метода БРВС позволяло получить дополнительный корригирующий эффект.

Заключение. У больных ювенильным ревматоидным артритом выявлены изменения функциональной активности тимуса, соматотропной функции гипофиза и ИФР-1. Проведенное стандартное санаторно-курортное лечение оказывало нормализующий эффект на динамику исследуемых показателей гормонального статуса: повышение низких уровней a1-тимозина и СТГ. Включение метода БРВС на область тимуса в комплекс санаторно-курортного лечения больных ювенильным ревматоидным артритом позволило получить дополнительный корригирующий эффект.

\section{ОЦЕНКА УРОВНЯ ГРАМОТНОСТИ ШКОЛЬНИКОВ В ВОПРОСАХ ЗДОРОВОГО ПИТАНИЯ \\ Соловьева Ю.В., Летучая Т.А., Горелова Ж.Ю., \\ Костин А.Г., Зарецкая А.Р. \\ ФГАУ «НМИЦ здоровья детей» Минздрава России, Москва}

Введение. Изучение знаний о здоровом питании остается важной задачей в организации питания школьников и обеспечения их полноценным питанием, в соответствии с пищевыми предпочтениями. Своевременная коррекция сформировавшихся знаний, пищевых привычек необходима для правильного формирования навыков здорового питания, составления здорового рациона и профилактики развития алиментарно-зависимых заболеваний.

Цель исследования. Оценка уровня грамотности школьников в вопросах здорового питания.

Материалы и методы. Обследовано 28 школьников 5 классов. Анкетирование проводилось по разработанному опроснику, согласно международным требованиям к валидации инструментов оценки. Использовали гигиенические, статистические, антропометрические методы.

Результаты. Анализ обследования и опроса по пищевой грамотности школьников в отношении выбора блюд, продуктов питания, сбалансирован- ности рациона, частоты приема пищи показал следующее: мальчики имели избыточную массу тела по сравнению с девочками, рост мальчиков ниже, чем у девочек. Рацион считали сбалансированным $79 \%$ участников, частично сбалансированным - 7\%, и не сбалансированным - 14\%. 4-5 раз в сутки питались $-68 \%, 3$ раза в сутки употребляли пищу $-4 \%$, менее 3 -х раз в день - $28 \%$ обследованных. Завтракали дома $57 \%$ детей, не завтракали - 20\%, иногда завтракали - 37\%. Знали о пользе и ежедневно употребляли фрукты 79\% школьников. Рыбу, как здоровый продукт употребляли - 2-3 раза в неделю-14\% обучающихся, иногда употребляли $-54 \%$, не употребляли вообще - 32\%. Пользу овощей отметили $-11 \%$ детей, риса и картофеля $-18 \%$. Сладости не употребляли-14\%, иногда употребляли - 43\%, ежедневно употребляли-43\%. Избыточно калорийным свой рацион считают $70 \%$, умеренно калорийным $-23 \%$ и $7 \%$ оптимальным по калорийности. Про свой индекс массы тела знают-25\%, не знали, что это такое и не знали свой индекс массы тела $-75 \%$ учеников. Отметили, что питание влияет на успеваемость в школе положительно $10 \%$ учащихся, не уверены $-20 \%$, не оказывает $-70 \%$.

Заключение. Школьники, имеющие правильные пищевые привычки владели знаниями и навыками в области здорового питания. Обучающиеся (75\%) с частично сформированными знаниями нуждаются в коррекции полученных знаний с использованием современных информационных технологий.

\section{ГИПЕРИММУНОГЛОБУЛИНЕМИЯ D С СИНДРОМОМ ПЕРИОДИЧЕСКОЙ ЛИХОРАДКИ (HIDS): СЛУЧАЙ ИЗ ПРАКТИКИ \\ Сомова T.М. \\ БУ ВО ХМАО-Югры Сургутский государственный университет, Сургут}

Введение. Гипер-IgD-синдром - одна из форм синдрома дефицита мевалонаткиназы (далееСДМК) - редкого заболевания, которое наследуется по аутосомно-рецессивному типу и вызывается мутацией/мутациями в гене мевалонаткиназы (далееMVK). СДМК относится к группе синдромов наследственной периодической лихорадки.

Цель - представить клиническое наблюдение аутовоспалительного заболеания у пациента.

Материалы и методы. Проведен анализ клинического случая гипериммуноглобулинемии D (синдрома дефицита мевалонаткиназы) у девочки 5 лет.

Результаты. Девочка Р., от 4 беременности на фоне отягощенного акушерского анамнеза (2-выкидыша на раннем сроке), 2-х срочных родов. С 2-х летнего возраста, после перенесенной ветряной оспы, с частотой каждые 20-30 дней стали отмечаться приступы - лихорадки до 39-40 градусов, сопро- 
вождающиеся болями в животе, рвотой, жидким стулом, налетами на миндалинах. Антибактериальная и жаропонижающая терапия не эффективны. Приступ купируется приемом преднизолона внутрь в дозировке 1,5-2мг/кг. Вне приступа состояние удовлетворительное, физическое развитие гармоничное по мезосоматическому типу. Интеллект сохранен. По внутренним органам без особенностей. Физиологические оправления в норме.

По данным общеклинических исследований вне приступа - без изменений. Иммунологические исследования (экстрагируемые ядерные антитела, антитела к кардиолипину (суммарные), антитела к односпиральной/двуспиральной ДНК, антитела к циклическим цитруллинированным пептидам, антитела к фосфолипидам) - все показатели в пределах нормы.

В результате генетического тестирования редких аутовоспалительных синдромов (дефицит мевалонаткиназы (MVK), TRAPS- синдром), а также семейной средиземноморской лихорадки (патологического генотипа гена MEFV) - обнаружена гетерозиготная мутация p.V377I (rs28934897). Выявление патологических мутаций в 11 экзоне (V377I) и 9 экзоне (I268T) гена MVK подтверждает диагноз синдрома дефицита мевалонаткиназы (СДМК).

Проведена коррекция терапии, ребенку назначено человеческое моноклональное антитело $\operatorname{IgG1/каппа~}$ изотипа к интерлейкину-1 $\beta$ (канакинумаб).

Заключение. Всем детям с синдромом периодической лихорадки показано генетическое исследование для своевременной диагностики редких аутовоспалительных заболеваний, назначение патогенетической терапии и тем самым улучшение качества жизни.

\section{ЛАПАРОСКОПИЧЕСКАЯ АДРЕНАЛЭКТОМИЯ У НОВОРОЖДЕНЫХ И ДЕТЕЙ ГРУДНОГО BOЗРАCTA}

Сухоцкая А.А., Баиров В.Г., Ганиев Ш.С., Салиев М.В., Щербаков А.А., Витовщик М.Г., Малышева Д.А.,

Каганиов И.М.

Федеральное государственное бюджетное учреждение, Национальный медицинский исследовательский центр, Санкт-Петербург, Россия

Введение. Опухоли надпочечников относятся к одному из важных и трудных в диагностическом плане разделов детской урологии, хирургии, онкологии. Опухоли надпочечников являются редкой патологией и составляют не более $0,6 \%$ всех злокачественных опухолей. В настоящее время благодаря широкому внедрению в повседневную клиническую практику УЗИ, КТ, МРТ, резко возросло число обнаруживаемых новообразований в забрюшинном пространстве.

В последние десятилетия в детской хирургии и урологии отмечается рост применения малоинва- зивных вмешательств, для удаления образований надпочечников все чаще используется лапароскопический доступ, применение данного подхода у детей первого года жизни недостаточно изучено.

Цель исследования - улучшения результатов путем применение малоинвазивного доступа при адреналэктомии у новорожденных и детей грудного возраста.

Материал и методы. За 5-лет с 2016 по 2021гг в отделении детской хирургии ФГБУ «НМИЦ им. В.А. Алмазова» лапароскопическим доступом произведено удаление образований надпочечника у 10 детей. Средний возраст 6,5мес (от 1мес до 12мес). Мальчиков было 4, девочек - 6. Образование локализовалось справа у 4, слева у 6. Средний объем опухоли по данным компьютерной томографии составил $8,3 \mathrm{~cm}^{3}$ (от 3,5 $\mathrm{cm}^{3}$ до $12,4 \mathrm{~cm}^{3}$ ).

Результаты. Всем детям проводилась стандартная адреналэктомия из лапароскопического доступа, с установкой 3 троакаров, у 1 потребовалась установка дополнительного троакара. Среднее время вмешательства составило 95 мин (от 75 до 170). По данным гистологического заключения: нейробластома у 6, недифференцированная нейробластома -1 , ангиофибролипома -2 , мезобластная нефрома -1 .

Случаев конверсии, интра- и послеоперационных осложнений не отмечено. Летальности и рецидива опухоли у данной группы пациентов не было.

Заключение. При диаметре образования надпочечника до $13 \mathrm{~cm}^{3}$ и отсутствии прорастания опухоли в магистральные сосуды может быть успешно применена адреналэктомия лапароскопическим доступом у новорожденных и детей грудного возраста.

\section{МИКРОВОЛНОВАЯ РАДИОТЕРМОМЕТРИЯ ЛОКТЕВЫХ СУСТАВОВ У ДЕТЕЙ ПРИ ЮВЕНИЛЬНОМ РЕВМАТОИДНОМ АРТРИТЕ - МЕТОД РАННЕГО ВЫЯВЛЕНИЯ ПЕРИАРТИКУЛЯРНОГО ВОСПАЛЕНИЯ}

Тараканов А.В., Лебеденко А.А. , Ладанова Е.С. ФГБОУ ВО «Ростовский государственный медицинский университет» Минздрава России, Ростов-на-Дону

Введение. Объективизация воспалительных и деструктивных процессов, происходящих в суставе и окружающих тканях у пациентов с ювенильным ревматоидным артритом (ЮРА), решается методами визуализации: рентгенография, ультразвук и МРТ. Однако, эти методы имеют свои показания, недостатки и ограничения, особенно в педиатрии. Для измерения температуры в суставе, как основного симптома воспаления, предлагается метод микроволновой радиотермометрии. Он основан на измерении интенсивности теплового излучения тканей в микроволновом (РТМ) и инфракрасном диапазонах (ИД). Положительные свойства: отсутствие лучевой нагрузки, проведение многократных измерений, 
неинвазивность, наглядность результатов, отсутствие противопоказаний.

Цель исследования. Определить глубинную температуру в проекции локтевого сустава у здоровых детей обоего пола 8-17 лет для формирования базы данных при ранней диагностике ЮРА.

Материалы и методы. Дети обследовались в «ПНЛ физических методов диагностики и лечения» РостГМУ и детском санаторно- оздоровительном лагере «Мир» (г. Таганрог). В когорте детей 1 и 2 групп здоровья девочек было 47 (8-12 лет, $n=29 ; 13$-17 лет, $n=18$ ), а мальчиков 51 (8-12 лет, $n=33$; 13-17 лет, $n=18)$. Было также обследовано 29 больных ЮРА. РТМ глубинной и кожной температур проводилась в одной проекции одномоментно на комплексе РТМ-02-РЭС (Москва), после адаптации к температуре помещения (23-25С $)$; по определенному протоколу (9 постановок), в проекции соответствующих анатомических структур.

Результаты. У детей 1 и 2 групп здоровья в возрасте 8-12 лет не выявлено достоверных различий в зонах измерения, отсутствует термоасимметрия между правым и левым суставом. $\mathrm{T}=\min$ в среднем $34,2^{\circ} \mathrm{C}$, a $\mathrm{t} \max -35,4^{\circ} \mathrm{C} . \Delta \mathrm{T}=\mathrm{t} \max -\mathrm{t} \min -1,2^{\circ} \mathrm{C}$. У детей 13-17 лет отмечается повышение температуры в локтевых суставах. Так, у девочек температура достоверно выше: $\mathrm{t} \min$ в среднем $34,7^{\circ} \mathrm{C}$, a t $\max -36,1^{\circ} \mathrm{C}$, у мальчиков соответственно на $0,3-0,4^{\circ} \mathrm{C}$ ниже. Отмечается достоверное повышение $\Delta \mathrm{T}$ у девочек до $1,4^{\circ} \mathrm{C}$, по сравнению с мальчиками $(\Delta \mathrm{T}=1,1)$. Изменения у больных ЮРА зависели от давности заболевания: повышение $\mathrm{t}$ max в проекции периартикулярных тканей были выше при длительности заболевания 1-2 года (1 гр.) и снижались в группах 3-5 лет и 6-10 лет. $\Delta$ Т в 1 группе составляла около $1,8^{\circ} \mathrm{C}$. Отмечалась значительная термоасимметрия суставов. Длительность заболевания приводила к смещению $\Delta \mathrm{T}$ в проекцию сустава.

Заключение: РТМ позволяет оценить глубинную температуру суставов у детей, $\mathrm{t} \min$ и $\mathrm{t} \max$, а при заболевании - выявлять термоасимметрию на разных этапах болезни, что позволяет оценить активность воспалительного процесса.

\section{КОМПЛЕКСНОЕ ПОСМЕРТНОЕ МРТ И МОРФОЛОГИЧЕСКОЕ ИССЛЕДОВАНИЕ ЛЕГКИХ ПРИ ВРОЖДЕННОЙ ДИАФРАГМАЛЬНОЙ ГРЫЖЕ ДЛЯ ОЦЕНКИ ЭФФЕКТИВНОСТИ ЛЕЧЕНИЯ}

Туманова У.Н., Быченко В.Г., Тетруашвили Н.К., Щеголев А.И.

ФГБУ НМИЦ АГП им. академика В.И. Кулакова

Минздрава России, Москва

Введение. Врожденная диафрагмальная грыжа (ВДГ) у новорожденных служит основанием для проведения оперативного лечения, исход которого в основном зависит от степени гипоплазии легких.
Цель исследования - изучить МРТ и морфологические характеристики легких при (ВДГ) у погибших новорожденных.

Материалы и методы. Проведен анализ тел 69 погибших новорожденных. Группы $1(n=16)$ и $2(n=23)$ составили новорожденные, страдавшие ВДГ и умершие после операции и без нее соответственно. Группу $3(n=30)$ составили тела новорожденных, умерших от врожденных аномалий развития при отсутствии пороков легких. После констатации смерти до аутопсии проводили МРТ. Определяли площади поперечного сечения правого и левого легкого на уровне среза их максимального размера и поперечный периметр грудной клетки. Рассчитывали легочно-торакальное соотношение (ЛТС). При аутопсии оценивали массу и микроскопическое строение ткани легких.

Результаты. При посмертной МРТ установлено, что в группе 1 средние значения площади легкого на стороне грыжи меньше контрлатерального на $30 \%$, тогда как в группе 2 площадь сечения ипсилатерального легкого в 1,7 раза меньше площади сечения легкого на контралатеральной стороне $(p<0,05)$. При этом средние значения площадей сечения легких на ипсилатеральной и контрлатеральной сторонах в наблюдениях группы 1 превышали соответствующие значения группы 2 в 2,6 раза $(p<0,05)$. Значения ЛТС имели минимальные значения в группе 2. В наблюдениях группы 1 средние значения ЛТС превышали показатели группы 2 в 2,5 раза $(p<0,05)$, оставаясь при этом меньше значений группы 3 на 31,5\% ( $p>0,05)$. При аутопсии средние значения массы легкого на стороне поражения и контралатеральной стороне в группе 1 превышали показатели группы 2 в 5,1 и в 3,4 раза соответственно $(p<0,05)$. При микроскопическом изучении гистологических препаратов ткани обоих легких в группах 1 и 2 количество радиальных альвеол составляло 2-3, что указывало на их гипоплазию.

Заключение. Гипоплазия легких определяет танатогенез при ВДГ. Значения ЛТС $<5$ свидетельствуют о гипоплазии легких как непосредственной причине смерти новорожденного независимо от лечения. Оперативное лечение приводит к увеличению размеров легких, но не всегда устраняет их гипоплазию.

\section{ЗДОРОВЬЕРАЗРУШАЮЩИЕ ФОРМЫ ПОВЕДЕНИЯ ПОДРОСТКОВ: ВОЗРАСТНЫЕ И ГЕНДЕРНЫЕ ОСОБЕННОСТИ, ЗАВИСИМОСТЬ ОТ МЕСТА ПРОЖИВАНИЯ \\ Утриванов А.В., Мещеряков В.В. \\ Сургутский государственный университет, Сургут}

Введение. По данным ВОЗ основными факторами риска здоровья подростков являются алкоголь, наркотики, курение, насилие, психическое здоровье, проблемы с питанием и недостаточная осведомленность 
о репродуктивном здоровье. Цель. Исследовать распространенность, структуру и гендерные особенности здоровьеразрушающих форм поведения подростков 15-18 лет в зависимости от места проживания. Материалы и методы. Проведено одномоментное сплошное когортное исследование - анонимное анкетирование 148 подростков 10-11 классов школ г.г. Москва, Сургут и поселка Приобье ХМАО-Югры. Разделы анкеты: психологическое состояние семьи, курение, употребление алкоголя и наркотиков, репродуктивное здоровье, пищевое поведение. Статистические методы - хи-квадрат, Краскела-Уоллиса, углового преобразования Фишера. Результаты. Удельный вес курящих составил $17 \%$, употребляющих наркотики - 6\%, индекс пачка/ лет среди курящих - 0,5[0,25;1,35] без статистически значимых гендерных различий и места проживания $(p>0,05)$. Употребление алкоголя отметили $61 \%$ подростков. Девушки характеризовались более ранним возрастом дебюта употребления алкоголя, чем юноши (девушки - 14\% в 10-12 лет, 32\% в 13-14 лет; юноши $42 \%$ в 15 и более лет, $p<0,01)$. В возрасте младше 10 лет $13 \%$ подростков в поселке и $3 \%$ в городах впервые пробовали алкоголь $(p<0,05)$. Возрастной пик дебюта употребления алкоголя в городах и поселке составил 15 и более лет (у $25 \%$ в городах и $39 \%$ в поселке, $p<0,05$ ). Чаще подвергались психологическому/физическому воздействию девушки, чем юноши: со стороны сверстников - $39 \%$ и $8 \%$; со стороны родственников - $28 \%$ и $7 \%$, соответственно, $p<0,01$. В городах сексуально активных подростков больше, чем в поселке (27\% и $8 \%$, $p<0,05)$ без гендерных различий $(p>0,05)$. Уровень знаний о строении и функциях репродуктивной системы по удельному весу правильных ответов у девушек оказался выше ( $37 \%$ и 23\%, $p<0,05)$. Девушки чаще, чем юноши, считают наличие у себя лишнего веса и соблюдают без медицинских показаний гипокалорийную диету (девушки $-45 \%$, юноши $-25 \%, p<0,05$ ). Заключение. Установленные закономерности определяют необходимость разработки и реализации образовательных программ для подростков с участием врачей и психологов отделений медико-социальной помощи поликлиник с учетом возрастных, гендерных особенностей и места проживания.

\section{МУЛЬТИМОДАЛЬНАЯ АНЕСТЕЗИЯ И АНАЛЬГЕЗИЯ ПРИ РЕКОНСТРУКТИВНО - ВОССТАНОВИТЕЛЬНЫХ ОПЕРАЦИЯХ ПЕРЕНЕСЩИЕ АБДОМИНАЛЬНЫЕ ОПЕРАЦИИ У ДЕТЕЙ РАННЕГО ВОЗРАСТА \\ Файзиев О.Я., Сатвалдиева Э.А., Юсупов А.С. Ташкентский педиатрический медицинский институт. Ташкент}

Введение. Одной из актуальных проблем, стоящей сегодня перед врачами анестезиологами-реаниматологами является прогнозирование и предупреждение развития осложнений на этапах анестезии и в послеоперационном периоде.

Цель исследования - оценить эффективность использования мультимодальной анестезии и анальгезии при реконструктивно-восстановительных операции у детей раннего возраста с оценкой центральной гемодинамики.

Материалы и методы. Перспективное исследование проводились в клиники ТашПМИ у 32 детей, методом мультимодальной анестезии и анальгезии с периода 2018 по 2020 г. Осуществлялось операции по поводу болезни Гиршпрунга, средний возраст

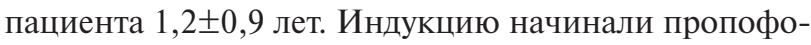
лом $1 \%$ - 2-3 мг/кг, фентанилом 3 мкг/кг, ардуаном 0,08 мг/кг, в/в, с последующей интубацией трахеи и переводом на ИВЛ.

Результаты. Анализ гемодинамики показал повышение САД, ДАД и АД ср на 2 этапе на 8,6\%, 24,5\% и $14,8 \%$ соответственно. ЧСС, МОК и УО одновременно повышались на $5,8 \%, 15,5 \%$ и $18,3 \%$ соответственно. На 3 этапе отмечена относительная стабилизация гемодинамики по отношению к предыдущему этапу, а в отношении к 1 этапу САД, ДАД И АД ср. оставались повышены на 12,2\% (p0,05), 27,1\% (p0,05) и $16,3 \%(\mathrm{p} 0,05)$ соответственно. ЧСС, МОК и УО оставались стабильными на этапах поддержания анестезии, повышенными по отношению к 1 этапу на $7,3 \%$ ( p 0,05), 17,7\% (p0,05)и 26,5\% (p0,05). На 4 этапе - САД, ДАД и АД ср оставались относительно стабильными, повышенными к исходу с заметным снижением по отношению к самому травматичному этапу операции. Так, САД, ДАД и АД ср снижались по отношению к предыдущему этапу на 6,4\%, $11 \%$ и $5,8 \%$, а по отношению к исходу были повышены на $5,1 \%, 13,4 \%(\mathrm{p} \mathrm{0,05)} \mathrm{и} \mathrm{9,6 \% .} \mathrm{ЧСС,} \mathrm{МОК} \mathrm{и} \mathrm{УО}$ на этапе пробуждения.

Заключение. Предложенный метод мультимодальной анестезии и аналгезии на этапах периоперационного периода уменьшает фармакологическую нагрузку, способствует раннему пробуждению, активной мобилизации, быстрому восстановлению перистальтики кишечника.

\section{К ВОПРОСУ О ЛЕЧЕНИИ АНКИЛОГЛОССИИ У ДЕТЕЙ}

Фоменко И.В., Касаткина А.Л., Тимаков И.Е., Кроман Ю.О.

Кафедра стоматологии детского возраста, Волгоград

Остаются актуальными вопросы лечения детей с пороками развития уздечек языка. Значимость проблемы определяется большой частотой этой патологии, которая встречается в 5,3-27\% наблюдений.

Цель исследования: Повысить эффективность диагностики, лечения детей с аномалиями развития уздечек языка. 
Материал и методы: работа выполнялась на кафедре стоматологии детского возраста ВолгГМУ. на базах кафедры (ДКСП № 2 и ГКБ №1). Нами было прооперировано 340 детей с данной патологией. Все дети предварительно обследованы педиатром, противопоказаний к оперативному вмешательству не было. У новорожденных детей показанием к проведению вмешательства были проблемы при кормлении ребенка, у детей 4-12 лет нарушение речевой функции, ортодонтические и пародонтологические. Дети с короткой уздечкой языка были распределены на три возрастные группы: I группа: новорожденные и дети раннего грудного возраст; II группа: 4-5 лет; III группа: 6-12 лет. Критериями эффективности проведенной операции детей II III групп являлись: формирование подвижного эластичного рубца; нормализация звукопроизношения; движения языка в полном объеме, отсутствие жалоб родителей.

Результаты и обсуждение. Операция у детей I группы проводилась перед кормлением. Сразу после проведения вмешательства предлагали провести кормление ребенка. Улучшение функции сосания у детей после операции отметили $78 \%$ матерей. В результате исследований установили, что $68 \%$ детей II и III групп имели нарушение функции звукопроизношения, ортодонтические показания отмечались у 19\%; у 13\% пациентов соответственно операция проведена с целью предупреждения заболеваний пародонта. Результаты свидетельствуют: длительность реабилитационного периода была минимальной и составила в среднем от 4 до 6 месяцев у детей II группы. Вопросы планирования послеоперационных мероприятий должны обязательно учитываться при подготовке к хирургическому лечению.

Считаем, что в случае диагностики заболевания в период новорожденности и грудном, целесообразно проводить простое рассечение уздечки языка. В большинстве случаев, этого достаточно, для нормализации акта сосания и предотвращения анатомо-функциональных нарушений. Если рассечение не было проведено, то оптимальным считаем - возраст 4-5 лет, когда возможно проведение комплекса реабилитационных мероприятий, включающих проведение логопедических занятий, миогимнастики.

\section{РОЛЬ СТРЕССОВЫХ ФАКТОРОВ ПРИ ПРЕЖДЕВРЕМЕННОМ ПОЛОВОМ СОЗРЕВАНИИ У ДЕВОЧЕК}

Чеботарева Ю.Ю. ${ }^{1}$, Родина М.А. ${ }^{2}$, Налетова Д.А. ${ }^{1}$

${ }^{1}$ Федеральное государственное бюджетное

образовательное учреждение высшего образования

«Ростовский государственный медицинский

университет» Министерства здравоохранения

Российской Федерации, Ростов-на-Дону;

${ }^{2}$ КДЦ «Здоровье» Ростов-на-Дону

Введение. Значительная часть репродуктивных нарушений связана со стрессом. Стресс не тождественен просто нервному напряжению, это неспецифическая реакция на изменения условий, которые требуют адаптации. Стрессорные факторы стратифицируют на физические, метаболические и психологические. Важную роль играют расстройства биологических ритмов организма, психологические особенности.

Цель исследования - изучение особенностей психоэмоционального статуса и адаптационных реакций у девочек, имеющих клинические признаки преждевременного полового созревания.

Материалы и методы. В исследование включено

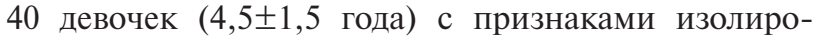
ванного телархе (основная группа). Контрольную группу составили 30 девочек 1, 2 групп здоровья (4,2 $\pm 1,2$ года). Проведен иммуноферментный анализ гормонов сыворотки крови (кортизол, пролактин, ЛГ, ФСГ, эстрадиол). Психоэмоциональные нарушения определяли по модифицированной шкале Цунга, адаптационные реакции по методу Л.Х. Гаркави и соавт. (1998).

Результаты. Выявлено, что у пациенток уровень тревожности был значимо выше, чем у дошкольниц контрольной группы $(32,8 \pm 2,0$ баллов против $12,3 \pm 2,1$, соответственно, $\mathrm{p}<0,05)$. Индекс тревоги у этих пациенток также был достоверно выше $(0,56 \pm 0,2$ баллов против $0,2 \pm 0,01$, соответственно, $\mathrm{p}<0,05)$. Установлено, что у пациенток основой группы имели место реакция стресса и переактивации, при этом у девочек контрольной группы повышенная и спокойная активация на высоких уровнях реактивности (p<0,05). У $30(75 \%)$ пациенток выявлено достоверное повышение возрастных уровней кортизола и пролактина $(\mathrm{p}<0,05)$. Концентрации ФСГ, ЛГ, эстрадиола достоверных отличий от аналогичных параметров девочек 1 и 2 групп здоровья не имели $(\mathrm{p}>0,1)$. Наличие аэробного бактериального вульвовагинита выявлено у 35 (87,5\%) пациенток. У 12 (30\%) пациенток при эхографии отмечались признаки мультифолликулярно измененных яичников.

Заключение. У девочек с преждевременным телархе в развитии гормонального дисбаланса играет огромную роль психоэмоциональный стресс. 
Последний реализуется через транзиторную гиперпролактинемию или активацию глюкокортикоидной функции надпочечников. Требуется междисциплинарный подход в решении проблемы диспансерного ведения данной когорты пациенток.

\section{ПЕРИНАТАЛЬНЫЕ ИСХОДЫ У ЖЕНЩИН С ПЛАЦЕНТА-АССОЦИИРОВАННЫМИ ОСЛОЖНЕНИЯМИ В АНАМНЕЗЕ}

Чулков В.С., Курносенко И.В., Московкина Е.И., Русакова Д.А.

ФГБОУ ВО Южно-Уральский государственный медицинский университет Минздрава России, Челябинск

Введение. Исследования по оценке влияния антитромботических препаратов на перинатальные исходы у женщин с плацента-ассоциированными осложнениями беременности являются противоречивыми и окончательно нерешенными.

Цель исследования. Провести оценку влияния антитромботической профилактики на рецидивы плацента-ассоциированных осложнений беременности.

Материалы и методы. В проспективное когортное исследование включены 80 женщин, которые были разделены на две группы в зависимости от назначенной антитромботической профилактики. Критерии включения: возраст старше 18 лет, наличие плацента-ассоциированных осложнений беременности в анамнезе, наличие медицинской документации. Критерии исключения: ВТЭО в анамнезе, наличие тромбофилий высокого риска, включая антифосфолипидный синдром. Группа 1 (40 человек) - получавшие эноксапарин в непрерывном режиме в профилактических дозах с ранних сроков гестации на протяжении всей беременности; группа 2 (40 человек) - получавшие ацетилсалициловую кислоту 75-100 мг/сут с 12 до 36 недель беременности. За совокупный неблагоприятный исход принималось наличие одного из перечисленных состояний: преэклампсия (ПЭ), синдром задержки роста плода, преждевременная отслойка плаценты, антенатальная гибель плода. Статистический анализ проведен с помощью пакета статистических программ MedCalc. Применялись критерии Манна-Уитни и хи-квадрат Пирсона. Статистически значимым принимался уровень $p<0,05$. Результаты и обсуждения. Результаты. Беременные обеих групп были сопоставимы по возрасту и паритету В структуре экстрагенитальной патологии в группе 1 чаще встречались женщины с сахарным диабетом 2 типа ( $20 \%$ vs $5 \%, p=0,0044)$. Только в группе 2 отмечались случаи развития ПЭ ( $10 \%$ vs $0 \%, p=0,041)$. Частота рождения детей с гипотрофией оказалась достоверно выше в группе 2 по сравнению с группой 1 ( $20 \%$ vs 2,5\%, $p=0,014)$. Совокупный неблагоприятный исход в 6 раз чаще встречался в группе 2 по сравнению с группой 1 (30\% vs $5 \%, p=0,004)$. Случаев значимых тромбогеморрагических осложнений не было отмечено ни в одной группе.

Заключение. Беременность у женщин с плацента-ассоциированными осложнениями в анамнезе на фоне применения профилактических доз низкомолекулярных гепаринов в сравнении с низкими дозами ацетилсалициловой кислоты ассоциировано со снижением частоты случаев преэклампсии и рождения детей с гипотрофией.

\section{ВЕГЕТАТИВНАЯ ДИСФУНКЦИЯ У ПОДРОСТКОВ С БРОНХИАЛЬНОЙ АСТМОЙ}

Чупак Э.Л., Арутюнян К.А., ФГБОУ ВО Амурская ГМА Минздрава России, Благовещенск

Введение. При бронхиальной астме психические и соматические факторы тесно переплетаются. Повышение активности центров парасимпатической нервной системы и активации холинэргических рефлексов имеют значение в развитие бронхоспазма. Возникновение и провокация приступов при эмоциональной нагрузке и психологическом стрессе подтверждает роль психических факторов в патогенезе заболевания.

Цель исследования. Изучить у детей с бронхиальной астмой психолого-вегетативный статус в период ремиссии.

Материалы и методы. Подростки с бронхиальной астмой в зависимости от исходного вегетативного тонуса были разделены на 2 группы: 1-с симпатикотонией (55), 2-с ваготонией (51). Проведена клиническая оценка исходного вегетативного тонуса (Г.Г. Осокина), кардиоинтервалография, тест Ч.Д. Спилбергера-Ю.Л. Ханина для определения уровня личностной и реактивной тревожности.

Результаты. У 18,2\% подростков 1 группы выявлена гиперсимпатикотоническая вегетативная реактивность, указывающая на избыточную активацию симпатического отдела с риском срыва адаптации. Выявлены средняя прямая корреляционная связь между значением вегетативной реактивности и уровнем реактивной тревожности $(r=0,54 ; p<0,05)$, умеренная обратная корреляционная связь между значением вегетативной реактивности и длительностью ремиссии $(r=-0,33 ; p<0,05)$. Умеренная прямая корреляционная связь между амплитудой моды и уровнем личностной тревожности $(r=0,37 ; p<0,05)$ указывает на тесную взаимосвязь исходной симпатикотонии с личностной тревожностью. У больных с исходной симпатикотонией тревожность активирует симпатическое звено вегетативной нервной системы, что подтверждается положительной корреляционной связью реактивной тревожности с индексом Кердо $(\mathrm{R}=0,83, p<0,05)$. 
Полученные результаты указывают на тесную связь психоэмоциональной сферы и вегетативной регуляции. У 15,6\% подростков 2 группы наблюдалась асимпатикотоническая реактивность, свидетельствующая об истощении адаптационных возможностей вегетативного гомеостаза. Выявлены умеренная обратная корреляционная связь между значением вегетативной реактивности и уровнем реактивной тревожности $(r=-$ $0,35 ; p<0,05)$, средняя прямая корреляционная связь между значением вегетативной реактивности и появлением симптомов заболевания на фоне базисной терапии $(r=0,61 ; p<0,05)$.

Заключение. Выявленный дисбаланс вегетативного гомеостаза у подростков с бронхиальной астмой сопровождается особенностями организации психо-эмоциональной сферы и влияет на течение заболевания.

\section{КЛИНИКО-ЛАБОРАТОРНАЯ ДИАГНОСТИКА ДЕФИЦИТА МАГНИЯ У ДЕТЕЙ}

Шанова O.В.

ФГБОУ ВО Амурская ГМА Минздрава России,

Благовещенск

Введение. Широкая распространенность и полисистемность клинической реализации дефицита магния (ДМ) у детей предопределяет особую диагностическую значимость для педиатров.

Цель исследования - изучение ДМ у детей на основании клинико-лабораторных критериев.

Материалы и методы. Было обследовано 43 ребенка, находившихся на лечении в ГАУЗ АО ДГКБ г. Благовещенск с различной соматической патологией. Средний возраст детей $-12,4 \pm 1,9$ лет. Гендерный состав: девочки (62,8\%), мальчики $(37,2 \%)$. ДМ определяли по клиническим признакам с использованием специальной шкалы (О.А. Громова и соавт., 2010) с подсчетом баллов и содержанию иона в сыворотке крови.

Результаты. Учитывая клинические проявления ДМ у 6 (14\%) обследованных детей он был маловероятен, а 37 (86\%) пациентов имели ДМ. У 19 пациентов $(51,4 \%)$ был определен легкий ДМ, у 17 (45,9\%) - умеренный и у 1 пациента $(2,7 \%)$ тяжелый. Доля детей с недостаточным потреблением магния с продуктами питания составила 86\%. Пациенты с легким ДМ употребляли его в количестве 114,26士7,56 мг, с умерен-

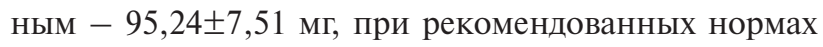
280мг в сутки. При определении магния в сыворотке крови у этих пациентов гипомагниемия была диагностирована только у 11 (25,6\%) детей. Гипомагниемия у детей с клиническими признаками легкого и умеренного ДМ встречалась достоверно реже $(2,7 \%$ и $24,3 \%$ соответственно) $(p<0,05)$. Средние значения уровня магния в сыворотке крови: в группе детей с маловероятным ДМ его уровень составил 0,78 $\pm 0,21$ ммоль/л, а у пациентов с ДМ по данным шкалы составил $0,74 \pm 1,2$ ммоль/л $(p>0,05)$. Нарушения ритма сердца на ЭКГ достоверно чаще встречались у детей с умеренным ДМ 71,4\% ( $<<0,001)$ и были представлены тахикардией и экстрасистолией. Кроме того, между этими изменениями отмечались положительные корреляционные связи: умеренный ДМ и экстрасистолия $(\mathrm{R}=0,63)$.

Заключение. Анализ результатов показал необходимость комплексного подхода к диагностике гипомагниемии, включая клинико-анамнестические признаки ДМ в организме. Полученные данные свидетельствуют о необходимости увеличения в рационе детей продуктов, богатых магнием, согласно рекомендуемым нормам питания.

\section{СОМАТОТИПОЛОГИЧЕСКИЕХАРАКТЕРИСТИКИ ДЕВУШЕК, ПРОЖИВАЮЩИХ НА ТЕРРИТОРИИ ТЮМЕНСКОЙ ОБЛАСТИ}

Юхвид Е.В., Орлов С.А., Ионина Е.В., Орлова И.С. ГБУЗ ТО ОКБ №2, ФГБОУ ВО Тюменский ГМУ

Минздрава России, Тюмень

Введение. Ведущими признаками здоровья являются уровень и гармоничность физического развития. В связи с этим, представляет особый интеpec c теоретической и практической точки зрения вопросы физического развития девушек.

Цель исследования. Провести сравнительные антропометрические исследования с определением структуры типов телосложения русских девушек 16-20 лет, проживающих на территории юга Тюменской области.

Материалы и методы. Проведено комплексное морфофункциональное обследование девушек 16-20 лет. Соматотипологическая диагностика девушек осуществлялась по методу М.В. Черноруцкого. Общее количество выборки составило 690 человек. В работе использован метод корреляционного анализа для определения тесноты и сопряженности между признаками. Рассматривалась парная корреляционная зависимость с вычислением коэффициента корреляции «г по Пирсону с учетом критерия достоверности р.

Результаты. Распределение соматотипов среди девушек в обследованной группе с астенической конституцией составило 244 человека или $35,4 \%$ от общей численности выборки, с нормостенической 360 - $(52,1 \%)$, а с гиперстеническим типом телосложения - 86 обследуемых девушек (12,5\%). Проведенный корреляционный анализ показал, что длина тела находится в прямой тесной коррелятивной связи с показателем площади поверхности тела $(r=0,73)$ и с костным компонентом $(r=0,61)$. Масса тела напрямую связана с такими размерами, как: среднегрудным сагиттальным и поперечным размерами грудной клетки $(r=0,71-0,75)$, с шири- 
ной плеч $(r=0,66)$, с обхватными размерами грудной клетки, плеча, бедра и ягодиц (r =0,76-0,86), площадью поверхности тела $(r=0,84)$, жировым компонентом $(r=0,84)$, костным компонентом $(\mathrm{r}=0,72)$ и мышечным компонентом $(r=0,90)$ подкожно-жировой складки под лопаткой $(\mathrm{r}=72)$, на живота $(r=0,70)$, d. spinarum, d. cristarum, d. trochanterica, c. externa $(r=0,75-0,85)$.

Заключение. Определены региональные соматометрические особенности, которые проявляются у девушек гиперстенического типа телосложения максимальными абсолютными величинами показателей, характеризующие габаритные компоненты сомы, тогда как для астеников рассматриваемые значения имеют минимальные значения.

\section{ОСОБЕННОСТИ РАСПРОСТРАНЕННОСТИ БОЛЕЗНЕЙ ОРГАНОВ ДЫХАНИЯ И КРОВООБРАЩЕНИЯ В РАЗЛИЧНЫХ ПОКОЛЕНИЯХ И КОГОРТАХ ЛИЦ ПОСЛЕ АВАРИИ НА ЧЕРНОБЫЛЬСКОЙ АЭС}

Якушева Е.Н., ${ }^{1}$ Сипягина А.Е., ${ }^{1}$ Малышев В.С., ${ }^{2}$ Балева Л.С., ${ }^{1}$ Карахан Н.M. ${ }^{1}$

${ }^{1}$ ОСП НИКИ педиатрии им. акад. Ю.Е. Вельтищева ФГАОУ ВО РНИМУ им. Н.И. Пирогова МЗ РФ, Москва, Россия

2 ФГБОУ ВО «НИУ «МЭИ», кафедра «Инженерная экология и охрана труда»

Введение. Основными медико-биологическими последствиями действия малых доз радиации являются радиационно-индуцированные стохастические заболевания: злокачественные новообразования, хромосомные, генные заболевания, врожденные аномалии (пороки) развития. Другой значимой проблемой после аварии на ЧАЭС явилось изучение особенностей реакции детского организма на хроническое облучение в малых дозах в поколениях и когортах лиц, рожденных от облученных родителей, оценка которой наиболее сложна и многогранна.

Цель исследования - оценить в динамике эпидемиологические особенности состояния органов дыхания и системы кровообращения у лиц различных поколений и когорт наблюдения, подвергшихся радиационному воздействию, для возможности верификации тканевых реакций радиационного воздействия.

Материалы и методы. Было проведено сравнительное динамическое эпидемиологическое исследование за 2015-2019 г.г. среди различных поколений и когорт населения, включенных в Федеральное Государственное статистическое наблюдение (форма №15, №16, № 12). Состав населения включал: детей (поколение F1) и внуков (поколение F2), родившихся от облученных родителей (поколение $\mathrm{F} 0$ ), а именно: от ликвидаторов аварии на ЧАЭС в 1986-
1987 г.г., и проживающих в радиационно загрязненных регионах.

Результаты исследования. При оценке в динамике показателей распространенности на 100000 человек болезней органов дыхания (класс болезней по МКБ-Х J 00-99) установлено, что в поколении F0 как у ликвидаторов аварии на ЧАЭС, так и у жителей радиационно загрязненных регионов имеет место снижение уровня распространенности заболеваний (с 36289,7 до 31222,8 и с 44859,9 до 14890,2; соответственно), вероятно в связи со снижением уровня дозовой нагрузки на органы дыхания - аэрозольные мишени радиационного воздействия. В то же время в поколениях потомков облученных родителей имеет место рост показателей распространенности заболеваний (с 23670,9 до 38118,8), что для 2019 г. является превышением как уровня заболеваемости у ликвидаторов, так и у родителей - жителей радиационно загрязненных регионов. Причем, при оценке уровня заболеваемости в поколении F1 (у детей) и F2 (у внуков) оказалось, что наиболее высокие показатели (более, чем в 4 раза) отмечены у внуков облученных лиц. Кроме того, в этой когорте наблюдаемых имеет место положительный тренд по 2015-2019 г.г. (c 81478,1 до 87771,7). Ранее проведенные нами исследования позволяют объяснить эту ситуацию увеличением доли заболеваемости бронхиальной астмой в поколении F2 от облученных родителей за счет иммунологических и нейрогуморальных изменений у лиц указанного поколения. Кроме того, совокупность индуцированных радиацией нарушений генома клеток родителей, попадая в зиготу потомков, дестабилизирует ее наследственный аппарат, увеличивая вероятность реорганизации ДНК в клетках потомства, и являются основанием для формирования трансгенерационной передачи.

Система кровообращения оценивалась в связи с тесным контактом ацинусов легких с системой артериовенозной микроциркуляции с преимущественным поражением эндотелиального сосудистого слоя. Данные исследования распространенности болезней системы кровообращения (класс болезней по МКБ-X I 00-99) в указанных поколениях и когортах наблюдения за период 2015-2019 г.г. свидетельствуют, что наиболее высокий уровень показателей отмечен в поколении F0 - у ликвидаторов аварии на ЧАЭС, в связи с воздействием высокого уровня дозовой нагрузки с формированием ишемической болезни сердца вследствие поражения коронарных артерий. В поколении F0 - у родителей - жителей радиационно загрязненных регионов уровень болезненности по сравнению с ликвидаторами ниже в 4-10 раз (по указанным годам наблюдения). У потомков облученных родителей уровень болезненности значительно ниже, чем у их родителей - ликвидаторов аварии на ЧАЭС и жителей радиационно загрязненных регионов. В то же время 
имеет место тенденция к росту показателей от 2015 до 2019 г.г. с 4858, 1 до 5895,8 (соответственно). Причем, наиболее высокие значения зарегистрированы у детей (в поколении F1) облученных родителей максимально до 6490,7 в 2019 г.

Заключение. Таким образом, полученные данные свидетельствуют, что максимальные значения распространенности болезней органов дыхания имеют место в поколении F2 (у внуков облученных родителей), независимо от снижения дозовой нагрузки у данной части населения, что можно объяснить ранее установленным изменением течения хронических обструктивных заболеваний легких, что явля- ется следствием напряженного режима функционирования дыхательной системы с ранними проявлениями фиброзирования легочной ткани. Прямой корреляционной связи распространенности заболеваний органов дыхания и системы кровообращения в данном исследовании не выявлено, что может в этом контексте объясняться поставленной целью исследования и необходимостью использования других более тонких методов обследования. В то же время, результаты исследования подтверждают особенности в течении болезней органов дыхания, что согласуется с проявлением тканевых реакций радиационного воздействия. 


\section{Раздел 14}

\section{КОНКУРС}

МОЛОДЫХ УЧЕНЫХ 
ПЕРВЫЙ ОПЫТ ИСПОЛЬЗОВАНИЯ ДУПИЛУМАБА ПРИ БРОНХИАЛЬНОЙ АСТМЕ У ДЕТЕЙ

Байрамова И.А.

ФГБОУ ВО Саратовский ГМУ им. В. И. Разумовского

Минздрава России

Актуальность. Бронхиальная астма - актуальная проблема медицины, обусловленная распространенностью, приводящая к нарушению качества жизни, к инвалидизации. К особенностям течения бронхиальной астмы у детей относится клинический полиморфизм (частые обструктивные бронхиты, ОР3, гендерные особенности в пубертатном периоде). Астма, как правило, сохраняется в течение всей жизни, а степень ее тяжести может варьировать. Контроль над симптомами бронхиальной астмы и уменьшения рисков, согласно глобальной инициативы против бронхиальной астмы (GINA 2021) предусматривает ступенчатый подход, который включает в себя: ингаляционные кортикостероиды, бронходилататоры коротко и длительно действующие, антагонисты рецепторов лейкотриена, M-холиноблокаторы, анти-IgE, анти-IL5/5R, антиIL4R, глюкокортикостероиды. Перспективным направлением течения БА является использование рекомбинантного, полностью человеческого моноклонального антитело изотипа IgG4 - дупилумаб. В Российской Федерации дупилумаб зарегестрирован с апреля 2019 г., применяемого для лечения пациентов с атопическим дерматитом средне-тяжелого и тяжелого течения старше 18 лет и в качестве дополнительной поддерживающе терапии средне-тяжелой и тяжелой бронхиальной астмы у взрослых и подростков старше 12 лет.

Цель: оценить эффективность использования дупилумаба в алгоритме лечения больных с бронхиальной астмой у детей старше 12 лет.

Пациенты и методы: в исследование включены 4 пациента, находившиеся на лечении в детском пульмонологическом отделении СГМУ им. В.И.Разумовского УКБ №1 им. С.Р.Миротворцева с бронхиальной астмой. Пациентам назначен дупилумаб 200 мг (2 предварительно заполненных шприца по 200 мг поочередно ввели подкожно в левое и правое плечо с интервалом в 15 минут, 1 раз в 2 недели). Проведен анализ историй болезни и результатов диагностических методов: общий анализ крови, биохимический анализ крови, исследование крови на атипичные возбудители, исследование крови на иммуноглобулин Е, рентгенография органов грудной клетки, спирография, импульсная осциллометрия. Оценка контроля течения бронхиальной астмы осуществлялась при помощи опросника качества жизни (AQLQ). Оценка эффективности терапии проводилась на основании данных спирографии, импульсной осциллометрии.

Результаты исследования: После двух инъекций отмечался положительный результат: увеличение ОФВ1, улучшение показателей качества жизни (опросник оценки качества жизни пациентов с астмой - AQLQ), изменения рентгенологических параметров (прозрачность легочной ткани; наличие/ отсутствие эмфиземы; усиление, сгущение легочного рисунка в прикорневых заднебазальных отделах легкого; уплотнение корней легкого). Был проведен анализ следующих спирометрических показателей - форсированная жизненная емкость легких (ФЖЕЛ), объем форсированного выдоха за первую секунд (ОФВ1), индекс Тиффно (ОФВ1/ ЖЕЛ), где до терапии дупилумабом у $n=1-$ ОФВ1 4,45, ЖЕЛ - 5,32, ФЖЕЛ - 5,41, ОФВ1/ЖЕЛ $82 \%$, а после - ОФВ1 - 4,45, ЖЕЛ - 4,32, ФЖЕЛ 4,41 , ОФВ1/ЖЕЛ - 101\%; у $n=2$ - ОФВ1 - 3,67, ЖЕЛ - 4,41, ФЖЕЛ - 5,41, ОФВ1/ЖЕЛ - 83\%, а после - ОФВ1 - 3,26, ЖЕЛ - 3,61, ФЖЕЛ 3,61, ОФВ1/ЖЕЛ - 90\%; у $n=3$ - ОФВ1 - 2,93, ЖЕЛ - 3,55, ФЖЕЛ - 3,53, ОФВ1/ЖЕЛ - 83\%, а после - ОФВ1 - 3,6, ЖЕЛ - 4,08, ФЖЕЛ 4,01, ОФВ1/ЖЕЛ - 90\%; у $n=4-$ ОФВ $1-2,78$, ЖЕЛ 3,31,ФЖЕЛ-3,27,ОФВ1/ЖЕЛ-85\%, апосле-ОФВ13,03, ЖЕЛ - 3,28, ФЖЕЛ - 3,04, ОФВ1/ЖЕЛ - 99\%.

Выводы:

1. На фоне начала терапии дупилумабом у подростков с бронхиальной астмой отмечена тенденция к улучшению показателей инструментальных методов исследования, качества жизни.

2. Исследование, проведенное у детей с бронхиальной астмой в условиях реальной клинической практики, продемонстрировало клиническую эффективность дупилумаба в отношении снижения частоты обострений и контроля симптомов астмы и доказывает перспективность использования в педиатрической практике.

\section{ОСНОВНЫЕ ПАРАМЕТРЫ СТОМАТОЛОГИЧЕСКОГО СТАТУСА У ДЕТЕЙ С САХАРНЫМ ДИАБЕТОМ 1 ТИПА}

Гутник A. $A$.

Учреждение: ФГБОУ ВО МГМСУ

им. А.И. Евдокимова МЗ РФ

Актуальность. Сахарный диабет 1 типа является наиболее частой встречающейся формой диабета среди детского населения. Заболеваемость сахарным диабетом по данным Росстата на 2018 год среди детского населения в возрасте 0-14 лет составила 5,4 тыс. заболевших, среди подростков в возрасте 15-17 лет заболеваемость составила 1,3 тысячи заболевших (ФСГС, «Здравоохранение в России», 2019). Деструктивные процессы, происходящие в поджелудочной железе при сахарном диабете 1 типа, вызывают нарушение гомеостаза полости рта (Доменюк Д.А., Давыдов Б.Н., 2018г.). Первыми признаками проявления сахарного диабета являются пастозность слизистой оболочки полости рта, гипосаливация, 
что способствует образованию большого количества зубных отложений и, как следствие, развитию хронического катарального гингивита (Силантьева Е.Н., Заболотный А.И., 2020г.). Кроме того, по мере развития основного основного заболевания, в пародонте возникают изменения, имеющие морфологический и функциональный характер, происходит прогрессирующая деминерализация твердых тканей зубов, нарушается фосфорно-кальциевый обмен в слюне (Доменюк Д.А., Давыдов Б.Н., 2018г.).

Цель исследования: оценить стоматологический статус детей с сахарным диабетом 1 типа.

Пациенты и методы исследования: в ходе исследования было осмотрено 30 детей в возрасте от 6 до 17 лет с различной длительностью основного заболевания - от 1 года до 15 лет. В рамках исследования проводилось анкетирование пациентов. Основными пунктами анкеты были следующие: «Регулярность ухода за полостью рта», «Длительность чистки зубов», «Частота смены зубной щетки», «Частота обращения к стоматологу», «Частота проведения профессиональной гигиены полости рта». Кроме того, всем пациентам проводилось базовое стоматологическое обследование, включающее в себя определение показателей распространенности кариеса зубов (КПУ (з), КПУ (п)), индексов гигиены полости рта OHI-s, API, для оценки состояния тканей пародонта проводилось определение индексов СРІ, РМА, также определялась скорость стимулированного слюноотделения. Стимулирование слюны проводилось путем внесения кристаллов лимонной кислоты в подъязычную область. Затем происходил сбор слюны в течение 6 минут.

Результаты анкетирования (рис.1.) показывают, что большинство (93\%) обследованных чистят зубы 1-2 раза в день и лишь 7\% нерегулярно ухаживают за полостью рта. Время чистки зубов у большинства (77\%) детей составляет 1-2 минуты, лишь у 20\% время чистки составляет более 3 минут и у $3 \%$ - менее 1 минуты. Частота смены зубной щетки у $80 \%$ обследованных составляет 1 раз в 3 месяца или чаще, у остальных 20\% - 1 раз в 4-6 месяцев. Тем не менее, большинство детей (63\%) обращаются к врачу-стоматологу

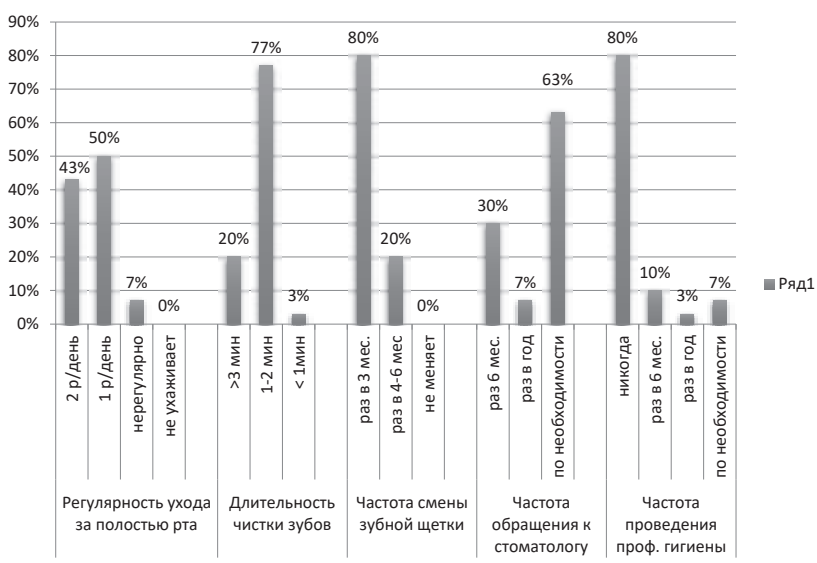

только по необходимости, в то время как остальные $37 \%$ - посещают врача-стоматолога с профилактической целью 1 раз в 6-12 месяцев. Анкетирование также показало, что 80\% обследованных детей никогда не обращались к стоматологу с целью проведения профессиональной гигиены полости рта, в то время как остальным $20 \%$ данная манипуляция проводилась с различной периодичностью.

По результатам клинического обследования среднее значение индекса КПУ (з) составило 3,3, а КПУ (п) $-3,5$.

Значения индекса гигиены полости рта ОНІ-s показали, что у 53\% обследуемых наблюдается удовлетворительный уровень гигиены, у остальных 47\% хороший уровень гигиены полости рта. Значения индекса API составили в среднем $87,1 \%$, что говорит о недостаточном уровне индивидуальной гигиены, вследствие недостаточного удаления мягкого зубного налета с апроксимальных поверхностей зубов.

При определении индекса CPI у $70 \%$ детей были выявлены признаки воспаления пародонта. При определении индекса РМА признаки воспаления десны наблюдались у 53\% детей, причем у $40 \%$ наблюдалась легкая степень гингивита, а у 13\% тяжелая степень гингивита.

При определении скорости стимулированного слюноотделения нормальное значение (1-2 мл/мин, K.А. Сундукова, 2018 г.) данного параметра наблюдалось у $30 \%$ обследуемых, у остальных $70 \%$ это значение колебалось в пределах 0,1-0,8 мл/мин, что говорит о снижении функциональной активности слюнных желез.

Выводы: по результатам анкетирования и данным оценки гигиенического состояния полости рта можно сделать вывод о том, что большинство детей обладают относительно низким уровнем знаний об индивидуальной гигиене полости рта, необходимости посещения врача-стоматолога с профилактической целью, а также о важности и регулярности проведения профессиональной гигиены. Неудовлетворительное гигиеническое состояние полости рта у большинства обследуемых способствует развитию хронического катарального гингивита. Среднее значение индекса КПУ указывает на средний уровень интенсивности кариеса. Кроме того, было отмечено, что у большинства детей (70\%) снижена функциональная активность слюнных желез.

Рис. 1. Результаты анкетирования пациентов. 


\section{СТОМАТОЛОГИЧЕСКИЙ СТАТУС И КАЧЕСТВО ЖИЗНИ У ДЕТЕЙ С ГЛОМЕРУЛОНЕФРИТОМ}

Киприна А. М.

ФГБОУ ВО Московский государственный медико-

стоматологический университет имени А.И. Евдокимова

Министерства здравоохранения России, кафедра

детской стоматологии

Актуальность. Особое место в группе заболеваний мочевыделительной системы занимает гломерулонефрит, тяжесть течения которого нередко отягощается различными осложнениями. Также, используемая лекарственная терапия при гломерулонефрите, тщательно изучается до настоящего времени как нефрологами, так и врачами смежных специальностей.

Существует взаимосвязь между состоянием различных систем организма и стоматологическим статусом. При обследовании полости рта у пациентов с хроническими заболеваниями почек выявлены: поражение зубов кариесом, воспаление пародонта, снижение скорости слюноотделения [2, 6]. У пациентов с гломерулонефриом наиболее выраженные изменения стоматологического статуса наблюдаются при длительном примере гормональной терапии.

В ряде работ отмечено, что при наличии сопутствующей патологии изменение стоматологического статуса может ухудшить качество жизни $[3,5]$. Наиболее часто используемым инструментом для определения качества жизни, связанного со здоровьем полости рта у детей разных возрастов, является опросник детского восприятия качества жизни (Child Perceptions Questionnaires - CPQ). Данный опросник используется для измерения влияния стоматологического статуса на повседневные функции у детей $[1,4]$. Однако влияние стоматологического статуса на качество жизни детей с гломерулонефритом ранее не была изучена. Учитывая распространенность данной патологии, возникает необходимость изучения влияние патологии полости рта на качество жизни у детей с гломерулонефритом.

Цель. Оценка основных параметров качества жизни у детей с гломерулонефритом, в зависимости от тяжести стоматологических проявлений основного заболевания.

Пациенты и методы. Проведено клиническое обследование состояния полости рта у 37 детей с острым и хроническим гломерулонефритом в возрасте от 8 до 14 лет в нефрологическом отделении ДГКБ Св. Владимира г. Москвы. Первую группу составили 26 пациентов с нефротическим синдромом, которые получали системную гормональную терапию не менее 2 недель на момент осмотра. Вторую группу составили 11 пациентов с нефритическим синдромом, которые не получали гормональную терапию вследствие формы заболевания.

Клиническое обследование стоматологического статуса заключалось в определении распространенно- сти кариеса и интенсивности кариеса зубов по индексу кП+КПУ и КПУ (суммарное число кариозных, пломбированных и удаленных зубов). Для оценки гигиенического состояния полости рта использовали упрощенный индекс гигиены полости рта - OHI S (Oral Hygiene Indices - Simpli ed, 1964 г.). Состояние десны определялось с помощью индекса PМА (папиллярно-маргинально-альвеолярного) в модификации Parma, 1960 г.

Для оценки качества жизни, связанного со здоровьем полости рта, использовали анкету-вопросник CPQ (Child Perceptions Questionnaire). Вопросы в анкете распределены по 4 основным направлениям: физический дискомфорт, функциональные нарушения, эмоциональное благополучие, социальное благополучие.

Во всех вопросах оценивается частота событий, которые кодировались от 1 балла - никогда, до 4 баллов - постоянно. Для выявления связи между основными показателями стоматологического статуса и качеством жизни, был проведен корреляционный анализ с применением коэффициента ранговой корреляции Спирмена (r). Также оценивалась взаимосвязь качества жизни от формы гломерулонефрита и проводимой общей патогенетической терапии.

Результаты. При обследовании полости рта средний показатель интенсивности кариеса по индексу кП+КПУ составил 4,2, по индексу КПУ - 3,1. Данные изучения уровня гигиены полости рта по индексу ОНI S составляют 1,9 . Хронический гингивит легкой степени тяжести $(\mathrm{PMA}=11,6 \%)$ выявлен у 15 детей.

В результате анализа данных стоматологического статуса и ответов на вопросы по каждому разделу анкеты-вопросника CPQ выявлены значимые корреляционные связи. Ответы на разделы эмоциональное благополучие и социальное благополучие имеют умеренную прямую взаимосвязь с индексом КПУ ( $r=0,539$ и $r=0,56$ соответственно, $p<0,001)$. Ответы на вопросы раздела физический дискомфорт в полости рта и индекс OHI-S имеют слабую прямую взаимосвязь $(r=0,427, p<0,05)$. Аналогичная тенденция выявлена и при анализе ответов на вопросы раздела функциональные нарушения и индексом OHI-S $(r=0,441, p<0,05)$. Прямая слабая корреляционная связь установлена между ответами на вопросы разделов функциональные нарушения, социальное благополучие и индексом гингивита РМА $(r=0,483$ и $r=0,469$ соответственно, $p<0,05$ ).

Более низкие показатели качества жизни отмечены в разделе, посвященном физическому дискомфорту в полости рта, где средний балл в первой группе составил 1,68 , во второй группе - 1,58 . В разделе функциональные стоматологические нарушения в первой группе средний показатель составил 1,38 , во второй - 1,35 . В разделе эмоциональное благополучие в первой группе средний балл равен 1,55 во второй $-1,27$. В разделе социальное благополучие в первой группе средний показатель равен - 1,35 балла, во второй $-1,25$. Анализируя полученные данные, 
можно отметить, что у детей с гломерулонефритом, находящихся на гормональной терапии более выражена стоматологическая патология и соответственно отмечаются более низкие показатели качества жизни по всем исследуемым параметрам.

Выводы. Полученные данные свидетельствуют об ухудшении стоматологического статуса и качества жизни у детей с гломерулонефритом. Отмечается взаимосвязь между тяжестью стоматологических проявлений и качеством жизни детей с гломерулонефритом. При длительном приеме гормональной терапии отмечаются более низкие показатели качества жизни. Данные результаты необходимо учитывать при профилактики и лечения стоматологических заболеваний у данных пациентов.

\section{Список литературы}

1. Зуева Т. Е., Кисельникова Л. П., Алибекова А. А., Романовская В. Н. Влияние гигиенического состояния полости рта на качество жизни детей подросткового возраста. Российская стоматология. 2016; 9(1): 66-66.

2. Мельниченко Э.М., Белик Л.П. Состояние органов полости рта у детей с хроническим гломерулонефритом. Стоматология. 2002; № 2: 53-54.

3. Elheeny AAH. Oral health status and impact on the oral health-related quality of life of Egyptian children and early adolescents with type-1 diabetes: a case-control study. Clin Oral Investig. 2020 Nov;24(11):4033-4042. DOI: 10.1007/ s00784-020-03273-w. Epub 2020 May 28. PMID: 32468484.

4. Jokovic A, Locker D, Stephens M, Kenny D, Tompson B, Guyatt G. Validity and reliability of a questionnaire for measuring child oral-health-related quality of life. J Dent Res. 2002 Jul;81(7):459-63. DOI: 10.1177/154405910208100705. PMID: 12161456

5. Najirad M, Ma MS, Rauch F, Sutton VR, Lee B, Retrouvey JM; Members of the BBD, Esfandiari S. Oral health-related quality of life in children and Teenagers with osteogenesis imperfecta: cross-sectional study. Orphanet J Rare Dis. 2018 Oct 25;13(1):187. DOI: 10.1186/s13023-018и0935-y. PMID: 30359278; PMCID: PMC6202869.

6. Subramaniam P, Gupta M, Mehta A. Oral health status in children with renal disorders. J Clin Pediatr Dent. 2012 Fall;37(1):89-93. DOI: $10.17796 / j c p d .37 .1 .71913347 q 0232 v 01$. PMID: 23342573.

\section{СТОМАТОЛОГИЧЕСКИЙ СТАТУС ДЕТЕЙ С РАССТРОЙСТВОМ АУТИСТИЧЕСКОГО СПЕКТРА И ОЦЕНКА УРОВНЯ ЗНАНИЙ РОДИТЕЛЕЙ ДЕТЕЙ С РАС ПО ПРОФИЛАКТИКЕ ОСНОВНЫХ СТОМАТОЛОГИЧЕСКИХ ЗАБОЛЕВАНИЙ}

Лямцева М.П. ${ }^{1}$, Добролежева T.A. ${ }^{1}$

${ }^{1}$ Московский государственный медико-

стоматологический университет им. А.И. Евдокимова

Актуальность. Расстройство аутистического спектра (РАС) характеризуется нарушением в общении и социальных отношениях и узким, повторяющимся стереотипным репертуаром деятельности, поведением и интересами [1]. Как показывают исследования, для детей с РАС характерны те же проблемы со здоровьем полости рта, что и у здоровых, но из-за таких факторов, как проявление нежелательного поведения, неспособности самостоятельно позаботиться о себе, склонности к самотравматизму, эти дети подвержены большему риску развития основных стоматологических заболеваний [2, 3, 4].

У детей, страдающих расстройствами аутистического спектра, наблюдается высокая интенсивность и распространенность кариеса, что связано со сложностью оказания им стоматологической помощи, неудовлетворительной гигиеной полости рта, особенностями соматического статуса и психологического состояния каждого отдельного ребенка [2, 5, 6, 7].

Причинами возникновения кариеса у детей с аутизмом является характер питания и плохая гигиена полости рта. Дети с РАС часто проявляют полное отсутствие сотрудничества в стоматологическом кабинете, что заставляет откладывать стоматологическое лечение этих детей [5]. Еще одной из причин является употребление большого количества сладкой и мягкой пищи и длительное пережевывание в ротовой полости (вялое жевание) [7]. Кроме того, проведенные исследования показали, что дети с РАС в отличии от нормотипичных детей, имеют низкое слюноотделение, низкую буферную емкость [8, 9].

Состояние здоровья полости рта у детей с аутизмом оценивается как плохое по следующим причинам: низкий уровень развития навыков самообслуживания, дефицит внимания и гиперактивность, низкая способность к обучению. У детей с РАС присутствуют сенсорные проблемы, например, гиперчувствительность к щетинкам щетки и вкусу пасты или зубного порошка, что заставляет их избегать чистки зубов. [10].

Нарушение социальной адаптации существенно снижает, а иногда делает невозможным способность к поддержанию гигиены полости рта, приводя к возникновению, или уже отягощению имеющихся заболеваний полости рта, таких как кариес и воспалительные заболевания пародонта. Так около 25\% осмотренных детей с РАС не чистят зубы [11].

У большинства детей с РАС выявлена плохая гигиена полости рта, и почти у всех имеются воспалительные заболевания пародонта. Эти изменения могут быть связаны с нерегулярной чисткой зубов из-за трудностей, с которыми родители сталкивались во время чистки зубов детям, так как многие дети с РАС не могут самостоятельно чистить зубы, а родители осуществляют эту функцию нерегулярно [12].

Дети с расстройством аутистического спектра испытывают трудности в обучении элементарным навыкам, общению. Одним из главных нарушений, которое препятствует успешной адаптации при расстройствах аутистического спектра, является недостаток коммуникативных навыков. Способность к коммуникации - это умение находить взаимосвязь с другими людьми; навыки продуктивного общения. 
Уровень развития личности определяет коммуникация - взаимный обмен информацией, который происходит в словесной форме (вербальной) и в невербальной $[13,14]$.

При планировании стоматологической реабилитации детей с РАС необходимо изучить уровень знаний родителей детей с РАС по профилактике стоматологических заболеваний и стоматологический статус в зависимости от способности детей с расстройством аутистического спектра к коммуникации.

Целью нашего исследования явилось изучение стоматологического статуса детей с расстройством аутистического спектра в зависимости их коммуникативных навыков и оценка уровня знаний родителей детей с РАС по профилактике стоматологических заболеваний.

Материалы и методы: В рамках проекта «Дружелюбная стоматология для детей с РАС», который реализуется Фондом «Импульс развития» с использованием гранта Президента Российской Федерации на развитие гражданского общества, предоставленного Фондом президентских грантов, в партнерстве с МГМСУ им. А.И. Евдокимова и Ассоциацией «Аутизм-Регионы», было проведено анкетирование 143 родителей детей с расстройством аутистического спектра возрасте от 4 до 16 лет, проживающих в Москве и Московской области, которое выполнялось на базе клиники детской стоматологии Клинического центра челюстно-лицевой, пластической хирургии и стоматологии Клиники Московского государственного медико-стоматологического факультета имени А.И. Евдокимова. Для оценки уровня гигиенических знаний родителей нами была разработана анкета, состоящая из 2 частей с 52 вопросами. Первая часть включала в себя общую информацию о ребенке (наличие диагноза РАC, посещение ребенком общеобразовательных учреждений, занятий с использованием прикладного анализа поведения и др.) Вторая часть включала с себя информацию о стоматологическом статусе ребенка. На каждый вопрос анкеты предоставлялось от 2 до 5 вариантов ответов. Также было обследовано 160 детей с расстройством аутистического спектра в возрасте от 4 до 16 лет, проживающих в Москве и Московской области, которое выполнялось на базе клиники детской стоматологии КЦЧЛПХ и стоматологии Клиники Московского государственного медико-стоматологического факультета имени А.И. Евдокимова. Дети были разделены на 3 группы по возрастным критериям. Первая группа включала 51 ребенка со временным прикусом в возрасте от 3 до 5 лет, из них 30 невербальных детей и 21 вербальный ребенок. Вторая группа включала 63 пациента со сменным прикусом в возрасте от 6 до 11 лет, из них 26 неговорящих и 37 с развитой речью. В третью группу входили 46 детей с постоянным прикусом в возрасте от 12 до 16 лет, среди которых 21 пациент имел неразвитую речь и 25 развитую. В соответствии с поведенческими реак- циями пациентов для оценки стоматологического статуса нами были выбраны индексы гигиены Федорова-Володкиной, OHI-S; для оценки и регистрации интенсивности кариеса кП, КПУ+кП, КПУ; для оценки состояния тканей пародонта - PМА.

Для регистрации полученных данных обследования нами были разработаны карты обследования для данной категории пациентов.

Результаты и их обсуждение. Полученные данные показали, что $34,7 \%$ опрошенных родителей не получали рекомендаций по гигиене полости рта, в то время как 32\% опрошенных родителей получали информацию по уходу за полостью рта от врача-стоматолога.

На вопрос о знании правил чистки зубов, 46,7\% опрошенных родителей ответили, что получали данную информацию от врача-стоматолога. Вторым источником информации был интернет (28\%), $24 \%$ опрошенных родителей не получали информацию о чистке зубов.

На вопрос «Требуется ли ваша помощь ребенку при чистке зубов?» почти 49,3\% опрошенных родителей ответили, что ребенок не может чистить зубы самостоятельно, 30,2\% родителей отметили, что ребенку нужна частичная помощь, 20,5\% детей с РАС чистят зубы самостоятельно.

На вопрос «Об отношении к фторидсодержащим зубным пастам» $41,7 \%$ опрошенных родителей ответили, что не знают о существовании фторидов в зубной пасте, 29,2\% отмечают вред фторидов, содержащихся в зубной пасте, 25\% не считают наличие фторидов в зубной пасте вредным.

Уровень гигиены полости рта у всех пациентов неудовлетворительный. В первой группе детей индекс Федо-

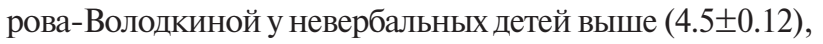

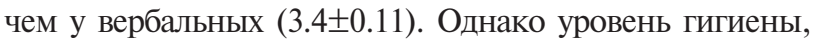
выявленный с помощью индекса OHI-S, у второй и третей групп детей одинаково плохой как у говорящих, так

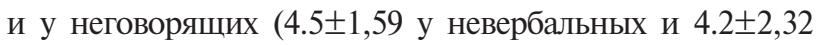

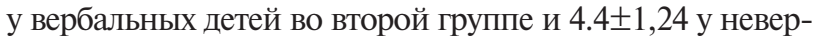

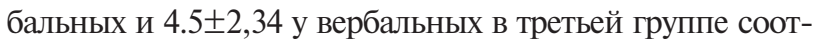
ветственно) (рис.1).

Распространенность кариеса среди детей с расстройствами аутистического спектра во всех группах составила $100 \%$. В первой группе у вербальных детей индекс кп(з) ниже $(6.6 \pm 2,91)$, чем у невербальных $(11.5 \pm 3,84)$. Во второй группе индекс КПУ(з) у говорящих детей составил $2.69 \pm 1,02$, у неговорящих $6.8 \pm 1,68$, а индекс кп(3) у вербальных 8,34 2,93 , у невербальных 16,78 2,48. В третьей группе индекс КПУ(з) у обеих групп очень высокий: у невербальных $18.6 \pm 2,65$ и $8.9 \pm 3,89$ у вербальных.

Индекс РМА показал легкую степень воспаления десны в первой $(7,8 \pm 4,24 \%$ у вербальных и $19,1 \pm 3,49 \%$ у невербальных и третьей группе детей $(11,3 \pm 2,78 \%$ у вербальных и $25,1 \pm 2,34 \%$ у невербальных). Во второй группе индекс РМА показал среднюю тяжесть воспаления десны $(31,1 \pm 3,21 \%$ у вербальных 


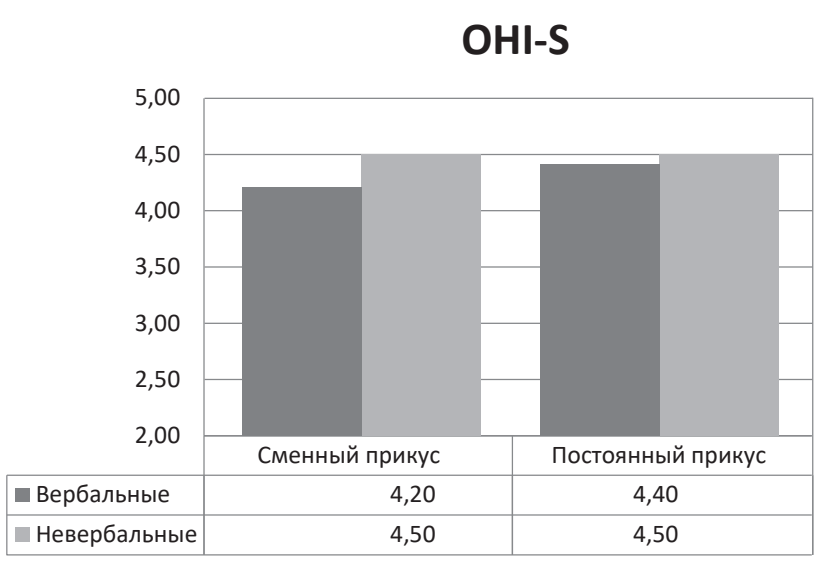

Рис. 1. Значения упрощенного индекса гигиены полости рта (OHI-S) во второй и третьей группах детей с PAC.

Fig. 1. Values of the simplified oral hygiene index (OHI-S) in the second and third groups of children with ASD. children with ASD.

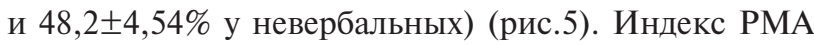
у вербальных детей, участвующих в исследовании $16,7 \pm 3,47$, у невербальных - 30,8 $\pm 4,25$.

Заключение. Проведенное исследование показало, что уровень знаний родителей детей с РАС о профилактике стоматологических заболеваний низкий, 34,7 $\%$ не получали рекомендаций по уходу за полостью рта.

Результаты анкетирования родителей детей с РАС показали, что лишь 20,5\% детей чистят зубы самостоятельно, в большинстве случаев детям с РАС необходима либо полная, либо частичная помощь при чистке зубов.

Проведенное исследование показало неудовлетворительный уровень гигиены полости рта во временном прикусе как у вербальных, так и невербальных детей с расстройством аутистического спектра во временном прикусе. В сменном и постоянном прикусе у детей с РАС был выявлен плохой уровень гигиены. Также у детей во всех возрастных группах была выявлена высокая распространенность кариеса: в обеих группах она составила 100\%. При оценке состояния тканей пародонта как у вербальных, так и невербальных детей была выявлена легкая степень воспаления десны.

Таким образом, при планировании профилактических мероприятий у детей с расстройством аутистического спектра необходимо учитывать уровень знаний родителей детей с РАС о профилактике стоматологических заболеваний и способность этих детей к навыкам коммуникации.

\section{Список литературы}

1. G.F. Ferrazzano, C. Salerno, C. Bravaccio, A. Ingenito, G. Sangianantoni, T. Cantile. Autism spectrum disorders and oral health status: review of the literature. DOI 10.23804/ejpd.2020.21.01.02

2. Christopher D, Prater MD, Robert G. Autism: a medical primer. Am Fam Physician 2002; 66:1667-74
3. Medina AC, Sogbe R, Gomez-Rey A, M Mata. Factitial oral lesions in an autistic paediatric patient. Int J Paediatr Dent 2003; 13:130-7

4. Jaber MA. Dental caries experience, oral health status and treatment needs of dental patients with autism. J Appl Oral Sci 2011; 19:212-7.

5. Loo, C. Y., Graham, R. M., \& Hughes, C. V. (2009). Behaviour guid- ance in dental treatment of patients with autism spectrum dis- order. International Journal of Paediatric Dentistry, 19(6), 390-398.

6. Morinushi, T., Ueda, Y., Tanaka, C. (2001). Autistic children: Expe- rience and severity of dental caries between 1980 and 1995 in Kagoshima City, Japan. Journal of Clinicial Pediatric Dentistry, 25, 323-328.

7. Orellana, L. M., Silvestre, F. J., Marti nez-Sanchis, S., Marti nez-Mihi, V., \& Bautista, D. (2012). Oral manifestations in a group of adults with autism spectrum disorder. Medicina Oral, Patologia Oral y Cirugia Bucal, 17(3), 415-419.

8. Bassoukou, I. H., Nicolau, J., \& dos Santos, M. T. (2009). Saliva flow rate, buffer capacity, and $\mathrm{pH}$ of autistic individuals. Clinical Oral Investigations, 13(1), 23-27.

9. Rai, K., Hegde, A. M., \& Jose, N. (2012). Salivary antioxidants and oral health in children with autism. Archives of Oral Biology, 57(8), 1116-1120.

10. Кисельникова Л.П., Дроботько Л.Н., Милосердова К.Б. Оказание стоматологической помощи детям с расстройствами аутистического спектра // Аутизм и нарушения развития. 2017. Т. 15. № 3. С. 9-15. DOI: $10.17759 /$ autdd.2017150302

11. Characteristics of Pre-school Children with Autistic Syndrome Disorder. J Clin Pediatr Dent 2016;40:21-5. DOI: $10.17796 / 1053-4628-40.1 .21$

12. Fakroon S, Arheiam A, Omar S. Dental caries experience and periodontal treatment needs of children with autistic spectrum disorder. Eur Arch Paediatr Dent 2015;16:205-9. DOI: 10.1007/s40368-014-0156-6

13. Диагностика раннего детского аутизма: Начальные проявления. // Лебединская К.С., Никольская О.С. М.: Просвещение, 1991.96 с.

14. Калинина О.В., ОСОБЕННОСТИ КОММУНИКАЦИИ У ДЕТЕЙ С АУТИЗМОМ, //Новая наука: ОПыт, традиции, инновации, 2016

\section{СОВЕРШЕНСТВОВАНИЕ СИСТЕМЫ КОНТРОЛЯ КАЧЕСТВА ПРИ СТОМАТОЛОГИЧЕСКОМ ЛЕЧЕНИИ ДЕТЕЙ ДОШКОЛЬНОГО ВОЗРАСТА}

Смелянеи М.П.

ФГБОУ ВО МГМСУ им. А.И. Евдокимова МЗ РФ

Актуальность. Полноценное и правильное заполнение первичной медицинской документации важно не только для хранения полученной диагностической информации, составления адекватного плана лечения, сохранения сведений о проведенных манипуляциях, но и для внутреннего контроля качества медицинской деятельности.

Цель. Совершенствование системы контроля качества деятельности стоматологических медицинских организаций при лечении пульпита временных зубов у детей дошкольного возраста.

Пациенты и методы. На базе «Клинического центра челюстно-лицевой, пластической хирургии и стоматологии МГМСУ» был проведен ретроспективный анализ 115 медицинских карт детей 
дошкольного возраста, обратившихся в клинику детской стоматологии с 2016 по 2018 годы с диагнозом К04.03 пульпит хронический. Анализ медицинской документации был проведен в соответствии с критериями оценки качества медицинской помощи, которые представлены в утвержденных Министерством Здравоохранения Российской Федерации Приказом №620 от 30.12.2003 г. протоколах ведения детей, страдающих стоматологическими заболеваниями и согласно алгоритму ведения пациентов с пульпитом временных зубов, который представлен в проекте клинических рекомендаций «Пульпит у детей». Медицинские карты соответствовали установленной Форме № 043/y, утвержденной Минздравом СССР от 04.10.1980 г. №1030. Следует отметить, что в 2017 году в «Клиническом центре челюстно-лицевой, пластической хирургии и стоматологии МГМСУ» были внедрены медицинская информационная система «1С:Медицина. Поликлиника» и стандартизированная анкета здоровья пациента.

Результаты. В ходе исследования по оформлению медицинской карты стоматологического больного (МКСБ) получены следующие результаты.

При заполнении общей информации о пациенте такие данные, как фамилия имя отчество пациента, его дата рождения, место жительства, данные официального представителя, дата заполнения МКСБ описаны во всех картах. Информированное добровольное согласие на проведение медицинских вмешательств, которое является обязательным к заполнению, получено от 115 представителей пациентов (100\%).

При анализе заполнения диагностической части медицинских карт установлено, что жалобы, предъявляемые пациентами указаны в 115 картах (100\%), история развития заболевания в 93 картах (80,9\%). Аллергоанамнез и сопутствующие заболевания описаны в 78 и 108 картах (67,8 и 93,9\%), соответственно. Общее состояние указано у 71 пациентов $(61,7 \%)$.

Установлено, что врачи-стоматологи детские не уделяют должного внимания описанию внешнего осмотра. Данные этого раздела медицинской карты распределились следующим образом: конфигурация лица описана в 113 картах (98,3\%), кожные покровы челюстно-лицевой области оценены в 8 (6,9\%), пальпация лимфатических узлов проведена у 105 пациентов $(91,3 \%)$, степень открывания рта оценена у 101 пациента $(87,8 \%)$.
Общее описание местного статуса имеется в 115 картах (100\%). При осмотре ротовой полости описаны ее цвет и влажность в 112 случаях $(97,4 \%)$. Относительно осмотра зубных рядов получены следующие данные: описание зубной формулы имеется в 102 картах (88,7\%), прикус определен у 101 ребенка $(87,8 \%)$, состояние гигиены рта у 92 детей (80\%). При проведении клинических методов обследования пациентов зондирование кариозной полости проведено у 103 пациентов (89,6\%), перкуссия зуба у 84 (73\%). Проведенный анализ показал неполное проведение обследования стоматологических пациентов при помощи клинических методов.

Согласно протоколу ведения детей, страдающих пульпитом, и алгоритму ведения пациента, который представлен в проекте клинических рекомендаций «Пульпит у детей», требуется рентгенологическое исследование для определения состояния твердых тканей зуба, наличия сообщения кариозной полости с полостью зуба, степени формирования корней, состояния костной ткани в области корней зубов, периапикальных тканей. Данные рентгенологического исследования позволяют врачу проанализировать ситуацию для определения оптимального метода лечения. В данной выборке карт наличие рентгенологического исследования зафиксировано в 40 случаях (34,8\%). В 115 картах (100\%) указан диагноз, во всех случаях соответствующий МКБ-10 (100\%).

Успех лечения напрямую зависит от правильного выбора метода лечения и медикаментов с учетом проведенного обследования пациента. В данном исследовании комплексный план лечения был описан в 88 картах (76,5\%). Лечебные записи проведены следующим образом: вид проведенной местной анестезии в 94 картах (81,7\%), наименование анестетика - в 77 (67\%), концентрация анестетика - в 50 (43,5\%), объем анестетика - в 72 картах $(62,6 \%)$, терапевтическое

Таблица 1. Сведения о результатах сбора аллергоанамнеза

\begin{tabular}{lccc}
\hline & $\begin{array}{c}\text { Общее } \\
\text { количество карт }\end{array}$ & $\begin{array}{c}\text { Количество карт } \\
\text { с указанием } \\
\text { аллергоанамнеза }\end{array}$ & $\%$ \\
\hline 2016 г. & 43 & 8 & 18,6 \\
2017 г. & 26 & 25 & 96,1 \\
2018 г. & 46 & 45 & 97,8 \\
\hline
\end{tabular}

\section{Таблица 2. Сведения о результатах клинических методов обследования}

Общее количество карт
Количество карт с указанием данных клинических методов обследования

Зондирование кариозной полости
Перкуссия зуба
Зондирование кариозной полости
$\%$

\begin{tabular}{lllllll}
2016 г. & 43 & 36 & 25 & 83,7 & 58,1 & \\
2017 г. & 26 & 22 & 17 & 84,6 & 65,4 \\
2018 г. & 46 & 44 & 42 & 95,6 & 91,3 \\
\hline
\end{tabular}


лечение проведено $100 \%$ пациентам. Подпись лечащего врача имелась во всех картах, профилактические осмотры рекомендованы 89 пациентам $(77,4 \%)$.

Проведенный анализ выявил недостаточное описание общего состояния пациентов. При проведении внешнего осмотра врачи-стоматологи детские в редких случаях описывают состояние кожных покровов. При описании местного статуса выявлен ряд недочетов, связанных с данными зондирования кариозной полости и перкуссии зуба. Менее чем в половине клинических случаев было описано рентгенологическое обследование на этапах диагностики и лечения, которое необходимо проводить согласно протоколу ведения детей при диагнозе «пульпит».

Следует отметить, что с внедрением медицинской информационной системы «1С: Медицина. Поликлиника» и стандартизированных анкет здоровья повысилась частота описания аллергоанамнеза (Таблица 1), данных о зондировании кариозной полости и перкуссии зуба (Таблица 2).

Анализ сведений, представленных в «Таблице 1» и «Таблице 2», позволяет утверждать, что с 2017 года значительно улучшились показатели качества заполнения медицинской документации с сохранением положительной тенденции в 2018 году.

Выводы. Анализ 115 медицинских карт стоматологического больного пациентов дошкольного возраста , обравшихся за стоматологической помощью в отделение детской стоматологии , выявил дефекты ведения пациентов в виде неполного обследования. Дефекты в оформлении медицинской документации создают определенные сложности при оценке полноты и качества оказания помощи пациентам, а также правильности выбранного метода лечения и его эффективности. Внедрение медицинской информационной системы в работу «Клинического центра челюстно-лицевой, пластической хирургии и стоматологии МГМСУ» выявило значительное улучшение качества заполнения медицинской документации. Таким образом, внедрение медицинской информационной системы вносит существенный вклад в совершенствование системы контроля качества деятельности стоматологической медицинской организации.

\section{ЛАБОРАТОРНЫЕ МАРКЕРЫ ПОРАЖЕНИЯ МИОКАРДА У ДЕТЕЙ С ДЕФЕКТОМ МЕЖЖЕЛУДОЧКОВОЙ ПЕРЕГОРОДКИ \\ Ющенко А.Ю., Каладзе Н.Н.}

ФГАОУ ВО «Крымский федеральный университет имени В.И.Вернадского», Медицинская академия имени С.И. Георгиевского, Симферополь

Актуальность. Поиск универсальных кардиомаркеров у детей с сердечно-сосудистой патологией является одной из приоритетных задач современных научных исследований. Востребованным у взрослых пациентов и малоизученным в детской популяции является использование тропонина I и NT-proBNP в диагностике миокардиального повреждения и сердечной недостаточности, особенно у детей с врожденными пороками сердца.

Цель исследования - изучить содержание и диагностическую значимость тропонина I и NT-proBNP у детей с дефектом межжелудочковой перегородки (ДМЖП), в зависимости от наличия и возраста оперативной коррекции порока.

Материал и методы. Обследован 91 ребенок с ДМЖП в возрасте 3-18 лет. В зависимости от наличия оперативной коррекции порока дети были разделены на 2 группы: 1 группу составили 74 ребенка, оперированных по поводу ДМЖП, медиана возраста - 9 [6; 13] лет, медиана послеоперационного периода - 6 [4; 11] лет; 2 группу - 17 человек без хирургического лечения порока, средний возраст $-10,8 \pm 3,74$ лет, средняя величина дефекта $4,11 \pm 0,99$ мм. Кроме этого, в зависимости от возраста оперативной коррекции ДМЖП дети 1 группы были разделены на 2 группы: группа А - 54 человека (73\%), оперированных в возрасте до 2 лет и группа В - 20 детей (27\%), оперированных в возрасте старше 2 лет жизни. Контрольную группу составили 30 здоровых детей без структурной патологии сердечно-сосудистой системы, средний возраст $10,7 \pm 3,47$ лет. Для определения степени сердечной недостаточности (СН) использовали классификации Нью-Йоркской ассоциации сердца (NYHA) и Ross. Нарушения ритма сердца (НРC) выявляли на стандартной ЭКГ и при холтеровском мониторировании. С помощью ИФА в крови определяли уровни тропонина I и NT-proBNP. Статистическую обработку данных осуществляли с использованием программы IBM SPSS Statistics версии 23.0.

Результаты. В 1 группе функциональный класс (ФК) СН 0 наблюдался у 64 (75,7\%) детей, ФК I у $16(21,6 \%)$, ФК II - у 2 (2,7\%) человек. У всех детей 2 группы наблюдался только ФК 0. В группе А ФК 0 имели большинство детей - $49(90,7 \%)$ человек, ФК I - 3 (5,6\%) детей, ФК II - 2 (3,7\%) пациента. В группе В у большинства детей - 13 (65\%) - был выявлен ФК I, у 7 (35\%) - ФК 0. По вариабельности ФК СН между группами А и В имелись достоверные отличия $(p<0,001)$.

Уровень тропонина I у детей 1 группы составил $0,48[0,21 ; 1,02]$ нг/мл, во 2 группе - 1,52 [0,5; 3] нг/мл, что достоверно выше, чем в КГ $0,17 \pm 0,04$ нг/мл ( $p=0,006$ и $p<0,001$ соответственно). Повышенное содержание тропонина I наблюдалось у детей, оперированных по поводу ДМЖП как в возрасте до 2 лет - 0,26 [0,19;0,8] нг/мл $(p=0,027)$, так и в возрасте старше 2 лет - 1,25 [0,5; 1,75] нг/мл $(p<0,001)$. При анализе парных корреляций установлены положительные средней силы корреляционные связи между уровнем тропонина I и возрастом опе- 
ративной коррекции $(\rho=0,4, p=0,003)$, степенью $\mathrm{CH}$ $(\rho=0,390, p=0,003)$. Кроме того, тропонина I коррелировал с наличием брадикардии $(\rho=0,333 ; p=0,013)$ и суправентрикулярной тахикардии ( $\rho=0,3 ; p=0,041)$.

У детей с ДМЖП было выявлено повышенное содержание NT-proBNP в сравнении с КГ $(216 \pm 15,8$ фмоль/л): в 1 группе - 268 [220; 350] фмоль/л $(p=0,036)$, во 2 группе - 310 [289; 432] фмоль/л $(p=0,004)$, в группе В - $345[260 ; 420]$ фмоль/л $(p=0,008)$. В группе А уровень маркера сердечной недостаточности $(260$ [210; 292] фмоль/л) был сопоставим со значением КГ $(p=0,103)$. Отмечены прямые корреляционные связи NT pro-BNP с возрастом оперативной коррекции ДМЖП ( $\rho=0,433 ; p=0,002)$, степенью СН ( $\rho=0,357 ; p=0,003)$, с величиной дефекта $(\rho=0,698 ; p=0,008)$, а также с уровнем тропонина I ( $\rho=0,350 ; p=0,007)$. Кроме того, NT pro-BNP коррелировал с наличием брадикардии $(\rho=0,321 ; p=0,023)$ и миграцией водителя ритма ( $\rho=0,3 ; p=0,036)$.

Выводы. У детей с ДМЖП были выявлены повышенные уровни тропонина I и NT-proBNP, которые коррелировали с возрастом коррекции порока, степенью $\mathrm{CH}$, наличием НРС и размером дефекта. Наиболее выраженное повышение исследованных кардиомаркеров было выявлено в группе детей, оперированных в возрасте старше 2 лет и без хирургической коррекции порока. Представленные данные свидетельствовали о важной роли тропонина I и NT-proBNP в выявлении субклинического поражения миокарда, диагностике и прогрессировании $\mathrm{CH}$ у детей с дефектом межжелудочковой перегородки.

\section{СУЩЕСТВУЕТ ЛИ КОМОРБИДНОСТЬ СИНДРОМА УДЛИНЕННОГО ИНТЕРВАЛА QТ ПЕРВОГО ТИПА И СИНДРОМА БЕКВИТА- ВИДЕМАНА?}

Парфененко Мария Алексеевна

Научно-исследовательский клинический институт педиатрии имени академика Ю. Е. Вельтищева ФГАОУ ВО РНИМУ им. Н. И. Пирогова Минздрава России

Введение и актуальность. Синдром удлиненного интервала QТ (СУИQТ) - гетерогенная группа наследственных электрофизиологических нарушений, характеризующаяся врожденной аритмией, а именно удлинением интервала QT на ЭКГ. По данным литературы, частота встречаемости СУИQТ составляет 1 на 2000 новорожденных, и это заболевание является одной из наиболее распространенных причин внезапной сердечной смерти (ВСС) у детей и подростков. В литературе описано 15 различных типов синдрома удлиненного интервала QT, каждый из которых имеет моногенную природу. Первый и самый распространенный тип, также известный как синдром Романо-Уорда, связывают с мутациями в $K C N Q 1$, приводящими к нарушению работы кодируемой им субъ- единицы калиевого канала. Ген $K C N Q 1$ имеет хромосомную локализацию $11 \mathrm{p} 15.5$-p15.4, то есть находится в критическом регионе для синдрома Беквита-Видемана, характеризующихся аномалиями физического развития по типу гигантизма, а также синдромов, при которых наблюдается дефицит физического развития, таких как синдром Силвера-Рассела или синдром IMAGE. Более того, экспрессия $K C N Q 1$, а также и других генов, являющихся частью этого импринтированного домена, регулируется центром импринтинга 2, находящимся в том же регионе. Среди этих генов есть $C D K N 1 C$ - ген-регулятор пролиферации клеток, нарушение экспрессии которого связывают с возникновением основных симптомов синдрома Беквита-Видемана, среди которых: аномально высокие показатели физического развития, висцеромегалия и повышенных риск развития онкологических заболеваний, и синдрома Силвера-Рассела, для которого характерны аномально низкие показатели физического развития. Также за счет центра импринтинга два подавляется экспрессия KCNQ1OT1 - гена, также связанного с синдромом Беквита-Видемана и взаимодействующего с другими генами в домене. То, какое именно нарушение физического развитие возникает вследствие изменения экспрессии импринтированных генов в данном регионе зависит от того, от кого из родителей было унаследовано патогенное изменение, так как для большинства генов в этом домене характерна моноаллельная экспрессия. В частности, синдром Беквита-Видемана, как правило, развивается в случае наследования нарушения от матери. В литературе описано несколько случаев сочетания СУИQТ и синдрома Беквита-Видемана и СУИQТ и синдрома Силвера-Рассела, с указанием возможной связи между ними [1]. Среди наиболее распространенных симптомов синдрома Беквита-Видемана: макроглоссия (у 82\% пациентов), омфалоцеле - грыжа пупочного канатика (у 75,2\% пациентов), высокие антропометрические параметры новорожденного (у 38,5\%), аномалии мочек ушных раковин (у $38,5 \%$ ), постнатальный гигантизм (у 32,7\%), висцеромегалия (у 32,1\%), гипогликемия (гиперинсулинемия) и повышенный аппетит (у 30,4\%), судороги (у 21,8\%), опережение костного возраста (у 21,3\%) и врожденные пороки сердца (у 15,5\%). Также пациенты с синдромом Беквита-Видемана имеют повышенный риск развития патологий почек и различных онкологических заболеваний. Помимо этого, в литературе описаны случаи сочетания синдрома Беквита-Видемана и легких нейропсихиатрических нарушений и поведенческих особенностей, а также отдельных признаков расстройств аутистического спектра, причем последние предположительно связаны именно с нарушениями в центре импринтинга 2 [8].

Актуальность данного исследования объясняется, в первую очередь, относительно высокой частотой встречаемости обеих патологий: 1 на 2000 
для СУИQТ, 1 на 10340 для синдрома Беквита-Видемана. Помимо этого, последние несколько лет в литературе появляется все больше данных, указывающих на связь между использованием вспомогательных репродуктивных технологий (ВРТ), в частности экстракорпорального оплодотворения и инъекции сперматозоида в цитоплазму ооцита, и увеличением риска возникновения болезни импринтинга у ребенка [6]. Так, частота встречаемости синдрома Беквита-Видемана у детей, рожденных с применением ВРТ - 1 на 1126 новорожденных, то есть примерно в 9 раз больше, чем у детей, зачатых естественным путем.

Кроме того, в $40 \%$ случаев течение СУИQТ не сопровождается синкопальными состояниями, а значит пациенты зачастую не имеют жалоб, из-за чего своевременная постановка диагноза и начало медикаментозного лечения затруднены. Без терапии риск внезапной смерти при этом синдроме превышает $70 \%$ [3].

Мы предполагаем, что нарушения в гене $K C N Q 1$, приводящее к СУИQТ первого типа, помимо нарушения структуры и функционирования соответствующего ионного канала, также приводят к изменению экспрессии других импринтируемых генов в домене, включая гены-регуляторы пролиферации клеток, в первую очередь $C D K N 1 C$, фенотипическим проявлением которого являются аномально высокие или аномально низкие показатели физического развития.

Цель. На основе анализа данных цифровой истории болезни и глубокого фенотипирования пациентов с СУИQТ первого типа, установить особенности физического развития и фенотипа, характерные для синдрома Беквита-Видемана.

Пациенты и методы. Для определения общих фенотипических закономерностей мы проанализировали выборку из 401 пациента с СУИQТ, чьи показатели физического развития были доступны нам благодаря системе цифровой истории болезни. Цифровая история болезни позволяет проанализировать данные значительного количества пациентов без прямого доступа к ним, благодаря чему есть возможность заметить связь между несколькими факторами, на которые мы потенциально не обратили бы внимание при анализе данных одного изолированного пациента. Такой метод уже был использован для выявления корреляции между генетическими нарушениями и ранее не ассоциированными с ними фенотипическими проявлениями у Bastarache L et al [9].

Статистический метод, использованный нами для выявления наличия статистически значимой разницы между показателями массы и роста пациентов - Т-критерий Стьюдента для независимых выборок - он лучше всего подходит для двух групп с разным числом значений и неочевидным различием. В качестве контрольной группы мы использовали 500 пациентов из пульмонологического, педиа- трического и оториноларингологического отделений, для которых не характерны отклонения от норм физического развития, ни в сторону избытка, ни в сторону дефицита. Также ни у одного из контрольной группы не наблюдалось нарушения ритма сердца. Вычисления проводились в перцентилях, так как возраст пациентов составлял от 1 года, до 17 лет, поэтому при расчете средних значений необходимо было учесть возрастные нормы.

Также было проведено глубокое фенотипирование и анализ родословной 9 пациентов с СУИQТ 1 типа и показателями роста и массы более 97 перцентиля, с целью обнаружить наиболее распространенные признаки синдрома Беквита-Видемана.

Результаты и обсуждение. Статистический анализ физического развития с СУИQТ по данным цифровой истории болезни.

Мы сравнили средние значения роста и массы всех пациентов с СУИQТ $(n=401)$ с контрольной группой, благодаря чему нам удалось выявить статистически значимую разницу между ростом пациентов с СУИQТ и детей, не имеющих нарушения ритма сердца. Средний рост пациентов примерно 65.88 перцентиль, в то время как в контрольной для контрольной группы значение было около 58.27. Т-значение для этих чисел составило 3.83, что означает практически стопроцентную гарантию значимости различия для $p=0.005$. Статистически значимых различий по массе пациентов и детей и контрольной группы выявлено не было.

Помимо этого нами было произведено сравнение пациентов с установленным СУИQТ первого типа $(n=105)$ с контрольной группой. В этом случае нам также удалось выявить статистически значимую разницу в росте пациентов, в то время как масса была примерно равной. Средний рост в выборке составил 64.50 перцентиль. Однако у многих пациентов в выборке тип СУИQТ не был установлен ни клинически, ни молекулярно-генетически, несмотря на то, что необходимость внедрять генетическое тестирование в диагностику наследственных болезней сердца в наше время не вызывает сомнений [2]. Если исходить данных литературы, на СУИQТ первого типа приходится от 40 до $55 \%$ всех случаев СУИQТ, а значит среди пациентов с недифференцированным удлинением интервала QT большинство, скорее всего, также имеют первый тип. Из-за этого установить существование различия в показателях массы и роста у пациентов с разным типом СУИQТ не удалось.

Учитывая, что синдром Беквита-Видемана проявляется при наследовании генетического нарушения от матери, мы сравнили показатели физического развития пациентов с СУИQТ первого типа, унаследованным по материнской линии $(n=20)$ с данными контрольной группы. Факт наследования был установлен благодаря анализу ЭКГ матерей и других род- 
ственников по материнской линии, а также случаев ВСС в анамнезе у родственников со стороны матери. Масса и рост этих пациентов оказалась 77.9 и 71.8 перцентиль соответственно, что значительно превышает показатели контрольной группы (составившие 64.82 перцентиль для массы и 58.27 - для роста).

Для пациентов с СУИQТ первого типа, унаследованным по отцовской линии, какие-либо репрезентативные данные собрать не удалось, так как их было только 4 пациента. Однако среди них был один пациент, наблюдающийся у эндокринолога с диагнозом «конституциональная низкорослость». Но помимо выраженного, недифференцированного дефицита массы и роста (>3 перцентиль) данных, говорящих за или против наличие у этого пациента клинических проявлений синдромов Силвера-Рассела или IMAGE в его истории болезни не содержалось.

Другими авторами подобные исследования не проводились, возможно, из-за того, что пациенты с СУИQТ наблюдаются в кардиологических стационарах, спектр обследований в которых более узкий, чем тот, который необходим для клинической диагностики синдрома Беквита-Видемана.

Глубокое фенотипирование пациентов с аномально высокими параметрами физического развития.

Мы провели глубокое фенотипирование и анализ родословной девяти пациентов - четырех девочек и пяти мальчиков - с СУИQТ первого типа с показателями массы и роста >97 перцентиль. Из них, у двоих диагноз подтвержден молекулярно-генетически, у остальных - тип определен по клинико-электрофизиологическим данным.

У четверых из них СУИQТ был унаследован по материнской линии, у четверых - по отцовской, а у одной пациентки в семейном анамнезе не было известных случаев СУИQТ или ВСС, а ЭКГ родителей не представлено. У троих из девяти беременность протекала на фоне многоводия, что является распространенным клиническим проявлением при синдроме Беквита-Видемана. У четверых пациентов масса при рождении была в промежутке от 25 до 75 перцентиль, у четверых - выше 75 перцентиль, причем у двоих из них - значительно превышала 97 перцентиль. Лишь одна из пациенток родилась родилась с дефицитом массы (<10 перцентиль) - роды произошли на 36 неделе, а беременность протекала на фоне медикаментозного лечения матери от ВИЧ-инфекции. Длина тела при рождении у трех пациентов была <25 перцентиль, у двух - в промежутке от 25 до 75 перцентиль, и у четверых - выше 75 перцентиль, причем у двоих из них - значительно превышала 97 перцентиль. Родители четверых из девяти пациентов отмечали повышенный аппетит у детей в раннем возрасте и необходимость кормить их с большей частотой, чем рекомендовано. У одного из пациентов вплоть до настоящего времени отмечаются периоды гиперинсулинемии, что также является характерным проявлением синдрома Беквита-Видемана.

Моторное развитие всех пациентов соответствовало возрасту, однако у двоих наблюдались нарушения психоречевого развития - у одного из детей в дошкольном возрасте диагностировали легкую ЗПРР, которая компенсировалась к моменту начала младшей школы, а у другого в раннем возрасте произошел регресс речевого развития вплоть до полного исчезновения речи. Речь восстановилась к трем годам. Также у 8 из 9 пациентов есть нарушения эмоционально-волевой сферы. Семь испытывают трудности в контроле эмоций и тяжело переживают любые стрессовые ситуации, пять склонны к тревоге - особенно обращает на себя один из детей, державший мать за руку в течение всего осмотра и впавший в панику, вплоть до гипервентиляции, на несколько секунд потеряв ее из поля зрения. У двоих пациентов отмечаются проблемы с агрессией. У одного - выраженная задержка эмоционально-волевого развития. Это соотносится с данными, полученными Kent L. et al. [8], о связи нейропсихических особенностей у пациентов с синдромом Беквита-Видемана с нарушениями в центре импринтинга 2. Одна из девяти пациентов в настоящее время проходит медикаментозную терапию эпилепсии.

У 3 из 9 пациентов есть аномалии почек, у одного из них -подковообразная почка. У одного из девяти пациентов в раннем детстве была грыжа пупочного канатика. Результаты ультразвукового исследования представлены только у одной из девяти пациентов у нее выраженная гепатомегалия. У другого, по словам матери, гепатомегалия непостоянная и возникает в период перенесения им инфекционных заболеваний.

У одного из пациентов была представлена рентгенограмма кистей - костный опережал паспортный на 1 год и 9 месяцев. У одного из пациентов в анамнезе есть онкологическое заболевание - врожденная атерома, удаленная в 9 месяцев. У другого на МРТ головного мозга была обнаружена киста прозрачной перегородки. У одной из пациентов помимо СУИQТ также был продиагностирован врожденный порок сердца - дефект межпредсердной перегородки.

Обращает на себя внимание наличие у шести из девяти пациентов насечек и/или ямочек на мочках ушей, что является характерной микроаномалией развития (МАР) при синдроме Беквита-Видемана. У 2 из 9 пациентов отмечается макроглоссия. Другая МАР, обнаруженная нами у семи из девяти пациентов - укорочение пятой плюсневой кости. Эта МАР не была описана ранее ни при синдроме Беквита-Видемана, ни при СУИQТ первого типа.

Таким образом, у девяти пациентов с СУИQТ типа 1 нами наблюдались признаки, характерные 
для синдрома Беквита-Видемана, такие как: неонатальный и постнатальный гигантизм, висцеромегалия, патологии почек и сердца, нейропсихические нарушения и др.

На основе доступных нам данных осмотра, анамнеза жизни и результатов инструментальных методов диагностики, а также родословных пациентов, мы предполагаем наличие у этих пациентов стертой формы синдрома Беквита-Видемана.

Подобный случай описан в работе Eßinger, C et al. [1], одного пациента, имевшего характерные признаки как синдрома Беквита-Видемана, так и СУИQТ типа 1. В его случае, нарушение ритма сердца было унаследовано по материнской линии.

На данный момент сложно судить о степени коморбидности синдрома Беквита-Видемана

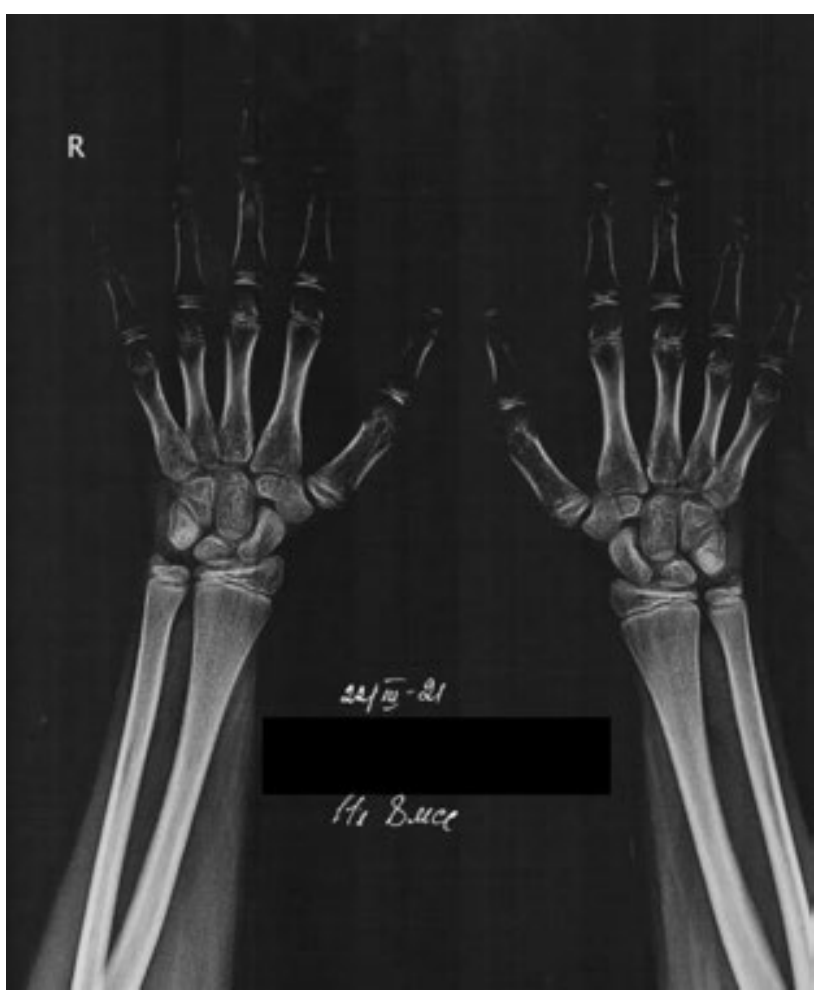

Рисунок 1. Рентгенограмма кистей пациента Г. Костный возраст - 13.5 лет. Паспортный 11 лет и 8 мес. Опережение костного возраста на 1 год и 9 мес.
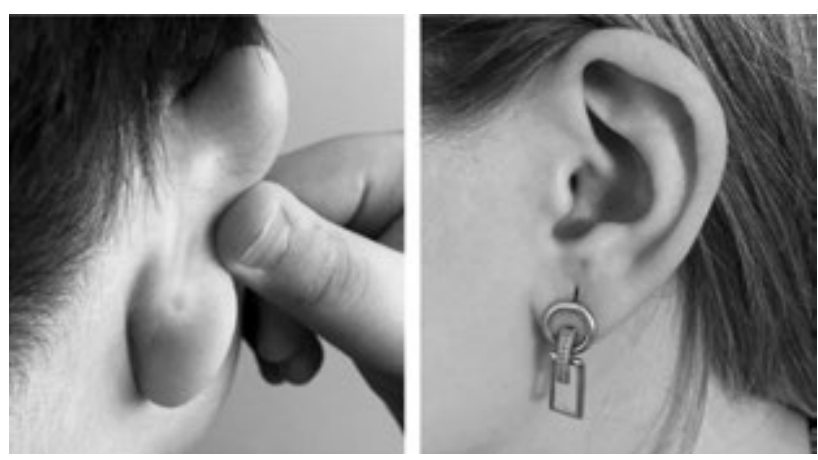

Рисунок 2. МАР ушной раковины у пациентов с СУИQТ типа 1. и СУИQТ типа 1, по причине недостаточного количества данных по состоянию внутренних органов, не связанных напрямую с сердечно-сосудистой системой, у пациентов, проходящих лечение в кардиологическом стационаре. Поскольку как пациенты с синдромом Беквита-Видемана, так и пациенты с СУИQТ первого типа нередко не имеют жалоб, послуживших бы показаниями для проведения более комплексного обследования.

Вывод. При анализе статистических данных было выявлено, что у детей как с недифференцированным СУИQТ, так и с клинически установленным СУИQТ типа 1, показатели роста превосходят средние показатели пациентов педиатрического стационара, не имеющих нарушения ритма сердца. Особенно значимые различия наблюдаются между контрольной группой (58.27 перцентиль) и пациентами с СУИQТ типа 1 , унаследованными по материнской линии.

При глубоком фенотипировании девяти детей с СУИQТ типа 1, имевших показатели физического развития выше 97 перцентиля, у всех из них было выявлено значительное количество клинических проявлений синдрома Беквита-Видемана, с разной частотой таких как гигантизм (у 9), характерные аномалии внутренних органов (у 3 - аномалии почек, у 2 - висцеромегалия, у 1 - врожденный порок сердца), специфические МАР, присущие этому синдрому (у 6) и нейропсихические нарушения (у 8).

Предлагаемая гипотеза. Исходя из полученных нами статистических данных о 401 пациенте с СУИQТ, а также проведенного нами глубокого фенотипирования девяти пациентов с СУИQТ типа 1, мы предлагаем гипотезу, что мутации в гене $K C N Q 1$, приводящие к развитию СУИQТ первого типа также вызывает изменение экспрессии генов, локализованных в данном импринтированном домене, что может приводить развитию стертого фенотипа синдрома Беквита-Видемана - в особенности данная мутация была унаследована по материнской линии, или во всяком случае оказывает значимое влияние на экспрессию генов, регулирующих физическое развитие.

Благодарности. Хотелось бы выразить особую благодарность руководству Научно-исследовательского клинического института педиатрии имени академика Ю. Е. Вельтищева, в лице д.м.н. Школьниковой Марии Александровны и д.м.н. Воиновой Виктории Юрьевны, за уникальную возможность работать под их руководством. Также хотелось бы поблагодарить других сотрудников института - к.м.н. Ильдарову Рукижат Абдул-Гафуровну из отдела детской кардиологии и аритмологии и Смирнова Ивана Сергеевича - начальника отдела поддержки и развития информационных систем - за помощь в проведении исследования и организацию доступа к необходимым материалам. 


\section{Список литературы.}

1. Eßinger, C., Karch, S., Moog, U. et al. Frequency of KCNQ1 variants causing loss of methylation of Imprinting Centre 2 in Beckwith-Wiedemann syndrome. Clin Epigenet 12, 63 (2020). https://doi.org/10.1186/s13148-020-00856-y

2. Щербакова, Н.В., Воинова, В.Ю., Школьникова, М.А. Генетика и сердце: Основания для внедрения генетического тестирования в клиническую практику. Педиатрия. Журнал им. Г.Н. Сперанского 99, стр 8-15 (2020)

3. DOI: $10.24110 / 0031-403 X-2020-99-3-8-15$

4. Школьникова, М.А., Чупрова, С.Н., Клинический и генетический полиморфизм наследственного синдрома удлиненного интервала QT, факторы риска синкопе и внезапной смерти. Вестник аритмологии 26, 35-42 (2002)

5. Õunap K. Silver-Russell Syndrome and Beckwith-Wiedemann Syndrome: Opposite Phenotypes with Heterogeneous Molecular Etiology. Mol Syndromol. 2016;7(3):110-121. DOI:10.1159/000447413

6. Syed Raza Shah, MD Ki Park, MD, Richard Alweis, MD, Long QT Syndrome: A Comprehensive Review of the Litera- ture and Current Evidence. Current Problems in Cardiology 44, Issue 3, pages 92-106 (2019). https://doi.org/10.1016/j. cpcardiol.2018.04.002

7. Owen CM, Segars JH Jr. Imprinting disorders and assisted reproductive technology. Semin Reprod Med. 2009;27(5):417428. DOI:10.1055/s-0029-1237430

8. Peter J. Schwartz, Lia Crotti, Roberto Insolia. Long-QT Syndrome

9. From Genetics to Management. Circulation: Arrhythmia and Electrophysiology. 5:868-877 (2012), https://doi. org/10.1161/CIRCEP.111.962019

10. Kent L, Bowdin S, Kirby GA, Cooper WN, Maher ER. Beckwith Weidemann syndrome: a behavioral phenotype-genotype study. Am J Med Genet B Neuropsychiatr Genet. 2008;147B(7):1295-1297. DOI:10.1002/ajmg.b.30729

11. Bastarache L, Hughey JJ, Hebbring S, et al. Phenotype risk scores identify patients with unrecognized Mendelian disease patterns. Science. 2018;359(6381):1233-1239. DOI:10.1126/ science.aal4043 